

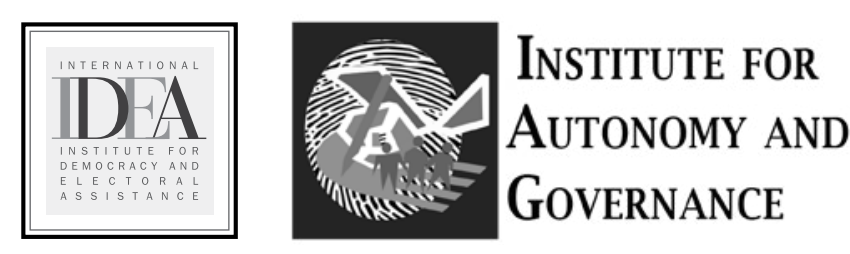

\title{
Kasangkapan sa Pagtatasa sa Karapatan ng mga Katutubo sa Konstitusyon
}

\author{
Amanda Cats-Baril
}


(C) 2020 International Institute for Democracy and Electoral Assistance (English edition)

(C) 2021 International Institute for Democracy and Electoral Assistance and Institute for Autonomy and Governance

International IDEA, Strömsborg

SE-103 34 Stockholm, Sweden

Tel: +4686983700

Email: info@idea.int

Website: <https://www.idea.int>

Ang elektronikong bersiyon ng publikasyong ito, maliban sa mga imahen, ay maaaring makita/ makuha sa ilalim ng lisensiya ng isang Creative Commons Attribution-Non Commercial-Share Alike 3.0 (CC BY-NC-SA 3.0). Maaaring libreng kumuha ng kopya, mamahagi at maghatid ng publikasyong ito gayundin ang maghalo at mag-angkop nito sa kondisyon na ito ay gagamitin hindi upang pagkakitaan, na kikilalanin mo ang kaugnay na publikasyon, at ipamahagi mo ito sa ilalim din ng naturang lisensiya. Para sa karagdagang impormasyon sa lisensiyang nabanggit, bisitahin ang http://creativecommons.org/ licenses/by-nc-sa/3.0/.

Ang publikasyon ng International IDEA ay malaya sa tiyak na politikal at nasyonal na interes. Ang mga pananaw na ipinahayag sa publikasyong ito ay hindi kailangang kumakatawan sa pananaw ng Internationa IDEA, sa kapulungan nito o kayày sa mga miyembro ng Konseho nito.

Ito ay tuwirang pagsasalin ng 2020 bersiyon sa Ingles ng Kasangkapan sa Pagtatasa sa Karapatan ng mga Katutubo sa Konstitusyon ng International IDEA. Ang kawastuhan ng salin ay hindi napatunayan ng International IDEA. Kung sakaling may pagdududa, ang orihinal na bersiyon sa Ingles ang mangingibabaw (ISBN: 978-91-7671-324-2 (PDF)).

Ang salin ay isinagawa nina Zahra Ibrahim Cerafica, Aisa Camar at Normie Pabinal.

Patnugot sa kopya at konsultant sa salin: Rogene A. Gonzales

Pagkakalatag ng salin : R. Jordan P. Santos

Disenyo ng grapiko at pabalat: Richard van Rooijen (batay sa isang konsepto na binuo ng KSB Design)

Imaheng pabalat at likhang sining: Ancestors (C) Sarrita King

Ang mga larawan/ pintura ng Sarrita’s Ancestors ay pinatungan ng mga tuldok. Ang mga marka na ginawa ay mula sa lupa ilang libong taong nakalipas na makikitang napupuluputan ng mga dibuho na sakop ng mga lupain ngayon, gaya ng buhanging burol, mga pananim at mga daanan o pilapil na gawa ng mga tao at hayop. Sa ibaba ng lupain ay ang mga daluyan ng tubig na siyang patuloy na nagbibigay sustansiya sa lupain, pananim, palahayupan at mga tao. Ito rin ang parehong mga daluyan ng tubig na tumutustos sa ating mga ninuno kung saan kaisa na ngayon ng mga lupain.

ISBN: 978-91-7671-446-1 (Print)

ISBN: 978-91-7671-447-8 (PDF)

DOI: https://doi.org/10.31752/idea.2021.69

Ang salin na ito ay ginawa gamit ang suportang pampinansyal ng European Union 


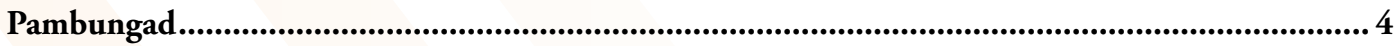

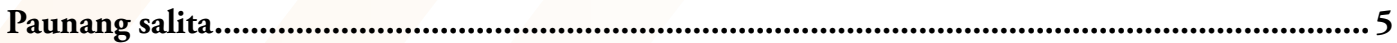

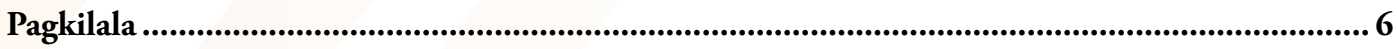

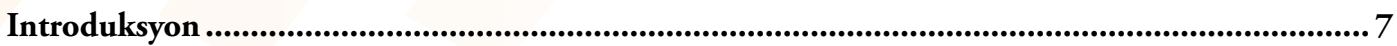

1. Pagtatasa sa karapatan ng mga katutubo sa mga konstitusyon........................................................ 8

1.1 Bakit isasama sa konstitusyon ang karapatan ng mga katutubo?................................................ 9

1.2 Bakit at kailan nakatutulong ang isang kasangkapan sa pagtatasa sa karapatan ng mga katutubo?........10

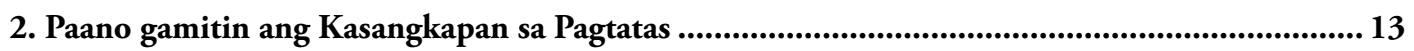

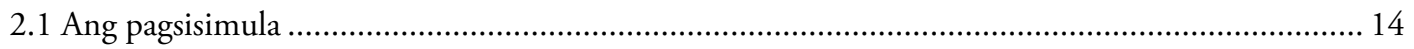

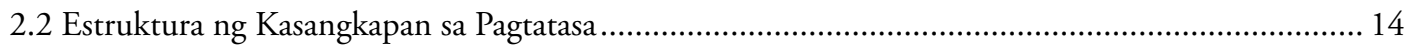

2.3 Mga mahahalagang konsiderasyon para sa mga gagamit .............................................................. 16

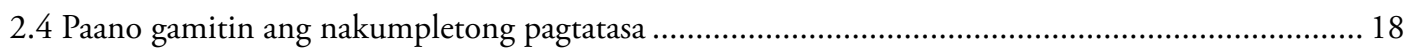

3. Mga susing termino at konsepto …….............................................................................................. 20

4. Kasangkapan sa Pagtatasa sa Karapatan ng mga Katutubo sa Konstitusyon ................................34

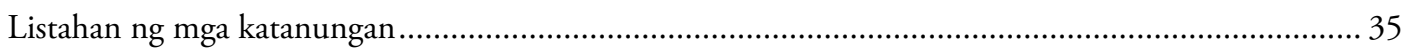

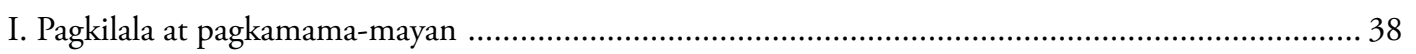

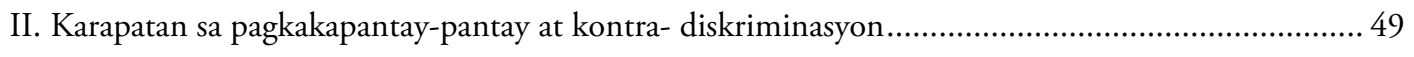

III. Mga pundasyon para sa mga karapatan ng mga katutubo ............................................................ 59

IV. Awtonomiya: Paggawa ng kasunduan at sariling pamahalaan ........................................................ 75

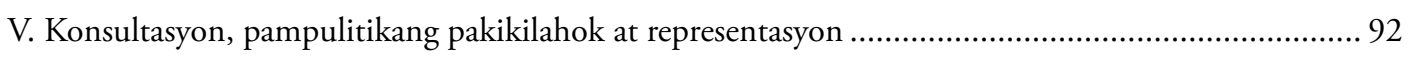

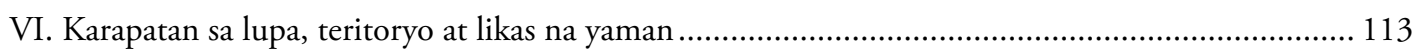

VII. Karapatan sa kultura, at panlipunan at pang-ekonomikong pag-unlad ....................................... 131

VIII. Pagprotekta at pagtataguyod sa mga karapatan ng mga katutubo ............................................... 160

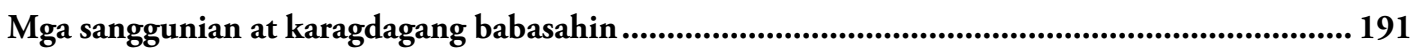

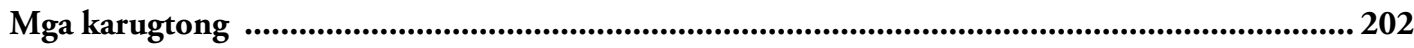

Karugtong 1. Kumbensyon ng ILO 169: Kumbensyon ng mga katutubo at tribong mamamayan, 1989.....203

Karugtong 2. Deklarasyon ng United Nations ukol sa Mga Karapatan ng Mga Katutubong .............. 213

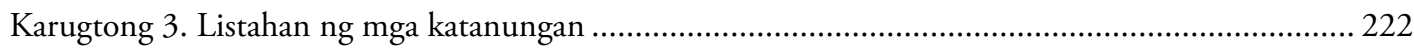

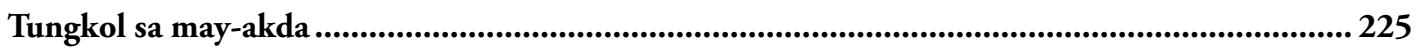

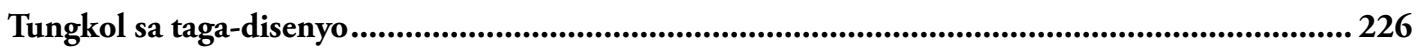

Tungkol sa International IDEA........................................................................................................ 227 


\section{Pambungad}

Ang International Working Group for Indigenous Affairs (IWGIA) ay nagsisilbi para sa isang mundo kung saan ay maririnig ang mga boses at hinaing ng mga katutubo at maipatupad ang kanilang mga karapatan. Simula noong 1969 , ang IWGIA ay nakagawa ng pakikipagsosyo sa mga pangkatutubong organisasyon at pandaigdigang institusyon upang magtaguyod ng pagkilala, pagpapahalaga at pagpapatupad ng mga karapatan ng mga katutubo. Ang Kasangkapan sa Pagtatasa sa Karapatan ng mga Katutubo sa Konstitusyon ay magbibigay ng makabuluhang gawain sa pamamagitan ng pagtulong sa mga katutubo sa mga komunidad at magbigay ng adbokasiya, gayundin bilang kapanalig sa pagtataguyod ng karapatang pangkatutubo, maunawaan ang sakop at mga bagay na maaaring mangyari sa pagtataguyod ng pandaigdigang karapatan at pamantayan sa pamamagitan ng lokal na pagkilala ayon sa batas.

Sa pamamagitan ng pakikipagsosyo at gawain hinggil sa pagtataguyod ng kapasidad at adbokasiya, gayundin ang taunang dokumentasyon at pag-aaral para sa pagtipon ng publikasyong The Indigenous World, mulat ang IWGIA sa pag-angkat ng mga konstitusyon upang maproteksyonan ang karapatan ng mga katutubo. Bilang tagapanguna sa pagtukoy sa saklaw ng mga karapatan ng mga katutubo, itinatala ng IWGIA ang kahalagahan ng mga pinangangalagaang pandaigdigang karapatan at pamantayan upang maisakatuparan ang pagkamit ng tunay na kapangyarihan, pagkakapantay-pantay at akses sa lupain at ibang likas-yaman para sa mga katutubo, sapagkat kritikal na usapin ang pangangalaga ng kanilang lokal na karapatan, sa bansa kung saan sila naninirahan. Bago pa man itong Kasangkapan sa Pagtatasa, walang kolektibo o holistikong imbentaryo ng konstitusyunal na praktis sa pangangalaga ng karapatan ng mga katutubo.

Para ganap na matamasa ang kanilang mga karapatan, kasama na ang kanilang paglahok at konsultasyon tungkol sa mga desisyon na makaaapekto sa kanilang mga buhay, pinaniniwalaan ng IWGIA na kailangan ng mga katutubo ng isang plataporma na makabuluhang maipatutupad ang mga prinsipyo at karapatan nila gaya ng sariling pagkilala at awtonomiya o pagsasarili. Ang mga ito, gayundin ang iba pang isyu tungkol sa karapatan ng mga katutubo, ay komplikado at madalas na mahirap idisenyo at itaguyod. Kaya, ang Kasangkapan sa Pagtatasa na ito ay makatutulong sa mga katutubo at iba pang gagamit nito hindi lang para maisadokumento ang katayuan ng kanilang karapatan sa bansa, kundi upang magkaroon ng mga adbokasiyang may pinanghahawakang mga ebidensya upang mas mapahusay pa ang mga pamamaraan at pagsasanay sa kanilang karapatan.

Sa pamamagitan ng pagdodokumento sa hindi pangkaraniwang saklaw at dibersidad nito sa global na komparatibong praktis-pagsaklaw ng mga konstitusyon pati ng mga batas, kasunduang pangkapayapaan at inobatibong mga institusyon —ang Kasangkapan sa Pagtatasa sa Karapatan ng mga Katutubo sa Konstitusyon ay sumusuporta sa pandaigdigan at panlokal na mga adbokasiya na tumutulong sa mga gobyerno at mga tao na maunawaan ang mabuting praktika at karanasan sa pangangalaga ng karapatan ng mga katutubo. Ibinibigay ng Kasangkapan sa Pagtatasa ang isang payak at malinaw na metodolohiya sa paglapit sa mga isyung komplikado na madalas ay masyadong napopolitika, na nagbibigay-pahintulot sa isang sistematiko at batay-sa-ebidensyang talakayan hinggil sa mga kritikal at sensitibong isyung ito. Dagdag pa, ang pormat ng Kasangkapan sa Pagtatasa na ito ay nagbibigay-daan din upang magamit ng iba't ibang tao na may magkakaibang kapasidad at kaisipan. Nakabubuo rin ito ng malinaw na ugnayan sa pagitan ng pandaigdigang mga karapatan at pamantayan at mga pagkakataon na maisama ang mga ito sa mga ligal na balangkas panlokal at pampamahalaang mga istruktura. Sa ganitong paraan, ang Kasangkapan sa Pagtatasa ay makatutulong sa mga gobyerno at internasyunal na mga eksperto at organisasyon na maunawaan at magbigay payo tungkol sa mga pagkakataong ito.

Ang pagkilala sa karapatan ng mga katutubo ay lalong naging kailangan habang ang mga krisis gaya ng pagbabago ng klima at mga pandemya ay patuloy na nagbibigay-diin sa kahinaan ng mga katutubo maging ang tama ng sistematikong pagsasantabi at patuloy na pang-aagaw ng mga karapatan sa kanilang buhay at mga komunidad. Sa panahong ito na mas mahalaga kailanman ang pagbibigay kakayahan sa inobatibo, sustenable at epektibongproteksiyon at promosyon ng karapatan ng mga katutubo, ang Kasangkapan sa Pagtatasa ng International IDEA ay nagbibigay sa ating lahat na dedikado sa isyung ito ng metodolohiyang magbibigay aksyon upang maisakatuparan ang gawain. Ang Kasangkapan sa Pagtatasa ay tiyak na makatutulong sa IWGIA at sa mga komunidad na kasama nito sa pagtataguyod ng gawain upang tiyakin ang isang mundo kung saan ang mga katutubo ay naipananatili at napauunlad ang kanilang lipunan batay sa kanilang sariling kaugalian, mga prayoridad at mga bisyon sa hinaharap. 


\section{Paunang salita}

Ang Kasangkapan sa Pagtatasa sa Karapatan ng mga Katutubo sa Konstitusyon ay isang susing publikasyon kung saan ipinagpatuloy nito ang gawain ng International IDEA hinggil sa marhinalisadong mga tao at ingklusibong pagtatag ng konstitusyon. Ang publikasyon nito sa taon ng pandemya na dulot ng COVID-19 ay napapanahon. Ang coronavirus (COVID-19) pandemic ay nagsasalang ng malagim na banta sa mga katutubo sa buong mundo. Gaya ng sinabi sa pahayag ng UN, ang mga tradisyunal na pamumuhay ng mga katutubo ang pinagmulan ng kanilang kakayahang bumangon at maaari ring umanyo bilang banta na mapigilan ang pagkalat ng virus (United Nations, 2020). Marami sa mga katutubong komunidad ang palaging nag-oorganisa ng malalaking tradisyunal na pagtitipon upang bigyang tanda ang mga espesyal na pangyayari, halimbawa ay anihan at mga seremonya sa pagtanda, gayundin ang manirahan sa iisang tirahan ang magkakapamilya kung saan malapit sa mga matatanda. Sa pagtaas ng bilang ng mga may impeksiyon ng COVID-19 sa buong mundo, ang datos sa pagtaas ng bilang ng mga katutubo na naimpeksiyon ay hindi pa maipakita batay sa etnisidad dahil na rin sa kakulangan ng pormal na pagkilala sa kanila ng pamahalaan. Gayundin ang mga kaugnay na impormasyon hinggil sa nakakahawang sakit at paano ito maiiwasan ay hindi pa naisasalin sa mga katutubong lengguwahe.

Bagaman ang mga isyung ito ay umusbong sa konteksto ng pandemya, sinalamin nito ang isang sistematikong disenyo ng diskriminasyon at ang mga paraan kung saan ang proteksyon sa karapatan ng mga katutubo sa legal na balangkas panlokal ay makatutulong upang mabigyang direksyon at mabago ang mga disenyong ito. Sa ganitong paraan, nabibigyang-tuon ng pandemya ang interseksyon sa pagitan ng mga karapatang konstitusyonal at mga buhay na katotohanan ng mga katutubo; binibigyang-diin, gayundin, ang pangangailangan para sa ganitong Kasangkapan sa Pagtatasa.

Ang mga konstitusyon ay nagbubukas ng mga plataporma o simulain upang maisakatuparan ang internasyunal na karapatan na ipinangako sa mga katutubo batay sa nakasaad sa United Nations Declaration on the Rights of Indigenous Peoples, Kumbensyon ng ILO 169 at iba pang instrumento. Ang Kasangkapan sa Pagtatasa sa Karapatan ng mga Katutubo sa Konstitusyon ay naghahain ng magkakaibang kaugalian ng mundo sa pangangalaga at pagtataguyod sa karapatan ng mga katutubo at magpakita ng isang payak at malinaw na mga plano na makatutulong upang maunawaan nang husto ang konstitusyonal na praktika, gayundin ang pagsusuri sa tiyak na balangkas para sa karapatan ng mga katutubo sa isang partikular na bansa. Ang metodolohiya ay nakabase sa Pagtatasa sa Konstitusyon hinggil sa Pagkakapantay-pantay ng Kababaihan ng IDEA.

Mula sa inilahad nitong internasyonal na pamantayan at naaangkop na mga halimbawang inihambing mula sa konstitusyon at mga batas ng mga bansang Afrika, Amerika, Asya at Pasipiko, pati na Europa, ang Kasangkapan sa Pagtatasa ay gumagabay sa mga gagamit nito sa pamamagitan ng pagsusuri sa wika ng konstitusyon, at pati na ang pagpapahintulot upang malinaw na maunawaan ang mga potensyal nito kung paano mapangalagaan at maitaguyod ng konstitusyon ang karapatan ng mga katutubo, pinakauna na rito ang pagtingin kung paano maipararating ng bawat bansa ang mga isyung ito sa kanilang konstitusyon. Ang Kasangkapan sa Pagtatasa ay maaaring magamit ng mga katutubong organisasyon at mga tagasuporta para sa nakabatay-sa-ebidensyang adbokasiya, gayundin ng mga pamahalaang estado at iba pang kumikilos na sangkot sa pagdidisenyo at pagpapatupad ng konstitusyon.

Ang mga sangkot sa pagtatag ng konstitusyon ay kinakailangang abot ang praktikal na mga metodolohiya at angkop na mapananaligang kaalaman upang tiyakin na maani ang potensyal ng nasasakupan sa pagprotekta sakarapatang pantao. Ang pag-unlad at pakikibahagi ng mapananaligang kaalaman hinggil sa pagtatag ng konstitusyon ay isa sa mga susing paraan ng International IDEA sa pagtatrabaho, at ang Kasangkapan sa Pagtatasa na ito ay kapwa pinagsama ang mapananaligang kaalaman at kasanayan, na kung saan ay gagamitin ito sa unang pagkakataon batay sa dulog-pangkarapatan para sa karapatan ng mga katutubo.

Ang Institusyon ay may mahabang rekord ng pagsuporta sa pinatibay na ingklusibong partisipasyon at representasyon sa politika, ito man ay sa gawain ng mga miyembro ng parliyamento o kayày ng mga nahirang na opisyales, o kaya naman kasama ang lipunang sibil at inisyatibong paglahok ng mga mamamayan sa lokal at nasyunal na antas. Ang Kasangkapan sa Pagtatasa na ito ay makasusuporta sa International IDEA sa pagpapalawak at pagpapatibay ng rekord na ito.

Ang Kasangkapan sa Pagtatasa sa Karapatan ng mga Katutubo sa Konstitusyonay isang mahalagang karagdagan sa mga kasangkapan at mapagkukunan ng impormasyon na inihahain ng International IDEA upang ang pagtatag ng konstitusyon ay mas aksesible, mas madaling maunawaan at higit na mas makatutugon sa lahat ng tao. 


\section{Pagkilala}

Nais naming pasalamatan ang lahat ng naging kabahagi sa pagbuo ng Kasangkapan sa Pagtatasa sa Karapatan ng mga Katutubo sa Konstitusyon; nakakuha ito ng malaking benepisyo mula sa magkakaibang perspektiba at mga ambag.

Espesyal na pasasalamat ang ipinaaabot sa mga dalubhasang tagasuri: kina Jeremie Gilbert, Sakuntala Kadirgamar at Shireen Morris; at sa mga katutubong organisasyon na tumulong upang subukan at linangin ang Kasangkapan sa Pagtatasa, ito ang sumusunod: ang Lawyers Association for the Human Rights of Nepalese Indigenous Peoples (LAHURNIP) at ang Indigenous Peoples Partnership (IPP) sa Myanmar, gayundin sa mga kinatawan ng mga katutubong komunidad sa Mindanao, sa Pilipinas, na siyang lumahok sa kauna-unang palihan ng Kasangkapan sa Pagtatasa, kasama sa naghanda nito ang Institute of Autonomy and Governance noong Hulyo 2019. Kritikal ang mga rebyu at pangungunang ito upang masigurado na hindi isinagawa hiwalay sa realidad itong Kasangkapan sa Pagtatasa sa Karapatan ng mga Katutubo sa Konstitusyon at talagang mapapakinabangan ito ng mga kasapiang pinagdisenyuhan nito.

Sa International IDEA, kay Leena Rikkila Tamang, ang Direktor ng programang Asya at Pasipiko ng International IDEA, na naglaan ng tuloy-tuloy na suporta para sa proyektong ito sa mga nakalipas na taon, na naniwala sa halaga nito sa simula pa lang; kay Erin Houlihan sa Constitution-Building Programme na naglaan ng walang kasinghalagang pananaliksik at mga ambag; at kay Lisa Hagman sa pangkat ng publikasyon na nakaranas ng maraming pagsubok upang matanaw ang kasalukuyang anyo ng Kasangkapan sa Pagtatasa.

Sa aming taga-disenyo, Richard van Rooijen, at patnugot sa kopya, Sarah Chatwin ng Accuracy Matters, na inilagay ang kanilang tungkulinsa panibagong antas at nagbigay rin ng makabuluhang paghubog sa Kasangkapan sa Pagtatasa sa Karapatan ng mga Katutubo sa Konstitusyon mula sa kanilang ambag na kadalubhasaan.

Ang International IDEA ay lubos na nagpapasalamat sa bawat isa at sa lahat ng inyong mga kontribusyon. 


\section{Introduksyon}

Ang Kasangkapan sa Patatasa sa Karapatan ng mga Katutubo sa Konstitusyon ay makatutulong sa mga gagamit nito upang suriin ang konstitusyon, burador na konstitusyon o amyenda ng konstitusyon mula sa perspektiba ng karapatan ng mga katutubo. Gamit ang isang serye ng mga tanong, maiksing mga paliwanag at mga halimbawang probisyon mula sa mga konstitusyon mula sa iba't ibang panig ng mundo, ang Kasangkapan sa Pagtatasa ay gagabay sa gagamit nito sa mga nakasulat sa konstitusyon at bukas para sa sistematikong pagsusuri ng wika at mga probisyon ng isang tekstong konstitusyunal upang tasahin kung gaano kalakas masasalamin ang karapatan ng mga katutubo dito. Maaari rin silang gumawa ng paghahambing sa ibang bansa, upang makita kung paano nila tinugunan ang mga isyu mula sa kanilang konstitusyon at nasyonal na batas. Ang Kasangkapan sa Pagtatasa ay binalangkas upang praktikal na magamit; sa pagbibigay ng halimbawang wika at komparatibong mga kaugalian, hindi lang para kilalanin at unahin ng mga gumagamit ang mga isyu para sa adbokasiya o wika para sa amyenda ng konstitusyon kundi sinisigurado rin na ang kanilang mga pagsisikap ay may mga pinagbatayang ebidensiya, at nagbibigay sa kanila ng kayamanan ng halimbawa na mapagkukunan ng inspirasyon.

Dinesenyo ang Kasangkapan sa Pagtatasa na ito para para sa mga tagapagsulong ng karapatan ng mga katutubo, gayundin sa mga lubog sa paksa ng pangangalaga at pagtataguyod ng konstitusyunal na mga karapatan ng mga katutubo sa unang pagkakataon, na maaaring miyembro ng isang konstitusyonal na kapulungan, tagapagbalangkas ng konstitusyon, miyembro ng lipunang sibil, mga mambabatas, hurado o kayày mga kinauukulang indibidwal. Sapagkat ang karapatan ng mga katutubo ay nakaaapekto sa kalidad ng demokrasya at ng lipunan, ang Kasangkapan sa Pagtatasa na ito ay balong mapagkukunan ng kaalaman para sa lahat ng interesado at gusto pang maunawaan nang mabuti at/o maisulong ang karapatan ng mga katutubo, at karapatang pantao sa mas malawak na saklaw, sa pamamagitan ng pagtatag ng konstitusyon.

Mula sa paghahambing sa mga konstitusyon ng Africa, Asia, Europa, Hilaga at Latin Amerika, at Oceania hinugot ang mga probisyon ng Kasangkapan sa Pagtatasa. Naglaan ito ng mga halimbawa mula sa mga rehiyong nabanggit upang maglatag ng praktika mula sa isang malawak na pagpipiliang mga bansa at mula sa mga bansang ang konstitusyon ay hindi pa gaanong napag-aaralan o kaya naman hindi madaling hagilapin di tulad ng nasa Europa at North America. Ngayong ang pagkilala sa mga katutubo sa mga konstitusyon ay isang makabagong kalakaran sa pagtatag ng konstitusyon, kalakip din sa Kasangkapan sa Pagtatasa ang mga halimbawa mula sa batas upang magbigay ng marami pang wika para sa komparatibong pagsusuri.

Ang mga katanungan sa Kasangkapan sa Pagtatasa ay kalakip ang pamantayang pang-internasyonal at rehiyonal na mga instrumento, gaya ng United Nations Declaration on tha Rights of Indigenous Peoples (UNDRIP), ang International Labour Organization's Indigenous and Tribal Peoples Convention (ILO Convention 169), ang International Convention on the Elimination of All Forms of Racial Discrimination (ICERD), ang International Covenant on Civil and Political Rights (ICCPR), at ang International Covenant on Economic, Social and Cultural Rights (ICESCR).

Ibinalangkas ng Tsapter 1 ang mga dahilan kung bakit kailangang konstitusyunal na pangalagaan ang karapatan ng mga katutubo, at bakit at kailan makatutulong ang isang kasangkapan sa pagtatasang konstitusyunal. Ipinaliwanag naman ng Tsapter 2 ang porma at estruktura ng Kasangkapan sa Pagtatasa, at kung paano ito gagamitin. Ipinaliwanag ng Tsapter 3 ang mga susing konsepto na kinakailangan sa Kasangkapan sa Pagtatasa at para sa mga katutubo at ang kanilang kaugnayan sa pamahalaan. Sa Tsapter 4 makikita ang mismong talatanungan ng Kasangkapan ng Pagtatasa, ito ay binubuo ng 34 na mga tanong na hinati sa 8 seksyon:

I. Pagkilala at pagkamamamayan

II. Karapatan sa pagkapantay-pantay at kontra-diskriminasyon

III. Mga pundasyon ng mga karapatan ng mga katutubo

IV. Awtonomiya: Paggawa ng kasunduan at sariling pamahalaan

V. Konsultasyon, pakikilahok sa politika at representasyon

VI. Karapatan sa lupa, teritoryo at likas na yaman

VII. Karapatan sa kultura, at panlipunan at pang-ekonomikong pag-unlad

VIII. Pagprotekta at pagsusulong ng mga karapatan ng mga katutubo

Ang Kasangkapan sa Pagtatasa sa Karapatan ng mga Katutubo sa Konstitusyon ay nagwawakas sa isang listahan ng mga sanggunian at karagdagang mga babasahin kaugnay sa karapatan ng mga katutubo, at ito'y sinundan ng mga bahagi na naglalaman ng teksto ng Kumbensyon ng ILO 169 at UNDRIP. 


\section{Pagtatasa sa karapatan ng mga katutubo sa mga konstitusyon}




\subsection{Bakit isasama sa konstitusyon ang karapatan ng mga katutubo?}

Ang isang konstitusyon ay nagpapahayag ng isang bisyon na sumasalamin sa mga pagpapahalaga at kasaysayan ng isang bansa, gayundin ang kanilang mga nilalayong aspirasyon para sa kinabukasan. Bilang pinakamataas na batas ng estado, inilalarawan ng konstitusyon ang estruktura nito at mga institusyon, namamahagi ng mga kapangyarihang politikal, at kumikilala at nangangalaga sa pundamental na mga karapatan, na kritikal na tinutukoy ang kaugnayan sa pagitan ng mamamayan at ng gobyerno. ${ }^{1}$ Ang pagpapaloob sa konstitusyon ng pagkilala at pangangalagang nakabatay sa karapatan para sa espesipikong mga grupo, tulad ng mga katutubo, ay maaaring magbigay sa mga grupong ito at sa kanilang karapatan ng pinahusay na pangangalaga. Ito ay maaari pang mapaunlad sa pamamagitan ng pagbibigay sa mga espesyalisadong institusyon at proseso upang mas mapalalim ang pagsasabuhay ng kanilang mga karapatan. Gaya ng binigyang-diin ni Eva Josefsen, isang Associate Professor sa Unibersidad ng Tromsø: 'Kung mayroon mang isang bagay na mahalaga, ito ay yaong may ligal na pundasyon', na sinasabi niyang 'nagsisilbing mas konkretong pundasyon kaysa anumang mga pagpapasya ng pamahalaan.' (Watson at Quince 2018). Sa katunayan, ang isang konstitusyon ay maaaring makapagbigay ng pinakamatibay na pundasyon sa lahat upang masiguro na ang mga katutubong karapatan ay mapangangalagaan at maitataguyod.

Ang isang konstitusyon ay makasusuporta upang tahakin ng mga katutubo ang buhay polika gayundin ang ekonomiko at panlipunang buhay, dahil ito ay nagkokontrol hindi lang sa relasyon sa pagitan ng estado at ng mga mamamayan, kundi sa bawat mga indibidwal, organisasyon at negosyo. Maaaringmakapag-ambag ang konstitusyon sa paggalang sa karapatan ng mga katutubo sa maraming paraan, gaya ng ipinapakita ng Kasangkapan sa Pagtatasa na ito, ngunit marami pang mga paraan ang nararapat na matukoy bilang pundamental:

- Maaaring kalakip ng mga konstitusyon ang mga probisyon na naglalaman ng malinaw at kayang ipatupad na proteksyon sa pundamental na mga karapatang pantao, na hinihimok ang pampublikong opisyal na protektahan at tuparin ang mga karapatang ito, at gumaganap bilang makapangyarihang indikasyon ng pangako ng estado sa karapatan ng mga katutubo. Maging ang mga ito man ay panlahat na karapatang pantao-gaya ng kawalan ng diskriminasyon at pagkakapantay-pantay—o ang mga espesipikong karapatan ng mga katutubo gaya ng karapatan sa edukasyon sa sariling wika, ang pagkilala sa mga tradisyunal na institusyon, at espesyalisadong iskema ng pagmamay-ari ng lupa at karapatang intelektwal.

- Ang mga katutubo ay may natatanging ligal na katayuan sa ilalim ng internasyunal na batas, na may katapat na pangkat ng espesyalisadong karapatan. Ang mga konstitusyon din ay makagagarantiya, sa lokal na batas, ng mga pangakong ginawa ng pamahalaan sa mga tratado at iba pang mga kasunduan. Ang mga konstitusyon, sa kalikasan nitong sumasaklaw sa lahat ng mamamayan kabilang na ang mga tagakilos ng pamahalaan, ay partikular na mahalaga para masigurado ang mga ligal na pangako sa mga karapatan at probisyon sa isang hindi sumasaklaw na pang-internasyonal na instrumento gaya ng UNDRIP. Habang ang mga deklarasyon at ratipikasyon ng tratado ay nagpapakita ng pangako sa mga prinsipyo at pamantayan, nagpapakita ang mga konstitusyon ng ligal at naipatutupad na pangako sa mga tiyak na mga karapatan at proteksyon sa antas ng estado. Samakatwid, ang pagkilala sa katutubo bilang may hinahawakang karapatan sa konstitusyon ng estado ay nagpapalakas sa kanila upang singilin ang pamahalaan sapangangalaga at pagtataguyod ng kanilang mga karapatan.

- Ang mga konstitusyon ay maaaring magbigay ng pagkilala sa karapatan at pagkakapantay-pantay ng mga katutubo upang maghatid ng isang malakas na senyas hinggil sa mga kahalagahan ng estado sa kanyang nasasakupan, kasama ang mga grupo na maaaring bumalikwas sa mga polisiya na nagtataguyod ng karapatan ng mga katutubo. Ang pagkilala sa maraming pambansang wika at kultura sa konstitusyon ay nagbibigay rin ng mga senyas sa isang partikular na pag-unawa kung sino ang pinapatungkulan nitong'sambayanan' sa isang nasyon-estado.

- Ang katotohanang ang mga konstitusyon ay mas mahirap na baguhin kumpara sa regular na batas, at hindi nasasalang sa pagbabago ng polisiyang preperensiya ng mga politiko at politikal na partido, ay nangangahulugan na ang mga espesipikong probisyon upang pangalagaan at itaguyod ang karapatan ng mga katutubo ay mas epektibo pa kaysa sa itinakda lang mismo ng batas.

- Ang mga probisyon ng konstitusyon na nangangalaga at nagtataguyod ng karapatan ng mga katutubo ay may potensyal na hubugin ang nilalaman ng lehislatura at mga ehekutibong polisiya, at mapataas ang pagkakataon sa desisyon ng korte na pupabor sa karapatan ng mga katutubo. Idinideklara ng 
mga konstitusyon ang mahahalagang ligal na mga prinsipyo na maaring maisagawa at positibong nabibigyang kahulugan ng korte at ng hudikatura, gayundin ng mga mambabatas.

- Ang mga konstitusyon din ay kumikilala ng higit pa sa isang pinagmumulan ng batas at maaaring palakasin ang iba’t ibang mambabatas_halimbawa, sa pamamagitan ng pagkilala sa paggamit ng nakaugaliang batas o kaya sa pagpapatupad at kawastuhan ng mga tratado at kasunduan sa kasaysayan, at karapatan ng mga katutubo upang gumawa ng panibagong mga kasunduan.

- Ang mga konstitusyon ay maaaring magtatag ng mga institusyon at magtalaga ng kanilang partikular na kapangyarihan—halimbawa, isang komisyon ng mga katutubo o isang espesyalisadong kinatawan o konsultatibong samahan upang magsulong ng perspektiba ng mga katutubo at karapatan sa pamamahala. Ang disenyo ng mga institusyong polikal at administratibong proseso ay esensyal upang makamit ang substantibong pagkakapantay at pagbibigay-suporta sa karapatan ng mga katutubo. Ang pagdidisenyo ng institusyon at mga proseso na aksesible, kumakatawan at tumutugon sa buhay na realidad ng mga katutubo ay nangangahulugan ng pagsasaalang-alang kung paanong ang mga proseso at institusyong ito ay magkaibang makaaapekto at makaiimpluwensya sa katutubo at hindi katutubong populasyon. Mga halimbawa ng ganitong disenyong tumutugon ay ang sistemang elektoral na nangangasiwa sa eleksiyon ng mga katutubo sa pamamagitan ng kanilang nakagawiang kaugalian, ang pagtatag ng mekanismong batas na mangangasiwa sang pagtatalaga ng mga katutubong hukom, ang pagtatag ng independiyenteng kinatawan sa pagmomonitor tulad ng isang komisyon para sa karapatan ng mga katutubo, at malawak na tuntunin sa paninindigan na itataguyod ang daan para sa hustisya ng mga katutubo at iba pang marhinalisadong mga komunidad.

- Ang mga konstitusyon ay maaaring magtatag ng bagong antas ng pamahalaan, pagmumulan ng awtonomiya at teritoryal na dibisyon sa isang bansa, na pinapahintulutan ang realisasyon ng karapatan ng mga katutubo sa pansariling pagpapasya, awtonomiya at sariling pamahalaan—halimbawa, sa pamamagitan ng pagkilala sa pagsasarili ng isang lugar na sakop ng nasyonal na teritoryo.

- Ang pagkilala ng konstitusyon sa identidad ng mga katutubo, sa kanilang espesyal na karapatan at mga pamamaraan, at sa mga pangako ng konstitusyon hinggil sa pagkakapantay-pantay at kawalang diskriminasyon, ay maaaring maging transpormatibo. Ang mga estadong binuo sa kolonisasyon o tunggalian ay madalas may kasaysayan ng diskriminasyon, pang-aagaw ng lupa at pagsasantabi sa mga katutubo. Sa pag-iral ng ganitong mga kasaysayan, ang mga konstitusyon ay maaaring maglaman ng mga probisyon na naglalayong ayusin ang mga ito sa pamamagitan ng positibong pagkilala sa mga katutubo at pagprotekta ng kanilang mga karapatan, ito'y upang iwasan na maulit muli ang kawalang hustisya, diskriminasyon at pagsasantabi. Kapag ang mga nabanggit na probisyon, mga karapatan at hakbangin ay isinali sa isang konstitusyon, ang mga ito ay magiging daan sa pagtatamo ng mga prinsipyo ng pagakakapantay-pantay at ingklusyon. Sa mga estado kung saan ang mga katutubo ay minorya, napakahalaga na magkaroon ng hakbangin para sa konstitusyonal na pagkilala at proteksiyon sa karapatan ng mga katutubo. Mga paraan ito upang matiyak na ang mga katutubo ay maaaring umunlad bilang natatanging mga tao sa loob ng estado, habang sila ay patuloy at pantay na nakikilahok sa mga demokratikong proseso ng estado at ng mga institusyon bilang kapantay na mga mamamayan.

\subsection{Bakit at kailan nakatutulong ang isang kasangkapan sa pagtatasa sa karapatan ng mga katutubo?}

Ang karapatan ng mga katutubo ay kumplikado at maraming panig, na sumasakop sa maraming magkakaibang paksa na maaaring masagot ng konstitusyon-halimbawa, representasyon sa institusyon, karapatan sa lupa at likas na yaman, at karapatan sa mga tradisyunal na institusyong panghustisya at kaugalian. Sa gayon, hindi lang ito simplemg pagtatanong kung ang isang konstitusyon ba ay nangangalaga sa karapatan ng mga katutubo o hindi. Bagkus, isang sistematikong pagsusuri ang kinakailangan, upang maisagawa ang pagtatasa ng konstitusyon kapwa sa kabuuan nito at sa ibang panig na may kabuluhan sa karapatan at interes ng karapatan ng mga katutubo. Ang Kasangkapan sa Pagtatasa na ito ay pangunahing idinesenyo upang magbigay ng balangkas at metodolohiya para sa ganitong pagsusuri. Ang pagtatasa sa isang konstitusyon ay maaaring makabuluhan sa anumang panahon ng pag-iral nito, bilang ang pagtatag ng konstitusyon sa ngayon ay 'binigyan ng malawak na kahulugan bilang pangmatagalang termino at prosesong historikal. Hindi ito isang pangyayari at hindi rin ito kahalintulad ng paggawa ng konstitusyon—sa panahon kung kailan ibinabalangkas ang konstituyon .... kabilang dito ang 
pagtatatag ng institusyon, mga pamamaraan at patakaran para sa pagbuo at pagbalangkas ng konstitusyon, pagbibigay ng epektong ligal para sa konstitusyon, at implementasyon' (Böckenförde, Hedling and Wahiu 2011: 2). Sa gayon, laging kritikal na ang mga mamamayan ay nauunawaan ang kanilang sariling konstitusyon at paano nila napapangalagaan nang mabuti ang kanilang mga karapatan at interes; ang ganitong pang-unawa ay nagbibigay ng mahahalagang basehan para sa pakikibahagi ng mga mamamayan sa prosesong pampamahalaan, pati na rin ang pagpapahintulot nito para magtaguyod ng mas mabuting implementasyon ng konstitusyon at, sa iba pang mga kalagayan, para sa konstitusyunal na reporma.

Nagiging makatotohanan lamang ang isang konstitusyon sa mga tao kung ang mga ito ay epektibong naipapatupad, kaya ang trabaho ng pagtatasa sa isang konstitusyon ay nangangailangang ng pagtingin nang lampas pa sa teksto lamang. Nangangailangan din ito ng pagsusuri ng mga institusyon at mga batas at mga desisyon sa korte na nagtagumpay o nabigo sa pagtransporma sa konstitusyonal na pangako tungo sa realidad. Habang ang Kasangkapan sa Pagtatasa ay hindi tumutugon sa kabuuang proseso ng pagtatag ng konstitusyon, inihahanda naman nito ang mga tagapagsulong ng karapatan ng mga katutubo na mas epektibong makilahok sa proseso. Nagagawa ng Kasangkapan sa Pagtatasa ito sa pamamagitan ng pagpapahintulot sa mga gumagamit na malalimang nilang pag-aralan ang konstitusyon o burador, hinuhudyatan sila sa sakop at mga isyu na maaaring tugunan ng konstitusyon, ipinapaalam sa kanila ang hinggil sa mabuting praktika sa buong mundo at tinutulungan sila na kilalanin ang mga prayoridad para sa pagbabago. Sa pamamagitan ng pag-alam kung ano ang mga mandato ng konstitusyon batay sa karapatan ng mga katutubo, ang mga tagapagtaguyod nito ay maaaring masundan nang mabuti ang ugali at pagganap ng mga institusyon at mga aktor sa pulitika upang makasiguro na iginagalang nila ang konstitusyon. Ang Kasangkapan sa Pagtatasa ay maaring gamitin upang makilala hindi lamang ang mga larang kung saan angkop ang pagbabago ng konstitusyon, kundi pati na rin sa mga larang ng sub-konstitusyonal na pagbabago sa panahon ng pangmatagalang pagtatag ng konstitusyon. Nangangahulugan ito na isa sa mga itinala sa seksyon ng Mga Napag-alaman sa paggamit ng Kasangkapan sa Pagtatasa na ito ay ang pagsusulong ng isang bagong batas o polisiya kaysa magtaguyod ng konstitusyunal na reporma.

\section{Paggamitng Kasangkapan sa Pagtatasa sa konteksto ng konstitusyonal na reporma}

Dahil lumawak ang internasyunal na pagkilala sa karapatan sa pakikilahok upang saklawin ang konstitusyonal na reporma, naging pamantayan ang pagkakaroon ng mas bukas at mapanghikayat na proseso ng pagpapatatag ng konstitusyon, at ang mga ito ay kritikal na isinaalang-alang para sa pagkalehitimo ng isang bagong konstitusyon. Ang konstitusyonal na reporma, na dati ay prosesong sarado at patakbo ng ilang pilang tao, ay ngayon kadalasang nilalahukan sa mga magkakaibang antas.

Sa ganitong uri ng paglahok sa mga proseso ng konstitusyonal na reporma, may kritikal na gampanin ang mamamayan, na nangangailangan ng mga mekanismo para sa pakikibahagi at edukasyon ng mamamayan upang maitaguyod ang pag-unawa sa mga susing isyu at sa mismong proseso, madalas kasama dito ang mekanismo ng pormal na konsultasyon sa publiko upang gumabay sa input ng mga mamamayan hinggil sa nilalaman ng bagong konstitusyon o ng amyenda ng konstitusyon. Ang mga referendum kung saan maaaring bumoto o hindi tanggapin ng publiko ang isinususog na balangkas ng konstitusyon o amyenda ay lalo na ring nagiging karaniwan. Ang mga mekanismong ito, na idinesenyo upang maging mas demokratiko ang pagtatag ng konstitusyon sa pamamagitan ng pagsasangkot sa mga mamamayan at ng mga inihalal na demokratikong lupon, ay nagbukas ng mga espasyo para sa mga mamamayan—kasali na ang mga katutubo-upang lumahok. Ang reporma sa konstitusyon ay hindi lamang para sa mga abogado ng konstitusyon at mga matataas na politiko: lahat ng mga mamamayan ay may karapatan na lumahok sa pamamaraan kung paano binuo ang konstitusyon at may bahagi kung ano ang mga nilalaman ng konstitusyon at kung paano ito ipapatupad. Hindi ito nangangailangan ng partikular na akademikong titulo, karanasan sa politika o panlipunang posisyon.

Ang mga proseso ng paglahok ay nagbukas ng espasyo para sa mga katutubo upang sumali bilang inihalal na mga kinatawan at miyembro ng partido politikal, bilang miyembro ng lipunang sibil at akademya, at bilang mga mamamayan at botante sa mga proseso ng konstitusyonal na reporma. Sa buong mundo, ang konstitusyonal na reporma ay nakapagbigay ng oportunidad upang muling kilalanin ang sakop ng kung sino ang itinuturing na isang 'mamamayan at magtaguyod para sa mas malawak na pagsasama ng pinalawak na pag-unawa hinggil sa karapatang pantao. Ang mga marhinalisadong grupo, gaya ng mga mamamayang lesbian, gay, bisexual, transgender and intersex (LGBTI), relihiyoso at mga minoryang etniko, kababaihan at ang mga maralita, ay lahat nakamit ang oportunidad na binuo ng konstitusyonal na reporma upang magtaguyod ng konstitusyonal na proteksyon sa kanilang mga karapatan. Ang mga katutubo, siyempre, ay bahagi rin ng mga grupong ito, na ang pagkakaroon ng konstitusyon ang siyang mahalagang palatandaan sa pangako ng estado na igalang, pangalagaan at tupdin ang mga karapatan ng mga katutubo, at bilang isang esensyal na mekanismo sa pagsusulong pa ng mas malalim na 
mga pangakong ito sa mga susunod na panahon. Sa kaso ng mga katutubo, ang kapangyarihan ng pagbabago ng konstitusyon, kapag nalikom, ay may positibong epekto sa proseso ng rekonsilyason at transisyunal na hustisya sa pagitan ng mga pamahalaan at ng mga katutubo, sa gayon ay makaaambag ito sa proseso ng pagbuo ng estado at sa pagpapayaman ng ugnayang sosyal.

Kasama sa karapatan ng mga katutubo ay ang karapatan upang makonsulta sa paglinang ng anumang plano, mga batas at desisyon na makaaapekto sa kanila bilang mamamayan, dahilan kung bakit ang pagsigurado sa partisipasyon ng mga katutubo sa pagtatag ng konstitusyon sa kabuuan, at sa espesipikong reporma sa konstitusyon, ay napakahalaga. Lahat ng konstitusyonal at lehislaturang hakbangin para sa pagkilala at pangangalaga sa karapatan ng mga katutubo ay dapat na paunlarin at ipatupad sa pakikipagkasundo sa mga katutubo na may layuning makamit ang kanilang pahintulot nang may magandang loob. Isang lapit na mapanghikayat sa paglahok sa konstitusyunal na reporma, kung saan ang mga katutubo ay maaaring lumahok - at makapag-impluwensiya —sa batas at proseso sa pagbuo ng desisyon ng estado, ay isa ring paraan para sa kanila upang gumanap ng kanilang karapatan para sa sariling pagpapasya (APF at OHCHR 2013: 22). Kinakailangan dito na ibigay sa mga katutubo ang respeto at ahensiya sa pagbuo ng mga desisyon na magtatakda ng kanilang pansariling ekonomiko, sosyal at politikal na katayuan. Ang Special Rapporteur ay nagpahayag na: 'Nagtatagumpay ang mga katutubo sa pagpapabuti ng kanilang pagkamamamayang karapatan katumbas ng kanilang malayang paglahok sa prosesong politikal at mga usapin ng Estado' (United Nations 2006: para. 15).

Sa kabila ng pagkakaroon ng malinaw na karapatan upang lumahok sa konstitusyunal na reporma, ang mga konstitusyon — at kung paano ito nakaaapekto sa buhay ng mga tao — ay nananatili pa ring mahirap unawain para sa maraming tao, lalo na sa mga taong nakaranas ng makasaysayang marhinalisasyon. Ang mga konstitusyon ay maaaring nakakatakot na dokumentong basahin, at ang epekto at kahihinatnan ng mga probisyong konstitusyunal ay mahirap maarok. Kung walang mga kasangkapan na makakatulong sa pagsuri sa kasalukuyang konstitusyon, mungkahing mga burador at ang mga posibilidad sa reporma, hindi madali para sa mga hindi dalubhasa na unawain ang kasalukuyang konstitusyunal at pampamahalaang konteksto o ang maglaan ng mga makabuluhang input para sa iba't ibang proseso ng reporma. Ang Kasangkapan sa Pagtatasa ay pinaunlad upang tumulong sa prosesong ito at upang masigurado na ang mga katutubo ay kayang magtaguyod at lumahok sa konstitusyunal na reporma ayon sa pag-usbong ng mga oportunidad. 


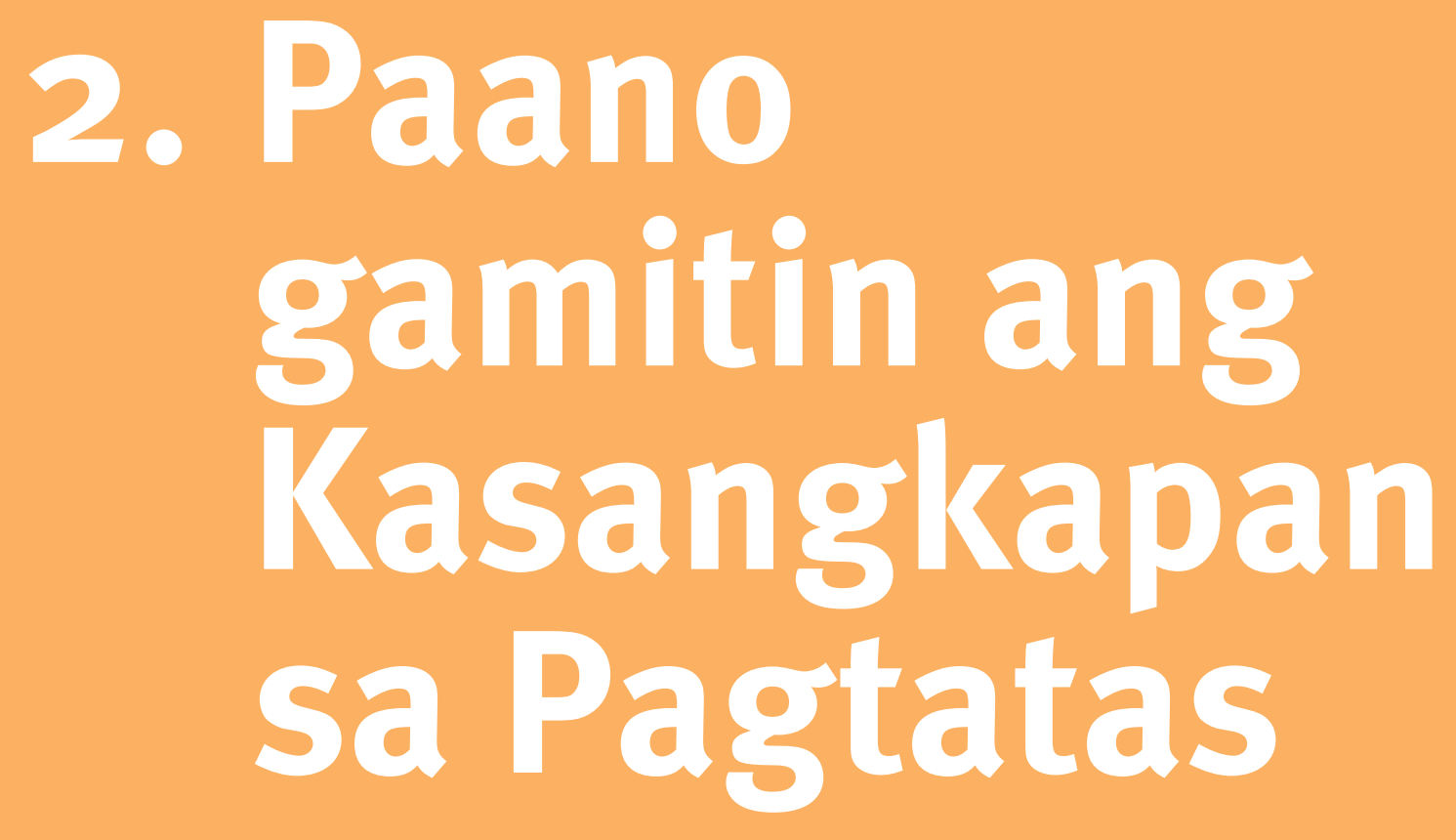




\subsection{Ang pagsisimula}

Ang isang indibidwal o grupo ay maaaring makakumpleto ng pagtatasa sa konstitusyon gamit ang Kasangkapan sa Pagtatasa. Ang pagtatrabaho sa isang grupo upang makumpleto ang pagtatasa ay kapaki-pakinabang upang talakayin ang kumplikado at nakalilitong mga isyu, gaya ng kahulugan ng isang konstitusyunal na probisyon o burador na probisyon, ang sakop ng isang partikular na isyu ng isang bansa, at kung ang partikular na isyu ay tinugunan sa ordinaryong batas.

Upang magamit ang Kasangkapan sa Pagtatasa, ang mga gagamit ay kailangan ng kopya ng konstitusyon o burador ng konstitusyon na tatasahin. Maaaring makatutulong ang pagkuha sa anumang susi, gayundin makabuluhang mga piraso ng batas-kung ang mga batas na ito ay hindi makukuha, ang mga gagamit ay maaaring magtala ng ligal na pananaliksik bilang kasunod na aksyon sa seksyon ng Mga Hakbang sa Kasangkapan sa Pagtatasa. Ang Kasangkapan sa Pagtatasa ay binubuo ng tatlumpu't apat (34) na katanungan, kung saan nahahati ito sa walong (8) seksyon batay sa mga isyu na ipinaparating sa mga pinakakontemporaneong konstitusyon. Ang mga ito ay bumalon sa UNDRIP, Kumbensyon ng ILO 169 at iba pang ubod na tratado ng karapatang pantao. Ang Kasangkapan sa Pagtatasa ay dinesenyo upang maging pleksible: ang mga gagamit ay maaring sagutan ang lahat ng tanong para sa isang komprehensibong pagsusuri ng isang konstitusyon o burador na konstitusyon o kaya ay pagtuunan ang mga espisipikong isyu. Ang walong (8) seksyon ay ang sumusunod:

I. Pagkakilalan at pagkamamamayan

II. Karapatan sa pagkapantay-pantay at kontra-diskriminasyon

III. Mga pundasyon ng mga karapatan ng mga katutubo

IV. Awtonomiya: Paggawa ng kasunduan at sariling pamahalaan

V. Konsultasyon, pakikilahok sa politika at representasyon

VI. Karapatan sa lupa, teritoryo at likas na yaman

VII. Karapatan sa kultura, at panlipunan at pang-ekonomikong pag-unlad

VIII. Pagprotekta at pagsusulong ng mga karapatan ng mga katutubo

Inirerekomenda muna ang pagbabasa sa buong Kasangkapan sa Pagtatasa — o kaya'y sa minimum, ang listahan ng mga tanong - upang maunawaan ang pormat at ang tipo ng mga tanong sa bawat seksyon. Ang mga gagamit ay maaaring magdesisyon kung tatapusin lahat $\mathrm{o}$ ang ilan lamang sa mga tanong.

Gayundin, ipinapayo na tapusing basahin at maging pamilyar sa batayang estruktura ng tekstong konstitusyunal na isasailalim sa pagsusuri. Pansinin ang kabanata at pamagat ng seksyon upang maunawaan kung paano ito inorganisa. Ang mga probisyon makahulugan sa mga karapatan ng mga katutubo ay maaaring ilimita sa isang pangkalahatang seksyon hinggil sa karapatan o sa katutubo o kayày ikalat sa buong konstitusyon.

\subsection{Estruktura ng Kasangkapan sa Pagtatasa}

Mahalaga na mabigyang-pansin ang dalawang kritikal na bagay hinggil sa estruktura ng Kasangkapan sa Pagtatasa:

1. Ang kaayusan ng mga seksyon at tanong ay hindi tumutugma sa importansya o sa halaga ng isyu. Ang Kasangkapan sa Pagtatasa ay idinesenyo nang malawak upang sundin ang daloy ng isang konstitusyon, nang may pagkilala na lahat ng konstitusyon ay may magkakaibang estruktura. Ang ibang naunang mga tanong ay maaaring ikonsiderang 'inisyal na mga tanong' kaugnay sa iba-halimbawa, Tanong 1 , 'Ang konstitusyon ba ay espesipikong tumutukoy, kumikilala o nagbibigay-kahulugan sa mga katutubo, kabilang ang pangangalaga sa karapatan sa sariling pagkakilanlan?' Kung ang sagot sa tanong na ito ay 'Hindi', at ang konstitusyon ay hindi talaga kinikilala ang mga katutubo, nangangahulugan ito na ang sagot sa iba pang tanong sa Kasangkapan sa Pagtataa ay 'Hindi' rin.

2. Marami sa mga tanong at mga isyu ay magkakaugnay. Ang mga paksa ay hinati-hati sa magkakahiwalay na mga seksyon at mga tanong, subalit hindi ito nangangahulugan na binalewala ang kanilang likas na ugnayan, na dapat tandaan ng mga gagamit. Halimbawa, ang Tanong 5 tungkol sa mga espesyal na hakbanginay napakahalaga pagdating sa pagkonsidera sa sagot sa iba pang mga tanong kaugnay ng representasyon sa mga pampamahalaang institusyon kabilang ang lehislatura at hudikatura (hal. 
kung mayroon bang mga quota upang magbigay-garantiya sa representasyon). Ang ibang mga tanong naman, sa espisipiko, ay sumasaklawsa lahat ng iba pa—halimbawa, ang karapatan sa sariling pagpapasya o kultura.

\section{Mga Seksyon, Katanungan at Paliwanag}

Bawat isa sa walong tematikong seksyon ng Kasangkapan sa Pagtatasa ay naglalaman ng mga pangkat ng tanong, at bawat tanong ay tumuturol sa isang isyu o isang aspekto sa tema ng seksyon. Ang kahon sa ilalim ng tanong, na pinamagatang 'Paliwanag', ay dinidetalye ang kabuluhan ng tanong sa mga karapatan ng katutubo, mula sa isang konstitusyunal na pananaw, at nagbibigay gabay para basahin ang kalakip na komparatibong halimbawa (tingnan sa ibaba). Kung ang isang gagamit ay hindi pamilyar sa alinman sa mga termino sa paliwanag, maaari silang kumonsulta sa Tsapter 3 hinggil sa susing mga termino at konsepto. Ang skesyon ng Kasunod pang babasahin sa dulo ng dokumentong ito ay naglalaman ng links para sa makabuluhang sanggunian.

Ang mga tanong ay ibinalangkas sa paghingi ng sagot na Oo o Hindi at dapat sa ganoong paraan ang pagsagot sa unang pagkakataon, ngunit ang pagsusuri ng mga gagamit ay hindi dapat doon lamang nagtatapos. Halimbawa, sa pagsagot sa Tanong 1, 'Ang konstitusyon ba ay espesipikong tumutukoy, kumikilala o nagbibigay kahulugan sa mga katutubo, kabilang ang pangangalaga sa karapatan ng sariling pagkakilanlan?', ang inisyal na sagot ay maaaring 'Hindi' subalit ang isang kumpletong sagot ay maaring "Hindi, ang konstitusyon ay hindi espesipikong kumikilala o nagbibigay kahulugan sa mga katutubo subalit kinikilala nito ang mga etnikong minorya'. Sa ganitong kumpletong sagot, ang gagamit ay napakitid ang isang punto ng makssyunang adbokasiya (samakatwid, ang etnikong minorya bilang daan upang maisulong ang mas espesipikong pagkilala). Ang isa pang sagot ay maaaring 'Oo', ngunit may kumpletong sagot na 'Oo, ang konstitusyon ay kumikilala sa mga katutubo subalit hindi kasali ang karapatan sa sariling pagkakilanlan'. Ang sagot at iba pang detalye ay dapat na nakarekord sa seksyon ng Mga Napag-alaman, na may potensyal na adbokasiyang hakbangin na palalawigin sa seksyon ng Mga Hakbang.

\section{Pamantayang Pang-internasyunal at mga Pambansang Halimbawa}

Sa ilalim ng seksyon na Paliwanag sa bawat tanong, isang talahanayan ang nakatala sa mga kaugnay na probisyon mula sa internasyunal na instrumento at ng mga konstitusyon sa buong mundo na mga halimbawa ng mabubuting praktika sa pagtugon sa mga kinakaharap na isyu. Sa unang kolum nakalista ang pangalan ng dokumento, pinagmulang bansa at ang petsa ng proklamasyon. ${ }^{22}$ Sa pangalawang kolum naman nakatala ang numero ng artikulo (at sa ibang kaso naman ang tsapter, seksyon o sub-artikulo) ng halimbawang probisyon. Sa pangatlong kolum nakatala ang teksto ng mga halimbawang probisyon at sa pang-apat na kolum nakalakip ang paliwanag kung bakit ang partikular na halimbawa ang isinaliat kung ano ang nais nitong patotohanan.

Tandaan na ang mga halimbawang pamantayan at mga probisyon ay naglalayong tulungan ang mga gagamit na maunawaan ang isyung kinakaharap at kung paano ito tinugunan ng mga konstitusyon at batas ng ibang bansa. Ang mga halimbawang ito ay maaaring panggalingan ng inspirasyon para sa adbokasiya ngunit hindi nangangahulugang mga rekomendasyon. May karaniwang lengguwaheng umuusbong sa ilang mga isyu, gaya ng kawalang diskriminasyon, at ang mga halimbawang ibinigay sa ibang kaso ay nagpapakita ng isang matatag o umuusbong na konsensus. Kaya lang, natatangi ang konteksto ng bawat bansa, at ang bawat partikular na ligal na balangkas ng bansa at panlipunang konteksto ay nararapat na isaalang-alang kung kailan (at paano) tutugunan ang partikular na isyu.

\section{Mga Napag-alaman at Mga Hakbang}

May dalawang blangkong kahon sa ibaba, na pinamagatang 'Mga Napag-alaman' at 'Mga Hakbang'. Ang Mga Napag-alaman ay para sa pagtatala ng sagot sa tanong na (O/H at iba pang detalye), at ang Mga Hakbang ay ang lugar upang magpaunlad at magpalawig batay sa potensyal na mga aksyong pang-adbokasiya, kung kinakailangan.

Habang ang kaugnay na (mga) probisyon ng teksto na sumasailalim sa pagtatasa ay natutukoy, gumawa ng tala sa seksyon ng Mga Napag-alaman, kasama ang (mga) numero ng artikulo at ang teksto ng (mga) probisyon. Kung may mga probisyon na hindi konsistent o kasalungat, ang mga ito din ay dapat itala sa seksyon ng Mga Napag-alaman. Ang mga obserbasyon ay dapat lapatan ng pagsusuri sa kung paano naging sapat ang pagtugon ng konstitusyon sa (mga) isyung ipinarating sa bawat tanong, at ang tiyak na mga hamon na kinakaharap ng mga katutubo kaugnay ng isyung ito sa bansang sumailalim sa eksamen. Ang isang kumpletong sagot ay nararapat na simulan sa Oo/Hindi na sagot, at pagkatapos palawigin sa pamamagitan ng pagtutukoy sa: (a) mga kaugnay na probisyon sa konstitusyunal na tekstong tinatasa; (b) anumang impormasyon tungkol sa konteksto ng bansa o ng 
isyung kinakaharap; at (c) mga halimbawang probisyon mula sa ibang bansa o ng internasyunal na pamantayan na may kaugnayan sa pagtatasa ng probisyon ng konstitusyong isinasailalim sa pagtatasa.

Ang pinakakritikal na seksyon ay ang Mga Aksyon. Ito ang lugar upang ibigay ang mga detalye ng nakabatay sa ebidensyang mga mungkahi para sa pagpapabuti ng teksto ng konstitusyon na tinatasa, na maaaring kalakip ang mga espesipikong mungkahi sa wika na sinusuportahan ng internasyunal na mga pamantayan at mga komparatibong mabubuting praktika mula sa ibang bansa. Para sa mga taggagawa ng konstitusyon at iba pang sangkot sa mga proseso ng konstitusyunal na reporma, ang mga panukalang aksyon ay maaaring maglakip ng mga mungkahi ng isang espesipikong probisyong isasama sa konstitusyon. Ito ay makatutulong sa pagsusulong ng pagtalima sa internasyunal na mga tratado at mga kumbensyon kung saan ang indibidwal na mga bansa ay kapartido. Sa pagkukulang na maabot ang konstitusyonal na adbokasiya o reporma, maraming aksiyon na maaring isama sa seksyon ng Mga Aksyon para sa ibang gagamit ng Kasangkapan sa Pagtatasa, gaya ng mga organisasyon ng panlipunang sibil at mga aktor sa midya. Halimbawa, mga kampanya sa radyo, proyektong pananaliksik na magiimbestiga kung paano ang isang partikular na probisyon ay nakapagbigay ng malaking epekto sa mga komunidad, mga naka-target na diyalogo na may sub-nasyonal at nasyonal na mga opisyal na magsusulong sa lehislatibo o mga pagbabago sa polisiya, at maging ang panibagong mga pampublikong pangako sa karapatan ng mga katutubo.

Ang mga gagamit ay nararapat ding bantayan ang anumang probisyon sa konstitusyon o ng burador na konstitusyon na maaaring makasira sa karapatan ng mga katutubo, kahit pa ang mga ito ay walang kaugnayan sa alinman sa mga tanong. Ang mga gagamit ay nararapat na tandaan ang anuman sa mga probisyong ito, at magsama ng mga mungkahi para sa pagpapabuti o pagtatanggal sa mga ito, bilang bahagi sa pagkumpleto sa seksiyon ng Mga Natuklasan at Mga Aksyon.

\subsection{Mga mahahalagang konsiderasyon para sa mga gagamit}

\section{Pagbasang konstitusyon}

Nagkakaiba ang mga konstitusyon ayon sa saklaw, nilalaman at estruktura, at ang inorganisang pamamaraan kung saan magkakaiba ang sistema ng pamahalaan at mga iba pang piniling institusyunal na disenyo. Ang mga pagkakaibang ito ay sumasalamin sa ilang mga isyu, kasama na halimbawa, ang edad ng konstitusyon (hal. ang mas lumang mga konstitusyon ay madalas mas maiksi at kulang sa mga detalye), ang galaw ng kasaysayan ng isang bansa at ang relasyon sa partikular na konstitusyonal na mga tradisyon (hal. ang nagdaang kolonyal na kasaysayan at mga ligal o institusyunal na kumbensyon), at ang mga kinalabasan ng mga kasunduang politikal (hal. kaugnay sa mga proseso ng pagbuo ng kapayapaan o ang mga popular na kilusang reporma). Ilang karaniwang tunguhin ang matutukoy sa mga konstitusyong nilinang sa ibałt ibang panahon, o mga alon, sa pagtatag ng konstitusyon. Mula pa noong panahon matapos ang Ikalawang Digmaang Pandaigdig, halimbawa, maraming bansa ang nagpalawak ng kanilang konstitusyonal na pangangalaga sa karapatang sosyal, ekonomiko at kultural, habang ang lahat ng mga konstitusyon na nalinang mula noong 2000 ay naglalaman ng ilang garantiya sa pagkakapantay-pantay sa sekso o kasarian. Ngunit upang maunawaan kung paanong ang isang konstitusyon ay pinalakad sa nakaraan, o kung paano ang isa ay maaaring gumanap sa kinabukasan, ang dokumento ay dapat na ituring bilang kabuuan, na dapat tandaan ang tungkulin ng hudikatura at mga internasyunal na pananagutang ligal (kabilang ang iba pang mga salik), sa paghikayat ng interpretasyon at implementasyon.

Habang ang indibidwal na mga probisyon ay ang mga tagabuo ng isang konstitusyon, ang mga ito ay dapat na magkakasamang basahin at unawain kaugnay ng relasyon nito sa isa't isa—at kaugnay sa konstitusyon bilang kabuuan. Halimbawa, ang isang konstitusyon ay maaaring maglakip ng isang preambulo o direktibang mga prinsipyo, na nagbabalangkas sa mga kahalagahan at layunin ng estado subalit hindi nangangahulugang nagsusulong sa mga espisipikong karapatan na maipatutupad. Gayunman, ang lahat ng iba pang bahagi ng konstitusyon ay maaaring basahin kasabay ng hindi maaaring ipatupad na seksyon upang maunawaan ang pangunahing mga layunin ng mga probisyon at ituloy ang nilalayong implementasyon at mga epekto. Halimbawa, ang lehislatura ay maaaring sumangguni sa mga kahalagang ito sa pagpapaunlad ng mga batas upang ipatupad at tupdin ang konstitusyon; at ang hudikatura ay maaaring sumangguni dito sa pagbibigay-interpretasyon sa kahulugan ng batas at ng mga probisyong konstitusyunal.Samakatwid, kung ang isa ay nagbabasa ng mga probisyon tungkol sa hudikatura sa konstitusyon, mahalagang huwag basahin ang teksto nang hiwalay. Sa halip, makatutulong ang pag-iisip tungkol sa kung paano, halimbawa, ang kalayaang panghudikatura ay nakaestruktura at protektado, at 
kung sino ang may posisyon upang dalhin ang konstitusyunal na mga hinaing sa korte, at kung paano ang saklaw ng panghudikaturang awtoridad na magpapaliwanag at magtataguyod dito ay makauugnay sa iba pang probisyon ng konstitusyon, katulad ng mga direktibang prinsipyo o karapatang pantao.

Liban sa kabuuang pagbasa sa konstitusyon, mahalagang itala na ang lahat ng konstitusyon ay magkakaiba ang estruktura. Ang ilan, halimbawa, ay naglalaman ng Katipunan ng Mga Karapatan na kung saan ang lahat ng konstitusyonal na karapatang pantao ay nakalista; ang iba ay magbabanggit ng ibang mga karapatan, katulad ng mga may kaugnayan sa lupa o pampulitikang partisipasyon, sa mga mahalagang seksyon ng isang konstitusyon na mas malawak na tumatalakay sa paksang ito. Dagdag pa, minsan ang mga bahaging may kaugnayan sa limitasyon ng karapatan ay parte ng mga probisyon sa indibidwal na karapatan, habang sa ibang mga kaso mayroong 'naroon ang lahat' na limitasyon ng probisyon. Sa ilang mga konstitusyon, ang mga susing karapatan o institusyon ay tahasang nangangailangan ng pag-implementa ng lehislasyon (na minsan ay tinatawag na probisyong 'by law'), na nangangahulugang ang saklaw ng proteksyon at mekanismo sa realisasyon ay hahanapan ng paraan sa proseso ng paggawa ng batas.

Partikular, para sa mga katutubo, mahalaga na isaalang-alang kung ang karapatan ba ng mga katutubo ay nakapaloob sa isang artikulo o sa marami pang iba, at gaano kalawak o kapartikular na binalangkas ang mga karapatan (at kalimitado at/o balanse sa iba pang karapatan). Halimbawa, ang Konstitusyon ng Pilipinas ay mayroon lamang isang tiyak at payak na pagtukoy sa karapatan ng mga katutubo sa Konstitusyon, kung saan mababasa na: 'Ang Estado ay kinikilala at itinataguyod ang karapatan ng mga katutubong kultural na mga komunidad sa loob ng balangkas ng nasyonal na pagkakaisa at pag-unlad' (Tsapter 2, seksyon 22). Ang mga karapatan ay hindi nakatala mismo sa Konstitusyon subalit pinalawig batay sa pambansang lehislasyon. Ang Konstitusyon ng Nicaragua ay katulad nito, kahit na bahagyang mas detalyado sa pagkilala ng mga karapatan (artikulo 5). Ang Mehico (artikulo 2A) at Bolivia (artikulo 30) ay kapwa kinikilala rin ang karapatan ng mga katutubo sa iisang artikulo, subalit ang mga artikulong ito at sinamahan ng isang mahaba at mas espisipikong listahan ng ganoong mga karapatan. Ang mga konstitusyon ng Equador at Colombia, sa paghahambing, ay hinabi ang karapatan ng mga katutubo sa kabuuang konstitusyon sa kaugnay ng mga probisyon (hal. maiparating ang karapatan sa hukumang pangtribu sa seksiyon ng panghudikaturang mga probisyon).

Sa pagbasa ng konstitusyon gamit ang Kasangkapan sa Pagtatasa, magsimula sa pagkuha ng mga susing salita at parirala mula sa tanong, paliwanag at halimbawang mga probisyon upang makahanap ng makabuluhang seksyon sa konstitusyon o burador ng konstitusyon na sumasailalim sa pagtatasa. Halimbawa, sa Tanong 26, 'Ang konstitusyon ba ay kinikilala ang karapatan ng mga katutubong komunidad sa intelektwal na pagmamay-ari kaysa sa kanilang tradisyunal na kaalaman at kultural na mga pagpapahayag?.' Ang mga tanong ay naglalatag ng ilang susing parirala katulad ng 'kultural na pagpapahayag' at 'tradisyunal na kaalaman'; ang paliwanag ay nagbibigay ng ibang potensyal na mga susing terminong maaaring hanapin, kasama na ang mga 'likhang-kamay' at 'hanapbuhay'. Subalit hindi lahat ng konstitusyon ay gumagamit ng parehong terminolohiya, kaya habang ang isang paghanap sa isang susing salita ay makatutulong sa simula, maging malay na maaring gamitin ang iba pang termino. .

Makatutulong ding tandaan na, habang ang nakapaloob na mga tanong sa Kasangkapan sa Pagtatasa ay madalas naiuugnay sa iisang probisyon ng konstitusyon, sa ibang kaso naman ay maaaring maraming makabuluhang mga probisyon. Halimbawa, sa Tanong 8, 'Ang konstitusyon ba ay kumikilala sa kolektibong karapatan? Kung gayon, ito ba ay sa pangkalahatang pagkilala o espisipiko sa mga katutubo?' Posibleng mayroong ilang probisyong kaugnay sa mga kolektibong karapatan sa iba't ibang bahagi ng konstitusyon-halimbawa, sa preambulo, sa probisyon ng kultural na mga karapatan o sa espesipikong seksyon hinggil sa karapatan ng mga katutubo. Lahat ng may makabuluhang probisyon ay dapat na tandaan, kasabay ng anumang institusyunal na estruktura o mga prinsipyo na makabuluhan para sa interpretasyon, implementasyon at pagpapatupad.

\section{Saklawng mga isyu}

Ang Kasangkapan sa Pagtatasa ay idinesenyo upang magtuon ng atensyon sa mga isyu na pundamental na pangangalaga, pagsusulong at pagtatamo ng karapatan ng mga katutubo sa buong mundo. Habang ang ilang mga tanong ay sumasakop sa mga isyu na kasama sa maraming bagong naisulat na konstitusyon, karamihan sa mga konstitusyon ay hindi tinutugunan ang bawat isyu na nakapaloob sa Kasangkapan sa Pagtatasa. Kahalintulad nito, hindi lahat ng isyu sa Kasangkapan sa Pagtatasa ay maaaring makabuluhan sa konteksto ng bawat bansa at maaari ding may mga isyu sa isang bansa na hindi nasasalamin sa Kasangkapan. Ang mga gagamit ay dapat na tingnan ang Kasangkapan sa Pagtatasa bilang paraan upang malikhaing makapag-isip hinggil sa mga konstitusyunal na pagpipilian upang mapabuti ang substantial na pagkakapantay-pantay kaugnay sa mga katutubo at upang masiguro ang paggalang sa kanilang mga karapatan.

Kaya ito ang dahilan kung bakit ang Kasangkapan sa Pagtatasa ay madaling makaangkop- 
ang mga gagamit ay maaring kumuha at pumili ng kung anong mga tanong ang kanilang sasagutin sa paggamit nito sa kanilang ginagawa. Kahit na ang isang isyu ay wala sa konstitusyon, mahalagang isipin kung ito ba ay natugunan na, o pinakamahusay na matugunan, sa pamamagitan ng pangkaraniwang batas, naunang desisyon ng hudikatura o sa ibang paraan, depende sa bansa at sa likas nitong konstitusyon. Hindi lahat ay dapat nasa konstitusyon.

Ang ibang mga isyung tinukoy ng Kasangkapan sa Pagtataya ay maaring magmukhang bago; ito ay bahagi ng layunin ng Kasangkapan sa Pagtatasa, upang tulungan ang gagamit na mag-isip hinggil sa mga isyu sa bagong paraan—halimbawa, ang mga isyu na hindi laging iniisip bilang konstitusyunal. Ang Kasangkapan sa Pagtatasa ay naglalayong magbigay ng inspirasyon sa pagkamalikhain, na kinikilala na ang pagtatag ng konstitusyon sa malawak nitong kahulugan ay isang natatanging oportunidad upang baguhin ang relasyon ng kapangyarihan sa pagitan ng mga katutubo at ng mga populasyong hindi katutubo. Ang mga naunang probisyon na lumalayo mula sa nakaraang praktika ng isang bansa ay maaring ipakilala at ang isang bansa ay pwedeng maging una sa buong mundo na magsusulong ng isang partikular na tipo ng probisyon, na magbibigay-daan para sa ibang inobasyon sa hinaharap. Ang ganoong paghahawan ng mga pagbabago ay maaring iugnay hindi lamang sa karapatan ng mga katutubo, kundi pati rin sa karapatang pantao nang mas malawak, estruktura ng pamahalaan, hangganan ng kapangyarihan ng iba’t ibang sangay ng pamahalaan, demokratikong mga proseso gaya ng eleksyon, paglikha ng mga bagong institusyon tulad ng mga independyenteng komisyon, at marami pang ibang isyu. Ang Kasangkapan sa Pagtatasa ay tumutulong sa mga gagamit na isipin ang mga isyu sa mas malawak na saklaw na ito.

\section{Pagtingin higit sa tekstong konstitusyunal}

Alam ng mga tagapagtaguyod ng karapatan ng mga katutubo na ang pagtiyak sa paggalang sa karapatan ng mga katutubo ay mas komplikado pa kaysa sa pagpasa sa mga batas o kahit ng mga pag-amyenda ng konstitusyon; kasama rito ang paglilipat sa hindi pantay na relasyon ng kapangyarihan sa pagitan ng mga katutubo at ng mga hindi katutubo na mas nakaaalwan sa lipunan, na nangangailangan ng pagbabago sa nakaugat na panlipunang aktitud at disenyo ng kaugalian sa mahabang panahon.

Ang pagkilala sa ganitong realidad ay hindi nagbabalewala sa kahalagahan ng mga batas at ng konstitusyon, o ng importansya ng pagsusuri kung paano ito pauunlarin mula sa pananaw ng karapatan ng mga katutubo. Subalit, binibigyang-diin nito ang importansya ng magkakaibang pagpapahalaga sa kontekstong politikal, pang-ekonomiya at panlipunan kung saan ang konstitusyon ang nagpapatakbo, at ng mga hamon na kinakaharap kapwa ng mga katutubo at hindi katutubong populasyon na maaaring nakaugat sa maraming mga sanhi. Ang Kasangkapan sa Pagtatasa ay sinadya upang magbigay ng metodolohiya para sa isang sistematikong pagsusuri ng konstitusyonal na teksto at isang tulay sa pagitan ng teksto at ng buhay na realidad ng mga katutubo; ngunit limitado ang kapasidad nito na makuha o maisalarawan ang mga buhay na realidad na ito. Sa halip, ang Kasangkapan sa Pagtatasa ay sinadya upang tulungan ang mga gagamit na malinang ang mga tamang tanong at isipin ang mga legal na sanhi, at potensyal na mga legal na solusyon, sa mga hamon na kanilang kinakaharap.

\subsection{Paano gamitin ang nakumpletong pagtatasa}

\section{Pagtatatasa hindipanghuhusga}

Ang Kasangkapan sa Pagtatasa na ito ay sinadya para maging relatibong obhetibo at dapat magamit tulad ng isang tseklist upang gumabay sa mga gagamit sa proseso ng pagsusuri kung gaano kahusay na inirerepresenta ang karapatan ng mga katutubo sa isang konstitusyon. Hindi ito nagreresulta ng isang grado para sa isang konstitusyon o nagmumungkahi na ang konstitusyon ng isang bansa ay mas mainam kaysa sa iba. Sa halip, ang pagsisikap ay upang humikayat ng batay sa ebidensyang pagsisiyasat at adbokasiya para mapabuti ang ligal at institusyunal na balangkas ng estado mula sa pananaw ng mga katutubo at ng kanilang mga karapatan. 
Ang sekyon ng Mga Hakbang ay sinadya upang tulungan ang mga gagamit na makabuo ng isang estratehiya para sa paggamit ng mga resulta. ${ }^{3}$ Ang stratehiyang ito ay bahagyang nakadepende sa tungkulin ng gagamit sa loob ng proseso ng pagtatag ng konstitusyon, mapa-tagapagtaguyod man o mambabatas, mamamahayag, tagapagbuo ng konstitusyon o isang nagmamalasakit na mamamayan. Subalit sa kabuuan, ang pangunahing mga layunin ay ang makapagpaunlad at makapagpahayag ng mga susing mensahe kaugnay sa mga natuklasan. Upang maging mabisa, ang mga mensahe ay dapat na maingat na nilikha, batay sa pag-unawa ng mga interes at priyoridad ng mga target na (mga) tagatanggap. Ang mga ito ay malamang mabibilang sa tatlong pangkalahatang kategorya:

1. mga pangunahing tagagawa ng desisyon, kabilang ang mga lider ng pampulitikang partido, mga miyembro ng kinatawan ng mga tagapagtatag ng konstitusyon, mga pinuno ng mga komite sa loob ng mga kinatawang ito at iba pa;

2. mga tagapagtaguyod at taga-impluwensya, kabilang ang mga organisasyon ng panlipunang sibil at ang midya; at

3. mga pangkalahatang kasapian, kasama na ang kabuuang publiko, mamamayan at hindi mamamayan.

Ang paraan kung paano ibabahagi ang mga natuklasan ay sa mga grupong ito ay magkakaiba, ngunit ang layunin at nilalaman ng mga mensahe ay dapat na malinaw at konsistent. Ang ibang potensyal na mga aksyon kaugnay ng pagpapalaganap ng mga natuklasan mula sa Kasangkapan sa Pagtatasa ay: sumulat ng ulat na may detalyadong pagsusuri ng mga natukalsan at mga rekomendasyon, upang magpasa sa mga makabuluhang konstitusyunal na komisyon at mga aktor ng panlipunang sibil; makapagpaunlad ng maikling patakaran o pangkalahatang balangkas na may maiikling susing pahayag sa tiyak na mga isyung tinukoy sa Kasangkapan sa Pagtatasa para sa mga miyembro ng partido politikal at ng midya; magsagawa ng round-table na talakayan o presentasyon sa subnasyonal na pamahalaan; at magpaunlad ng mga kampanya sasocial media at tradisyunal na midya (radyo, TV at pahayagan) na tutuon sa pangkalahatang publiko. 


\section{Mga susing termino at konsepto}


Ang mga susing termino at konsepto sa ibaba ay ilan sa mga pinakakritikal sa pag-unawa sa kabuuan ng Kasangkapan sa Pagtatasa. Ang ibang termino ay binigyang-kahulugan din sa mga seksyon ng ppaliwanag sa mga tanong, bilang may kabuluhan sa mismong mga katanungan. Ang mga termino at konsepto ay inilahad nang paalpabeto.

\section{Apirmatibong aksyon at mga espesyal na hakbang}

Ang apirmadong aksyon at espesyal na mga hakbang ay may kaugnayan sa konsepto ng 'pormal at substantibong pagkakapantay-pantay' na inilalarawan sa ibaba. Kung ang isang estado ay humiram o kahit nagmandato ng mga prinsispyo ng substantibong pagkakapantay-pantay, kinakailangang itong magkaroon ng mga polisiya at mekanismo upang gawin itong makatotohanan.

Ang mga estado ay maaaring - at, depende sa lenggwahe ng kanilang konstitusyon, ay maaaring kinakailangan na - gamitan ng apirmatibong aksyon (tinatawag din na positibong diskriminasyon o kayáy mga espesyal na hakbang) upang pabilisin ang pagkamit ng substantibong pagkakapantay-pantay para sa mga katutubo. Ang ganoong mga hakbang ay naglalakip ng mga mga instrumentong lehislatibo, ehekutibo, administratibo, pambadyet at pangregula, ganu'n din sa mga plano, polisiya, programa at kinakatigang rehimen sa mga larang gaya ng trabaho, pabahay, edukasyon, kultura, kinatawan sa pamahalaan at partisipasyon sa pampublikong buhay. Ang mga halimbawa sa mga hakbang na ito ay kasama ang (United Nations Development Group, 2009:13):

- $\quad$ mga quota sa parlamento upang damihan ang representasyon ng mga katutubo (United Nations 2006: para. 16);

- nakatarget na pagrekluta sa mga miyembro ng mga katutubong komunidad para sa serbisyong sibil, militar at iba pang institusyon ng estado;

- mga programa (iskolarsip o mga reserbadong puwesto) upang damihan ang bilang ng mga katutubo sa unibersidad;

- $\quad$ pinansiyal na tulong para sa mga katutubong kandidato sa politika;

- $\quad$ mga programa na nagbibigay ng mga insentibo para sa mga katutubong pamilya upang mapaaral ang kanilang mga anak sa paaralan;

- $\quad$ paglalaan ng pondo upang mapaunlad ang akses ng mga katutubo sa pangangalaga ng kalusugan; at

- mga programang pagsasanay para sa mga katutubo upang matuto ng mga kasanayan para makapasok sa pangunahing ekonomiya nang hindi kinakailangang isuko ang kanilang tradisyonal na mga kabuhayan at likhang-kamay.

\section{Awtonomiva at sariling pamahalaan}

Ang awtonomiya ay nangangahulugang 'ligal at praktikal na kapasidad ng isang indibidwal na gumawa at kumilos ayon sa kanyang pansariling mga pagpapasya sa buhay (Howard-Kassman 2011: 433). Ang awtonomiya ay nagsasangkot sa karapatan ng mga katutubo na independiyenteng tukuyin ang kanilang sariling interes, upang gumawa ng mga kapasyahan batay sa mga interes na ito at upang matanto ang epektibidad ng mga kapasyahang ito. Ang malayang politikal, ekonomiko at panlipunang estruktura ng mga katutubo ang nagbibigay-buhay sa kanilang mga karapatan sa sariling kapasyahan at nagpapahintulot para sa makabuluhang pagsasapraktika ng kanilang karapatan (APF at OHCHR 2013: 20). Ang karapatan ng mga katutubo sa awtonomiya at sariling pamahalaan ay masasalamin sa kabuuan ng UNDRIP, ngunit karamihan ay nasa artikulo 3 at $4 .{ }^{4}$ Ang sariling pamahalaan ay espesipikong tumutukoy sa karapatan na mamahala sa sarili kahit man lang sa tiyak na mga usapin o teritoryo. Ang pagkakaroon ng sariling pamahalaan ay maaaring nakabatay sa kapangyarihan (samakatwid, ang karapatan sa sariling pamahalaan sa larang ng turismo o ng konserbasyon ng likas na yaman) o teritoryal, na tumutukoy sa itinakdang subnasyonal na lugar kung saan ang mga katutubo ay mabibigyan ng karapatan na mamahala, bagaman karaniwan ay sakop ito ng nasyonal na konstitusyon.

Kahit pa ang ganap na awtonomiya alinman sa mga pagpapahalagang ito ay hindi kinilala, ang karapatan sa sariling pagpapasya at konsultasyon ay nangangahulugan na ang mga polisiya ng estado ay hindi dapat lumabag o humadlang sa kapasidad ng mga katutubo na gumawa at umakto sa kanilang mga naisin na makaaapekto sa kanilang buhay, ${ }^{5}$ lalo na hindi sa pamamagitan ng pagdulog sa protekstiyonista at paternalistikong mga lapit na ipinapalagay na ang estado o ang hindi katutubong populasyon ay nasa mas mabuting posisyon upang gumawa ng desisyon sa ngalan ng mga katutubo. 
Ang isang kolektibong karapatan ay karapatan ng grupo na iginawad sa isang partikular na komunidad o grupohalimbawa, ang karapatan ng kababaihan, ang karapatan ng mga katutubo o ang karapatan ng mga taong nakatira sa mga desbentahadong rehiyon. Sa pamamagitan ng mga probisyon ng reserbasyon, apirmatibong aksyon o garantiya ng representasyon sa pampublikong kalipunan, ang estado ay maaaring maglaan ng kolektibong mga karapatan para sa partikular na mga komunidad. Ang mga karapatang ito ay kinikilala sa artikulo 1 ng UNDRIP. ${ }^{6}$ Idiniin, at patuloy na idinidiin, ng mga katutubo ang pangangailangan para sa pagkilala sa kolektibong mga paraan, sapagkat ang mga karapatang ito ay inoorganisa ang lipunan ng mga katutubong grupo bilang mga angkan, bansa, komunidad, atbp, habang ang kalakhan sa mga pamantayan sa karapatang pantao ay nilinang nang may tutok sa mga indibidwal. Para sa mga katutubo, ang kolektibong karapatan ay maaaring kalakip ang karapatan na humawak ng pangkulturang kaalaman, ari-arian at mga tradisyon bilang grupo gayundin bilang karapatan na kolektibong isasapraktika ang awtonomiya at sariling pagpapasya.

\section{Konstitusyon}

Walang payak na depinisyon ang isang konstitusyon, subalit may ilang magkakatulad na katangian at gampanin na maaaring makatulong sa paghubog ng pag-unawa kung ano ang konstitusyon at ano ang gawain nito. Ang 'malawak na mayorya ng mga kontemporaneong konstitusyon ay inilalarawan ang batayang mga prinsipyo ng estado, ang estruktura at mga proseso ng pamahalaan at ang pundamental na mga karapatan ng mamamayan sa mataas na batas na hindi maaaring baguhin sa unilateral na paraan ng isang karaniwang batas' (Bumer, 2014). Mula sa pananaw na ito, ang isang konstitusyon ay nagbibigay ng balangkas sa lahat ng institusyon, mga batas, regulasyon, mga hakbang at gawain ng serbisyo publiko, at ang mismong mga mekanismo kung saan nagaganap ang politikal na partisipasyon, napangangalagaan ang karapatan at natitiyak ang pampublikong polisiya. Ito ay isang instrumento na bumubuo, nag-aayos at naglilimita sa paggamit sa kapangyarihan ng pamahalaan. Higit pa rito, ang konstitusyon ay maaaring ibigay ang ninanais sa buhay ng mga tao, ang pagkakakilanlan at maipahayag ang kanilang bisyon sa lipunan — halimbawa, sa pamamagitan ng pagtatakda ng pundamental na mga pagpapahalaga at mga prinsipyo, at magdambana ng mga pundamental na karapatan. Samakatwid, ang isang konstitusyon ay namamahala nang sabay-sabay sa pagitan ng mga dimensyong legal, politikal at sosyal, at ito rin ay may labis na simbolikong repleksiyon ng mga pagpapahalaga ng isang estado at ng kanyang mamamayan.

Ang mga konstitusyon ay maaaring magkaroon ng marami, minsan ay nag-aagawang mga gampanin at layunin sa pagitan ng mga dimensyong ito-halimbawa, pagbalanse ng pangangailangang maiparating ang nakaraan ng isang bansa at paghihirap upang magtakda ng hinahangad na bisyon para sa kinabukasan ng bansa. Habang mayroon ding tiyak na pangunahin at global na gampanin ang isinasagawa ng konstitusyon, ang mga gampanin ng konstitusyon ay signipikanteng nagkakaiba rin sa konteksto kung saan nangangasiwa ang isang konstitusyon. Sa isang lipunan na nangako para sa demokrasya at mga pagsunod sa batas, ang mga sumusunod ang tinutukoy na mga gampanin ng isang konstitusyon na nilalayong maisasagawa:

(a) pagsang-ayon sa magkatulad na mga kahalagahan at pagkilanlan na kung wala ito ay hindi magkakaroon ng isang politikal na komunidad; (b) pagmumungkahi ng mga tuntunin upang kilalanin ang pagiging bahagi ng naturang komunidad; (c) pangangako ng isang pisikal at emosyonal na seguridad sa pamamagitan ng pagmonopolyo ng estado, para sa lehitimong mga layunin, para sa paggamit ng dahas; (d) pagsang-ayon sa pamamaraan kung paano at kung anong mga institusyon, gagamitin ang kapangyarihan ng estado; (e) pagbibigay ng paglahok ng mga mamamayan sa mga usapin ng estado, partikular na ang eleksyon, at iba pang anyo ng panlipunang gawain; (f) pangangalaga ng karapatan (kung saan nagbibigay kapangyarihan sa mga mamamayan gayundin aynaglilimita sa gawain ng estado); (g) pagtatag ng mga patakaran para sa mapayapang mga pagbabago ng pamahalaan; (h) pagtiyak na masusukat ang gawain ng estado at seguridad ng mga pribadong transaksiyon sa pamamagitan ng sistemang ligal; (i) pagtatag ng mga hakbang para sa kasunduan ng mga alitan; at (j) pagbibigay ng malinaw at pinagkasunduang mga hakbang para mabago ang mga pundamental na kaayusang ito.

Sa ngayon, karamihan sa mga konstitusyon sa mundo ay mga nakasulat na dokumento. Hindi kasali ang mga bansang Israel, New Zealand, at ang United Kingdom, kung saan nakaayos ang kanilang konstitusyonal na balangkas sa magkakaibang pamaraan (Comparative Constitutions Project 2016). Ang kalakarang ito na tumutungo sa nasusulat na konstitusyon ay nagpapakita na, sa pangkalahatan, ang mga mamamayan at bansa

6 Nakasaad sa Artikulo 1: 'Ang mga katutubo ay mayroong karapatan sa buong pagtamasa, bilang kolektibo o bilang mga indibidwal, sa lahat ng karapatang pantao at pundamental na kalayaan na kinikilala sa Charter of the Nations, ang Pandaigdigang Deklarasyon ng Karapatang Pantao at internasyunal na mga batas sa karapatang pantao' (United Nations 2007) 
ay kinikilala na ang konstitusyon bilang isa sa mahalagang kasangkapan upang maorganisa ang pamahalaan at lipunan.

\section{Pagbuong konstitusyon}

Ang pagtatag ng konstitusyon ay 'higit na komplikado pa kaysa sa proseso lang ng pagbuo ng konstitusyon'. Ang pag-unawa sa pagtatag ng konstitusyon ay nangangailangan ng pagbuo ng 'kaibahan sa pagitan ng nakasulat na teksto na ang mismong konstitusyon at ang mga praktikang lumago at napapanatili sa konstitusyon', at pagkatapos ay pagsasagawa upang kapwa mabuo ang dalawa (Ghai and Galli 2006: 9). Ang International IDEA ay binigyangkahulugan ang konstitusyon bilang:

... ang proseso kung saan ang isang politikal na entidad ay nangako na makapagtatag at makapagpamalas ng isang sistema ng kahalagahan at pamahalaan. Ang pagtatag ng konstitusyon ay umabot na sa mahabang panahon at nagsasangkot sa estado gayundin ang mga hindi-pang-estadong mga organisasyon. Ang pabuo din ng konstitusyon sa ganitong kahulugan ay halos naging ebolusyonaryong proseso ng paglilinang sa teksto at pagsasagawa ng paglalahad ng mgalohika at dinamika nito.

(Ghai and Galli, 2006: 9)

Ang International IDEA ay nagdadalumat sa pagtatag ng konstitusyon, na salungat sa makitid na proseso ng pagbuo ng konstitusyon, bilang ingklusibo, at mapanghikayat na prosesong naglalayong pagsamahin ang ligal, politikal at sosyal na aspekto ng transpormasyon ng estado. Ito ay lumago mula sa pakikipagtawaran sa iilan (madalas sinimulan sa pagtatag ng kapayapaan sa mga kalagayan ng tunggalian) na pinalawak sa pamamagitan ng pagsasama at paglahok ng mga magkakaibang pangkat at grupo na nagsasama-sama upang kilalanin o muling bigyan ng kahulugan ang kanilang estado at ng mga kahalagahan nito. Ang pagtatag ng konstitusyon ay hindi nagwawakas sa isang proklamasyon ng teskto sa konstitusyon, bagkus pinalawak pa ito sa implementasyon nito, ang maayos na ugnayan ng mga batas, at iba pang mga pagsisikap upang suportahan ang transisyon at makapagbigay ng makabuluhang epekto sa mga probisyon ng konstitusyon. Tinutukoy ng balangkas ng pagtatag ng konstitusyon ang konstitusyunal na dokumento ay hindi ito sapat upang upang mainstitusyonalisa ang bagong kaayusan ng konstitusyon.

\section{Pederal at desentralisadong sistema}

Sa mga sistemang pederal at desentralisado, ang kapangyarihan at mga pananagutan ay nahahati sa pagitan ng nasyonal at subnasyonal na mga antas ng pamahalaan. Sa mga sistemang kumikilala sa mas mababang awtonomiya o sariling pamahalaan, ito ay maaaring sumaklaw sa alokasyon ng pormal na kapangyarihan para sa pamahalaan ng mga katutubo o gobyerno ng mga lugar na may awtonomiya, bilang karagdagan sa ibang subnasyonal na mga yunit. Ang isang konstitusyon ay kadalasang ipinahahayag kung anong kapangyarihan ang inilalaan sa bawat antas at maaaring magpahiwatig ng hindi espesipikong mga kapangyarihan, wala sa pook ng anumang antas ('mga latak'). Sa pagdedesisyon kung anong mga isyu ang pangunahin sa pook ng nasyonal at subnasyonal na antas, ang tagaplano ng konstitusyon ay dapat na isipin kung anong antas ang may kapasidad upang mas epektibong makatutugon sa kinakaharap na isyu, at kung ang isyu ay aplikable sa buong bansa o kayay sa isang tiyak na teritoryo. Sa kabuuan, ang nasyonal na antas ng pamahalaan ay may kakayahan na makapag-angat ng malaking kita, kaya nagkakaroon ng maraming mapagkukunang mga serbisyo na maihahatid, kabilang ang mga serbisyo na siyang susi para sa pantay na karapatan ng mga katutubo, gaya ng pangangalaga sa kalusugan at edukasyon. Subalit, ang lokal na antas ng pamahalaan ay maaring mas makatutugon sa mga pangangailangan ng mga komunidad na pinaglilingkuran. Ang mga konstitusyon ay maaring magtukoy ng mga prinsipyo na gagabay sa distribusyon ng mga kapangyarihan sa pagitan ng magkakaibang antas ng pamahalaan ${ }^{7} \mathrm{o}$ kumilala sa mga layunin ng subnasyunal na mga antas ng pamahalaan upang gumabay sa distribusyon ng mga kapangyarihan at responsibilidad. ${ }^{8}$ Ang

$7 \quad$ Tingnan ang Konstitusyon ng Sudan 2005, atikulo 25(c): "Ang mga sumusunod na prinsipyo ang gagabay sa pagbababa at distribusyon ng mga kapangyarihan sa pagitan ng lahat ng antas ng pamahalaan:... (c) pagkilala sa gampanin ng Estado sa pagsusulong ng kapakanan ng mga mamamayan at ang proteksiyon ng kanilang karapatang pantao at saligang mga kalayaan.'

8 Tingnan ang Konstitusyon ng Timog Aprika 1996, artikulo 152: '1. Ang mga obheto ng mga lokal na pamahalaan ay: (a) ang magbigay ng isang demokratiko at may pananagutang gobyerno sa mga lokal na komunidad; (b) ang magtiyak na makapagbigay ng mga serbisyo sa mga komunidad sa sustenableng paraan; (c) upang isulong ang sosyal at ekonomikong pag-unlad; (d) upang isulong ang ligtas at malusog na kapaligiran; at (e) upang hikayatin ang pakikisangkot ng mga komunidad at organisasyong pangkomunidad sa usapin ng lokal na pamahalaan. 2. Ang isang munisipalidad ay dapat magsikap, sa loob ng pinansyal at administratibo nitong kapasidad, na makamit ang mga obhetong inilatag sa subseksyon (1).' 
mga prinsipyo o layuning ito ay maaaring iugnay sa gampanin ng estado sa pangangalaga at pagsasakatuparan ng karapatan ng mga tao at ng probisyon ng mga serbisyo.

Bilang isang karapatan, gayundin bilang pinakamahusay na praktika, ang mga katutubo ay nararapat na bigyan ng karapatan sa sariling pamahalaan at para sa rehiyonal na awtonomiya; gayunpaman, ang mga ugnayan sa pagitan ng mga katutubo at ng pamahalaan, at ang mga pananagutan para magbigay ng mga karapatan at serbisyo sa mga katutubo ay madalas 'naiaatas' sa isang antas o iba pa sa isang pamahalaan. Kung saan mang antas ng pamahalaan maiataas ang kakayahang ito ay makapagsusulat, at madalas nagpapatupad, sa mga batas na may kaugnayan sa mga katutubo. Walang isang paraan sa pagtugon ng isyung ito (tingnan ang Tanong 28 sa Tsapter 4). Iminumungkahi ng praktika na karamihan a mga bansa ay inililista ang usapin ng mga katutubo bilang nasyonal/ sentral na kakayahan ng pamahalaan. Ito ay batay sa ideya na ang mga karapatan ng katutubo ay hindi dapat naiiba sa buong bansa, at ang mga kapangyarihang kaakibat ng pagrealisa sa pundamental na mga karapatan ay maaaring mas epektibong napangangalagaan sa nasyonal na lebel.

\section{Pormal at substantibong pagkakapantay-pantay}

Ang pormal na pagkakapantay-pantay ay isang susing prinsipyo na tumutukoy sa pantay na pakikitungo sa mga tao sa harap ng batas. Ang uring ito ng pagkakapantay-pantay ay tinutugunan ng konstitusyon na may mga probisyon na (a) ipinagbabawal ang diskriminasyon na ang basehan ay nauukol sa katutubo o sa ibang pagkakakilanlan (kontra-dikriminasyon na mga probisyon); at (b) ipinapahayag na ang katutubo at hindi katutubong mamamayan ay pantay sa harap ng batas (mga probisyon ng pagkakapantay-pantay). Sa ganito, ang karapatan sa pagkakapantaypantay ay nakatali sa pagbabawal sa (o karapatan na maging malaya mula sa) diskriminasyon. Ang pormal na pagkakapantay-pantay ay mahalaga sa konteksto ng pagtatamasa sa maraming karapatan, gaya ng karapatan sa malayang pamamahayag at sa tamang proseso (patas at pantay na ligal na hakbang). Halimbawa, kung ang isang tao ay naakusahan ng pagkakasala sa isang krimen, sila ay marapat na bigyan ng pantay na pagkakataon sa isang patas na paglilitis, hindi alintana kung sila ay katutubo o hindi katutubo.

\section{Ano ang diskriminasyon?}

... maaaring ilarawan ang diskriminasyon bilang isang pag-iiba, intensyonal man o hindi subalit nakabatay ito sa pag-ugnay sa mga personal na katangian ng mga indibidwal o grupo na may epektong pagpataw ng mabibigat na pasanin, mga obligasyon, o mga pagkakait sa isang indibidwal o grupo na hindi ipinataw sa iba, o iyong pagkaitan o limitahan na makakuha ng mgaoportunidad, mga benipisyo, at mga pakinabang na nakukuha ng ibang miyembro ng lipunan. Pag-iiba batay sa mga personal na katangian na maiugnay sa isang indibidwal dahil lamang sa pagkakaugnay nito sa isang grupo ay bihirang makawala sa paratang ng diskriminasyon, samantalang iyong nakabatay sa mga katangian at kapasidad ng isang indibidwal ay bihira lamang na maililihim.

Sanggunian: Interpreted in Supreme Court of Canada, Andrew v Law Society of British Columbia, [1989] 1 SCR 143

Ang konsepto ng substantibong pagkakapantay-pantay ay kumilos ng higit pa sa pormal na pagkakapantaypantay para kilalanin ang mga nakaraang diskriminasyon at ang politikal, pang-ekonomiya at sosyal na mga hadlang na dinanas ng mga katutubo sa pag-akses ng mga oportunidad, paggamit ang kanilang mga karapatan at pagbuo ng mga desisyon na makapagbibigay ng epekto sa kanilang buhay. Ang mga patakaran at polisiya na magtataguyod ng substantibong pagkakapantay-pantay ay isasaalang-alang ang konteksto at kalagayan ng isang grupo, at tatahiin ang mga patakaran sa paraang magdadala sa mga grupo sa mas pantay na panimulang punto. Ang substantibong pagkakapantay-pantay ay nakapokus sa mga resulta na bunga ng isang espesipikong patakaran at polisiya, at kumikilala sa mga kaibahan sa pagitan ng mga inibiwal at grupo, na partikular na ang may kinalaman sa sistematikong marhinalisasyon, pagpapalayas at pag-aangaw ng ari-arian. Ang substantibong pagkakapantay-pantay ay tumitingin sa historikal na marhinalisasyon o pagmamaltrato, at kinikilala na ang kasaysayan ay nag-iwan sa partikular na mga grupo sa isang hindi patas na pagsisimula—halimbawa, mga polisiya na nagtataguyod sa substantibong pagkakapantay-pantay ay kumikilala sa hadlang na kinakarap ng mga katutubo para maging edukado (hal.wika), pagtungo sa mga pribadong pagtatrabahuan at pagsulong sa politikal na posisyon ng kapangyarihan, at humanap ng mga bagay para masolusyunan ang mga hadlang na ito, gaya ng paglalaan ng isang tiyak na bilang ng mga posisyon sa edukasyon at mga pampamahalaang institusyon para sa mga katutubo.

Sa pagtatala ng mga buhay na realidad ng mga katutubo, ang substantibong pagkakapantay-pantay ay nilalayon ang pantay na akses sa mga oportunidad at pagkakapantay-pantay sa mga pagkakataon kaya ito ay isang mas komprehensibong kuro-kuro para sa pagkakapantay-pantay kaysa pormal na pagkakapantay-pantay. Kung ang 
isang grupo ay hindi nakaranas ng substantibong pagkakapantay-pantay, ang pormal na pantay na pagtrato sa harap ng batas ay hindi nangangahulugangmagbubunga ng parehong kinalabasan, sapagkat ang grupong iyon ay nagsimula na mula sa posisyong walang pagkakapantay-pantay at kaya sa ganu'n ding paraan hindi sila nagkaroon ng akses o makabenepisyo ng maraming oportunidad. Halimbawa, ang isang unibersidad ay maaaring ituring nang pantay ang mga katutubo at mga hindi katutubo at mayroong parehong nakatakdang pamantayan sa pagtanggap, subalit kung ang isang aplikanteng katutubo ay mayroong limitadong oportunidad upang pumasok at manguna sa primarya at sekondaryang paaralan kaysa sa isang hindi katutubo, desbentahado ang aplikanteng katutubo sa pag-aaplay sa isang unibersidad at marahil hindi matatanggap sa parehong bilang gaya ng mga hindi katutubong aplikante.

Bilang karagdagan sa hindi pantay na kinalabasan, ang pormal na pagtratong pantay sa harap ng batas ay maaring makasasama sa mga katutubo at makapag-ambag pa sa kawalan ng pagkakapantay-pantay sa kanila. Batay sa halimbawang inilahad kanina, kung ang katutubo ay hindi makapasok sa isang unibersidad sa katulad na bilang ng mga hindi katutubo, sila ay maaaring hindi makakuha ng permanenteng trabaho, na ginagawa silang bulnerable sa kahirapan at sa malalang kahihinatnan ng kanilang kalusugan at lipunan. Dagdag pa, maaaring hindi nila kayang paaralin ang mga anak kung mayroon lamang silang limitadong pinansyal na pagkukunan, kung gayon mauulit pa rin ang siklo ng kawalan ng pagkakapantay-pantay at marhinalisasyon.

Ang mga katutubo ay madalas nasa hindi pantay na posisyon kaugnay sa mga hindi katutubo sa politikal, pang-ekonomiko at sosyal na buhay dahil sa maraming bilang ng mga salik na maiuugnay sa direkta at hindi direktang diskriminasyon. ${ }^{9}$ Kabilang sa mga ito ang: sinadya at hindi sinadyang pagkiling at pagkakahon tungkol sa kakayahan ng mga katutubo (kabilang na ang kawalan ng pagkilala sa kapasidad ng mga katutubo bilang lehitimong gumagawa ng desisyon para sa pampublikong buhay); estruktural na desbentaha sa anyo ng diskriminasyon sa porma ng batas, mga patakaran, programa at kanilang tagapangasiwa; at tradisyonal at kultural na aktitud na nagpapakita ng hindi pantay na katayuan ng mga katutubo.

Ang kaugnayan at epekto ng mga salik na ito ay nababago ayon sa konteksto. Ang mga anyong ito ng diskriminasyon ay nagsasalimbayan upang limitahan ang oportunidad at mapagkukunang yaman na magagamit para sa mga katutubo at pinahihina ang kanilang kakayahan na gumawa at magpatupad ng mga desisyon. Ang diskriminasyon laban sa mga katutubo ay nauugnay rin sa iba pang anyo ng diskriminasyon batay sa ibảt ibang katangian gaya ng relihiyon, edad, sekswal na oryentasyon, kasarian, katayuang pang-ekonomiya at kapansanan upang mas palalimin ang mga desbentaha na kinahaharap ng mga katutubo, na lilikha ng marami pang hadlang sa pagkamit nila ng pagkakapantay-pantay at pagtamasa ng mga karapatan. Ang dinamikong ito na magkakaugnay na mga anyo ng diskriminasyon ay tinutukoy na maramihang diskriminasyon.

Ang substantibong pagkakapantay-pantay ay kinikilala ang historikal, pang-ekonomiya at politikal na pagkakaiba sa pagitan ng mga katutubo at populasyon ng mga hindi katutubo at nagsisikap upang palawakinkaysa limitahan — ang mga oportunidad at pagkakataon para sa mga katutubo sa konteksto ng mga pagkakaibang ito. Para sa marami pang impormasyon hinggil sa substantibong pagkakapantay-pantay kaugnay ng mga katutubo, tingnan ang Tanong 5 sa Tsapter 4 .

\section{Malaya, nauna at malinang na kapahintulutan}

Kapag ang pamahalaan ay gumagawa ng mga patakaran at batas o mga proyekto na makaaapekto sa mga katutubo (gaya ng paggamit ng kanilang banal na lugar para sa pag-aayos ng kalsada o pambansang pasyalan, o ang proklamasyon ng bagong konstitusyon o polisiya hinggil sa wika ng estado), mayroon silang obligasyong humingi ng malaya, nauna at malinang na kapahintulutan o free prior informed consent (FPIC) mula sa mga katutubo, sa pamamagitan ng kanilang mga piniling kinatawan. Higit pa sa obligasyon ng simpleng paghingi pagbigay ng impormasyon o pagkonsulta, ang karapatang ito ay tumuturol sa isang tapat at bukas na usapan sa mga katutubo sa mabuting kalooban, walang pamimilit (malaya), bago magsimula ang aktibidad o ang patakarang ipapatupad (nauna), kasama ang lahat ng mga impormasyong magagamit (malinang). Ang 'Kapahintulutan' ay nangangahulugang lahat ng panig na sangkot sa proseso ng negosasyon ay pantay dapat at ang mga prosesong tradisyonal sa pagpapasya ng mga katutubo ay pahihintulutang gamitin (Working Group on Indigenous Populations 2005: para. 56).

Ang kahingian ng pahintulot mula sa pinatutungkulang katutubo ay unang hingin bago ang paggamit ng lupang ninuno at likas na yaman ay nakasaad ayon sa Kumbensyon ng ILO 169 (ILO 1989: artikulo 6 at 16) at sa

9 Lumulutang ang hindi direktang diskriminasyon kapag ang isang patakaran, aktitud o kaugalian ay hindi tahasang nagdidiskrimina, subalit ang kinakalabasan ay negatibong nakaaapekto sa mga katutubo. Halimbawa, ang isang amo na may kahingian sa trabaho na parehong aplikable sa mga katutubo at hindi katutuboo, subalit mas mahirap itong maabot ng mga katutubo. Kung walang makatarungang dahilan para sa mga kahingiang ito, ito ay nangangahulugang hindi direktang diskriminasyon. 
UNDRIP (United Nations 2007: artikulo 10, 11, 19, 28, 32). Ang FPIC ay maaring gamitin din sa paggamit at karapatang magpalathala ng tradisyonal na kaalaman at kasanayan (International IDEA 2014: 48), at sa paggamit ng tradisyonal na medisina at kaalaman. Ang FPIC ay naangangahulugan din na ang mga katutubo ay dapat na kasali sa pagdidisenyo, paglilinang, implementasyon, pamamahala at ebalwasyon ng lahat ng mga programa, patakaran at lehislasyon na makaapekto sa kanila (Australian Human Rights Commission 2010: 25) —mahalaga pa, ito ay sumasaklaw sa konstitusyon at sa anumang repormang konstitusyunal.

\section{Karapatang pantao}

Ang ubod ng ng internasyonal na mga tratado sa karapatang pantao, na kung saan sakop ang ICERD (United National, 1965), ang ICCPR (United Nations, 1966a) at ang ICESCR (United Nations 1966b), gayunding ang Universal Declaration of Human Rights (UDHR; United Nations 1948), ay naglalaman ng mga batayang karapatan na iginagalang, pinangangalagaan at kinikilala bilang mga balangkas na kumakatawan sa internasyunal na karapatang pantao. ${ }^{10}$ Dapat na may akses ang mga katutubo sa lahat ng mga karapatang ito nang walang diskriminasyon. Bilang karagdagan sa ubod ng karapatang pantao, may mga kinilalang karapatan sa internasyunal na pag-aari ng ibang magkakaibang grupo o sektor ng lipunan-halimbawa, karapatan ng kababaihan, karapatan sa paggawa, karapatan ng mga bata at, siyempre, ang karapatan ng mga katutubo. Kritikal na dapat ang miyembro ng lahat ng grupong ito ay mabigyan ng lahat ng karapatang nararapat sa kanila bata sa kanilang identidad. Ito ay maaaring mangahulugan na ang isang katutubong babae o bata ay bahagyang iba ang karapatan mula sa isang lalaking katutubo.

Ang internasyunal na karapatang pantao ay kinilala at pinangangalagaan sa loob ng internasyunal na batas (tingnan sa ibaba). Maaaring pagtibayin ng estado ang kanilang pangako para sa karapatang pantao sa pamamagitan ng pagsasama-sama ng mga ito sa isang pambansang konstitusyon at sa pambansang batas at mga patakaran. Sinumang indibidwal ay dapat na may karapatan sa lahat ng karapatang pantao ayon sa ipinangako sa mga mamamayan ng kanilang estado, gayundin ang lahat ng makabuluhang karapatan na nakalagay sa mga tratado na pirinmahan ng estado. Ang pratika sa mga bayan ay nagkakaiba sa kung ang mga internasyunal na karapatang pantao ay direktang naipapatupad sa mga pambansang korte ng batas (tingnan Tanong 32 sa Tsaper 4).

\section{Mga katutubo}

Ang representasyon ng mga katutubo sa internasyonal na mga legal na pagtitipon ay madalas kontra sa pagampon sa isang mahigpit, unibersal, internasyonal na depinisyon ng mga 'katutubo', sa halip, kanilang binigyangdiin ang 'hangarin at ang karapatan ng bawat katutubo na kilalanin ang kanilang mga sarili' (APF at OHCHR, 2013:6). Kung gayon, walang umiiral na unibersal at ligal na depinisyon ng mga 'katutubo', subalit may tiyak na pamantayan na karaniwang ginagamit sa ibang panig ng mundo upang tumulong sa proseso ng identipikasyon. Ang Kumbensyon ng ILO 169 ay gumagamit ng isang praktikal na dulog para sa isyu ng pagbibigay depinisyon at nagbibigay ng mga layunin at subhektibong pamantayan para sa identipikasyon ng pinatutungkulang mga mamamayan (tingnan ang ILO 169: artikulo 1). Ang mga pamantayang ito ay maibubuod ayon sa sumusunod (ILO n.d.): 
Mga suhetibong pamantayan

Mga katutubo
Pagkakakilanlan sa sarili bilang bahagi ng mga katutubo
Mga obhetibong pamantayan

Nagmula sa populasyon, na nanirahan sa bansa o heograpikong rehiyon sa panahon ng pananakop, kolonisasyon o pagtatag ng kasalukuyang hangganan ng estado.

Pinanatili ang ilan o lahat ng kanilang pansariling sosyal, pang-ekonomiya, kultural at politikal na mga institusyon, anuman ang kanilang ligal na katayuan.

\section{Mga tribo}

\author{
Pagkakakilanlan sa sarili bilang \\ bahagi ng mga katutubo
}

\begin{abstract}
Ang kanilang mga kondisyong sosyal, kultural, at pang-ekonomiya ang nagpapabukod-tangi sa kanila mula sa ibang seksiyon ng nasyonal na komunidad.

Ang kanilang katayuan ay pinamamahalaan nang buo o bahagi lamang sa pamamagitan ng kanilang sariling kultura o tradisyon o ng mga espesyal na batas o regulasyon.
\end{abstract}

Sa Pag-aral ni Martinez Cobo, ${ }^{11}$ sa pamamagitan ng Special Rapporteur of the Sub-Commission on Prevention of Discrimination and Protection of Minorities, ay nagmungkahi rin ng isang mapagkakasunduang depinisyon (Martínez Cobo 1987: para. 379):

Ang katutubong komunidad, mga mamamayan at nasyon ay iyong may historikal na pagpapatuloy sa lipunan bago ang pananakop at pre-kolonyal na nabuo sa loob ng kanilang teritoryo, na isinasaalangalang ang kanilang mga sarili naiiba sa ibang sektor ng lipunan na nananaig ngayon sa mga teritoryong iyon, o ilang bahagi nito. Nabuo sila sa kasalukuyan bilang mga hindi-dominanteng sektor ng lipunan at determinadong pangalagaan, paunlarin at dalhin ang kanilang minanang teritoryo sa susunod na mga henerasyon, at ang kanilang etnikong identidad, alinsunod sa kanilang patuloy na pag-iral bilang mamamayan, ayon sa kanilang sariling sinusunod na kultura, sosyal na institusyon at mga legal na sistema.

Ang ulat ay nagpaliwanag din na (Martínez Cobo 1987: para. 380):

Itong ipinagpapatuloy na kasaysayan ay maaaring binuo ng pagpapatuloy, para sa mas mahabang panahon abot hanggang kasalukuyan, sa isa o higit pa sa mga sumusunod na salik:

(a) Okupasyon ng lupang ninuno, o bahagi lamang nito;

(b) Karaniwang ninuno sa orihinal na okupante ng mga lupaing ito;

(c) Kultura sa pangkalahatan, o sa mga espesipikong manipestasyon (gaya ng relihiyon, pamumuhay sa ilalim ng sistemang tribal, kasapian ng isang katutubong komunidad, pananamit, paraan ng kabuhayan, estilo ng pamumuhay;

(d) Wika (kung ito ba ay tanging ginagamit na wika, bilang inang wika, bilang nakasanayang paraan ng pakikipagkomunikasyon sa tahanan o sa pamilya, o bilang pangunahin, pinipili, nakasanayan, pangkalahatan o karaniwang wika);

(e) Mga tirahan sa isang tiyak na bahagi ng bansa, o ng mga rehiyon sa mundo;

(f) Iba pang mga kaugnay na salik.

11 Isang mahalagang punto sa pag-aaral ng diskriminasyon laban sa populasyon ng mga katutubo ay dumating noong 1970, noong nagrekomenda ang United Nations Sub-Commission on Prevention of Discrimination and Protection of Minorities na isang pag-aaral ang gawin hinggil sa diskriminasyon laban sa mga katutubo. Upang maisakatuparan ang pag-aaral na ito, isang Special Rapporteur, si José R. Martínez Cobo, mula sa Ecuador, ang hinirang. Ang kanyang huling ulat ay isinumite sa Sub-Komisyon mula 1981 hanggang 1984 (tingnan ang United Nations 2014), at ang kanyang kongklusyon at rekomendasyon ay nalimbag noong 1987 (Martinez Cobo 1987), 'ay mga mahahalagang pananda sa pagkunsidera ng United Nations sa suliraning kinaharap ng mga katutubo hinggil sa karapatang pantao' (United Nations 1997a). 
Sa wakas, ang Tagapangulong Rapporteur ng United Nations' Working Group on Indigenous Populations na si Erica-Irene A. Daes, ay nagtalaga ng 'iba pang salik kung saan ang mga modernong pandaigdigang organisasyon at mga ligal na dalubhasa (kabilang ang ligal na dalubahasa ng mga katutubo at miyembro ng sektor ng akademiya) na isinasalang-alang na makabuluhan sa pag-unawa sa konsepto ng "katutubo" ' (United Nations 1996b: para. 69):

(a) Priyoridad sa panahon, na may paggalang sa pagmamay-ari at sa paggamit ng espesipikong teritoryo;

(b) Ang kusang-loob na pagpapanatili ng natatanging mga kultura, kung saan kabilang ang aspekto ng wika, sosyal na organisasyon, relihiyon at espiritwal na pagpapahalaga, moda ng produksyon, mga batas at institusyon;

(c) Sariling pagkakilanlan, gayundin ang pagkilala ng ibang grupo, o ng mga awtoridad ng Estado, bilang natatanging kolektibidad; atd

(d) Isang karanasan ng pagsupil, marhinalisayon, pang-aagaw ng ari-arian, pagpapatalsik o diskriminasyon, nagpapatuloy man o hindi ang mga kondisyong ito.

Ang Tagapangulong Rapporteur, gayumpaman, ay binigyang diin ang katotohanan na 'ang mga salik na ito ay hindi magagawa, at hindi maaaring bumuo sa ingklusibo o komprehensibong depinisyon' (United Nations 1996b: para. 70), at itinala sa iba pa na 'ang mga katutubo ay pinagdusahan ang mga depinisyon na ipinataw sa kanila ng iba' (United Nations 1995: para. 6), bilang karagdagan sa madalas ay hindi man lang pagkikilala. Nararapat na makilahok ang mga katutubo sa pagbuo ng anumang depinisyon na gagamitin upang makilala sila at dapat may karapatan sila na pumili kung papaloob o hindi sa pagkilala sa depinisyon.

\section{Batas internasyunal}

Bagama't ang mga konstitusyon ay pinakamataas na mga dokumento, ang batas sa bawat bansa ay nakapaloob sa isang sistema ng pandaigdigang batas. Ang mga tratado sa internasyonal at rehiyonal na karapatang pantao, kasama ang kinatawan ng pangangasiwa, at ang internasyonal at rehiyonal na mga korte o ng iba pang mekanismong pandinig ang bumubuo sa batayan ng global na pamumuno sa karapatang pantao. Ang konstitusyon ay kailangang nakahanay sa internasyonal na obligasyon ng estado, na matatagpuan sa mga nilagdaang tratado. Dagdag pa, mayroong mga pagkukunan ng 'mababang batas' o walang bisa at hindi tratadong mga obligasyon-gaya ng mga deklarasyon at resolusyon ng United Nations, mga pahayag, prinsipyo at mga pamantayan ng pag-uugali-na bumubuo sa bahagi sa pamumuno ng global na karapatan, sa dapat ay isinasaalang-alang din sa pagsusuri ng isang konstitusyon.

Ang mga isyung tinugunan ng Kasangkapan sa Pagtatasa na nag-uugat sa internasyonal na batas at ng internasyonal na pamantayan kasama na ang bawat tanong na inilaan ay nriyan upang tulungan ang mga gagamit nito upang makalinang ng isang pagdulog batay sa karapatan sa pagsasagawa ng kanilang adbokasiya.

\section{Ligal na pluralismo at nakaugaliang mga batas}

Isang komplikadong salik sa pagsusuri ng konstitusyon mula sa pananaw ng karapatan ng mga katutubo ang ligal na pluralismo: kung ang isang bansa ay kinikilala ang maramihang sistema ng batas. Ang ligal na pluralismo ay isinasagawa ng maraming bansa kung saan, bilang dagdag na batas ng estado, ang ibang ligal na sistema gaya ng nakaugaliang batas at/o pangrelihiyong batas ay kinilala din at ginagamit. Halimbawa, sa ibang bansa ang isyung pampamilya gaya ng pag-aasawa, diborsyo, kustodya sa anak at mana, ay didinggin batay sa panrelihiyon batas o kaugalian at mga nakasanayang gawi, na maaaring kaagapay sa pagsasagawa, o ibahin mula sa, o maisama sa batas ng estado at sistemang panghukuman. Sa iba namang bansa, ang indibidwal na miyembro ng katutubong komunidad ay maaaring mamili kung anong ligal na sistema ang kanilang gagamitin (halimbawa, tungkol sa pagaasawa), habang ang ibang bansa naman ay wala silang maaaring pagpilian. Madalas, ang nakaugaliang batas o legal na sistema ng mga katutubo ay magagamit lamang sa mga miyembro ng grupo, subalit sa ibang sitwasyon, ay ginagamit din nila ito sa mga hindi kabilang sa grupo.

Sa ibang mga konteksto, ang ligal na pluralismo ay nangangahulugan na maraming pagkukunan ang batas, at ang espesipikong relihiyon ay maaaring isa sa pagkukunan ng batas bilang karagdagan sa estado. Maaari ring ito ang kaso na ang relihiyon ang isasaalang-alang bilang pagmumulan ng lahat ng batas, na ibig sabihin ay kahit ang mga mambabatas ng estado ay dapat isaalang-alang ang panrelihiyong batas kung magpapatupad ng lehislasyon. 
Ang Kasangkapan sa Pagtatasa ay naglalaman ng mga tanong na nauukol sa nakaugaliang batas sa konstitusyon, sapagkat ang mga tipong ito ng ligal na sistema ay mayroong malalimang epekto sa mga katutubo. Dagdag pa, ang pagkilala ng pamahalaan sa institusyon ng mga katutubo o tila-hudisyal na awtoridad at mga nakaugaliang batas ay makapagbibigay ng gabay hinggil sa kanilang karapatan sa sariling pagpapasya (United Nations General Assembly 2009: paras 78-82). Ang Special Rapporteur ay nagpaliwanag na:

Ang bagong pluralistang konstitusyon ay binigyang halaga ang pagkilala sa mga katutubo bilang politikal na sabjek, hindi lamang bilang obheto para sa mga patakaran na idinidikta ng iba; ang pagbabago sa identidad ng estado ng bansa, na ngayon ay kinilala bilang multi-etniko at multi-kultural; ang indibiwal at kolektibong karapatan sa sariling identidad, at ang pagkilala sa ligal na pluralismo. (United Nations 2006: para. 9)

Ang nakaugaliang legal na sistema ay maaari ring unang (at tanging) dulugan ng hustisya ng mga katutubo, lalo na sa mga rural na lugar. Sa gayon, sa pagtatasa ng konstitusyon ng isang bansa na nagsasagawa ng legal na pluralismo, mahalagang maunawaan ang lugar ng panrelihiyon at nakaugaliang batas kaugnay ng konstitusyon. Halimbawa, tungkol sa herarkiya ng mga batas, mahalagang maisaalang-alang kung ang konstitusyon ay may katayuan ng kataas-taasang batas, higit sa lahat ng iba pang ligal na sistema at mga prinsispyong itinatag kung saan ang lahat ng iba pang sistemang legal ay kinakailangang tumalima, o kung ang mga ito ay sabay na isinasagawa (o ito'y subsidiyaryo lamang sa) ibang mga ligal na sistema. Mahalaga na may kahit isang batayang pag-unawa sa katayuan at saklaw ng pagkilala sa maramihang sistemang ligal batay sa mga susing isyu hinggil sa karapatan ng mga katutubo, at kung paano sila naaapektuhan ng magkakaibang sistema ng batas.

Ang Special Rapporteur ay binigyang diin na mahalaga na makapagtatag ng mekanismo para sa epektibong pagkilala sa ligal na pluralismo, upang ang nasyonal na batas at ang katutubo o nakaugaliang batas ay maaaring umiral sa isa't isa, at maging ang korte ay makapaglaan ng kapasyahan at kapangyarihang sang-ayon sa mga katutubo nang walang nililikhang napakaraming pagkakasalungatan sa pagitan ng mga hurisdiksiyon, at habang pinagkakasundo at binabalanse ang mga karapatang ito kasama ng iba pa, gaya ng karapatan ng kababaihan (United Nations 2006: paras 31-39). Ang alitan sa mga batas at ang resultang kalituhan ay maaaring magdulot ng mga paglabag sa karapatan ng mga katutubo (United Nations 2006: para. 45), subalit mahalaga na matapat na kilalanin na 'madalas may mga kahirapan kaugnay ng mabisang pagkilala sa katutubong batas, kahit pa sa mga bansa kung saan ang ligal na pluralismo ay opisyal na kinilala' (United Nations 2006: para. 37).

\section{Karapatan sa sariling pagpapasya}

Isang pangunahing prinsipyo ng internasyunal na batas at sentral na karapatan sa UNDRIP, ang sariling pagpapasya ay maaring bigyang kahulugan bilang '(a) ang akto o kapangyarihan sa pagbuo ng sariling desisyon at pagkilala sa sariling katayuang politikal; o (b) ang kalagayan ng pagiging malaya mula sa kontrol o kapangyarihan ng iba. Ang karapatan sa sariling pagpapasya ay isang pundamental na simulain ng internasyunal na batas, na nakaiimpluwensiya sa ugnayan ng estado at kasama na ang mga sub-yunit at ang mga mamamayan na bumubuo sa mga estadong iyon' (Cats-Baril 2018: 1). Ang Internasyunal na Kasunduan sa Ekonomiko, Sosyal at Kultural na Karapatan at ang Internasyunal na Kasunduan sa Sibil at Politikal na Karapatan, sa kanilang komung artikulo 1 (para. 1), ay isinasaad na: 'Lahat ng mamamayan ay may karapatan sa sariling pagpapasya. Sa bisa ng karapatang iyon ay malaya nilang kinikilala ang kanilang katayuang politikal at malayang ipagpatuloy ang kanilang sosyal, kultural at ekonomikong kaunlaran' (United Nations 1966a, 1966b). Ang Internasyunal na Hukuman ng Katarungan (1975: para. 59) ay binigyang kahulugan ang sariling pagpapasya bilang ang pangangailangan upang magbigay-galang para sa malayang pagpapahayag ng saloobin ng mga mamamayan.

Ang internasyunal na pagkilala ng karapatan sa sariling pagpapasya ay may dalawang dimensiyon-internal at eksternal. Ang internal ay tumutukoy sa paggamit ng sariling pagpapasya sa loob ng umiiral na estado; ang eksternal naman ay tumutukoy sa karapatan ng mga mamamayan na kilalanin ang kanilang lugar sa loob ng pandaigdigang komunidad. Ang UN Committee on the Elimination of Racial Discrimination's General Recommendation No. 21, hinggil sa karapatan sa sariling pagpapasya, ay kritikal sa pagpapakahulugan sa dalawang dimensiyong ito. Tinukoy nito ang internal na sariling pagpapasya bilang ang mga karapatan 'ng lahat ng mamamayan na ipagpatuloy ang kanilang malayang ekonomiko, sosyal at kultural na kaunlaran nang walang panghihimasok mula sa labas; karugtong ito sa karapatan ng bawat mamamayan na makibahagi sa pagsasagawa ng usaping pampubliko sa anumang antas' (United Nations 1996a). 
Noong 2007, isang espesipikong karapatan sa internal na sariling pagpapasya para sa mga katutubo ang kinodipika sa artikulo $3 \mathrm{ng}$ UN Declaration on the Rights of Indigenous Peoples. 'Ang mga praktika sa pagsasagawa ng karapatang ito ay patuloy na nagbabago subalit kalakip ang mga kaayusan sa awtonomiya, ang pagkilala sa kolektibong karapatan sa wika at kultura, at ang karapatan sa paghingi ng malaya, nauna at malinang na kapahintulutan at konsultasyon.' (Cats-Baril 2018: 3). Ang pagsasagawa sa karapatan ng mga katutubo sa pagsasarili ay hinihigpitan pambansang konstitusyon at madalas nililimitahan habang ang gawain ay hindi dapat lumabag sa mga karapatan ng ibang komunidad. Ang sariling pagpapasya ay isang kolektibong karapatan para sa mga katutubo na pangalagaan ang kanilang awtonomiya na mamahala ng kanilang mga usapin at upang lumahok nang makabuluhan sa mga desisyon na makaaapekto sa kanila. Isang malinaw na koneksiyon sa pagitan ng karapatan ng mga katutubo sa sariling pagpapasya at sa awtonomiya ay nabuo sa UNDRIP artikulo 4: 'Ang mga katutubo, sa pagsasagawa ng kanilang karapatan sa sariling pagpapasya, ay may karapatan sa awtonomiya o sariling pamahalaan sa mga bagay na may kinalaman sa kanilang internal at lokal na mga usapin, gayundin ang mga pamamaraan at kondisyon para matustusan ang kanilang awtonomong tungkulin' (United Nations 2007). Ito ay hindi nangangahulugan sa karapatan para sa malayang pagkakaroon ng estado subalit, sa minimum, nagrerepresenta ng karapatan sa kaayusan sa mas mababang awtonomiya at sariling pamahalaan, gayundin ang pagtamasa para sa makabuluhang representasyon sa pagpapasya at sa mga proseso na makaapekto sa mga katutubo at sa kanilang mga karapatan.

Sa pagkilala ng karapatang ito, ang mga pamahalaan ay nararapat na kilalanin ang pangkolektibo at panggrupong identidad ng mga katutubo (nasyon, grupo ng mga wika, angkan, alyansang pampamilya, atbp.) at umanib sa kanila sa mabuting kalooban at sa batayan ng pagkakapantay-pantay, paggalang at dignidad. Ang pagsasagawa sa kanilang karapatan sa sariling pagpapasya ay nangangahulugan, halimbawa, ng lokal na sariling pamahalaan sa pamamagitan ng mga konsehong kontrolado ng komunidad, na may pagmamay-ari ng tradisyonal na lupain at nteritoryo at maging ang pasya kung paano gamitin at paunlarin ang mga ito, pagkontrol sa mga probisyon ng mga batayang serbisyo gaya ng serbisyong pangkalusugan, at ang ligal na pagkilala sa identidad at karapatan ng grupo kabilang na ang konstitusyonal na pagkilala. Mahalaga dito, mangangahulugang maliit ang mga karapatang ito maliban na lamang kung ang mga katutubo ay gagarantiyahan ng mga pagkukunang yaman at pondo mula sa pamahalaan para sa mabisang pagganap ng kanilang sariling pamahalaan (United Nations General Assembly 2011: para. 78).

\section{Mga karapatan at ang tungkulinng estado}

Sa ilalim ng batas ng internasyonal na karapatang pantao, ang estado ay may pananagutang igalang, pangalagaan at tuparin ang mga karapatang pantao. Mangyari pa, ang mga estado ay may tungkuling igalang ang lahat ng kinikilalang karapatan na nakalaan sa isang nasyonal na konstitusyon. Hindi lamang ito tungkulin upang pigilin ang masasakit na gawi subalit isa ring apirmatibong responsibilidad na pangalagaan at tuparin ang mga karapatan. Ang mga korte at/o iba pang lupon ng patas na awtoridad panghukuman ay dapat na magtatag at gumawa ng mga daan para sa mga tao upang kaya nilang hamunin ang mga paglabag sa kanilang mga karapatan. Ang mga institusyon ay nararapat na magkaroon ng mga patakaran para sa pagsusulong ng karapatan sa lahat ng serbisyong pampamahalaan, at ang mga gumaganap sa pamahalaan ay dapat na sinanay sa mga karapatang ito. Lampas sa mga proteksiyong ito, ang estado ay maaring kumuha ng positibong mga aksyon (tingnan din ang Apirmatibong aksyon at mga espesyal na hakbang), gaya ng paggawa ng batas, mga patakaran at programa at pagtatag ng mga institusyon na may kakayahan na kumilala sa hindi pantay na posisyon sa lipunan ng mga katutub at pangarapin ang pagtatanggal sa nakasanayang mga praktika ng diskriminasyon at paniniwala na nasa ugat nito at upang maagap na makontrol ang pagharap sa mga negatibong resulta.

\section{Mga may hawakng karapatan}

Ang konsepto ng paghawak ng karapatan ay tungkol sa katayuan ng yunit na kinikilala bilang humahawak ng karapatan sa harap ng estado ng pamahalaan at ng iba pang kaugnay na institusyon. Ang isang humahawak ng karapatan ay maaring isang indibidwal, isang samahan o grupo, o isang korporasyon. Bilang may hawak ng karapatan, pinahihintulutan ang isang indibidwal o kolektibo na gumawa ng lehitimong panukala laban sa estado at ng iba pang aktor na maaaring ligal na mapananagot sa mga paglabag sa karapatan ng mga humahawak ng karapatan. Kung sino ang humahawak ng batas at sino ang 'tagahawak ng tungkulin' (indibidwal o institusyon na responsable sa pangangalaga at paglalaan para sa karapatan) ay depende sa batas na pinaguusapan. Halimbawa, ang isang estado ay maaaring maging tagahawak ng tungkulin sa ilalim ng internasyonal na batas o konstitusyunal na batas; ang mga konstitusyon, at minsan lehislasyon, ay maaari ding magtatag ng mga tungkulin sa mga pribadong aktor gaya ng mga korporasyon at maging ang kapantay na hinahawakang 
tungkulin sa pagitan ng mga indibidwal. Ang eksaktong karapatan na mayroon ang humahawak ng karapatan ay nakadepende sa batas. Pinagkakalooban ng batas ng karapatan ang humahawak ng karapatan, halimbawa: karapatan sa pribadong pag-aari, kalayaan sa pamamahayag, o gaya ng sa ibang bansa, ang karapatan sa pabahay at pagkain. Ang ilang tiyak na karapatang pantao ay mas nagiging kilala bilang unibersal, ibig sabihin, ito ay pag-aari ng lahat ng mga tao. Bilang karugtong, ito ang dahilan na ang lahat ng tao ay maituturing na humahawak ng karapatan.

Mahalaga pa, na sa pamamagitan ng unibersalisasyon na ito, ang pagkilala bilang humahawak ng karapatan ay naging paraan sa pagkilala sa dignidad ng tao. Ang humahawak ng karapatan ay hindi na kailangang dumulog sa estado o sa ibang may hawak ng tungkulin upang humingi ng pabor. Sa halip, ang karapatan ay isang paggawad at isang plataporma upang ang humahawak ng karapatan ay maaring dalhin ang lehitimong panukala hinggil sa anumang paglabag sa kanyang karapatan. Ang humahawak ng karapatan ay maaring dumulog sa tagahawak ng tungkulin nang may tiwala at bilang kapantay sa paglaban para sa pananagutan.

Sa Kasangkapan sa Pagtatasang ito, mahalaga ang konsepto ng kung ang samahan ba ay kinikilala bilang humahawak ng karapatan (tingnan ang Tanong 8). Ang karapatan ng mga katutubo ay madalas na kolektibo ang kalikasan nito, ibig sabihin, na ang humahawak ng karapatan para sa karapatan ng mga katutubo ay kolektibo rin—ang komunidad, nasyonalidad, tribo, o mga mamamayang pinag-uusapan. Sa ganoong paraan, ang isang katutubong indibidwal ay puwedeng magkaroon ng pansariling karapatan (gaya ng kalayaan sa pamamahayag) subalit maari ring magkaroon ng karagdagang kolektibong karapatan, halimbawa, sa mga komunal na pag-aari ng lupain, sa pamamagitan ng pagpapamiyembro sa kolektibo.

\section{Tungkulin ng hudikatura}

Gumaganap ng mahalagang gampanin ang hudikatura sa pangangalaga ng karapatan ng mga katutubo (tingnan, halimbawa, sa United Nations 2006: paras 36 at 42). Binibigyang kahulugan ng korte ang konstitusyon, domestikong lehislasyon at pamantayan ng internasyunal na karapatang pantao ngunit sila rin ay 'instrumental sa pagbibigay-solusyon sa tunggalian ng batas, hindi pagpapatupad ng ganoong batas, at ang hakbang na ginawa ng mga awtoridad sa magkakaibang anyo at nilalagay sa panganib ang karapatan ng mga katutubo at ng mga komunidad.' (United Nations 2006: para. 89).

Upang mabisang maisakatuparan ang gampanin nito, ang hudikatura ay dapat na walang pinapanigan, walang partido at malaya sa anumang politikal na panghihimasok at panggigipit. Ang kalayaan nito ay dapat ginagarantiyahan at pinangangalagaan ng konstitusyon. Ang iba pang mahalagang aspekto ng kalayaan nito ay ang: mga proseso sa paghirang, pagtanggal at promosyon ng mga hukom; pampublikong paglilitis; ang pondo ng hudikatura; pananagutan ng mga hukom; at ang pakikipag-ugnayan ng ehekutibo at lehilatibo sa hudikatura. Ang isang malayang hudikatura ay mas may kakayanang makaiwassa politikal at popular na panggigipit na siyang dahilan upang mahirapan ang hudikatura na mapangalagaan ang mga minoryang grupo; kung ang hudikatura at ang mga pasya nito ay isinailalim sa pag-censor mula sa ibang sangay ng pamahalaan o ng makapangyarihang interes, mahina na makabuo ito ng progresibong desisyon hinggil sa mga isyu ng panlipunang hustisya na nakikita ng iilang politiko bilang banta o laban sa kanilang pansariling interes.

\section{Pagkilala sa sarili}

Ipinapahayag sa preambulo ng UNDRIP na 'ang mga katutubo ay kapantay ng lahat ng tao,' at pinagtitibay na 'ang karapatan ng lahat ng tao na maging iba, ang pagsasaalang sa sarili bilang iba, at upang sa gayon ay maigalang (United Nations 2007). Sa Pag-aaral ni Martínez Cobo para sa UN Sub-Commission on the Prevention of Discrimination of Minorities ay isinasaalang-alang ang pagkilala sa sarili bilang esensyal na elemento sa pagbibigay kahulugan sa mga katutubo at inuugnay ito sa konsepto ng sariling pagpapasya ayon sa sumusunod (Martínez Cobo 1987: paras 381-82): 'Sa indibidwal na batayan, ang isang katutubo ay yaong kabilang sa grupo ng mga katutubo ayon sa pagkilala sa sarili bilang katutubo (panggrupong kamalayan) at kinikilala at tinatanggap ng grupo bilang isa sa kasapi nito (pagtanggap ng grupo). Ito ang nangangalaga sa mga komunidad hinggil sa kanilang pinakamataas na karapatan at kapangyarihan upang magpasya kung sino ang kabilang sa kanila, nang walang panghihimasok mula sa labas.' 
Para sa mga layunin ng Kasangkapan sa Pagtatasa, ang salitang 'estado' ay ginagamit upang tukuyin ang isang 'bansa'. Ang estado ay nangangahulugan bilang isang internasyonal na kinikilalang malayang teritoryo na may sariling kaakibat na pampamahalaang institusyon at mga mamamayan. Kaugnay ng ibinigay na pagpapakahulugan, ang mga bansang Pransya, Indonesia, Nepal, Peru at ang Estados Unidos ay mga halimbawa ng 'estado'. Ang isang nasyon, sa kabilang banda, ay binigyang kahulugan bilang grupo ng mga tao na magkakaugnay sa isa't isa sa pamamagitan ng kanilang kasaysayan, kultura, wika, teritoryo o identidad. Sa kasaysayan, ang salitang 'nasyon' ay ginamit upang ilarawan ang mga katutubo at 'katutubong nasyonalidad', gayundin ang iba pang etniko at minoryang grupo. Halimbawa, ang Nasyon ng Navajo sa Estados Unidos. Ang isang estado ay maaring maging multinasyonal basta't ang mamamayan nito ay binubuo ng magkakaibang nasyon (o grupo ng mga mamamayan).

\section{Mga teritoryo, lupa at likas na yaman}

Ang mga karapatan sa lupa, likas na yaman at mga teritoryo ay madalas tinitingnan na esensyal na karapatan para sa mga katutubo, batay sa mga naunang okupasyon sa mga lupain at teritoryo at ang kahalagahan ng mga ito at ng likas na yaman para sa mga katutubo. Minsan, ang mga karapatang ito ay dumadating sa anyong una (gagamit) karapatan', na nangangahulugang ang mga katutubo ay 'may karapatan upang maging unang benepisyado sa paglinang sa mga likas na kayaman at iba pang lokal na mapagkukunan na maaaring gamitin sa kanilang sariling teritoryo' (International IDEA 2014: 47). Ang unang mga karapatan ay minsan tinutukoy din na karapatan sa bansa, partikular na sa konteksto ng Australia.

Ang karapatan sa mga teritoryo, lupain at likas na yaman ay dinetalye sa artikulo 25 at 26 ng UNDRIP (United Nations 2007). Ang artikulo 25 ay nagpapahayag na ang mga katutubo 'ay may karapatan upang panatilihin at pagtibayin ang kanilang natatanging ugnayang pang-espiritwal sa kanilang tradisyonal na pagmamay-ari o dili kaya'y inokupa at ginamit na mga lupain, teritoryo, mga katubigan at baybay-dagat at iba pang likas na yaman at upang pagtibayin ang kanilang mga pananagutan para sa susunod na henerasyon kaugnay nito', samantala nakasaad naman sa artikulo 26 na:

1. Ang mga katutubo ay may karapatan sa mga lupain, teritoryo at likas na yaman kung saan ay tradisyonal na nilang pagmamay-ari, inokupa o dili kaya’y ginamit o kinuha.

2. Ang mga katutubo ay may karapatan na magmay-ari, gumamit, maglinang at kumontrol sa mga lupain, teritoryo, at likas na yamang naroon sa dahilan ng tradisyunal na pagmamay-ari o iba pang tradisyunal na okupasyon o gamit, gayundin doon na nakuha nila sa ibang paraan.

3. Ang estado ay nararapat na magbigay ng ligal na pagkilala at pangangalaga sa mga lupain, teritoryo at likas na yamang ito. Ang ganoong pagkilala ay nararapat isagawa nang may paggalang sa kaugalian, mga tradisyon at sistema ng pananatili sa lupain ng kinauukulang mga katutubo.

Inilalakip nito ang karapatan sa aktwal na lupain, teritoryo at katubigan, pati na rin ang likas nilang yaman (mga hayop, gulayan, mineral, at iba pa.). Binalangkas naman sa artikulo $27 \mathrm{ng}$ UNDRIP ang mga pananagutan ng pamahalaan sa pagtupad ng mga karapatang ito: kailangan silang magtatag at magpatupad ng walang pagkiling, bukas at malinaw na mga proseso upang ibigay ang naayong pagkilala at pormal na karapatan sa lupain, teritoryo at likas na yaman. Sa parehong artikulo rin nakasaad na ang mga katutubo ay may karapatan na makilahok sa mga prosesong ito.

\section{Mga tratado at kasunduan}

Ang tratado ay ang mga umiiral na may bisang mga kasunduan o kaayusan na nilagdaan sa pagitan ng isa o higit pang pinakamataas na kapangyarihan. Sa proseso ng kolonisasyon sa kasaysayan at pang-aagaw sa ari-arian ng mga katutubo mula sa kanilang lupain at teritoryo, marami sa mga pangkasaysayan tratado ay kanilang nilagdaan mismo na magsisilbing patunay na ang mga katutubo ay itinuring bilang makapangyarihang taggaganapaktor, kung hindi man mga kapantay. Isang masaklaw na katangian ng pagbubuo ng tratado ay samakatwid ang prisipyo ng resiprosidad, 'ito rin ay ibinunga ng pag-unawa na ipinalalaganap ng iba't ibang Katutubong partido hinggil sa batayang kalikasan ng kaugnay ng tratado (United Nations 1999: para. 67). Kung ang makasaysayang mga tratado ay nilagdaan sa pagitan ng mga katutubo at ng pampamahalaang estado, pinanghahawakan ng UNDRIP na nararapat na sila ay kilalanin ayon sa batas na umiiral at dapat magkaroon ng pagsisikap upang maisakatuparan ang anumang pangakong ginawa para sa mga katutubo sa mga tratadong ito. Upang sumunod sa United Nations, ang 
mga sumusunod na dokumento ay maaring isaalang-alang kung ang mga tratado at kasunduan ay pagbabatayan sa Kasangkapan sa Pagtatasang ito: '1) mga tratado pinagkasunduan sa pagitan ng Estado at ng Mga Katutubo; 2) ang mga kasunduang binuo sa pagitan ng mga Estado o ibang entidad at ng mga Katutubo; 3) ang ibang konstruktibong kaayusang kinahantungan na may partisipasyon ng mga pinatutungkulang Katutubo; [at] 4) ang mga tratadong pinagkasunduan sa pagitan ng mga Estado na naglalaman ng mga probisyon na makaaapekto sa mga katutubo bilang pangatlong partido...' (United Nations 1999: para. 37). 


\section{Kasangkapan} sa Pagtatasa sa Karapatan ng mga Katutubo sa Konstitusyon 


\section{Listahan ng mga katanungan}

I. Pagkilala at pagkamamamayan

1 Partikular ba na kinikilala, tinutukoy o binibigyang kahulugan ng konstitusyon ang mga katutubo, kasama ang proteksyon ng karapatan sa pagkilala sa sarili?

2 Kinikilala ba ng konstitusyon ang estado bilang multikultural, multinasyunal o multi-etniko, o nagtataguyod ng mga kahalagahan ng pagkakaiba-iba at pagsasama sa iba pang mga paraan?

3 Tinitiyak ba ng konstitusyon ang pambansang pagkamamamayan para sa mga katutubo at may kasamang garantiya na ang pag-angkin ng katutubong pagkakakilanlan ay hindi makaaapekto sa karapatan sa pambansang pagkamamamayan?

\section{Karapatan sa pagkakapantay-pantay at kontra-diskriminasyon}

4 Tinitiyak ba ng konstitusyon ang pagkakapantay-pantay sa harap $\mathrm{ng}$ batas at ipinagbabawal ang diskriminasyon? Kung gayon, kinikilala ba ang pang-etniko, panglahi o pangkultural na identidad bilang isa sa maraming ipinagbabawal na batayan para sa diskriminasyon?

5 Pinapayagan ba ng konstitusyon ang magmandato ng mga espesyal na hakbang na naglalayong makamit ang substantibong pagkakapantay-pantay para sa mga katutubo?

\section{Mga pundasyon para sa mga karapatan ng mga katutubo}

Kinikilala ba ng konstitusyon ang mga karapatan ng mga katutubo bilang karagdagan sa, at hindi kapalit ng, mga pundamental na karapatan na ginagarantiya sa lahat ng mga mamamayan?

7 Kinikilala ba ng konstitusyon ang karapatan ng mga katutubo sa sariling pagpapasya bilang isang pundasyon para sa mga karapatan ng ibang mga katutubo?

8 Kinikilala ba ng konstitusyon ang mga kolektibong karapatan? Kung gayon, ito ba ay isang pangkalahatang pagkilala o espesipiko sa mga katutubo?

9 Ang konstitusyon ba ay naglalaan ng kung paano ang mga pundamental na mga karapatan ng mamamayan at karapatang pantao, kabilang ang pagkakapantay-pantay sa harap ng batas at mga proteksyon para sa kababaihan at iba pang mga magkakaugnay na bulnerableng grupo, ay dapat na maipagkasundo sa mga karapatan ng mga katutubo?

IV. Awtonomiya: Paggawa ng kasunduan at sariling pamahalaan

10 Iginagalang ba ng konstitusyon ang makasaysayan at panghinaharap na paggawa ng kasunduan o mga pagsasaayos ng tratado sa pagitan ng mga katutubo at ng estado sa paraan na nagpapatunay sa likas na soberanya (awtonomiya) ng mga katutubo?

11 Kinikilala ba ng konstitusyon ang mga karapatan ng mga katutubo sa awtonomiya at sariling pamahalaan, teritoryo o hindi?

12 Ang konstitusyon ba ay nagbibigay ng karapatan sa mga katutubo upang mapanatili at mailapat ang kanilang mga nakaugaliang batas at proseso $\mathrm{ng}$ paglutas ng hindi pagkakasundo sa kanilang mga teritoryo? 
13 Pinoprotektahan ba ng konstitusyon ang karapatan ng mga katutubo sa konsultasyon sa pamamagitan ng kanilang piniling mga kinatawan sa pormal na pagkilala sa mga samahan ng mga katutubo o kung hindi man ay sa pagtatatag ng isang espesyalisadong mekanismo ng pagkonsulta sa pagitan ng mga katutubo at ng gobyerno?

14 Kinikilala ba at naglalaan ang konstitusyon ng isang mekanismong elektoral para matiyak ang karapatan ng mga katutubo sa pulitikal na pakikilahok at representasyon, partikular sa lehislatura ng estado?

15 Naglalaan ba ang konstitusyon ng mga mekanismo upang maisulong ang representasyon ng mga katutubo sa ehekutibong sangay ng pamahalaan?

16 Tinitiyak ba ng konstitusyon na ang representasyon ng mga katutubo sa hudisyal na sangay ay isinasaalang-alang at ang mga mekanismo ng hudisyal na pagtatalaga, lalo na ang sa mga kataas-taasan o konstitusyonal na korte, ay nagsusulong sa ingklusyon ng mga katutubo?

17 Iginagarantiya o isinusulong ba ng konstitusyon ang pangangalap o pagtatalaga ng mga katutubo sa mga posisyon ng serbisyo sibil, mga independiyenteng kinatawan at militar?

\section{Karapatan sa lupa, teritoryo at likas na yaman}

18 Kinikilala ba ng konstitusyon ang espesyal na ugnayan sa pagitan ng mga katutubo at sa lupa, kasama na ang pagprotekta sa kolektibong mga karapatan sa pagmamay-ari sa mga lupang ninuno at teritoryo at pagtataguyod ng mataas na pataw para sa pang-aagaw sa mga lupain ng mga katutubo?

19 Makakaya ba ng konstitusyon ang mga espesyal na karapatan ng mga katutubo sa kanilang mga likas na yaman sa loob/mismo/ilalim ng kanilang mga lupain at teritoryo? Humihiling ba ang konstitusyon sa mga katutubo ng pagbabahagi ng benepisyo sa mga kapwa katutubo hinggil sa mga isinasagawang gawain sa kanilang lupain na nauugnay sa likas na yaman?

20 Inaatasan ba ng konstitusyon ang gobyerno na kumunsulta nang may mabuting hangarin sa mga katutubo o humingi ng kanilang malaya, nauna at malinang na kapahintulutan (FPIC) bago ipatupad ang mga proyektong pangkaunlaran at iba pang mga patakaran na may epekto sa mga katutubong lupain, teritoryo, karapatan at yaman?

\section{Karapatan sa kultura, at panlipunan at pang-ekonomikong pag-unlad}

21 Pinoprotektahan ba ng konstitusyon ang mga karapatan ng mga katutubo na panatilihin at paunlarin ang kanilang mga kultura, pagkakakilanlan at kasanayan sa kultura, at igalang sila?

22 Kinikilala ba ng konstitusyon ang mga katutubong wika at ang mga kaugnay na karapatan sa wika?

23 Pinoprotektahan ba ng konstitusyon ang karapatan ng mga katutubo sa sariling wika at angkop-sa-kulturang edukasyon?

24 Pinoprotektahan ba ng konstitusyon ang karapatan ng mga komunidad ng katutubo upang patuloy na magsanay ng kanilang mga aktibidad sa pamumuhay (tradisyunal na paraan ng hanapbuhay)?

25 Pinoprotektahan ba ng konstitusyon ang karapatan sa kalusugan ng mga katutubo, kasama na ang paggamit sa mga tradisyunal na gamot at serbisyo?

26 Kinikilala ba ng konstitusyon ang mga karapatan ng mga katutubong komunidad sa pagmamay-ari ng intelektwal na ari-arian sa kabila ng kanilang tradisyunal na kaalaman at tradisyunal na ekspresyon sa kultura? 


\section{Pangangalaga at pagtataguyod sa mga karapatan ng mga katutubo $\quad$ Pahina}

$27 \quad$ Nagtatatag ba ang konstitusyon ng pambansang komisyon ng mga katutubo,

ministeryo o iba pang espesyalisadong kinatawan ng gobyerno upang itaguyod at protektahan ang mga karapatan ng mga katutubo?

28 Ipinapahiwatig ba ng konstitusyon, sa maraming latag na estruktura ng estado, kung aling (mga) antas ng pamahalaan ang pangunahing responsable para sa koordinasyon, proteksyon at pagsulong ng mga karapatan ng mga katutubo?

29 Kasama ba sa konstitusyon ang mga patakaran para sa 'paninindigan' na bukas sa publiko at aksesible upang matiyak ang karapatan ng mga katutubo sa pag-abot sa korte?

30 Ginagarantiya ba ng konstitusyon ang ligal na tulong para sa mga tao at pangkat na hindi kayang bayaran ang pribadong ligal na representasyon?

31 Malinaw bang tinukoy ng konstitusyon ang mga pinapayagang batayan o proseso para sa mga limitasyon ng mga karapatan, at tinitiyak na makatarungan ang mga ito?

32 Nakasaad ba sa konstitusyon na ang mga tratadong pang-internasyonal na karapatang pantao ay awtomatikong eepekto sa sandaling mapagtibay, o kinakailangan pa ang pangalawang proseso ng domestikasyon?

33 Pinahihintulutan, hinihikayat o hinihiling ba ng konstitusyon ang mga korte na isaalangalang ang mga dayuhang batas kapag binibigyang kahulugan nila at inilalapat ang mga probisyon ng karapatang pantao?

34 Hinihikayat o hinihingi ba ng konstitusyon ang mga korte at iba pang mga kinatawan na isaalang-alang ang internasyunal na batas kapag binibigyang kahulugan nila at inilalapat ang mga probisyon ng karapatang pantao? 
$\therefore$

$88: 8: 8: 8$

30
30 3\%:

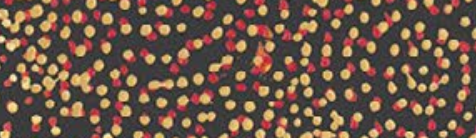

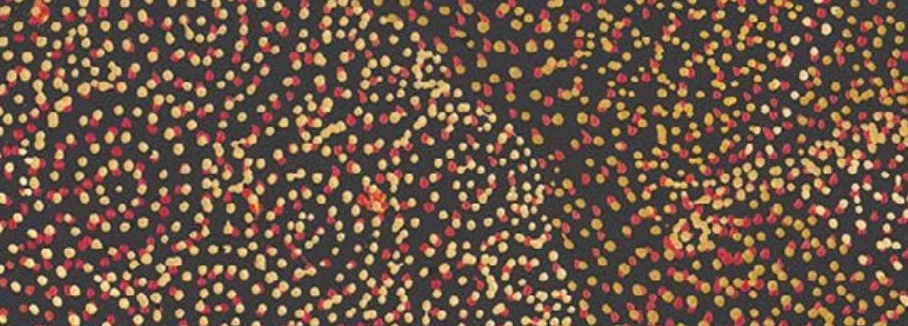

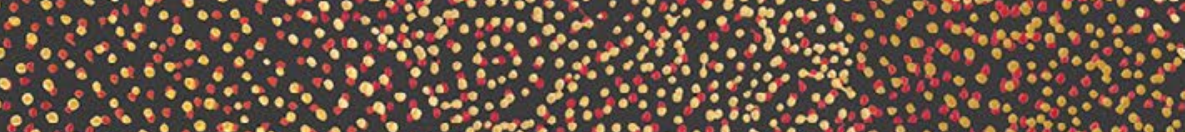

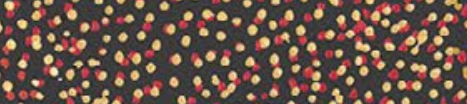

$8 \%$
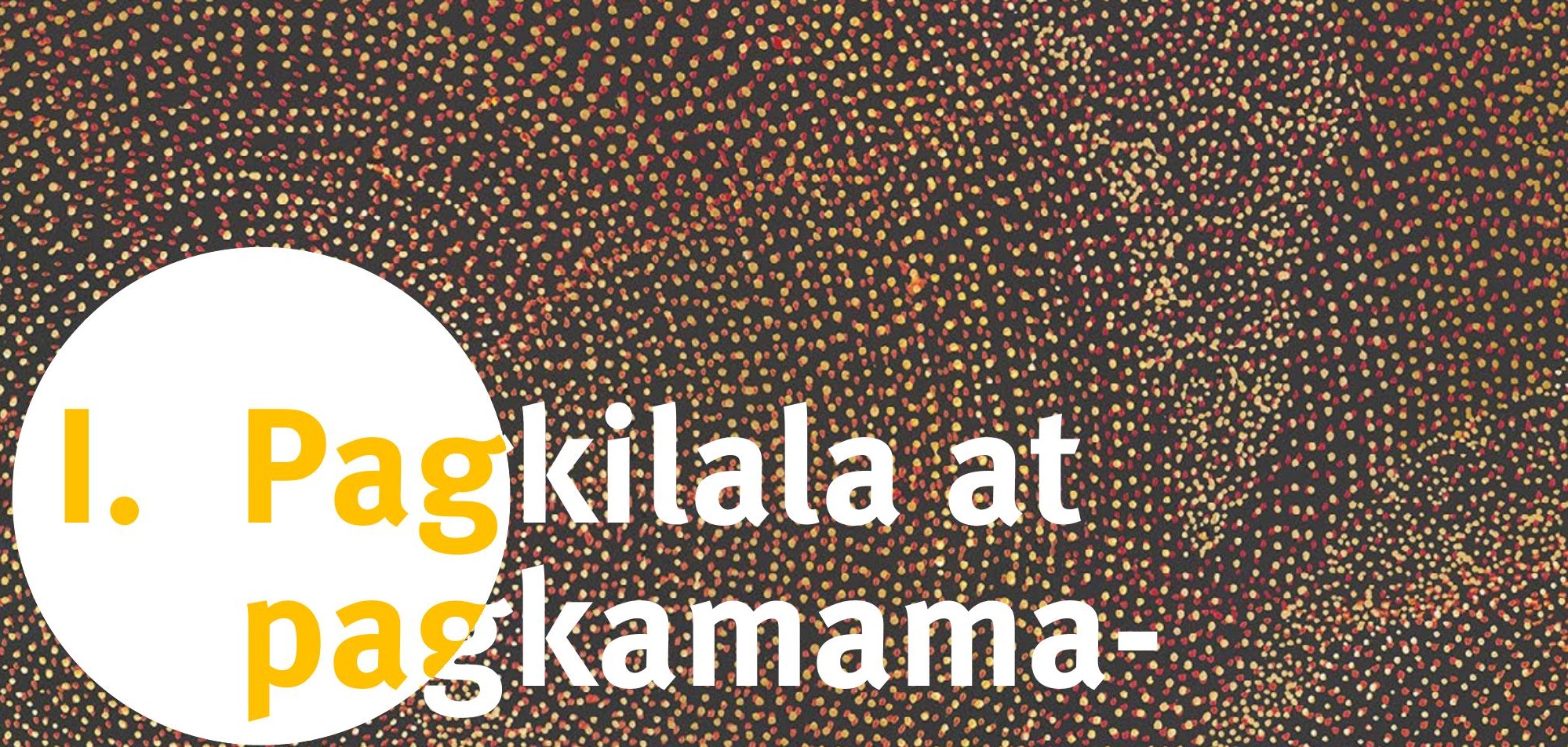

$110 \mathrm{H}: 14 \%$

Quostons 1 3

$\therefore$

89

46.8.

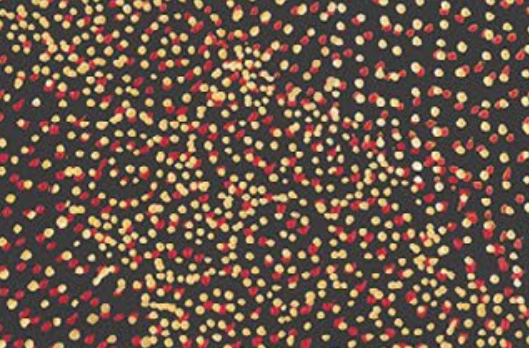

0
0

30 


\section{Pagkilala at pagkamamamayan}

\section{Partikular ba na kinikilala, tinutukoy o binibigyang kahulugan ng konstitusyon ang mga katutubo, kasama ang proteksyon ng karapatan sa pagkilala sa sarili?}

\section{PALIWANAG}

Bilang isang paunang kondisyon para sa pagkilala at pagpapatupad ng anumang mga karapatang tinalakay sa kasangkapang ito, kapaki-pakinabang para sa mga katutubo na malinaw na kilalanin at/o 'bigyang kahulugan' bilang mga mamamayan sa loob ng konstitusyon. Ang mga konstitusyon ay madalas na nagsasama ng mga proteksyon para sa o pagkilala sa mga minorya at/o marhinalisadong pangkat, at kung minsan ay ipinapalagay na ang mga katutubo ay kabilang sa kategoryang ito; gayunpaman, upang marespeto ang karapatan ng mga katutubo, mahalagang kilalanin ang natatanging identidad ng mga katutubo sa pamamagitan ng isang natatanging katayuang ligal. Ang pagkilala sa katutubong identidad ay nagbibigay ng karapatan sa mga katutubo sa isang tiyak na hanay ng mga karapatan na naiiba sa pangkalahatang mga karapatan ng minorya. Kung ang isang detalyadong kahulugan ng mga katutubo ay hindi kasama sa konstitusyon, maaari din itong tugunan sa pamamagitan ng lehislasyon, na maaaring magsama ng mas detalyadong pamantayan para sa pagtukoy sa kung sino ang katutubo. Saanman binibigyang kahulugan ang mga katutubo, mahalaga na ang ligal na balangkas ay tumutukoy din sa isang malinaw na proseso sa kung paano maaaring praktikal na makuha ng mga katutubong indibidwal at grupo ang pormal na pagkilala mula sa estado, o katulad na dokumentasyon.

Ang mga kahulugan ng mga katutubo ay dapat na kontekstwalisado at paunlarin sa pamamagitan ng mga konsultasyon sa mismong mga katutubo. Ang mga kahulugan ay dapat na dinisenyo upang hindi maging labis na ingklusibo (halimbawa, sa pamamagitan ng pagsasama ng iba pang mga pangkat na minorya) o kulang na ingklusibo (halimbawa, sa pamamagitan ng hindi pagsasama sa ilang mga katutubo). Habang ang mga kahulugan ay magkakaiba batay sa konteksto, ang ilang mga karaniwang 'obhetibong' mga elemento ng kahulugan, na naaayon sa mga pamantayang pang-internasyonal, ay: pagpapatuloy ng kasaysayan bago ang pananakopat/o prekolonyal na mga lipunan na nabuo sa kanilang mga teritoryo; pagkakaiba-iba; hindi pangingibabaw; at ang pagpapasiya na pangalagaan, paunlarin at ipadala sa mga susunod na henerasyon ang mga teritoryo ng kanilang mga ninuno at pagkakakilanlan bilang mga mamamayan, alinsunod sa kanilang sariling mga disenyo sa kultura, mga institusyong panlipunan at sistemang ligal (Martínez Cobo 1987; tingnan ang Seksyon VI at VII para sa karagdagang detalye ng paksang ito). Bilang karagdagan, ang mga kahulugan ng mga katutubo ay madalas na nagsasama ng mga sanggunian sa isang espesyal na ugnayan o malakas na pagkakadugtong sa mga teritoryo at likas na yaman, magkakaibang mga panlipunan, pang-ekonomiya o pampulitikang sistema, at magkakaibang mga wika, kultura, at paniniwala.

Kritikal na ang karapatan ng mga katutubo sa pakilala sa sarili ay masasalamin sa kahulugan at ang mga katutubo ay hindi maaaring malagyan ng tatak nang walang pahintulot na nakasaad sa Kumbensyon ng ILO 169 (ILO 1989: artikulo 1 (2)). Bagama't walang iisang kahulugan ng 'mga katutubo', itinataguyod ng Kumbensyon ng ILO 169 ang prinsipyo ng pagkilala sa sarili: na ang mga katutubo at indibidwal ay may karapatang maging bahagi ng isang katutubong komunidad o nasyon alinsunod sa mga tradisyon at kaugalian ng partikular na pamayanan o nasyon. Dahil dito, ang mga katutubo ay dapat magkaroon ng karapatang kilalanin ang sarili bilang katutubo, at ang mga indibidwal ay dapat ding magkaroon ng karapatang isaalang-alang ang kanilang mga sarili na katutubo o hindi. Kasama rito, samakatwid, ang isang karapatang humiwalay sa isang katutubong pagkakakilanlan. 


\begin{tabular}{|c|c|c|c|}
\hline $\begin{array}{l}\text { Kumbensyon } \\
\text { ng ILO } 169 \\
1989\end{array}$ & $\begin{array}{l}\text { Artikulo 1(1) } \\
\text { at 1(2) }\end{array}$ & 2. & $\begin{array}{l}\text { Nailalapat ang Kumbensyon na ito sa: } \\
\text { (a) mga tribung mamamayan sa mga } \\
\text { malayang bansa na ang mga kalagayang } \\
\text { panlipunan, pangkultura, at pang- } \\
\text { ekonomiya ay nakikilala mula sa iba pang } \\
\text { mga seksyon ng pambansang pamayanan, } \\
\text { at ang kanilang katayuan ay kinokontrol } \\
\text { nang buo o bahagya ng kanilang sariling } \\
\text { mga kaugalian o tradisyon o ng mga } \\
\text { espesyal na batas o regulasyon; } \\
\text { (b) mga mamamayan sa mga malayang } \\
\text { bansa na itinuturing na katutubo dahil } \\
\text { sa kanilang pinagmulan mula sa mga } \\
\text { populasyon na nanirahan sa bansa, } \\
\text { o isang heograpikong rehiyon kung } \\
\text { saan kabilang ang bansa, sa panahon } \\
\text { ng pananakop o kolonisasyon o ang } \\
\text { pagtatatag ng kasalukuyang mga } \\
\text { hangganan ng estado at sinuman, nang } \\
\text { hindi alintana ang kanilang ligal na } \\
\text { katayuan, na pinananatili ang ilan o lahat } \\
\text { ng kanilang sariling mga institusyong } \\
\text { panlipunan, pang-ekonomiya, pangkultura } \\
\text { at pampulitika. } \\
\text { Ang pagkakakilanlan sa sarili bilang } \\
\text { katutubo o tribo ay dapat ituring bilang } \\
\text { isang pundamental na pamantayan } \\
\text { para sa pagtukoy ng mga pangkat kung } \\
\text { saan nalalapat ang mga probisyon ng } \\
\text { Kumbensyong ito. }\end{array}$ \\
\hline
\end{tabular}

\begin{tabular}{|c|c|c|}
\hline $\begin{array}{l}\text { UNDRIP } \\
2007\end{array}$ & Artikulo 9 & $\begin{array}{l}\text { Ang mga katutubo at indibidwal ay may } \\
\text { karapatang mapabilang sa isang katutubong } \\
\text { komunidad o nasyon, alinsunod sa mga tradisyon } \\
\text { at kaugalian ng pinatutungkulang komunidad o } \\
\text { bansa. Walang anumang uri ng diskriminasyon } \\
\text { ang maaaring umusbong mula sa paggamit ng } \\
\text { naturang karapatan. }\end{array}$ \\
\hline
\end{tabular}

\begin{tabular}{|c|c|c|}
\hline $\begin{array}{l}\text { Konstitusyon } \\
\text { ng Bolivia } \\
2009\end{array}$ & Artikulo $30(\mathrm{I})$ & $\begin{array}{l}\text { I. Ang isang nasyon at natibong rural na mga } \\
\text { katutubo ay binubuo ng bawat kolektibong } \\
\text { tao na mayroong iisang pagkakakilanlan sa } \\
\text { kultura, wika, tradisyon ng kasaysayan, mga } \\
\text { institusyon, teritoryo at pananaw sa mundo, } \\
\text { na ang kairalan ay nauna pa sa kolonyal na } \\
\text { pananakop ng mga Espanyol. }\end{array}$ \\
\hline
\end{tabular}

\begin{tabular}{l|l}
$\begin{array}{l}\text { Konstitusyon } \\
\text { ng Mehiko }\end{array}$ & Artikulo 2 \\
\hline 1917 &
\end{tabular}

Ang Bansang Mehico . . . ay nag-ugat sa mga katutubo, na binubuo ng mga nagmula sa mga taong naninirahan sa kasalukuyang teritoryo ng bansa sa simula ng kolonisasyon at napanatili ang bahagya ng kanilang sariling mga institusyong panlipunan, pang-ekonomiya, pangkultura, at pampulitika. Ang pagkakaroon ng kamalayan sa kanilang katutubong pagkakakilanlan ay dapat maging isang pangunahing pamantayan sa pagtukoy sa kanino naglalapat ang mga probisyon sa mga katutubo.Ang mga pamayanan ng mga katutubo ay ang mga bumubuo ng isang panlipunan, pang-ekonomiya, at pangkulturang yunit, na matatagpuan sa isang teritoryo, at mayroong kani-kanilang mga awtoridad alinsunod sa kanilang tradisyon at kaugalian.

\begin{tabular}{l|l}
$\begin{array}{l}\text { Konstitusyon } \\
\text { ng Paraguay } \\
1992\end{array}$ & Article 62 \\
\hline
\end{tabular}

Kinikilala ng Konstitusyon ang kairalan ng mga katutubo, na tinukoy bilang mga pangkulturang grupo bago ang pagbuo at pag-aayos ng estado ng Paraguay.
Nagbibigay ng halimbawang wika sa pamantayan at mga karaniwang katangian na maaaring magamit upang tukuyin ang mga katutubo

Kinikilala ang pagkakakilanlan sa sarili bilang isang pundamental na pamantayan

Nagbibigay para sa karapatan ng mga katutubo na maging kabilang sa isang pamayanan o bansa, nang walang diskriminasyon

Nagbibigay ng listahan ng pamantayan na 'layunin' para sa pagtukoy sa mga katutubo

Nagbibigayng halimbawang pamantayan kung saan matutukoy kung sino ang katutubo, kasama ang 'kamalayan sa kanilang katutubong pagkakakilanlan'sa ngalan ng mga indibidwal (pagkilala sa isang karapatang kilalanin ang sarili)
Kinikilala at isinasama ang batayang kahulugan ng mga katutubo (kairalan bago ang estado). 


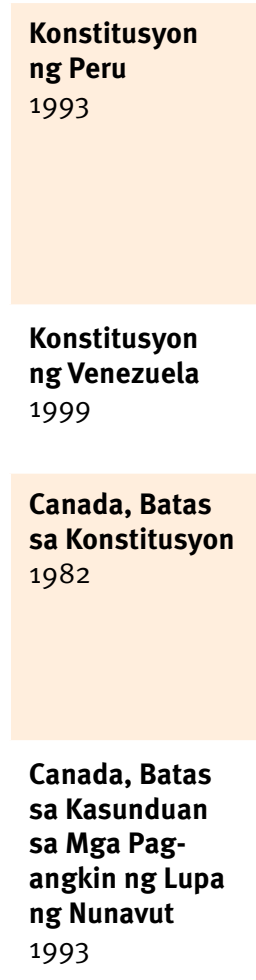

Artikulo 89

Artikulo 126

Artikulo 126

Bahagi II (Mga

Karapatan

ng Mga

Aborihinal na

Mamamayan

ng Canada),

seksyon 35 (2)

Artikulo 35

(Pag-aasikaso)

35.1.1 Sa artikulong ito:

\begin{tabular}{l|l}
$\begin{array}{l}\text { Finland, Batas } \\
\text { sa Parlamento } \\
\text { ng Sámi }\end{array}$ & Tsapter 1, \\
1995 & seksyon 3 \\
\hline
\end{tabular}

Para sa layunin ng Batas na ito, ang isang Sámi

Nepal, Batas ng Artikulo 2(a) Pambansang

Pundasyon

para sa

Pagpapaun-lad

ng Katutubong

Nasyonalidad

2002 (a) kinikilala na ang Inuit ang may pinakamahusay na kakayahang tukuyin kung sino ang isang Inuk para sa mga layunin ng Kasunduang ito;

(b) ginagarantiya na ang Inuit ng Nunavut Settlement Area ay kikilalanin alinsunod sa kanilang sariling pag-unawa sa kanilang mga sarili, at ang Inuit ay tutukoy kung sino ang isang Inuk para sa mga layunin ng Kasunduang ito, at may karapatang magpatala sa ilalim ng Kasunduan.

Kahulugan ng isang Sámi ay nangangahulugang isang tao na isinasaalangalang ang kanyang sarili na isang Sámi, yayamang:

(1) Siya mismo o kaya'y isa sa kanyang mga magulang o lolo’t lola ay natutuhan ang Sámi bilang kanyang unang wika;

(2) Siya ay apo ng isang tao na pumasok sa pagrehistro ng lupain, pagbubuwis o populasyon bilang isang bundok, kagubatan o pangisdaang Lapp; 0

(3) Kahit isa sa kanyang mga magulang ay nakarehistro o maaaring nakarehistro bilang isang tagahalal para sa isang eleksyon sa Delegasyon ng Sámi o sa Parlamento ng Sámi.

Kinikilala ang ligal na pag-iral ng mga katutubo at komunidad bilang mga korporadong entidad (mga ligal na implikasyon hinggil sa mga kolektibong karapatan, tingnan ang Tanong 8) at nananawagan sa estado na igalang ang pagkakakilanlang ito

Kinikilala ang mga katutubo bilang bahagi ng estado (na may kaukulang obligasyon na igalang ang 'integridad' ng nasyon)

Nagbibigay sa espesipikong mga tribong katutubo ng konstitusyonal na pagkilala bilang mga katutubo (aborihinal)

Kinikilala ang buong karapatan sa pagkilala sa sarili

Pinagsasama-sama ang mga obhetibong pamantayan at subhetibong pagkakakilanlan sa sarili upang bigyang kahulugan ang mga katutubo (Sámi)

Nagbibigay ng kahulugan sa mga katutubo na may mga obhetibong

'Ang mga katutubog nasyonalidad' ay nangangahulugang isang tribo o pamayanan katulad ng nabanggit sa iskedyul na may sariling wika at tradisyonal na ritwal at kaugalian, natatanging pagkakakilanlang pangkultura, natatanging estrukturang panlipunan at nakasulat o hindi nakasulat na kasaysayan. mga pamantayan (kriteryo) 


\section{MGA NAPAG-ALAMAN}

Sagot sa tanong (Oo/Hiindi) at iba pang mga tala at obserbasyon tungkol sa kung gaano kahusay na tinutugunan $n g$ konstitusyon ang (mga) isyu na itinanong. Isama ang mga makabuluhang mga probisyon ((mga) numero $n g$ artikulo at teksto $n g$ (mga) probisyon). Tandaan din ang hindi konsistent at/o magkasalungat na mga probisyon, o kung walang umiiral na mga kaugnay na probisyon.

\section{MGA HAKBANG}

Iminungkahing adbokasiya at iba pang mga kasunod na hakbang upang matugunan o mapalaganap ang mga natuklasan. 


\section{Pagkilala at pagkamamamayan}

\section{Kinikilala ba ng konstitusyon ang estado bilang multikultural, multinasyunal, o multi-etniko, o nagtataguyod ng mga kahalagahan ng pagkakaiba-iba at pagsasama sa iba pang mga paraan?}

PALIWANAG

Ang ilang mga konstitusyon ay nagsasama ng mga simbolikong deklarasyon na naghahangad na maipahayag at tukuyin 'ang mga mamamaya' na bumubuo ng isang estado. Ang isang bisyon ng 'mga mamamayan' ay maaaring mailatag sa preambulo_-ang seksyon ng introduksyon ng konstitusyon—na maaaring magsama ng isang paglalarawan ng: kasaysayan ng konstitusyon, ang mga kahalagahan at mithiin ng mga mamamayan, ang likas na katangian ng estado, at ang awtoridad kung saan nilikha ang konstitusyon. Ang paggalang sa pagkakaibaiba, dignidad ng tao at pagkakapantay-pantay sa lipunan ay maaaring maging partikular na mahalaga sa mga konteksto pagkatapos ng tunggalian o sa mga bansa na may kinagisnang makasaysayang marhinalisasyon at/o panlipunan pagbubukod.

Ang mga nasabing simbolikong probisyon, bagama’t hindi kinakailangang may bisa sa isang korte, ay isinasaad ang pangako ng estado sa mga kahalagang inilalarawan nito, at inilaan upang gabayan ang lehislatura, ehekutibo, at hudikatura. Ang mga preambula at direktibang prinsipyo ay maaaring isangguni ng lehislatura o hudikatura upang gabayan ang interpretasyon ng iba pang mga bahagi ng konstitusyon. Sa ganitong paraan, maaari silang magsilbing daan ng pagpasok para sa karagdagang adbokasiya. Habang nagbibigay ng naturang paraan ng pagpasok, ang bersyon ng pagkilalang ito ay mas mahina kaysa sa ipinaliwanag sa Tanong 1 tungkol sa espesipikong pagkilala at kahulugan ng mga katutubo bilang bahagi ng pambansang populasyon.

Habang ang simbolikong pagkilala sa halaga ng pagkakaiba-iba sa lipunan ay maaaring maging kritikal para sa kung paano ang ibang bahagi ng konstitusyon ay nagbibigay-daan sa mga karapatan ng mga katutubo at namamahala sa pagkakaiba-iba, madalas na hindi ito sapat na batayan para sa pagbibigay ng masiglang proteksyon sa mga karapatan at interes ng mga katutubo. Mahalaga na ang tiyak na pagkakakilanlan at mga karapatan ng mga katutubo, at ang pangako ng estado na tiyakin ang proteksyon ng naturang mga karapatan, ay protektado sa isang konstitusyon. Ang simbolikong pagkilala at paggalang sa pagkakaiba-iba ay maaaring mapatibay sa pamamagitan ng pagkilala sa pagkakapantay-pantay sa harap ng batas at pagbabawal ng diskriminasyon, o sa pagkilala sa ilang mga karapatan, tulad ng karapatan sa panlipunang hustisya, bilang mga karapatang konstitusyonal. 


\begin{tabular}{|c|c|c|c|}
\hline $\begin{array}{l}\text { Konstitusyon } \\
\text { ng Bolivia } \\
2009\end{array}$ & $\begin{array}{l}\text { Preambulo at } \\
\text { artikulo }\end{array}$ & $\begin{array}{l}\text { Preambulo } \\
\text { Kami, ang mga mamamayan ng Bolivia, na may } \\
\text { maramihang komposisyon, mula sa kailaliman } \\
\text { ng kasaysayan, na inspirado ng mga pakikibaka } \\
\text { ng nakaraan, ng anti-kolonyal na pag-aalsa ng } \\
\text { mga katutubo, at sa kalayaan, ng mga tanyag } \\
\text { na pakikibaka ng paglaya, ng mga katutubo, } \\
\text { panlipunan at obrerong martsa, sa katubigan at } \\
\text { digmaang Oktubre, sa pakikibaka para sa lupa } \\
\text { at teritoryo, ay bumuo ng isang bagong Estado } \\
\text { bilang alaala ng aming mga martir. } \\
\text { Isang Estadong nakabatay sa paggalang at } \\
\text { pagkakapantay-pantay para sa lahat, sa mga } \\
\text { prinsipyo ng soberenya, dignidad, pagkakaugnay- } \\
\text { ungay, pagkakaisa, armonya, at ekidad sa } \\
\text { pamamahagi at muling pamamahagi ng yamang } \\
\text { panlipunan, kung saan nangingibabaw ang } \\
\text { paghahanap para sa isang mabuting buhay; } \\
\text { batay sa paggalang sa pang-ekonomiya, } \\
\text { panlipunan, huridikal, pulitikal at pangkulturang } \\
\text { pluralismo ng mga naninirahan sa lupaing ito; at } \\
\text { sa sama-samang pamumuhay na may karapatan } \\
\text { sa tubig, trabaho, edukasyon, kalusugan at } \\
\text { pabahay para sa lahat. } \\
\text { Artikulo } 3 \\
\text { Ang bansang Bolivia ay binubuo ng mga Bolivian, } \\
\text { mga katutubong nasyon at mga mamamayan, at } \\
\text { ang mga inter-kultural at Afro-Bolivian na mga } \\
\text { pamayanan na, sa pagsasama-sama, ay bumubuo } \\
\text { sa sambayanang Bolivia. }\end{array}$ & $\begin{array}{l}\text { Sinasangguni ang } \\
\text { 'maramihangkomposisyon' ng } \\
\text { pambansang populasyon, pati na rin } \\
\text { ang pag-aalsa ng mga katutubo at } \\
\text { mga martsa ng mga katutubo bilang } \\
\text { isang kontribusyon sa lipunan } \\
\text { Inilalarawan ang konsepto ng } \\
\text { 'kolektibongpag-iiralan' bilang isang } \\
\text { pinagbabatayang bisyon ng estado } \\
\text { Kinikilala ang mga katutubong } \\
\text { bansa at mamamayan bilang bahagi } \\
\text { ng 'mamamayang Bolivia' }\end{array}$ \\
\hline $\begin{array}{l}\text { Konstitusyon } \\
\text { ng Fiji } \\
2013\end{array}$ & Preambulo & $\begin{array}{l}\text { KAMI, ANG MGA MAMAMAYAN NG FIJI, NA } \\
\text { KINIKILALA ang mga katutubo o ang iTaukei, ang } \\
\text { kanilang pagmamay-ari sa mga lupain ng iTaukei, } \\
\text { ang kanilang natatanging kultura, kaugalian, } \\
\text { tradisyon at wika; NA KINIKILALA ang mga } \\
\text { katutubo o ang Rotuman mula sa isla ng Rotuma, } \\
\text { ang kanilang pagmamay-ari ng mga lupain ng } \\
\text { Rotuman, ang kanilang natatanging kultura, } \\
\text { kaugalian, tradisyon, at wika; NA KINIKILALA ang } \\
\text { mga apo ng mga inalilang manggagawa mula } \\
\text { sa British India at mga Isla sa Pasipiko, kang } \\
\text { anilang kultura, kaugalian, tradisyon at wika; at } \\
\text { NA KINIKILALA ang mga apo ng mga naninirahan at } \\
\text { migrante sa Fiji, ang kanilang kultura, kaugalian, } \\
\text { tradisyon at wika, AY IPINAPAHAYAG na lahat } \\
\text { tayo ay mga Fijian na pinag-isa ng komun at } \\
\text { pantay na pagkamamamayan; AY KINIKILALA ang } \\
\text { Konstitusyon bilang kataas-taasang batas ng } \\
\text { ating bansa na nagbibigay ng balangkas para sa } \\
\text { kondukta ng Pamahalaan at lahat ng mga Fijian; } \\
\text { AY NANGANGAKO sa aming sarili ng pagkilala } \\
\text { at proteksyon sa mga karapatang pantao, at } \\
\text { paggalang sa dignidad ng tao; AY IPINAHAHAYAG } \\
\text { ang aming pangako sa katarungan, pambansang } \\
\text { soberenya at seguridad, kagalingang panlipunan } \\
\text { at pang-ekonomiya, at pangalaga sa ating } \\
\text { kapaligiran, AY SAMAKTWID ITINATAGUYOD ANG } \\
\text { KONSTITUSYON NA ITO PARA SA REPUBLIKA NG FIJI. }\end{array}$ & $\begin{array}{l}\text { Kinikilala ang iba t ibang mga } \\
\text { katutubo at ang kanilang mga } \\
\text { natatanging kultura at kasaysayan, } \\
\text { ngunit ang lahat ay pantay sa } \\
\text { pagkamamamayan at bahagi ng } \\
\text { mamamayang Fijian }\end{array}$ \\
\hline $\begin{array}{l}\text { Konstitusyon } \\
\text { ng Guatemala } \\
1985\end{array}$ & Artikulo 66 & $\begin{array}{l}\text { Ang Guatemala ay binubuo ng iba`t ibang mga } \\
\text { pangkat etniko kabilang ang mga natibong } \\
\text { pangkat na may lahi ng Mayan. Kinikilala, } \\
\text { iginagalang, at isinusulong ng Estado ang } \\
\text { kanilang anyo ng pamumuhay, kaugalian, } \\
\text { tradisyon, anyo ng samahang panlipunan, ang } \\
\text { pagsusuot ng damit na Indian ng mga kalalakihan } \\
\text { at kababaihan, ang kanilang mga wika, at } \\
\text { diyalekto. }\end{array}$ & $\begin{array}{l}\text { Kinikilala ang mga katutubo at ang } \\
\text { katunayan na sila ay bahagi ng } \\
\text { populasyon ng Guatemala }\end{array}$ \\
\hline
\end{tabular}




\begin{tabular}{l|l|l|}
$\begin{array}{l}\text { Konstitusyon } \\
\text { ng Mehiko } \\
1917\end{array}$ & Artikulo 2 \\
\hline $\begin{array}{l}\text { Konstitusyon } \\
\text { ng Nepal } \\
2015\end{array}$ & Preambulo \\
\hline & \\
\hline $\begin{array}{l}\text { Konstitusyon } \\
\text { ng Estados } \\
\text { Unidos } \\
\text { 1789 }\end{array}$ & Preambulo \\
\hline
\end{tabular}

Ang Bansang Mehico ay iisa [única] at hindi nahahati. Ang Bansa ay may multikultural na komposisyon na nakaugat sa mga katutubo nito. .

Pagprotekta at pagtataguyod ng pakikiisa ng lipunan at kultura, pagpapaubaya at pagkakasundo, at pagkakaisa sa pagkakaibaiba sa pamamagitan ng pagkilala sa iba't ibang katutubong pangkat, iba't ibang wika, iba't ibang paniniwala, iba't ibang kultura, at magkakaibang mga panrehiyong katangian, na nagreresolbang bumuo ng isang egalitaryong lipunan na itinatag sa proporsyonal na ingklusibo at mapanghikayat na mga prinsipyo ...

Kami ang Mamamayan ng Estados Unidos, upang makabuo ng isang mas perpektong Unyon, magtatag ng Hustisya, magsigurado ng domestikong Kapayapaan, maglaan para sa komun na depensa, magtaguyod ng pangkalahatang Kapakanan, at magtiyak na ligtas ang Basbas ng Kalayaan sa ating sarili at sa Salinlahi, ay nagtatalaga at nagtatatag ng Konstitusyong ito para sa Estados Unidos.

Ang Pilipinas,
Batas sa
Karapatan ng
Mga Katutubo
1997

Seksyon 31

Pagkilala sa Pagkakaiba-iba ng Kultura. Magsisikap ang Estado na magkaroon ng dignidad at pagkakaiba-iba ng mga kultura, tradisyon, kasaysayan, at mithiin ng mga ICC/ IP [mga katutubong pamayanang pangkultura/ katutubo] na naaangkop sa lahat ng uri ng edukasyon, impormasyong pampubliko, at palitang kultural-edukasyonal. Dahil dito, ang Estado ay magsasagawa ng mga mabisang hakbang, sa konsultasyon sa mga kinauukulang ICC/IP, upang mawala ang prehuwisyo at diskriminasyon at itaguyod ang pagpapaubaya, pag-unawa, at mabuting ugnayan sa mga ICC/ IP at lahat ng mga saray ng lipunan. Dagdag pa, ang Pamahalaan ay dapat gumawa ng mga mabisang hakbang upang matiyak na ang mga midyang pagmamay-ari ng Estado ay dapat na sumasalamin sa pagkakaiba-iba ng katutubong kultura. Titiyakin din ng Estado ang pakikilahok ng mga naaangkop na pinuno ng katutubo sa mga paaralan, pamayanan at mga gawaing kooperatiba sa internasyonal tulad ng pagdiriwang, kumperensya, seminar at palihan upang itaguyod at mapahusay ang kanilang natatanging pamana at kahalagahan.
Kinikilala ang multikultural na komposisyon at pag-iral ng mga katutubo bilang pundasyon ng estado

Kinikilala ang multi-etniko, multilinggwal, multirelihiyoso, multikultural na katangian ng estado at nangangako sa pagbuo ng isang lipunan batay sa pagkakapantaypantay at ingklusibidad

\section{Nagpapakita ng malawak} na pananaw ng "kami ang mamamayan' na maaaring unawain nang ingklusibo, nang walang espesipikong pagbanggit ng pagkakaiba-iba o mga grupo na bumubuo sa pagkamamamayan

Kinikilala ang pagkakaiba-iba ng kultura at ang dignidad ng lahat ng mga grupo at nananawagan para sa mga espesipikong aksyon upang matiyak na iginagalang ang pagkakaiba-ibang ito, kabilang ang (pagmamay-ari ng estadong) midya 


\section{MGA NAPAG-ALAMAN}

Sagot sa tanong (Oo/Hiindi) at iba pang mga tala at obserbasyon tungkol sa kung gaano kahusay na tinutugunan $n g$ konstitusyon ang (mga) isyu na itinanong. Isama ang mga makabuluhang mga probisyon ((mga) numero $n g$ artikulo at teksto $n g$ (mga) probisyon). Tandaan din ang hindi konsistent at/o magkasalungat na mga probisyon, o kung walang umiiral na mga kaugnay na probisyon.

\section{MGA HAKBANG}

Iminungkahing adbokasiya at iba pang mga kasunod na hakbang upang matugunan o mapalaganap ang mga natuklasan. 


\section{Pagktilala at tragkanamanamyan}

\section{Tinitiyak ba ng konstitusyon ang pambansang pagkamamamayan para sa mga katutubo at may kasamang garantiya na ang pag-angkin ng katutubong pagkakakilanlan ay hindi makaaapekto sa karapatan sa pambansang pagkamamamayan?}

\section{PALIWANAG}

Ang pantay na mga kondisyon ng pagkamamamayan ay nagbibigay-daan sa mga indibidwal na ganap na angkinin ang mga karapatan at proteksyon na ipinagkaloob sa mga mamamayan, at lumahok nang buong-buo sa buhay publiko. Dapat na magarantiya sa mga katutubo hindi lamang ang karapatang kilalanin ang sarili bilang katutubo kundi hindi rin dapat ito negatibong makaaapekto sa kanilang karapatan sa pambansang pagkamamamayan. Ang karapatan sa pagkamamamayan ng isang estado ay madalas na sinasamahan ng maraming mga karapatan, kabilang ang karapatang bumoto at ang karapatang humawak ng isang pasaporte o iba pang uri ng pagkakakilanlan na nagbibigay ng kalayaan sa pagkilos. Ang pagiging mamamayan ay pinagtitibay ang isang indibidwal bilang may-ari ng mga karapatan hinggil sa estado/pamahalaan. Tingnan ang Tanong 6 sa pagtiyak na ang mga karapatan ng mga espesyal na katutubo ay nakikita bilang isang karagdagan sa, sa halip na isang kapalit lang ng, mga pundamental na karapatang ipinangako sa lahat ng mga mamamayan.

Nagbibigay ang Bolivia ng isang mahusay na halimbawa ng praktika sa pamamagitan ng karagdagang hakbang sa isyung ito at tinitiyak na ang mga katutubo ay may karapatang kilalanin ang kanilang katutubo/tribong identidad na kinikilala sa kanilang mga opisyal na dokumento ng pagkamamamayan, kabilang ang mga pasaporte.

PAMANTAYANG PANG-INTERNASYUNAL AT PAMBANSANG MGA HALIMBAWA

\begin{tabular}{|l|l|}
\hline $\begin{array}{l}\text { UNDRIP } \\
2007\end{array}$ & $\begin{array}{l}\text { Artikulo } 6 \text { at } \\
33(1)\end{array}$ \\
\hline & \\
\hline & \\
\hline $\begin{array}{l}\text { Konstitusyon } \\
\text { ng Bolivia } \\
\text { 2009 }\end{array}$ & Artikulo 30(II, 3) \\
\hline
\end{tabular}

\begin{tabular}{l|l} 
Konstitusyon & Artikulo 6(2) \\
ng Ecuador \\
2008
\end{tabular}

Artikulo 6

Ang bawat indibidwal ay may karapatan sa isang nasyonalidad.

Artikulo 33

1. Ang mga katutubo ay may karapatang matukoy ang kanilang sariling pagkakakilanlan o pagiging miyembro alinsunod sa kanilang kaugalian at tradisyon. Hindi nito pinipinsala ang karapatan ng mga indibidwal na makakuha ng pagkamamamayan ng mga Estado kung saan sila nakatira.

$\mathrm{Na}$ ang kultural na pagkakakilanlan ng bawat miyembro, kung nanaisin niya, ay nakasulat kasama ng pagkamamamayan sa Bolivia sa kanyang kard sa pagkakakilanlan, pasaporte at iba pang mga dokumento sa pagkakakilanlan na may ligal na bisa.

Ang nasyonalidad ng Ecuador ay isang pampulitika at ligal na ugnayan sa pagitan ng mga indibidwal at ng Estado, nang walang pinsala sa kanilang pagkakasali sa alinman sa iba pang mga katutubong nasyon na magkakasabay na umiiral sa plurinasyunal na Ecuador.

\section{Konstitusyon Tsapter 3} ng Uganda 1995

\section{Ang mga sumusunod ay dapat na maging} mamamayan ng Uganda dulot ng kapanganakan-

a. bawat tao na ipinanganak sa Uganda na ang isa sa mga magulang o lolo't lola o miyembro ng alinman sa mga katutubong pamayanan na umiiral at naninirahan sa loob ng mga hangganan ng Uganda mula unang araw ng Pebrero 1926 at itinakda sa Ikatlong Iskedyul ng Konstitusyong ito ...
Nagbibigay ng mga pamantayang pang-internasyonal para sa pagkamamamayan ng katutubo kasama ang mga katutubo na may karapatan sa nasyonalidad at ang pagkilala bilang katutubo ay hindi makaaapekto sa kakayahan ng isang indibidwal na makuha ang naturang nasyonalidad

Nagbibigay ng karapatang maisama ang katutubong pagkakakilanlan sa mga pambansang papel ng pagkakakilanlan

Kinikilala na ang bisa ng pagkamamamayan ay umiiral kahit sa mga indibidwal na kabilang sa mga katutubong nasyon sa plurinasyunal na Ecuador

Tinutukoy nang malinaw ang mga mamamayan na isama ang mga tao na ang mga ninuno ay kabilang sa mga pamayanan ng katutubo 


\section{MGA NAPAG-ALAMAN}

Sagot sa tanong (Oo/Hiindi) at iba pang mga tala at obserbasyon tungkol sa kung gaano kahusay na tinutugunan $n g$ konstitusyon ang (mga) isyu na itinanong. Isama ang mga makabuluhang mga probisyon ((mga) numero $n g$ artikulo at teksto $n g$ (mga) probisyon). Tandaan din ang hindi konsistent at/o magkasalungat na mga probisyon, o kung walang umiiral na mga kaugnay na probisyon.

\section{MGA HAKBANG}

Iminungkahing adbokasiya at iba pang mga kasunod na hakbang upang matugunan o mapalaganap ang mga natuklasan. 


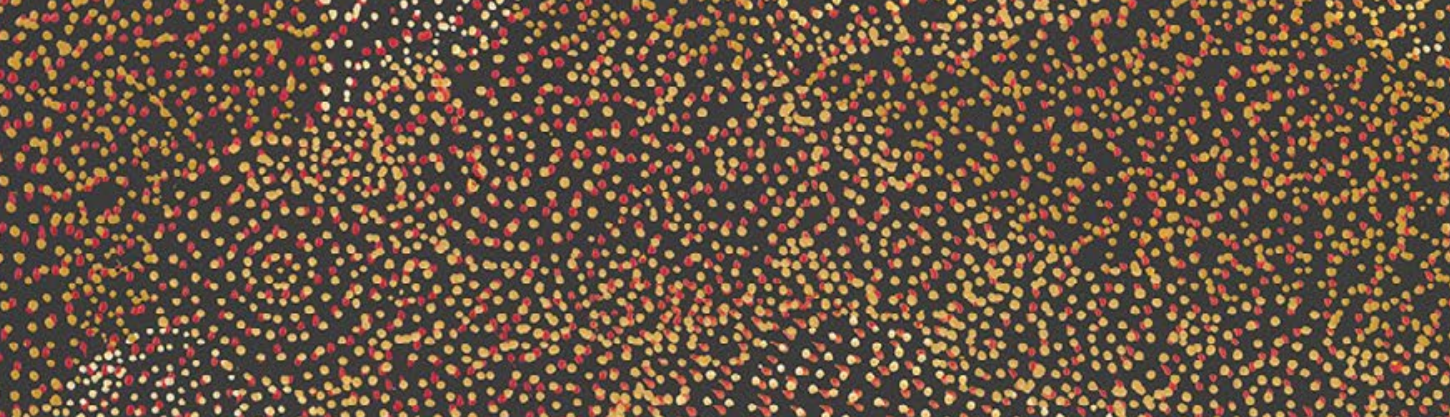

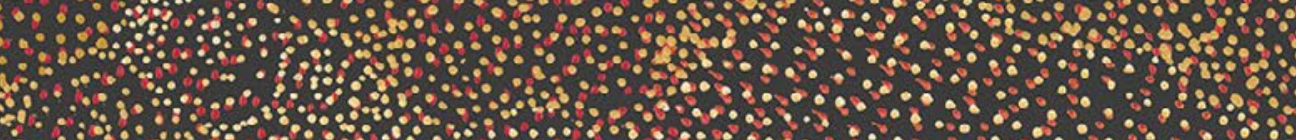

\%

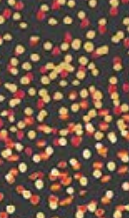

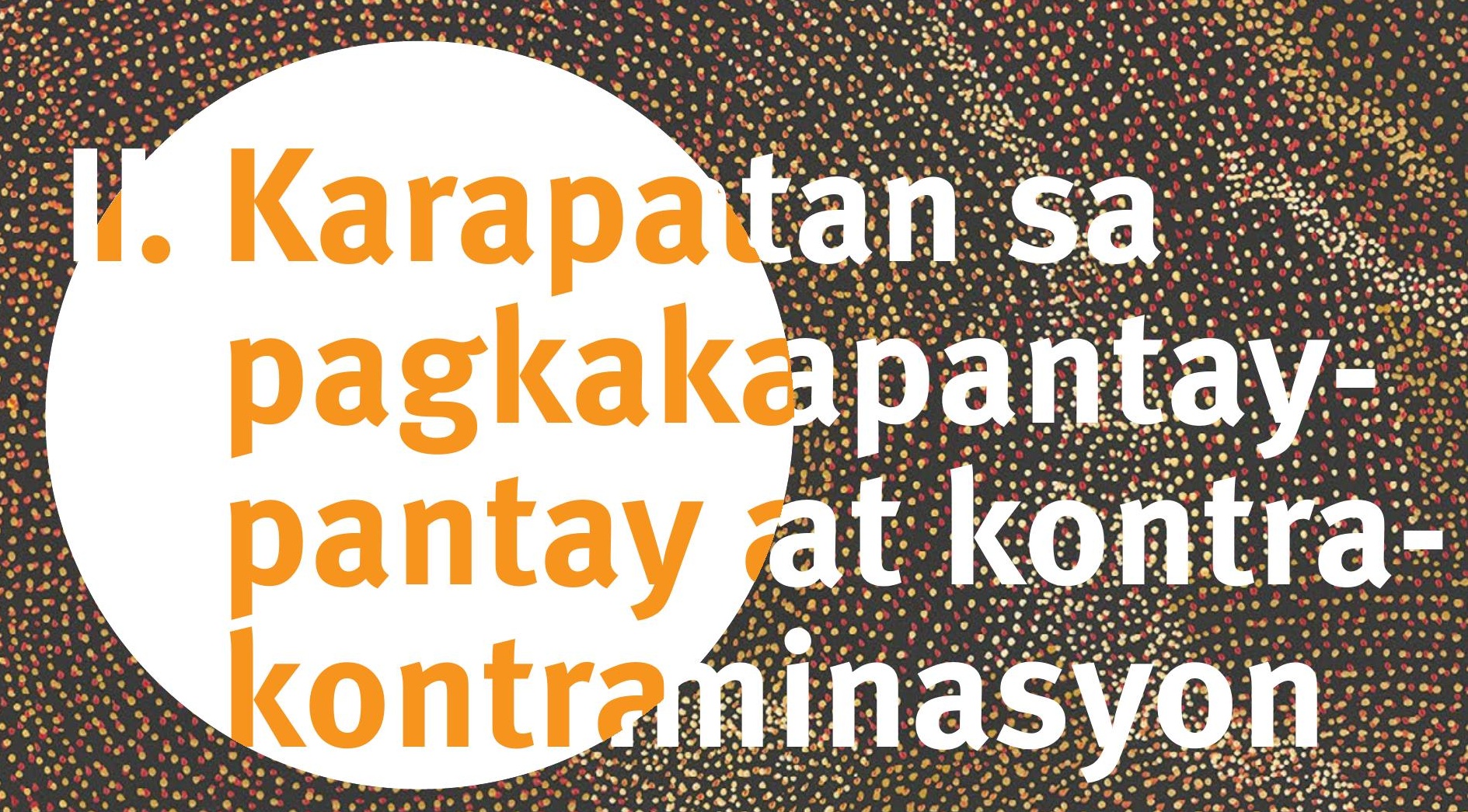
Mga Tanons/4;

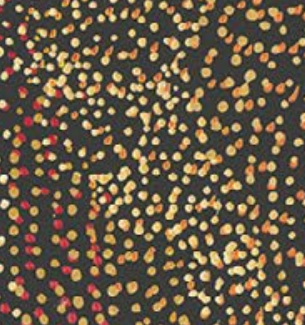

W
W 


\section{Karapatan sa pagkakapantay-pantay at kontra-diskriminasyon \\ Tinitiyak ba ng konstitusyon ang pagkakapantay-pantay sa harap ng batas at ipinagbabawal ang diskriminasyon? Kung gayon, kinikilala ba ang pang-etniko, panglahi, o pangkultural na identidad bilang isa sa maraming ipinagbabawal na batayan para sa diskriminasyon?}

\section{PALIWANAG}

Ang pagpangako sa lahat ng mga grupo at indibidwal ng karapatan sa pagkakapantay-pantay sa harap ng batas at ang pagbabawal ng diskriminasyon ay isang sentral na pangako ng karamihan sa mga demokratikong lipunan at tampok ng maraming konstitusyon; ito ang saligan sa likod ng konsepto ng 'bulag na hustisya'. Ang Internasyonal na Kumbensyon sa Pagtanggal sa Lahat ng Mga Porma ng Diskriminasyon sa Lahi ay tumutukoy sa 'diskriminasyon sa lahi' bilang: 'anumang pagkakaiba, pagbubukod, paghihigpit o pagpili batay sa lahi, kulay, pinagmulan, o nasyonal o etnikong pinagmulan na may layunin o epekto ng pagpapawalang-bisa o pagpinsala sa pagkilala, kasiyahan o pag-eehersisyo, sa pantay na pamantayan, ng mga karapatang pantao at pundamental na mga kalayaan sa pulitikal, ekonomiko, panlipunan, kultural o ano pa mang larangan ng buhay publiko' (United Nations 1965: artikulo 1(1)). Alinsunod sa kahulugang ito, ang lahat ng mga mamamayan ay dapat na tumatamasa ng pantay na pagkakaroon ng mga karapatan at proteksyon nang walang pamimili o pagtatangi batay sa kanilang pagkakakilanlan.

Ang mga katutubo ay may maraming mga katangian, pagkakakilanlan, at paniniwala na maaaring gawin silang bulnerable sa diskriminasyon at hindi patas na pakikitungo. Ang isa sa mga tampok na mga katangian ng mga katutubo ay ang katotohanang mayroon silang mga kultura, tradisyon, wika, at praktika na naiiba sa mga natagpuan sa iba pang (madalas na karamihan) mga bahagi ng populasyon. Ang karapatang mapanatili ang kaibahang ito sa kawalan ng diskriminasyon at mapaminsalang pakikitungo ay susi para sa mga katutubo.

Mga batayan $n g$ diskriminasyon: Ang mga pangkalahatang sugnay ng kontra-diskriminasyon ay maaaring malayo ang maaabot sa pagprotekta sa mga katutubo mula sa mapaminsalang pakikitungo batay sa kanilang pagkakakilanlan; gayunpaman, ang mga sugnay na kontra-diskriminasyon ay maaari ding mas detalyado at maglista ng mga tiyak na batayan kung saan ipinagbabawal ang diskriminasyon, tulad ng kasarian o lahi. Maaari itong magbigay ng higit na proteksyon para sa mga katutubong grupo sa pamamagitan ng paggabay sa pagpapatupad ng sugnay na kontra-diskriminasyon upang matiyak na mailalapat ito sa diskriminasyong nakabatay sa pagkakakilanlan. Ang tiyak na proteksyon laban sa diskriminasyon batay sa mga pang-etnikong pinagmulan o kultural na pagkakakilanlan, o kaya mga uri sa ilang mga lipunan (ang terminolohiya ay depende sa konteksto), ay nagsesenyas na ang estado ay magkakaiba at ang pagkakaiba-ibang ito ay dapat pinoprotektahan at hindi inaatake. Gayundin, ang pagkilala ng maraming batayan para sa diskriminasyon ay nagbibigay ng mas maraming puwang para sa pagkilala sa 'maraming diskriminasyon' o 'interseksyonalidad' kapag ang isang indibidwal o grupo ay nahaharap sa eksponensyal na diskriminasyon sa higit sa isang batayan-halimbawa, dahil sa pagiging mahirap at mula sa marhinalisadong lahi, o pagiging katutubo at babae, o katutubo at kabataan. Kung ang maraming mga batayan para sa diskriminasyon ay kinikilala, mahalaga ring suriin kung ang listahang ito ay isinulat upang maging eksklusibo o kung bukas ito upang isama ang mga hindi espesipikong karagdagang batayan sa hinaharap. Ang mga pagkakakilanlan at karapatan ay nagbabago sa paglipas ng panahon at ang isang hindi kumprehensibo o hindi eksklusibong listahan ay magbibigay-daan sa higit na kakayahang umangkop at tumugon sa konstitusyonal na pagpapatupad.

Layunin o epekto? Ang isa pang tampok na katangian na dapat tingnan sa mga sugnay ng pagkakapantaypantay at kontra-diskriminasyon ay kung ipinagbabawal nila ang mga aksyon na may impluwensya (o epekto) ng diskriminasyon, kung ang mga aksyon mang ito inspirado o hindi ng diskriminasyong hangarin (o layunin). Ang ilang mga konstitusyon ay tatahimik sa isyung ito, at maaari itong mapagpasyahan ng mga korte at iba pang mga aktor batay sa kanilang mga mandato at pagpapasya sa hinaharap.

Kung hindi kinakailangan ang hangarin (layunin), ang isang batas o aksyon ng gobyerno ay maaaring maituring na diskriminasyon kung ito ay negatibong makaaapekto sa pagkilala, kasiyahan, o paggamit ng kanilang mga karapatan at kalayaan sa pantay na antas sa iba pang mga miyembro ng populasyon. Ang puntong ito ay kritikal, bilang isang tila walang kinikilingan na batas o patakaran (iyon ay, iyong hindi litaw na nagdidiskrimina nang harapan) ay maaari pa ring magkaroon ng isang diskriminasyong epekto. Sa ilalim ng malawak na pagbabawal ng diskriminasyon, 
ang mga katutubo ay may karapatang humingi ng tulong sa mga korte, ombudsman, komite ng karapatang pantao/pagkakapantay-pantay, atbp., upang baligtarin ang mga batas at patakaran na maaaring mapatunayan na may diskriminatoryong epekto, kahit na ang diskriminatoryong hangarin ay hindi mapatunayan. Minsan, kahit na ang mga probisyon ng konstitusyon ay maaaring hindi sinasadyang magdiskrimina laban sa mga katutubohalimbawa, ang ilang mga kinakailangang kalipikasyon para sa pampublikong tanggapan ay maaaring magkaroon ng isang diskriminatoryong epekto sa mga katutubo na maaaring hindi nagkaroon ng pantay na makasaysayang mga pagkakataon upang makamit ang mga kalipikasyong ito-at ang isang probisyon na nagpoprotekta laban sa hindi sinasadyang diskriminasyon ay nagbibigay-daan para sa pagtunggali sa mga ganitong uri ng mga probisyon.

\section{MGA PAMANTAYANG PANG-INTERNASYUNAL AT PAMBANSANG MGA HALIMBAWA}

\begin{tabular}{|c|c|c|}
\hline $\begin{array}{l}\text { Kumbensyon } \\
\text { ng ILO } 169 \\
1989\end{array}$ & Artikulo 3(1) & $\begin{array}{l}\text { 1. Ang mga katutubo at tribo ay dapat tamasahin } \\
\text { nang buo ang mga karapatang pantao at } \\
\text { pundamental na mga kalayaan nang walang } \\
\text { sagabal o diskriminasyon. }\end{array}$ \\
\hline $\begin{array}{l}\text { UNDRIP } \\
2007\end{array}$ & Artikulo 2 at 22 & $\begin{array}{l}\text { Artikulo } 2 \\
\text { Ang mga katutubo at indibidwal ay malaya at } \\
\text { kapantay ng iba pang mga tao at indibidwal } \\
\text { at may karapatang maging malaya mula sa } \\
\text { anumang uri ng diskriminasyon, sa pag-ehersisyo } \\
\text { ng kanilang mga karapatan, sa partikular } \\
\text { batay sa kanilang katutubong pinagmulan o } \\
\text { pagkakakilanlan. } \\
\text { Artikulo } 22 \\
\text { 1. Ang partikular na pansin ay itutuon sa mga } \\
\text { karapatan at espesyal na pangangailangan } \\
\text { ng mga katutubong matatanda, kababaihan, } \\
\text { kabataan, bata at mga taong may kapansanan } \\
\text { sa pagpapatupad ng Deklarasyong ito. } \\
\text { 2. Ang mga Estado ay magsasagawa ng mga } \\
\text { hakbang, kaugnay ng mga katutubo, upang } \\
\text { matiyak na ang mga katutubong kababaihan } \\
\text { at bata ay matatamasa ang buong proteksyon } \\
\text { at maggagarantiya laban sa lahat ng uri ng } \\
\text { karahasan at diskriminasyon. }\end{array}$ \\
\hline
\end{tabular}

\begin{tabular}{l|l|} 
Konstitusyon & Artikulo 13 \\
ng Colombia \\
1991
\end{tabular}

\begin{tabular}{|l|l|}
\hline at pakikitungo mula sa mga awtoridad, at \\
dapat tatangkilik ng parehong mga karapatan, \\
kalayaan, at mga pagkakataon nang walang \\
anumang diskriminasyon dahil sa kasarian, lahi, \\
pinagmulang bansa o pamilya, wika, relihiyon, \\
pampulitikang opinyon, o pilosopiya.
\end{tabular}

\begin{tabular}{l|l} 
Konstitusyon & Tsapter 2 \\
ng Fiji & (Katipunan \\
2013 & ng mga \\
& Karapatan), \\
& artikulo 26(3)
\end{tabular}

Ang lahat ng mga indibidwal ay ipinanganak na malaya at pantay sa harap ng batas, ay dapat makatanggap ng pantay na proteksyon at pakikitungo mula sa mga awtoridad, at dapat tatangkilik ng parehong mga karapatan, anumang diskriminasyon dahil sa kasarian, lahi, pampulitikang opinyon, o pilosopiya.

3. Ang isang tao ay hindi dapat dinidiskrimina, direkta o hindi direkta sa mga batayan ng kanyang:

a. aktwal o dapat na personal na mga katangian o sirkunstansyai, kabilang ang lahi, kultura, etniko o panlipunang pinagmulan, kulay, lugar na pinagmulan, sekso, kasarian, oryentasyong sekswal, pagkakakilanlan at ekspresyon ng kasarian, kapanganakan, pangunahing wika, katayuan sa ekonomiya o panlipunan o pangkalusugan, kapansanan, edad, relihiyon, budhi, katayuan sa pagaasawa o pagbubuntis; 0

b. mga opinyon o paniniwala, maliban sa saklaw ng mga opinyon o paniniwalang ito na nagsasangkot ng pinsala sa iba o ang pagbawas ng mga karapatan o kalayaan ng iba, o sa anp pa mang batayang ipinagbabawal ng Konstitusyong ito.
Naglalaan na ang mga katutubo ay dapat na makamit ang kanilang mga sariling mga karapatan at mga kaugnay na proteksyon nang walang diskriminasyon

\section{Kinikilala ang karapatang maging} malaya mula sa diskriminasyon

\section{Kinikilala ang mga taong} nahaharap sa maraming diskriminasyon, at ang pangangailangang protektahan ang mga bulnerable, at minoryasa-loob-ng-minoryang populasyon

Ginagawa ang malinaw na ugnayan sa pagitan ng pagkakapantay-pantay sa harap ng batas at ng karapatang matamasa ang pareho nang malaya sa diskriminasyon

Kinikilala ang maraming mga batayan para sa diskriminasyon

May kasamang pagbanggit

ng 'aktwal o dapat' na pagkakakilanlan bilang ipinagbabawal na batayan para sa diskriminasyon, mas malawak na sumasaklaw sa pagkakahon at mga mapang-insultong palagay, pati na rin ang naipagkakamaling identidad (hal. kawalang-muwang sa totoong identidad ay hindi isang depensa) 


\begin{tabular}{l|l}
$\begin{array}{l}\text { Konstitusyon } \\
\text { ng Nepal }\end{array}$ & $\begin{array}{l}\text { Artikulo 18(2) } \\
2015\end{array}$ \\
\hline
\end{tabular}
2012

Konstitusyon Artikulo 21(1)
ng Venezuela
1999

\section{Canada, Batas ng Konstitusyon 1982}

Konstitusyon Artikulo 11(2)
ng Somalia

Bahagi I

(Katibayan ng

Mga Karapatan at Kalayaan ng Canada), seksyon (15(1)
(2) Walang diskriminasyon na dapat gawin sa paglalapat ng mga pangkalahatang batas sa batayan ng pinagmulan, relihiyon, lahi, uri, tribo, kasarian, kondisyong pisikal, kondisyon ng kalusugan, katayuan sa pag-aasawa, pagbubuntis, kondisyong pang-ekonomiya, wika o rehiyon, ideolohiya, o sa magkatulad na mga batayan.

(3) Hindi dapat magdiskrimina ang Estado ng mga mamamayan batay sa pinagmulan, relihiyon, lahi, uri, tribo, kasarian, kondisyong pang-ekonomiya, wika, rehiyon, ideolohiya o sa magkatulad na iba pang mga batayan.

(2) Ang diskriminasyon ay itinuturing na nagaganap kung ang epekto ng isang pagkilos ay nakapipinsala o naglilimita sa mga karapatan ng isang tao, kahit na hindi nilayon ng aktor ang epektong ito.

Ang lahat ng mga tao ay pantay-pantay sa harap ng batas, at, dahil dito:

1. Walang diskriminasyon batay sa lahi, kasarian, uri o katayuan sa lipunan ang pahihintulutan, o, sa pangkalahatan, ang anumang diskriminasyon na may hangarin o epekto ng pagpapawalang-bisa o pagsapaw sa pagkilala, pagtamasa o pag-ehersisyo, sa pantay na termino, ng mga karapatan at kalayaan ng bawat indibidwal.

(1) Ang bawat indibidwal ay pantay-pantay sa harap at sa ilalim ng batas at may karapatan sa pantay na proteksyon at pantay na pakinabang ng batas nang walang diskriminasyon at, sa partikular, nang walang diskriminasyon batay sa lahi, nasyonal o etnikong pinagmulan, kulay, relihiyon, kasarian, edad o kaisipan o kapansanan sa katawan.

\footnotetext{
Ang Pilipinas,

Batas sa

Karapatan ng

Mga Katutubo

1997
}

Seksyon 23
Ipinagbabawal ang diskriminasyon sa maraming mga batayan

Tinutukoy ang diskriminasyon sa mga tuntunin ng epekto $n g$ isang aksyon, hindi ng layunin (hindi kinakailangan ng hangarin)

Tinutukoy ang diskriminasyon sa mga tuntunin ng epekto $n g$ isang aksyon, hindi ng layunin (hindi kinakailangan ng hangarin)

Nangangako ng pagkakapantaypantay sa harap ng batas nang walang diskriminasyon

Kinikilala ang maraming mga batayan para sa diskriminasyon

Kinikilala ang kalayaan mula sa diskriminasyon sa konteksto ng hanapbuhay at nananawagan para sa mga espesyal na hakbang upang maitaguyod ang substantibong pagkakapantaypantay sa pagkakataon 


\section{MGA NAPAG-ALAMAN}

Sagot sa tanong (Oo/Hiindi) at iba pang mga tala at obserbasyon tungkol sa kung gaano kahusay na tinutugunan $n g$ konstitusyon ang (mga) isyu na itinanong. Isama ang mga makabuluhang mga probisyon ((mga) numero $n g$ artikulo at teksto $n g$ (mga) probisyon). Tandaan din ang hindi konsistent at/o magkasalungat na mga probisyon, o kung walang umiiral na mga kaugnay na probisyon.

\section{MGA HAKBANG}

Iminungkahing adbokasiya at iba pang mga kasunod na hakbang upang matugunan o mapalaganap ang mga natuklasan. 


\section{Karapatan sa pagkakapantay-pantay at kontra-diskriminasyon}

\section{Pinapayagan ba ng konstitusyon ang magmandato ng mga espesyal na hakbang na naglalayong makamit ang substantibong pagkakapantay- pantay para sa mga katutubo?}

\section{PALIWANAG}

Ang katanungang ito ay kaugnay sa Tanong 4 tungkol sa karapatan sa pagkakapantay-pantay at kontra-diskriminasyon, ang konsepto nito ay hinamon sa mga nagdaang taon ng isang higit na pag-unawa at pangako sa prinsipyo ng substantibong pagkakapantay-pantay. Ang pagkakaiba sa pagitan ng pormal at substantibong pagkakapantaypantay (tingnan ang Tsapter 3 sa mga pangunahing termino at konsepto) ay malawak na kinikilala at, habang ang pagkakapantay-pantay sa harap ng batas ay maaaring maging isang sapat na batayan para sa pagtataguyod ng pormal na pagkakapantay-pantay, ang substantibong pagkakapantay-pantay ay madalas na hindi maisasakatuparan nang walang mga espesyal na patakaran upang 'pagpantayin ang larangan' (Arneson 2015). Kadalasan, ang mga pangako sa pormal at substantibong pagkakapantay-pantay ay nagtutulungan. Halimbawa, sa mga probisyon sa konstitusyon ng Canada: ang seksyon 15(1) ay nagbibigay ng isang pangako sa pormal na pagkakapantay-pantay, at ang seksyon 15(2) ay nagsasama ng isang proviso na nagbibigay ng puwang para sa mga espesyal na hakbang na nakatuon sa pagkamit ng substantibong pagkakapantay-pantay. Natuklasan ng Korte Suprema ng Canada na: 'Ang Seksyon 15(1) at 15(2) ay nagtutulungan upang itaguyod ang bisyon sa substantibong pagkakapantay-pantay na pinagbabatayan ang s. 15 sa kabuuan. Ang Seksyon 15(1) ay naglalayong pigilan ang mga diskriminatoryong pag-iiba na nakaaapekto nang masama sa mga kasapi ng mga pangkat na kinilala ng mga batayan na inilahad sa s. 15 at magkatulad na batayan. Ito ay isang paraan ng paglaban sa diskriminasyon. Gayunpaman, maaaring hilingin din ng mga gobyerno na labanan ang diskriminasyon sa pamamagitan ng pagbuo ng mga programa na naglalayong tulungan ang mga desbentahang grupo na mapabuti ang kanilang sitwasyon. Sa pamamagitan ng s. 15(2), pinapanatili ng Tsarter ang karapatan ng mga gobyerno na ipatupad ang mga nasabing programa, nang walang takot sa hamon sa pagtutol sa ilalim ng s. 15(1)' (Korte Suprema ng Canada 2008: talata 16). Ipinapakita nito ang kahalagahan ng pagkakaroon ng mga tahasang pahintulot para sa substantibong pagkakapantay-pantay at mga espesyal na hakbang sa konstitusyonpinangangalagaan nito ang mga karapatan ng mga gobyerno na magsagawa ng mga progresibong hakbangin nang walang takot sa pagtutol mula sa istriktong tagapagtaguyod ng pormal na pagkakapantay-pantay.

Habang ang ilan ay maaaring pumuna sa mga espesyal na hakbang bilang isang paglabag sa demokratikong pamantayan ng pagkakapantay-pantay sa harap ng batas, o kumakatawan sa isang uri ng diskriminasyon sa sarili nito, ang konstitusyon ay maaaring malinaw na mag-ukit ng puwang upang payagan ang mga ganitong uri ng mga espesyal na hakbang, na kilala rin bilang apirmadong aksyon o positibong mga patakaran sa diskriminasyon. Sa pagkilala sa substantibong pagkakapantay-pantay o apirmatibong aksyon nang malinaw, ang konstitusyon ay maaaring magmandato o magpahintulot para sa mas kanais-nais na pakikitungo para sa mga katutubo sa edukasyon, hanapbuhay, pulitikal na pakikilahok, buhay pang-ekonomiya, at iba pang mga larangan. Ang isang malinaw na pangako sa prinsipyo ng substantibong pagkakapantay-pantay sa isang konstitusyon ay maaaring magbigay ng puwang para sa mga espesyal na hakbang, kung hindi malinaw na tumatawag para dito; ang mga naturang probisyon ay maaaring maprotektahan ang mga espesyal na hakbang mula sa pagkakatanggal bilang hindi konstitusyonal dahil sa paglabag sa isang prinsipyo ng pormal na pagkakapantay-pantay.

Ang mga pagsisikap na makamit ang substantibong pagkakapantay-pantay ay nangangailangan na ang tunay na mga pagkakaiba-iba sa mga sirkunstansyang panlipunan, pang-ekonomiya at pampulitika sa pagitan ng mga katutubo at mga kasapi ng mga di-katutubong pamayanan ay kinikilala at tinutugunan. Dahil ang mga katutubo ay nahaharap sa mga partikular na hadlang sa buhay pampulitika, pang-ekonomiya at panlipunan, at matinding makasaysayang marhinalisasyon, ang karapatan sa pormal na pagkakapantay-pantay ay madalas na hindi sapat sa at mismong sa sarili nito sa paggarantiya ng substantibong pagkakapantay-pantay sa lahat ng larangan ng buhay. Ang mga katutubo ay napailalim sa makasaysayang prehuwisyo, pang-aagaw ng ari-arian, marhinalisasyon at diskriminasyon sa karamihan ng mga bansa sa buong mundo. Ang makasaysayang pagkikitungo sa mga katutubo ay madalas na nagresulta sa isang sistemang may saray, kung saan ang mga kakayahan at oportunidad ng mga katutubo sa kalusugan, pang-ekonomiya, edukasyon, propesyonal at pampulitikang mga larangan ay mas mababa kaysa sa mga kabilang sa karamihan ng mga bahagi ng pambansang populasyon. Ang mga katutubo ay madalas na hinihiling ang estado na gumawa ng maagap/positibong diskriminasyon (ibig sabihin, mga espesyal na hakbang) 
upang matiyak na ang kanilang karapatan sa pagkakapantay-pantay ay makabuluhang matamasa.Ipinagpalagay ng pamayanang internasyonal na ang mga espesyal na hakbang at mga apirmatibong patakaran ng pagkilos ay dapat na tiyak (hindi labis na ingklusibo o kulang na ingklusibo), may takdang oras at isinadya upang tugunan ang makasaysayang pinsala na nilalayon nilang gamutin. Ang mga espesyal na hakbang ay maaaring sabihin bilang isang karapatan (garantisado) o isang mungkahi o maaari lamang payagan. Ang Komite ng Karapatang Pantao ng United Nations, sa pagbibigay kahulugan sa Internasyunal na Kasunduan sa Sibil at Pulitikal na mga Karapatan (ICCPR), ay nagsaad na 'hangga't ang [mga espesyal na hakbangin] ay naglalayong itama ang mga kondisyon na pumipigil o pumipinsala sa pagtamasa ng mga karapatang garantisado sa ilalim ng artikulo 27 [karapatan ng minorya], maaari silang bumuo ng isang lehitimong pagtukoy ng pagkakaiba sa ilalim ng Kasunduan, sa kondisyon na sila ay batay sa makatuwiran at obhetibong mga pamantayan' (United Nations 1994: artikulo 6.2)

MGA PAMANTAYANG PANG-INTERNASYUNAL AT PAMBANSANG MGA HALIMBAWA

\begin{tabular}{|c|c|c|}
\hline $\begin{array}{l}\text { Kumbensyon } \\
\text { ng ILO } 169 \\
1989\end{array}$ & Artikulo 2 at 20 & $\begin{array}{l}\text { Artikulo } 2 \\
\text { 1. Ang mga pamahalaan ay may pananagutan } \\
\text { para sa pagbuo, na may pakikilahok ng mga } \\
\text { mamamayang kinauukulan, ng mga koordinado } \\
\text { at sistematikong pagkilos upang protektahan } \\
\text { ang mga karapatan ng mga mamamayang ito at } \\
\text { upang magarantiya ang kanilang integridad. }\end{array}$ \\
\hline
\end{tabular}

2. Ang nasabing pagkilos ay dapat magsama ng mga hakbang para sa:

(a) tinitiyak na ang mga kasapi ng mga mamamayang ito ay nakikinabang sa pantay na paraan mula sa mga karapatan at oportunidad na ibinibigay ng mga pambansang batas at pahintulot na regulasyon sa iba pang mga miyembro ng populasyon;

(b) nagtataguyod ng buong pagsasakatuparan ng mga karapatang panlipunan, pangekonomiya at pangkultura ng mga mamamayang ito na may paggalang sa kanilang panlipunan at pangkulturang identidad, sa kanilang kaugalian at tradisyon at kanilang mga institusyon;

(c) pagtulong sa mga miyembro ng kinauukulang mamamayan na alisin ang mga sosyo-ekonomikong agwat na maaaring umiiral sa pagitan ng mga katutubo at iba pang mga kasapi ng pambansang pamayanan, sa paraang umaayon sa kanilang mga hangarin at paraan ng pamumuhay.

Artikulo 20

1. Ang mga pamahalaan ay dapat, sa loob ng balangkas ng mga pambansang batas at regulasyon, at sa pakikipagtulungan sa mga kinauukulang mamamayan, maghalaw ng mga espesyal na hakbang upang matiyak ang mabisang proteksyon hinggil sa pagrekluta at mga kondisyon ng hanapbuhay ng mga manggagawa na kabilang sa mga mamamayang ito, na umaabot sa puntong hindi sila epektibong napoprotektahan ng mga batas na aplikable sa mga manggagawa sa pangkalahatan.

\begin{tabular}{l|l}
$\begin{array}{l}\text { Konstitusyon } \\
\text { ng Bangladesh }\end{array}$ & Bahagi III, \\
1972 & artikulo 28
\end{tabular}

1. Ang Estado ay hindi dapat nagdidiskrimina laban sa sinumang mamamayan batay lamang sa relihiyon, lahi, uri, kasarian o lugar ng kapanganakan.

$$
\text { ... }
$$

4. Wala sa artikulong ito ang pipigil sa Estado na gumawa ng mga espesyal na probisyon na pabor sa mga kababaihan o bata o para sa pagsulong ng anumang atrasadong seksyon ng mga mamamayan.
Naglalaan $n g$ isang apirmatibong tungkulin sa mga pamahalaan na bumuo ng mga patakaran para sa mga katutubo, sa konsultasyon sa mga katutubo, upang matiyak na pantay silang nakikinabang sa mga karapatan at pagkakataon
Partikular na nananawagan para sa mga espesyal na hakbang para sa hanapbuhayng mga katutubo
Nagbibigay ng espesipikong pahintulot para sa gobyerno na gumawa ng mga espesyal na probisyon para sa mga bulnerableng grupo 


\begin{tabular}{l|l|} 
Konstitusyon & Artikulo 57 \\
ng Ecuador \\
2008
\end{tabular}

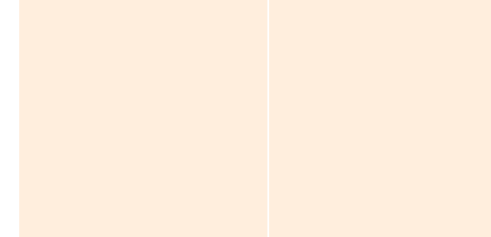

\section{Konstitusyon ng India}

1949
2. Upang hindi maging target $\mathrm{ng}$ rasismo 0 anumang uri ng diskriminasyon batay sa kanilang pinagmulan o etniko o kultural na pagkakakilanlan.

3. Para sa pagkilala, pag-aayos, at kompensasyon sa mga pangkat ng pamayanan na apektado ng rasismo, xenophobia at iba pang kaugnay na anyo ng pagkamuhi at diskriminasyon.

Artikulo 15 at 16 Artikulo 15

1. Ang Estado ay hindi dapat nagdidiskrimina laban sa sinumang mamamayan batay lamang sa relihiyon, lahi, uri, kasarian, lugar ng kapanganakan, o alinman dito. ...

4. Wala sa artikulong ito o sa sugnay (2) ng artikulo 29 ang pipigil sa Estado na gumawa ng anumang espesyal na probisyon para sa pagsulong ng anumang atrasado sa panlipunan at pang-edukasyong aspektong mga uri ng mamamayan o para sa Mga Nakaiskedyul na Kasta at Mga Nakaiskedyul na Tribo.5. Wala sa artikulong ito o sa kasunod na sugnay (g) ng sugnay (1) ng artikulo 19 ang pipigil sa Estado na gumawa ng anumang espesyal na probisyon, ayon sa batas, para sa pagsulong ng anumang mga atrasado sa panlipunan at pangedukasyong aspekto ng mga uri ng mamamayan o para sa Mga Nakaiskedyul na Kasta o Mga Nakaiskedyul na Tribo basta’t ang mga katulad na espesyal na probisyon ay nauugnay sa kanilang pagpasok sa mga institusyong pang-edukasyon kabilang ang mga pribadong institusyong pang-edukasyon, tinulungan man o hindi tinulungan ng Estado, maliban sa minorya ng mga institusyong pang-edukasyon na tinukoy sa sugnay (1) ng artikulo 30.

Artikulo 16

1. Magkakaroon ng pantay na pagkakataon para sa lahat ng mga mamamayan sa mga bagay na nauugnay sa hanapbuhay o paghirang sa anumang tanggapan sa ilalim ng Estado. ...

4. Walang anumang bagay sa artikulong ito ang pipigil sa Estado na magsagawa ng anumang probisyon para sa reserbasyon ng paghirang o posisyon na pabor sa anumang atrasadong klase ng mga mamamayan na, sa palagay ng Estado, hindi sapat na kinakatawan sa mga serbisyo sa ilalim ng Estado.

4A. Walang anumang bagay sa artikulong ito ang pipigil sa Estado na magsagawa ng anumang probisyon para sa reserbasyon sa mga usapin ng promosyon, na may kahihinatnang senyoridad, sa anumang klase o klase ng mga posisyon sa mga serbisyo sa ilalim ng Estado na pabor sa Mga Nakaiskedyul na Kasta at sa Mga Nakaiskedyul na Tribo na sa palagay ng mga Estado, ay hindi sapat na kinakatawan sa mga serbisyo sa ilalim ng Estado.
Kinikilala ang kalayaan mula sa diskriminasyon bilang isa sa maraming kolektibong mga karapatan ng mga katutubo

Kinikilala ang karapatan sa kompensasyon at pag-aayos mula sa diskriminasyong pinagdusahan, na maaaring maging batayan para sa mga espesyal na hakbang

Gumagawa ng puwang para sa positibong diskriminasyon sa ngalan ng 'pagsulong' ng ilang mga pangkat

Partikular na binabanggit ang karapatan sa 'mga espesyal na probisyon' sa sektor ng edukasyon at sa pampublikong hanapbuhay 


\begin{tabular}{l|l}
$\begin{array}{l}\text { Konstitusyon ng } \\
\text { Mehiko }\end{array}$ & Artikulo 2(B) \\
1917 &
\end{tabular}

1917

Konstitusyon

Artikulo 18(3)

ng Nepal

2015

\author{
Konstitusyon ng Seksyon 9(2) \\ Timog Aprika \\ 1996
}

Canada, Batas

ng Kostitusyon

1982
Itataguyod ng gobyerno ang pantay na oportunidad para sa mga katutubo at tatanggalin ang mga praktika ng diskriminasyon sa pamamagitan $\mathrm{ng}$ pagtaguyod $\mathrm{ng}$ mga institusyon at mga patakaran na ididisenyo at papatakbuhin kasabay ng mismong mga katutubo.

[Mga espesipikong hakbang na gagawin ay nakalarawan sa iba pang bahagi ng artikulo.]

(3) Hindi dapat magdiskrimina ang Estado ng mga mamamayan batay sa pinagmulan, relihiyon, lahi, uri, tribo, kasarian, kondisyong pang-ekonomiya, wika, rehiyon, ideolohiya o sa magkatulad na iba pang mga batayan.

Sa kondisyon na walang maipapalagay na pumipigil sa paggawa ng mga espesyal na probisyon ng batas para sa proteksyon, pagbibigay-kapangyarihan o pag-unlad ng mga mamamayan kasama na ang mga kababaihang atrasado sa lipunan o kultura, Dalit, mga katutubo, mga katutubong nasyonalidad, Madhesi, Tharu, Muslim, aping uri, klase ng Pichhada, mga minorya, ang marhinalisado, mga magsasaka, manggagawa, kabataan, bata, matatanda, mga minorya sa kasarian at sekswal, mga taong may mga kapansanan, mga taong nagbubuntis, walang kakayahan o walang magawa, atrasadong rehiyon at mga maralitang Khas Arya.

2. Kasama sa pagkakapantay-pantay ang ganap at pantay na pagtamasa ng lahat ng mga karapatan at kalayaan. Upang maitaguyod ang pagkamit ng pagkakapantaypantay, ang lehislatibo at iba pang mga hakbang na idinisenyo upang protektahan $\mathrm{o}$ isulong ang mga tao, o kategorya ng mga tao, na dinesbentaha ng hindi patas na diskriminasyon, ay maaaring gawin.

(1) Pagkakapantay-pantay sa harap at sa ilalim ng batas at pantay na proteksyon at benepisyo $\mathrm{ng}$ batas

Ang bawat indibidwal ay pantay-pantay sa harap at sa ilalim ng batas at may karapatan sa pantay na proteksyon at pantay na pakinabang $\mathrm{ng}$ batas nang walang diskriminasyon at, sa partikular, nang walang diskriminasyon batay sa lahi, nasyonal o etnikong pinagmulan, kulay, relihiyon, kasarian, edad o kaisipan o pisikal na kapansanan.

(2) Mga apirmatibong mga programa sa pagkilos Ang subseksyon (1) ay hindi pumipigil sa anumang batas, programa o aktibidad na may hangaring paunlarin ang mga kondisyon ng mga desbentahang indibidwal o grupo kabilang ang mga dinesbentaha dahil sa lahi, pambansa o etnikong pinagmulan, kulay, relihiyon, kasarian, edad o kapansanan sa mental o pisikal.
Ipinapangako ang gobyerno na tatanggalin ang mga praktika ng diskriminasyon upang maisulong ang substantibong pagkakapantay-pantay ng mga katutubo

Tinutukoy ang diskriminasyon batay sa epekto ng isang aksyon, hindi layunin (hindi kinakailangan ang hangarin)
Nagbibigay ng pahintulot sa gobyerno na magdisenyo ng mga hakbang upang gamutin ang makasaysayang diskriminasyon at kinikilala na kinakailangan ito para sa pantay na pagtamasa ng mga karapatan at kalayaan

Kinikilala ang karapatan sa pormal na pagkakapantay-pantay sa proviso na ang isang karapatan sa pagkakapantay-pantay ay hindi magiging batayan para sa pagtatanggal ng mga programa na tumuturol sa mga desbentahang grupo 


\section{MGA NAPAG-ALAMAN}

Sagot sa tanong (Oo/Hiindi) at iba pang mga tala at obserbasyon tungkol sa kung gaano kahusay na tinutugunan $n g$ konstitusyon ang (mga) isyu na itinanong. Isama ang mga makabuluhang mga probisyon ((mga) numero $n g$ artikulo at teksto $n g$ (mga) probisyon). Tandaan din ang hindi konsistent at/o magkasalungat na mga probisyon, o kung walang umiiral na mga kaugnay na probisyon.

\section{MGA HAKBANG}

Iminungkahing adbokasiya at iba pang mga kasunod na hakbang upang matugunan o mapalaganap ang mga natuklasan. 


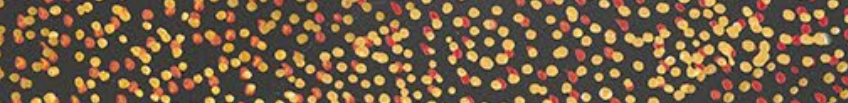

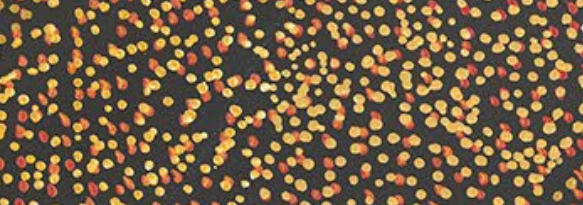

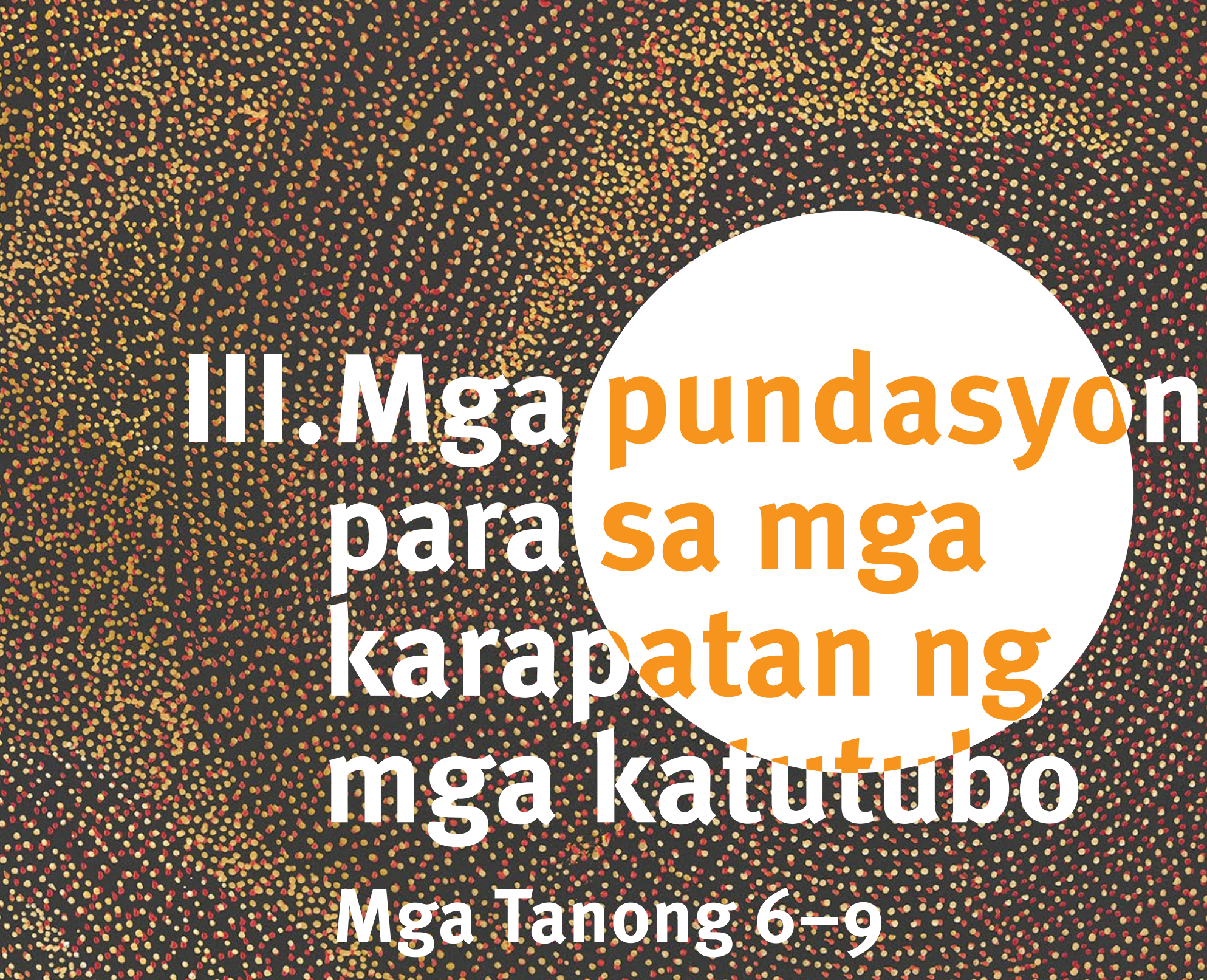

\&8s

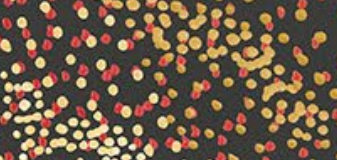

$$
\begin{aligned}
& \because 38
\end{aligned}
$$$$
\begin{array}{cc}
0 \\
8
\end{array}
$$

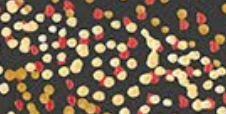

30: $8:$ 


\section{Mga pundasyon para sa mga karapatan ng mga katutubo}

\section{Kinikilala ba ng konstitusyon ang mga karapatan ng mga katutubo bilang karagdagan sa, at hindi kapalit ng, mga pundamental na karapatan na ginagarantiya sa lahat ng mga mamamayan?}

\section{PALIWANAG}

Ang mga katutubo, na hiwalay sa anumang partikular na garantiya ng kanilang mga espesyalisadong karapatan na kinikilala ng batas internasyunal, ay dapat na garantisadong kolektibo at indidbidwal ang mga karapatang ipinangako sa lahat ng iba pang mga kasapi ng lipunan sa ilalim ng pambansa at internasyunal na batas. Kasama dito ang mga pundamental na karapatan, pinakamahalaga para sa mga katutubo ang karapatan sa kalayaan sa pamamahayag, relihiyon at asosasyon, at ang karapatan sa pagkakapantay-pantay at kawalang diskriminasyon. Ang garantiya ng lahat ng mga karapatan ay bahagi ng isang pangako sa 'pagkakapantay-pantay sa harap ng batas' (tingnan ang Tanong 4).

Para sa mga layunin ng katanungang ito, ang pangunahing pagsasaalang-alang ay kung ang mga espesyalisadong (o iba pang) karapatan ng katutubo ay nakikitang umaakma sa iba pang mga karapatang ginagarantiya sa mga katutubo bilang mamamayan ng isang partikular na bansa. Ang mga karapatan ng mga katutubo ay hindi dapat tingnan bilang kapalit sa iba pang mga karapatang pantao, ngunit bilang isang karagdagan sa mga ito. Ang isang katutubong indibidwal ay hindi dapat makaranas ng diskriminasyon kapag naghahanap ng proteksyon at pagpapatupad ng karapatang pantao na ipinangako sa ibang mga mamamayan.

Sa pangkalahatan, ang mga iskema ng karapatan ay hindi dapat gamitin upang mapahina ang bawat isa. Partikular na totoo ito para sa mga karapatan ng mga katutubo kung saan maaaring maraming mapagkukunan ng batas sa pamamahala, kabilang ang — halimbawa — mga tratado na nilagdaan sa pagitan ng mga katutubo at pamahalaan. Ang mgatratadong ito ay hindi dapat gamitin bilang batayan upang pagkaitan ang mga katutubo ng mga karapatang nakapaloob sa konstitusyon at iba pang pambansang lehislasyon. 


\begin{tabular}{|l|l|l|}
\begin{tabular}{|l|l|} 
Kumbensyon ng \\
ILO 169
\end{tabular} & $\begin{array}{l}\text { Artikulo 3(1) at } \\
1989\end{array}$ & Artikulo 3 \\
\hline & & $\begin{array}{l}\text { 1. } \\
\text { Ang mga katutubo at tribo ay tatamasa } \\
\text { nang buo sa mga karapatang pantao at } \\
\text { pundamental na mga kalayan nang walang } \\
\text { balakid o diskriminasyon. Ang mga probisyon } \\
\text { ng Kumbensyon ay mailalapat nang walang } \\
\text { diskriminasyon sa mga kalalakihan at } \\
\text { kababaihang kasapi ng mga mamamayang } \\
\text { ito. }\end{array}$ \\
\hline
\end{tabular}

Artikulo 4

3. Ang pagtamasa ng pangkalahatang mga karapatan ng pagkamamamayan, nang walang diskriminasyon, ay hindi dapat napeprehuwisyo sa anumang paraan ng naturang mga espesyal na hakbang.

UNDRIP $\quad$ Artikulo 1
2007

2007

Konstitusyon Artikulo 13
ng Bolivia
2009

\begin{tabular}{l|l} 
Konstitusyon & Artikulo 75 \\
ng Serbia & \\
2006 &
\end{tabular}

\begin{tabular}{l|l}
$\begin{array}{l}\text { Konstitusyon } \\
\text { ng Nicaragua } \\
2014\end{array}$ & Artikulo 5 \\
\hline
\end{tabular}

Ang mga katutubo ay may karapatan sa buong pagtamasa, bilang isang kolektibo o bilang indibidwal, ng lahat ng mga karapatang pantao at pundamental na mga kalayaan na kinikilala sa Charter ng United Nations, ang Unibersal na Deklarasyon ng Karapatang Pantao, at internasyonal na batas para sa karapatang pantao.

I. Ang mga karapatang kinikilala sa Konstitusyong ito ay hindi dapat malabag, unibersal, magkakaugnay, hindi nahahati at progresibo. Ang Estado ay may tungkulin na itaguyod, protektahan at igalang ang mga ito.

II. Ang mga karapatang idineklara sa Konstitusyong ito ay hindi dapat unawain upang ipagkait ang iba pang mga karapatang hindi nakasaad.III. Ang klasipikasyon ng mga karapatang itinatag sa Konstitusyong ito ay hindi tumutukoy sa anumang herarkiya o superyoridad ng ilang mga karapatan kaysa sa iba.

Kinikilala ng Estado ang pagkakaroon ng mga katutubo... na nagtatamasa ng mga karapatan, tungkulin, at mga garantiyang itinalaga sa Konstitusyon.
Pinoprotektahan ang karapatan ng mga katutubo na matamasa ang lahat ng mga internasyunal na karapatang pantao at ginagarantiyaha na ang pangkalahatang mga karapatan sa pagkamamamayan ay hindi maaapektuhan ng mga espesyal na hakbang para sa mga katutubo
Binibigyang diin ang karapatan ng mga katutubo sa pagtamasa ng lahat ng mga internasyunal na karapatang pantao
Kinikilala na ang lahat ng mga karapatan ay nasa pantay na antas (walang herarkiya ng mga karapatan)

Ipinagbabawal ang isang karapatan na magamit upang mapawalang-bisa ang isa pa
Ipinapangako sa mga katutubo ang lahat ng mga karapatan at garantiya sa konstitusyon

\begin{tabular}{l|l}
$\begin{array}{l}\text { Canada, Batas } \\
\text { ng Konstitusyon }\end{array}$ & $\begin{array}{l}\text { Bahagi I } \\
\text { (Tsarter ng }\end{array}$ \\
$\begin{array}{ll}\text { Mga Karapatan } \\
\text { Mat Kalayaan }\end{array}$ \\
& sa Canada) \\
& seksyon 25
\end{tabular}

New Zealand, Artikulo 3
Tratado ng
Waitangi
1840

Ang mga taong kabilang sa pambansang mga minorya ay magagarantiyahan ng espesyal na indibidwal o kolektibong mga karapatan bilang karagdagan sa mga karapatang ginagarantiyaha sa lahat ng mga mamamayan ng Konstitusyon.

Ang garantiya sa Tsarter na ito ng ilang mga karapatan at kalayaan ay hindi dapat ipakahulugang magbabasura o manghahamak mula sa anumang mga katutubo, tratado, o iba pang mga karapatan o kalayaan na nauugnay sa mga katutubo ng Canada.

Sa pagsasaalang-alang dito, ang Kamahalang Reyna ng Inglateraay nag-aabot sa Mga Katutubo ng New Zealand ng kanyang maharlikang proteksyon at ibinibigay sa kanila ang lahat ng mga Karapatan at Pribilehiyo ng Mga Mamamayang Briton.
Kinikilala na ang mga espesyal na karapatan ay isang karagdagan sa mga karapatang ginagarantiyaha sa lahat ng mga mamamayan

Tinitiyak na ang mga kasalukuyang kasunduan ay hindi negatibong nakaaapekto sa mga kasunduan mula sa nakaraan (pakikipagugnayan ng mga konstitusyonal na karapatan sa mga karapatan ng tratado)

Nangangako sa mga katutubo ng New Zealand ng parehong mga karapatan at pribilehiyo ng lahat (sa panahong iyon, mga Briton) na mamamayan 


\section{MGA NAPAG-ALAMAN}

Sagot sa tanong (Oo/Hiindi) at iba pang mga tala at obserbasyon tungkol sa kung gaano kahusay na tinutugunan $n g$ konstitusyon ang (mga) isyu na itinanong. Isama ang mga makabuluhang mga probisyon ((mga) numero $n g$ artikulo at teksto $n g$ (mga) probisyon). Tandaan din ang hindi konsistent at/o magkasalungat na mga probisyon, o kung walang umiiral na mga kaugnay na probisyon.

\section{MGA HAKBANG}

Iminungkahing adbokasiya at iba pang mga kasunod na hakbang upang matugunan o mapalaganap ang mga natuklasan. 


\title{
Mga pundasyon para sa mga karapatan ng mga katutubo
}

\author{
Kinikilala ba ng konstitusyon ang karapatan ng mga katutubo sa sariling \\ pagpapasya bilang isang pundasyon para sa mga karapatan ng ibang \\ mga katutubo?
}

\section{PALIWANAG}

Sa ilalim ng internasyunal na batas, ang mga katutubo ay may natatanging karapatan sa sariling pagpapasya, na nagsisilbing pundasyon para sa mga karapatan ng ibang mga katutubo. Dahil dito, ang sariling pagpapasya ay isang isyu na tumatawid sa Kagamitan sa Pagtatasang ito. Ang pagbibigay ng tahasang pagkilala sa karapatan ng mga katutubo sa sariling pagpapasya sa isang pambansang konstitusyon ay maaaring maging isang plataporma para sa pagsasakatuparan ng maramipang ibang mga karapatan ng mga katutubo.

Tulad ng ipinaliwanag sa Tsapter 3 sa mga pangunahing termino at konsepto, ang sariling pagpapasya ay may panloob at panlabas na mga dimensyon. Habang ang lahat ng mga mamamayan ay may kinikilalang karapatan sa sariling pagpapasya sa ilalim ng internasyunal na batas, ang espesyal na karapatan ng mga katutubo sa panloob na sariling pagpapasya ay unang kinilala sa UNDRIP. Habang kinikilala ng Kumbensyon ng ILO 169 ang karapatan ng mga katutubo 'na tukuyin at paunlarin ang mga priyoridad at estratehiya para sa paggamit ng kanilang karapatan sa kaunlaran ... upang maging aktibong kasangkot sa pagbuo at pagtukoy ng mga programang pangkalusugan, pabahay at iba pang pang-ekonomiya at panlipunan programa na nakaaapekto sa kanila at, hangga't maaari, upang pangasiwaan ang mga nasabing programa sa pamamagitan ng kanilang sariling mga institusyon (ILO 1989: artikulo 23), kulang ito sa pagkilala sa katutubong karapatan sa sariling pagpapasya.

Gayunpaman, malinaw na kinikilala ng UNDRIP ang karapatan ng mga katutubo sa sariling pagpapasiya bilang isang pangunahing saligan; pinagbabatayan nito ang lahat ng mga karapatan ng mga katutubo, partikular ang mga sa konsultasyon, pakikilahok, at awtonomiya. Halimbawa, ang karapatan sa panloob na sariling pagpapasya ay nagpapahiwatig na ang mga tao ay may karapatang lumahok sa demokratikong proseso ng pamamahala at para pangasiwaan at idirekta ang kanilang mga pang-ekonomiya, panlipunan at pangkulturang estratehiya sa pagunlad. Ang pagpapatupad ng karapatan sa sariling pagpapasya ay likas sa pagpapatupad ng iba pang mga karapatan at upang matiyak na ang mga ito ay ipinatupad sa isang hindi paternalistikong paraan.

Batay sa kasaysayan, ang mga katutubo sa buong mundo ay kinilala bilang mga ward ng estado, tinitingnan at tinatrato na parang hindi nila kayang pamahalaan ang kanilang sarili. Ang kanilang kakayahang kumilos bilang mga awtonomong lipunan ay mabisang ipinagkait. Ang mga katutubong kultura, wika, at tradisyunal na kasanayan at institusyon ay hindi pinahintulutan o napinsala bilang bahagi ng sapilitang asimilasyon, at sa ilang mga kaso ay napuksa, sa pagtataguyod ng iba pang mga kultura. Ang pakikitungo sa mga katutubo bilang mga ward, o parang wala silang kakayahan sa sariling pamamahala, ay nakakasama at walang respeto, at hindi nakakapasa sa pamantayang pang-internasyunal na nagmamandato sa pantay na pagtrato sa mga katutubo. Ang karapatan ng mga katutubo sa sariling pagpapasya ay bumabalikwas sa mga kasanayang ito at maaaring payagan ang mga katutubong komunidad na labanan ang kultural na asimilasyon at itaguyod ang kanilang sariling bisyon at mga hangarin para sa kinabukasan ng kanilang mamamayan.

Ang karapata ng katutubo sa sariling pagpapasya ay nagpapahiwatig na ang mga katutubo ay dapat magkaroon ng awtonomiya sa paglulunsad, pagbuo at pagpapanatili ng kanilang mga estrukturang institusyonal at natatanging kaugalian, kabanalan, tradisyon, pamamaraan at kasanayan, kabilang ang mga sistemang panghukuman o kaugalian. Ang kanilang mga karapatan ay dapat protektahan sa paraang nakabatay sa paggalang sa dignidad ng kanilang mga pagkakakilanlan, kultura, tradisyon at wika. Ang sariling pagpapasya ay nagpapahiwatig din na ang mga katutubo ay may karapatang gumawa ng mga pagkakataon sa kung paano balansehin ang kanilang mga kultura at tradisyon sa pang-ekonomiyang pag-unlad: ang karapatan sa sariling pagpapasya ay nagbibigay din ng karapatan sa mga katutubo na matukoy ang kanilang sariling mga priyoridad sa pag-unlad, partikular na tungkol sa kanilang lupa at likas na yaman.

Mahalaga sa lahat, ang karapatan ng katutubo sa sariling pagpapasya ay hindi kasama ang panlabas na elemento ng paghihiwalay; ito ay nililinaw sa UNDRIP: 'Wala sa Deklarasyong ito ang maaaring ipakahulugan bilang 
nagpapahiwatig para sa anumang Estado, mamamayan o pangkat ng anumang karapatang makisali sa anumang aktibidad o gumawa ng anumang kilos na salungat sa Tsarter ng United Nations o binibigyang kahulugan bilang pagpapahintulot o panghihikayat sa anumang pagkilos na makasisira o makapipinsala, ganap o sa bahagi, ng integridad ng teritoryo o pampulitikang pagkakaisa ng mga soberano at malayang Estado' (United Nations 2007: artikulo 46 (1)). Hindi pangkaraniwan na makita ang magkatulad na wika sa mga konstitusyon na kinikilala ang ilang uri ng sariling pagpapasya, ngunit pinapanatili ang isang pangako sa teritoryal na integridad ng estado.

\section{MGA PAMANTAYANG PANG-INTERNASYUNAL AT PAMBANSANG MGA HALIMBAWA}

\section{United Nations 1996}

\begin{tabular}{|c|c|}
\hline & \\
\hline $\begin{array}{l}\text { UNDRIP } \\
2007\end{array}$ & Artikulo 3 at 4 \\
\hline $\begin{array}{l}\text { Kontitusyon } \\
\text { ng Bolivia } \\
2009\end{array}$ & $\begin{array}{l}\text { Mga artikulo } 2 \\
\text { at } 30(I I, 4)\end{array}$ \\
\hline
\end{tabular}

\section{Artikulo 2}

Dahil sa pagkakaroon ng pre-kolonyal na mga bansa at mga katutubong rural at pamamahala ng kanilang mga ninuno sa kanilang mga teritoryo, ang kanilang malayang pagpapasya, na binubuo ng karapatan sa awtonomiya, pamamahala ng sarili, kanilang kultura, pagkilala sa kanilang mga institusyon, at pagsasama-sama ng kanilang teritoryo ang mga nilalang, ay ginagarantiyahan sa loob ng balangkas ng pagkakaisa ng Estado, alinsunod sa Konstitusyon na ito at ng batas.

\section{Artikulo 30}

II. ... tinatamasa ng mga katutubo ang mga sumusunod na karapatan:

...

4. Sa sariling pagpapasya at teritoryalidad.

\section{Tinutukoy ang panloob na sariling pagpapasya}

\section{Kinikilala ang tiyak na \\ karapatan ng mga katutubo sa sariling pagpapasya at ang mga implikasyon nito para sa pakikilahok sa politika pati na rin ang mga karapatang pang- ekonomiya, panlipunan, at pangkultura, pati na rin ang mga link sa pamamahala ng sarili at awtonomiya}

Kinikilala ang karapatan ng mga katutubo sa sariling pagpapasya at iniuugnay ito sa karapatan sa awtonomiya, kultura, pagkilala ng mga institusyon, atbp

Nagpapakita ng pundasyunal na katayuan ng sariling pagpapasya 


\section{Konstitusyon ng Ecuador}

2008

\begin{tabular}{l|l} 
Konstitusyon & Artikulo 2 \\
ng Mehiko & \\
1917 &
\end{tabular}

\section{Konstitusyon ng Seksyon 235} Timog Aprika

1996
Artikulo 57 at 96 Artikulo 57

Ang mga teritoryo ng mga mamamayang naninirahan sa kusang-loob na isolasyon ay hindi mababago at hindi mababaling pagmamayari ng mga ninuno at lahat ng mga uri ng mga aktibidad ng pagkukuhaay ipinagbabawal doon. Ang Estado ay dapat magpatibay ng mga hakbang upang matiyak ang kanilang buhay, ipatupad ang paggalang sa sariling pagpapasya at ang hangaring manatili sa isolasyon at upang matiyak ang pagsunod sa kanilang mga karapatan. Ang paglabag sa mga karapatang ito ay dapat bumuo ng isang krimen ng etnosidyo, na ikaklasipika ng gayon $\mathrm{ng}$ batas.

\section{Artikulo 96}

Ang lahat ng mga anyo pag-oorganisa ng lipunan ay kinikilala bilang isang pagpapahayag ng soberenya ng mga tao upang makabuo ng mga proseso ng sariling pagpapasya at maimpluwensyahan ang mga pampublikong desisyon at paggawa ng patakaran at para sa panlipunang pagsubaybay sa lahat ng antas ng gobyerno, pati na rin ang pampubliko at pribadong mga institusyong nagbibigay $\mathrm{ng} \mathrm{mga}$ serbisyong pampubliko. Ang mga samahan ay maaaring ipahayag sa iba't ibang antas upang mabuo ang kapangyarihan ng mamamayan at ang mga anyo ng pagpapahayag; dapat nilang igarantiya ang panloob na demokrasya, ang pagikot ng kapangyarihan ng kanilang mga pinuno, at pananagutan.

Ang karapatan ng mga katutubo sa sariling pagpapasya ay dapat gamitin sa loob ng isang konstitusyonal na balangkas ng awtonomiya na tinitiyak ang pambansang pagkakaisa. Ang mga katutubo at pamayanan ay kikilalanin sa mga konstitusyon at batas ng mga pederal na entidad, na isasaalang-alang, bilang karagdagan sa mga pangkalahatang prinsipyo na itinatag sa mga nakaraang talata ng artikulong ito, pamantayan sa etnolinggwistiko at lokasyong pisikal.

A. Kinikilala at iginagarantiya ng Konstitusyong ito ang karapatan ng mga katutubo at pamayanan sa sariling pagpapasya at, bilang isang resulta, ang kanilang awtonomiya patungkol sa:

$$
\cdots
$$

Ang mga konstitusyon at batas ng mga pederal na entidad ay magtataguyod ng mga katangiang elemento ng sariling pagpapasya at awtonomiya na pinakaangkop sa mga kalagayan at mithiin ng mga katutubo sa bawat entidad, pati na rin sa mga patakaran ng pagkilala sa mga katutubong komunidad bilang entidad ng pampublikong interes.

Ang karapatan ng mamamayan ng South Africa bilang isang kabuuan sa sariling pagpapasya, tulad ng ipinakita sa Konstitusyong ito, ay hindi pumipigil, sa loob ng balangkas ng karapatang ito, sa pagkilala sa nosyon ng karapatan ng sariling pagpapasya ng anumang pamayanan na nagbabahagi ng isang komun na pangkultura at pangwikang pamana, sa loob ng isang teritoryal na entidad sa Republika o sa anumang ibang paraan, na tinutukoy ng pambansang lehislasyon.
Kinikilala ang sariling pagpapasya, ngunit tila limitado sa ilang mga katutubong pangkat

Kinikilala ang sariling pagpapasya bilang kolektibong aksyon upang maimpluwensyahan ang patakaran

\section{Malinaw na kinikilala ang} karapatan ng mga katutubo sa panloob na sariling pagpapasya, kasama ang garantiya ng pagpapatupad
Ipinapahayag ang pagkakaiba sa pagitan ng pambansang sariling pagpapasya at ang karapatan sa sariling pagpapasya ng anumang komunidad na may komun na pamana sa kultura 


\section{MGA NAPAG-ALAMAN}

Sagot sa tanong (Oo/Hiindi) at iba pang mga tala at obserbasyon tungkol sa kung gaano kahusay na tinutugunan $n g$ konstitusyon ang (mga) isyu na itinanong. Isama ang mga makabuluhang mga probisyon ((mga) numero $n g$ artikulo at teksto $n g$ (mga) probisyon). Tandaan din ang hindi konsistent at/o magkasalungat na mga probisyon, o kung walang umiiral na mga kaugnay na probisyon.

\section{MGA HAKBANG}

Iminungkahing adbokasiya at iba pang mga kasunod na hakbang upang matugunan o mapalaganap ang mga natuklasan. 


\section{Mga pundasyon para sa mga karapatan ng mga katutubo}

\section{Kinikilala ba ng konstitusyon ang mga kolektibong karapatan? Kung gayon, ito ba ay isang pangkalahatang pagkilala o espesipiko sa mga katutubo?}

\section{PALIWANAG}

Ang mga katutubo ay kadalasan mayroong isang kolektibo o komunal na pagkakakilanlan; ang kanilang indibidwal na pagkakakilanlan ay nakatali sa pagkakakilanlan ng kanilang pamayanan. Sa pagsusulong sa proklamasyon ng UNDRIP, sinabi ng isang tagapagtaguyod sa karapatan ng mga katutubo na: 'Ang konsepto ng mga kolektibong karapatan ng mga katutubo ay pinakamahalaga. Ito ang pagtataguyod ng mga karapatan ng mga mamamayan bilang mga grupo, at hindi lamang pagkilala sa mga karapatang indibidwal, na isa sa pinakamahalagang layunin ng Deklarasyong ito. Kung wala ito, ang Deklarasyon ay hindi maaaring sapat na maprotektahan ang atming pinakabatayang interes. Hindi ito dapat ikompromiso'(United Nations Sub-Commission 1989). Dahil dito, pundamental para sa mga katutubo na ang konsepto ng mga kolektibo bilang may-ari ng mga karapatan, kung hindi partikular na mga karapatang pangkomunal para sa mga katutubo, ay kasama sa konstitusyon. Ang internasyunal na batas na tiyak para sa mga katutubo ay nabuo sa paligid ng palagay na ang mga katutubong komunidad, bilang mga kolektibong kabuuan, ay maaaring gumawa ng mga panukala sa mga pamahalaan na igalang at bigyan ng kinakailangang pampulitikal espasyo upang paunlarin ang kanilang mga sarili alinsunod sa kanilang kolektibong kahalagan at pananaw sa mundo.

Habang ang konstitusyon ay maaaring magarantiya ng mga karapatan, tulad ng pundamental na karapatan sa kalayaan sa pamamahayag, sa lahat ng mga mamamayan, ang ilan sa mga karapatang ito ay maaaring mabigo sa pagkatawan sa kalidad ng karapatan sapagkat pinapatungkulan nito ang pamayanan bilang kolektibo. Samakatuwid, ang mga katutubo ay madalas na nagtataguyod para sa pagkilala sa kolektibo, bilang karagdagan sa indibidwal na mga karapatan. Ang mga kolektibong karapatan ay maaaring mailapat sa pag-aari (lupa at intelektwal), pamamahala ng likas na mapagkukunan, wika, sariling pagpapasya, mga espesyal na hakbang/apirmadong aksyon at ang pagpapanatili sa 'integridad ng kultura' o pagkakaiba-iba. Ang isang konstitusyon ay maaaring magbigay ng pangkalahatang pagkilala para sa mga kolektibong pag-aari o mga karapatan sa partikular na mga larangan tulad ng lupa o intelektwal na pag-aari.

MGA PAMANTAYANG PANG-INTERNASYUNAL AT PAMBANSANG MGA HALIMBAWA

\begin{tabular}{|c|c|c|c|}
\hline $\begin{array}{l}\text { Kumbensyon } \\
\text { ng ILO } 169 \\
1989\end{array}$ & Artikulo 13(1) & $\begin{array}{l}\text { Sa paglalapat ng mga probisyon ng Bahagi ng } \\
\text { Kumbensyong ito ay dapat igalang ng mga pamahalaan } \\
\text { ang espesyal na kahalagahan para sa mga kultura at } \\
\text { mga espiritwal na kahalagahan ng mga mamamayan na } \\
\text { nauukol sa kanilang ugnayan sa mga lupain o teritoryo, o } \\
\text { pareho kung naaangkop, na sinasakop nila o kung hindi } \\
\text { man ginagamit, at lalo na ang kolektibong aspekto ng } \\
\text { ugnayan na ito. }\end{array}$ & $\begin{array}{l}\text { Kinikilala ang kahalagahan } \\
\text { ng 'kolektibong aspekto' } \\
\text { ng katutubong kultura, } \\
\text { partikular ang mga } \\
\text { karapatan na may } \\
\text { kaugnayan sa lupa }\end{array}$ \\
\hline $\begin{array}{l}\text { UNDRIP } \\
2007\end{array}$ & $\begin{array}{l}\text { Preambulo at } \\
\text { artikulo } 7(2)\end{array}$ & $\begin{array}{l}\text { Preambulo } \\
\text { Pagkilala at muling pagkumpirma... na ang mga } \\
\text { katutubo ay nagtataglay ng kolektibong mga karapatan } \\
\text { na esensyal sa kanilang kairalan, kagalingan, at integral } \\
\text { na kaunlaran bilang mga mamamayan. }\end{array}$ & $\begin{array}{l}\text { Kinikilala ang mga } \\
\text { karapatan ng mga katutubo } \\
\text { bilang pinanghahawakan } \\
\text { ng mga 'kolektibo' o mga } \\
\text { pamayanan sa kabuuan }\end{array}$ \\
\hline
\end{tabular}

Article 7(2)

Ang mga katutubo ay may kolektibong mga karapatan na mabuhay sa kalayaan, kapayapaan, at seguridad bilang natatanging mga mamamayan.

$\begin{array}{lll}\begin{array}{l}\text { Konstitusyon } \\ \text { ng Angola }\end{array} & \begin{array}{l}\text { Seksyon } 1 \\ \text { (Titulo) }\end{array} & \text { Indibidwal at Kolektibong Mga Karapatan at Kalayaan } \\ 2010 & & \end{array}$

Malinaw na kinikilala sa pamagat ng kabanata na ang mga karapatan ay parehong indibidwal at kolektibo 


Konstitusyon $\quad$ Artikulo 134
ng Brazil
1988

1988

\begin{tabular}{l|l}
$\begin{array}{l}\text { Konstitusyon } \\
\text { ng Ecuador }\end{array}$ & Artikulo 11(1), \\
\hline 2008 & at 403
\end{tabular}

Ang Opisina ng Pampublikong Tagapagtanggol ay isang permanenteng institusyon, esensyal sa pagpapatupad ng hurisdiksyon ng Estado, at ito ay pundamental na responsable, bilang isang ekspresyon at instrumento ng demokratikong rehimen, para sa ligal na oryentasyon, pagsulong ng mga karapatang pantao, at ang integral at di kinakailangang depensa, sa lahat ng antas, hudisyal at ekstra-hudisyal, ng indibidwal at kolektibong mga karapatan ng mga nangangailangan, tulad ng itinakda sa art. 5, LXXXIV.

Artikulo 11

Ang paggamit ng mga karapatan ay dapat mapamahalaan ng mga sumusunod na prinsipyo:

(1) Ang mga karapatan ay maaaring gamitin, maisulong, at maipatupad nang indibidwal o kolektibo sa harap ng mga may kakayahang awtoridad; ang mga awtoridad na ito ang gagarantiya sa kanilang pagpapatupad.

Artikulo 57

Ang mga katutubong komyun, pamayanan, mamamayan at nasyon ay kinikilala at iginagarantiya, na naaayon sa Konstitusyon at mga kasunduan sa karapatang pantao, mga kumbensyon, deklarasyon at iba pang mga instrumentong pang-internasyonal, ang mga sumusunod na kolektibong karapatan:

... Igagarantiya ng Estado ang pagpapatupad ng mga kolektibong karapatang ito nang walang anumang diskriminasyon, sa mga kondisyon ng pagkakapantaypantay at pagkakapatas ng kalalakihan at kababaihan.

Artikulo 58

Upang maitaguyod ang kanilang pagkakakilanlan, kultura, tradisyon at mga karapatan, ang kolektibong mga karapatan ng mamamayang Afro-Ecuadorian ay kinikilala, na nakalagay sa Konstitusyon, batas, at mga kasunduan sa karapatang pantao, mga kombensyon, deklarasyon at iba pang mga internasyonal na instrumento.

Artikulo 59

Ang kolektibong mga karapatan ng mga mamamayang nasa baybaying bayan (montubios) ay kinikilala upang igarantiya ang kanilang proseso $\mathrm{ng}$ integral, sustenable at matibay na pag-unlad ng tao, ang mga patakaran at estratehiya para sa kanilang pagsulong at kanilang mga anyo ng pamamahala ng lipunan, batay sa kaalaman tungkol sa kanilang realidad at paggalang sa kanilang kultura, pagkakakilanlan, at sariling bisyon, alinsunod sa batas.

\section{Artikulo 257}

Sa loob ng balangkas ng ppulitikal-administratibong organisasyon, maaaring mabuo ang mga katutubo o Afro-Ecuadorian na mga teritoryal na distrito. Ang mga ito ay magkakaroon ng hurisdiksyon sa kanikanilang teritoryal na awtonomong pamahalaan at pamamahalaan ng mga prinsipyo ng interkulturalismo at plurinasyunalismo, at alinsunod sa mga kolektibong karapatan.

Artikulo 403

Ang Estado ay hindi dapat gumawa ng mga pangako sa mga kasunduan sa kooperasyon o mga kasunduan na may kasamang mga sugnay na nagpapahina sa pangangalaga at sustenableng pamamahala ng pagkakaiba-iba, kalusugan ng tao, mga kolektibong karapatan, at mga karapatan ng kalikasan.
Nagbibigay ng malinaw na mandato sa Opisina ng Pampublikong Tagapagtanggol upang protektahan ang parehong mga indibidwal at kolektibong mga karapatan upang itaguyod ang pagpapatupad

Pinoprotektahan ang pagsasagawa at pagpapatupad ng mga kolektibong karapatan na partikular para sa mga katutuboo, mamamayang Afro-Ecuadorian, at mga montubio.

\section{Nagbibigayng}

pagkakataon upang itaas ang mga karapatan nang indibidwal o kolektibo.

Ipinagbabawal ang estado sa pagkontrata sa mga kasunduan na lumalabag sa kolektibong mga karapatan 
Konstitusyon Artikulo 67 ng Guatemala 1985

\begin{tabular}{|l|l|}
$\begin{array}{l}\text { Konstitusyon } \\
\text { ng Serbia } \\
2006\end{array}$ & Artikulo 75 \\
\hline & \\
\hline $\begin{array}{l}\text { Konstitusyon } \\
\text { ng Venezuela } \\
1999\end{array}$ & \begin{tabular}{l} 
Artikulo 119 at \\
\hline
\end{tabular} \\
\hline
\end{tabular}

New Zealand, Artikulo 2
Kasunduan ng
Waitangi
1840

Ang mga lupain ng mga kooperatiba, katutubong pamayanan, $o$ anumang iba pang mga uri ng pagmamayaring komyunal o kolektiba ng agraryong pagmamayari, pati na rin ang pamana ng pamilya at popular na pabahay ay tatangkilikin ang espesyal na proteksyon ng Estado, ginustong kredito, at teknikal na tulong, na maaaring ginagarantiya ang kanilang pagmamay-ari at pag-unlad upang masigurado ang isang pinahusay na kalidad $\mathrm{ng}$ buhay sa lahat $\mathrm{ng}$ mga naninirahan.

Ang mga taong kabilang sa mga pambansang minorya ay igagarantiyang may espesyal na indibidwal o kolektibong mga karapatan bilang karagdagan sa mga karapatang iginagarantiya sa lahat ng mga mamamayan ng Konstitusyon.

\section{Artikulo 119}

Kinikilala ng Estado ang pag-iral ng mga katutubo at pamayanan, ang kanilang samahang panlipunan, pampulitika at pang-ekonomiya, ang kanilang mga kultura, kasanayan at kaugalian, wika at relihiyon, pati na rin ang kanilang tirahan at orihinal na mga karapatan sa mga lupain ng kanilang ninuno at tradisyonal na sinasakop, at kung alin ang kinakailangan upang paunlarin at igarantiya ang kanilang paraan ng pamumuhay. Magiging responsibilidad ng Pambansang Tagapagpaganap, kasama ang pakikilahok ng mga katutubo, na tukuyin at igarantiya ang karapatan sa kolektibong pagmamay-ari ng kanilang mga lupain, na hindi maisusuko, hindi napapailalim sa batas $\mathrm{ng}$ mga limitasyon o kawalang muwang, at hindi maililipat, alinsunod sa Konstitusyong ito at sa batas.

Artikulo 124

Ang sama-samang mga karapatan sa intelektwal na pag-aari sa kaalaman, teknolohiya at pagbabago ng mga katutubo ay ginagarantiyahan at protektado. Ang anumang aktibidad na nauugnay sa mga mapagkukunang genetiko at ang kaalamang nauugnay sa pareho ay dapat magtuloy ng sama-samang mga benepisyo. Ang pagpapatala ng mga patent sa kaalaman ng ninuno na ito at ang mga mapagkukunang ito ay ipinagbabawal.

Ang Mahal na Reyna ng Inglatera ay kinumpirma at ginagarantiya sa mga pinuno ng mga tribo ng New Zealand at sa kani-kanilang pamilya at indibidwal dito ang buong eksklusibo at hindi magagambalang pag-aari ng kanilang mga Lupain at mga Ari-ariang Kagubatan at Pangisdaan at iba pang mga pag-aari na maaari nilang kolektibo o indibidwal na panghawakan hangga't kanilang hangarin at naisin na parehong panatilihin bilang kanilang pagmamay-ari.
Kinikilala ang komyunal na pagmamay-ari ng lupain

Nagbibigay ng malakas na wika tungkol sa pagpapatupad ng kolektibong karapatan kahit na hindi espesipiko sa mga katutubo (para sa lahat ng mga pambansang minorya)

Kinikilala ang tiyak na mga kolektibong karapatan sa lupa at intelektuwal na pag-aari para sa mga katutubong pamayanan

Pinapayagan para sa kolektibong pagmamayaring lupa (pati na rin sa indibidwal) 


\section{MGA NAPAG-ALAMAN}

Sagot sa tanong (Oo/Hiindi) at iba pang mga tala at obserbasyon tungkol sa kung gaano kahusay na tinutugunan $n g$ konstitusyon ang (mga) isyu na itinanong. Isama ang mga makabuluhang mga probisyon ((mga) numero $n g$ artikulo at teksto $n g$ (mga) probisyon). Tandaan din ang hindi konsistent at/o magkasalungat na mga probisyon, o kung walang umiiral na mga kaugnay na probisyon.

\section{MGA HAKBANG}

Iminungkahing adbokasiya at iba pang mga kasunod na hakbang upang matugunan o mapalaganap ang mga natuklasan. 


\section{Mga pundasyon para sa mga karapatan ng mga katutubo}

Ang konstitusyon ba ay naglalaan ng kung paano ang mga pundamental
na mga karapatan ng mamamayan at karapatang pantao, kabilang ang
pagkakapantay-pantay sa harap ng batas at mga proteksyon para sa
kababaihan at iba pang mga magkakaugnay na bulnerableng grupo, ay
dapat na maipagkasundo sa mga karapatan ng mga katutubo?

PALIWANAG

Ang pagkilala sa mga karapatan ng mga katutubo ng isang konstitusyon ay hindi darating nang walang mga komplikasyon. Maraming mga pagkakataon kung saan ang mga karapatan ng mga katutubo ay maaaring magkasalungat sa iba pang mga konstitusyonal na karapatan. Sa pagprotekta sa mga karapatan ng mga katutubo na magsagawa ng tradisyunal na pamamahala o mga mekanismo ng hustisya, halimbawa, ang isang estado ay maaaring hindi sinasadya na protektahan ang isang sistema na nagpapahintulot sa korporal na parusa o isang namamayaning kaugalian na nagbubukod sa mga kabataan o kababaihan. Dahil dito, ang pagbabawal ng isang konstitusyon sa diskriminasyon ay maaaring sumalungat, sa pagsasagawa, ng ilang mga katutubong kaugalian at sistema kung saan ang mga kababaihan at kalalakihan ay magkaiba ang trato, tulad ng mga sistema ng panunungkulan ng lupa o pagkakasunud-sunod ng pamumuno. Sa mga pagkakataong ito, alinman sa isang karapatan o iba pa ay dapat na limitado-halimbawa, alinman sa pundmental na karapatang konstitusyonal sa pantay na pakikilahok sa pamahalaan para sa lahat ng mga mamamayan (hindi alintana ang kasarian o edad), o ang karapatang konstitusyonal para sa mga katutubo na magsagawa ng sariling pamamahala at mga tradisyunal na kasanayan, na maaaring maituring na eksklusibo sa mga kababaihan o kabataan.

Mahalaga na ang isang konstitusyon ay nagbibigay ng isang mekanismo upang magkasundo ang mga karapatan at kalayaan na maaaring magkaroon ng hindi pagkakasundo sa isa't isa o maging hindi angkop sa pagsasanay. Ginagawa ito sa iba't ibang paraan, kasama ang pagbibigay ng kapangyarihan sa mga korte na balansehin ang mga karapatan; o sa pamamagitan ng mga malinaw na pangako na ang mga karapatan ng mga katutubo ay malilimitahan sa lawak na hindi sila sumasalungat sa iba pang mga karapatan sa konstitusyon; o sa pamamagitan ng pagbubukod ng mga pamayanan ng mga katutubo mula sa ilang pamantayan sa mga karapatan sa pamamagitan ng pagpapahintulot sa mga karapatan sa pamamahala ng sarili sa mga isyu tulad ng batas ng pamilya, halimbawa, na mauna. Ang isyu ay madalas na malinaw na tinutugunan sa mga konstitusyon patungkol sa mga katutubo at kaugaliang karapatan kumpara sa mga karapatang konstitusyonal sa pagkakapantay-pantay, kawalang diskriminasyon at iba pang mga substantibong garantiya tulad ng mga karapatan sa angkop na proseso, buhay at kalayaan.

Ang isang patakaran para sa pag-aayos ng mga karapatan ay partikular na mahalaga mula sa pananaw ng interseksyonalidad ng mga pagkakakilanlan. Ang isang interseksyonal na dulog sa mga karapatang pantao ay kumikilala na ang buhay na karanasan ng mga tao ay pinapamagitanan ng kanilang maraming pagkakakilanlan, kabilang, halimbawa, ang lahi, uri, etnisidad, pagiging miyembro ng isang katutubong komunidad, pambansang pinagmulan, oryentasyong sekswal, kasarian, edad, pagkamamamayan, geopolitikal na konteksto at kalusugan. Ang isang normatibong pagtatasa ng iba’t ibang mga dulog sa pagbabalanse ng mga isyung ito at pagkakakilanlan sa praktika ay nakasalalay sa konteksto ng bansa at sa espesipikong pagkakakilanlang interseksyonal na nasa isyu.

Ang sitwasyon ng mga kababaihang katutubo, sa partikular, ay dapat na espesipikong isinasaalang-alang sa pagsusuring ito. Ang mga kababaihang katutubo ay madalas na nakaharap sa maraming uri ng diskriminasyon, kapwa sa loob ng mas malawak na sistema ng estado at may kaugnayan sa mga lalaking kasapi ng kanilang katutubong komunidad. Samakatwid, mahalagang isaalang-alang kung paano lumalapit ang isang konstitusyon sa pangangailangan upang matiyak na ang kanilang pundamental na mga karapatan (hal. sa pagkakapantay-pantay, kawalang diskriminasyon, pakikilahok) ay hindi nakompromiso ng pagkilala sa mga karapatan ng mga katutubo. 


\begin{tabular}{|c|c|c|}
\hline $\begin{array}{l}\text { Konstitusyon } \\
\text { ng Bolivia } \\
2009\end{array}$ & $\begin{array}{l}\text { Artikulo } 190 \text { at } \\
210(I)\end{array}$ & $\begin{array}{l}\text { Artikulo } 190 \\
\text { I. Ang mga nasyon at rural na katutubong mamamayan } \\
\text { ay dapat gamitin ang kanilang mga hurisdiksyonal na } \\
\text { tungkulin at kapasidad sa pamamagitan ng kanilang } \\
\text { mga awtoridad, at ilalapat ang kanilang sariling mga } \\
\text { prinsipyo, kahalagahang pangkultura, pamantayan at } \\
\text { pamamaraan. } \\
\text { II. Ang rural na katutubong hurisdiksyon ay } \\
\text { rumerespeto sa karapatang mabuhay, ang karapatan } \\
\text { sa pagtatanggol at iba pang mga karapatan at } \\
\text { garantiyang itinatag sa Konstitusyong ito. } \\
\text { Artikulo } 210 \\
\text { Ang samahan at tungkulin ng mga samahan ng mga } \\
\text { bansa, mga rural na katutubo, at mga asosasyon ng } \\
\text { mamamayan at mga pulitikal na partido ay dapat na } \\
\text { demokratiko. }\end{array}$ \\
\hline
\end{tabular}

\begin{tabular}{l|l} 
Konstitusyon & Artikulo 246 \\
ng Colombia \\
1991
\end{tabular}

\begin{tabular}{l|l|}
$\begin{array}{l}\text { Konstitusyon } \\
\text { ng Ecuador }\end{array}$ & $\begin{array}{l}\text { Artikulo } 57 \text { at } \\
2008\end{array}$ \\
\hline
\end{tabular}

Ang mga awtoridad ng mga katutubo [Indian] ay maaaring gamitin ang kanilang mga hurisdiksyonal na tungkulin sa loob ng kanilang nasasakupang teritoryo alinsunod sa kanilang sariling mga batas at pamamaraan hangga't ang mga ito ay hindi salungat sa Konstitusyon at mga batas ng Republika.

Ang mga katutubong komyun, pamayanan, mamamayan at nasyon ay kinikilala at ginagarantiyahan, na naaayon sa Konstitusyon at mga kasunduan sa karapatang pantao, mga kumbensyon, deklarasyon at iba pang mga instrumentong pang-internasyunal, ang mga sumusunod na kolektibong karapatan:

$$
\cdots
$$

10. Upang lumikha, bumuo, maglapat at magsanay ng kanilang sariling sistemang ligal o karaniwang batas, na hindi makakasira sa mga karapatan sa konstitusyon, lalo na ng mga kababaihan, bata at kabataan.

$$
\cdots
$$

Gagarantiyahan ng Estado ang pagpapatupad ng mga kolektibong karapatang ito nang walang anumang diskriminasyon, sa mga kondisyon ng pagkakapantaypantay sa pagitan ng kalalakihan at kababaihan.

\section{Artikulo 171}

Ang mga awtoridad ng mga katutubong pamayanan, mamamayan, at mga nasyon ay dapat gampanan ang mga tungkulin sa hurisdiksyon, batay sa tradisyon ng kanilang mga ninuno at ksariling sistema ng batas, sa loob ng kanilang sariling mga teritoryo, na may garantiya para sa paglahok ng, at paggawa ng desisyon ng, kababaihan. Ang mga awtoridad ay dapat maglapat ng kanilang sariling mga pamantayan at pamamaraan para sa pag-areglo ng mga panloob na tunggalian, hangga't hindi sila salungat sa Konstitusyon at karapatang pantao na nakalagay sa mga internasyunal na instrumento.

Ginagarantiya ng Estado na ang mga desisyon ng katutubong hurisdiksyon ay sinusunod ng mga pampublikong institusyon at awtoridad. Ang mga pagpapasyang ito ay sasailalim sa pagsubaybay sa kanilang konstitusyonalidad. Ang batas ay magtatatag ng mga mekanismo para sa koordinasyon at kooperasyon sa pagitan ng katutubong hurisdiksyon at regular na hurisdiksyon.
Nililimitahan ang pagpapatupad ng katutubong hurisdiksyon at kaugalian hanggang sa hindi nila nasusunod ang mga karapatang konstitusyonal

Pinapayagan na maitaguyod ang mga katutubong samahan ngunit nagmamandato na sila ay maging 'demokratiko'sa pagsasagawa

\section{Nililimitahan ang} pagpapatupad ng katutubong pamamahala sa sariling teritoryo sa loob ng konstitusyon at mga pambansang batas

\section{Pinapayagan ang} katutubong kaugalian hangga't hindi lumalabag sa Kostitusyon at iba pang mga kasunduan sa karapatang pantao

Malinaw na binabanggit na ang mga karapatan ng mga katutubo na ipapatupad upang maitaguyod ang pagkakapantaypantay sa pagitan ng kalalakihan at kababaihan (kinikilala ang panganib ng interseksyonal na diskriminasyon)

Nagmamandato na dapat na isama ng sariling pamamahala ang pakikilahokng kababaihan sa paggawa ng desisyon

Nagmamandato na ang mga panloob na pagtatalo ay lulutasin ng nakaugaliang praktika hangga't walang pagsalungat sa konstitusyon at internasyunal na karapatang pantao Iginagarantiya na ang mga desisyon ng mga institusyon at awtoridad ng mga katutubo ay napapailalim sa pagsusuri para sa konstitusyonalidad 


\begin{tabular}{l|l}
$\begin{array}{l}\text { Konstitusyon } \\
\text { ng Kenya }\end{array}$ & $\begin{array}{l}\text { Artikulo 2(4) } \\
2010\end{array}$ \\
at 24
\end{tabular}

\begin{tabular}{l|l}
$\begin{array}{l}\text { Konstitusyon ng } \\
\text { Timog Aprika } \\
1996\end{array}$ & Seksyon 30 \\
\hline
\end{tabular}

\section{Canada, Batas ng Konstitusyon 1982}

South Sudan,
Batas sa
Pamahalaang
Lokal
2009

ng Canada),

seksyon $35(4)$
Artikulo 2(4)

(4) Ang anumang batas, kabilang ang kaugalian na batas, na hindi naaayon sa Konstitusyong ito ay walang bisa sa lawak ng hindi pagkakapare-pareho, at ang anumang kilos o pagkukulang na taliwas sa Konstitusyong ito ay hindi balido.

Artikulo 24(4)

(4) Ang mga probisyon ng Tsapter na ito sa pagkakapantay-pantay ay magiging karapat-dapat sa saklaw na istriktong kinakailangan para sa paglalapat ng batas ng Muslim sa harap ng mga korte ng Kadhis, sa mga taong nagpapahayag ng relihiyong Muslim, sa mga bagay na nauugnay sa personal na katayuan, kasal, diborsyo at mana.

Ang bawat isa ay may karapatang gamitin ang wika at upang lumahok sa kultural na buhay na kanilang napili, ngunit walang sinuman na gumagamit ng mga karapatang ito ay maaaring gawin ito sa paraang hindi naaayon sa anumang pagkakaloob ng Katipunan ng mga Karapatan.

(4) Sa kabila ng anumang iba pang probisyon ng Aktong ito, ang mga katutubo at tratadong karapatan na tinutukoy sa subseksyon (1) ay garantisadong pantay sa mga kalalakihan at kababaihang mamamayan.

Seksyon 98(3)

(3) Sa pagpapasya ng mga kaso, ang Korte sa Kaugaliang Batas ay dapat, magkakaugnay na ilapat ang mga sumusunod na alituntunin:

(a) ang hustisya ay dapat gawin sa lahat, anuman ang kalagayang panlipunan, pang-ekonomiya at pampulitika, lahi, nasyonalidad, kasarian, edad, relihiyon, paninindigan o paniniwala;

(b) ang hustisya ay hindi dapat maantala o ipagkakait;

(c) ang sapat na kabayaran ay dapat igagawad sa mga biktima ng pagkakamali;

(d) kusang-loob na kasunduan sa pagpapagitna at pagkakasundo sa pagitan ng mga partido ay dapat kilalanin at ipatupad; at

(e) ang substantibong hustisya ay dapat ibigay nang walang pag-aalang-alang sa mga teknikalidad
Binibigyang diin ang kataas-taasang kapangyarihan ng konstitusyon kung saan ang anumang batas na salungat sa konstitusyon ay mawawalan ng bisa ngunit nagbibigay-daan para sa ilang kwalipikasyon sa paglalapat $n g$ batas $n g$ Muslim ng mga korte ng Kadhis sa mga personal na usapin

Nagbibigay ng mas pangkalahatang mga limitasyon sa mga karapatan, ibig sabihin, kalayaan sa pagpapahayag na nililimitahan ng Katipunan ng mga Karapatan

Pinoprotektahan ang pagkakapantaypantay ng kasarian sa pagsasakatuparan ng mga karapatan ng mga katutubo

Binibigyan ng

kapangyarihan ang mga Korte sa Kaugaliang Batassa lokal na antas upang ipagkasundo ang iba't ibang mga karapatan sa loob ng pangangasiwa ng kaugaliang batas, kasama na ang pag-uutos ng paglalapat ng mga prinsipyo ng kawalang diskriminasyon at angkop na proseso (tungkol sa walang pagkaantala o pagkait sa hustisya at ang karapatan sa isang mabisang lunas) 


\section{MGA NAPAG-ALAMAN}

Sagot sa tanong (Oo/Hiindi) at iba pang mga tala at obserbasyon tungkol sa kung gaano kahusay na tinutugunan $n g$ konstitusyon ang (mga) isyu na itinanong. Isama ang mga makabuluhang mga probisyon ((mga) numero $n g$ artikulo at teksto $n g$ (mga) probisyon). Tandaan din ang hindi konsistent at/o magkasalungat na mga probisyon, o kung walang umiiral na mga kaugnay na probisyon.

\section{MGA HAKBANG}

Iminungkahing adbokasiya at iba pang mga kasunod na hakbang upang matugunan o mapalaganap ang mga natuklasan. 


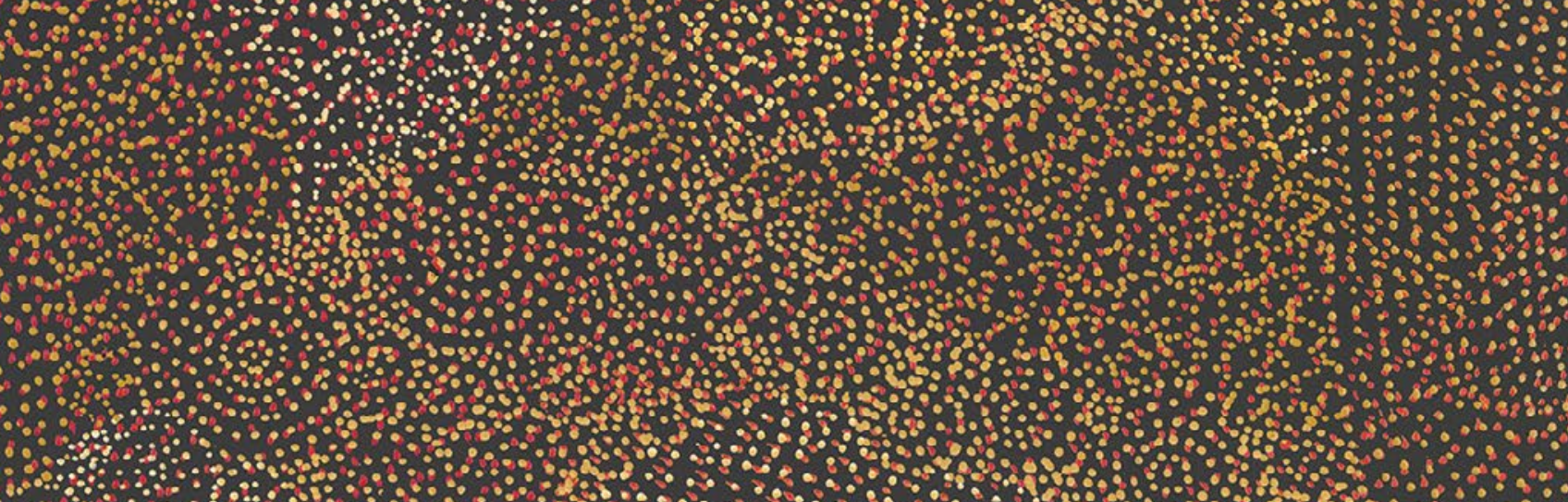

\%
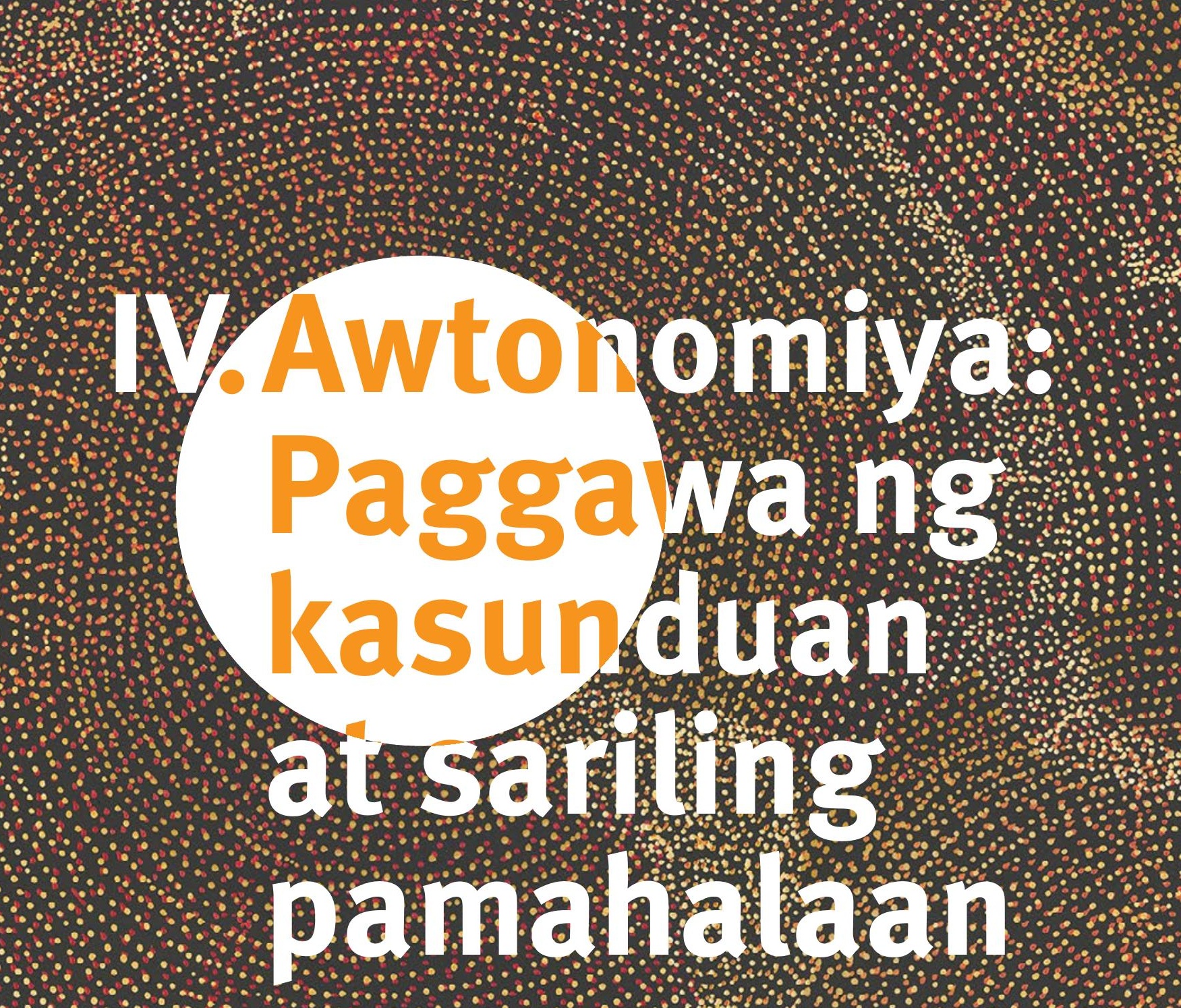
Msa Tanong 


\section{Awtonomiya: Paggawa ng kasunduan at sariling pamahalaan}

\section{Iginagalang ba ng konstitusyon ang makasaysayan at panghinaharap na paggawa ng kasunduan o mga pagsasaayos ng tratado sa pagitan ng mga katutubo at ng estado sa isang paraan na nagpapatunay sa likas na soberanya (awtonomiya) ng mga katutubo?}

\section{PALIWANAG}

Ang mga ugnayan sa pagitan ng mga katutubo at mga gobyerno ng mga estado kung saan sila nakatira ay madalas na may ligal at/o makasaysayang pundasyon sa mga tratado, kasunduan at iba pang pormal na kaayusan. Ang isang pangunahing halimbawa ay ang Tratado ng Waitangi sa New Zealand, na binanggit sa buong Kasangkapan sa Pagtatasa. Marami sa mga nasabing kasunduan ay nagsimula pa noong nakaraang mga siglo hanggang sa maagang panahon ng kolonyal, at inintindi sa kasaysayan bilang usapin ng batas sa internasyunal, bilang mga kasunduan na nilagdaan ng dalawang pantay at soberenong kapangyarihan/mamamayan. Ngayon, ang ligal na konstruksyon na ito ay bahagyang nagbago sa pag-angat ng estado at mga kaugnay na proseso upang 'idomestika' ang mga ugnayan sa pagitan ng mga gobyerno ng estado at mga katutubo. Sa kabila ng mga pagbabago ligal at normatibong pag-unawa, ang mga naturang kasunduan ay bumubuo ng isang mahalagang aspekto ng karapatan sa sariling pagpapasya at mananatiling isang napakahalagang kasangkapan upang maprotektahan ang mga karapatan ng mga katutubo at (muling) makipag-ayos sa mga relasyon sa estado sa paghiling ng modernong konteksto. Bukod dito, ang mga nasabing tratado at kasunduan ay nagdadala ng mahalagang simboliko, diplomatiko at normatibong halaga at kumakatawan sa isang batayan para sa mas malakas na pagtutulungan sa estado, kasama sa ang ilang mga kaso ang pagsasama-sama para sa makasaysayang pang-aagaw ng ari-arian at marhinalisasyon. Sa ilalim ng UNDRIP, ang mga katutubo ay may karapatan sa pagkilala, pagtalima at pagpapatupad ng mga tratado, kasunduan at iba pang konstruktibong kaayusan na ipinagkasundo sa mga estado o kanilang mga kahalili, at upang igalang ng mga estado ang mga naturang tratado, pati na rin ang karapatang pumasok sa mga bagong kasunduan bilang mga soberanong aktor. Nangyayari ito sa maraming ibåt ibang paraan sa buong mundo, ngunit ang pagsunod at pagpapatupad ng mga kasunduang ito ay mananatiling mahirap. Nanghimok ang United Nations para sa malawak at makabagong interpretasyon ng mga tratado at paggawa ng kasunduan (United Nations 1999).

Ang mga makasaysayang tratado ay maaaring maging isang mahalagang batayan sa paghubog ng paraan kung saan isinasama ng isang estado ang mga katutubo sa pangkalahatang balangkas ng pamamahala. Sa kasamaang palad, ang kasaysayan ng karamihan sa mga modernong estado ay batay sa mga prosesong ito, kung saan ang mga katutubo 'ay, kahit na pormal lamang, inilagay sa ilalim ng isang estruktura ng Estado na nagsasama ng pambansang, panlipunan at pangkulturang mga katangian na iba sa kanila' (Martínez Cobo 1972). Kung ang mga makasaysayang tratado ay maaasahan bilang isang pagpapakita ng paggalang sa soberanya ng mga katutubo, maaari itong bumuo ng isang malakas na batayan para sa mga modernong pagsisikap sa pagbuo ng estado at pagbabawas ng mga pagkakataong maulit ang marahas na asimilasyon at pang-aagaw ng ari-arian.

Bahagyang bihira para sa mga konstitusyon na malinaw na kilalanin ang mga makasaysayang tratado o igarantiya ang karapatan ng mga katutubong komunidad na pumasok sa mga bagong tratado o iba pang mga kasunduan sa estado o iba pang mga partido, partikular bilang dalawang magkakapantay na mga soberanong entidad. Kabilang sa mga pangunahing pagbubukod, halimbawa, ang Estados Unidos at Canada (kahit na muling binigyan ng kahulugan ng Estados Unidos ang mga nauugnay na probisyon ng konstitusyon at umatras mula sa mga pangunahing obligasyon sa tratado sa paglipas ng panahon). Gumagawa ang Canada ng isang mas progresibong lapit sa paggawa ng kasunduan at, batay sa seksyon 35 ng Konstitusyon, ay napanatili ang mga karapatan ng tratadosa modernong panahon. Noong 1973, kinilala ng Korte Suprema ng Canada ang mga karapatan ng Aborihinal sa kauna-unahang pagkakataon, sa desisyon nitong Calder et al. v. Attorney-General ng British Columbia. Ang desisyon na ito ay humantong sa pagbuo ng Patakaran sa Komprehensibong Pag-aangkin ng Lupa at ang unang modernong paglagda ng tratado sa Canada noong 1975, ang Kasunduan ni James Bay at Hilagang Québec. Mula noon, nilagdaan ng Canada ang humigit-kumulang na 25 bagong mga tratado na bumubuo sa batayan ng ugnayan sa pagitan ng Canada at ng 97 kinikilalang mga katutubong komunidad. Ang mga tratado sa Canada ay nagbigay para sa: 'Pagmamay-ari ng katutubo sa higit sa $600,000 \mathrm{~km}^{2} \mathrm{ng}$ lupa, paglipat ng kapital na higit sa $\$ 3.2$ bilyon, proteksyon ng tradisyunal na paraan ng pamumuhay, pag-akses sa mga pagkakataon sa pag-unlad ng mapagkukunan, pakikilahok sa mga desisyon sa pamamahala ng lupa at mga mapagkukunan, katiyakan patungkol 
sa mga karapatan sa lupa sa tinatayang 40\% ng kalupaan ng Canada [at] nauugnay na mga karapatan sa sariling pamahalaan at pulitikal na pagkilala'(Pamahalaan ng Canada 2018). Sinimulan din ng Canada ang isang proseso ng 'bilateral na mekanismo', kung saan mga bagong memorandum ng pagkakaintindihan at mga kasunduan ay pinag-uusapan at nilalagdaan sa pagitan ng Pamahalaang Canada at mga katutubong nasyon-halimbawa, ang Canada-Metis Nation Accord at ang Memorandum of Understanding sa pagitan ng Punong Ministro at ang Pambansang Pinuno ng Assembly of First Nations (Pamahalaan ng Canada 2020).

Sa New Zealand, ang sangkap ng pangunahing mga kasunduang pangkasaysayan ay nananatiling naipapatupad sa antas na dinomestika sila sa pamamagitan ng lehislatura sa pagsasama ng Tratado ng Waitangi sa batas. Ang pagtatatag ng Waitangi Tribunal (higit na tinalakay sa Tanong 27) ay tiniyak na ang mga katutubo ay maaaring magdala ng mga paghahabol laban sa gobyerno kaugnay ng nagpapatuloy na paglabag sa mga makasaysayang karapatang ito. Sa Australia, ang mga mambabatas at mga katutubo ay matagal nang isinasaalang-alang ang mga paraan ng konstitusyonal na pagkilala at ang potensyal na paggamit ng mga tratado upang makontrol ang mga relasyon ng mga katutubo at estado. Kinikilala rin ng Denmark ang sariling katutubong pamamahala ng Greenland na pumasok sa mga bagong transnasyunal na kontrata sa mga lugar ng kakayahan nito, ayon sa konstitusyon at umiiral na batas.

Ang pagkakaiba-iba ng mga lapit at limitadong paghahambing ng mga konstitusyonal na balangkas na tumutukoy sa karapatang ito ay nangangahulugang ang isyu ay maaaring sub-konstitusyonal na matugunan sa pamamagitan ng lehislasyon o sa mga kaugnay na patakaran na nagsasama ng mga makasaysayang tratado. Gayunpaman, sa maraming mga kaso, ang proseso at kalikasan ng naturang pagkilala ay maaaring mangailangan ng karagdagang pagtaas ng kamalayan sa lokal na antas, pangangalap ng data, pagsasaliksik, at adbokasiya upang mas maunawaan ang kasalukuyang katayuan ng mga makasaysayang tratado sa loob ng bansang isinasailalim sa pagtatasa at kung ang isang modernong kasunduan o iba pang konstruktibong pag-aayos ay isang magagamit na instrumento kung saan upang mapalakas ang mga ugnayan ng mga mamamayan ng estado at katutubo at pagsasagawa ng sariling pagpapasya.

MGA PAMANTAYANG PANG-INTERNASYUNAL AT PAMBANSANG MGA HALIMBAWA

\begin{tabular}{|c|c|c|c|}
\hline $\begin{array}{l}\text { UNDRIP } \\
2007\end{array}$ & $\begin{array}{l}\text { Artikulo } 36 \text { at } \\
37(1)\end{array}$ & $\begin{array}{l}\text { Artikulo } 36 \\
\text { 1. Ang mga katutubo, lalo na ang mga } \\
\text { nahahati sa mga internasyunal na } \\
\text { hangganan, ay may karapatang panatilihin } \\
\text { at paunlarin ang mga pakikipag-ugnay, }\end{array}$ & $\begin{array}{l}\text { Kinikilala ang karapatan ng mga } \\
\text { katutubo na pumasok sa mga } \\
\text { transnasyunal na kontrata at } \\
\text { kasunduan sa kooperasyon bilang } \\
\text { mga soberanong aktor }\end{array}$ \\
\hline
\end{tabular}
relasyon at kooperasyon, kasama ang mga aktibidad para sa pang-espiritwal, pangkultura, pampulitika, pang-ekonomiya at panlipunang mga hangarin, kasama ng kanilang sariling mga miyembro pati na rin ang ibang mga tao sa mga hangganan.

2. Ang mga Estado, sa konsultasyon at kooperasyon sa mga katutubo, ay dapat gumawa ng mabisang hakbang upang mapangasiwaan ang pagsasagawa at matiyak ang pagpapatupad ng karapatang ito.

Artikulo 37

1. Ang mga katutubo ay may karapatan sa pagkilala, pagtalima at pagpapatupad ng mga tratado, kasunduan at iba pang konstruktibong kaayusan na naipagkasundo sa mga Estado o kanilang mga kahalili at upang igalang ng mga Estado ang mga naturang tratado, kasunduan at iba pang konstruktibong kaayusan.

\begin{tabular}{l|l}
$\begin{array}{l}\text { Konstitusyon } \\
\text { ng Bolivia }\end{array}$ & $\begin{array}{l}\text { Artikulo } 304 \\
(\mathrm{I}, 17)\end{array}$ \\
2009 &
\end{tabular}

I. Dapat maisagawa ng mga rural na katutubong autonomiya ang mga sumusunod na eksklusibong awtoridad:

...

17. Upang itaguyod at lagdaan ang mga kasunduan ng kooperasyon sa ibang mga bayan at pampubliko at pribadong entidad.

Nagbibigay ng karapatan sa mga katutubo na makilala ang mga umiiral na mga tratado

Kinikilala ang karapatan ng mga katutubo na itaguyod at lagdaan ang mga kasunduan ng kooperasyon sa mga pribado at pampublikong entidad 


\begin{tabular}{l|l|}
$\begin{array}{l}\text { Konstitusyon ng } \\
\text { Estados Unidos } \\
1789\end{array}$ & Artikulo VI \\
\hline
\end{tabular}

\section{Canada, Batas ng Konstitusyon 1982}

Bahagi II (Mga Karapatan ng Mga Katutubo ng Canada), seksyon 35

\begin{tabular}{l|l|}
$\begin{array}{l}\text { New Zealand, } \\
\text { Tratado sa }\end{array}$ & $\begin{array}{l}\text { Pamagat, } \\
\text { preambulo at }\end{array}$ \\
$\begin{array}{l}\text { Batas ng } \\
\text { Waitangi }\end{array}$ & artikulo 3 \\
\hline 1975 & \\
\hline
\end{tabular}

Ang Konstitusyongito, at ang mga Batas ng Estados Unidos na dapat gawin Alinsunod dito; at lahat ng mga Tratado na ginawa, o kung saan ay gagawin, sa ilalim ng Awtoridad ng Estados Unidos, ay dapat na maging kataas-taasang Batas ng Lupa.
Ang Artikulo VI ay orihinal na binigyang kahulugan na ibig sabihin ay ang Pamahalaan ng Estados Unidos ay nagpatibay at pinahintulutan ang mga nakaraang kasunduan sa mga bansang India, na implisitong kinikilala ang kanilang mga kapangyarihan sa paggawa ng kasunduan at soberanya. Gayunpaman, ang Indian Appropriation Act noong 1871, ay nagbigay ng isang bagong interpretasyon sa Artikulo VI na nagbabago sa katayuang ligal ng mga bansa at tribo at pinagkaitan silang kilalanin bilang mga 'independiyenteng' mamamayan sa ilalim ng internasyunal na batas. Itinaguyod ng Korte Suprema ang posisyon na ito, na binibigyang diin ang kahalagahan ng pagbibigaykahulugan sa konstitusyonal at ang papel na ginagampanan ng mga korte at mambabatas sa prosesong iyon, partikular para sa karaniwang mga hurisdiksyon ng batas

Kinikilala ang lahat ng umiiral na mga tratadong karapatan ngunit naipaliwanag din ng mga korte bilang pagbibigay ng patuloy na karapatan sa negosasyon $\mathrm{ng} \mathrm{mga}$ kasunduan sa pagitan ng mga katutubong lugar at ng gobyerno

(3) Para sa higit na katiyakan, sa subseksyon (1) ang 'mga tratadong karapatan' ay nagsasama ng mga karapatang mayroon na ngayon sa pamamagitan ng mga kasunduan sa mga pag-angkin ng lupa o anumang maaaring paraan ng pagkuha.

(4) Sa kabila ng anumang iba pang probisyon ng Batas na ito, ang mga katutubo at tratadong karapatan na tinutukoy sa subseksyon (1) ay garantisadong pantay sa mga kalalakihan at kababaihang mamamayan.

\section{Pamagat}

Isang Batas na maglalaan para sa pagtalima, at kumpirmasyon, ng mga prinsipyo ng Tratado ng Waitangi sa pamamagitan ng pagtataguyod $\mathrm{ng}$ isang Tribunal upang gumawa ng mga rekomendasyon sa mga paghahabol na nauugnay sa praktikal na aplikasyon ng Tratado at upang matukoy kung ang ilang mga bagay ay hindi naaayon sa mga prinsipyo ng Tratado.

Preambulo

Sapagkat noong 6 Pebrero 1840 isang Tratao ay ipinasok sa Waitangi sa pagitan ng Kanyang yumaong Kamahalan na si Reyna Victoria at ng mga mamamayang Maori ng New Zealand: At samantalang ang teksto ng Kasunduan sa wikang Ingles ay naiiba sa teksto ng Tratado sa teksto ng Tratado sa wikang Maori:

At samantalang kanais-nais na ang isang Tribunal ay maitatag upang gumawa $\mathrm{ng}$ mga rekomendasyon sa mga paghahabol na nauugnay sa praktikal na aplikasyon ng mga prinsipyo ng Tratado at, para sa hangaring iyon, upang matukoy ang kahulugan at epekto nito at kung ang ilang mga bagay ay hindi naaayon sa mga alituntuning iyon.

Artikulo 3

Ang Batas na ito ay magbubuklod sa Korona.
Ibubuklod ang korona sa mga obligasyon ng tratado na napagkasunduan noong 1840

Isinasama ang Tratado ng Waitangi sa konstitusyonal na balangkas ng

Nilinaw na ang mga prinsipyo ay may bisa sa pagpapatuloy ng pamahalaan (pinapayagan ang serye ng mga pag-aayos at kasunduan). New Zealand 


Greenland,
Batas ng
Greenland
sa Sariling
Pamamahala
2009

Preambulo at artikulo 12

2009

\section{Preambulo}

Kinikilala na ang mga tao sa Greenland ay mga mamamayan alinsunod sa internasyunal na batas na may karapatan ng sariling pagpapasya, ang Batas ay batay sa isang hangaring palakasin ang pagkakapantay-pantay at paggalang sa isa't isa sa pakikipagtulungan sa pagitan ng Denmark at Greenland. Alinsunod dito, ang Batas ay batay sa isang kasunduan sa pagitan ng Naalakkersuisut [Pamahalaang Greenland] at ng Pamahalaang Denmark bilang pantay na kapareha.

\section{Artikulo 12}

(1) Ang Naalakkersuisut ay maaaring, sa ngalan ng Kaharian, makipagnegosasyon at magpasya sa mga kasunduan sa ilalim ng internasyunal na batas sa mga banyagang estado at mga organisasyong pang-internasyunal, kasama na ang mga kasunduang pang-administratibo na eksklusibong nauukol sa Greenland at ganap na nauugnay sa mga larangan ng responsibilidad na kinuha.

(2) Ang mga kasunduan sa ilalim ng internasyunal na batas na eksklusibong patungkol sa Greenland at Faroe Islands at ganap na nauugnay sa mga larangan $\mathrm{ng}$ responsibilidad na kinuha ay maaaring, sa ilalim ng desisyon ng Naalakkersuisut pati na rin ng Faroe Islands Landsstyre [Pamahalaang ng Faroes], mapag-usapan at mapagpasyahan na magkasama sa ngalan ng Kaharian ng Naalakkersuisut at ng Faroe Islands Landsstyre.

(3) Ang mga kasunduan sa ilalim ng batas sa internasyunal na napagpasyahan alinsunod sa subseksyon (1) o subseksyon (2) ay maaaring wakasan alinsunod sa parehong mga probisyon.

(4) Ang mga kasunduan sa ilalim ng batas na pang-internasyunal na nakaaapekto sa patakaran sa pagtatanggol at seguridad pati na rin ang mga kasunduan sa ilalim ng internasyunal na batas na mailalapat sa Denmark, o kung saan nakipag-ayos sa loob ng isang pandaigdigang samahan na kung saan ang Kaharian ng Denmark ay kasapi ay dapat makipag-ayos at magpasya alinsunod sa mga patakarang inilatag sa seksyon 13.

(5) Ang Naalakkersuisut ay dapat ipaalam sa Pamahalaan ang mga negosasyong isinasaalang-alang bago ang mga ito ay pasisimulan at ang pagbuo ng negosasyon bago ang mga kasunduan sa ilalim ng internasyunal na batas ay mapagpasyahan o mawakasan. Ang isang mas detalyadong balangkas para sa kooperasyon alinsunod sa probisyon na ito ay matutukoy pagkatapos ng negosasyon sa pagitan ng Naalakkersuisut at ng Pamahalaan.
Inuugnay ang pagkilala sa

kasunduan sa pagitan ng Denmark at Greenland sa karapatan sa sariling pagpapasya at kinikilala ang soberanya ng Greenland sa pamamagitan ng pagsasama sa pagbanggit ng respeto sa isa't isa bilang pantay na kapareha

Kinikilala na ang Pamahalaang Greenland ay may karapatang pumasok sa mga kasunduang pang-internasyunal na nakaaapekto lamang sa Greenland sa mga nabansot na kakayahan bilang bahaging kaayusan sa panuntunan sa paninirahan kasama ang Denmark 


\section{MGA NAPAG-ALAMAN}

Sagot sa tanong (Oo/Hiindi) at iba pang mga tala at obserbasyon tungkol sa kung gaano kahusay na tinutugunan $n g$ konstitusyon ang (mga) isyu na itinanong. Isama ang mga makabuluhang mga probisyon ((mga) numero $n g$ artikulo at teksto $n g$ (mga) probisyon). Tandaan din ang hindi konsistent at/o magkasalungat na mga probisyon, o kung walang umiiral na mga kaugnay na probisyon.

\section{MGA HAKBANG}

Iminungkahing adbokasiya at iba pang mga kasunod na hakbang upang matugunan o mapalaganap ang mga natuklasan. 


\title{
Awtonomiya: Paggawa ng kasunduan at sariling pamahalaan
}

\author{
Kinikilala ba ng konstitusyon ang mga karapatan ng mga katutubo sa \\ awtonomiya at sariling pamahalaan, teritoryo o hindi?
}

\section{PALIWANAG}

Ang mga karapatan sa awtonomiya at sariling pamahalaan ay konektado sa karapatan sa sariling pagpapasya. Bilang mga pamayanan na nagpapasya sa sarili, ang mga katutubo ay dapat bigyan ng kinakailangang estruktural na awtoridad at mga paraan upang payagan ang pagpapatupad ng mga tradisyonal na kasanayan sa pamamahala sa loob teritoryo ng kanilang mga ninuno at sa kanilang mga pamayanan, pati na rin upang makapagpasya tungkol sa kung paano maisusulong at paano mabubuo ang kanilang mga komunidad sa hinaharap. Ang awtonomiya at sariling pamahalaan ay maaaring hindi teritoryal o teritoryal, at madalas na nagsasalimbayan.

\section{Hindi teritoryal na sariling pamahalaan at awtonomiya.}

Ang hindi teritoryal na sariling pamahalaan at awtonomiya ay tumutukoy sa pagtatalaga ng mga tiyak na lugar ng awtonomiya o awtoridad, kung hindi man ay kilala bilang 'mga kakayahan', kung saan ang mga katutubo ay maaaring gumamit ng sariling pamahalaan sa diwa ng sariling pagpapasya. Maraming mga katanungan sa Kasangkapan sa Pagtatasa na ito ang mas detalyadong tumitingin sa kung anong mga partikular na larangan ng pamamahala, o kakayahan ng batas at patakaran, ang mga katutubo ay binibigyan ng awtonomiya o mga karapatan sa sariling pamahalaan (hal. paggamit ng lupa at likas na mapagkukunan, wika, edukasyon, pangangalagang pangkalusugan), ngunit ang konstitusyonal na proteksyon ng hindi bababa sa prinsipyo at ang posibilidad ng awtonomiya at sariling pamahalaan ay isang kritikal na puntong papasok para sa mga katutubo, na maaaring makatulong sa pagtukoy ng eksaktong mga ayos at saklaw ng awtonomiyang ito sa paglipas ng panahon. Ang hindi teritoryal na awtonomiya ay maaaring umiiral sa tabi ng teritoryal na awtonomiya. Kaya, halimbawa, sa Greenland Self-Government Act, binibigyan ang Greenland ng teritoryal na mga karapatan sa sariling pamamahala ngunit tinukoy din ng Batas ang mga espesipikong lugar ng isyu o mga 'awtoridad' na maaaring gamitin ng Greenland ang awtonomiya.

Upang matiyak na maisasakatuparan ang mga tungkulin, ang awtonomiya sa pangalan ay dapat na kasabay ng isang makabuluhang paglalaan ng mga espesipiko at signipikanteng kapangyarihan at may mga garantiya ng pagpipinansya, na inilaan para sa alinman sa gobyerno ng estado bilang isang pagbibigay o pagbabahagi ng pambansang badyet $o$ sa pamamagitan ng pabababa ng mga kapangyarihan ng pagbubuwis o iba pang mobilisasyon ng mapagkukunan sa mga katutubo. Kung gayon, kung ang mga katutubo ay bibigyan ng awtonomiya upang magpatakbo ng kanilang sariling mga paaralan o korte, halimbawa, kakailanganin din nila ang pananalapi upang gawin ito at mga pantulong na kapangyarihan upang kumuha ng kawani o mga sibil na tagapaglingkod para sa mga institusyong ito. Ang mga detalye ng kung anong mga awtoridad at kapangyarihan ang ibibigay sa mga nagsasariling komunidad o katutubo para sa kanilang sariling pamahalaan ay maaaring ibigay sa loob ng lehislasyon kung hindi ito tinukoy sa konstitusyon, tulad ng ginawa sa Greenland Self-Government Act. Ang mga kapangyarihang ito ay dapat kilalanin at tukuyin sa konsultasyon sa mga katutubo, alinsunod sa kanilang malaya, nauna at malinang na kapahintulutan (FPIC).

\section{Teritoryal na sariling pamahalaan at awtonomiya}

Ang teritoryal na sariling pamahalaan at awtonomiya ay maaaring mapatakbo sa pamamagitan ng pagtatatag ng mga awtonomong rehiyon sa mga lugar kung saan ang mga katutubong komunidad ay heograpikal na nakakonsentra. Sa pag-aaral ng mga probisyon ng mga awtonomong rehiyon, mahalagang isaalang-alang ang uri ng katayuang ibinibigay sa mga nasabing rehiyon— kung sila ay isa pang antas ng pamahalaan sa isang pederal na desentralisadong sistema, o iba pang espesyal na porma. Mahalaga rin na matukoy kung ang mga awtoridad ng mga rehiyon o hindi, at ang anumang mga probisyon tungkol sa inter-pamahalaan na relasyon sa pagitan ng mga namamahala sa sariling teritoryo o mga awtonomong komunidad at sangay at antas ng mga gobyerno ng estado, ay malinaw na binigyang kahulugan.

Ang isang konstitusyon ay maaaring magtaguyod ng mga awtonomong rehiyon o magbigay ng mga pamantayan para sa, o isang batayan kung saan, ang mga rehiyon na ito ay maaaring makilala sa hinaharap; ang mga pamamaraang ito ay dapat na isama ang mga katutubo at ang kanilang sariling mga kinatawan at idinedisenyo alinsunod sa prinsipyo ng pagkuha ng malaya, nauna at malinang na kapahintulutan ng mga katutubo, pati na rin ang paggalang sa mga karapatan ng mga katutubo sa lupa, mga teritoryo at likas na yaman (tingnan ang Seksyon VI ng kabanatang ito) sariling pagpapasya. 


\begin{tabular}{|c|c|c|c|}
\hline $\begin{array}{l}\text { UNDRIP } \\
2007\end{array}$ & Artikulo 4 & $\begin{array}{l}\text { Ang mga katutubo, sa pagpapatupad ng kanilang karapatan } \\
\text { sa sariling pagpapasya, ay may karapatan sa awtonomiya o } \\
\text { sariling pamahalaan sa mga usapin na nauugnay sa kanilang } \\
\text { panloob at lokal na usapin, pati na rin ang mga daan at } \\
\text { pamamaraan para sa pagtustos ng kanilang mga awtonomong } \\
\text { tungkulin. }\end{array}$ & $\begin{array}{l}\text { Pagprotekta sa } \\
\text { karapatan sa } \\
\text { awtonomiya o sariling } \\
\text { pamahalaan at sa } \\
\text { pagpinansya na } \\
\text { tungkulin nito bilang } \\
\text { bahagi ng sariling } \\
\text { pagpapasya }\end{array}$ \\
\hline $\begin{array}{l}\text { Konstitusyon } \\
\text { ng Bolivia } \\
2009\end{array}$ & Artikulo 304 & 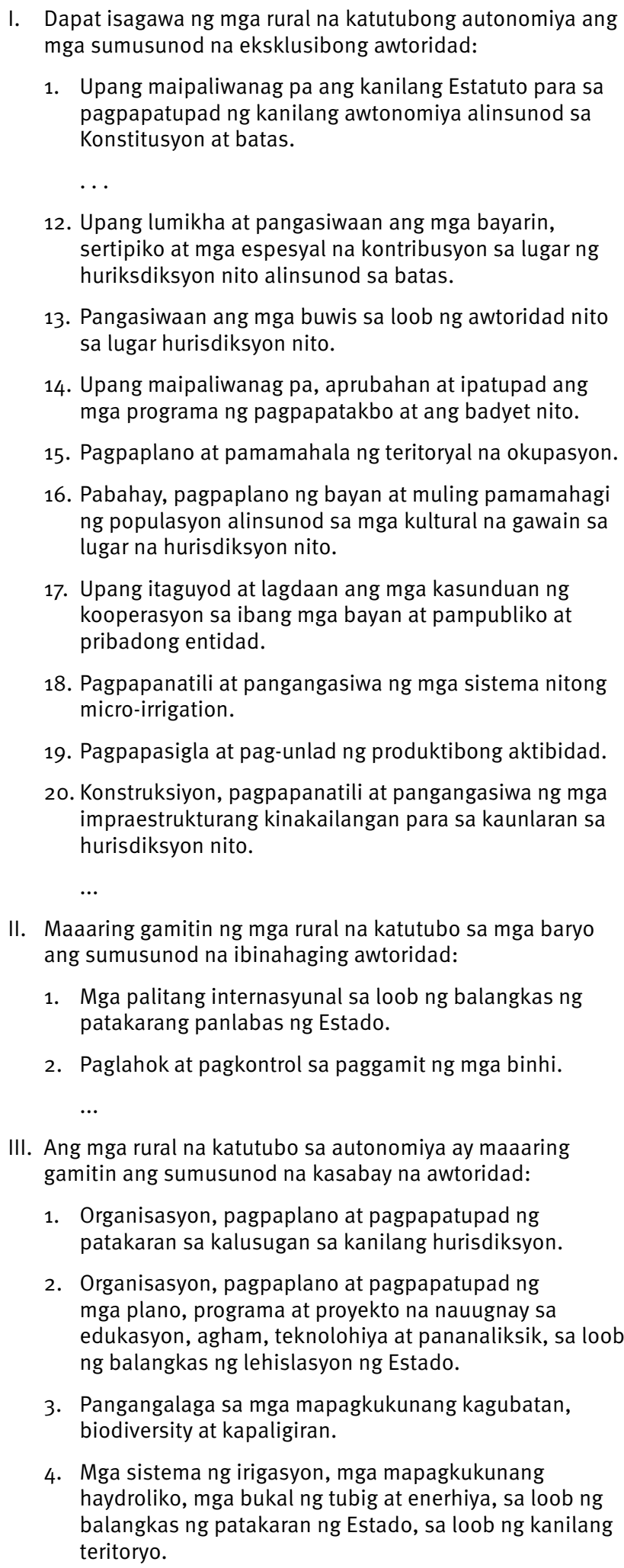 & $\begin{array}{l}\text { Tinutukoy ang mga } \\
\text { kakayahan kung saan } \\
\text { ang mga katutubong } \\
\text { pamayanan ay may } \\
\text { eksklusibong awtoridad } \\
\text { (awtonomiya) at } \\
\text { kasabay na awtoridad- } \\
\text { mga halimbawa ng } \\
\text { hindi teritoryal na } \\
\text { awtonomiya }\end{array}$ \\
\hline
\end{tabular}


5. Pagtatayo ng mga sistemang micro-irrigation.

6. Pagtatayo ng mga lokal at komyunal na kalsada.

7. Pagtataguyod ng pagbuo ng produktibong impraestruktura.

8. Pagsulong at pagpapasigla ng agrikultura at pag-aalaga ng hayop.

9. Pagkontrol at sosyo-kapaligirang pagsubaybay sa mga aktibidad ng hydrocarbon at mga aktibidad ng pagmimina na isinasagawa sa kanilang hurisdiksyon.

10. Mga sistema ng kontrol sa pananalapi at pangangasiwa sa mga ari-arian at serbisyo.

\begin{tabular}{|c|c|c|c|}
\hline $\begin{array}{l}\text { Konstitusyon } \\
\text { ng Colombia } \\
1991\end{array}$ & $\begin{array}{l}\text { Artikulo } 287 \\
\text { at } 330\end{array}$ & $\begin{array}{l}\text { Artikulo } 287 \\
\text { Ang mga entidad ng teritoryo ay nagtatamasa ng awtonomiya } \\
\text { para sa pamamahala ng kanilang mga interes sa loob ng mga } \\
\text { limitasyon ng Konstitusyon at ang kaugnay na batas. Dahil dito } \\
\text { magkakaroon sila ng mga sumusunod na karapatan: } \\
\text { 1. Upang pamahalaan ang kanilang sarili sa ilalim ng kanilang } \\
\text { sariling mga awtoridad. } \\
\text { Artikulo } 330 \\
\text { Alinsunod sa Konstitusyon at mga batas, ang mga katutubong } \\
\text { teritoryo ay pamamahalaan ng mga binuong konseho at } \\
\text { ireregula alinsunod sa gamit at kaugalian ng kanilang mga } \\
\text { pamayanan at isasaalang-alang ang mga sumusunod na } \\
\text { tungkulin: } \\
\text { 1. Subaybayan ang aplikasyon ng mga ligal na regulasyon } \\
\text { tungkol sa paggamit ng lupa at pag-areglo ng kanilang mga } \\
\text { teritoryo. } \\
\text { 2. Idisenyo ang mga patakaran, plano at programa ng pang- } \\
\text { ekonomiya at panlipunang pag-unlad sa loob ng kanilang } \\
\text { teritoryo, alinsunod sa Pambansang Plano sa Pag-unlad. } \\
\text { 3. Itaguyod ang mga pamumuhunan sa publiko sa kanilang } \\
\text { mga teritoryo at pangasiwaan ang kanilang naaangkop na } \\
\text { pagpapatupad. } \\
\text { 4. Kolektahin at ipamahagi ang kanilang pondo. } \\
\text { 5. Pamahalaan ang pangangalaga sa mga likas na yaman. } \\
\text { 6. Iugnay ang mga programa at proyekto na isinulong ng iba`t } \\
\text { ibang pamayanan sa kanilang teritoryo. } \\
\text { 7. Makipagtulungan sa pagpapanatili ng kaayusan ng publiko } \\
\text { sa loob ng kanilang teritoryo alinsunod sa mga tagubilin at } \\
\text { probisyon ng pambansang pamahalaan. } \\
\text { batas. } \\
\text { isinama; at }\end{array}$ & $\begin{array}{l}\text { Itinataguyod ang mga } \\
\text { katutubong konseho } \\
\text { na may mga tiyak na } \\
\text { tungkulin at awtoridad, } \\
\text { kabilang ang sa mga } \\
\text { lugarng lupain at likas } \\
\text { na yaman }\end{array}$ \\
\hline $\begin{array}{l}\text { Konstitusyon } \\
\text { ng Finland } \\
1999\end{array}$ & Seksyon 121 & $\begin{array}{l}\text { Ang mga probisyon sa sariling pamahalaan sa mga } \\
\text { administratibong lugar na mas malaki sa isang munisipalidad } \\
\text { ay inilalagay ng isang Batas. Sa kanilang katutubong rehiyon, } \\
\text { ang Sami ay mayroong pangwika at pangkulturang sariling } \\
\text { pamahalaan, na isinaad ng isang Batas. }\end{array}$ & $\begin{array}{l}\text { Nagbibigay para sa } \\
\text { Saming pangwika } \\
\text { at pangkulturang } \\
\text { sariling pamahalaan } \\
\text { a mga katutubong } \\
\text { rehiyon, ngunit } \\
\text { pinahahalagahan na } \\
\text { ito ay mareregula nang } \\
\text { mas detalyado ng batas }\end{array}$ \\
\hline
\end{tabular}




\begin{tabular}{|c|c|c|}
\hline $\begin{array}{l}\text { Konstitusyon } \\
\text { ng Nicaragua } \\
2014\end{array}$ & Artikulo 181 & $\begin{array}{l}\text { Ang Estado ay dapat mag-ayos sa pamamagitan ng isang } \\
\text { batas ng rehimen ng awtonomiya para sa mga katutubo at mga } \\
\text { pamayanang etniko ng Atlantic Coast, na dapat maglaman, } \\
\text { bukod sa iba pang mga patakaran: ang mga tungkulin ng } \\
\text { kanilang mga organo sa gobyerno, ang kanilang ugnayan } \\
\text { sa Ehekutibo at Lehislatibong Kapangyarihan at sa mga } \\
\text { munisipalidad, at ang paggamit ng kanilang mga karapatan. } \\
\text { Ang batas na ito ay kakailanganin para sa pag-apruba nito at } \\
\text { reporma ang mayoryang itinatag para sa pag-amyenda ng mga } \\
\text { batas na konstitusyonal. } \\
\ldots \\
\text { Ang mga miyembro ng Regional Autonomous Council ng Atlantic } \\
\text { Coast ay maaaring mawalan ng kanilang kondisyon para sa mga } \\
\text { kadahilanan at pamamaraan na itinatag ng batas. }\end{array}$ \\
\hline
\end{tabular}

Konstitusyon ng Panama $1904^{\star}$ at 1972
Artikulo 5

Ang teritoryo ng Estado ng Panamanian ay pulitikal na nahahati sa mga Probinsya, ang mga ito, kalaunan, sa mga Distrito at sa Mga Distrito sa Boroughs.

Ang iba pang mga pulitikal na paghahati ay maaaring likhain ng batas, upang mapailalim man sa mga espesyal na patakaran, o para sa mga kadahilanan ng kaginhawaang pangadministratibo o serbisyo publiko.
Nagmamandato sa estado na magtatag ng isang sistema ng awtonomiya para sa mga katutubo at mga pamayanang etniko at isinasaad na dapat igalang ng sistema ang karapatan sa sariling pamahalaan na may mga kapangyarihan ng ehekutibo at lehislatibo

Pinapayagan na bawiin ang awtonomong katayuan

Pinapayagan ang pangkalahatan para sa paglikha ng mga espesyalisadong pulitikal na hatian, na ginamit upang maitaguyod ang teritoryo ng sariling pamahalaaan ng Guna Yala sa ilalim ng Batas Blg. 16 (1953). Tinutukoy ng Batas ang tiyak na saklaw ng mga karapatan sa sariling pamahalaan sa Guna Yala

* Tala: Ang Artikulo 5 ay ginamit mula sa mas matandang mga konstitusyon, tulad ng 1904 Konstitusyon, na unang kinilala ang Guna Yala. Ang mga kasunod na konstitusyon at pag-aayos para sa awtonomiya ay nagbigay ng patuloy na proteksyon para sa pangakong ito na kilalanin ang mga awtonomong rehiyon sa Panama

Lumilikha ng mga awtonomong teritoryo ng rehiyon sa loob ng balangkas ng pambansang soberanya, kasama ang rehiyon ng Cordillera kabilang ang mayorya nitong katutubong populasyon 
Bangladesh,

Ang Batas ng

Rehiyonal na

Konseho ng

Chittagong Hill

Tracts

1998

\author{
Ang Pilipinas, \\ Batas sa \\ Karapatan ng \\ Mga Katutubo \\ 1997
}

Buong batas, partikular ang artikulo 22

$\sqrt{2+2}$

Mga tungkulin ng Konseho: a) Pangkalahatang pangangasiwa at koordinasyon ng lahat ng mga aktibidad sa pag-unlad sa ilalim ng Mga Konseho ng Hill District at lahat ng iba pang mga bagay na ipinagkatiwala sa kanila: Sa kondisyon na kung ang Rehiyonal na Konseho, sa panahon ng pangangasiwa at koordinasyon sa ilalim ng seksyong ito, ay mayroong anumang pagtatalo sa isang bagay sa isang konseho ng hill district o may higit sa isang konseho ng hill district, kung gayon ang desisyon ng Rehiyonal na Konseho, sa ilalim ng Batas na ito, ay magiging pinal; b) Pangangasiwa at koordinasyon ng mga lokal na konseho kabilang ang mga munisipalidad; c) Pangkalahatang pangangasiwa at koordinasyon ng Ordinansa ng Chittagong Hill Tracts Development Board na itinatag sa ilalim ng Ordinansa ng Lupon, 1976 (LXXVII ng 1976); d) Pangangasiwa at koordinasyon ng pangkalahatang administrasyon ng mga hill district, batas at kaayusan at kaunlaran; e) Pangangasiwa at koordinasyon ng mga tradisyon ng tribo, kasanayan atbp. at panlipunang hustisya; f) Nagbibigay ng mga lisensya para sa pagtataguyod ng mabibigat na industriya sa mga hill district alinsunod sa Pambansang Industriyal na Patakaran g) Upang magsagawa ng pamamahala sa sakuna at gawain pantulong at kapwa koordinasyon ng mga aktibidad ng NGO.

Seksyon 13

at 14

SEKSYON 13. Sariling Pamamahala. -

Kinikilala ng Estado ang likas na karapatan ng mga ICC/IP [mga katutubong pamayanang pangkultura / katutubo] sa sariling pamamahala at sariling pagpapasya at nirerespeto ang integridad ng kanilang mga kahalagahan, kasanayan, at institusyon. Dahil dito, igagarantiya ng Estado ang karapatan ng mga ICC/IP na malayang ituloy ang kanilang pang-ekonomiya, panlipunan at pangkulturang pag-unlad.

SEKSYON 14. Suporta para sa Mga Awtonomong Rehiyon. - Ang Estado ay magpapatuloy na palakasin at suportahan ang mga awtonomong rehiyon na nilikha sa ilalim ng Konstitusyon ayon sa maaaring hingin o kailanganin. Dapat ding hikayatin ng Estado ang iba pang mga ICC/IP na hindi kasama o nasa labas ng Muslim Mindanao at ng Cordilleras na gamitin ang porma at nilalaman ng kanilang mga pamumuhay na maaaring umaayon sa mga pundamental na karapatan na tinukoy sa Konstitusyon ng Republika ng Pilipinas at iba pang internasyunal na kinikilalang mga karapatang pantao.
Lumilikhang

Pamahalaang

Panrehiyong

Chittagong Hill

Tracts bilang bahagi

ng kasunduan sa

kapayapaan sa

Bangladesh upang

igalang ang karapatan ng mga katutubo sa sariling pamahalaan, partikular sa mga umuunlad na lugar, sa Chittagong Hill Tract

Kinikilala ang sariling pamahalaan at sariling pagpapasya bilang likas na mga karapatan ng mga katutubo at nanawagan sa gobyerno na magbigay ng suporta sa mga awtonomong rehiyon kung kinakailangan 


\section{MGA NAPAG-ALAMAN}

Sagot sa tanong (Oo/Hiindi) at iba pang mga tala at obserbasyon tungkol sa kung gaano kahusay na tinutugunan $n g$ konstitusyon ang (mga) isyu na itinanong. Isama ang mga makabuluhang mga probisyon ((mga) numero $n g$ artikulo at teksto $n g$ (mga) probisyon). Tandaan din ang hindi konsistent at/o magkasalungat na mga probisyon, o kung walang umiiral na mga kaugnay na probisyon.

\section{MGA HAKBANG}

Iminungkahing adbokasiya at iba pang mga kasunod na hakbang upang matugunan o mapalaganap ang mga natuklasan. 


\title{
Awtonomiya: Paggawa ng kasunduan at sariling pamahalaan
}

\author{
Ang konstitusyon ba ay nagbibigay ng karapatan sa mga katutubo \\ upang mapanatili at mailapat ang kanilang mga nakaugaliang batas at \\ proseso ng paglutas ng hindi pagkakasundo sa kanilang mga teritoryo?
}

\section{PALIWANAG}

Maaaring kilalanin ng konstitusyon ang awtoridad ng mga katutubo sa sariling pamamahala sa ibát ibang isyu ng lugar, awtoridad o kakayahan tulad ng nakikita sa Tanong 11. Isa sa mga mahahalagang partikular na kakayahan na marahil na madalas na napagtutuunan ng konstitusyon ay ang karapatan ng mga katutubo na patuloy na magpatupad ng tradisyonal na proseso ng paglutas sa hindi pagkakaunawaan at mga nakaugaliang batas. Ito ay nakatali sa maraming paraan sa pundamental na tanong kung kinikilala ng estado ang ligal na pluralismo (tingnan ang Tsapter 3 sa mga susing termino at konsepto), o sa iba;t ibang mga batayan para sa batas. Karamihan sa mga katutubong hustisya at paglutas ng pagtatalo ay nagmula sa mga tradisyon at kaugalian na radikal na naiiba mula sa mga tumutukoy sa katarungan na ginawa ng estado o 'pormal' sa mga nakatalagang bansa—halimbawa, rmapag-ayos laban sa mapagparusa, indibidwal laban sa kolektibo, o awtoritatibo laban sa mapanghikayat na mga porma ng hustisya. Anuman ang mga tradisyong ito, ang paglalapat ng sariling mga batas at mga kasanayan sa paglutas ng hindi pagkakaunawaan ay sentral sa mga karapatan ng ibang mga katutubo, tulad ng kanilang karapatang magpatuloy sa mga kultural at tradisyunal na kasanayan at institusyon at ng kanilang karapatang umasa sa tradisyunal na mga sistema ng panirikan sa lupa.

Ang nakaugaliang batas ay hindi dapat mailapat sa sinumang hindi katutubo sa pamayanan, at maging ang mga indibidwal na katutubo ay dapat payagan na mamili kung tatalima o hindi sa mga nakaugaliang sistemang ito. Ito ay bahagi ng pagtiyak na ang iba pang mga karapatang pantao ay hindi nalalabag sa paglalapat ng nakaugaliang batas, na dapat na nakatali sa mga pamantayan ng internasyunal na karapatang pantao sa pamamahala ng hustisya (lalo na sa kriminal na hustisya dahil sa mga karapatan sa proseso at mga karapatan laban sa mga korporal na parusa). Hindi madalang na makita ang wika na naglilimita sa karapatan ng mga katutubo na maglapat ng nakaugaliang batas at kasanayan batay sa internasyunal na mga karapatang pantao-ang isang tiyak na pagsusuri sa mga rekonsilyasyong ito ay matatagpuan sa Tanong 9.

Maaari itong maging kapaki-pakinabang para sa konstitusyon, o may-katuturang lehislasyon, upang matukoy kung paano nakikipag-ugnayan ang mga sistema ng pantribo, tradisyunal, nakaugalian, at o mga katutubong hustisya sa mas malawak na 'pormal' na sistemang panghustisya na ginawa ng estado. Sa mga tuntunin ng hurisdiksyon, maraming mga konstitusyon ang naglilimita sa aplikasyon ng tradisyunal na mekanismo ng paglutas ng hindi pagkakaunawaan at nakaugaliang batas sa mga isyu sa pamilya/personal na katayuan, mga sibil na alitan, at/o menor na impraksiyong kriminal. Minsan, ang mga pakikipag-ugnayan sa pagitan ng estado at tradisyunal na mga sistema ng hustisya ay maaaring lumikha ng ligal na kalabuan, na humahantong sa pag-agaw ng mga karapatang ligal sa mga litigante. Ito ay mas karaniwan sa mga sitwasyon kung saan ang estado at mga tradisyunal na sistema ay mayroong nagsasalimbayang mga hurisdiksyon, o kung saan ang mga tradisyunal na sistema ay hindi dapat sumalungat sa iba pang mga karapatan sa konstitusyon at may limitadong kamalayan sa mga karapatang ito at obligasyon mula sa mga tradisyunal na pinuno.

Ang mga katagang 'tradisyunal na hustisya', 'katutubong hustisya' at 'nakaugaliang hustisya' ay madalas na magkakahalo, ngunit may mga mahahalagang pagkakaiba sa pagitan ng mga sistemang ito at kanilang pag-unlad sa kasaysayan. Ang tradisyunal na hustisya ay isang malawak at komprehensibong kategorya. Ang isang sistema ay 'tradisyunal' kung ito ay isinasagawa sa mahabang panahon—sa pangkalahatan ay umaabot hanggang sa panahon ng pre-kolonyal—at umunlad kasama ng lipunan. Hindi ito inangkat mula sa labas (ibig sabihin, sa pamamagitan ng mga pamahalaang kolonyal). Ang nakaugaliang hustisya ay katulad na nakaugat sa isang matagal at umuunlad na kasaysayan. Gayunpaman, ang 'nakaugaliang batas' ay madalas na tinukoy at ginamit ng mga kolonyal na pinuno bilang isang kasangkapan sa pamamahala, at samakatwid ang nilalaman ng nakaugaliang batas sa ilang mga bansa ay lubos na naiimpluwensyahan ng mga kolonyal na karanasan. Hindi ito kinakailangang magmula sa isang tao o lugar. Ang katutubong katarungan, sa pamamagitan ng paghahambing, ay madalas na magkasingkahulugan sa 'tradisyunal' na hustisya, na ito ay nakaugat sa mga tiyak na karanasan sa kasaysayan at tradisyon ng isang partikular na tao o lugar, at nauna pa sa kolonisasyon ng Europa. Bagama't ang 'tradisyunal' at 'katutubong' hustisya ay maaaring mapagpalit ang gamit, sa ilang mga bansa, partikular sa Gitna at Latin America, ang termino 
na 'katutubong hustisya' ay tumutukoy sa mga tradisyon ng mga partikular na pangkat etniko na nanirahan sa lugar bago ang kolonyalisasyon, samantalang ang 'tradisyunal' o 'nakaugaliang' hustisya ay maaaring mailapat sa ibang mga pangkat etniko o tribo na may isang mas mahabang kasaysayan ng pisikal na presensya. Sa mga terminong konstitusyonal, ang napiling terminolohiya ay dapat na batay sa mga partikular na kasaysayan ng iba't ibang mga tao sa loob ng estado, pati na rin mga karanasan sa kasaysayan sa kolonyalismo, kung mayroon man. Sa lahat ng mga kaso, ang mga patakaran at kasanayan ay karaniwang hindi nakasulat at ipinapasa sa tradisyong oral, bagama’t ang ilang mga bansa ay nagtangkang isakodigo ang tradisyunal/nakaugalian/ katutubong batas.

MGA PAMANTAYANG PANG-INTERNASYUNAL AT PAMBANSANG MGA HALIMBAWA

\begin{tabular}{|c|c|c|}
\hline $\begin{array}{l}\text { Kumbensyon } \\
\text { ng ILO } 169 \\
1989\end{array}$ & $\begin{array}{l}\text { Artikulo 8(1), } \\
8(2) \text { at } 9\end{array}$ & $\begin{array}{l}\text { Artikulo } 8 \\
\text { 1. Sa paglalapat ng mga pambansang batas at } \\
\text { regulasyon sa mga kinauukulang mamamayan, } \\
\text { nararapat na mabigyan ng pansin ang kanilang } \\
\text { kaugalian o mga nakaugaliang batas. } \\
\text { 2. Ang mga taong ito ay may karapatang panatilihin } \\
\text { ang kanilang sariling mga kaugalian at } \\
\text { institusyon, kung saan ang mga ito ay hindi } \\
\text { palyado sa pundamental na mga karapatang } \\
\text { tinukoy ng pambansang ligal na sistema at may } \\
\text { internasyunal na kinikilalang mga karapatang } \\
\text { pantao. Ang mga pamamaraan ay dapat } \\
\text { maitaguyod, kung kinakailangan, upang malutas } \\
\text { ang mga tunggalian na maaaring lumitaw sa } \\
\text { paglalapat ng prinsipyong ito. } \\
\text { Artikulo } 9 \\
\text { (1) Sa lawak na katugma sa pambansang ligal } \\
\text { na sistema at internasyunal na kinikilalang } \\
\text { mga karapatang pantao, igagalang ang mga } \\
\text { pamamaraang nakaugaliang isinasagawa ng mga } \\
\text { taong namamahala para sa pagharap sa mga } \\
\text { pagkakasala na ginawa ng kanilang mga kasapi. }\end{array}$ \\
\hline
\end{tabular}

(2) Ang mga kaugalian ng mga taong ito hinggil sa mga usapin sa parusa ay dapat isaalang-alang ng mga awtoridad at korte na tumatalakay sa mga nasabing kaso.

\begin{tabular}{l|l}
$\begin{array}{l}\text { Konstitusyon } \\
\text { ng Bolivia }\end{array}$ & Artikulo 192 \\
2009 &
\end{tabular}

I. Ang bawat pampublikong awtoridad o tao ay dapat sumunod sa mga desisyon ng hurisdiksyon ng rural na katutubo.

II. Upang matiyak ang pagsunod sa mga pasya ng rural na katutubong hurisdiksyon, ang mga awtoridad nito ay maaaring humiling ng suporta ng mga may kakayahang kinatawan ng Estado.

III. Itataguyod at palalakasin ng Estado ang hustisya ng rural na katutubong pamayanan. Ang batas ng Jurisdictional Demarcation ang tutukoy sa mga mekanismo ng koordinasyon at kooperasyon sa pagitan ng rural na katutubong pamayanang hurisdiksyon at ordinaryong hurisdiksyon at hurisdiksyon ng agro-environment at lahat ng kinikilalang hurisdiksyon ng konstitusyon.
Kinikilala ang karapatan ng mga katutubo na panatilihin ang kanilang sariling kaugalian at institusyon, partikular na patungkol sa mga usaping parusa
Nagtatatag ng rural na katutubong hurisdiksyon at nananawagan para sa koordinasyon sa mga mekanismo ng estado at hurisdiksyon 


\begin{tabular}{|c|c|c|c|}
\hline $\begin{array}{l}\text { Konstitusyon } \\
\text { ng Colombia } \\
1991\end{array}$ & Artikulo 246 & $\begin{array}{l}\text { Ang mga awtoridad ng mga katutubo [Indian] ay } \\
\text { maaaring gamitin ang kanilang hurisdiksyunal na } \\
\text { mga tungkulin sa loob ng kanilang nasasakupang } \\
\text { teritoryo alinsunod sa kanilang sariling mga batas } \\
\text { at pamamaraan hangga't ang mga ito ay hindi } \\
\text { salungat sa Konstitusyon at mga batas ng Republika. } \\
\text { Ang isang Batas ay magtataguyod ng mga anyo ng } \\
\text { koordinasyon ng espesyal na hurisdiksyon na ito sa } \\
\text { pambansang sistemang panghukuman. }\end{array}$ & $\begin{array}{l}\text { Pinapayagan ang mga } \\
\text { katutubo na magsagawa ng } \\
\text { ligal na hurisdiksyon sa loob } \\
\text { ng kanilang mga teritoryo } \\
\text { hangga't walang sumasalungat } \\
\text { sa mga pambansang batas at } \\
\text { Konstitusyon } \\
\text { Tumatawag para sa pagtatatag ng } \\
\text { mekanismo ng koordinasyon sa } \\
\text { pambansang sistema ng hustisya }\end{array}$ \\
\hline $\begin{array}{l}\text { Konstitusyon } \\
\text { ng Ecuador } \\
2008\end{array}$ & Artikulo 171 & $\begin{array}{l}\text { Ang mga awtoridad ng mga katutubo ay } \\
\text { magsasagawa ng mga tungkuling panghukuman, } \\
\text { paglapat ng mga pamantayan at pamamaraan } \\
\text { para sa solusyon ng mga panloob na tunggalian } \\
\text { alinsunod sa kanilang kaugalian o nakaugaliang } \\
\text { batas, sa tuwing hindi sila salungat sa Konstitusyon } \\
\text { at mga batas. Gagawing katugma ng batas ang } \\
\text { mga tungkuling iyon sa mga nasa panghukuman } \\
\text { pambansang sistema. }\end{array}$ & $\begin{array}{l}\text { Itinutulak ang mga katutubong } \\
\text { awtoridad upang isama ang } \\
\text { pagpapatupad ng mga tungkuling } \\
\text { panghukuman at paglalapat ng } \\
\text { mga pamantayan at pamamaraan } \\
\text { ayon sa kaugalian ng mga } \\
\text { katutubo }\end{array}$ \\
\hline $\begin{array}{l}\text { Ang Pilipinas, } \\
\text { Batas sa } \\
\text { Karapatan ng } \\
\text { Mga Katutubo } \\
1997\end{array}$ & $\begin{array}{l}\text { Seksyon } 15 \\
\text { at } 65\end{array}$ & $\begin{array}{l}\text { SEKSYON 15. Sistema ng Hustisya, Mga Institusyon } \\
\text { sa Paglutas ng Hidwaan, at Mga Proseso sa Pagbuo } \\
\text { ng Kapayapaan. - Ang ICCs/ IPs [mga katutubong } \\
\text { pangkulturang pamayanan/mga katutubo] ay may } \\
\text { karapatang gumamit ng kanilang karaniwan at } \\
\text { sariling tinatanggap na mga sistema ng hustisya, } \\
\text { mga institusyon sa paglutas ng hidwaan, mga } \\
\text { proseso o mekanismo ng pagbuo ng kapayapaan at } \\
\text { iba pang nakaugaliang mga batas at kasanayan sa } \\
\text { loob ng kani-kanilang mga pamayanan at maaaring } \\
\text { naaayon sa ang pambansang sistemang ligal at } \\
\text { may internasyonal na kinikilalang mga karapatang } \\
\text { pantao. } \\
\text { SEKSYON 65. Superyoridad ng mga Naaugaliang } \\
\text { Batas at Kasanayan.-Kapag ang mga pagtatalo ay } \\
\text { nagsasangkot ng mga ICC/IP, ang mga nakaugaliang } \\
\text { batas at kasanayan ay dapat gamitin upang malutas } \\
\text { ang alitan. }\end{array}$ & $\begin{array}{l}\text { Pinoprotektahan ang karapatan } \\
\text { ng mga katutubo na gumamit ng } \\
\text { kanilang karaniwan at sariling } \\
\text { tinatanggap na mga sistema ng } \\
\text { hustisya at mga nakaugaliang } \\
\text { batas hanggang sa naaangkop } \\
\text { sa pambansang batas at } \\
\text { internasyunal na mga karapatang } \\
\text { pantao }\end{array}$ \\
\hline
\end{tabular}


South Sudan, Batas sa Lokal na Pamahalaan 2009
Seksyon 95, 96, 97 at 98

Seksyon 95. Mga Gamit at Tungkulin ng Konseho ng Nakaugaliang Batas

(1) Ang Konseho ng Nakaugaliang Batas ay dapat protektahan, itaguyod at mapanatili ang mga tradisyon, kaugalian, kultura, kahalagahan at pamantayan ng mga pamayanan.

(2) Ang Konseho ng Nakaugaliang Batas ay dapat na pangasiwaan, panatilihin, subaybayan at tiyakin ang wastong pangangasiwa ng nakaugaliang batas.

Seksyon 96. Awtoridad ng Konseho ng Nakaugaliang Batas

(1) Ang awtoridad ng Konseho ng Nakaugaliang Batas ay magmumula sa kaugalian at tradisyon ng mga mamamayan ng Bansa...

(2) Ang Konseho ng Nakaugaliang Batas ay responsable para sa pagpili, pangangalap, at pagsasanay ng kawani ng Mga Korte ng Nakaugaliang Batas at ang pagpapanatiling mga propesyonal na pamantayan ng...

(3) Titiyakin ng Konseho ng Nakaugaliang Batas na ang pakikilahok ng kababaihan ay hindi bababa sa dalawampu't limang porsyento ng kasapian.

(4) Titiyakin ng Konseho ng Nakaugaliang Batas na ang mga kalayaan at mga karapatang nakalagay sa Konstitusyon ay sinusuportahan at iginagalang sa Mga Korte ng Nakaugaliang Batas.

Seksyon 97. Pagtaguyod ng Mga Korte ng Nakaugaliang Batas

(1) Magkakaroon ng mga naitaguyod na Mga Korte ng Nakaugaliang Batas. . .

$\ldots$

(2) Dapat tiyakin ng Awtoridad ng Lokal na Pamahalaan ang sapat na representasyon ng mga kababaihan sa Mga Korte ng Nakaugaliang Batas.

Seksyon 98. Mga Kakayahan ng Mga Korte sa Nakaugaliang Batas

(1) Ang Mga Korte ng Nakaugaliang Batas ay magkakaroon ng kakayahang panghukuman upang manghusga hinggil sa alitan sa kaugalian at gumawa ng mga paghuhukom alinsunod sa kaugalian, tradisyon, pamantayan at etika ng mga pamayanan.

(2) Ang Mga Korte ng Nakaugaliang Batas ay hindi magkakaroon ng kakayahan na husgahan ang mga kasong kriminal maliban sa mga kasong kriminal na may kaugnayan sa kaugalian.

(3) Sa pagpapasya ng mga kaso, ang Mga Korte ng Nakaugaliang Batas ay dapat, magkakaugnay na ilapat ang mga sumusunod na prinsipyo:

(a) ang hustisya ay dapat ibigay sa lahat, anuman ang kalagayang panlipunan, pang-ekonomiya at pampulitika, lahi, nasyonalidad, kasarian, edad, relihiyon, paninindigan o paniniwala;

(b) ang hustisya ay hindi iaantala o ipagkakait;

(c) ang sapat na danyos ay igagawad sa mga biktima ng kamalian;

(d) ang kusang-loob na kasunduan sa pagpapagitna at pagkakasundo sa pagitan ng mga partido ay dapat kilalanin at ipatupad; at

(e) ang substantibong hustisya ay dapat ibigay nang walang pagsasaalang-alang sa mga teknikalidad.
Nagtatatag ng Konseho ng Nakaugaliang Batas na may tiyak na tungkulin na tulungang mapanatili at masigurado ang wastong pangangasiwa ng nakaugaliang batas sa lokal na antas alinsunod sa konstitusyon

Itinataguyod ang Mga Korte ng Nakaugaliang Batas at nireregula kung anong uri ng mga kaso ang maaaring madinig sa kanila (hindi kasama ang mga kasong kriminal), pati na rin ang pagbibigay ng tiyak na patnubay sa kung paano balansehin at siguraduhing ang iba pang mga proteksyon sa karapatang tao ay iginagalang sa pangangasiwa ng nakaugaliang batas 


\section{MGA NAPAG-ALAMAN}

Sagot sa tanong (Oo/Hiindi) at iba pang mga tala at obserbasyon tungkol sa kung gaano kahusay na tinutugunan $n g$ konstitusyon ang (mga) isyu na itinanong. Isama ang mga makabuluhang mga probisyon ((mga) numero $n g$ artikulo at teksto $n g$ (mga) probisyon). Tandaan din ang hindi konsistent at/o magkasalungat na mga probisyon, o kung walang umiiral na mga kaugnay na probisyon.

\section{MGA HAKBANG}

Iminungkahing adbokasiya at iba pang mga kasunod na hakbang upang matugunan o mapalaganap ang mga natuklasan. 
$h^{2}$

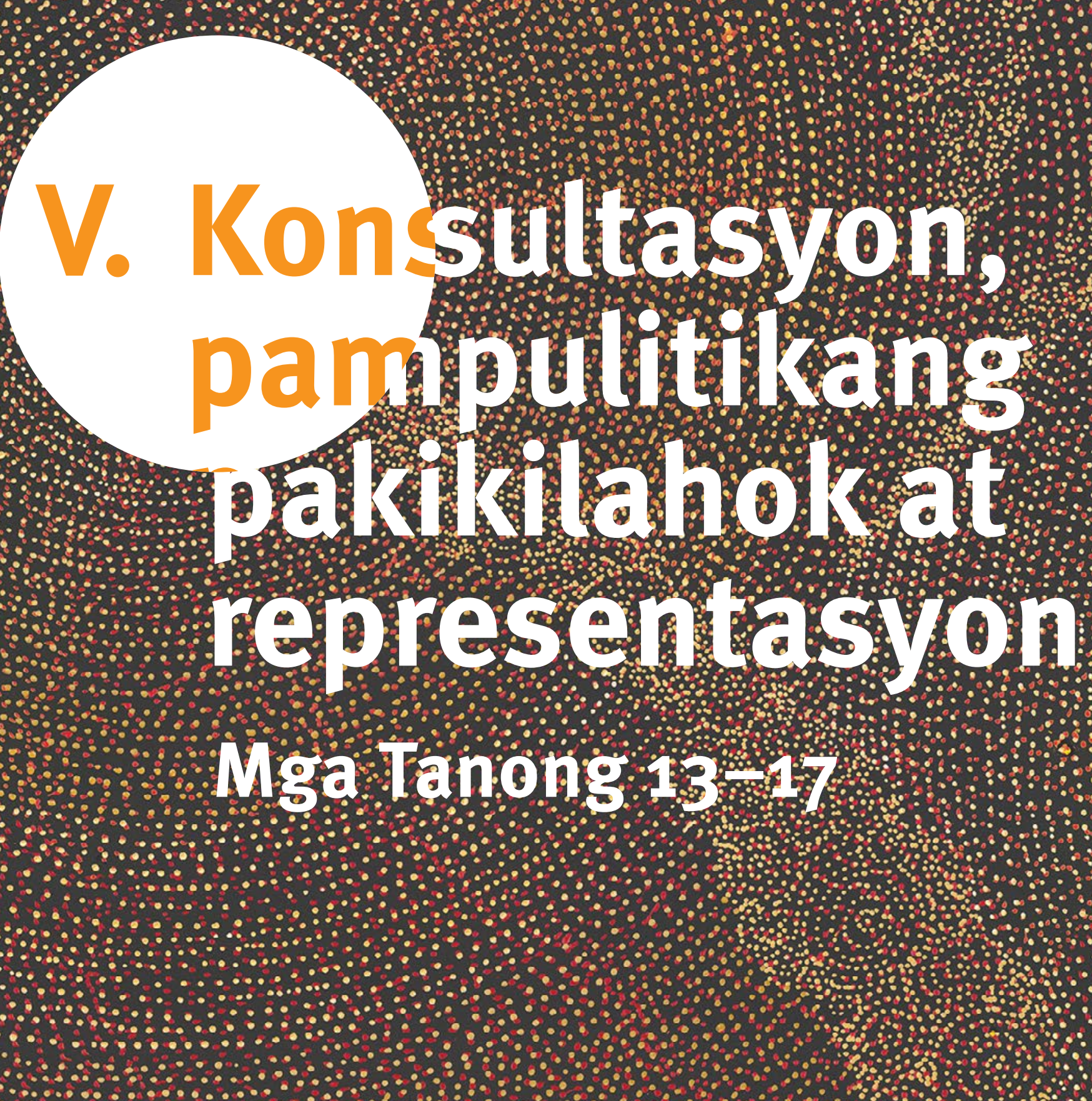

ois: 


\section{Konsultasyon, pulitikal na pakikilahok at representasyon}

\section{Pinoprotektahan ba ng konstitusyon ang karapatan ng mga katutubo sa konsultasyon sa pamamagitan ng kanilang piniling mga kinatawan sa pormal na pagkilala sa mga samahan ng mga katutubo o kung hindi man ay sa pagtatatag $\mathrm{ng}$ isang espesyalisadong mekanismo ng pagkonsulta sa pagitan ng mga katutubo at ng gobyerno?}

\section{PALIWANAG}

Ang mga katutubo, ayon sa kabutihan at pagpapalawak ng kanilang karapatan sa sariling pagpapasya (tingnan ang Tanong 7), ay may karapatang makonsulta sa pamamagitan ng kanilang sariling mga representante at kinatawan. Noong nakaraan, sa pagtupad sa tungkulin na kumunsulta, ang mga estado at pribadong aktor ay madalas na pipili para sa kanilang sarili ng mga miyembro ng mga katutubong komunidad na nais nilang konsultahin. Ang mga indibidwal na ito ay hindi kinakailangang kilalaning mga pinuno sa loob ng mga katutubong pamayanan na sinabi nilang kinkatawanan, at hindi rin sila kinakailangang magkaroon ng awtoridad na magbigay pahintulot sa ngalan ng mga pamayanan. Upang maiwasan ang gawing ito, ang karapatan ng mga katutubo sa konsultasyon ay umunlad sa paglipas ng panahon upang matiyak na ang pagkonsulta ay nangyayari sa pamamagitan ng mga mekanismo, indibidwal at proseso na batay sa sariling pangkultura at pampamahalaang mga kasanayan ng mga katutubo.

Sa konstitusyonal na paraan, ang karapatan sa konsultasyon ay maaaring maprotektahan sa maraming iba’t ibang paraan:

- Ang pangkalahatang pagkilala sa karapatan ng mga katutubo na makonsulta ay maaaring maisama sa isang konstitusyon—mas mabuti—alinsunod sa layunin ng pagkuha ng malaya, nauna at malinang na kapahintulutan (FPIC) na itinakda ng UNDRIP. Ang mga tiyak na halimbawa nito ay matatagpuan sa Tanong 20 tungkol sa likas na yaman.

- Maaaring kilalanin at bigyan ng kapangyarihan ng isang konstitusyon ang mga umiiral na mga tradisyunal na organisasyon (IPO) o iba pang mga pampamahalaang estruktura ng mga katutubo, na nagmamandato sa pamahalaang pambansa na kumunsulta sa mga kinatawan/gobyerno tungkol sa mga isyu na nakaaapekto sa kanila o sa kanilang mga teritoryo. Ang mga organisasyong ito ay dapat na maitaguyod ng mga katutubo na may mandato na kumatawan sa kanilang pamayanan o mga pamayanan na may paggalang sa kanilang natatanging mga karapatan at interes.

- Ang mga konstitusyon ay maaari ring magtatag ng mga bago o pinagsamang mekanismo, tulad ng Maluvumauri ng Vanuatu o Pambansang Konseho ng mga Pinuno kung saan ang mga lider ng katutubo ay pipili ng isang subset ng mga lider upang kumatawan sa kanila. Maaari rin itong maganap sa isang panrehiyong antas at magkaroon ng teritoryal na kalikasan, tulad ng nakita sa Bangladesh kasama ang Chittagong Hill Tracts Regional Council.

- Ang iba pang mga bansa tulad ng Finland at Norway ay nagtatag ng mga kahaliling parlamentong Sami na hindi lamang gumagampan ng mga tungkulin sa sariling pamahalaan, ngunit nagsisilbi ring pormal na mekanismo ng pagkonsulta upang kumatawan sa mga isyu ng Sami sa pambansang antas at upang makipag-ugnayan sa pambansang parlamento. Ang mga ito ay maaaring maging lubhang mabisa, tulad ng naobserbahan ni Eva Josefsen, Associate Professor ng University of Tromsø, sa Parlyamento ng Sami ng Norway: 'Hindi lamang ito nagpapayo. Nakikipagtalo ito, ipinapasa nito ang mga panukala at hinihingi nito ang mga sagot mula sa pamahalaang Norwegian' (Watson at Quince 2018).

Kinakailangan dito ang isang pagkakaiba rsa pagitan ng mga institusyon at mekanismo na isinasaalang-alang sa katanungang ito at sa mga nasa Tanong 27 tungkol sa mga komisyon ng mga katutubo at mga ministeryo ng mga usapin ng mga katutubo. Ang mga institusyong tinalakay sa Tanong 27 ay mga institusyong pangestado na sa pangkalahatan ay may mandato na pangalagaan, subaybayan at kahit gumawa ng aksyon sa mga katutubong usapin, ngunit ang mga ito ay nananatiling mga institusyon ng gobyerno, na karaniwang binubuo ng mga pampulitikang itinalagang komisyonado, ministro at burukrata na maaari o hindi mula sa katutubong pinagmulan at na ang pagtatalaga ay karaniwang pinamamahalaan ng estado at hindi ng mga katutubo. Ang 
isang modernong sub-konstitusyonal na halimbawa ng kung paano ang mga institusyong isinasaalang-alang sa Tanong 27 ay gagawing mga mekanismo ng pagkonsulta ay ibinibigay ng Greenland Committee sa Parlamento ng Denmark, ang Folketinget. Kasama sa Komite ang dalawang kinatawan sa Folketinget na direktang nahalal mula sa Greenland (tingnan ang Tanong 14), at mga kinatawan mula sa lahat ng iba pang mga partido sa Parlamento. Ang Komite ay nagbibigay ng isang forum para sa mga kinatawan ng Greenland upang itaas ang kamalayan sa mga isyu sa Greenland at talakayin ang mga panukalang batas at hakbang na nalalapat sa Greenland o may kahalagahan sa Greenland kasama ang iba pang mga miyembro ng Parlamento bago ipadala sa bulwagan ang mga panukalang batas o hakbang (tingnan ang Parlamento ng Denmark n.d., para sa karagdagang impormasyon).

\section{MGA PAMANTAYANG PANG-INTERNASYUNAL AT PAMBANSANG MGA HALIMBAWA}

\begin{tabular}{|c|c|c|c|}
\hline $\begin{array}{l}\text { Kumbensyon } \\
\text { ng ILO } 169 \\
1989\end{array}$ & Artikulo 6(1a) & $\begin{array}{l}\text { 1. Sa paglalapat ng mga probisyon ng Kumbensyon } \\
\text { na ito, ang mga gobyerno ay dapat: } \\
\text { (a) kumunsulta sa mga taong kinauukulan, sa } \\
\text { pamamagitan ng naaangkop na mga pamamaraan } \\
\text { at sa partikular sa pamamagitan ng kanilang } \\
\text { kinatawan na mga institusyon, tuwing isasaalang- } \\
\text { alang ang mga lehislatibo o administratibong } \\
\text { hakbang na maaaring makaapekto sa kanila nang } \\
\text { direkta. }\end{array}$ & $\begin{array}{l}\text { Nagtatag ng karapatang } \\
\text { kumonsulta sa pamamagitan ng } \\
\text { mga kinatawang institusyon tuwing } \\
\text { ang mga usapin sa lehislatibo o } \\
\text { administratibo ay nagkakaroon ng } \\
\text { epekto sa mga katutubo }\end{array}$ \\
\hline $\begin{array}{l}\text { UNDRIP } \\
2007\end{array}$ & Artikulo 19 & $\begin{array}{l}\text { Ang mga Estado ay dapat kumunsulta at } \\
\text { makipagtulungan nang may mabuting hangarin sa } \\
\text { mga kinauukulang katutubo sa pamamagitan ng } \\
\text { kanilang sariling kinatawang mga institusyon upang } \\
\text { makakuha ng kanilang malaya, nauna at malinang } \\
\text { na kapahintulutan bago gamitin at ipatupad ang } \\
\text { mga lehislatibo o administratibong hakbang na } \\
\text { maaaring makaapekto sa kanila. }\end{array}$ & $\begin{array}{l}\text { Pinahuhusay ang karapatan sa } \\
\text { konsultasyonna dapat tungkol } \\
\text { sa kapahintulutan (FPIC), sa } \\
\text { pamamagitan ng paghingi sa } \\
\text { pamahalaan na kumunsulta } \\
\text { nang may mabuting hangarin sa } \\
\text { mga katutubo sa pamamagitan } \\
\text { ng kanilang sariling kinatawang } \\
\text { mga institusyon tungkol sa mga } \\
\text { lehislatibo o administratibong } \\
\text { hakbang }\end{array}$ \\
\hline
\end{tabular}

\begin{tabular}{|c|c|c|}
\hline $\begin{array}{l}\text { Konstitusyon } \\
\text { ng Ecuador } \\
2008\end{array}$ & Artikulo 57 & $\begin{array}{l}\text { Ang mga katutubong komunidad, pamayanan, } \\
\text { mamamayan at nasyon ay kinikilala at } \\
\text { ginagarantiya, na naaayon sa Konstitusyon at } \\
\text { mga kasunduan sa karapatang pantao, mga } \\
\text { kumbensyon, deklarasyon at iba pang mga } \\
\text { instrumentong pang-internasyonal, ang mga } \\
\text { sumusunod na kolektibong karapatan: } \\
\ldots \\
\text { (15) Bumuo at magtaguyod ng mga samahan na } \\
\text { kumakatawan sa kanila, sa isang konteksto ng } \\
\text { pluralismo at kultural, pulitikal, at organisasyonal } \\
\text { na dibersidad. Kikilalanin at isusulong ng Estado } \\
\text { ang lahat ng anyo ng pamamahayag at samahan. }\end{array}$ \\
\hline $\begin{array}{l}\text { Konstitusyon } \\
\text { ng Peru }\end{array}$ & Artikulo 89 & $\begin{array}{l}\text { Ang mga rural at katutubong pamayanan ay may } \\
\text { legal na pag-iral at mga korporadong entidad. }\end{array}$ \\
\hline
\end{tabular}

Nagbibigay ng ligal na pagkilala sa mga katutubo at sa kanilang mga samahan

Kinikilala ang kolektibong ligal na pag-iral ng mga katutubo bilang mga korporadong entidad (nakakakontrata, atbp.) 


\begin{tabular}{|c|c|c|c|}
\hline $\begin{array}{l}\text { Konstitusyon } \\
\text { ng Vanuatu } \\
1980\end{array}$ & $\begin{array}{l}\text { Tsapter 5, mga } \\
\text { artikulo 29-32 }\end{array}$ & 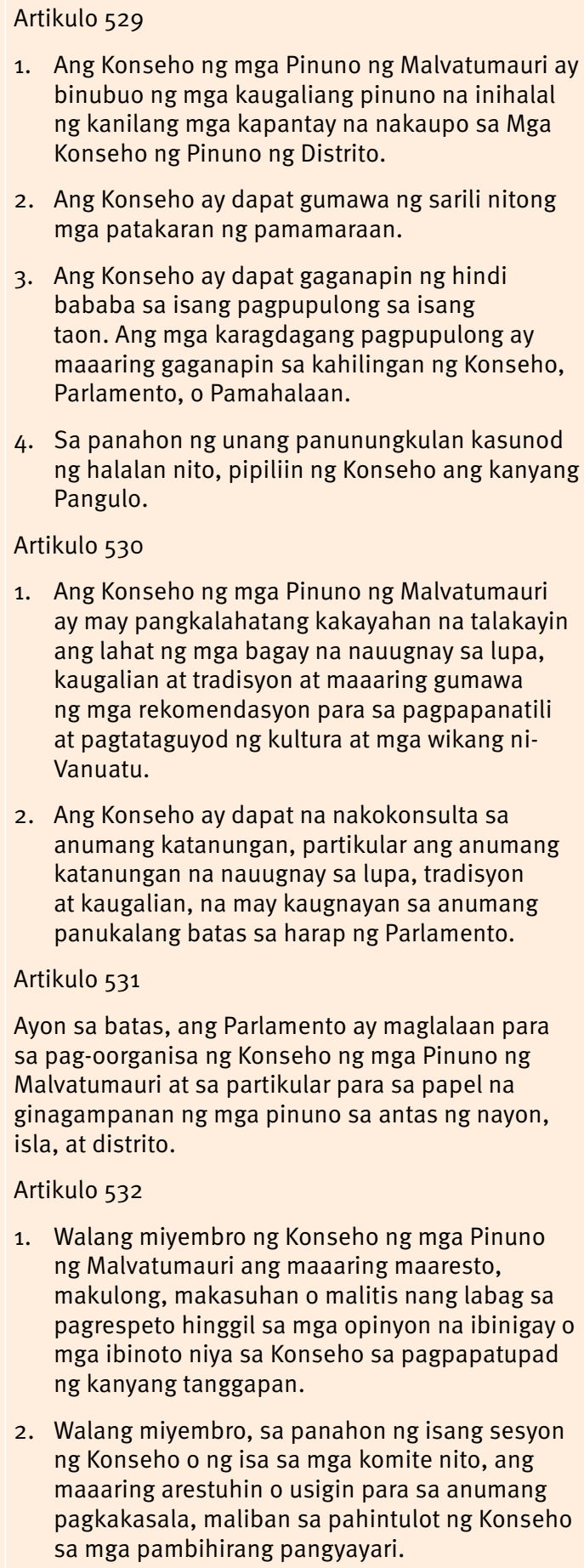 & $\begin{array}{l}\text { Nagtatatag ng espesyalisadong } \\
\text { konseho upang kumatawan sa mga } \\
\text { katutubo }\end{array}$ \\
\hline $\begin{array}{l}\text { Canada, Nasyon } \\
\text { ng Inuit, } \\
\text { Deklarasyon ng } \\
\text { Inuit Nunangat } \\
\text { sa Inuit-Crown } \\
\text { Partnership* } \\
2017\end{array}$ & $\begin{array}{l}\text { Kabuuang } \\
\text { Deklarasyon }\end{array}$ & $\begin{array}{l}\text { Kung saan ang Inuit ay mga katutubong } \\
\text { mamamayang humahawak ng karapatan sa ilalim } \\
\text { ng Konstitusyon. Batay sa espesyal na ugnayang } \\
\text { ito na ang Inuit ay pumapasok sa isang bilateral } \\
\text { na pakikipagtulungan sa Pamahalaan ng Canada } \\
\text { upang gumawa ng aksyon sa ibinahaging mga } \\
\text { priyoridad; } \\
\text { Kung saan ang Pamahalaan ng Canada ay } \\
\text { nangako sa pagbabago ng ugnayan ng Inuit-Crown } \\
\text { batay sa pagkilala sa mga karapatan, respeto, } \\
\text { kooperasyon, at pakikipagtulungan bilang bahagi } \\
\text { ng mas malawak na layunin nitong makamit ang } \\
\text { pagkakasundo sa pagitan ng pamahalaang pederal } \\
\text { at mga katutubo. Ang paglikha ng Komite ng } \\
\text { Pakikipagtulungan ng Inuit-Crown, at ang pagbuo } \\
\text { ng magkasanib na mga tuntunin ng sanggunian, ay } \\
\text { isang mahalagang hakbang sa direksyon na ito. }\end{array}$ & $\begin{array}{l}\text { Itinataguyod ang Komite ng } \\
\text { Pakikipagtulungan ng Inuit-Crown } \\
\text { para sa direktang konsultasyon sa } \\
\text { pagitan ng Pamahalaan ng Canada } \\
\text { at ng nasyong Inuit at ang mga } \\
\text { piling kinatawan nito } \\
\text { * Tala: nabuo batay sa pagkilala } \\
\text { sa seksyon } 35 \text { na mga karapatan } \\
\text { ng tratado at ng mga katutubo } \\
\text { bilang mga soberanong nasyon na } \\
\text { may kakayahang pumasok sa mga } \\
\text { ligal at pampulitikang kasunduan } \\
\text { (tingnan ang Tanong 10) }\end{array}$ \\
\hline
\end{tabular}




$\begin{array}{ll}\text { Finland, Batas } & \text { Kabuuang batas } \\ \text { sa Parlamento } & \text { ngunit partikular } \\ \text { ng Sámi } & \text { sa seksyon 1, 5 } \\ 1995 & \text { at } 9\end{array}$

\section{Seksyon 1 - Layunin ng Akto (1279/2002)}

(1) Ang Sámi, bilang katutubo, ay may lingguwistika at kultural na awtonomiya tinubuang bayan ng Sámi na inilgaya sa Batas na ito at sa iba pang lehislasyon. Para sa mga gawaing nauugnay sa awtonomiya sa kultura, ang Sámi ay dapat pumili mula sa kanilang sarili ng Parlamento ng Sámi.

(2) Ang Parlamento ng Sámi ay nabibilang sa saklaw ng Ministro sa Hustiya.

Tsapter 2 - Mga Tungkulin ng Parlamento ng Sámi

Seksyon 5 - Pangkalahatang kapangyarihan

(1) Ang gawain ng Parlamento ng Sámi ay alagaan ang wika at kulturang Sámi, pati na rin ang alagaan ang mga bagay na nauugnay sa kanilang katayuan bilang mga katutubo.

(2) Sa mga bagay na nauugnay sa mga gawain nito, ang Parlamento ng Sámi ay maaaring gumawa ng mga pagkukusa at panukala sa mga awtoridad, pati na rin ang paglalabas ng mga pahayag. Sa pagsunod sa mga bagay na ito, ang Parlamento ng Sámi ay higit na gagamit ng mga kapangyarihang inireseta sa Batas na ito o saanman sa batas.

\section{Seksyon 9-Obligasyon sa negosasyon}

(1) Makikipagnegosasyon ang mga awtoridad sa Parlamento ng Sámi sa lahat ng malalawak at mahahalagang hakbangin na maaaring direkta at sa isang tiyak na paraan ay makakaapekto sa katayuan ng Sámi bilang mga katutubo at kung saan tungkol sa mga sumusunod na bagay sa tinubuang bayan ng Sámi: (1) pagpaplano ng komunidad; (2) ang pamamahala, paggamit, pagpapaupa at pagtatalaga ng mga lupain ng estado, mga lugar ng konserbasyon at mga kaparangan; (3) mga aplikasyon para sa mga lisensya na magtataya sa mga panukala sa minahan ng mineral o maghain ng mga patente sa pagmimina; (4) pagbabagong lehislatibo o administratibo sa mga okupasyong kabilang sa uri ng kultura ng Sámi; (5) ang pag-unlad ng pagtuturo ng at sa wikang Sámi sa mga paaralan, pati na rin ang mga serbisyong panlipunan at pangkalusugan; o (6) ano pa mang mga bagay na nakaaapekto sa wika at kulturang Sámi o ang katayuan ng Sámi bilang mga katutubo.

(2) Upang matupad ang obligasyon nito na makipagnegosasyon, ang may-kabuluhang awtoridad ay magbibigay sa Parlamento ng Sámi ng pagkakataong marinig at talakayin ang mga bagay. Ang kabiguang gamitin ang oportunidad na ito sa anumang paraan ay humahadlang sa awtoridad mula sa pagpapatuloy sa bagay na ito.

Tsapter 3 - Panahon ng tanggapan, mga sakop at negosyo

Seksyon 10 - Komposisyon at panahon ng opisina

(1) Ang Parlamento ng Sámi ay binubuo ng 21 mga miyembro at 4 na miyembrong deputy na pinili sa isang halalan sa Parlamento ng Sámi kada apat na taon ng kalendaryo. Mayroong hindi kukulangin sa tatlong miyembro at isang miyembrong deputy para sa bawat munisipalidad sa tinubuang bayan ng Sámi.
Itinataguyod ang Parlamento ng Sami, bagama't bilang bahaging Ministro ng Hustisya ng Finland (hindi ganap na independyente), ngunit ito ang una sa uri nito noong orihinal na nabuo noong 1973

Naglalagay ng positibong obligasyon sa Pamahalaang makipag-ayos sa Parlamento ng Sami tungkol sa ilang mga itinalagang isyu; may kasamang pagkakataon na mapakinggan 
Norway, Batas ng Sami 1987

Kamara de
Representantes
ng US State of
Maine, Mga
Panuntunan sa
Kamara
2018

Panuntunan 525, Nasyon ng Penobscot at Tribong Passamaquoddy

Seksyon 2.1, 2.3 §2.1. Ang negosyo at awtoridad ng Sameting at 2.4 [Parlamento ng Sami].

Ang negosyo ng Sameting ay anumang bagay na sa pananaw ng parlamento ay partikular na nakaaapekto sa mga mamamayang Sami.

$\S 2.3$ Paraan ng halalan, oras ng halalan, at termino ng eleksyon.

Ang halalan sa Sameting ay sa pamamagitan ng direktang balota.

§2.4 Mga nasasakupan at distribusyon ng mga puwesto.

Sa halalan sa Sameting, tatlong miyembro na may kahalili ay ihahalal mula sa bawat isa sa mga sumusunod na nasasakupan:

[Listahan ng 13 nasasakupan]

Ang miyembro ng Nasyong Penobscot, ang miyembro ng Houlton Band ng Maliseet Indians at ang miyembro ng Tribong Passamaquoddy na nahalal o hinirang upang kumatawan sa kanilang mga mamamayan sa sesyong biennial ng Lehislatura ay dapat bigyan ng mga puwesto sa Kamara de Representantes; dapat gawaran, sa pamamagitan ng pahintulot ng Tagapagsalita, ng pribilehiyo ng pagsasalita sa nakabinbin na batas; dapat na italaga upang umupo kasama ng magkatuwang na nakatayong mga komite bilang mga miyembrong hindi bumoboto sa panahon $\mathrm{ng}$ deliberasyon $\mathrm{ng}$ mga komite; at dapat bigyan ng iba pang mga karapatan at pribilehiyo na tuwi-tuwina ay maaaring pagbotohan ng Kamara de Representantes. Sa mga ulat mula sa mga komite kung saan naglilingkod ang isang miyembro $\mathrm{ng}$ tribo, ang posisyon $\mathrm{ng}$ kasapi ay dapat tandaan at isama. Ang mga pangalan $\mathrm{ng}$ miyembro ng Nasyong Penobscot, ang miyembro ng Houlton Band ng Maliseet Indians at ang miyembro ng Tribong Passamaquoddy na nahalal o hinirang upang kumatawan sa kanilang mga mamamayan sa sesyong biennial ng Lehislatura ay dapat isama sa roll call board para lamang sa mga hangarin ng elektronikong pagrekord ng kanilang pagdalo.
Itinataguyod ang Parlamento ng Sami bilang isang paralelong lehislatibong institusyon upang payuhan ang pambansang parlamento at gamitin ang sariling pamahalaan-mayroon itong relatibong malakas na mandato kumpara sa iba pang mga parlamento ng Sami

Ginagarantiya ang mga piling kinatawan ng mga katutubo sa puwesto ng Kamara de Representantes ng State of Maine* sa sesyong biennial nito sa at pribilehiyo na magsalita tungkol sa nakabinbing batas at lumahok sa Mga Pagdinig ng Komite bilang isang paraan upang matiyak ang kanilang konsultasyon sa mga patakarang may kahalagahan

*Tala: Ang Maine ay is a sa 50 estado sa Estados Unidos ng Amerika. Mayroon itong sariling mga institusyon at ang pagkakaloob na ito ay nalalapat sa kanyang Kapulungan ng mga Kinatawan (hindi ang Kamara de Representantes ng Estados Unidos bilang isang kabuuan) 


\section{MGA NAPAG-ALAMAN}

Sagot sa tanong (Oo/Hiindi) at iba pang mga tala at obserbasyon tungkol sa kung gaano kahusay na tinutugunan $n g$ konstitusyon ang (mga) isyu na itinanong. Isama ang mga makabuluhang mga probisyon ((mga) numero $n g$ artikulo at teksto $n g$ (mga) probisyon). Tandaan din ang hindi konsistent at/o magkasalungat na mga probisyon, o kung walang umiiral na mga kaugnay na probisyon.

\section{MGA HAKBANG}

Iminungkahing adbokasiya at iba pang mga kasunod na hakbang upang matugunan o mapalaganap ang mga natuklasan. 


\section{Kinikilala ba at naglalaan $\mathrm{ng}$ konstitusyon $\mathrm{ng}$ isang mekanismong elektoral para matiyak ang karapatan ng mga katutubo sa pulitikal na pakikilahok at representasyon, partikular sa lehislatura ng estado?}

\section{PALIWANAG}

Ang karapatan sa pulitikal na pakikilahok at representasyon ay isang pundamental na karapatan ng lahat ng mga tao, batay sa Internasyunal na Kasunduan sa Sibil at Pulitikal na Karapatan (United Nations 1966a). Pagdating sa mga katutubo, ang karapatang ito ay pinahusay ng mga ugnayan nito sa sariling pagpapasya; sa pagtukoy sa panloob na sariling pagpapasya, sinabi ng Komite sa Pag-aalis ng Diskriminasyon ng Lahi: 'Ang karapatan sa sariling pagpapasya ng mga tao ay may panloob na aspekto, ibig sabihin, ang mga karapatan ng lahat ng mga tao na malayang ipagpatuloy ang kanilang pang-ekonomiya, panlipunan at pangkulturang pag-unlad nang walang panghihimasok sa labas. Samakatwid, mayroong umiiral na ugnayan sa karapatan ng bawat mamamayan na makilahok sa pagsasagawa ng mga gawaing pampubliko sa anumang antas tulad ng tinukoy sa artikulo 5 (c) ng International Convention on the Elimination of All Forms of Racial Discrimination. Bilang kahihinatnan, ang mga pamahalaan ay dapat kumatawan sa buong populasyon nang walang pagkakaiba sa lahi, kulay, ninuno o nasyonal o etnikong pinagmulan' (United Nations 1996a: 125, para. 9). Kadalasan, ang mga karapatan sa pulitikal na pakikilahok ay binibigyang kahulugan upang matupad ng mga proseso ng hindi direktang pakikilahok, halimbawa sa pamamagitan ng halalan ng sariling hinirang na kinatawan. Habang ang mga halimbawang naisip sa itaas sa Tanong 13 tungkol sa mga mekanismo ng pagkonsulta ay kumakatawan sa isang paralelong tract ng pamamahala ng katutubo na nagsasalimbayan sa mainstream na mga institusyon ng gobyerno at nagsisilbi rin upang itaas ang boses ng mga katutubo sa politika, ang mga halimbawa sa katanungang ito ay tungkol sa garantisadong pakikilahok ng mga katutubo at ng kanilang napiling representante sa mainstream na mga parte ng gobyerno.

Ang pagkilala sa kahalagahan ng pakikilahok at representasyon ng mga katutubo sa mga pampulitikang proseso at lahat ng sangay ng gobyerno (lehislatibo, ehekutibo at hudisyal, pati na rin sa mga independyenteng komisyon) ay nagpapahayag ng isang kritikal na halaga at lumilikha ng ligal na puwang para sa pulitikal na diyalogo, mga batas at patakaran sa loob ng primaryang mga institusyon ng estado. Habang ang mga espesyalisadong mekanismo para sa konsultasyon (tingnan ang Tanong 13) ay nagbibigay ng isang paraan ng pakikilahok, ang mga katutubo ay dapat ding garantisadong makilahok sa pamamagitan ng representasyon sa mainstream na mga parte ng gobyerno, lalo na ang mga gumagawa ng batas tulad ng lehislatura. Ang mga katutubo ay dapat mabisang naroroon sa lahat ng mga larangan ng paggawa ng batas at patakaran upang matiyak na ang kanilang mga karanasan, alalahanin at interes ng kanilang mga komunidad ay kinakatawan sa mga batas at patakaran na nakaaapekto sa kanila bilang mga mamamayan. Sa mga pederal o desentralisadong sistema, mahalaga na ang mga hakbang upang matiyak ang pulitikal na pakikilahok ng mga katutubo ay mailapat sa bawat antas ng gobyerno.

Ang mga espesyal na hakbang sa halalan ay isang pangkaraniwang pamamaraan para masiguro ang pantay na pakikilahok at representasyon ng mga katutubo sa mga kinatawan tulad ng pambansang parlamento, kung minsan batay sa prinsipyo ng proporsyonal na representasyon. Ang mga espesyal na hakbang ay maaaring magkaroon ng iba't ibang anyo; maaaring may nakalaan na mga upuan sa parlamento para sa mga kinatawan ng mga katutubo na maaaring ihalal sa hiwalay na nasasakupan; o ang mga pulitikal na partido ay maaaring kailanganin upang punan ang isang quota ng mga puwestong napanalunan nila sa mga kandidato mula sa marhinalisadong estado; $o$ ang sistemang elektoral ay maaaring buuin sa paraang nais itaguyod at/o kailanganing isama ang mga katutubong kandidato sa mga listahan ng partido (karaniwan sa pamamagitan ng proporsyonal na mga representasyon sa mga lahi). Ang mga karagdagang pamamaraan, tulad ng pagsulong ng sariling mga tradisyon ng eleksyon ng mga katutubo at pagtatag ng mga espesyal na na nasasakupang mga katutubo, ay maaaring makatulong sa pagtiyak sa pakikilahok na naaayon sa karapatan ng mga katutubo na ilapat ang kanilang sariling mga gawi at pamantayan para sa pagpili ng pormal na kinatawan ng kanilang mga pamayanan. ${ }^{12}$

Ang pagkakaroon lamang ng representasyon sa lehislatura ay hindi ibig sabihing ginagarantiya ang makabuluhang pakikilahok ng mga kinatawan ng mga katutubo. Habang nasa labas ng saklaw ng mga konstitusyon, mahalaga na tingnan din ang lehislasyon at pormal at di-pormal na mga patakaran ng mga pamamaraang nagreregula sa mga isyu tulad ng mga opisyal ng partido, pagbuo ng komite o kokus, at mga veto ng minorya, upang tunay na maunawaan ang saklaw at mga plataporma na ibinigay para sa mga inihalal na kinatawan upang ipahayag ang kanilang mga opinyon at maglingkod bilang mga makabuluhang tagapag-alaga o interes ng kanilang mga nasasakupan. Ang 
mga espesyal na hakbang at paninindigan na mga patakaran ng pagkilos ay madalas na pinupuna dahil sa hindi pagtugon sa isyung ito ng makabuluhang representasyon, kaya mahalagang tingnan kung paano nakikipag-ugnay ang mga hakbang na ito sa iba pang mga batas at patakaran na namamahala sa kondukta ng estado.

MGA PAMANTAYANG PANG-INTERNASYUNAL AT PAMBANSANG MGA HALIMBAWA

\begin{tabular}{|c|c|c|c|}
\hline $\begin{array}{l}\text { Kumbensyon } \\
\text { ng ILO } 169 \\
1989\end{array}$ & Artikulo 6(1b) & $\begin{array}{l}\text { 1. Sa paglalapat ng mga probisyon ng } \\
\text { Kumbensyon na ito, ang mga gobyerno ay dapat: } \\
\text {... } \\
\text { (b) magtaguyod ng mga paraan kung saan } \\
\text { malayang makikilahok ang mga mamamayan } \\
\text { na ito, na hindi bababa sa parehong saklaw } \\
\text { ng iba pang mga sektor ng populasyon, sa } \\
\text { lahat ng antas ng paggawa ng desisyon sa } \\
\text { mga elektibong institusyon at administratibo } \\
\text { at iba pang mga parteng responsable para sa } \\
\text { mga patakaran at programa na mahalaga sa } \\
\text { kanila. }\end{array}$ & $\begin{array}{l}\text { Naglalagay ng positibong } \\
\text { obligasyon sa mga signatoryo } \\
\text { ng estado upang magtaguyod } \\
\text { ng mga paraan para sa malaya } \\
\text { at pantay na pakikilahokng } \\
\text { mga katutubo sa lahat ng antas } \\
\text { ng paggawa ng desisyon }\end{array}$ \\
\hline $\begin{array}{l}\text { UNDRIP } \\
2007\end{array}$ & Artikulo 5 at 18 & $\begin{array}{l}\text { Artikulo } 5 \\
\text { Ang mga katutubo ay may karapatang panatilihin } \\
\text { at palakasin ang kanilang natatanging } \\
\text { pampulitika, legal, pang-ekonomiya, panlipunan } \\
\text { at pangkulturang mga institusyon, habang } \\
\text { pinapanatili ang kanilang karapatang lumahok } \\
\text { nang buo, kung pipiliin nila, sa pampulitika, } \\
\text { pang-ekonomiya, panlipunan at pangkulturang } \\
\text { buhay ng Estado. } \\
\text { Artikulo } 18 \\
\text { Ang mga katutubo ay may karapatang lumahok } \\
\text { sa paggawa ng desisyon sa mga bagay na } \\
\text { makaaapekto sa kanilang mga karapatan, sa } \\
\text { pamamagitan ng mga kinatawan na pinili nila } \\
\text { alinsunod sa kanilang sariling mga pamamaraan, } \\
\text { pati na rin mapanatili at mapaunlad ang kanilang } \\
\text { sariling mga mapagpasyang katutubong } \\
\text { institusyon. }\end{array}$ & $\begin{array}{l}\text { Tinitiyak na ang karapatan } \\
\text { ng mga katutubo sa kanilang } \\
\text { sariling mga institusyon ay } \\
\text { hindi pinipigilan ang kanilang } \\
\text { karapatang lumahok sa mga } \\
\text { institusyon ng estado } \\
\text { Kinikilala ang karapatan ng } \\
\text { mga katutubo na lumahok } \\
\text { sa paggawa ng desisyon sa } \\
\text { mga bagay na nakaapekto } \\
\text { sa kanilang mga karapatan, } \\
\text { sa pamamagitan ng mga } \\
\text { kinatawan na pinilialinsunod } \\
\text { sa kanilang sariling mga } \\
\text { pamamaraan }\end{array}$ \\
\hline
\end{tabular}




\begin{tabular}{|c|c|c|}
\hline $\begin{array}{l}\text { Konstitusyon } \\
\text { ng Bolivia } \\
2009\end{array}$ & $\begin{array}{l}\text { Artikulo } 147 \text { (II) at } \\
(\text { III), } 210(\text { III) at } 211\end{array}$ & $\begin{array}{l}\text { Artikulo } 147 \\
\text { II. Ang proporsyonal na pakikilahok ng mga } \\
\text { bansa at mga rural na katutubo ay garantisado } \\
\text { sa halalan ng mga miyembro ng pagpupulong. } \\
\text { III. Tutukuyin ng batas ang mga espesyal na } \\
\text { distrito ng mga rural na katutubo, na kung } \\
\text { saan ang laki ng populasyon at heograpiyal } \\
\text { na pagpapatuloy ay hindi isasaalang-alang } \\
\text { bilang pamantayan sa kondisyon. } \\
\text { Artikulo } 210 \\
\text { III. Ang mga nasyon at rural na katutubo } \\
\text { ay maaaring maghalal ng kanilang mga } \\
\text { kandidato alinsunod sa kanilang sariling mga } \\
\text { demokratikong komunitaryong gawi. } \\
\text { Artikulo } 211 \\
\text { I. Ang mga nasyon at katutubo ay maaaring } \\
\text { pumili ng kanilang mga kinatawan sa pulitika } \\
\text { tuwing kinakailangan, alinsunod sa kanilang } \\
\text { sariling mga anyo ng halalan. } \\
\text { II. Titiyakin ng Organong Elektoral na ang mga } \\
\text { pamantayan ng mga mamamayang iyon at } \\
\text { mga nasyon ay istriktong masusunod sa } \\
\text { mga halalan ng mga awtoridad, kinatawan } \\
\text { at kandidato ng mga nasyon at mga rural na } \\
\text { katutubo, gamit ang kanilang sariling mga } \\
\text { pamantayan at pamamaraan. }\end{array}$ \\
\hline
\end{tabular}

\section{Konstitusyon ng Burundi \\ 2005}

Artikulo 168

Ang mga halalan ng mga deputy ay nagaganap kasunod ng balota ng mga listahan ng bloc sa pamamagitan ng proporsyonal na representasyon. Ang mga listahang ito ay dapat magkaroon ng isang multi-etnikong katangian at isinasaalang-alang ang balanse sa pagitan ng kalalakihan at kababaihan. Para sa tatlong kandidato na nakarehistro sa isang listahan, dalawa lamang ang maaaring mapasama sa parehong pangkat etniko, at di kukulanging isa sa tatlo ay dapat na isang babae.

\begin{tabular}{l|l|l|}
$\begin{array}{l}\text { Konstitusyon } \\
\text { ng Colombia }\end{array}$ & Artikulo 171 & $\begin{array}{l}\text { Ang Senado ng Republika ay bubuo ng isang } \\
\text { daang (100) miyembro na nahalal sa isang } \\
\text { pambansang nasasakupan. }\end{array}$ \\
\hline 1991 & &
\end{tabular}

Magkakaroon ng karagdagang dalawang (2) senador na inihalal sa isang espesyal na pambansang nasasakupan para sa mga katutubong pamayanan. . .

Ang sistema ng electoral quotient ay malalapat sa espesyal na nasasakupan para sa halalan ng mga senador ng mga katutubong komunidad.

Ang mga kinatawan ng mga pamayanang katutubo na nagnanais na maging miyembro ng Senado ng Republika ay dapat na gumamit $\mathrm{ng}$ isang posisyon $\mathrm{ng}$ tradisyunal na awtoridad sa kani-kanilang pamayanan o naging pinuno ng isang katutubong organisasyon, kung saan ang kwalipikasyon ay mapatutunayan $\mathrm{ng}$ isang sertipiko mula sa kani-kanilang samahan, na inendorso ng Ministro ng Pamahalaan.

\begin{tabular}{l|l}
$\begin{array}{l}\text { Konstitusyon } \\
\text { ng Denmark }\end{array}$ & Artikulo 28 \\
1953 &
\end{tabular}

Nanawagan para sa proporsyonal na pakikilahokng mga katutubo sa pambansang pagpupulong batay sa pagtukoy ng mga espesyal na distrito para sa mga katutubo; ang mga halalan para sa mga pulitikal na kinatawan ay dapat sundin ang tradisyonal na mga katutubong kasanayan

\section{Nananawagan para sa} proporsyonal na representasyon sa pamamagitan ng paggamit ng mga listahan ng bloc at pangangailangan na ito ay maging 'multi-etniko'

Ginagarantiva ang mga puwesto sa pambansang Senado para sa mga katutubo na kinikilalang pinuno sa kanilang mga pamayanan

Ginagarantiyahan ang Greenland at ang Faroe Islands ng dalawang miyembro bawat isa sa Parlamento ng Denmark, na ihahalal ng kanilang sariling nasasakupan 


\begin{tabular}{|c|c|c|c|}
\hline $\begin{array}{l}\text { Kontitusyon } \\
\text { ng Nepal } \\
2015\end{array}$ & $\begin{array}{l}\text { Artikulo } 84(2) \text { at } \\
176(6)\end{array}$ & $\begin{array}{l}\text { Artikulo } 84 \\
\text { (2) Ipagkakaloob ng Pederal na batas na, sa } \\
\text { paglalatag ng kandidatura ng mga pulitikal } \\
\text { na partido para sa halalan sa Kamara de } \\
\text { Representantes sa ilalim ng proporsyonal na } \\
\text { sistemang elektoral, ang representasyon ay } \\
\text { titiyakin batay sa isang saradong listahan } \\
\text { mula rin sa mga kababaihan, Dalit, mga } \\
\text { katutubo, Khas Arya, Madhesi, Tharu, } \\
\text { Muslim at mga atrasadong rehiyon, batay sa } \\
\text { populasyon. Sa paglalatag ng kandidatura, } \\
\text { dapat ding ituon ang pansin sa heograpiya at } \\
\text { balanse sa teritoryo. } \\
\text { Artikulo } 176 \\
\text { (6) Ipagkakaloob ng batas Pederal na, sa } \\
\text { paglatag ng kandidatura ng mga pulitikal } \\
\text { na partido para sa halalan sa Kapulungan } \\
\text { ngEstado sa ilalim ng proporsyonal na } 116 \\
\text { na sistemang elektoral, ang representasyon } \\
\text { ay titiyakin batay sa isang saradong listahan } \\
\text { mula rin sa mga kababaihan, Dalit, katutubo, } \\
\text { katutubong nasyonalidad, Khas Arya, } \\
\text { Madhesi, Tharu, Muslim at atrasadong mga } \\
\text { rehiyon, mga komunidad ng minorya, batay } \\
\text { sa populasyon. Sa paglalatag ng kandidatura, } \\
\text { dapat din ituon ang pansin sa balanse sa } \\
\text { heograpiya ng kinauukulang Estado. }\end{array}$ & $\begin{array}{l}\text { Ginagarantiya ang proporsyonal } \\
\text { na representasyon para sa lahat } \\
\text { ng mga pangkat, kabilang ang } \\
\text { mga katutubo }\end{array}$ \\
\hline $\begin{array}{l}\text { Konstitusyon } \\
\text { ng Uganda } \\
1995\end{array}$ & $\begin{array}{l}\text { Panlimang } \\
\text { Iskedyul: Mga } \\
\text { Pamahalaang } \\
\text { Panrehiyon, } \\
\text { artikulo 2(2) }\end{array}$ & $\begin{array}{l}\text { Ang komposisyon ng isang panrehiyong } \\
\text { pagpupulong ay dapat na inireseta ng Batas ng } \\
\text { Parlamento at dapat binubuo ng- } \\
\text {... } \\
\text { (d.) mga kinatawan ng mga katutubong kultural } \\
\text { na interes sa mga lugar kung saan mayroong } \\
\text { isang tradisyonal o kultural na lider, na } \\
\text { hinirang ng tradisyunal o kultural na lider } \\
\text { ngunit hindi hihigit sa labinlimang porsyento } \\
\text { ng mga miyembro ng pagpupulong ng rehiyon. }\end{array}$ & $\begin{array}{l}\text { Nagmamandato na ang mga } \\
\text { panrehiyong pagpupulong ay } \\
\text { may kasamang mga kinatawan } \\
\text { ng mga katutubong komunidad } \\
\text { (hindi hihigit sa 15\%) }\end{array}$ \\
\hline $\begin{array}{l}\text { Konstitusyon } \\
\text { ng Venezuela } \\
1999\end{array}$ & Artikulo 125 & $\begin{array}{l}\text { Ang mga katutubo ay may karapatang lumahok } \\
\text { sa politika. Gagarantiyahan ng Estado ang } \\
\text { katutubong representasyon sa Pambansang } \\
\text { Pagpupulong at ang mga organo ng deliberasyon } \\
\text { mula sa pederal at lokal na mga entidad na may } \\
\text { katutubong populasyon, alinsunod sa batas. }\end{array}$ & $\begin{array}{l}\text { Kinikilala ang karapatan ng } \\
\text { mga katutubo na lumahok } \\
\text { sa politika at ginagarantiya } \\
\text { ang representasyon ng mga } \\
\text { katutubo sa mga ahensyang } \\
\text { gumagawa ng batas sa } \\
\text { pambansa, federal at ilang mga } \\
\text { lokal na antas }\end{array}$ \\
\hline $\begin{array}{l}\text { Konstitusyon } \\
\text { ng Zimbabwe } \\
2013\end{array}$ & $\begin{array}{l}\text { Artikulo } 120(1 a) \\
\text { at }(1 b)\end{array}$ & $\begin{array}{l}\text { 1. Ang Senado ay binubuo ng walumpung } \\
\text { Senador, na kung saan- } \\
\text { a. anim ay inihalal mula sa bawat isang } \\
\text { lalawigan kung saan nahahati ang } \\
\text { Zimbabwe, ng isang sistema ng } \\
\text { proporsyonal na representasyon na } \\
\text { umaayon sa subseksyon (2); } \\
\text { b. labing-anim ang mga pinuno, kung saan } \\
\text { ang dalawa ay inihalal ng pagpupulong } \\
\text { ng mga Pinunong panlalawigan mula sa } \\
\text { bawat isa sa mga lalawigan, bukod sa } \\
\text { mga lalawigan ng metropolitan, kung saan } \\
\text { nahahati ang Zimbabwe. }\end{array}$ & $\begin{array}{l}\text { Ginagarantiya ang mga } \\
\text { puwesto sa pambansang } \\
\text { Senado (lehislatura) para sa } \\
\text { mga pinuno }\end{array}$ \\
\hline
\end{tabular}




\begin{tabular}{|c|c|c|}
\hline $\begin{array}{l}\text { New Zealand, } \\
\text { Batas sa } \\
\text { Representasyon } \\
\text { ng Maori } \\
1867\end{array}$ & Artikulo 3 at 6 & $\begin{array}{l}\text { Artikulo } 3 \\
\text { 3. ... magkakaroon ng apat na miyembro ng } \\
\text { nasabing Kamara [Kamara de Representantes } \\
\text { na ihahalal sa ilalim ng mga probisyon ng } \\
\text { Batas na ito upang kumatawan doon sa mga } \\
\text { naninirahan sa Kolonya ng lahi ng Maori. } \\
\text { Artikulo } 6 \\
\text { 6. Ang mga nasabing kasapi ay pipiliin mula } \\
\text { sa at sa pamamagitan ng mga boto ng mga } \\
\text { Maoris na naninirahan sa bawat isa sa mga } \\
\text { nasabing distrito. }\end{array}$ \\
\hline
\end{tabular}

Ang Pilipinas,

Artikulo VII,

Organikong

Batas ng

Bangsamoro

2018

Seksyon 8. Halalan para sa Nakareserbang

Puwesto para sa mga Katutubong Hindi Moro.

Sa kabila ng mga sumusunod na seksyon, ang nakalaang mga upuan para sa mga katutubong hindi Moro, tulad ng Teduray, Lambangian,
Rule 525,

Penobscot

Nation at

Passamaquoddy

Tribe Dulangan Manobo, B'laan, at Higaonon, ay dapat sumunod sa kanilang mga nakaugaliang batas at mga katutubong proseso batay sa mga sumusunod:

(a) Superyoridad ng mga kaugalian na batas at kasanayan

(b) Superyoridad ng pagbuo ng pinagkasunduan;

(c) Pagtanggap ng pamayanan;

(d) Ingklusibidad at buong pakikilahok;

(e) Representasyon ng kolektibong interes at mithiin ng mga katutubong hindi Moro;

(f) Pagpapanatili at pagpapalakas ng mga estrukturang pampulitika ng katutubo;

(g) Subaybayan ang track record at kakayahan; at

(h) Pagkakapantay-pantay ng kasarian.

Ang miyembro ng Nasyong Penobscot, ang miyembro ng Houlton Band ng Maliseet Indians at ang miyembro ng Tribung Passamaquoddy na nahalal o hinirang upang kumatawan sa kanilang mga mamamayan sa sesyong biennial ng Lehislatura ay dapat bigyan ng mga puwesto sa loob ng Kamara de Representantes; dapat gawaran, sa pahintulot ng Tagapagsalita, ng pribilehiyo ng pagsasalita tungkol sa nakabinbing batas; dapat italaga upang umupo kasama ng magkatuwang na nakatayong mga komite bilang mga hindi bumobotong kasapi sa panahon ng deliberasyon ng mga komite; at mabigyan ng iba pang mga karapatan at pribilehiyo na maaaring sa pana-panahon iboto ng Kamara de Representantes. Sa mga ulat mula sa mga komite kung saan naglilingkod ang isang miyembro ng tribo, ang posisyon ng kasapi ay dapat tandaan at isama. Ang mga pangalan ng miyembro ng Nasyon ng Penobscot, ang miyembro ng Houlton Band ng Maliseet Indians at ang miyembro ng Tribong Passamaquoddy na nahalal o hinirang upang kumatawan sa kanilang mga mamamayan sa sesyong biennial ng Lehislatura ay dapat isama sa roll call board para lamang sa layunin ng elektronikong pagrekord ng kanilang pagdalo.
Pinanghahawakang magkakaroon ng isang minimum na apat na kinatawan ng Maori sa Parlamento ng New Zealand

Naglalaan na papayagan ang mga katutubo na maglapat ng kanilang sariling mga kasanayan sa halalan/ seleksyon upang pumiling mga kinatawan na punan ang mga quota ng puwesto sa Parlamento ng Bangsamoro
Ang mga kinatawan ng mga katutubong nasyon/tribo ay maaaring mahalal o direktang hihirangin ng mga pamayanang ito at dapat bigyan ng puwesto sa loob ng Kamara de Representantes*

* Tala: Ang Maine ay isa sa 50 estado sa Estados Unidos ng Amerika. Mayroon itong sariling mga institusyon at ang probisyong ito ay nalalapat sa kanyang Kamara de Representantes (hindi sa pambansang Kamara de Representantes ng Estados Unidos sa kabuuan) 


\section{MGA NAPAG-ALAMAN}

Sagot sa tanong (Oo/Hiindi) at iba pang mga tala at obserbasyon tungkol sa kung gaano kahusay na tinutugunan $n g$ konstitusyon ang (mga) isyu na itinanong. Isama ang mga makabuluhang mga probisyon ((mga) numero $n g$ artikulo at teksto $n g$ (mga) probisyon). Tandaan din ang hindi konsistent at/o magkasalungat na mga probisyon, o kung walang umiiral na mga kaugnay na probisyon.

\section{MGA HAKBANG}

Iminungkahing adbokasiya at iba pang mga kasunod na hakbang upang matugunan o mapalaganap ang mga natuklasan. 


\section{Konsultasyon, pulitikal na pakikilahok at representasyon}

\section{Naglalaan ba ang konstitusyon ng mga mekanismo upang maisulong ang representasyon ng mga katutubo sa ehekutibong sangay ng pamahalaan?}

\section{PALIWANAG}

Ang buong pagkakapantay-pantay ay nangangahulugan na ang mga katutubo ay maaaring (at, sa katunayan, ay) tumaas sa antas ng ehekutibo bilang mga pinuno ng estado, pinuno ng gobyerno at mga miyembro ng gabinete. Sa mga sistemang parlamentaryo at mala-presidensyal, ang mga miyembro ng gabinete ay hinirang mula sa mga nakaupong mambabatas, at ang senyoridad ng pulitikal na partido at iba pang mga dinamika ay nakaaapekto sa proseso ng pagpili. Samakatwid, ang representasyon ng mga katutubo sa lehislatura at sa pamumuno ng mga partido ay kritikal bilang isang hangganan para sa pagsulong sa mga pampulitikang ranggo sa ehekutibong sangay. Ang isang pangkalahatang probisyon na nagpapahayag ng prinsipyo at halaga ng pagkakapantay-pantay sa paghirang ng mga ehekutibong opisyal at mga ministro ng gabinete ay maaaring makatulong upang mapagtagumpayan ang diskriminasyon at kampihan sa proseso ng pagpili.

Yamang ang mga karapatan sa sariling pamahalaan ng mga katutubo ay madalas na nagsasama ng kakayahang magpatupad ng mga batas sa kanilang mga teritoryo (di kukulanginsa ilang mga lugar na may kakayahan-tingnan ang Tanong 11 tungkol sa awtonomiya at sarili pamahalaan), ang pinakamahusay na kasanayan ay ang bigyan ng kapangyarihan ang mga ehekutibong tungkulin ng sariling institusyon ng mga katutubo, di kukulangin sa lokal na antas. Gayunman, ang katanungang ito ay higit na nakatuon sa pagtiyak na ang mga katutubo ay bibigyan ng pantay na pagkakataon na maglingkod sa ehekutibong sangay ng gobyerno ng estado.

MGA PAMANTAYANG PANG-INTERNASYUNAL AT PAMBANSANG MGA HALIMBAWA

\begin{tabular}{|l|l|l|}
$\begin{array}{l}\text { Konstitusyon } \\
\text { ng Bolivia } \\
2009\end{array}$ & $\begin{array}{l}\text { Artikulo } 172 \\
\text { at } 209\end{array}$ & $\begin{array}{l}\text { Artikulo } 172 \\
\text { (22) Upang italaga ang mga Ministro ng Estado, } \\
\text { paggalang sa katangiang Pluri-Nasyonal ng } \\
\text { bansa at pagkakapantay-pantay ng kasarian sa } \\
\text { komposisyon ng ministro ng gabinete. }\end{array}$ \\
& $\begin{array}{l}\text { Artikulo } 209 \\
\text { Ang mga kandidato para sa mga pampublikong halal na } \\
\text { posisyon, maliban sa mga halal na posisyon ng Organong } \\
\text { Hudisyal at ang Pluri-Nasyonal na Konstitusyonal na Korte } \\
\text { (Tribunal Constitucional Plurinacional), ay ipapanukala ng } \\
\text { mga samahan ng mga nasyon at mga rural na katutubo, } \\
\text { mga asosasyon ng mamamayan at pulitikal na partido, sa } \\
\text { pantay na kondisyon at alinsunod sa batas. }\end{array}$ \\
\hline
\end{tabular}

Konstitusyon ng Ecuador 2008

\begin{tabular}{l|l}
$\begin{array}{l}\text { Konstitusyon } \\
\text { ng Uganda }\end{array}$ & $\begin{array}{l}\text { Ikalimang } \\
\text { Iskedyul, }\end{array}$ \\
1995 & $\begin{array}{l}\text { artikulo } \\
4(2 a)\end{array}$
\end{tabular}

Artikulo 65

Itataguyod ng Estado ang pagkakapantay-pantay hinggil sa representasyon ng mga kababaihan at kalalakihan sa itinalagang pampubliko o halal na tanggapan, sa mga ehekutibo at mapagpasyang mga institusyon, at mga pulitikal na partido at kilusan. Para naman sa mga kandidatura sa halalan ng maraming tao, ang kanilang pakikilahok ay igagalang sa pamamagitan ng pag-ikot ng kapangyarihan at pagkakasunuod-sunod. Ang Estado ay dapat magpatibay ng mga panukalang apirmatibong aksyon upang magarantiya ang pakikilahok ng mga nadiskriminang mga sektor.

2. Ang isang mamamayan ay hindi magiging karapatdapat na ihalal bilang isang tagapangulo ng rehiyon maliban kung-

a. siya ay isang mamamayan ng Uganda sa pamamagitan ng kapanganakan na tinukoy sa artikulo $10 \mathrm{ng}$ Konstitusyon na ito at isa sa kanyang mga magulang o lolo't lola ay naninirahan o dating residente sa rehiyon at isang miyembro ng mga katutubong pamayanan na umiiral at naninirahan sa loob ng mga hangganan ng rehiyon sa unang araw ng Pebrero, 1926.
Nananawagan para sa ministrong gabinete upang maging kinatawan ng plurinasyunal na komposisyon ng bansa

Pinanghahawakan na lahat ng mga halal na posisyon ay mapupunan ng mga kandidatong iminungkahing mga katutubo, bukod sa iba pang mga pangkat

Inoobliga ang estado na itaguyod ang substantibong pagkakapantay-pantay (kasarian) bilang representasyon para sa lahat ng mga inihalal na tanggapan kabilang ang ehekutibo at mga institusyong mapagpasya sa pamamagitan ng pagtaguyod $n g$ mga apirmatibong aksyong hakbang para sa 'mga nadiskriminang mga sektor' at pagpapalit ng posisyon ng kapangyarihan

Ang pagiging miyembro $n g$ isang katutubong pamayanan ng rehiyon na pinag-uusapan ay kinakailangang tumakbo para sa konstitusyonal na tanggapan ng pinuno $n g$ rehiyon (ehekutibo) 


\section{MGA NAPAG-ALAMAN}

Sagot sa tanong (Oo/Hiindi) at iba pang mga tala at obserbasyon tungkol sa kung gaano kahusay na tinutugunan $n g$ konstitusyon ang (mga) isyu na itinanong. Isama ang mga makabuluhang mga probisyon ((mga) numero $n g$ artikulo at teksto $n g$ (mga) probisyon). Tandaan din ang hindi konsistent at/o magkasalungat na mga probisyon, o kung walang umiiral na mga kaugnay na probisyon.

\section{MGA HAKBANG}

Iminungkahing adbokasiya at iba pang mga kasunod na hakbang upang matugunan o mapalaganap ang mga natuklasan. 


\section{Konsultasyon, pulitikal na pakikilahok at representasyon}

\section{Tinitiyak ba ng konstitusyon na ang representasyon ng mga katutubo sa hudisyal na sangay ay isinasaalang-alang at ang mga mekanismo ng hudisyal na pagtatalaga, lalo na ang sa mga kataas-taasang konstitusyonal na korte, ay nagsusulong sa ingklusyon ng mga katutubo?}

\section{PALIWANAG}

Upang makamit ang ligal na pagkakapantay-pantay, ang mga katutubo ay dapat na may kinatawan sa lahat ng antas ng hudikatura at sa iba’t ibang uri ng korte. Ang lahat ng mga hukom ay nagdudulot ng natatanging mga karanasan sa buhay, na, sa isang tiyak na antas, kinkulayan ang kanilang mga paghuhusga. Ang interpretasyon ng batas ay hindi dapat limitado sa isang bahagi ng populasyon — ang mga hukom mula sa mga katutubo at iba pang mga marhinalisadong pamayanan ay nagdadala ng ibang pananaw sa korte, na maaaring makatulong sa ligal na interpretasyon. Totoo ito lalo na sa mga lipunang pagkatapos ng tunggalian, pagkatapos ng proklamasyon ng isang bagong konstitusyon, o pagkatapos ng muling pagbubuo ng hudikatura. Ang ingklusyon sa hudikatura ay maaaring makatulong na matiyak ang higit na pagiging sensitibo sa mga isyu ng mga katutubo at pagsunod sa karapatan ng mga katutubo na lumahok sa lahat ng mga organo ng estado sa pantay na antas sa iba pang mga bahagi ng populasyon.

Ang mga mekanismo para sa mga hudisyal na pagtatalaga ay maaaring makaapekto sa dibersidad ng mga nominado at hinirang. Sa pangkalahatan, ang isang pormal na proseso para sa pagkilala sa mga kwalipikadong nominado na nagsasangkot ng higit sa isang sangay ng pamahalaan ay mas malamang na magbunga ng magkakaibang hanay ng mga nominado kaysa sa isa na kung saan ang mga miyembro ng ehekutibo o ibang mga institusyon ay maaaring gumawa ng unilateral na mga tipanan batay sa mga preperensya. Ang isang hindi partisan na hudisyal na komisyon o komite na nagnonomina ng mga hukom ay maaaring magpalawak ng balon ng mga nominado na isinasaalang-alang para sa mga posisyon sa hudikatura. Mahalaga na ang komisyon na ito ay kinatawan mismo ng dibersidad ng bansa at ng pagkakaiba-iba ng karanasan sa ligal na propesyon (bilang karagdagan sa hudikatura, ang mga miyembro ng komisyon ng hudisyal na serbisyo ay maaaring makuha mula sa pagsasanay ng mga abugado, akademiko, kinatawan ng publiko, mga kasapi ng lehislatura, atbp.). Upang maitalaga sa pinakamataas na korte, ang mga katutubo ay dapat ding magkaroon ng mga pagkakataong maglingkod bilang mga hukom sa mas mababang mga korte at bumuo ng isang rekord ng serbisyo. Ang pag-rekluta sa konstitusyonal na korte batay sa senyoridad sa ligal na pamayanan ay maaaring lalong magdesbentaha ng mga katutubo na sa kasaysayan ay hindi ma-akses ang pamayanang ito; para sa mga dagdag tungkol dito tingnan ang Tanong 4 tungkol sa antidiskriminasyon (epekto laban sa hangad na diskusyon) at Tsapter 3 sa mga susing termino at konsepto para sa mga detalye sa substantibo laban sa pormal na pagkakapantay-pantay. 


\begin{tabular}{|c|c|c|}
\hline $\begin{array}{l}\text { Konstitusyon } \\
\text { ng Bolivia } \\
2009\end{array}$ & $\begin{array}{l}\text { Artikulo } 182(\mathrm{VI}) \text {, } \\
197(\mathrm{I}) \text { at } 206(\mathrm{~V})\end{array}$ & $\begin{array}{l}\text { Artikulo } 182 \\
\text { VI. Upang maging isang Mahistrado ng Korte } \\
\text { Suprema ng Hustisya, dapat matugunan } \\
\text { ng isang tao ang mga sumusunod } \\
\text { na kinakailangan: maabot ang mga } \\
\text { pangkalahatang kahilingan na itinatag para sa } \\
\text { mga pampublikong tagapaglingkod; maging } \\
\text { tatlumpung taong gulang; magkaroon ng } \\
\text { degree sa batas; matapat at etikal na gumanap } \\
\text { sa mga tungkuling hudisyal, gumampan bilang } \\
\text { isang abugado o naging isang propesor sa } \\
\text { unibersidad sa loob ng walong taon; at hindi } \\
\text { pinatawan ng pagtatanggal ng Konseho ng } \\
\text { mga Mahistrado. Ang pagpapasya sa merito ay } \\
\text { isasaalang-alang ang pagganap bilang isang } \\
\text { katutubong awtoridad sa ilalim ng sistema ng } \\
\text { hustisya. } \\
\text { Artikulo 197 } \\
\text { I. Ang Pluri-Nasyonal na Konstitusyonal na } \\
\text { Korte ay dapat binubuo ng mga Hukom na } \\
\text { hinalal batay sa pluri-nasyonalidad, na may } \\
\text { representasyon mula sa ordinaryong sistema at } \\
\text { rural na katutubong sistema. } \\
\text { Artikulo } 206 \\
\text { Ang Pangkagawarang Lehislatibong } \\
\text { Kapulungan o Pangkagawarang Mga Konseho } \\
\text { ay pipili, sa pamamagitan ng dalawang-katlo } \\
\text { ng mga boto ng kanilang mga kasapi na } \\
\text { naroroon, ng isang listahan ng mga kandidato } \\
\text { para sa bawat isa sa mga bumotong miyembro } \\
\text { ng Pangkagawarang Elektoral na Korte. } \\
\text { Ang Kamara ng mga Deputado (Camara de } \\
\text { Diputados) ay dapat, sa pamamagitan ng } \\
\text { nalawang-katlo ng mga boto ng mga kasapi na } \\
\text { miyembro ng Pangkagawarang Elektoral na } \\
\text { Jorte, nagawaran. }\end{array}$ \\
\hline
\end{tabular}

Konstitusyon Artikulo 213 ng Burundi 2005

\begin{tabular}{|l|l|}
\hline $\begin{array}{l}\text { Konstitusyon } \\
\text { ng Timog } \\
\text { Aprika } \\
1996\end{array}$ & Seksyon 174(2) \\
\hline & \\
\hline $\begin{array}{l}\text { Konstitusyon } \\
\text { ng Vanuatu } \\
1980\end{array}$ & Artikulo 48(1) \\
\hline
\end{tabular}

Ang kapangyarihang hudisyal ay nakabalangkas upang maipakita ang komposisyon nito sa buong populasyon.

Ang mga pamamaraan ng pagrekluta at pagtatalaga sa mga pangkat hudisyal ay imperatibong sinusunod ang usapin ng paglulunsad ng mga panrehiyon, pang-etniko, at pangkasariang balanse.

Kasama sa pagiging Mahistrado ang halos $60 \%$ Hutu at higit sa $40 \%$ Tutsi. Di kukulanging 30\% ng mga kababaihan ang ginagarantiyahan.

\section{Ang pangangailangan para sa hudikatura na maipakita nang malawakan ang komposisyon ng lahi at kasarian ng Timog Aprika ay dapat isaalang-alang kapag ang mga hudisyal na opisyal ay hinirang.}

1. Ang Komisyon ng Hudisyal na Serbisyo ay dapat binubuo ng Ministro na responsable para sa hustisya, bilang Tagapangulo, Punong Mahistrado, Tagapangulo ng Komisyon sa Serbisyo Publiko, at isang kinatawan ng Konseho ng mga Pinuno ng Malvatumauri na hinirang ng Konseho.
Hinihingi na sa pagsusuring mga kwalipikasyon para sa isang hukom ng Korte Suprema, ang karanasan sa 'katutubong awtoridad' (katutubong sistema ng hustisya) ay dapat isaalangalang

Nananawagan para sa halohalong komposisyon ng korte batay sa 'plurinasyonalidad' na may representasyon mula sa parehong nakaugalian at ordinaryong ligal na mga sistema.

Nananawagan para sa representasyon ng mga katutubo sa mga Pangkagawarang Elektoral na Korte

Nagsasaad na ang hudikatura ay dapat na sumasalamin sa komposisyon ng pambansang populasyon at ang pagrekluta at pagtatalaga ay gagawin upang itaguyod ang mga etnikong pagbalanse (eksaktong proporsyon na inireseta)

Nagmamandato sa pagsasaalang-alang ng dibersidad sa paghirang ng mga hukom

Inilalakip ang garantisadong representante ng katutubong Konseho ng Malvatumauri sa Komisyon ng Hudisyal na Serbisyo para sa paghihirang at pagmamatyag sa mga hukom 


\section{MGA NAPAG-ALAMAN}

Sagot sa tanong (Oo/Hiindi) at iba pang mga tala at obserbasyon tungkol sa kung gaano kahusay na tinutugunan $n g$ konstitusyon ang (mga) isyu na itinanong. Isama ang mga makabuluhang mga probisyon ((mga) numero $n g$ artikulo at teksto $n g$ (mga) probisyon). Tandaan din ang hindi konsistent at/o magkasalungat na mga probisyon, o kung walang umiiral na mga kaugnay na probisyon.

\section{MGA HAKBANG}

Iminungkahing adbokasiya at iba pang mga kasunod na hakbang upang matugunan o mapalaganap ang mga natuklasan. 


\section{Konsultasyon, pulitikal na pakikilahok at representasyon}

\section{Iginagarantiya $\mathrm{o}$ isinusulong ba $\mathrm{ng}$ konstitusyon ang pangangalap $\mathrm{o}$ pagtatalaga ng mga katutubo sa mga posisyon sa serbisyo sibil, mga independiyenteng katawan at militar?}

\section{PALIWANAG}

Ipinapahiwatig ng ilang konstitusyon na ang lahat ng mga parte ng estado ay dapat sumasalamin sa dibersidad ng isang bansa. Minsan nalilimitahan ito sa mga kinatawan na institusyon tulad ng lehislatura (tinalakay sa Tanong 14) ngunit sa ideal, ang prinsipyo ng proporsyonal na representasyon ay dapat ding ibigay sa pagpili ng mga hindi nahalal, administratibong aktor ng gobyerno na nirekluta sa mga posisyon sa serbisyong sibil, mga institusyong panseguridad at iba pang mga independyenteng kinatawan (tulad ng ombudsman at mga komisyon para sa karapatang pantao). Ang mga institusyong ito ay madalas na gulugod ng estado, responsable para sa pakikipagugnay sa mga mamamayan at pinangangasiwaan din ang mga proseso at serbisyo ng gobyerno. Tulad ng naturan, kritikal na kilalanin ng isang estado kahit naang prinsipyo lang ng pagpapahalaga sa dibersidad o ang proporsyonal na representasyon ay isasaalang-alang sa mga paghihirang.

Ang mas malakas na wika ay maaaring magsuri muli sa mga pamantayang itinatag para sa pagtatalaga o pagrerekluta. Halimbawa, ang mga pamantayan na nakatuon lamang sa merito o kakayahan ay maaaring lumitaw na walang kinikilingan, ngunit malamang na magdesbentaha sa mga katutubo dahil sa makasaysayang hindi pagkakapantay-pantay at marhinalisasyon. Nalalapat din dito ang prinsipyo ng substantibong pagkakapantaypantay at mga espesyal na hakbang (tinalakay sa Tanong 5 at Tsapter 3 sa mga susing termino at konsepto).

MGA PAMANTAYANG PANG-INTERNASYUNAL AT PAMBANSANG MGA HALIMBAWA

\begin{tabular}{|c|c|c|}
\hline $\begin{array}{l}\text { Kumbensyon } \\
\text { ng ILO } 169 \\
1989\end{array}$ & Artikulo 6(1b) & $\begin{array}{l}\text { 1. Sa paglalapat ng mga probisyon ng Kumbensyon } \\
\text { na ito, ang mga gobyerno ay dapat: } \\
\text {... } \\
\text { (b) magtaguyod ng mga paraan kung saan } \\
\text { malayang makikilahok ang mga mamamayan } \\
\text { na ito, sa di kukulanging parehong saklaw ng } \\
\text { iba pang mga sektor ng populasyon, sa lahat } \\
\text { ng antas ng paggawa ng desisyon sa mga } \\
\text { elektibong institusyon at administratibo at iba } \\
\text { pang mga kinatawang responsable para sa mga } \\
\text { patakaran at programa na kinuukulan nila. }\end{array}$ \\
\hline
\end{tabular}

Konstitusyon Artikulo 57 ng Ecuador 2008

\begin{tabular}{l|l}
$\begin{array}{l}\text { Konstitusyon } \\
\text { ng India }\end{array}$ & Artikulo 16 \\
1949 &
\end{tabular}

\begin{abstract}
Ang mga katutubong komyun, pamayanan, mamamayan at nasyon ay kinikilala at iginagarantiya, na naaayon sa Konstitusyon at mga kasunduan sa karapatang pantao, mga kumbensyon, deklarasyon at iba pang mga internasyunal na instrumento, ang mga sumusunod na kolektibong karapatan:

$\cdots$

(16) Upang lumahok sa pamamagitan ng kanilang mga kinatawan sa mga opisyal na samahan na itinatag ng batas upang maglabas ng mga pampublikong patakaran patungkol sa kanila, pati na rin ang magdisenyo at magpasya ng kanilang mga priyoridad sa mga plano at proyekto ng Estado.
\end{abstract}

1. Magkakaroon ng pagkakapantay-pantay sa pagkakataon para sa lahat ng mga mamamayan sa mga bagay na nauugnay sa hanapbuhay o pagtatalaga sa anumang tanggapan sa ilalim ng Estado.
Pinanghahawakan na ang karapatan sa malaya at pantay na pakikilahok ay dapat umabot sa mga administratibo at hindi inihalal na institusyon ng estado

Ginagarantiya ang pakikilahok ng mga katutubo sa pamamagitan $n g$ representasyon sa mga opisyal na kinatawan ng estado na itinatag ng batas
Tinitiyak ang pantay na oportunidad sa trabaho nang walang diskriminasyon sa estado ngunit pinapayagan ang mga espesyal na hakbang upang matiyak ang pagkakaroon ng substantibong pagkakapantay-pantaysa mga pagtatalaga ng gobyerno 


\begin{tabular}{|c|c|c|c|}
\hline & & $\begin{array}{l}\text { 2. Walang mamamayan ang dapat, sa mga batayan } \\
\text { lamang ng relihiyon, lahi, uri, kasarian, ninuno, } \\
\text { lugar ng kapanganakan, tirahan o alinman } \\
\text { sa mga ito, ang hindi karapat-dapat para sa, } \\
\text { o diidiskriminahan patungkol sa, anumang } \\
\text { hanapbuhay o tanggapan sa ilalim ng Estado. } \\
\text { 3. Walang nasasaad sa artikulong ito ang pipigil sa } \\
\text { Parlamento na magsagawa ng anumang batas } \\
\text { na magrereseta, patungkol sa isang uri o klase } \\
\text { ng trabaho o pagtatalaga sa isang tanggapan sa } \\
\text { ilalim ng Pamahalaan ng, o anumang lokal o iba } \\
\text { pang awtoridad sa loob, isang teritoryo ng Estado } \\
\text { o Unyon, ng anumang kinakailangan tungkol } \\
\text { sa paninirahan sa loob ng teritoryo ng Estado o } \\
\text { Unyon bago ang naturang trabaho o pagtatalaga. } \\
\text {.. } \\
\text { 4A. Walang nasasaad sa artikulong ito ang pipigil sa } \\
\text { Estado na magsagawa ng anumang probisyon } \\
\text { para sa pagpapareserba sa mga usapin ng } \\
\text { promosyon, na may kinahinatnang senyoridad, } \\
\text { sa anumang uri o mga klase ng mga posisyon sa } \\
\text { mga serbisyo sa ilalim ng Estado na pabor sa Mga } \\
\text { Naka-iskedyul na Uri at mga Nakaiskedyul na Tribo } \\
\text { na sa palagay ng mga Estado, ay hindi sapat na } \\
\text { kinakatawan sa mga serbisyo sa ilalim ng Estado. }\end{array}$ & \\
\hline $\begin{array}{l}\text { Konstitusyon } \\
\text { ng Nepal } \\
2015\end{array}$ & $\begin{array}{l}\text { Artikulo } 267(3) \\
\text { at } 285(2)\end{array}$ & $\begin{array}{l}\text { Artikulo } 267 \\
\text { 3. Ang pagpasok ng mga kababaihan, Dalit, mga } \\
\text { katutubo, mga katutubong nasyonalidad, Khas } \\
\text { Arya, Madhesi, Tharu, klase ng Pichhada at mga } \\
\text { mamamayan ng atrasadong rehiyon sa Hukbo } \\
\text { ng Nepal ay dapat, batay sa mga prinsipyo ng } \\
\text { pagkakapantay-pantay at pagsasama, matiyak } \\
\text { ng Pederal na batas. } \\
\text { Artikulo } 285 \\
\text { 2. Ang mga posisyon sa Pederal na serbisyong } \\
\text { sibil, pati na rin ang lahat ng mga serbisyo } \\
\text { ng pamahalaang Pederal, ay dapat mapunan } \\
\text { sa pamamagitan ng mga pagsusulit na } \\
\text { kompetitibo, batay sa bukas at proporsyonal na } \\
\text { ingklusibong prinsipyo. }\end{array}$ & $\begin{array}{l}\text { Nilalapat ang mga prinsipyo } \\
\text { ng pagkakapantay-pantay at } \\
\text { ingklusyon sa militar at ng } \\
\text { proporsyonal na ingklusyon sa } \\
\text { pangangalap ng serbisyo sibil }\end{array}$ \\
\hline $\begin{array}{l}\text { Canada, Batas } \\
\text { sa Karapatang } \\
\text { Pantao ng Canada } \\
1977\end{array}$ & Artikulo 3(1) at 7 & $\begin{array}{l}\text { Artikulo } 3 \\
\text { 1. Para sa lahat ng layunin ng Batas na ito, ang } \\
\text { ipinagbabawal na batayan ng diskriminasyon } \\
\text { ay lahi, nasyonal o etnikong pinagmulan, } \\
\text { kulay, relihiyon, edad, kasarian, oryentasyong } \\
\text { sekswal, katayuan sa pag-aasawa, katayuan } \\
\text { ng pamilya, kapansanan at paniniwala para } \\
\text { sa isang pagkakasala kung saan nabigyan ng } \\
\text { kapatawaran o tungkol sa kung saan ang isang } \\
\text { rekord ng suspensyon ay iniutos. } \\
\text { Artikulo } 7 \\
\text { 7. Ito ay isang diskriminatoryong kasanayan, } \\
\text { direkta o hindi direkta, } \\
\text { (a) ang tanggihan na pagtrabahuhin o } \\
\text { magpatuloy na pagtrabahuhin ang } \\
\text { sinumang indibidwal, o } \\
\text { (b) sa kurso ng trabaho, upang tahasan } \\
\text { ipagkaiba kaugnay sa isang empleyado, } \\
\text { sa isang ipinagbabawal na batayan ng } \\
\text { diskriminasyon. }\end{array}$ & $\begin{array}{l}\text { Ipinagbabawal ang } \\
\text { diskriminasyon sa parekluta sa } \\
\text { trabaho sa estado }\end{array}$ \\
\hline
\end{tabular}




\section{MGA NAPAG-ALAMAN}

Sagot sa tanong (Oo/Hiindi) at iba pang mga tala at obserbasyon tungkol sa kung gaano kahusay na tinutugunan $n g$ konstitusyon ang (mga) isyu na itinanong. Isama ang mga makabuluhang mga probisyon ((mga) numero $n g$ artikulo at teksto $n g$ (mga) probisyon). Tandaan din ang hindi konsistent at/o magkasalungat na mga probisyon, o kung walang umiiral na mga kaugnay na probisyon.

\section{MGA HAKBANG}

Iminungkahing adbokasiya at iba pang mga kasunod na hakbang upang matugunan o mapalaganap ang mga natuklasan. 



\section{Karapatan sa lupa, teritoryo at likas na yaman \\ Kinikilala ba ng konstitusyon ang espesyal na ugnayan \\ sa pagitan ng mga katutubo at sa lupa, kasama na ang \\ pagprotekta sa kolektibong mga karapatan sa pagmamay-ari \\ sa mga lupang ninuno at teritoryo at pagtataguyod ng mataas \\ na pataw para sa pang-aagaw sa mga lupain ng mga katutubo?}

PALIWANAG

Ang mga katutubo ay may espesyal na koneksyon sa lupa, na sumasaklaw ngunit lumalawak nang higit pa sa mga ideya ng pag-aari at posesyon sa mga ligal na sistema ng maraming bansa. Ang ugnayan ng mga katutubo sa lupa ay kinikilala at protektado sa Kumbensyon ng ILO 169 at UNDRIP. Ang karapatan ng mga katutubo na protektahan ang kanilang mga lupain, matukoy ang mga priyoridad para sa kanilang paggamit, at itaguyod ang kanilang agrikultural at iba pang mga pamamahala sa lupang kasanayan ay magkakaugnay at itinatag batay sa karapatan ng mga katutubo sa sariling pagpapasya.

Tulad ng pagkilala ng Inter-American Court of Human Rights: 'Para sa mga katutubong komunidad, ang mga ugnayan sa lupa ay hindi lamang isang bagay na pagmamay-ari at produksyon ngunit isang materyal at espiritwal na elemento na dapat nilang ganap na matamasa, gayundin ang mapanatili ang kanilang pamana sa kultura at isalin ito sa mga susunod pang henerasyon' (Inter-American Court of Human Rights 2001: para. 149). Dahil dito, ang mga karapatan sa lupa ay malalim na nakatali sa karapatan ng mga katutubo sa kultura, pagkakakilanlan at sariling pagpapasya (tingnan ang Tanong 7 at 21). Ang lupa ay isang simbolo ng soberanya at higit pa para sa mga katutubo. Ang ilan sa mga pinakamahalagang hamon na kinakaharap ng mga katutubo ay iyong mga nagmumula sa mga panggigipit sa kanilang mga lupain, teritoryo at likas na yaman. Ang mga lupang ninuno ay masalimuot na nakatali sa kaligtasan ng kultura ng mga katutubo, at ang pangkalahatang pagsusulong ng kanilang mga karapatan na patuloy na umiral bilang mga natatanging entidad.

Sa isa pang kaso, kinilala ng Inter-American Court of Human Rights na: 'Ang kultura ng mga miyembro ng mga katutubong komunidad ay sumasalamin sa isang partikular na paraan ng pamumuhay, ng pagiging, pagtingin at pagkilos sa mundo, ang panimulang punto ay kung saan ang kanilang malapit na ugnayan sa kanilang tradisyunal na mga lupain at likas na yaman, hindi lamang dahil ito ang kanilang pangunahing paraan ng kaligtasan, ngunit dahil din bumubuo ito sa bahagi ng kanilang pananaw sa mundo, ng kanilang pagiging relihiyoso, at dahil dito, ng kanilang kultural na pagkakakilan' (2006: para. 118). Ang Korte ay nagpatuloy na sinabi na ang pragmatikong implikasyon ng kultural na realidad na ito ay:

120. Gayundin, isinasaalang-alang ng Korte na ang mga katutubong komunidad ay maaaring magkaroon ng kolektibong pag-unawa sa mga konsepto ng pag-aari at posesyon, sa diwa na ang pagmamay-ari ng lupa 'ay hindi nakasentro sa isang indibidwal ngunit sa halip ay sa grupo at sa pamayanan nito.' Ang ideyang ito ng pagmamay-ari at posesyon ng lupa ay hindi kinakailangang sumunod sa klasikong konsepto ng pag-aari, ngunit nararapat na bigyan ng pantay na proteksyon sa ilalim ng Artikulo 21 ng American Convention...

128. Ang mga sumusunod na kongklusyon ay nakuha mula sa mga naunang nabanggit: 1 ) ang tradisyunal na posesyon ng kanilang mga lupain ng mga katutubo ay may katumbas na mga epekto sa mga naibigay ng estado na buong titulo ng pag-aari; 2) ang tradisyunal na posesyon ay nagbibigay ng karapatan sa mga katutubo na humiling ng opisyal na pagkilala at pagrehistro ng titulo ng pag-aari; 3) ang mga kasapi ng mga katutubo na sapilitang pinaalis sa kanilang tradisyunal na mga lupain, o nawala ang pagmamay-ari, ay papanatilihin ang mga karapatan sa pag-aari dito, kahit na wala silang ligal na titulo, maliban kung ang mga lupa ay nailipat sa pamamagitan ng batas sa mga ikatlong partido nang may mabuting hangarin; at 4) ang mga kasapi ng mga katutubo na sapilitang nawalan ng pag-aari ng kanilang mga lupa, kapag ang mga lupaing iyon sa pamamagitan ng batas ay nailipat sa inosenteng mga ikatlong partido, ay may karapatang sa restitusyon dito o upang makakuha ng iba pang mga lupaing pantay ang plawak at kalidad. Dahil dito, ang posesyon ay hindi isang kinakailangang pagkondisyon sa pag-iral ng mga karapatan sa pagpapanumbalik ng lupa ng mga katutubo. (Inter-American Court of Human Rights 2006)

Ang desisyon na ito ay mahalaga dahil kinikilala nito na ang pagprotekta sa karapatan ng mga katutubo sa lupa at mga teritoryo ay nangangailangan ng pagtinging lampas sa mga titulo at paniniwala ng iginawad ng estadong pag-aari. Bilang karagdagan sa karaniwang mga karapatan sa pag-aari, ang konstitusyonal na pagkilala sa 
ugnayan sa pagitan ng mga katutubo at kanilang mga lupain ay maaaring makatulong upang maisulong ang mas mahusay na mga patakaran na umaayon sa mga pamantayang pang-internasyunal sa karapatan ng mga katutubo sa lupa, mga teritoryo at likas na yaman. Ang mga karapatan ng mga katutubo sa mga lupaing ito ay dapat na may kasamang mga karapatan sa pagmamay-ari (titulo) at praktikal na kakayahang mapanatili ang mga lupa sa ikinabubuhay na nangangahulugang (ibig sabihin, mga eksensiyon ng buwis mula sa gobyerno). Ang mga kolektibong karapatan sa mga lupa, teritoryo, at mapagkukunan ay katumbas ng mga karapatan sa indibidwal na pag-aari sa isang kontekstong hindi pangkatutubo. Hangga't maaari, ang katutubong mga kasanayan at kasaysayan sa paligid ng pagmamay-ari at pamamahala ng lupa ay dapat protektahan.

Tulad ng lahat ng mga karapatan ng mga katutubo, ang mga kolektibong karapatan ay dapat isaalang-alang kaugnay sa mga lupang ninuno (tingnan ang Tanong 8). Ang kolektibong pagmamay-ari ng lupa ay nagdadala ng matinding kahalagahan para sa mga katutubo, at nakatali sa pagkilala sa mga lupaing ninuno at teritoryo. Ang kolektibong pagmamay-ari ay maaari ring magbigay ng batayan para sa pagpapatupad ng iba pang mga karapatan, kabilang ang awtonomiya at pagbabahagi ng benepisyo para sa pagpapaunlad ng impraestruktura at mga proyekto sa paggamit ng likas na mapagkukunan (tingnan ang Tanong 19).

Bukod dito, dahil sa espesyal na ugnayan ng mga katutubo sa lupa, sila ay nagdurusa nang disproporsyonal mula sa sapilitang pagpapalayas. Ang mga patakaran ay dapat ipatupad na may layuning maglagay ng isang makabuluhang pasanin sa estado upang maipakita ang pagbibigay-katwiran sa paglipat ng mga katutubo mula sa kanilang mga lupain; kung minsan ang pasaning ito ay maaaring mas mataas kaysa sa inilalapat sa pagpapalayas sa mga pamayanang hindi katutubo. Ang anumang makatwirang paglipat sa ilalim ng eminenteng dominyo o iba pang mga pangyayari ay dapat magresulta sa patas na kompensasyong sa mga apektadong katutubo.

Panghuli, sa pagbibigay-diin ng UNDRIP, mayroong isang makasaysayang isyu sa pag-okupa ng mga militar, sa paggamit at/o pagpasok sa mga katutubong teritoryo nang walang pahintulot mula sa mga katutubong grupo. Ito ay isang paglabag sa sariling pagpapasya at mga karapatan sa awtonomiya, pati na rin ang pagkatawan sa isang mas malawak na isyu ng pag-unawa sa soberanya ng mga katutubong lupain. Nakasaad sa UNDRIP: '1. Ang mga militar na aktibidad ay hindi dapat maganap sa mga lupain o teritoryo ng mga katutubo, maliban kung nabigyang-katwiran ng isang makabuluhang pampublikong interes o kung hindi man malayang sumang-ayon o hiniling ng mga kinauukulang katutubo. 2. Ang mga Estado ay magsasagawa ng mabisang konsultasyon sa mga kinauukulang katutubo, sa pamamagitan ng naaangkop na mga pamamaraan at sa partikular sa pamamagitan ng kanilang kinatawan na mga institusyon, bago gamitin ang kanilang mga lupain o teritoryo para sa mga aktibidad ng militar' (United Nations 2007: artikulo 30). Habang hindi gaano karami ang konstitusyonal na praktika dito, ito ay isang mahalagang isyung dapat isaalang-alang.

MGA PAMANTAYANG PANG-INTERNASYUNAL AT PAMBANSANG MGA HALIMBAWA

\begin{tabular}{|c|c|c|}
\hline $\begin{array}{l}\text { Komite sa mga } \\
\text { Pang-ekomomiya, } \\
\text { Panlipunan, at } \\
\text { Pangkulturang } \\
\text { Karapatan, } \\
\text { Pangkalahatang } \\
\text { Komento Blg, } 21 \\
21 \text { Disyembre } \\
2009\end{array}$ & $\begin{array}{l}\text { Part IIE, article } 7, \\
\text { para. } 36\end{array}$ & $\begin{array}{l}\text { Samakatwid ang mga partido ng Estado ay dapat } \\
\text { gumawa ng mga hakbang upang kilalanin at } \\
\text { protektahan ang mga karapatan ng mga katutubo } \\
\text { upang magmay-ari, magpaunlad, magkontrol, at } \\
\text { gumamit ng kanilang mga komyunal na lupain, } \\
\text { teritoryo, at mapagkukunan, at, kung saan sila } \\
\text { ay sa kabilang banda inokupahan o ginamit nang } \\
\text { walang wala ang kanilang malaya at malinang na } \\
\text { pahintulot, ay gumawa ng mga hakbang upang } \\
\text { maibalik ang mga lupa at teritoryong ito. }\end{array}$ \\
\hline $\begin{array}{l}\text { Kumbensyon } \\
\text { ng ILO } 169 \\
1989\end{array}$ & Artikulo 13 at 14 & $\begin{array}{l}\text { Artikulo } 13 \\
\text { 1. Sa paglalapat ng mga probisyon ng Bahagi ng } \\
\text { Kumbensyon na ito ay dapat igalang ng mga } \\
\text { pamahalaan ang espesyal na importansya } \\
\text { para sa mga kultura at mga espiritwal na } \\
\text { kahalagahan ng mga mamamayan na malapit sa } \\
\text { kanilang ugnayan sa mga lupain o teritoryo, o } \\
\text { pareho na naaangkop, na sinasakop nila o kung } \\
\text { hindi man ginagamit, at sa partikular ang sama- } \\
\text { samang aspekto ng ugnayan na ito. } \\
\text { 2. Ang paggamit ng terminong lupain sa Artikulo } \\
\text { 15 at } 16 \text { ay dapat isama ang konsepto ng } \\
\text { mga teritoryo, na sumasaklaw sa kabuuang } \\
\text { kapaligiran ng mga lugar na sinasakop ng mga } \\
\text { kinauukulang mamamayan o kung hindi man ay } \\
\text { ginagamit. }\end{array}$ \\
\hline
\end{tabular}

Kinikilala ang ugnayan sa pagitan ng karapatan ng mga katutubo sa sariling pagpapasya at mga karapatan sa lupa ng mga katutubo

Nananawagan sa mga pamahalaan na igalang ang espesyal na importanya ng lupa at mga teritoryo sa mga katutubo at nagtatakda ng mga kondisyon para sa pagmamay-ari at posesyon ng mga lupain, pati na rin ang mga pamamaraan para sa pagtataguyod ng pareho 


\section{Artikulo 14}

1. Ang mga karapatan ng pagmamay-ari at posesyon ng mga mamamayang umuukol sa mga lupain na tradisyunal nilang inookupa ay kikilalanin. Bilang karagdagan, ang mga hakbang ay dapat gawin sa mga naaangkop na kaso upang mapangalagaan ang karapatan ng mga mamamayang umuukol sa paggamit ng mga lupain na hindi nila eksklusibong inookupahan, ngunit kung saan nagkaroon sila ng tradisyonal na pag-akses para sa kanilang pamumuhay at tradisyunal na mga gawain. Ang partikular na pansin ay ilalaan sa sitwasyon ng mga nomadikong mamamayan at ang mga palipat-lipat na magsasaka sa ganitong respeto.

2. Ang mga pamahalaan ay dapat gumawa ng mga kinakailangang hakbang upang makilala ang mga lupain na ang mga kinauukulang mamamayan ay umookupa, at upang igarantiya ang mabisang proteksyon ng kanilang mga karapatan sa pagmamay-ari at posesyon.

3. Ang mga sapat na pamamaraan ay dapat maitatag sa loob ng pambansang ligal na sistema upang malutas ang mga pag-angkin sa lupa ng mga taong kinauukulan.

\begin{tabular}{|c|c|c|c|}
\hline & Artikulo 25-29 & $\begin{array}{l}\text { Artikulo } 25 \\
\text { Ang mga katutubo ay may karapatang panatilihin at } \\
\text { palakasin ang kanilang natatanging espiritwal na } \\
\text { ugnayan sa kanilang tradisyunal na pinagmamay- } \\
\text { arian o kung hindi man ay inookupahan at } \\
\text { ginagamit na mga lupain, teritoryo, katubigan at } \\
\text { baybaying dagat at iba pang mga mapagkukunan } \\
\text { at mapanatili ang kanilang mga responsibilidad sa } \\
\text { mga susunod na henerasyon hinggil dito. } \\
\text { Artikulo } 26 \\
\text { 1. Ang mga katutubo ay may karapatan sa mga } \\
\text { lupa, teritoryo at mapagkukunan na tradisyunal } \\
\text { nilang pinagmamay-arian, inookupahan o kung } \\
\text { hindi man ginamit o nakuha. } \\
\text { 2. Ang mga katutubo ay may karapatang magmay- } \\
\text { ari, gumamit, magpaunlad at kumontrol ng mga } \\
\text { lupa, teritoryo at mapagkukunan na nasa kanila } \\
\text { sa dahilan ng tradisyunal na pagmamay-ari o iba } \\
\text { pang tradisyunal na okupasyon o paggamit, pati } \\
\text { na rin ang mga nakuha nila sa ibang paraan. } \\
\text { 3. Ang mga estado ay dapat magbigay ng legal na } \\
\text { pagkilala at proteksyon sa mga lupa, teritoryo at } \\
\text { mapagkukunan na ito. Ang naturang pagkilala } \\
\text { ay dapat isagawa nang may paggalang sa } \\
\text { kaugalian, tradisyon at mga sistema ng panirikan } \\
\text { ng lupa ng mga kinauukulang katutubo. } \\
\text { Artikulo } 27 \\
\text { Itataguyod at ipapatupad ng mga estado, kasabay ng } \\
\text { mga kinauukulang katutubo, ang isang patas, malaya, } \\
\text { walang kinikilingan, bukas at malinaw na proseso, na } \\
\text { nagbibigay ng angkop na pagkilala sa mga katutubong } \\
\text { batas, tradisyon, kaugalian at mga sistema ng } \\
\text { panirikan ng lupa, upang kilalanin at pagdesisyunan } \\
\text { ang mga karapatan ng mga katutubo na nauukol sa } \\
\text { kanilang mga lupain, teritoryo at mapagkukunan, } \\
\text { kabilang ang mga tradisyonal na pinagmamay-arian } \\
\text { o kung hindi man ay inokupahan o ginamit. Ang mga } \\
\text { katutubo ay may karapatang lumahok sa prosesong ito. }\end{array}$ & $\begin{array}{l}\text { Kinikilala ang karapatan ng } \\
\text { mga katutubo na panatilihin at } \\
\text { palakasin ang kanilang ugnayan } \\
\text { sa mga lupaing tradisyonal } \\
\text { na pinagmamay-arian at } \\
\text { inookupahan }\end{array}$ \\
\hline
\end{tabular}


1. Ang mga katutubo ay may karapatang magtuwid, sa pamamagitan ng mga paraan na maaaring pagbibigay danyos o, kung hindi ito posible, makatarungan, patas at pantay na kompensasyon, para sa mga lupa, teritoryo at mapagkukunan na tradisyonal nilang pagmamayarian o kung hindi man inookupahan o ginamit, at kung saan nakumpiska, kinuha, inokupahan, ginamit o pininsala nang wala ang kanilang libre, nauna at malinang na kapahintuluan.

2. Maliban kung malayang napagkasunduan ng mga kinauukulang mamamayan, ang kompensasyon ay dapat nasa anyo ng mga lupa, teritoryo at mapagkukunan na pantay ang kalidad, laki at ligal na katayuan o ng monetaryong kompensasyon o iba pang naaangkop na mga pagtutuwid.

Artikulo 29

1. Ang mga katutubo ay may karapatan sa pangangalaga at proteksyon ng kalikasan at ng produktibong kakayahan ng kanilang mga lupain o teritoryo at mapagkukunan. Ang mga estado ay magtataguyod at magpapatupad ng mga programa ng pagtulong para sa mga katutubo para sa naturang pangangalaga at proteksyon, nang walang diskriminasyon.

2. Magsasagawa ang mga estado ng mabisang hakbang upang matiyak na walang pag-iimbak o pagtatapon ng mga mapanganib na materyales ang magaganap sa mga lupa o teritoryo ng mga katutubo nang wala ang kanilang malaya, nauna at malinang na kapahintulutan.

\section{Konstitusyon ng Argentina 1994}

Konstitusyon
ng Brazil
1988

Artikulo 231(1), (2) at (5)

Artikulo 75(17)

Ang Kongreso ay magkakaroon ng kapangyarihan:

- .

$17 . .$.

... kilalanin ang ligal na paninindigan ng kanilang mga pamayanan, at ang posesyon at pag-aari ng pamayanan sa mga lupain na tradiyonal nilang inokupahan, at upang maregula ang paglipat ng iba pang mga lupa na akma at sapat para sa kaunlaran ng tao - na wala sa alinman ay maaaring mailipat, maipadala o madaling maapektuhan ng mga balakid o mga kalakip.

\section{Artikulo 231}

Ang samahang panlipunan, kaugalian, wika, kredo at tradisyon ng mga Indian ay kinikilala, pati na rin ang kanilang orihinal na mga karapatan sa mga lupain na tradisyonal nilang inookupa. Ang Unyon ay may responsibilidad na ilarawan ang mga lupaing ito at protektahan at matiyak ang paggalang sa lahat ng kanilang pag-aari.

(1) Ang mga lupain na tradisyunal na inokupa ng mga Indian na kung saan sila nakatira sa isang permanenteng batayan, ang mga ginagamit para sa kanilang mga produktibong aktibidad, mga kinakailangan para sa pagpapanatili ng mga mapagkukunang kapaligiran na kinakailangan para sa kanilang kagalingan at mga kinakailangan para sa kanilang pisikal at kultural na reproduksiyon, ayon sa kanilang mga gamit, kaugalian at tradisyon.
Ipinagbabawal ang pagtatapon ng mga mapanganib na materyales sa mga teritoryo ng mga katutubo

Kinikilala ang posesyon $\mathrm{ng}$ mga pag-aari ng pamayanan batay sa tradisyunal na okupasyon

Tinutukoy ang mga tradisyunal na lupain ng mga pamayanang katutubo at pinoprotektahan ang mga ito para sa kanilang 'permanenteng posesyon'; nagtatatag ng mataas na pataw para sa pagpapalayas $n g \mathrm{mga}$ katutubo mula sa kanilang mga lupain 
(2) Ang mga lupain na tradisyunal na inookupa ng mga Indianay nakatadhana para sa kanilang permanenteng posesyon, at sila ay may karapatang sa eksklusibong usuprukto ng mga kayamanan ng lupa, mga ilog at lawa na umiiral doon. $\cdots$

(5) Ang pagtanggal ng mga katutubong pangkat mula sa kanilang mga lupain ay ipinagbabawal maliban sa pamamagitan ng referendum ng Pambansang Kongreso, sakaling magkaroon ng sakuna o epidemya na nilalagay sa peligro ang populasyon o sa interes ng pambansang soberanya, pagkatapos ng deliberasyon ng Pambansang Kongreso, ginagarantiya, sa ilalim ng lahat pangyayari, ang agarang pagbabalik sa sandaling tumigil ang panganib.

\section{Konstitusyo ng Colombia 1991}

\begin{tabular}{|l|l|}
\hline $\begin{array}{l}\text { Konstitusyon } \\
\text { ng Paraguay } \\
1992\end{array}$ & Artikulo 64 \\
\hline & \\
\hline $\begin{array}{l}\text { Konstitusyon } \\
\text { ng Peru }\end{array}$ & Artikulo 89 \\
\hline 1993 & \\
\hline $\begin{array}{l}\text { Konstitusyon } \\
\text { ng Uganda }\end{array}$ & Artikulo 237(3) at \\
\hline & \\
\hline
\end{tabular}

Ang pagsasaayos ng mga teritoryo ng mga katutubo [Indian] ay napapailalim sa mga probisyon ng Institutional Act of Territorial Plan, at ang kanilang delimitasyon ay ipatutupad ng pambansang pamahalaan na may partisipasyon ng mga kinatawan ng mga katutubong komunidad na sumusunod sa plano ng Komisyon ng Pagpaplano ng Teritoryo.

Ang mga pag-iingat na nailalapat ay nauugnay sa kolektibong pag-aari na maaaring hindi maipagbili.

Ang mga katutubo ay may karapatan sa pagmamayari ng komyunal na lupain sa [isang] pagpapalawak at kalidad na sapat para sa pangangalaga at pag-unlad ng kanilang mga partikular na uri ng pamumuhay. Ang Estado ay magbibigay sa kanila ng walang bayad sa mga lupaing ito, na kung saan ay hindi makukuha, hindi maibabahagi, hindi maililipat, hindi mababawi, hindi madaling mapinsala upang magarantiyaha ang mga kontraktwal na obligasyon o hindi maipaupa; gayundin, sila ay ligtas sa mga buwis. Ang pagpapaalis o pagpapalipat sa [mga katutubo] mula sa kanilang tirahan nang walang malinaw na pahintulot nila ay ipinagbabawal.

Ang mga rural at katutubong pamayanan ... ay awtonomo sa kanilang samahan, gawain sa pamayanan, at malayang pag-abandona ng kanilang mga lupain, pati na rin sa mga aspektong pang-ekonomiya at pang-administratibo sa loob ng balangkas na inilaan ng batas. Ang pagmamayari ng kanilang mga lupa ay maaaring hindi iminungkahi, maliban sa kaso ng pag-abandona na inilarawan sa naunang artikulo.

3. Ang lupa sa Uganda ay pagmamay-arian nang naaayon sa mga sumusunod na sistema ng panirikan ng lupa-
a. kaugalian;
b. malayang paggamit;
c. mailo; at
d. paupahan.

4. Sa pagsasakapangyarihan ng Batas na ito-

a. ang lahat ng mamamayan ng Uganda na nagmamay-ari ng lupa sa ilalim ng nakaugaliang panirikan ay maaaring kumuha ng mga sertipiko ng pagmamay-ari sa paraang iminungkahi ng Parlamento; at

b. ang lupa na nasa ilalim ng nakaugaliang panirikan ay maaaring mapalitan sa pagmamay-ari ng lupang malayang gamitin sa pamamagitan ng pagrehistro.
Nangangako sa mga katutubo ng karapatang lumahok sa pagkilala sa kanilang mga teritoryo

Nagbibigay ng mga pagiingat laban sa pagbebenta ng kolektibong pag-aari

Pinoprotektahan ang kolektibong pagmamay-aring lupa at nagbibigay ng mga eksensiyon ng buwis sa lupa sa mga teritoryo ng mga katutubo

Ipinagbabawal ang pagkontrata ng gobyerno sa mga teritoryo ng mga katutubo at hinihiling ang pahintulot ng mga katutubo bago tanggalin o ilipat mula sa mga lupa at teritoryo

Pinipigilan ang estado na magregula ng katutubong pagmamay-aring lupain

Kinikilala ang nakaugaliang sistema ng panirikan ng lupa

Tinitiyak na ang lahat ng mga mamamayan na may nakaugaliang panirikan ay maaaring makakuha ng mga sertipiko ng pagmamay-ari mula sa Estado 
Ang Pilipinas,

\section{Batas sa}

Karapatan $\mathbf{n g}$

Mga Katutubo

1997
Seksyon 7 at 8

SEKSYON 7. Mga Karapatan sa Mga Ninunong Dominyo. - Ang mga karapatan ng pagmamayari at posesyon ng mga ICC/IP [mga katutubong kultural na pamayanan /katutubo] sa kanilang mga lupang ninuno ay dapat kilalanin at protektahan. Ang nasabing mga karapatan ay isasama ang:

a) Karapatan sa Pagmamay-ari. - Ang karapatang mag-angkin ng pagmamay-ari sa mga lupa, mga katubigan na tradisyunal at aktwal na inokupa ng mga ICC/IP, mga banal na lugar, tradisyonal na lugar ng pangangaso at pangingisdaan, at lahat ng mga pagpapabuti na ginawa nila sa anumang oras sa loob ng mga dominyo;

b) Karapatan na Paunlarin ang mga Lupa at Likas na Yaman. - Napapailalim sa Seksyon 56 dito, ang karapatang paunlarin, kontrolin at gamitin ang mga lupain at teritoryo na tradisyunal na inokupahan, pinagmamay-arian, o ginamit; upang pamahalaan at pangalagaan ang likas na yaman sa loob ng mga teritoryo at itaguyod ang responsibilidad para sa susunod na henerasyon; upang makinabang at ibahagi ang mga kita mula sa paglalaan at paggamit ng likas na yaman na matatagpuan dito; karapatang makipag-ayos sa mga tuntunin at kondisyon para sa paggalugad ng likas na yaman sa mga lugar para sa hangaring matiyak ang pangangalagang ekolohikal, pangkapaligiran at mga hakbang sa konserbasyon, alinsunod sa pambansa at nakaugaliang mga batas; ang karapatan sa isang malinang at matalinong pakikilahok sa pagbubuo at pagpapatupad ng anumang proyekto, pamahalaan o pribado, na makaaapekto o makaiimpluwensya sa mga lupang ninuno at upang makatanggap ng makatarungan at patas na kompensasyon para sa anumang pinsala na maaari nilang natamo bilang resulta ng proyekto; at ang karapatan sa mabisang hakbangin ng gobyerno upang maiwasan ang anumang pagkagambala sa, paglalayo at panghihimasok sa mga karapatang ito;

c) Karapatan na Manatili sa mga Teritoryo. Ang karapatang manatili sa teritoryo at hindi matanggal mula doon. Walang mga ICC/IP ang maililipat nang wala ang kanilang malaya, nauna at malinang na kapahintulutan, o sa anumang paraan maliban sa eminenteng dominyo. Kung saan ang relokasyon ay itinuturing na kinakailangan bilang isang pambihirang hakbang, ang nasabing relokasyon ay magaganap lamang sa malaya, nauna at malinang na kapahintulutan $\mathrm{ng}$ mga kinauukulang ICC/IP at hangga't maaari, garantisado sila ng karapatang bumalik sa kanilang mga lupang ninuno, sa sandaling ang mga batayan para sa paglilipat ay tumigil na. Kapag hindi posible ang naturang pagbabalik, na tinukoy sa pamamagitan ng kasunduan o sa pamamagitan ng naaangkop na mga pamamaraan, ang mga ICC/IP ay dapat bigyan sa lahat ng mga posibleng pagkakataon ng mga lupain na may kalidad at ligal na katayuan na hindi kukulanging katumbas ng lupang dati na nilang inokupahan, na angkop na magbibigay para sa kanilang kasalukuyang mga pangangailangan at pag-unlad sa hinaharap. Ang mga taong inilipat sa gayon ay ganap ding makokompensa nang buo para sa anumang nagresultang pagkawala o pinsala;
Nagbibigayng komprehensibong proteksyon ng lupang ninuno at ang lupain ng mga katutubo kasama ang karapatan sa pagmamay-ari, karapatang magpaunlad ng lupa at likas na yaman at upang makinabang mula sa pareho, at ang karapatang manatili sa kanilang lupain na may mas mataas na mga pataw na inilagay para sa pagpapalikas at alienasyon 
d) Karapatan sa Kaso ng Paglikas. - Kung sakaling maganap ang paglikas bilang resulta ng natural na mga sakuna, magsisikap ang Estado na muling bigyan ng tirahan ang mga lumikas na ICC/IP sa mga naaangkop na lugar kung saan maaari silang magkaroon ng mga pansamantalang sistema ng suporta sa buhay: Basta't, Ang mga lumikas na ICC/IP ay may karapatang bumalik sa kanilang mga inabandunang lupa hanggang sa panahon na matukoy ang normalidad at kaligtasan ng mga nasabing lupain: Basta't, sa karagdagan, $\mathrm{Na}$ kung ang kanilang lupang ninuno ay tumigil sa pag-iral at ang normalidad at kaligtasan ng mga nakaraang pamayanan ay hindi posible, ang mga lumikas na ICC/IP ay tatamasa ng seguridad ng panirikan sa mga lupain kung saan sila ay muling nakapanirahan: Basta't, sa karagdagan, Ang pangunahing mga serbisyo at kabuhayan ay ibibigay sa kanila upang matiyak na ang kanilang mga pangangailangan ay sapat na natutugunan.

SEKSYON 8. Mga Karapatan sa Mga Lupang Ninuno. - Ang karapatan ng pagmamay-ari at posesyon ng mga ICC/IP sa kanilang mga lupang ninuno ay kikilalanin at poprotektahan.

a) Karapatan na maglipat ng lupa/pag-aari. - Ang nasabing mga karapatan ay dapat isama ang karapatang ilipat ang mga karapatan sa lupa o pag-aari / sa mga miyembro ng parehong mga ICC/IP, napapailalim sa mga nakaugaliang batas at tradisyon ng kinauukulang pamayanan.

b) Karapatan sa Katubusan. - Sa mga kaso kung saan ipinakita na ang paglipat ng mga karapatan sa lupa/pag-aari sa bisa ng anumang kasunduan o plano, sa isang hindi kasapi ng mga kinauukulang ICC/ IP ay nabahiran ng manipuladong pahintulot ng mga ICC/ $I P$, o inilipat para sa isang labis-labis na pagsasaalang-alang o presyo, ang tagalipat na ICC/IP ay may karapatang tubusin ang pareho sa loob ng isang panahon na hindi hihigit sa labinlimang (15) taon mula sa araw ng paglipat.

\begin{tabular}{|c|c|c|c|}
\hline $\begin{array}{l}\text { New Zealand, } \\
\text { Tratado ng } \\
\text { Waitangi } \\
1840\end{array}$ & Artikulo 2 & $\begin{array}{l}\text { Ang Mahal na Reyna ng England ay nagkukumpirma } \\
\text { at nagagarantiya sa mga Pinuno at Tribo ng New } \\
\text { Zealand at sa kani-kanilang pamilya at indibidwal } \\
\text { dito ang buong eksklusibo at hindi nagagambalang } \\
\text { posesyon ng kanilang mga Lupain at mga Ari-arian, } \\
\text { Kagubatan, Pangisdaan at iba pang mga pag- } \\
\text { aari na maaari nilang kolektibo o indibidwal na } \\
\text { taglayin basta’t ito ang kanilang hiling at hangarin } \\
\text { na panatilihin ang pareho sa kanilang posesyon; } \\
\text { ngunit ang mga Pinuno ng Nagkakaisang Tribo at } \\
\text { ang mga indibidwal na mga Pinuno ay nagbibigay } \\
\text { sa Kanyang Kamahalan ng eksklusibong karapatan } \\
\text { ng Preemption sa mga nasabing upang ang mga } \\
\text { Proprietor nito ay maaaring pumili na humiwalay sa } \\
\text { mga naturang presyo na maaaring mapagkasunduan } \\
\text { sa pagitan ng kani-kanilang mga Proprietor at } \\
\text { mga taong hinirang ng Kanyang Kamahalan upang } \\
\text { makitungo sa kanila sa ngalan na iyon. }\end{array}$ & $\begin{array}{l}\text { Ginagarantiyaha sa mga } \\
\text { katutubo ng New Zealand ang } \\
\text { kanilang mga karapatan sa } \\
\text { lupa, habang nakalaan ang } \\
\text { karapatan ng gobyerno na } \\
\text { mag-angkin ng lupa-bagama't } \\
\text { para lamang sa isang presyo } \\
\text { na napagkasunduan sa pagitan } \\
\text { ng mga katutubong grupo at ng } \\
\text { gobyerno }\end{array}$ \\
\hline
\end{tabular}




\section{MGA NAPAG-ALAMAN}

Sagot sa tanong (Oo/Hiindi) at iba pang mga tala at obserbasyon tungkol sa kung gaano kahusay na tinutugunan $n g$ konstitusyon ang (mga) isyu na itinanong. Isama ang mga makabuluhang mga probisyon ((mga) numero $n g$ artikulo at teksto $n g$ (mga) probisyon). Tandaan din ang hindi konsistent at/o magkasalungat na mga probisyon, o kung walang umiiral na mga kaugnay na probisyon.

\section{MGA HAKBANG}

Iminungkahing adbokasiya at iba pang mga kasunod na hakbang upang matugunan o mapalaganap ang mga natuklasan. 


\section{Karapatan sa lupa, teritoryo at likas na yaman \\ Makakaya ba ng konstitusyon ang mga espesyal na karapatan ng mga katutubo sa kanilang mga likas yaman sa loob/mismo/ilalim ng kanilang mga lupain at teritoryo? Humihiling ba ang konstitusyon sa mga katutubo ng pagbabahagi ng benepisyo sa mga kapwa katutubo hinggil sa mga isinasagawang gawain sa kanilang lupain na nauugnay sa likas na yaman?}

PALIWANAG

Tulad ng lupa, ang likas na yaman ay makabuluhang nakatali sa mga kultura, kasanayan at tradisyon ng mga katutubo, pati na rin sa kanilang ikinabubuhay at trabaho. Ang pagkilala sa ugnayang ito, pati na rin bago ang kairalan ng mga katutubo sa mga teritoryo na naglalaman ng likas na yaman na mahalaga sa modernong ekonomiya, ay makakatulong upang matiyak na ang mga katutubo ay maaaring pumili sa pagitan at balansehin ang tradisyunal at pang-ekonomiyang paggamit ng kanilang likas na yaman. Ito ay malalim na nakatali sa karapatan ng mga katutubo sa (panloob) na sariling pagpapasya, at ang kanilang kaugnay na karapatang matukoy ang kanilang sariling mga priyoridad sa pag-unlad. Ang mga katutubo ay dapat na may pundamental na pagpipilian sa kung hanggang saan at sa anong paraan nais nilang makisali sa kaunlaran; dapat silang hayaan upang timbangin ang mga benepisyo at kahihinatnan ng mga proyektong pangkaunlaranat magkaroon ng pinal na awtoridad sa pagpahintulot sa mga proyektong ito.

Ang proteksyon ng konstitusyon sa isyung ito ay mula sa batayang pagkilala sa kahalagahan ng likas na yaman sa mga katutubo, hanggang sa unang mga karapatan ng gumagamit sa mga mapagkukunan sa/ng kanilang lupain at mga teritoryo; sa pagbabawal sa mga gobyerno na mag-isyu ng mga kontrata para sa pagkuha ng likas na yaman sa katutubong lupain, na kung minsan ay buo at minsan ay walang pahintulot ng mga pamayanan. Ang mga pamantayan para sa pahintulot — hango sa internasyunal na batas-ay tinalakay sa Tanong 20. Mahalagang suriin nang mabuti ang mga salita sa mga probisyong ito. Kung ang mga katutubo ay binibigyan ng mga karapatan sa paggamit ng likas na yaman, ito ba ay eksklusibong paggamit? Kailangan ba silang makasama sa proseso ng pagtukoy ng paggamit? Ang paggamit ba ay limitado sa ilang mga mapagkukunan (sa itaas o sa ibaba ng lupain)? Ano ang mga kinakailangan para sa konsultasyon at pahintulot? Kinakailangan ba ang konsultasyon, o payo lamang tulad ng sa kaso ng Colombia? Kung ang pamahalaan ay nagpapanatili ng kontrol sa pagkontrata, pagkuha o iba pang mga industriyang umaasa sa likas na yaman sa katutubong lupain, hinihimok ng mga pamantayang panginternasyunal ang pagbabahagi ng benepisyo upang matiyak na ang buhay at mga ekonomiya ng mga katutubo ay makinabang nang pantay sa mga aktibidad. Kasama sa mga kaugnay na isyu ang kung ang mga katutubo at ang kanilang mga samahan ay binibigyan ng ligal na katayuan upang makipagkontrata sa mga ikatlong partido o hindi.

MGA PAMANTAYANG PANG-INTERNASYUNAL AT PAMBANSANG MGA HALIMBAWA

\begin{tabular}{l|l|}
$\begin{array}{l}\text { Kumbensyon } \\
\text { ng ILO 169 }\end{array}$ & Artikulo 15 \\
\hline 1989 &
\end{tabular}

1. Ang mga karapatan ng mga mamamayang nangangalaga sa likas na yaman na nauukol sa kanilang mga lupain ay espesyal na pag-iingatan. Kasama sa mga karapatang ito ang karapatan ng mga mamamayang ito na lumahok sa paggamit, pamamahala at pag-iingat ng mga mapagkukunang ito.

2. Sa mga kaso kung saan pinapanatili ng Estado ang pagmamay-ari ng mga mineral o sub-surface na mapagkukunan o mga karapatan sa iba pang mga mapagkukunan na nauugnay sa mga lupain, ang mga gobyerno ay magtatatag o magpapanatili ng mga pamamaraan kung saan sila ay kokonsulta sa mga mamamayang ito, na may layuning alamin kung at sa anong antas ang kanilang interes ay mapeprehuwisyo, bago magsagawa o payagan ang anumang mga programa para sa paggalugad o pagsasamantala sa mga naturang mapagkukunan na nauugnay sa kanilang mga lupain. Ang mga taong kinauukulan ay dapat na lumahok sa kung saan posible sa mga benepisyo ng naturang $\mathrm{mga}$ aktibidad, at tatanggap ng patas na kompensasyon para sa anumang pinsala na maaari nilang natamo bilang isang resulta ng naturang mga aktibidad.
Nananawagan para sa espesyal na pangangalaga ng mga karapatan sa likas na yaman sa kanilang mga lupain at mga karapatang lumahok sa paggamit, pamamahala at pagiingat ng mga mapagkukunang ito

Hinihiling ang konsultasyon, pagbabahaging benepisyo, at/o patas na kompensasyon kapag ang Estado ay may mga karapatang kumuha ng likas na yaman sa mga lupain $\mathrm{ng}$ mga katutubo 


\section{Konstitusyon ng Argentina} 1994

\section{Konstitusyon} ng Bolivia 2009
1. Ang mga katutubo ay may karapatang matukoy at mabuo ang mga priyoridad at estratehiya para sa pag-unlad o paggamit ng kanilang mga lupain o teritoryo at iba pang mapagkukunan.

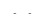

3. Ang mga estado ay dapat magbigay ng mabisang mekanismo para sa makatarungan at patas na pagwawasto para sa anumang mga naturang aktibidad, at ang mga naaangkop na hakbang ay gagawin upang mapagaan ang masamang pangkapaligiran, pang-ekonomiya, panlipunan, pangkultura o pang-espiritwal na epekto.

Artikulo 75(17) Ang Kongreso ay magkakaroon ng kapangyarihan:. . 17. ...

... Upang matiyak ang pakikilahok ng [mga katutubo] na nauugnay sa pangangasiwa ng kanilang likas na yaman at ng iba pang mga interes na nakakaapekto sa kanila.

\section{Artikulo 30, Artikulo 30}

352,353 at 403

II. Sa balangkas ng pagkakaisa ng Estado, at alinsunod sa Konstitusyong ito, tinatamasa ng mga nasyon at mga rural na katutubo ang mga sumusunod na karapatan: $\cdots$

15. Upang konsultahin ng mga naaangkop na pamamaraan, sa partikular sa pamamagitan ng kanilang mga institusyon, sa tuwing maaaring makita ang mga lehislatiboo administratibong hakbang na makaapekto sa kanila. Sa balangkas na ito, ang karapatan sa kinakailangan paunang konsultasyon ng Estado patungkol sa pagsasamantala ng hindi nababagong likas na yaman sa teritoryo na kanilang tinitirhan ay igagalang at garantisado, sa mabuting diwa at sa kasunduan.

16. Upang makilahok sa mga pakinabang ng pagsasamantala ng mga likas na yaman sa kanilang teritoryo.

17. Sa awtonomong katutubong pamamahala ng teritoryo, at sa eksklusibong paggamit at pagsasamantala ng mga nababagong likas na yaman na umiiral sa kanilang teritoryo nang walang pagtatangi sa mga lehitimong karapatan na nakuha ng mga pangatlong partido.

Artikulo 352

Ang pagsasamantala ng mga likas na yaman sa isang tinukoy na teritoryo ay sasailalim sa isang proseso ng konsultasyon sa apektadong populasyon, na tinawag ng Estado, na malaya, nauna sa tiyempo at may kaalaman. Ang pakikilahok ng mamamayan ay ginagarantiyahan sa proseso ng pamamahala ng kapaligiran, at ang pangangalaga ng mga ecosystem ay itataguyod, alinsunod sa Konstitusyon at batas. Sa mga bansa at rural na katutubo, isasagawa ang konsultasyon na may paggalang na ibinigay sa kanilang sariling mga pamantayan at pamamaraan.

Artikulo 353

Ang mamamayan ng Bolivia ay magkakaroon ng pantay na pakinabang sa mga benepisyo na nagmula sa paggamit ng lahat ng likas na yaman. Ang may priyoridad na paglahok ay itatalaga sa mga teritoryo kung saan matatagpuan ang mga mapagkukunang ito, at sa mga nasyon at rural na katutubo.
Nagbibigay ng karapatan sa mga katutubo na tukuyin ang kanilang sariling mga priyoridad sa pag-unlad pati na rin ang mga estratehiya para sa paggamit ng kanilang mga lupain o iba pang mga mapagkukunan

Nagmamandato $n g$ patas at makatarungang pagwawasto para sa anumang mga aktibidad na magaganap

Nagmamandato sa gobyerno na tiyakin ang pakikilahokng mga katutubo sa 'pangangasiwa'ng likas na yaman

Kinikilala ang mga eksklusibong karapatan ng mga katutubo upang magamit ang likas na yaman sa kanilang lupain at nangangailangan $n g$ konsultasyon sa sariling mga institusyon bago ang pagsasamantala o iba pang mga aktibidad

Nangangako ng pagbabahaging pakinabang, na parehong tiyak sa mga katutubo, at sa lahat ng mga mamamayan sa Bolivia 


\section{Artikulo 403}

Kinikilala ang integridad ng teritoryo ng rural na katutubo sa probinsya, na kinabibilangan ng karapatang sa lupa, sa paggamit at eksklusibong pagsasamantala sa nababagong likas na yaman sa ilalim ng mga kondisyong tinukoy ng batas, sa nauna at may kaalamang konsultasyon, sa pakikilahok sa mga benepisyo $\mathrm{ng}$ pagsasamantala sa hindi nababagong likas na yaman na matatagpuan sa kanilang teritoryo, sa awtoridad na maglalapat ng kanilang sariling mga pamantayan, na pinangangasiwaan ng kanilang mga estruktura ng representasyon, at upang tukuyin ang kanilang pag-unlad alinsunod sa kanilang sariling pamantayan sa kultura at mga prinsipyo ng payapang pakipamuhayan sa kalikasan. Ang mga rural na katutubong teritoryo ng kanayunan ay maaaring binubuo ng mga komunidad.

\begin{tabular}{l|l}
$\begin{array}{l}\text { Konstitusyon } \\
\text { ng Brazil }\end{array}$ & Artikulo 231 \\
\hline 1988 & \\
\hline
\end{tabular}

(3) Ang paggamit ng mga mapagkukunan ng tubig, kabilang ang kanilang potensyal na enerhiya, at pag-asam at pagmimina ng yamang mineral sa mga katutubong lupain ay maaaring magawa lamang sa pahintulot ng Pambansang Kongreso, pagkatapos ng pagdinig mula sa mga pamayanan na kasangkot, na makasisiguro sa pakikilahok sa mga resulta ng pagmimina, na isinaad $\mathrm{ng}$ batas.

\section{Konstitusyon} ng Colombia 1991

\section{Artikulo 330 at Artikulo 330} 334

Alinsunod sa Konstitusyon at mga palatuntunan, ang mga katutubong teritoryo ay dapat pamahalaan ng mga konseho na nabuo at nireregula alinsunod sa gamit at kaugalian ng kanilang mga pamayanan at dapat gamitin ang mga sumusunod na tungkulin:

..

5. Subaybayan ang pangangalaga ng mga likas na mapagkukunan.

Ang pagsasamantala sa mga likas na yaman sa mga katutubong teritoryo ay dapat gawin nang hindi pinipinsala ang pangkultura, panlipunan, at pang-ekonomiyang integridad ng mga katutubong pamayanan. Sa mga desisyon na pinagtibay patungkol sa nasabing pagsasamantala, dapat hikayatin ng gobyerno ang pakikilahok ng mga kinatawan ng kani-kanilang mga pamayanan.

\section{Artikulo 334}

... Sa pamamagitan ng mandato ng isang Batas, mamamagitan ang estado sa pagsasamantala ng mga likas na yaman, paggamit ng lupa, produksyon, pamamahagi, paggamit, at pagkonsumo ng mga kalakal, at sa pampubliko at pribadong mga serbisyo upang bigyang-katwiran ang ekonomiya sa layuning makamit, sa antas pambansa at panrehiyon at sa loob ng balangkas ng pagpapanatili ng pananalapi, pagpapabuti ng kalidad ng buhay ng mga naninirahan, ang pantay na pamamahagi ng mga pagkakataon, at ang mga pakinabang $\mathrm{ng}$ kaunlaran at pag-iingat sa isang malusog na kapaligiran.

\begin{tabular}{l|l|l|}
$\begin{array}{l}\text { Konstitusyon } \\
\text { ng Kenya } \\
2010\end{array}$ & Artikulo 69(1a) & $\begin{array}{l}\text { (1) Ang Estado ay dapat- } \\
\text { (a) }\end{array}$ \\
& $\begin{array}{l}\text { tiyakin ang sustenableng pagsasamantala, } \\
\text { paggamit, pamamahala, at pag-iingat ng } \\
\text { kalikasan at likas na yaman, at tiyakin ang } \\
\text { pantay na pagbabahagi ng mga naipong } \\
\text { benepisyo. }\end{array}$ \\
\hline
\end{tabular}

Hinihingi na kumonsulta ang Pambansang Kongreso sa mga katutubo bago mag-isyu ng mga pag-apruba para sa paggamit ng mga mapagkukunan ng tubig o iba pang yamang mineral sa kanilang mga lupain

Binibigyan ng karapatan ang mga katutubo na pangasiwaan ang pangangalaga ng mga likas na yaman sa kanilang mga teritoryo

Nagdidirekta na ang anumang pagsasamantala ay dapat gawin nang hindi pinipinsala ang 'integridad' ng mga katutubong komunidad; ang pakikilahok ay 'hinihikayat' ngunit hindi kinakailangan

Binibigyan ang estado ng karapatang makialam sa paglinang sa mga likas na yaman

Pangkalahatang probisyon sa pagbabahagi ng pakinabang 


\section{Konstitusyon ng Mehiko}

1917
Artikulo 2(A) karapatan ng mga katutubo sa sariling pagpapasya at, dahil dito, ang karapatan sa awtonomiya, upang maaari nilang:

VI. Makamit naang may nais na paggamit ng mga likas na mapagkukunan ng mga lugar na pinaninirahan ng kanilang mga katutubong komunidad, maliban sa mga estratehikong mapagkukunan na tinukoy ng Konstitusyong ito. Ang mga nabanggit na karapatan ay dapat gamitin nang may respeto sa mga uri ng pagmamay-ari ng ari-arian at posesyon ng lupa na itinatag sa Konstitusyong ito at sa mga batas sa bagay na ito pati na rin ang paggalang sa mga karapatan ng mga pangatlong partido. Upang makamit ang mga layuning ito, ang mga katutubong komunidad ay maaaring bumuo ng pakikipagtulungan sa ilalim ng mga tuntuning itinatag ng Batas.

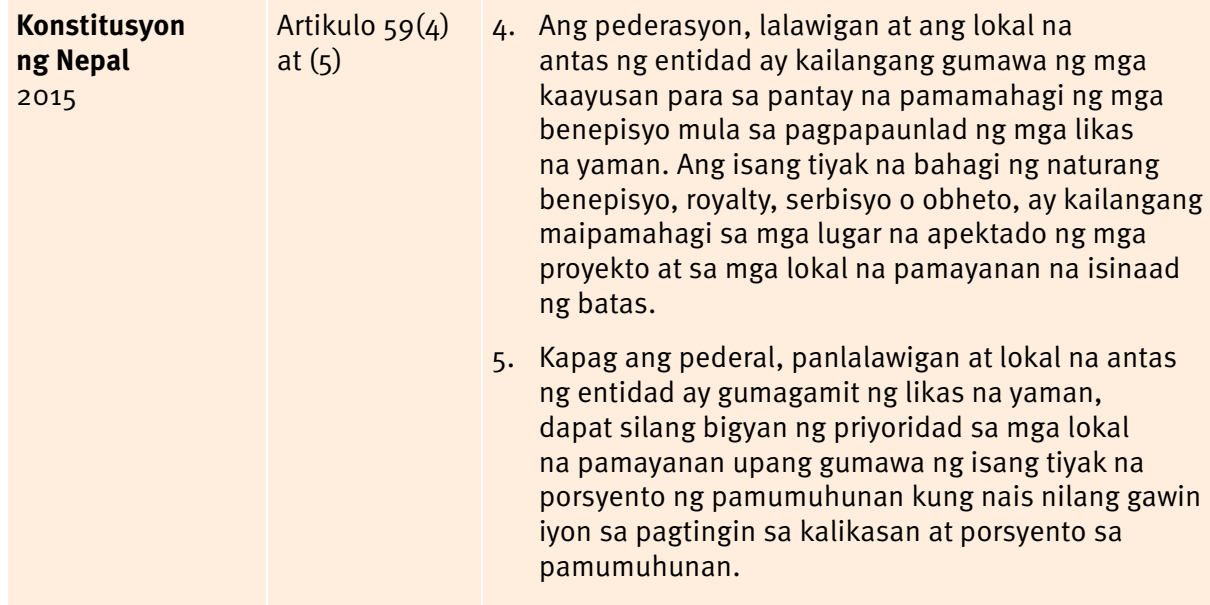

Konstitusyon ng Nicaragua 2014

$\begin{array}{ll}\begin{array}{l}\text { Ang Konstitusyon } \\ \text { ng Pilipinas }\end{array} & \begin{array}{l}\text { Artikulo X, } \\ \text { seksyon }\end{array} \\ 1987 & 20 \text { (Mga } \\ & \begin{array}{l}\text { Awtonomong } \\ \text { Rehiyon) }\end{array}\end{array}$

Ginagarantiyahan ng Estado ang mga pamayanang ito [ng Caribbean Coast] ng mga benepisyo ng kanilang likas na yaman, ang pagiging epektibo ng kanilang mga anyo ng pagmamay-aring komyunal, at ang libreng halalan ng kanilang mga awtoridad at kinatawan.

Sa loob ng nasasakupang hurisdiksyon nito at napapailalim sa mga probisyon ng Konstitusyon na ito at mga pambansang batas, ang organikong akto ng mga awtonomong rehiyon ay dapat magbigay $\mathrm{ng} \mathrm{mga}$ lehislatibong kapangyarihang sa:

$\cdots$

3. Lupang ninuno at mga likas na yaman.
Pinoprotektahan ang nais na paggamit ng mga katutubo sa likas na yaman, na malinaw na maiuugnay ito sa sariling pagpapasya at awtonomiya

Pinapayagan ang mga katutubo na kumilos bilang isang ligal na entidad sa pagbubuo ng mga pakikipagtulungan para sa paggamit ng likas na yaman

Tinitiyak ang pagbabahagi ng pakinabang para sa 'mga lokal na pamayanan' para sa paggamit ng likas na yaman at mga kaugnay na benepisyo sa pananalapi

Ginagarantiyahan ang $m g a$ katutubong/awtonomong komunidad sa Nicaragua ng karapatang makinabang mula sa kanilang likas na yaman.

Nagbibigay ng awtoridad sa mga awtonomong rehiyon sa lupang ninuno at paggamit ng likas na mapagkukunan

Tala: Hindi tiyak sa mga katutubo, bagama't ang Rehiyon ng Kordilyera (mayoryang katutubong lugar) ay isa sa mga awtonomong rehiyon na pinangalanan sa Konstitusyon kung saan nalalapat ang probisyong ito. 


\section{MGA NAPAG-ALAMAN}

Sagot sa tanong (Oo/Hiindi) at iba pang mga tala at obserbasyon tungkol sa kung gaano kahusay na tinutugunan $n g$ konstitusyon ang (mga) isyu na itinanong. Isama ang mga makabuluhang mga probisyon ((mga) numero $n g$ artikulo at teksto $n g$ (mga) probisyon). Tandaan din ang hindi konsistent at/o magkasalungat na mga probisyon, o kung walang umiiral na mga kaugnay na probisyon.

\section{MGA HAKBANG}

Iminungkahing adbokasiya at iba pang mga kasunod na hakbang upang matugunan o mapalaganap ang mga natuklasan. 


\section{Karapatan sa lupa, teritoryo at likas na yaman}

\section{Inaatasan ba ng konstitusyon ang gobyerno na kumunsulta nang may mabuting hangarin sa mga katutubo o humingi ng kanilang malaya, nauna at malinang na kapahintulutan (FPIC) bago ipatupad ang mga proyektong pangkaunlaran at iba pang mga patakaran na may epekto sa mga katutubong lupain, teritoryo, karapatan at yaman?}

PALIWANAG

Ang mga pamantayang pang-internasyunal ay inoobliga ang mga pamahalaan na kumuha ng malaya, nauna at malinang na kapahintulutan (FPIC) ng mga katutubo bago magpatupad ng mga batas, proyekto at patakaran kung saan ang kanilang mga karapatan at ang pangangalaga ng kanilang mga mapagkukunang pangkultura (kabilang ang mga lupain, teritoryo at mapagkukunan), lalo na ang nauugnay sa kanilang paraan ng pamumuhay at pag-angkop sa buhay bilang natatanging kultura at mga mamamayan, ay maaaring nasa peligro. Ang isang maipatutupad na pangako sa FPIC ay may pinakamataas na importansya sa pagtiyak sa proteksyon ng mga karapatan ng mga katutubo sa mga lupa at likas na yaman, pati na rin sa mas malawak na sariling pagpapasya at awtonomiya. Sa dumaraming paraan, ang mga estado ay pinipilit na magpatibay ng mga kasanayan na higit sa konsultasyon lamang. Halimbawa, ang African Commission on Human and Peoples' Rights na ginanap kaugnay sa teritoryo ng mga katutubo ng Endorois sa Kenya na para sa "anumang mga proyekto sa pag-unlad o pamumuhunan na magkakaroon ng malaking epekto sa loob ng teritoryo ng Endorois, ang Estado ay may tungkulin hindi lamang kumonsulta kasama ang pamayanan, ngunit upang makakuha ng kanilang malaya, nauna, at malinang na kapahintulutan, ayon sa kanilang mga kaugalian at tradisyon' (African Commission on Human and Peoples' Rights 2003: para. 291).

Ang unang sangkap, malaya, ay nagpapahiwatig na ang mga katutubo ay tunay na pinapayagan ang awtonomiya sa paggawa ng desisyon at sa pagbibigay ng kanilang pahintulot. Saklaw nito ang patas na mga pamamaraan ng pakikipagsosyo, marangal na diyalogo, at pagbabawal sa paggamit ng puwersa, pisikal man o panlipunan. Ibig sabihin ng nauna ay ang pahintulot ng mga katutubo ay dapat makuha mula sa pinakamaagang yugto ng pagkonsepto ng isang programa sa pag-unlad na may epekto sa kanilang mga lupain. Ang pahintulot ay tiyak na dapat makuha bago ang anumang pagpapatupad, at sa ideal na sitwasyon ay bago ang pag-apruba ng proyekto. Hinihiling ng pagiging malinang na, sa pagbibigay ng kanilang pahintulot, ang mga katutuboay may akses sa lahat ng nauugnay na impormasyon sa mga potensyal na benepisyo pati na rin ang mga potensyal na negatibong epekto. Ang pangangailangang ito ay nirerespeto ang karapatan ng mga pamayanang katutubo na tukuyin ang kanilang sariling mga priyoridad sa pag-unlad sa pamamagitan ng pagtiyak na bibigyan sila ng pagkakataong gumawa ng pinakamahusay na desisyon para sa kanilang pamayanan, ayon sa lahat ng mga pangyayari. Ang eksaktong haba ng oras at impormasyong ibinigay para sa proseso ay mag-iiba depende sa konteksto. Ang pangwakas na kompenent - pahintulot - ay nagmumungkahi na, sa kaso ng mga epekto sa lupa, mga teritoryo at likas na yaman, ang gobyerno ay dapat lumampas sa konsultasyon lamang upang bigyan ang mga katutubong komunidad ng huling pasya tungkol sa mga proyekto na nakaaapekto sa kanila at sa mga mapagkukunang ito. Ang malawak na karapatan sa konsultasyon, kasama ang karapatan sa FPIC, ay dapat mailapat sa mga plano, patakaran, batas, at lehistlasyon ng gobyerno na nakaaapekto sa mga katutubo, na may FPIC na nagbubuklod sa kaso ng epekto sa lupa o likas na yaman.

Ang FPIC bilang isang konsepto ay medyo bago sa ilalim ng internasyunal na batas, kayàt may kaunting mga konstitusyon na isinasama ito sa buong porma. Ang iba pang mga konstitusyon ay gumagamit ng wika ng FPIC, ngunit nabigo sa pagprotekta sa katutubong karapatang magpahintulot, sa halip na maglapat ng malaya, nauna, at malinang na mga kinakailangan sa mga proseso ng pagkonsulta, na pinagbabatayan ng isang hiwalay na karapatan sa konsultasyon sa mga bagay na nakaaapekto sa kanila (tingnan ang Kumbensyon ng ILO 169). Ang ilang mga interpretasyon ng internasyonal na mga karapatan ng mga katutubo ay nangangahulugan na kinakailangan ang konsultasyon para sa lahat ng mga batas at patakaran na nakaaapekto sa mga katutubo, samantalang kinakailangan ang FPIC kapag ang may kaugnay ito sa lupa, mga teritoryo at likas na yaman (tingnan ang Tanong 13 sa konsultasyon). Ang mga katutubong aktibista, sa kabilang banda, ay nagtataguyod ng isang mas malawak na pagunawa sa FPIC, na pinanghahawakang dapat itong mailapat sa lahat ng mga isyu at institusyong nakaaapekto sa mga katutubo at hindi limitado sa mga desisyon na nauugnay sa lupa at mapagkukunan. 


\begin{tabular}{|c|c|c|c|}
\hline $\begin{array}{l}\text { Kumbensyon } \\
\text { ng ILO } 169 \\
1989\end{array}$ & Artikulo 15 & $\begin{array}{l}\text { 2. Sa mga kaso kung saan pinapanatili ng Estado ang } \\
\text { pagmamay-ari ng mga mineral o sub-surface na } \\
\text { mapagkukunan o mga karapatan sa iba pang mga } \\
\text { mapagkukunan na nauugnay sa mga lupain, ang } \\
\text { mga gobyerno ay magtatatag o magpapanatili ng } \\
\text { mga pamamaraan kung saan sila ay kokonsulta sa } \\
\text { mga mamamayang ito, na may hangarin na alamin } \\
\text { kung at sa anong antas mapeprehuwisyo ang } \\
\text { kanilang mga interes, bago magsagawa o payagan } \\
\text { ang anumang mga programa para sa eksplorasyon } \\
\text { o pagsasamantala ng mga naturang mapagkukunan } \\
\text { na nauugnay sa kanilang mga lupain. Ang mga } \\
\text { mamamayang sangkot ay dapat na lumahok sa mga } \\
\text { benepisyo ng naturang mga aktibidad, at tatanggap } \\
\text { ng patas na kompensasyon para sa anumang } \\
\text { pinsala na maaari nilang natamo bilang isang resulta } \\
\text { ng naturang mga aktibidad. }\end{array}$ & $\begin{array}{l}\text { Bago ang UNDRIP, ang } \\
\text { pamantayan ay 'konsultasyon' } \\
\text { na itinakda ng Kumbensyon } \\
\text { ng ILO } 169 \text {. Itinulak ng UNDRIP } \\
\text { ang konseptong ito pasulong } \\
\text { sa pamamagitan ng paghingi } \\
\text { ng pahintulot sa kaso ng mga } \\
\text { aktibidad na may epekto sa lupa } \\
\text { at likas na yaman }\end{array}$ \\
\hline $\begin{array}{l}\text { UNDRIP } \\
2007\end{array}$ & Artikulo 32(2) & $\begin{array}{l}\text { 2. Ang mga Estado ay dapat kumonsulta at } \\
\text { makipagtulungan na may mabuting hangarin sa mga } \\
\text { katutubo na sangkot sa pamamagitan ng kanilang } \\
\text { sariling kinatawang mga institusyon upang makuha } \\
\text { ang kanilang malaya at malinang na kapahintulutan } \\
\text { bago ang pag-apruba ng anumang proyekto na } \\
\text { nakaaapekto sa kanilang mga lupain o teritoryo at } \\
\text { iba pang mapagkukunan, lalo na sa may kaugnayan }\end{array}$ & $\begin{array}{l}\text { Nangangailangan ng } \\
\text { konsultasyon sa mga katutubong } \\
\text { komunidad sa pamamagitan ng } \\
\text { kanilang sariling kinatawang } \\
\text { mga institusyon na may layuning } \\
\text { makakuha ng malaya, nauna at } \\
\text { malinang na kapahintulutan }\end{array}$ \\
\hline
\end{tabular}
iba pang mapagkukunan, lalo na sa may kaugnayan sa kaunlaran, paggamit o pagsasamantala ng mineral, tubig o iba pang mapagkukunan.

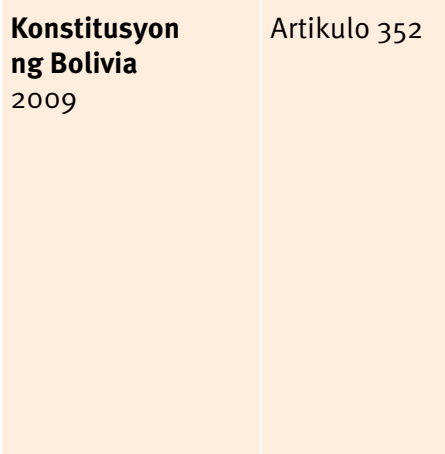

Konstitusyon ng Artikulo 120 Venezuela 1999
Artikulo 352

Ang paggamit ng mga likas na yaman sa isang tinukoy na teritoryo ay sasailalim sa isang proseso $\mathrm{ng}$ konsultasyon sa apektadong populasyon, na tinawag ng Estado, na malaya, nauna ang tiyempo at malinang. Ang pakikilahok ng mamamayan ay iginagarantiya sa proseso ng pamamahala ng kapaligiran, at ang pangangalaga ng mga ecosystem ay isusulong, alinsunod sa Konstitusyon at batas. Sa mga nasyon at rural na katutubo, isasagawa ang konsultasyon na may paggalang na ibinigay sa kanilang sariling mga pamantayan at pamamaraan.

Ang pagsasamantala ng Estado sa likas na yaman sa mga katutubong tirahan ay dapat isagawa nang hindi makakasama sa pangkultura, panlipunan at pang-ekonomiyang integridad ng naturang $\mathrm{mga}$ tirahan, at napapailalim din sa naunang impormasyon at konsultasyon sa mga kinauukulang katutubong pamayanan. Ang mga kita mula sa naturang pagsasamantala ng mga katutubo ay napapailalim sa Konstitusyon at batas.
Kailangang malaya, nauna at malinang na 'konsultasyon' at pakikilahok sa mga proseso ng pag-unlad

Ipinapahiwatig nito na ang mga konsultasyon sa mga katutubo ay dapat sundin ang kanilang sariling mga pamantayan at pamamaraan

Nangangailangan ng paunang impormasyon at konsultasyon sa mga pamayanang katutubo 


\begin{tabular}{|c|c|c|}
\hline $\begin{array}{l}\text { Canada, Batas } \\
\text { sa Kasunduan sa } \\
\text { Mga Pag-angkin } \\
\text { ng Lupa ng } \\
\text { Nunavut } \\
1993\end{array}$ & Preambulo & $\begin{array}{l}\text { Sapagkat ang Mahal na Reyna sa karapatan ng } \\
\text { Canada at ang Inuit ng Nunavut Settlement Area ay } \\
\text { nakipagnegosasyon sa isang Kasunduan batay sa at } \\
\text { sumasalamin sa mga sumusunod na layunin: } \\
\text { upang magbigay ng katiyakan at kalinawan ng mga } \\
\text { karapatan sa pagmamay-ari at paggamit ng mga } \\
\text { lupain at mapagkukunan at ng mga karapatan para } \\
\text { sa Inuit na lumahok sa paggawa ng desisyon tungkol } \\
\text { sa paggamit, pamamahala at pagpapahalaga sa } \\
\text { lupa, tubig at mga mapagkukunan, kabilang ang } \\
\text { dalampasigan, upang magbigay sa Inuit ng mga } \\
\text { karapatan sa pag-aani ng yamang-gubat at mga } \\
\text { karapatang lumahok sa paggawa ng desisyon hinggil } \\
\text { sa pag-aani ng yamang-gubat, upang mabigyan ang } \\
\text { Inuit ng kompensasyong pinansyal at paraan ng } \\
\text { paglahok sa mga oportunidad sa ekonomiya, upang } \\
\text { hikayatin ang pag-asa sa sarili at ang pangkulturang } \\
\text { at panlipunang kapakanan ng Inuit. }\end{array}$ \\
\hline
\end{tabular}

Ginagarantiya ang pakikilahok ng Inuit sa paggawa ng desisyon hinggil sa paggamit, pamamahala at pagpapahalaga sa lahat ng mga mapagkukunan sa teritoryo kung saan sila ay mayroong titulong pangkatutubo. Partikular:

- pantayna representasyon sa gobyerno sa bagong pamamahala ng yamanggubat, pamamahala ng mapagkukunan at mga environmental board;

- titulo sa humigit-kumulang na 350,000 km2 ng lupa, kung saan, 35,257 km2 ay may kasamang mga karapatan sa mineral;

- ang karapatang mag-aning yamang-gubat sa mga lupa at tubig sa buong Nunavut;

- isang bahaging mga pederal na pampamahalaang royalty mula sa pag-unlad ng langis, gas at mineral sa mga lupain ng kaharian;

- karapatang makipagnegosasyon sa industriya para sa mga benepisyong pang-ekonomiya at panlipunan mula sa pagpapaunlad ng mga hindi nababagong mapagkukunan sa mga lupang pag-aari ng Inuit;

- ang paglikha ng tatlong pederal na pinondohang pambansang mga parke;

- kabayaran sa paglipatng kapital na CAD 1.9 bilyon sa loob ng 15 taon at isang CAD 13 milyong Training Trust Fund para sa pagtatatag ng Pamahalaang Nunavut.

Ang Pilipinas,

\section{Batas sa}

Karapatan ng Mga Katutubo 1997
Seksyon 3(g)

Malaya at Naunang Malinang na Kapahintulutan - tulad ng ginamit sa Batas na ito ay nangangahulugang ang pagsang-ayon ng lahat ng mga kasapi ng mga ICC/ IP [mga katutubong pamayanang pangkultura/mga katutubo] na matutukoy alinsunod sa kani-kanilang mga nakaugaliang batas at kasanayan, na malaya sa anumang panlabas na pagmamanipula, pagkagambala at pamimilit, at nakuha matapos na buong ilahad ang hangarin at saklaw ng aktibidad, sa isang wika at proseso na naiintindihan ng pamayanan.

\section{Tinutukoy ang FPIC sa} pangdepinisyong seksyon ng batas at pagkatapos ay nilalapat sa ilang mga pangyayari at artikulo, pinakamakabuluhan iyong mga pagharap sa mga karapatan sa lupa at intelektuwal na pag-aari 


\section{MGA NAPAG-ALAMAN}

Sagot sa tanong (Oo/Hiindi) at iba pang mga tala at obserbasyon tungkol sa kung gaano kahusay na tinutugunan $n g$ konstitusyon ang (mga) isyu na itinanong. Isama ang mga makabuluhang mga probisyon ((mga) numero $n g$ artikulo at teksto $n g$ (mga) probisyon). Tandaan din ang hindi konsistent at/o magkasalungat na mga probisyon, o kung walang umiiral na mga kaugnay na probisyon.

\section{MGA HAKBANG}

Iminungkahing adbokasiya at iba pang mga kasunod na hakbang upang matugunan o mapalaganap ang mga natuklasan. 


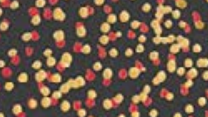
\% 


\section{Karapatan sa kultura, at panlipunan at pang-ekonomikong pag-unlad

\author{
Pinoprotektahan ba ng konstitusyon ang mga karapatan ng mga katutubo \\ na panatilihin at paunlarin ang kanilang mga kultura, pagkakakilanlan at \\ kasanayan sa kultura, at igalang sila?
}

PALIWANAG

Ang mga katutubo ay madalas na tiningnan at tinutukoy din bilang 'mga kultura', na nagpapatunay sa antas ng kahalagahan ng mga kasanayan sa kultura at mga produkto na nakukuha sa mga katutubong pamayanan. Malinaw na kinikilala at iginagalang ng mga konstitusyon ang pagkakaroon ng mga katutubong kultura at isinasama ang mga probisyon na humihiling ng proteksyon at pagsulong ng mga kulturang ito (o pamana sa kultura) sa isang marangal na pamamaraan. Kapansin-pansin, ang karapatang ito ay nagpapatuloy sa sumunod na panahon, na nangangahulugang sumasaklaw ito ng isang karapatang kilalanin at igalang ang makasaysayang mga kasanayan at kaalaman, ngunit may karapatang isabuhay din ang mga kultural na kasanayan sa kasalukuyan at patuloy na gawin ito sa hinaharap, sa gayon ay sumasaklaw din ng isang karapatan upang maipasa ang kultura sa susunod na mga henerasyon.

Nailalapat ang karapatan sa katutubong kultura sa mga nakagawiang aktibidad, pamamahala ng mga lupang ninuno, teritoryo at likas na yaman, mga institusyon at kasanayan sa pamamahala, pamumuhay, sining, paniniwala at kasanayan sa relihiyon, at mga wika. Sa internasyunal na hurisprudensiya, ang mga aspekto ng kultura ay tinukoy nang malawakan upang mailapat sa isang malawak na hanay ng mga karapatan, kabilang ang mga kasanayan sa pamilya, wika, tradisyunal na mga gamot, at mga sistemang panghukuman. Sa ganitong paraan, ang karapatan sa kultura ay sumasaklaw sa kabuuan ng maraming mga isyung isinasaalang-alang sa Kasangkapan sa Pagtatasang ito, at malalim ding sinusuportahan ng karapatang sa sariling pagpapasya.

Ang karapatan sa kultura para sa mga katutubo ay partikular na mahalaga at binigyan ng espesyal na pagkilala at pagpapatibay sa internasyunal na batas. Kapansin-pansin, ang pagsasaalang-alang sa mga kasaysayan ng pangaagaw ng ari-arian, ang karapatan sa kultura ng mga katutubo ay pinalawig upang maisama ang isang karapatang laban sa asimilasyon ng kultura o iba pang mga kasanayan at patakaran na mabisang ibinababa o sinisira ang mga katutubong kultura (tingnan ang UNDRIP artikulo 8 sa talahanayan sa ibaba).

Ang isang karapatan sa kultura ay maaari ring hikayatin ang mga korte na isaalang-alang ang mga pangkulturang kasanayan habang isinasaalang-alang ang mga kaso ng mga pangkat etniko at mga katutubo. Halimbawa, ang UN Human Rights Committee ay nagpasya sa pagbibigay kahulugan sa 'karapatan sa pamilya' ng France (sa kaso ng Hopu and Bessert v. France) na ang terminong 'pamilya' ay dapat 'bigyan ng isang malawak na interpretasyon upang maisama ang lahat ng mga binubuo ng pamilya tulad ng naintindihan sa pinag-uusapang lipunan. Sinusundan nito na ang mga kultural na tradisyon y dapat isaalang-alang kapag tinutukoy ang terminong "pamilya" sa isang tiyak na sitwasyon' (United Nations 1997b: para. 10.3).

MGA PAMANTAYANG PANG-INTERNASYUNAL AT PAMBANSANG MGA HALIMBAWAS

\begin{tabular}{|c|c|c|c|}
\hline $\begin{array}{l}\text { Kumbensyon } \\
\text { ng ILO } 169 \\
1989\end{array}$ & Artikulo 2 & $\begin{array}{l}\text { 1. Ang mga pamahalaan ay may pananagutan para sa } \\
\text { pagbuo, na may paglahok ng mga mamamayang } \\
\text { kinauukulan, ng ikinoordina at sistematikong } \\
\text { pagkilos upang protektahan ang mga karapatan ng } \\
\text { mga mamamayang ito at upang magarantiya ang } \\
\text { paggalang sa kanilang integridad. } \\
\text { 2. Ang nasabing hakbang ay dapat magsama ng mga } \\
\text { hakbang para sa: } \\
\text {... } \\
\text { (b) pagtataguyod ng buong pagsasakatuparan } \\
\text { ng mga panlipunan, pang-ekonomiko at } \\
\text { pangkulturang mga karapatan ng mga } \\
\text { mamamayang ito na may paggalang sa } \\
\text { kanilang panlipunan at kultural na identidad, } \\
\text { kanilang kaugalian at tradisyon at kanilang mga } \\
\text { institusyon. }\end{array}$ & $\begin{array}{l}\text { Ang responsibilidad ng gobyerno } \\
\text { ay maglagay ng mga espesyal } \\
\text { na hakbang upang maisulong } \\
\text { ang pagsasakatuparan ng mga } \\
\text { pang-ekonomiko, panlipunan at } \\
\text { pangkulturang mga karapatan } \\
\text { ng mga katutubo kasama na } \\
\text { ang paggalang sa kultural na } \\
\text { identidad }\end{array}$ \\
\hline
\end{tabular}


1. Ang mga katutubo at mga indibidwal ay may karapatang hindi mapailalim sa sapilitang asimilasyon o pagsira sa kanilang kultura.

2. Ang mga estado ay dapat magbigay ng mabisang mekanismo para sa pag-iwas sa, at pagwawasto para sa:

(a) Anumang aksyon na may layunin o epekto ng pagkakait sa kanila ng kanilang integridad bilang natatanging mamamayan, o ng kanilang mga kultural na halagahan o pagkakakilanlang etniko;

...

(d) Anumang anyo ng sapilitang asimilasyon o integrasyon;

(e) Anumang uri ng propaganda na idinisenyo upang itaguyod o hikayatin ang diskriminasyon ng lahi o etniko na ididirekta laban sa kanila.

Artikulo 11

1. Ang mga katutubo ay may karapatang magsagawa at buhayin ang kanilang mga kultural na tradisyon at kaugalian. Kasama rito ang karapatang panatilihin, protektahan at paunlarin ang nakaraan, kasalukuyan, at hinaharap na manipestasyon ng kanilang mga kultura, tulad ng mga arkeolohikal at makasaysayang mga lugar, artipakto, disenyo, seremonya, teknolohiya, at biswal at itinatanghal na sining at panitikan.

2. Ang mga Estado ay dapat maglaan ng pagwawasto sa pamamagitan ng mga mabisang mekanismo, na maaaring magsama ng restitusyon, na binuo kasabay ng mga katutubo, na may kinalaman sa kanilang kultural, intelektwal, relihiyoso, at pang-espiritwal na pag-aari na kinuha nang walang malaya, nauna, at malinang na kapahintulutan o lumalabag sa kanilang mga batas, tradisyon, at kaugalian.

Artikulo 12

1. Ang mga katutubo ay may karapatang magpakita, magsagawa, magpaunlad at magturo ng kanilang mga espiritwal at relihiyosong tradisyon, kaugalian at seremonya; ang karapatang magpanatili, protektahan, at pribadong makagamit ng kanilang mga relihiyoso at kultural na pook; ang karapatan sa paggamit at kontrol ng kanilang mga seremonyal na bagay; at ang karapatan sa pagpapauwi ng kanilang mga labi ng tao.

2. Hangad ng mga Estado na paganahin ang akseso at/o pagpapabalik ng mga seremonyal na bagay at mga labi ng tao na posesyon nila sa pamamagitan ng patas, malinaw, at mabisang mekanismo na binuo kasabay ng mga kinauukulang katutubo.

Artikulo 13

1. Ang mga katutubo ay may karapatang buhayin, gamitin, paunlarin at ipadala sa mga susunod na henerasyon ang kanilang mga kasaysayan, wika, oral na tradisyon, pilosopiya, sistema ng pagsulat at panitikan, at italaga at panatilihin ang kanilang sariling mga pangalan para sa mga pamayanan, lugar at tao.

2. Magsasagawa ang mga Estado ng mabisang hakbang upang matiyak na ang karapatang ito ay protektado at upang matiyak din na ang mga katutubo ay nakauunawa at maunawaan sa pampulitika, ligal at administratibong paglilitis, kung saan kinakailangan sa pamamagitan $\mathrm{ng}$ pagkakaloob ng interpretasyon o ng iba pang naaangkop na pamamaraan.
Kinikilala na ang mga katutubo ay may karapatang hindi maranasan ang pagkasira ng kanilang kultura at sapilitang asimilasyon

Ipinagbabawal ang nanghahamak na propaganda

Pinoprotektahan ang mga karapatan ng mga katutubo na magsagawa ng mga tradisyon at maipasa ito sa mga susunod na henerasyon
Nagbibigay ng positibong obligasyon sa estado upang matiyak na maisasakatuparan ang mga karapatan at protektado ang mga kultura 


\begin{tabular}{|l|l|}
\hline $\begin{array}{l}\text { Konstitusyon } \\
\text { ng Kenya } \\
2010\end{array}$ & Artikulo 11 \\
\hline & \\
\hline Konstitusyon & Artikulo $51(j)(8)$ \\
\hline 2015 Nepal & \\
\hline
\end{tabular}

1) Kinikilala ng Konstitusyong ito ang kultura bilang pundasyon ng nasyon at bilang pinagsama-samang sibilisasyon ng mga mamamayan at bansang Kenya.

(2) Ang Estado ay dapat-

(a) itaguyod ang lahat ng porma ng pambansa at kultural na pagpapahayag sa pamamagitan $\mathrm{ng}$ panitikan, sining, tradisyonal na pagdiriwang, agham, komunikasyon, impormasyon, mass media, publikasyon, aklatan, at iba pang kultural na pamana;

(b) kilalanin ang papel na ginagampanan ng agham at mga katutubong teknolohiya sa pagpapaunlad ng bansa; at

(c) itaguyod ang mga karapatan sa intelektwal na pag-aari ng mga mamamayan ng Kenya.

(3) Ang parlamento ay dapat magpatupad ng batas sa-

(a) tiyakin na ang mga pamayanan ay makatatanggap ng kompensasyon o royalties para sa paggamit ng kanilang mga kultura at kultural na pamana; at

(b) kilalanin at protektahan ang pagmamay-ari ng mga katutubong binhi at iba't ibang halaman, kanilang genetiko at dibersibong katangian at gamit sa mga pamayanan ng Kenya.

(8) Ang paggawa ng mga espesyal na kaayusan upang matiyak ang mga karapatan ng Adivasi Janajatis (mga katutubong pangkat etniko) na humantong sa isang marangal na buhay sa kani-kanilang mga pagkakakilanlan, at gawin silang kalahok sa mga proseso ng paggawa ng desisyon na nauukol sa kanila, at mapangalagaan at mapanatili ang tradisyunal na kaalaman, kasanayan, karanasan, kultura, at mga kaugaliang panlipunan ng Adivasi Janajatis at mga lokal na pamayanan.

\begin{tabular}{l|l|}
$\begin{array}{l}\text { Konstitusyon } \\
\text { ng Norway } \\
1814\end{array}$ & Artikulo 108 \\
\hline $\begin{array}{l}\text { Konstitusyon } \\
\text { ng Peru } \\
1993\end{array}$ & $\begin{array}{l}\text { Mga artikulo } \\
\text { 2(19) at } 89\end{array}$ \\
\hline
\end{tabular}

Ang mga awtoridad ng estado ay lilikha ng mga kondisyon na nagbibigay-daan sa mga mamamayang Sami na mapanatili at mapaunlad ang kanilang wika, kultura at pamumuhay.

Artikulo 2

Ang bawat tao ay may karapatan:

...

19. Sa kanyang etniko at kultural na pagkakakilanlan. Kinikilala at pinoprotektahan ng Estado ang etniko at kultural na dibersidad ng Nasyon.

Artikulo 89

Ang mga rural at katutubong pamayanan ay may ligal na pag-iral at mga korporadong entidad.

... Iginagalang ng Estado ang kultural na pagkakakilanlan ng mga rural at katutubong pamayanan.

\begin{tabular}{l|l}
$\begin{array}{l}\text { Konstitusyon } \\
\text { ng Sweden } \\
1974\end{array}$ & Artikulo 2 \\
\hline
\end{tabular}

Ang mga oportunidad ng mga mamamayan ng Sami at etniko, linggwistiko at relihiyosong mga minorya upang mapreserba at mapaunlad ang sarili nilang kultural at panlipunang buhay ay itataguyod.
Kinikilala ang kahalagahan ng kultura at inoobligado ang estado na itaguyod at protektahan ang pagpapahayag ng kultura at kaalaman ng katutubo kabilang ang pagmandato sa parlamento na ipasa ang mga batas upang maprotektahan ang mga karapatan sa intelektwal na pagaaring mga katutubo sa kanilang kaalaman at teknolohiya

Inoobliga ang estado na gumawa ng mga espesyal na kaayusan upang matiyak na ang mga katutubo ay maaaring mabuhay na may paggalang sa kanilang pagkakakilanlan

Inoobliga ang estado upang lumikha ng mga kondisyon na nagbibigay-kakayahan para sa pagpapanatiling kultura ng Sami

Kinikilala ang karapatan ng mga katutubo sa kultural na pagkakakilanlan at inoobligado ang estado na kilalanin at protektahan ang dibersidad ng kultura ng nasyon

Itinataguyod ang karapatan ng mga mamamayan ng Sami paunlarin ang sarili nilang kulturanl at panlipunang buhay 
Konstitusyon ng Thailand

Seksyon 70

2017

Konstitusyon

Artikulo 121

1999

Artikulo 33

Konstitusyon

2013
Dapat itaguyod at magbigay ng proteksyon ang Estado para sa iba`t ibang mga pangkat etniko upang magkaroon ng karapatang mabuhay sa lipunan ayon sa tradisyunal na kultura, kaugalian, at mga paraan ng pamumuhay nang kusang-loob, payapa at walang pagkagambala, basta't hindi ito salungat sa pampublikong kaayusan o mabuting moral o hindi ipinapanganib ang seguridad, kalusugan o kalinisan.

Ang mga katutubo ay may karapatang panatilihin at paunlarin ang kanilang etniko at kultural na entidad, pagtingin sa mundo, mga halagahan, espiritwalidad at mga banal na lugar at lugar ng kulto. Itataguyod ng Estado ang pagpapahalaga at pagpapalaganap ng mga kultural na manipestasyon ng mga katutubon.

Ang Estado ay dapat gumawa ng mga hakbang upang mapanatili, protektahan at itaguyod ang mga katutubong sistema ng kaalaman, kabilang ang kaalaman sa medisina at iba pang mga katangian ng buhay ng hayop at halaman na taglay ng mga lokal na pamayanan at mamamayan.
Ipinapanagot ang estado para sa pagtataguyod at pagprotekta ng mga kultura ng iba't ibang mga pangkat etniko

Pinoprotektahan ang karapatang magpanatili at magpaunlad ng kultura

Naglalagay ng positibong obligasyon sa estado upang itaguyod ang pagpapahalaga sa katutubong kultura

Naglalagay ng positibong obligasyon sa estado na gumawa ng mga hakbang upang mapangalagaan, maprotektahan at maitaguyod ang katutubong kaalaman, kasama na ang kaalaman sa mga medisinal na katangian ng mga likas na yaman tulad ng mga halaman 


\section{MGA NAPAG-ALAMAN}

Sagot sa tanong (Oo/Hiindi) at iba pang mga tala at obserbasyon tungkol sa kung gaano kahusay na tinutugunan $n g$ konstitusyon ang (mga) isyu na itinanong. Isama ang mga makabuluhang mga probisyon ((mga) numero $n g$ artikulo at teksto $n g$ (mga) probisyon). Tandaan din ang hindi konsistent at/o magkasalungat na mga probisyon, o kung walang umiiral na mga kaugnay na probisyon.

\section{MGA HAKBANG}

Iminungkahing adbokasiya at iba pang mga kasunod na hakbang upang matugunan o mapalaganap ang mga natuklasan. 


\title{
Karapatan sa kultura, at panlipunan at pang-ekonomikong pag-unlad
}

\author{
Kinikilala ba ng konstitusyon ang mga katutubong wika at ang \\ mga kaugnay na karapatan sa wika?
}

\section{PALIWANAG}

Ang mga tradisyon, relihiyon, at kultura ng mga katutubo ay nakabatay sa wika. Ang wika ay nakatanim sa pagkakakilanlan ng mga katutubo, at madalas din ang paraan para mapalakas ang pagkakakilanlangiyon sa pamamagitan ng mga oral na kasaysayan, mga awit, at iba pang pamamahala at mga relihiyosong kaugalian. Sa kabila ng kanilang sentralidad sa mga katutubong kultura, ang mga katutubong wika ay madalas na sinasalita ng mga maliliit na populasyon at marami ang nasa peligro ng pagkapuksa. Ang mga katutubo ay madalas na hindi binibigyan ng puwang upang magamit ang kanilang mga wika sa mga proseso ng gobyerno, at kung hindi sila nagsasalita ng pambansang lingua franca ay madalas silang nahaharap sa mga desbentaha sa paggamit sa mga serbisyo, halimbawa, at pati na rin sa paglahok sa pangunahing ekonomiya. Ayon sa mga pamantayang pang-internasyunal, ang mga estado ay dapat gumawa ng mga aktibong hakbang upang maprotektahan ang mga katutubong wika, at mga nauugnay na karapatan na gumamit ng mga wika o makakuha ng interpretasyon, bilang bahagi ng mga karapatan ng mga katutubo.

Ang pagbibigay ng konstitusyonal na pagkilala sa mga katutubong wika ay dapat na bahagi ng mga hakbang na iyon. Ang pagkilala sa kalikasang multilingguwal ng estado ay malayo ang maiaambag sa pagsimbolo ng pagkilala ng isang estado sa dibersidad at pag-iral ng mga katutubo. Bilang karagdagan, ang pagkilala sa pantay na halaga ng mga wika ay maaaring maging isang paraan ng pagpapakita ng paggalang sa mga katutubong kultura at dignidad ng mga katutubo. Halimbawa, malinaw na sinabi ng Sami Act ng Noruwega: 'Ang Sami at Norwega ay mga wika na pantay ang halaga. Sila ay bibigyan ng pantay na katayuan' (Pamahalaan ng Norway 1987: seksyon 1(5)). Ang mga bansa ay maaari ring magtatag ng mga institusyon upang maprotektahan at itaguyod ang mga katutubong wika (mga pagsisikap na dapat palaging makisali sa kanilang mga katutubong komunidad at igalang ang karapatan ng mga pamayanang ito na pamahalaan ang pag-aaral, paggamit, at representasyon ng kanilang sariling mga wika). Sa New Zealand, ang Batas sa Wikang Maori ay nagtatatag ng Komisyon ng Wikang Maori.

Upang matiyak na makakamit ng mga katutubo ang iba pang mga karapatan, tulad ng edukasyon, pag-akses sa hustisya at pakikilahok sa politika, mas malawak na mga karapatan sa wika na nagpapahintulot sa mga katutubo na gamitin ang kanilang wika sa mga institusyon at proseso ng estado o, halimbawa, upang makatanggap ng pagsasalin/interpretasyon ang mga serbisyo sa korte at iba pang mga institusyon ng estado, ay napakahalaga. Kritikal na protektahan hindi lamang ang mga wika mismo, kundi ang karapatan ding gamitin ang wika at upang hindi madiskrimina nang dahil lang sa pagsasalita ng mga katutubong wika. 


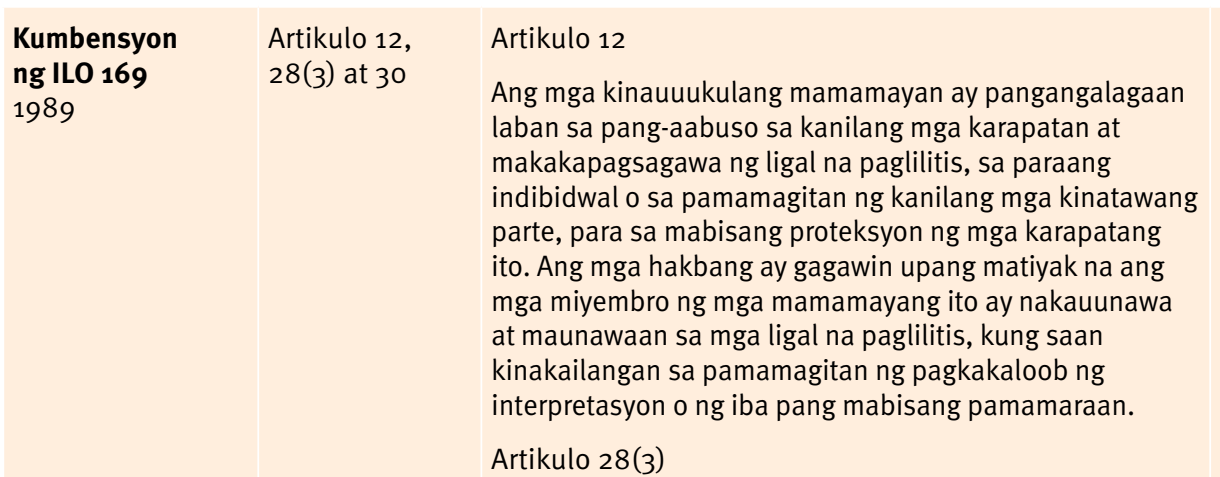

UNDRIP

2007

\begin{tabular}{l|l} 
Konstitusyon & Artikulo 5 \\
ng Bolivia \\
2009
\end{tabular}

3. Gagawin ang mga hakbang upang mapanatili at maitaguyod ang pag-unlad at pagsasanay ng mga katutubong wika ng mga kinauukulang tao.

Artikulo 30

1. Ang mga pamahalaan ay dapat gumamit ng mga hakbang na naaangkop sa mga tradisyon at kultura ng mga taong kinauukulan, upang maipaalam sa kanila ang kanilang mga karapatan at tungkulin, lalo na tungkol sa paggawa, mga pang-ekonomikong oportunidad, mga usapin sa edukasyon at kalusugan, panlipunang kapakanan, at ang kanilang mga karapatan na nagmula sa Kumbensyon na ito.

2. Kung kinakailangan, magagawa ito sa pamamagitan ng nakasulat na mga pagsasalin at sa pamamagitan ng paggamit ng mga pangmasang komunikasyon sa mga wika ng mga mamamayang ito.

Idinedetalye ang karapatan sa interpretasyon sa mga korte

Naglalagay ng positibong obligasyon sa mga estado na gumawa ng mga hakbang upang mapanatili at maitaguyod ang paggamit ng katutubong wika

Nananawagan para sa mga estado na matiyak na mauunawaan ang mga karapatan sa pamamagitan ng 'pangmasang komunikasyon'sa mga katutubong wika

Karapatan na muling buhayin, gamitin, bumuo at magpadala ng mga wika, kabilang ang Ang mga katutubo ay may karapatang buhayin,
gamitin, paunlarin at ipadala sa mga susunod na henerasyon ang kanilang mga kasaysayan, wika, oral na tradisyon, pilosopiya, sistema ng pagsulat at tradisyunal na mga pangalan panitikan, at magtalaga at panatilihin ang kanilang para samgalugar sariling mga pangalan para sa mga pamayanan, lugar, at tao.

2. Magsasagawa ang mga Estado ng mabisang hakbang upang matiyak na ang karapatang ito ay protektado at upang matiyak din na ang mga katutubo ay nakauunawa at mauunawaan sa pampulitika, ligal at administratibong paglilitis, na kung saan kinakailangan sa pamamagitan ng pagkakaloob ng interpretasyon o ng iba pang naaangkop na pamamaraan.

I. Ang mga opisyal na wika ng Estado ay Espanyol at lahat ng mga wika ng mga rural na katutubong nasyon at mga mamamayan, ay ang Aymara, Araona, Baure, Bésiro, Canichana, Cavineño, Cayubaba, Chácobo, Chimán, Ese Ejja, Guaraní, Guarasu'we, Guarayu, Itonama, Leco, Machajuyaikallawaya, Machineri, Maropa, Mojeñotrinitario, Mojeño-ignaciano, Moré, Mosetén, Movima, Pacawara, Puquina, Quechua, Sirionó, Tacana, Tapiete, Toromona, Uruchipaya, Weenhayek, Yaminawa, Yuki, Yuracaré and Zamuco.

II. Ang Pamahalaang Pluri-Nasyonal at ang mga gobyerno ng departamento ay dapat gumamit ng hindi bababa sa dalawang opisyal na wika. Ang isa sa kanila ay dapat na Espanyol, at ang isa pa ay idedetermina na isinasaalang-alang ang paggamit, kaginhawaan, mga sirkunstansya, mga kinakailangan, at kagustuhan ng populasyon bilang isang buo o ng teritoryong pinag-uusapan. Ang iba pang mga awtonomong pamahalaan ay dapat gumamit ng wilang kinakatangianan ng kanilang teritoryo, at ang isa sa kanila ay dapat na Espanyol.

\section{Naglalagay ng positibong} obligasyon sa mga estado upang matiyak na ang mga katutubo ay nakakaunawa at mauunawaan sa pamamagitan ng interpretasyon o iba pang mga paraan

Kinikilala ang maraming mga opisyal na wika ng estado

Nagmamandato na ang mga proseso ay dapat na iakma at patakbuhin sa mga lokal na wika depende sa paggamit ng lokal na populasyon lahat ng pulitikal na proseso, sa 


\begin{tabular}{|c|c|c|}
\hline $\begin{array}{l}\text { Konstitusyon } \\
\text { ng Colombia } \\
1991\end{array}$ & Artikulo 10 & $\begin{array}{l}\text { Espanyol ang opisyal na wika ng Colombia. Ang mga } \\
\text { wika at diyalekto ng mga pangkat etniko ay opisyal din } \\
\text { sa kanilang mga teritoryo. }\end{array}$ \\
\hline
\end{tabular}

\begin{tabular}{l|l|}
$\begin{array}{l}\text { Konstitusyon } \\
\text { ng Costa Rica } \\
2011\end{array}$ & Artikulo 76 \\
\hline $\begin{array}{l}\text { Konstitusyon } \\
\text { ng Finland } \\
1999\end{array}$ & Artikulo 17 \\
\hline
\end{tabular}

\begin{tabular}{l|l}
$\begin{array}{l}\text { Konstitusyon } \\
\text { ng Kenya }\end{array}$ & Artikulo 7 \\
2010 &
\end{tabular}

Konstitusyon Artikulo 19 ng Peru

1993

\begin{tabular}{l|l} 
Konstitusyon ng & Seksyon 6(1) at \\
Timog Aprika & $6(2)$ \\
1996 &
\end{tabular}

Espanyol ang opisyal na wika ng Nasyon. Gayunpaman, pamamahalaan ng Estado ang pagpapanatili at paglilinang ng pambansang mga katutubong wika.

Ang mga pambansang wika ng Finland ay Finnish at Swedish.

Ang Sami, bilang isang katutubo, pati na rin ang mga Roma at iba pang mga pangkat, ay may karapatang panatilihin at paunlarin ang kanilang sariling wika at kultura. Ang mga probisyon sa karapatan ng Sami na gamitin ang wikang Sami sa harap ng mga awtoridad ay inilatag sa isang Batas.

7. Pambansa, opisyal, at iba pang mga wika

(1) Ang pambansang wika ng Republika ay Kiswahili.

(2) Ang mga opisyal na wika ng Republika ay Kiswahili at Ingles.

(3) Ang Estado ay dapat-

(a) itaguyod at protektahan ang dibersidad ng wika ng mga mamamayan ng Kenya; at

(b) itaguyod ang pagbuo at paggamit ng mga katutubong wika, Kenyan Sign language, Braille at iba pang mga format ng komunikasyon at teknolohiya na nagagamit ng mga taong may kapansanan.

Ang bawat Peruvian ay may karapatang gumamit ng kanyang sariling wika sa harap ng anumang awtoridad sa pamamagitan $\mathrm{ng}$ isang interpreter.

6. Mga Wika

1. Ang mga opisyal na wika ng Republika ay ang Sepedi, Sesotho, Setswana, siSwati, Tshivenda, Xitsonga, Afrikaans, English, isiNdebele, isiXhosa, at isiZulu.

2. Kinikilala ang makasaysayang pagkupas ng paggamit at katayuan ng mga katutubong wika ng ating mga mamamayan, ang estado ay dapat gumawa ng praktikal at positibong hakbang upang maiangat ang katayuan at isulong ang paggamit ng mga wikang ito.
Kinikilala ang isang opisyal na wika ng estado, ngunit iniba ang naisalokal na mga opisyal na wika sa iba't ibang mga katutubong teritoryo

Nakatuon sa pagpapanatili at paglilinang ng mga katutubong wika

Isang opisyal na wika ng estado ngunit ang karapatang gumamit ng mga wika at kultura nang lokal, at para magamit ng Sami ang kanilang wika sa harap ng mga awtoridad ng estado

Naglalagay ng positibong obligasyon sa estado upang itaguyod at protektahan ang magkakaibang mga wika

Isinasaad ang karapatang gumamit ng sariling wika kapag nakikipag-ugnay sa estado, kasama ang karapatan sa interpretasyon

Kinikilala ang kalikasang multilinggwal ng estado

Naglalagay ng positibong obligasyon sa gobyerno na magpatupad ng mga positibong hakbang upang maisulong ang mga katutubong wika 
Finland, Batas sa Seksyon 1 at 4 Wika ng Sámi 2003
Seksyon 1

Ang layunin ng Batas na ito ay upang matiyak, para sa bahagi nito, ang konstitusyonal na karapatan ng Sámi na mapanatili at mapaunlad ang kanilang sariling wika at kultura.

Ang Batas na ito ay naglalaman ng mga probisyon sa karapatan ng Sámi na gumamit ng kanilang sariling wika sa harap ng mga korte at iba pang mga awtoridad sa publiko, pati na rin sa tungkulin ng mga awtoridad na ipatupad at itaguyod ang mga karapatang pangwika ng Sámi.

Ang layunin ay tiyakin ang karapatan ng Sámi sa isang patas na paglilitis at mabuting pangangasiwa anuman ang wika at upang masiguro ang mga karapatang pangwika ng Sámi nang hindi nila kinakailangang partikular na sumangguni sa mga karapatang ito.

Seksyon 4

Ang isang Sámi ay may karapatang gamitin ang wikang Sámi, sa kanyang sariling usapin o sa isang usapin kung saan siya ay dinidinig, sa harap ang anumang awtoridad na tinukoy sa Batas na ito. Ang isang awtoridad ay hindi dapat paghigpitan o tanggihan na ipatupad ang mga karapatang pangwika na ibinigay sa Batas na ito sa kadahilanang alam din ng Sámi ang ilang ibang wika, tulad ng Finnish o Sweden.
Ang buong batas ay nakatuon sa pangangalaga at promosyon ng wikang Sami at pagprotekta sa paggamit ng wikang Sami sa mga pampublikong proseso 


\section{MGA NAPAG-ALAMAN}

Sagot sa tanong (Oo/Hiindi) at iba pang mga tala at obserbasyon tungkol sa kung gaano kahusay na tinutugunan $n g$ konstitusyon ang (mga) isyu na itinanong. Isama ang mga makabuluhang mga probisyon ((mga) numero $n g$ artikulo at teksto $n g$ (mga) probisyon). Tandaan din ang hindi konsistent at/o magkasalungat na mga probisyon, o kung walang umiiral na mga kaugnay na probisyon.

\section{MGA HAKBANG}

Iminungkahing adbokasiya at iba pang mga kasunod na hakbang upang matugunan o mapalaganap ang mga natuklasan. 


\section{Karapatan sa kultura, at panlipunan at pang-ekonomikong pag-unlad katutubo sa sariling wika at angkop-sa-kulturang edukasyon?}

\section{PALIWANAG}

Ang mga katutubo ay madalas na nahuhuli sa ibang mga bahagi ng populasyon sa mga estado na kanilang tinitirahan, partikular na tungkol sa kalusugan at edukasyon na mga tagapagpahiwatig ng pag-unlad ng tao. Sa buong mundo, ang mga tantos ng literasiya ay mas mababa sa mga katutubong komunidad kung ihahambing sa mas malaking mga pambansang populasyon, at limitado ang mga oportunidad sa edukasyon (Hanemann 2005: 5). Ang mga katutubo ay madalas na dehado sa mga institusyong pang-edukasyon dahil ang tagubilin ay ibinibigay kung hindi man sa isang pamamaraan (pedagohiya) ay sa isang wikang hindi nila maintindihan. Dahil sentralisado, ang binuo ng pamahalaan na mga kurikulum ay madalas na nabibigong isaalang-alang ang mga pangangailangan sa pag-aaral ng mga katutubong komunidad o salaminin ang kanilang kaalaman at mga kasaysayan. Dahil dito, alinsunod sa UNDRIP, ang mga katutubo ay may karapatang magtaguyod ng kanilang sariling mga institusyong pang-edukasyon, at/o ma-akses ang edukasyon na naaayon sa kanilang mga tradisyon sa pag-aaral at kasanayan, pati na rin ang pagbibigay nito sa isang wikang naiintindihan nila.

Ang edukasyon ay dapat na garantisado para sa lahat ng mga mamamayan, ngunit—sa kaso ng mga katutuboang mga serbisyong pang-edukasyon ay dapat ibigay upang isaalang-alang ang mga aspektong kultural ng mga buhay na realidad at kasanayan ng mga katutubo, pinakamahalaga na rito ang wika. Mayroong katibayan na ang mga mamamayan ay mas natututo nang higit sa kanilang unang wika, at sa katunayan ang mga katutubo ay may karapatan sa edukasyon sa unang wika sa pangunahing paaralan, kahit papaano, sa ilalim ng batas internasyunal (Benson 2004). Samakatwid, ang edukasyon sa mga katutubong wika ay hindi dapat palitan ang edukasyon sa pambansa/opisyal na mga wika, na maaaring iwanang dehado ang mga katutubo sa pag-akses sa mga pangedukasyon at pang-ekonomoking oportunidad sa hinaharap. Mahalaga na ang mga katutubo ay mabigyan ng pagkakataon na matuto sa mga pambansang wika at/o mga internasyunal na wika (tulad ng Ingles) upang maitaguyod ang kanilang pakikilahok sa mas mataas na antas na edukasyon at kanilang kakayahang makakuha ng trabaho sa isang lalong nagiging pandaigdigang merkado.

MGA PAMANTAYANG PANG-INTERNASYUNAL AT PAMBANSANG MGA HALIMBAWA

\begin{tabular}{|c|c|c|}
\hline $\begin{array}{l}\text { UNDRIP } \\
2007\end{array}$ & Artikulo 14 & $\begin{array}{l}\text { 1. Ang mga katutubo ay may karapatang maitaguyod } \\
\text { at kontrolin ang kanilang mga sistemang pang- } \\
\text { edukasyon at institusyong nagbibigay ng edukasyon } \\
\text { sa kanilang sariling mga wika, sa paraang } \\
\text { naaangkop sa kanilang mga kulturang pamamaraan } \\
\text { ng pagtuturo at pag-aaral. } \\
\text { 2. Ang mga katutubong indibidwal, partikular ang mga } \\
\text { bata, ay may karapatan sa lahat ng antas at anyo ng } \\
\text { edukasyon ng Estado nang walang diskriminasyon. } \\
\text { Ang mga estado ay dapat na, kasabay ng mga } \\
\text { katutubo, magsagawa ng mabisang hakbang, upang } \\
\text { ang mga katutubong indibidwal, partikular ang } \\
\text { mga bata, kasama ang mga nakatira sa labas ng } \\
\text { kanilang mga komunidad, na magkaroon ng akses, } \\
\text { kung maaari, sa isang edukasyon sa kanilang } \\
\text { sariling kultura at inilaan sa kanilang sariling wika. }\end{array}$ \\
\hline
\end{tabular}


Artikulo 26, 27, Artikulo 26

28 at 29
Gagawin ang mga hakbang upang matiyak na ang mga miyembro ng kinauukulang mamamayan ay may pagkakataong makakuha ng edukasyon sa lahat ng antas nang hindi bababa sa pantay na pamantayan sa iba pang pambansang pamayanan.

Artikulo 27

1. Ang mga programa at serbisyo sa edukasyon para sa mga kinauukulang mamamayan ay dapat paunlarin at ipatupad sa kooperasyon sa kanila upang matugunan ang kanilang mga espesyal na pangangailangan at isasama ang kanilang mga kasaysayan, kanilang kaalaman at teknolohiya, kanilang mga sistema ng halagahan, at ang kanilang karagdagang mga panlipunan, pang ekonomiko, at pangkulturang hangarin.

2. Ang may kakayanang awtoridad ay magtitiyak na ang pagsasanay ng mga kasapi ng mga mamamayang ito at ang kanilang pagkakasangkot sa pagbubuo at pagpapatupad ng mga programang pang-edukasyon, na may pananaw sa progresibong paglipat ng responsibilidad para sa pagsasagawa ng mga programang ito sa mga mamamayang ito bilang naaangkop.

3. Bilang karagdagan, kikilalanin ng mga gobyerno ang karapatan ng mga mamamayang ito na magtaguyod ng kanilang sariling mga institusyong pang-edukasyon at pasilidad, sa kondisyon na ang mga nasabing institusyon ay nakakatugon sa pinakamaliit na pamantayan na itinatag ng may kakayanang awtoridad sa konsultasyon sa mga mamamayang ito. Ang mga naaangkop na mapagkukunan ay dapat ibigay para sa hangaring ito.

Artikulo 28

1. Ang mga bata na kabilang sa mga kinauukulang mamamayan ay dapat, saanmang praktikal, turuan na magbasa at sumulat sa kanilang sariling katutubong wika o sa wikang pinakakaraniwang ginagamit ng pangkat na kanilang kinabibilangan. Kung hindi ito maisasagawa, ang mga may kakayanang awtoridad ay dapat magsagawa ng mga konsultasyon sa mga mamamayang ito na may hangarin na maghalaw ng mga hakbang upang makamit ang layuning ito.

2. Sapat na mga hakbangin ang gagawin upang matiyak na ang mga mamamayang ito ay may pagkakataong makamit ang katatasan sa wikang pambansa o sa isa sa mga opisyal na wika ng bansa.

3. Ang mga hakbang ay gagawin upang mapanatili at maitaguyod ang pag-unlad at praktika ng mga katutubong wika ng mga kinauukulang mamamayan.

Artikulo 29

Ang pagbibigay ng pangkalahatang kaalaman at kasanayan na makakatulong sa mga bata na kabilang sa mga mamamayang kinauukulan upang makilahok nang buo at sa pantay na pamantayan sa kanilang sariling pamayanan at sa pambansang pamayanan ay magiging isang layunin ng edukasyon para sa mga taong ito.
Nananawagan sa mga gobyerno na magbigay sa mga katutubo ng pantay na pagkakataon na makakuha ng edukasyon

Inoobliga ang mga estado na bumuo at magpatupad $n g$ mga serbisyong pang-edukasyon sa pakikipagtulungan sa mga katutubo at sa paraang naaangkop sa kanilang mga kasaysayan, kultura at mga pangangailangan sa pag-aaral

Kinikilala ang karapatan ng mga katutubo na magtatag ng kanilang sariling mga pangedukasyong institusyon at pasilidad

Pinoprotektahan ang karapatan sa edukasyon sa unang wika para sa mga katutubong bata pati na rin ang karapatang matuto ng wikang 'pambansa' 


\begin{tabular}{|c|c|c|}
\hline $\begin{array}{l}\text { Konstitusyon } \\
\text { ng Argentina } \\
1994\end{array}$ & Artikulo 75(17) & $\begin{array}{l}\text { Ang Kongreso ay magkakaroon ng kapangyarihan: } \\
\text {... } \\
\text { 17. Upang makilala ang etniko at kultural na sinaunang } \\
\text { pag-iral ng mga katutubo ng Argentina. } \\
\text { Upang igarantiya ang paggalang sa kanilang } \\
\text { pagkakakilanlan at kanilang karapatan sa } \\
\text { edukasyong bilinggwal at interkultural. . . }\end{array}$ \\
\hline $\begin{array}{l}\text { Konstitusyon } \\
\text { ng Bolivia } \\
2009\end{array}$ & $\begin{array}{l}\text { Artikulo 78(II), } \\
80(I I), 91(I I), \\
95(I I)\end{array}$ & $\begin{array}{l}\text { Artikulo } 78 \\
\text { II. Ang edukasyon ay intra-kultural, inter-kultural } \\
\text { at multi-linggwal sa buong sistema ng pang- } \\
\text { edukasyon. } \\
\text { Artikulo } 80 \\
\text { II. Ang edukasyon ay dapat mag-ambag sa } \\
\text { pagpapalakas ng pagkakaisa at pagkakakilanlan ng } \\
\text { bawat isa bilang bahagi ng Pluri-Nasyonal na Estado } \\
\text { (Estado Plurinacional), pati na rin ang pagpapatibay } \\
\text { ng pagkakakilanlan at pagpapaunlad ng kultura ng } \\
\text { mga miyembro ng bawat bansa at rural na katutubo, } \\
\text { at ang interkultural na pag-unawa at pagpapayaman } \\
\text { sa loob ng Estado. } \\
\text { Artikulo } 91 \\
\text { II. Ang mas mataas na edukasyon ay intra-kultura, } \\
\text { interkultural at multi-linggwal, at mayroon itong } \\
\text { misyon na komprehensibong pagbuo ng lubos na } \\
\text { kwalipikado at may kakayahang propesyonal at may } \\
\text { kapasidad na mapagkukunan ng tao ... } \\
\text { Artikulo 95 } \\
\text { II. Dapat magpatupad ang mga pamantasan ng mga } \\
\text { programa para sa pagpapanumbalik, pagpapanatili, } \\
\text { pag-papaunlad, pag-aaral at pagpapalaganap ng } \\
\text { iba't ibang mga wika ng mga bansa at mga rural na } \\
\text { katutubo. }\end{array}$ \\
\hline
\end{tabular}

\begin{tabular}{|c|c|c|}
\hline $\begin{array}{l}\text { Konstitusyon } \\
\text { ng Brazil } \\
1988\end{array}$ & Artikulo $210(2)$ & $\begin{array}{l}\text { (2) Ang regular na edukasyon sa elementarya ay } \\
\text { ibibigay sa wikang Portuges, na tinitiyak din sa mga } \\
\text { pamayanang katutubo ang paggamit ng kanilang } \\
\text { mga katutubong wika at kanilang sariling mga } \\
\text { pamamaraan sa pag-aaral. }\end{array}$ \\
\hline
\end{tabular}

\begin{tabular}{l|l|}
$\begin{array}{l}\text { Konstitusyon } \\
\text { ng Colombia } \\
1991\end{array}$ & Artikulo 10 \\
\hline
\end{tabular}

\begin{tabular}{l|l|}
$\begin{array}{l}\text { Konstitusyon } \\
\text { ng Venezuela } \\
1999\end{array}$ & Artikulo 121 \\
\hline
\end{tabular}
1999

Finland, Batas
Wika ng Sámi

2003

\section{... Ang edukasyong ibinigay sa mga pamayanan na} may kani-kanilang mga linggwistikong tradisyon ay magiging bilinggwal.

... Itataguyod ng Estado ang pagpapahalaga at pagpapalaganap ng mga kultural na manipestasyon ng mga katutubo, na may karapatan sa kanilang sariling edukasyon, at isang sistemang pang-edukasyon ng isang interkultural at bilinggwal na kalikasan, na isinasaalang-alang ang kanilang mga espesyal na panlipunan at pangkulturang katangian, mga halagahan, at tradisyon.

Seksyon 32 - Katayuan ng wikang Sámi sa ilang mga kontekstong pang-administratibo.

Ang magkakahiwalay na mga probisyon ay nalalapat sa karapatan ng Sámi na makatanggap ng pangunahin at mababang sekundaryong edukasyon sa kanilang sariling wika, sa pagtuturo sa wikang Sámi, at sa katayuan ng wikang Sámi bilang isang wika ng pagtuturo, isang disiplina at isang antas ng wika.

Ang Batas sa Pangangalaga sa Bata (36/1973) naglalaman ng mga probisyon sa karapatan ng Sámi upang makatanggap ng pangangalaga sa kanilang sariling wika.
Iginagarantiya ang karapatan sa edukasyong bilinggwal at interkultural

Nangangako ng interkultural at multilinggwal na edukasyon

Nagdadagdag ng positibong obligasyon sa mga pamantasan upang itaguyod ang mga katutubong wika
Kinikilala na ang mga katutubong komunidad ay maaaring gumamit ng kanilang sariling mga wika at mga pamamaraan sa pag-aaral kasabay ng regular na edukasyon sa Portuges

Iginagarantiya ang karapatan sa edukasyong bilinggwal

Iginagarantiya ang karapatang pagmamay-ari ng sistema ng edukasyon para sa mga katutubo, na isinasaalang-alang ang mga salik na pangwika at pangkultura

Pinoprotektahan ang karapatan ng Sami sa pangunahin at mababang sekundaryong edukasyong sa unang wika; pinalawak sa day-care sa pamamagitan ng lehislasyon 
Norway, Batas

ng Sami

1987

Seksyon 3(8)

Timog Aprika,

White Paper para

sa Panlipunang

Kapakanan

1997

Artikulo 25
Ang sinuman ay may karapatang makatanggap ng matrikula sa Sami. Maaaring mag-isyu ang Hari ng karagdagang mga patakaran tungkol sa pagpapatupad ng probisyong ito.

25. Hihikayatin ng Kagawaran ng Kapakanan ang mga institusyon na repasuhin ang kasalukuyang mga programa sa edukasyon at pagsasanay sa kapakanan at mga kurikulum, partikular sa mga pamantasan at teknikon.

(a) Ang mga pangunahing kurso ay dapat na muling idisenyo at gawing pleksible at sensitibo sa mga baryasyong panlalawigan at inter-panlalawigan.

Ang mga materyales sa kurikulum at pagsasanay ay dapat na katutubo at sensitibo sa kultura, at dapat mapanatili ang isang balanse sa pagitan ng mga nakagagamot at nakapagpapaunlad na metodolohiya. Ang Curricula ay dapat na binuo sa pagkonsulta sa mga tagalaan ng serbisyo.
Nangangako ng karapatan sa edukasyon sa unang wika

Ang pagbibigay ng edukasyon ay dapat na maiakma sa mga pangangailangan ng katutubo at sensitibo sa kultura 


\section{MGA NAPAG-ALAMAN}

Sagot sa tanong (Oo/Hiindi) at iba pang mga tala at obserbasyon tungkol sa kung gaano kahusay na tinutugunan $n g$ konstitusyon ang (mga) isyu na itinanong. Isama ang mga makabuluhang mga probisyon ((mga) numero $n g$ artikulo at teksto $n g$ (mga) probisyon). Tandaan din ang hindi konsistent at/o magkasalungat na mga probisyon, o kung walang umiiral na mga kaugnay na probisyon.

\section{MGA HAKBANG}

Iminungkahing adbokasiya at iba pang mga kasunod na hakbang upang matugunan o mapalaganap ang mga natuklasan. 


\section{Karapatan sa kultura, at panlipunan at pang-ekonomikong pag-unlad}

\section{Pinoprotektahan ba ng konstitusyon ang karapatan ng mga komunidad ng katutubo upang magpatuloy na magsanay ng kanilang mga aktibidad sa pamumuhay (tradisyunal na paraan ng hanapbuhay)?}

PALIWANAG

Ang mga pagkakakilanlan ng mga katutubo ay madalas na malapit na maiuugnay sa kanilang mga gawi sa lupa at pamumuhay, kabilang ang ilang uri ng agrikultura, produksyon ng likhang-kamay, pangingisda o panggugubat. Kapag ang mga katutubo ay marhinalisado sa lipunan at/o naihiwalay mula sa kanilang lupain, ang kanilang kakayahang magpatuloy sa pagsasanay ng mga aktibidad sa pamumuhay ay madalas na pinipigilan na may mga negatibong kahihinatnan sa pagkakakilanlan ng pamayanan at sosyo-ekonomikong kapakanan. Ang mga patakaran sa kapaligiran at ang epekto nito sa lupain samakatwid ay napakahalaga sa mga katutubo, at ang mga gobyerno ay dapat na mangako na kumonsulta sa mga katutubo sa pagpapaunlad ng naturang mga patakaran. Kung gayon, may mga panahon na ang mga patakarang ito o iba pang pagsisikap na "konserbasyon", ay maaaring kasalungat sa tradisyunal na hanapbuhay ng mga katutubo-halimbawa, kung ang mga katutubo ay umaani ng halaman o kung hindi man ay nakasalalay sa likas na yaman sa isang pambansang parke. Sa mga kasong ito, kinakailangan ng mga pagtatangka na pamahalaan ang mga paglampas sa pagitan ng mga karapatan ng mga katutubo at pagunlad ng mga pambansang parke at pagsisikap sa konserbasyon. Kadalasan, ang mga isyung ito ay natutugunan sa pamamagitan ng lehislasyon na kasunod sa isang konstitusyon; gayunman, ang konstitusyonal na patnubay na pinoprotektahan ang karapatan ng mga katutubo sa kanilang tradisyunal na hanapbuhay ay maaaring magbigay ng isang magandang plataporma para sa lehislatibong pag-unlad sa kalaunan.

Halimbawa, sa Canada, ang Aktong Konstitusyon ng 1982 ay idinagdag ang Tsarter ng Mga Karapatan at Kalayaan ng Canada at ilang bilang ng mga probisyon sa konstitusyonal na utos ng Canada. Kasama sa mga probisyon na ito ang seksyon 35 na nagpoprotekta sa mga katutubo at sa kanilang makasaysayang mga tratadong karapatan. Batay sa batas na ito, pinalawak ng Korte Suprema ng Canada ang proteksyon ng mga kasanayan sa pamumuhay ng katutubo upang saklaw ang mga aktibidad sa pamumutol ng kahoy at pangangaso. Tinukoy ng Korte Suprema na 'upang maging isang karapatan ng mga katutubo ang isang aktibidad ay dapat na isang elemento ng isang kasanayan, kaugalian o tradisyon na isinama sa natatanging kultura ng grupong mga katutubo na nagpapahayag ng karapatan' (Korte Suprema ng Canada 1995).

Higit pa sa mga aktibidad ng pamumuhay na nakabatay sa lupa, ang katanungang ito ay nagsasaad din ng pagsasaalang-alang ng tradisyunal na kaalaman at mga karapatan sa intelektwal na pag-aari sa pareho (tingnan ang Tanong 26). Ang mga likhang-kamay at sining ng mga katutubo ay isang bagay na ipinagmamalaki ng pamayanan, isang simbolo ng kultura, gayundin mga potensyal na mapagkukunan ng kita. Ang pagtiyak na ang mga katutubo ay maaaring magpatuloy na magsanay ng kanilang mga aktibidad sa pamumuhay ay nagsasama ng tradisyunal na mga sining at mga likhang-kamay. Ang kasamang kasiguruhan na ang mga katutubo ay may mga karapatan sa pag-aari sa mga likhang-sining, awit, sayaw at iba pang mga aspekto ng kanilang kultura na maaaring higit na makapagprotekta sa mga karapatan ng mga katutubo sa merkado at makatanggap ng patas na bahagi ng mga ekonomikong benepisyo para sa kanilang produksyon. Siyempre, ang mga makatwirang alituntunin at kahulugan ng kung ano ang bumubuo ng kultura ng mga katutubo at sa parehong mga karapatan ay maaaring hilingin ng estado ngunit ang mga katutubo ay dapat konsultahin sa prosesong ito. 


\begin{tabular}{|c|c|c|}
\hline $\begin{array}{l}\text { Kumbensyon } \\
\text { ng ILO } \mathbf{1 6 9} \\
1989\end{array}$ & Artikulo 23 & $\begin{array}{l}\text { 1. Ang mga likhang-kamay, mga industriya na } \\
\text { nakabase sa rural at komunidad, at ekonomiya } \\
\text { sa pamumuhay at tradisyonal na mga gawain ng } \\
\text { mga taong kinauukulan, tulad ng pangangaso, } \\
\text { pangingisda, pagbitag at pagtitipon, ay kikilalanin } \\
\text { bilang mahalagang mga salik sa pagpapanatili } \\
\text { ng kanilang mga kultura at sa kanilang pang- } \\
\text { ekonomikong pag-asa sa sarili at kaunlaran. Ang } \\
\text { mga pamahalaan ay dapat, sa pakikilahokng } \\
\text { mga mamamayang ito at kahit kailan naaangkop, } \\
\text { siguraduhing ang mga aktibidad na ito ay } \\
\text { pinalalakas at naisusulong. } \\
\text { 2. Sa kahilingan ng mga kinauukulang mamamayan, } \\
\text { ang naaangkop na tulong teknikal at pinansyal ay } \\
\text { dapat ibigay saanman posible, isinasaalang-alang } \\
\text { ang mga tradisyunal na teknolohiya at katangian } \\
\text { ng kultura ng mga mamamayang ito, pati na rin ang } \\
\text { kahalagahan ng sustenable at pantay na pag-unlad. }\end{array}$ \\
\hline
\end{tabular}

UNDRIP

2007

Article 20

\begin{tabular}{|c|c|}
\hline $\begin{array}{l}\text { Konstitusyon } \\
\text { ng Bolivia }\end{array}$ & $\begin{array}{l}\text { Artikulo } 397(\text { I) } \\
\text { at (II) }\end{array}$ \\
\hline
\end{tabular}

1. Ang mga katutubo ay may karapatang panatilihin at paunlarin ang kanilang mga pampulitika, pang-ekonomiya at panlipunang mga sistema o institusyon, upang maging ligtas sa pagtamasa ng kanilang sariling paraan ng pamumuhay at kaunlaran, at malayang makisali sa lahat ng kanilang tradisyonal at iba pang ekonomikong gawain.

2. Ang mga katutubo na pinagkaitan ng kanilang paraan ng pamumuhay at kaunlaran ay may karapatan sa makatarungang at patas na pagwawasto.

I. Ang trabaho ay ang pangunahing paraan kung saan ang agraryong pagmamay-ari ay nakuha at pinapanatili. Dapat gamitin ang mga pag-aari upang maglingkod sa isang layuning panlipunan o isang panlipunang pang-ekonomikong layunin upang mapangalagaan ang karapatan sa kanila, depende sa likas na katangian ng pag-aari.

II. Maunawaan ang hangaring panlipunan na nangangahulugang ang sustenableng pagsasamantala sa lupa ng mga mamamayan at mga rural na katutubong komunidad, pati na rin ang isinasagawa sa mga maliliit na pag-aari, at ito ang bumubuo ng mapagkukunan ng pamumuhay at kapakanan at pag-unlad na sosyo-kultural ng mga may-ari nito. Ang mga pamantayan ng mga pamayanan ay kinikilala sa pagtupad ng hangaring panlipunan.

\begin{tabular}{l|l}
$\begin{array}{l}\text { Konstitusyon } \\
\text { ng Sweden } \\
1974\end{array}$ & Artikulo 17 \\
\hline
\end{tabular}

Ang mga limitasyon na nakaaapekto sa karapatan sa kalakal o pagsapraktika ng isang propesyon ay maaaring ipakilala lamang upang maprotektahan ang pagtukoy sa mga interes ng publiko at hindi kailanman dahil lamang sa layon na mapalago ang mga ekonomikong interes $\mathrm{ng}$ isang partikular na tao o negosyo.

Ang karapatan ng populasyon ng Sami na magsagawa $\mathrm{ng}$ pag-aalaga $\mathrm{ng}$ mga reindeer ay nireregula sa batas.
Pinanghahawakan na itaguyod at tiyakin ng mga gobyerno ang pagpapatuloyng pamumuhay at tradisyonal na mga gawaing pang-ekonomiya ng mga katutubo, kasama ang pagbibigay ng mga mapagkukunan para sa pareho kapag hiniling ng mga katutubo

Kinikilala ang karapatan ng mga katutubo upang mapanatili ang mga sistemang pang-ekonomiya at matamasa ang kanilang sariling paraan ng pamumuhay

Nagsasaad ng para sa pagwawasto para sa mga katutubong tinanggihan ang kanilang mga aktibidad sa pamumuhay

Kinikilala ang mga tradisyonal na katutubong paggamit ng lupa bilang isang sapat na batayan upang maangkin at mapanatili ang pag-aari

Gumuguhit ng mga proteksyon para sa tradisyunal na kabuhayan ng Sami (pag-aalaga ng reindeer), habang iniiwan ang mga detalye sa lehislasyon 
Konstitusyon ng Venezuela 1999
Artikulo 123

Ang mga katutubo ay may karapatang panatilihin at itaguyod ang kanilang sariling mga kasanayan sa ekonomiya batay sa tumbasan, pagkakaisa at palitan; ang kanilang tradisyonal na produktibong mga aktibidad at ang kanilang pakikilahok sa pambansang ekonomiya, at upang tukuyin ang kanilang mga priyoridad. Ang mga katutubo ay may karapatan sa mga serbisyong propesyonal na pagsasanay at upang lumahok sa paghahanda, pagpapatupad at pamamahala ng mga tiyak na programa sa pagsasanay at mga serbisyong panteknikal at pampinansyal upang mapalakas ang kanilang mga gawaing pangekonomiya sa loob ng balangkas ng sustenableng lokal na kaunlaran. Ang Estado ay gagarantiyahan ang mga manggagawa na kabilang sa mga katutubo ang pagtamasa ng mga karapatang ipinagkaloob sa ilalim ng lehislasyon sa paggawa.
Pinoprotektahan ang mga karapatan ng mga katutubo upang mapanatili at itaguyod ang kanilang mga kasanayan sa ekonomiya at tradisyonal na produktibong mga aktibidad, habang tinitiyak din ang pag-akses sa mga serbisyong propesyonal na pagsasanay kung gugustuhin man ng mga katutubo na pumasoksa pangunahing ekonomiya 


\section{MGA NAPAG-ALAMAN}

Sagot sa tanong (Oo/Hiindi) at iba pang mga tala at obserbasyon tungkol sa kung gaano kahusay na tinutugunan $n g$ konstitusyon ang (mga) isyu na itinanong. Isama ang mga makabuluhang mga probisyon ((mga) numero $n g$ artikulo at teksto $n g$ (mga) probisyon). Tandaan din ang hindi konsistent at/o magkasalungat na mga probisyon, o kung walang umiiral na mga kaugnay na probisyon.

\section{MGA HAKBANG}

Iminungkahing adbokasiya at iba pang mga kasunod na hakbang upang matugunan o mapalaganap ang mga natuklasan. 


\title{
Karapatan sa kultura, at panlipunan at pang-ekonomikong pag-unlad
}

\author{
Pinoprotektahan ba ng konstitusyon ang karapatan sa kalusugan ng mga \\ katutubo, kasama na ang paggamit sa mga tradisyunal na gamot at serbisyo?
}

PALIWANAG

Ang karapatan sa kalusugan ay nagpapahiwatig hindi lamang sa isang indibidwal na karapatang makagamit sa mga serbisyong pangkalusugan, ngunit isang obligasyon para sa estado na magbigay (o mapadali ang kakayahang magamit ang) pangangalagang pangkalusugan sa lahat ng mga mamamayan. Ang isang pangkalahatang karapatan sa kalusugan at sa pangangalagang pangkalusugan ay madalas na kasama sa mga konstitusyon, at ang mga katutubo ay dapat na garantisado ang parehong karapatang ito nang walang diskriminasyon.

Para sa mga katutubo, ang karapatan sa kalusugan ay maaaring mapahusay kung ito ay partikular na nakasulat o binibigyang kahulugan upang isama ang pagkilala, kung hindi man probisyon, sa mga tradisyunal na gamot at kasanayan bilang bahagi ng isang karapatan sa kalusugan. Para sa maraming mga komunidad, ito ang mga kasanayan at gamot na pinagkakatiwalaan at inaasahan nila at pati na rin ang mga pinakaabot-kaya sa kanila. Maaaring protektahan at maitaguyod ng isang konstitusyon ang mga kasanayan na ito at matiyak na ang itinatag na pambansang iskema ng pangangalaga sa kalusugan ay sumasaklaw sa paggamit sa mga kasanayan at produktong ito. Dahil ang mga kasanayang ito ay bahagi ng kultura ng mga katutubo, mangyaring tingnan din ang Tanong 21. Kung ang mga katutubong kasanayan ay pagmamasdan o isasalin para sa pangkalahatang publiko, mahalaga din na ang mga katutubo ay kilalanin at mabayaran para sa mga kontribusyong ito (tingnan ang Tanong 26 para sa karagdagang detalye).

Siyempre, ang mga katutubo ay hindi dapat pipilitin na umasa sa mga kasanayang ito at dapat garantisado nang walang prehuwisyo sa pag-abot sa regular na mga serbisyong pangkalusugan ng estado, ayon sa kanilang kagustuhan. Minsan ang sub-konstitusyonal na pagbabago ay maaaring matiyak na ang mga katutubo ay tumatanggap ng mga serbisyong pangkalusugan na naaangkop sa kultura. Halimbawa, ang Ministry of Indigenous Peoples' Affairs sa Guyana ay lumikha ng isang tiyak na Kagawaran ng Kapakanang Panlipunan at Pangkalusugan na

responsable para sa pagbuo, pamamahala at pag-uugnay ng mga tugon sa mga isyung panlipunan na nakaaapekto sa mga Katutubo ng Guyana. . . Hangad nito na tugunan ang mga isyu sa Paggawa at Kapakanan, na kinabibilangan ng pagtulong sa mga tao na mag-apply para sa mga benepisyo na karapatdapat sa kanila mula sa National Insurance Scheme (NIS) at sa matandang pamamaraan ng pensyon. Ang mga Opisyal ng Kagawaran ay nakikipagtulungan din kasama ang mga opisyal ng tagapagpatupad ng batas at ang Ministry of Social Protection at iba pang mga makabuluhang kinauukulan upang siyasatin o iulat ang mga kaso na nauugnay sa Domestikong Karahasan, Karahasang Sekswal, Pagtatalo sa Paggawa, ang Kalakalan sa Tao at iba pang mga isyu na nakaaapekto sa mga katutubo ng Guyana. Ibinibigay din ang suporta sa mga tao sa Georgetown Public Hospital pati na rin sa mga nasa koreksyonal na pasilidad. Pinadali din ng Kagawaran ang late na Pagpaparehistro ng Mga Kapanganakan. (Ministry of Indigenous Peoples' Affairs, Guyana n.d.) 


\begin{tabular}{|c|c|c|}
\hline $\begin{array}{l}\text { Kumbensyon } \\
\text { ng ILO } 169 \\
1989\end{array}$ & Article 25 & $\begin{array}{l}\text { 1. Titiyakin ng mga pamahalaan na ang sapat na } \\
\text { mga serbisyong pangkalusugan ay maabot na } \\
\text { mga kinauukulang mamamayan, o dapat bigyan } \\
\text { sila ng mga mapagkukunan upang payagan silang } \\
\text { magdisenyo at maghatid ng mga nasabing serbisyo } \\
\text { sa ilalim ng kanilang sariling responsibilidad at } \\
\text { kontrol, upang matamasa nila ang pinakamataas } \\
\text { na maabot na pamantayan ng kalusugang pisikal at } \\
\text { mental. } \\
\text { 2. Ang mga serbisyong pangkalusugan ay, hangga't } \\
\text { maaari, nakabatay sa pamayanan. Ang mga } \\
\text { serbisyong ito ay dapat planuhin at pangasiwaan } \\
\text { sa kooperasyon ng mga mamamayang kinauukulan } \\
\text { at isasaalang-alang ang kanilang pang-ekonomiko, } \\
\text { heyograpiko, panlipunan at kultural na kalagayan } \\
\text { pati na rin ang kanilang tradisyonal na prebensyong } \\
\text { pangangalaga, mga kasanayan sa pagpapagaling at } \\
\text { mga gamot. } \\
\text { 3. Ang sistema ng pangangalagang pangkalusugan } \\
\text { ay dapat magbigay ng pansin sa pagsasanay at } \\
\text { pagtatrabaho ng mga lokal na manggagawang } \\
\text { pangkalusugan sa komunidad, at ituon ang pansin } \\
\text { sa pangunahing pangangalaga ng kalusugan } \\
\text { habang pinapanatili ang matibay na ugnayan sa iba } \\
\text { pang mga antas ng mga serbisyong pangkalusugan. } \\
\text { 4. Ang pagkakaloob ng naturang mga serbisyong } \\
\text { pangkalusugan ay dapat maiugnay sa iba pang mga } \\
\text { panlipunan, pang-ekonomiko at pangkulturang } \\
\text { hakbang sa bansa. }\end{array}$ \\
\hline
\end{tabular}

UNDRIP

2007

\begin{tabular}{l|l}
$\begin{array}{l}\text { Konstitusyon } \\
\text { ng Bolivia }\end{array}$ & Artikulo 42(II) \\
2009 &
\end{tabular}

Artikulo 24
1. Ang mga katutubo ay may karapatan sa kanilang tradisyunal na mga gamot at panatilihin ang kanilang mga kasanayan sa kalusugan, kasama ang pangangalaga ng kanilang mga mahahalagang halamang-gamot, hayop at mineral. Ang mga katutubong indibidwal ay may karapatan ding makagamit, nang walang anumang diskriminasyon, ng lahat ng mga serbisyong panlipunan at pangkalusugan.

2. Ang mga indibidwal na katutubo ay may pantay na karapatan sa pagtamasa sa pinakamataas na maaabot na pamantayan ng pisikal at mental na kalusugan. Gagawin ng mga estado ang mga kinakailangang hakbang na may pananaw na makamit nang progresibo ang pagsasakatuparan ng karapatang ito.

II. Ang pagtataguyod ng tradisyunal na gamot ay dapat isama ang talaan ng mga natural na gamot at ng kanilang mga nakapagpapagaling na katangian, pati na rin ang proteksyon ng kanilang kaalaman bilang intelektwal, makasaysayan, kultural na pagaariat bilang patrimonya ng mga bansa at mga rural na katutubo.

\begin{tabular}{l|l} 
Konstitusyon & Artikulo 32 \\
ng Ecuador \\
2008
\end{tabular}

Ang kalusugan ay isang karapatang iginagarantiya ng Estado at ang katuparan ay nauugnay sa paggamit ng iba pang mga karapatan, bukod dito ang karapatan sa tubig, pagkain, edukasyon, isports, trabaho, panlipunang seguridad, malusog na kapaligiran at iba pa na sumusuporta sa isang mabuting pamumuhay. Igagarantiya ng Estado ang karapatang ito sa pamamagitan ng mga pang-ekonomiko, panlipunan, pangkultura, pang-edukasyon, at pangkapaligirang patakaran; at ang permanente, napapanahon, at hindi eksklusibong paggamit sa mga programa, aksyon at serbisyo na nagtataguyod at nagbibigay ng integral na pangangalagang pangkalusugan, sekswal na kalusugan, at reproduktibong kalusugan.
Naglalagay ng pananagutan sa mga pamahalaan na magbigay ng sapat na mga serbisyong pangkalusugan na, hangga't at dinisenyo na may pansin sa mga lokal na kasanayan maaari, nakabase sa pamayanan
Pinoprotektahan ang karapatan ng mga katutubo sa mga tradisyunal na gamot at upang makagamit din $n g$ mga pambansang serbisyong pangkalusugan nang walang diskriminasyon

Inoobligado ang mga estado sa progresibong pagsasakatuparan ng karapatan sa kalusugan ng mga katutubo
Iminumungkahi ang pagsusulong ng tradisyunal na gamot kabilang ang isang database $n g$ lahat ng mga katutubong gamot at ang kanilang mga natuklasang katangian

\section{Isinasaadang isang} pangkalahatang karapatan sa kalusugan para sa lahat ng mga mamamayan at naglalagay ng obligasyon sa estado na magdisenyo ng mga patakaran para makamit ang karapatang ito 


\begin{tabular}{|c|c|c|c|}
\hline $\begin{array}{l}\text { Konstitusyon } \\
\text { ng Kenya } \\
2010\end{array}$ & Artikulo 43(1A) & $\begin{array}{l}\text { (1) Ang bawat tao ay may karapatan- } \\
\text { (a) sa pinakamataas na maaabot na pamantayan } \\
\text { ng kalusugan, na kinabibilangan ng karapatan } \\
\text { sa mga serbisyo sa pangangalaga ng kalusugan, } \\
\text { kabilang ang pangangalaga sa reproduktibong } \\
\text { kalusugan. }\end{array}$ & $\begin{array}{l}\text { Isinasaad ang isang pangkalahatang } \\
\text { karapatan sa kalusugan para sa } \\
\text { lahat ng mga mamamayan }\end{array}$ \\
\hline $\begin{array}{l}\text { Konstitusyon } \\
\text { ng Mehiko } \\
1917\end{array}$ & Artikulo 2(B)(III) & $\begin{array}{l}\text { III. Tinitiyak na mabisang nakagagamit sa mga } \\
\text { serbisyong pangkalusugan sa pamamagitan ng } \\
\text { pagpapalawak ng saklaw ng pambansang sistema, } \\
\text { na mahusay na ginagamit ang tradisyunal na } \\
\text { gamot, at sinusuportahan ang nutrisyon ng mga } \\
\text { katutubo sa pamamagitan ng mga programa sa } \\
\text { pagkain, lalo na para sa populasyon ng bata. }\end{array}$ & $\begin{array}{l}\text { Nagbibigay ng obligasyon sa } \\
\text { estado na magbigay ng mga } \\
\text { serbisyo sa pangangalaga ng } \\
\text { kalusugan at palawakin ang } \\
\text { kanilang aplikabilidadkasama na } \\
\text { ang paggamit ng mga katutubong } \\
\text { kasanayan }\end{array}$ \\
\hline $\begin{array}{l}\text { Konstitusyon } \\
\text { ng Venezuela } \\
1999\end{array}$ & Artikulo 122 & $\begin{array}{l}\text { Ang mga katutubo ay may karapatan sa isang buong } \\
\text { sistemang pangkalusugan na isinasaalang-alang ang } \\
\text { kanilang mga kasanayan at kultura. Kinikilala ng Estado } \\
\text { ang kanilang tradisyunal na gamot at mga suplementong } \\
\text { anyo ng terapiya, na napapailalim sa mga prinsipyo ng } \\
\text { bioethics. }\end{array}$ & $\begin{array}{l}\text { Kinikilala ang espesyalisadong } \\
\text { karapatan sa buong mga } \\
\text { sistemang pangkalusugan } \\
\text { para sa mga katutubo, at } \\
\text { pinanghahawakan na } \\
\text { dapat kilalanin ng sistema ang mga } \\
\text { katutubong gamot at kilalanin ang } \\
\text { mga ito bilang mga pandagdag na } \\
\text { uri nq pagpapagaling }\end{array}$ \\
\hline
\end{tabular}




\section{MGA NAPAG-ALAMAN}

Sagot sa tanong (Oo/Hiindi) at iba pang mga tala at obserbasyon tungkol sa kung gaano kahusay na tinutugunan $n g$ konstitusyon ang (mga) isyu na itinanong. Isama ang mga makabuluhang mga probisyon ((mga) numero $n g$ artikulo at teksto $n g$ (mga) probisyon). Tandaan din ang hindi konsistent at/o magkasalungat na mga probisyon, o kung walang umiiral na mga kaugnay na probisyon.

\section{MGA HAKBANG}

Iminungkahing adbokasiya at iba pang mga kasunod na hakbang upang matugunan o mapalaganap ang mga natuklasan. 


\section{Karapatan sa kultura, at panlipunan at pang-ekonomikong pag-unlad}

Kinikilala ba ng konstitusyon ang mga karapatan ng mga katutubong komunidad sa pagmamay-ari ng intelektwal na ari-arian sa kabila ng kanilang tradisyunal na kaalaman at tradisyonal na ekspresyon sa kultura?

PALIWANAG

Ang karapatan sa kultura (Tanong 21) ay maaaring palakasin ng isang karapatan sa pagmamay-ari / mga karapatan sa intelektwal na pag-aari sa mga aspekto ng kultura. Tinitiyak nito na ang mga katutubo ay may awtonomiya sa kung paano kinakatawan ang kanilang imahen at kultura ay nirerepresenta at, sa ilang mga kaso, kinokopya.

Ang mga katutubo ay may yaman ng tradisyunal na kaalaman at tradisyunal na mga ekspresyong pangkulturang maaaring potensyal na mahalaga at maibebenta. Kasama sa kaalamang ito ang pag-unawa sa mga halamang-gamot at mga teknik sa pamamahala sa kapaligiran, pati na rin ang lokasyon at tamang paggamit ng mga likas na yaman. Sa maraming mga bansa, ang mga katutubo ay binibigyan din ng mga karapatan sa intelektuwal na pag-aari sa kanilang mga kasanayang kultural at tradisyon, mga likhang-kamay at kabuhayan at iba pang mga aspekto ng kultura. Maaari itong maging isang mahalagang mapagkukunan ng parehong pagkilala at kita para sa mga kultura ng mga katutubo.

Ang kolektibong pagmamay-ari ng mga katutubo sa tradisyunal na kaalaman at tradisyunal na ekspresyon ng kultura ay kinikilala sa ilalim ng batas internasyunal at maaaring maprotektahan sa loob ng bansa sa isang konstitusyon. Samakatwid, ang karapatang ito ay madalas na nilalabag sa nakaraan at ang mga katutubo ay pinagkaitan ng kaalamang ito o hinayaan ang paggamit sa kaalamang ito ng ibang mga aktor nang walang pagkilala o kompensasyon para sa kanilang mga kontribusyon. Ang pandaigdigang batas ay pinalawak upang isama ang isang karapatang magwasto para sa mga makasaysayang paglabag na ito sa karapatan ng mga katutubo sa pagmamay-ari ng intelektuwal na ari-arian sa kanilang tradisyunal na kaalaman at tradisyunal na mga anyo ng pagpapahayag ng kultura.

MGA PAMANTAYANG PANG-INTERNASYUNAL AT PAMBANSANG MGA HALIMBAWA

\begin{tabular}{|c|c|c|c|}
\hline $\begin{array}{l}\text { Kumbensyon sa } \\
\text { Biyolohikal na } \\
\text { Dibersidad } \\
1992\end{array}$ & Artikulo 8(j) & $\begin{array}{l}\text { (j) Napapailalim sa pambansang lehislasyon, } \\
\text { paggalang, pangangalaga at pagpapanatili ng } \\
\text { kaalaman, mga inobasyon at kasanayan ng mga } \\
\text { katutubo at lokal na pamayanan na sumasalamin } \\
\text { sa mga tradisyunal na pamumuhay na nauugnay } \\
\text { sa pangangalaga at sustenableng paggamit ng } \\
\text { biyolohikal na dibersidad at itaguyod ang kanilang } \\
\text { malawak na aplikasyon na may pag-apruba } \\
\text { at paglahok ng mga humahawak sa naturang } \\
\text { kaalaman, mga inobasyon at kasanayan at } \\
\text { hinihikayat ang pantay na pagbabahagi ng mga } \\
\text { benepisyo na nagmumula sa paggamit ng mga } \\
\text { nasabing mga inobasyon at kasanayan. }\end{array}$ & $\begin{array}{l}\text { Nananawagan para sa } \\
\text { pagbabahagi ng pakinabang } \\
\text { mula sa aplikasyon o iba pang } \\
\text { paggamit ng katutubong } \\
\text { kaalaman, inobasyon } \\
\text { at mga kasanayan sa lugarng } \\
\text { biyolohikal na dibersidad }\end{array}$ \\
\hline $\begin{array}{l}\text { Deklarasyon ng } \\
\text { Mataatua tungkol } \\
\text { sa Mga Karapatan } \\
\text { sa Kultural at } \\
\text { Intelektwal na } \\
\text { Pag-aari ng mga } \\
\text { Katutubo } \\
1993\end{array}$ & $\begin{array}{l}\text { Artikulo 2.1, } \\
2.2 \text { at } 2.4\end{array}$ & $\begin{array}{l}\text { Sa pagpapaunlad ng mga patakaran at kasanayan, ang } \\
\text { mga Estado, Nasyonal at Internasyonal na Ahensya ay } \\
\text { dapat } \\
\text { 2.1 Kinikilala na ang mga Katutubo ang tagapag- } \\
\text { alaga ng kanilang kaugaliang kaalaman at } \\
\text { may karapatang protektahan at kontrolin ang } \\
\text { pagpapalaganap ng kaalamang iyon. } \\
\text { 2.2 Kilalanin na ang mga Katutubo ay may karapatan din } \\
\text { na lumikha ng bagong kaalaman batay sa tradisyon } \\
\text { sa kultura. } \\
\text {... } \\
\text { 2.4 Tanggapin na ang mga karapatan sa kultural } \\
\text { at intelektuwal na pag-aari ng mga Katutubo ay } \\
\text { ipinagkaloob sa mga lumikha sa kanila. }\end{array}$ & $\begin{array}{l}\text { Kinikilala ang mga katutubo } \\
\text { bilang tagapangalaga ng } \\
\text { tradisyunal na kaalaman na } \\
\text { may karapatang kontrolin ang } \\
\text { pagpapalaganap ng kaalamang } \\
\text { ito sa ilalim ng mga karapatan } \\
\text { sa kultural at intelektuwal na } \\
\text { pag-aari }\end{array}$ \\
\hline
\end{tabular}




UNDRIP
2007

Artikulo 30(II, 11), 42, 304(II, 3)
Artikulo 11

1. Ang mga katutubo ay may karapatang magsanay at buhayin ang kanilang mga tradisyon at kaugalian sa kultura. Kasama rito ang karapatang panatilihin, protektahan at paunlarin ang nakaraan, kasalukuyan at hinaharap na manipestasyon $\mathrm{ng}$ kanilang mga kultura, tulad ng mga arkeolohikal at makasaysayang mga lokasyon, mga artepakto, mga disenyo, seremonya, teknolohiya at biswal at itinatanghal na sining at panitikan.

2. Ang mga estado ay magkakaloob ng pagwawasto sa pamamagitan ng mabisang mekanismo, na maaaring magbigay $n g$ restitusyon, na binuo kasabay ng mga katutubo, hinggil sa kanilang kultural, intelektwal, relihiyoso at espiritwal na pag-aari na kinuha nang wala silang malaya, nauna at malinang na kapahintulutan o lumalabag sa kanilang mga batas, tradisyon at kaugalian.

Artikulo 31

1. Ang mga katutubo tao ay may karapatang panatilihin, kontrolin, protektahan at paunlarin ang kanilang pamana sa kultura, tradisyonal na kaalaman at tradisyonal na pagpapahayag ng kultura, pati na rin ang mga manipestasyon ng kanilang mga agham, teknolohiya at kultura, kabilang ang mga mapagkukunan $\mathrm{ng}$ tao at genetiko, binhi, gamot, kaalaman sa mga katangian ng fauna at flora, oral na tradisyon, panitikan, disenyo, isports at tradisyunal na mga laro at biswal at itinatanghal na sining. Mayroon din silang karapatang magpanatili, magkontrol, magprotekta at magpaunlad ng kanilang intelektuwal na pag-aari sa naturang pamana ng kultura, tradisyonal na kaalaman, at tradisyonal na pagpapahayag ng kultura.

2. Kasabay ng mga katutubo, ang mga Estado ay magsasagawa ng mabisang hakbang upang kilalanin at protektahan ang paggamit ng mga karapatang ito.

Artikulo 30

II. Sa balangkas ng pagkakaisa ng Estado, at alinsunod sa Konstitusyong ito, tinatangkilik ng mga bansa at mga rural na katutubo ang mga sumusunod na karapatan:

...11. Sa kolektibongng pagmamay-ari ng intelektuwal na pag-aari na nasa kanilang kaalaman, agham at pag-aaral, pati na rin sa ebalwasyon, paggamit, promosyon at pag-unlad nito.

Artikulo 42

I. Responsibilidad ng Estado na itaguyod at garantiyahan ng paggalang sa, at ang paggamit ng, pagsasaliksik at pagsasagawa ng tradisyunal na gamot, pagsasalba ng mga ninunong kaalaman at kasanayan na nilikha mula sa pag-iisip at pagpapahalaga ng lahat ng mga nasyon at mga rural na katutubo.

II. Ang pagtataguyod ng tradisyunal na gamot ay dapat isama sa talaan ng mga natural na gamot at ng kanilang mga nakapagpapagaling na katangian, pati na rin ang proteksyon ng kanilang kaalaman bilang intelektwal, historikal, kultural na pag-aari at bilang patrimonya ng mga nasyon at mga rural na katutubo.

Artikulo 304

II. Maaaring gamitin ng mga katutubong rural ang sumusunod na ibinahaging awtoridad:

...3. Ang pag-iingat at pagpaparehistro ng

kolektibong intelektuwal na pag-aari na nauugnay sa kaalaman sa mga henetikong mapagkukunan, tradisyonal na gamot at germ plasma, alinsunod sa batas.
Inoobliga ang mga estado na magbigay ng mabisang mekanismo at pagwawasto para sa mga paglabag sa karapatan ng malaya, nauna at malinang na kapahintulutan (FPIC) hinggil sa kanilang 'kultural, intelektwal, relihiyoso at espiritwal na pag. aari

Kinikilala ang karapatan ng mga katutubo na kontrolin, protektahan at paunlarin ang pamana ng kultura at kaalaman at ang kanilang karapatan sa intelektwal na pag-aari sa parehong kalagayan

\section{Pinoprotektahan ang mga kolektibong karapatan sa intelektwal na pag-aari}

Inoobliga ang estado na itaguyod ang pananaliksik at pamumuhunan sa tradisyunal na kaalaman, mga gamot at kasanayan 


\begin{tabular}{|c|c|c|}
\hline $\begin{array}{l}\text { Konstitusyon } \\
\text { ng Ecuador } \\
2008\end{array}$ & Artikulo 57(12) & $\begin{array}{l}\text { Ang mga katutubong komyun, pamayanan, mamamayan } \\
\text { at bansa ay kinikilala at iginagarantiya, na naaayon } \\
\text { sa Konstitusyon at mga kasunduan sa karapatang } \\
\text { pantao, mga kumbensyon, deklarasyon at iba pang } \\
\text { mga instrumentong pang-internasyonal, ang mga } \\
\text { sumusunod na kolektibong karapatan: } \\
\text {... } \\
\text { (12) Itaguyod, protektahan at paunlarin ang kolektibong } \\
\text { kaalaman; ang kanilang agham, teknolohiya, at } \\
\text { ninunong karunungan; ang mga mapagkukunang } \\
\text { henetiko na naglalaman ng dibersidad sa } \\
\text { biyolohikal at biyodibersidad ng agrikultura; } \\
\text { kanilang gamot at tradisyunal na kasanayan sa } \\
\text { medisina, kasama ang karapatang ibalik, itaguyod, } \\
\text { at protektahan ang mga ritwal at banal na lugar, pati } \\
\text { na rin mga halaman, hayop, mineral at ecosystem } \\
\text { sa kanilang mga teritoryo; at kaalaman tungkol sa } \\
\text { mga mapagkukunan at katangian ng mga fauna at } \\
\text { flora. }\end{array}$ \\
\hline
\end{tabular}

\section{Konstitusyon} ng Kenya 2010
Artikulo 11 at 69 Artikulo 11

(2) Ang Estado ay dapat -

(c) magtaguyod ng mga karapatan sa intelektuwal na pag-aari ng mga mamamayan ng Kenya.

(3) Ang Parlamento gagawa ng lehislasyon sa -

(a) tiyakin na ang mga pamayanan ay makakatanggap ng kompensasyon o mga royalty para sa paggamit ng kanilang mga kultura at pamana sa kultura; at

(b) kilalanin at protektahan ang pag-aari sa katutubong mga binhi at iba't ibang tipo ng halaman, ang kanilang mga henetiko at magkakaibang katangian at ang kanilang gamit sa mga komunidad ng Kenya.

Artikulo 69

69. Mga obligasyong may paggalang sa kapaligiran

(1) Ang Estado ay dapat -

$\ldots$

(c) protektahan at pagbutihin ang intelektuwal na pag-aari sa, at katutubong kaalaman ng, biodiversity at ang mga mapagkukunang henetiko ng mga pamayanan.

\begin{tabular}{|c|c|c|}
\hline $\begin{array}{l}\text { Konstitusyon } \\
\text { ng Venezuela } \\
1999\end{array}$ & Artikulo 124 & $\begin{array}{l}\text { Ang kolektibong mga karapatan sa intelektwal na } \\
\text { pag-aari sa kaalaman, teknolohiya, at mga inobasyon } \\
\text { ng mga katutubo ay ginagarantiyahan at protektado. } \\
\text { Ang anumang aktibidad na parehong nauugnay sa mga } \\
\text { mapagkukunang henetiko at kaalaman kaugnay nito } \\
\text { ay magkakaroon ng mga kolektibongbenepisyo. Ang } \\
\text { talaan ng mga patent sa ninunong kaalamangito at ang } \\
\text { mga mapagkukunang ito ay ipinagbabawal. }\end{array}$ \\
\hline
\end{tabular}

Ang Pilipinas, Batas sa Karapatan $\mathbf{n g}$ Mga Katutubo 1997
Seksyon 32, 34 at 35
SEKSYON 32. Mga Karapatan sa Intelektwal na

Komunidad. - Ang mga ICC/ IP[mga katutubong kultural na pamayanan/katutubo] ay may karapatang magsanay at buhayin ang kanilang sariling mga tradisyon sa kultura at kaugalian. Ang Estado ay dapat pangalagaan, protektahan at paunlarin ang nakaraan, kasalukuyan, at hinaharap na manipestasyon ng kanilang mga kultura pati na rin ang karapatan sa pagpapanumbalik ng kultural, intelektwal, relihiyoso, at pang-espiritwal na pag-aari na kinuha nang walang malaya, nauna at malinang na kapahintulutan o lumalabag sa kanilang batas, tradisyon, at kaugalian.
Isinasama ang intelektwal na pag-aari sa listahan ng iba pang mga kolektibong karapatan para sa mga katutubo

Nananawagan sa parlamento na magpatupad ng lehislasyon na nangangako ng kompensasyon para sa paggamit

ng at pagmamay-ari sa tradisyunal na kaalaman
Ginagarantiya ang kolektibong mga karapatan sa intelektwal na pag-aari
Pinoprotektahan ang 'Mga

Intelektwal na Karapatan ng Komunidad 'kasama ang pagoobliga sa malaya, nauna at malinang na kapahintulutan (FPIC) na may kaugnayan sa paggamit ng intelektuwal, kultural, relihiyoso o espiritwal na pag-aari 
SEKSYON 34. Karapatan sa Mga Sistema at Kasanayan ng Katutubong Kaalaman at upang Bumuo ng sariling Agham at Teknolohiya. - Ang mga ICC/IP [mga katutubong kultural na pamayanan/katutubo] ay may karapatang kilalanin ang buong pagmamay-ari at kontrol at proteksyon ng kanilang mga karapatang kultural at intelektwal. Magkakaroon sila ng karapatan sa mga espesyal na hakbang upang kontrolin, paunlarin at protektahan ang kanilang mga agham, teknolohiya at manipestasyon ng kultura, kabilang ang mga mapagkukunan ng tao at iba pang henetiko, mga binhi, kabilang ang mga deribatibo ng mga mapagkukunang ito, mga tradisyunal na gamot at kasanayan sa kalusugan, mahahalagang halamang-gamot, mga hayop at mineral, mga sistema at kasanayan sa katutubong kaalaman, kaalaman sa mga katangian ng fauna at flora, oral na tradisyon, panitikan, disenyo, at biswal at itinatanghal na sining.

SEKSYON 35. Paggamit sa Mga Biyolohikal at Genetikong Mapagkukunan. - Ang paggamit sa mga biyolohikal at genetikong mapagkukunan at sa katutubong kaalaman na nauugnay sa pangangalaga, paggamit, at pagpapahusay ng mga mapagkukunang ito, ay papayagan sa loob ng mga lupang ninuno at mga dominyo ng mga ICC/IP kung mayroon lamang malaya, nauna, at malinang na kapahintulutan sa naturang mga pamayanan, na nakuha alinsunod sa mga nakaugaliang batas ng kinauukulang pamayanan. 


\section{MGA NAPAG-ALAMAN}

Sagot sa tanong (Oo/Hiindi) at iba pang mga tala at obserbasyon tungkol sa kung gaano kahusay na tinutugunan $n g$ konstitusyon ang (mga) isyu na itinanong. Isama ang mga makabuluhang mga probisyon ((mga) numero $n g$ artikulo at teksto $n g$ (mga) probisyon). Tandaan din ang hindi konsistent at/o magkasalungat na mga probisyon, o kung walang umiiral na mga kaugnay na probisyon.

\section{MGA HAKBANG}

Iminungkahing adbokasiya at iba pang mga kasunod na hakbang upang matugunan o mapalaganap ang mga natuklasan. 


\section{Pagprotekta at pagtataguyod sa mga karapatan ng mga katutubo

\author{
Nagtatatag ba ang konstitusyon ng pambansang komisyon ng mga katutubo, \\ ministeryo o iba pang espesyalisadong kinatawan ng gobyernoupang \\ itaguyod at protektahan ang mga karapatan ng mga katutubo?
}

PALIWANAG

Ang mga independiyenteng komisyon, tribunal, at ombudsman ay maaaring umakma sa mga hudikatura at pumapel ng isang mahalagang pangangasiwa at tungkulin ng pagpapatupad sa mga konstitusyonal na utos. Ang mga bahaging ito ay maaari ding mas madaling magamit sa publiko kaysa sa hudikatura, lalo na para sa mga desbentahado sa ekonomiya at kung hindi man ay marhinalisado na maaaring nahihirapan sa pag-abot sa mga korte. Sa paglipas ng panahon, ang mga 'pang-apat na sangay' ng institusyong ito ay dumami sa mga konstitusyon, kasama ang pagtaas ng panlipunang ingklusyon at maging ang mga komisyon na partikular para sa mga katutubo kasama ang karagdagang tradisyunal na pang-apat na sangay ng mga institusyon. Ang pagkakalagay sa Konstitusyon ng mga kinatawang ito ay ang pinakamahusay na kasanayan dahil binibigyan sila ng mas mataas na katayuan at tagal kaysa sa mga kinatawang itinatag sa pamamagitan ng lehislasyon; samaktwid, kahit na ang pagtataguyod ng naturang mga kinatawan sa pamamagitan ng lehislasyon ay maaaring makatulong nang malaki sa pagsusulong ng mga karapatan ng mga katutubo.

Ang mandato ng mga institusyong ito ay dapat na malawak na matiyak na ang mga entidad at proseso ng gobyerno ay gumana ayon sa pagsunod sa mga karapatan ng mga katutubo sa konstitusyon, ngunit magkakaiba ang mga tiyak na mandato. Halimbawa, ang isang tiyak na mandato ng isang komisyon ay maaaring magsama ng mga kakayahan sa imbestigasyon upang tingnan ang mga paglabag sa mga karapatan. Ang isang independiyenteng komisyon ng mga katutubo ay maaaring maghatid upang magbigay ng ekspertong payo at rekomendasyon sa mga isyu ng mga katutubo, itaas ang kamalayan at itaguyod ang pagsasama at koordinasyon ng mga aktibidad na nauugnay sa mga isyung ito, at ihanda at ipakalat ang impormasyon tungkol sa kanila. Ang mga komisyon ay maaaring permanenteng tampok ng kaayusang konstitusyonal o maaaring maitaguyod sa isang batayang adhoc upang malutas ang mga tiyak na reklamo o imbestigahan ang mga tiyak na pagkakamali-halimbawa, ang National Enquiry ng Canada sa Nawawala at Pinatay na Mga Katutubong Kababaihan at Batang Babae, na pansamantalang itinayo ( 2016-2018) na may mandato na 'tingnan ang lahat ng pinagbabatayanga mga sanhi ng karahasan laban sa mga Katutubong kababaihan at batang babae kabilang ang mga sistematikong isyu; upang gumawa ng mga kongkretong rekomendasyon upang wakasan ang hindi katanggap-tanggap na mataas na tantos ng karahasan; upang suriin ang mga patakaran at kasanayan sa institusyon tulad ng pamumulis o kapakanan ng bata' (Pamahalaang Canada 2019). Minsan ang mga komisyon na ito ay maaaring gumawa ng mga rekomendasyon, may bisa o walang bisa, sa iba pang mga aktor at kinatawan ng gobyerno; kung minsan sila ay binibigyan ng kapangyarihan upang suportahan ang mga legal na kaso (tingnan ang Tanong 29 sa pagtayo) sa ngalan ng mga mamamayang kinakatawan nila, sa pagdadala man ng mga kasong ito sa korte o sa pamamagitan ng pagbibigay ng mga pinansyal na mapagkukuna o ebidensya — halimbawa, sa pamamagitan ng pagsampa ng mga amicus na salaysay o iba pang sumusuportang dokumentasyon sa mga kasong ito.

Bukod sa mga komisyon, ang ilang mga bansa ay humingi din ng pagtataguyod ng mga ministeryo o kalihiman ng mga katutubong usapin upang matiyak na ang ehekutibong portfolio at ang mga aksyon ay tumutugon sa mga karapatan at isyu ng mga katutubo. Ang iba pang mga bansa ay lumikha ng mga espesyalisadong komite o kagawaran sa loob ng mga parlamento o iba pang mga ahensya ng gobyerno at institusyon upang pangunahan ang pagsasaalang-alang sa mga isyu ng mga katutubo-halimbawa, ang Komite ng Senado ng Estados Unidos para sa Indian Affairs ng Estados Unidos. Upang maging malinaw, ang mga kinatawang ito ay hindi kwalipikado bilang mga mekanismo ng pagkonsulta ng mga katutubo o kahit na mga mekanismo para sa representasyon ng mga katutubo sa gobyerno (tingnan ang Mga Katanungan 13 at 14), dahil hindi nila kasama ang representasyon ng mga katutubo, ngunit sinasagisag nila ang isang pagsisikap ng gobyerno na isaalang-alang at alagaan ang mga isyu ng mga katutubo sa nasyunal na antas, at, sana, isang pangako din ng gobyerno sa mga karapatan ng mga katutubo na kasama sa konstitusyon at pambansang lehislasyon.

Ang inobasyon sa institusyon upang itaguyod at protektahan ang mga karapatan ng mga katutubo ay isang prosesong nagpapatuloy. Nagbibigay ang New Zealand ng isang mahusay na halimbawa. Sa kabila ng pagtataguyod ng progresibong Waitangi Tribunal (1975) upang imbestigahan ang nagpapatuloy na mga pag-angkin sa tratado 
sa pagitan ng mga katutubo ng Maori at ng gobyerno, itinatag din ng New Zealand ang Office for Māori Crown Relations-Te Arawhiti, sa pamamagitan ng Desisyon ng Gabinete noong 2018, upang suportahan ang gobyerno sa pagiging isang 'patas na kasosyo sa tratado' at iginagalang ang pangako nito sa mga bansang Maori sa Tratado sa Waitangi. Ipinapakita nito na posible na magkaroon ng higit sa isang institusyong nakatuon sa mga gawain ng mga katutubo, at ang bawat institusyon ay maaaring maghatid ng bahagyang naiibang tungkulin.

Ang United Nations Permanent Forum on Indatives Issues ay naglalahad ng isang mahusay na halimbawa ng kasanayan kung paanong kahit na ang uri ng mga institusyong gobyerno na tinalakay sa katanungang ito (halimbawa, mga komisyon, ministro, atbp.) ay maaaring gawing mas kinatawan at, sa parehong panahon, maaaring umunlad patungo sa pagiging mga institusyon ng kapwa-pamamahala, pakikipagtulungan at konsultasyon sa mga katutubo. Ang Permanent Forum ay binubuo ng 16 na independyenteng eksperto, na kumikilos sa kanilang personal na kakayahan, na nagsisilbi sa isang termino sa tatlong taon bilang mga miyembro at maaaring muling ihalal o muling italaga para sa isang karagdagang termino (United Nations Permanent Forum on Indatives Issues 2007: 7 -8). Walo sa mga kasapi ang nominado ng mga gobyerno at walo ang direktang nominado ng mga katutubong organisasyon sa kanilang mga rehiyon. Ang mga kasapi na hinirang ng mga samahang katutubo ay hinirang ng Pangulo ng United Nations Economic and Social Council (ECOSOC) at kumakatawan sa pitong mga sosyokultural na rehiyon upang magbigay ng malawak na representasyon sa mga katutubo sa buong mundo. Ang mga rehiyon ay: Africa; Asya; Gitna at Timog Amerika at ang Caribbean; ang Arctic; Silangang Europa, ang Russian Federation, Gitnang Asya at Transcaucasia; Hilagang Amerika; at ang Pasipiko. Ipinapakita nito kung paano, sa pamamagitan ng makabagong mga pamamaraan ng pagtatalaga, ang mga estado ay maaaring magsimulang pagbutihin ang mga kasanayan at ang epekto ng mga institusyong naitayo nila at matiyak na nakahanay ang mga ito sa pundasyonal na karapatan ng mga katutubo sa sariling pagpapasya. 


\begin{tabular}{|l|l|l|}
\hline $\begin{array}{l}\text { Angola, } \\
\text { Naitaguyod ng } \\
\text { Konstitusyon ang } \\
\begin{array}{l}\text { Ombudsman } \\
2010\end{array}\end{array}$ & Artikulo 192(1) & (1) $\begin{array}{l}\text { Ang Ombudsman ay dapat na isang } \\
\text { independyenteng pampublikong kinatawan na ang } \\
\text { layunin ay upang ipagtanggol ang mga karapatan, }\end{array}$ \\
& $\begin{array}{l}\text { kalayaan at garantiya ng mga mamamayan na } \\
\text { tinitiyak, sa pamamagitan ng impormal na paraan, } \\
\text { ang hustisya at legalidad ng administrasyong } \\
\text { publiko. }\end{array}$ \\
\hline
\end{tabular}

Guyana, Komisyon ng Mga Katutubo na Itinaguyod ng Konstitusyon

2016

\begin{tabular}{l|l|l|} 
Nepal, Komisyon & Artikulo 261 \\
ng mga Katutubong & \\
Nasyonalidad & \\
na Itinatag ng \\
Konstitusyon \\
2015
\end{tabular}
gumawa ng mga rekomendasyon upang mapabuti

\section{T. Mga Tungkulin ng Komisyon ng Mga Katutubo}

Bilang karagdagan sa mga tungkulin na tinukoy sa artikulong 212J (2) ang mga tungkulin ng Komisyon ng Mga Katutubo ay upang-

a. itaguyod at protektahan ang mga karapatan ng mga katutubo;

b. itaas ang kamalayan sa kontribusyon ng, at mga problemang kinakaharap ng, mga katutubo;

c. itaguyod ang pagbibigay kapangyarihan ng mga katutubo, lalo na tungkol sa konseho ng baryo sa lokal na sistema ng pamahalaan at ang saklaw at awtoridad ng Konseho ng Toshaos;

d. gumawa ng mga rekomendasyon sa mga patakaran sa ekonomiya at edukasyon upang maisulong ang interes ng mga katutubo;

e. gumawa ng mga rekomendasyon para sa pangangalaga, preserbasyon at pagpalaganap ng kultural na pamana at wika ng mga katutubo;

f. itaguyod ang konsultasyon at kooperasyon sa mga katutubo lalo na tungkol sa kanilang pakikilahok sa pambansang pagpapasya at iba pang mga desisyon na nakaaapekto sa kanilang buhay;

g. inirerekomenda at itataguyod ang pagsasanay at tulong na panteknikal upang suportahan ang inisyatiba ng at para sa mga katutubo;

h. turuan ang mga tagapag-empleyo at publiko at ang mga kasanayan sa hanapbuhay na nauugnay sa mga katutubo; at

i. subaybayan ang pangangailangan para sa at magrekomenda kung saan nararapat ang pagtatatag ng mga mekanismo upang magbigay ng payo para sa mga katutubo.

(1) Magkakaroon $\mathrm{ng}$ isang Komisyon ng mga Katutubong Nasyonalidad ng Nepal, na binubuo ng isang Tagapangulo at hindi hihigit sa apat na iba pang mga kasapi.

(2) Ang Presidente ay dapat, sa rekomendasyon ng Konsehong Konstitusyunal, na hihirangin ang Tagapangulo at mga kasapi ng Komisyon ng mga Katutubong Nasyonalidad.

(3) Ang termino ng tanggapan ng Tagapangulo at mga kasapi ng Komisyon ng mga Katutubong Nasyonalidad ay dapat na anim na taon mula sa araw ng pagkakatalaga.

(4) Ang iba pang mga usapin na nauugnay sa kwalipikasyon para sa Tagapangulo at mga kasapi ng Komisyon ng mga Katutubong Nasyonalidad, mga pangyayari kung saan nabakante ang kanilang mga tanggapan, ang kanilang kabayaran at mga kondisyon ng paglilingkod at ang mga tungkulin, pananagutan at kapangyarihan ng Komisyong ito ay ibibigay ayon sa Batas Pederal.
Nagbibigay ng pangkalahatang proteksyon para sa lahat ng mga karapatan ng mga mamamayan sa pamamagitan ng pagtatatag $n g$ isang independyente at abot-kamay na ombudsman

Itinataguyod ang Komisyon ng Mga Katutubo na may mandato na protektahan ang mga karapatan ng mga katutubo pati na rin ang bilang ng iba pang mga natukoy na tungkulin

(1)

Nagmamandato sa pagtatakda ng isang Komisyon ng mga Katutubong Nasyunalidad bilang ikaapat na sangay na institusyon sa Nepal 
Timog Aprika,

Komisyon para

sa Promosyon at

Proteksyon ng mga

Karapatan ng Mga

Kultural, Relihiyoso

at Linggwistikong

Komunidad na

Itinaguyod ng

Konstitusyon

1996

\section{Bangladesh, \\ Ministeryo ng \\ Chittagong Hill \\ Tracts Affairs na \\ Itinaguyod ng \\ Chittagong Hill \\ Tracts Accord \\ 1997}

Brazil, Fundação

Nacional do Índio

(FUNAI) Itinaguyod

ng Batas Blg. 5,371,

5 Disyembre

1967
Seksyon 181(1) 1. Ang mga sumusunod na institusyon ng estado ay nagpapalakas ng konstitusyonal na demokrasya sa Republika:

$\cdots$

c. Ang Komisyon para sa Pagtataguyod at Proteksyon ng mga Karapatan ng Mga Kultural, Relihiyoso at Linggwistiko Komunidad.

Bahagi D, artikulo 18

Ang isang ministeryo sa Chittagong Hill Tracts Affairs ay dapat itaguyod sa pamamagitan $\mathrm{ng}$ paghirang $\mathrm{ng}$ isang Ministro mula sa mga tribo.

Buong batas na Pinapahintulutan ang institusyon ng 'Fundação kinakatawan ng Nacional do Índio' at gumagawa ng iba pang mga Titulo pagsasaayos.
Nagtatag ng isang komisyong konstitusyonal para sa pagsulong at pagprotekta ng mga karapatan ng mga "kultural, relihiyoso at linggwistikong komunidad
Ipinapangako na gagawin ng gobyerno ang pagtatatag ng isang Ministeryo upang maipadaloy ang Chittagong Hill Tract (tribo) na mga usapin sa loob ng pamahalaan; Ang ministeryo ay itinatag noong 1998

Itinataguyod ang Indian National Foundation (Fundação Nacional do Indio, FUNAI) bilang opisyal na katutubong organo ng bansa, na napasailalim sa Ministeryo ng Hustisya

Minamandato angFUNAI bilang tagapag-ugnay at pangunahing tagapagpatupad ng patakaran sa mga katutubo ng pederal na gobyerno na may misyon na protektahan at itaguyod ang mga karapatan ng mga katutubo ng Brazil

\section{Nagbibigay ng isang} detalyadong paglalarawan ng $m$ ga responsibilidad $n g$ Ministeryo ng iba pang mga ministro at mga institusyong pang-estado

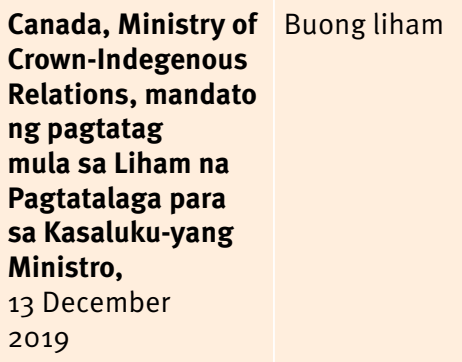

Bilang Ministro ng Crown-Indigenous Relations, ipagpapatuloy mo ang gawain upang mabago ang bansa-sa-bansa, Inuit-Crown at ang ugnayan ng pamahalaan-sa-pamahalaan sa pagitan ng Canada at mga Katutubo. Kasama rito ang patuloy na gawing makabago ang estrukturang pang-institusyon at pamamahala upang ang mga Unang Bansa, Inuit at Métis ay maaaring bumuo ng kapasidad na

sumusuporta sa pagpapatupad ng kanilang pananaw sa sariling pagpapasya.

Sa partikular, ikaw ay:

- Manguna sa isang buong-gobyernong lapit sa patuloy na pagbabago ng isang bansa-sa-bansa, Inuit-Crown at gobyerno-sa-gobyerno na relasyon sa mga Katutubo, na isinusulong ang patakaran na kapwa binuo ng mga pagkakaiba-iba at pinapabuti ang aming kakayahan bilang isang Pamahalaan upang isaalang-alang at tumugon sa mga natatanging katotohanan ng mga Katutubo.

- Suportahan ang Ministro ng Hustisya at Attorney General ng Canada sa gawaing ipakilala ang kapwabinuong batas upang ipatupad ang Deklarasyon ng United Nations sa Mga Karapatan ng mga Katutubo sa pagtatapos ng 2020.

- Manguna at makipag-uganyan sa gawaing kinakailangan ng lahat ng mga Ministro upang magpatuloy na ipatupad ang Panawagan sa Pagkilos ng Truth and Reconciliation Commission. 
- Manguna at iugnay ang gawaing kinakailangan ng lahat ng mga Ministro sa pagtaguyod ng isang National Action Plan bilang tugon sa National Inquiry into Missing and Murdered Indatives Women and Girls' 'Calls for Justice, sa pakikipagtulungan sa First Nations, Inuit at Métis Peoples.

- Makipagtulungan sa mga Katutubo para sa isang bagong proseso na nakabatay sa mga pagkakaibaiba para sa patuloy na pagsusuri, pagpapanatili at pagpapatupad ng mga tratadong obligasyon ng Canada sa pagitan ng mga Crown at katutubong pamayanan. Ang gawaing ito ay susuportahan $\mathrm{ng}$ isang bagong National Treaty Commissioner's Office na ididisenyo at maitatatag kasama ang mga kapartner na Katutubo.

- Patuloy na suportahan ang mga proseso na pinamumunuan ng mga katutubo para sa muling pagtatayo at muling pagbuo ng kanilang makasaysayang mga nasyon, pagsulong ng sariling pagpapasya at, para sa First Nations, pagtransisyon palayo sa Batas ng India.

- Ipagpatuloy ang pakikipagtulungan sa First Nations upang muling idisenyo ang mga pederal na patakaran sa mga pagdaragdag sa mga reserba, at sa proseso ng mga Espesipikong Pag-angkin.

- Ipagpatuloy ang pakikipagtulungan sa First Nations, Inuit at Métis upang muling idisenyo ang Comprehensive Claims at Inherent Rights Policies.

- Makipagtulungan sa Ministro ng Pananalapi at sa Ministro ng Likas na Yaman upang makabuo ng isang bagong pambansang balangkas na pagbabahagi ng benepisyo para sa pangunahing mga proyekto sa mapagkukunan sa teritoryo ng mga Katutubo.

- Palalimin ang pakikipagtulungan sa Ministro ng Pananalapi, na nakikipagtulungan sa Ministro ng mga Katutubong Serbisyo, upang magtaguyod $\mathrm{ng}$ isang bagong ugnayan sa pananalapi sa mga Katutubo na nagsisigurado ng sapat, prediktable, at sustenableng pagpopondo para sa mga pamayanan, at ang mga bansa ay mayroong pagpapasulpot ng kita at kapasidad sa pananalapi para sa mabisang pamamahala at magbigay ng mga programa at serbisyo sa mga taong pananagutan nila.

- Makipagtulungan sa pamumuno ng First Nations, Inuit, at Métis Nation, sa suporta ng Ministro ng Public Services and Procurement, upang tapusin ang kontribusyon ng Gobyerno sa puwang para sa Mga Katutubosa Parlamentong Presinto.

- Sa suporta ng Ministro ng Hilagang Usapin, kapwa bumuo at magpatupad ng isang patakaran ng Inuit Nunangat, at ganap na ipatupad ang mga kasunduan sa pag-angkin ng lupain ng Inuit.

- Ipagpatuloy ang aming regular na pagpupulong sa mga priyoridad ng Katutubo sa pamamagitan ng Assembly of First Nations- Canada Memorandum of Understanding on Joint Priorities, ang Inuit-Crown Partnership Committee, at ang Canada-Métis Nation Accord.

- Makipagtulungan sa Deputy Prime Minister at Ministro ng Intergovernmental Affairs at kasama ko upang suportahan ang Pulong ng Unang Mga Ministro tungkol sa Pakikipagkasundo sa mga Katutubo, at patuloy na isulong ang makabuluhang pagsasama ng First Nations, Inuit at Métis na kapartner sa mga proseso ng paggawa ng desisyong federal at intergovernmental na may epekto sa mga karapatan at interes ng mga Katutubo. 
\begin{tabular}{l|l} 
Chile, Fondo de & Tsapter III, \\
Desarrollo Indigena & para. 1
\end{tabular} (CONADI)

Itinatag ng Batas

Blg. 19.253

\begin{tabular}{l|l}
$\begin{array}{l}\text { New Zealand, } \\
\text { Waitangi Tribunal } \\
\text { na Itinaguyod ng }\end{array}$ & $\begin{array}{l}\text { Buong Batas, } \\
\text { partikular } \\
\text { na ang mga }\end{array}$ \\
$\begin{array}{l}\text { Tratado ng Batas } \\
\text { Waitangi }\end{array}$ & seksyon 4-8; \\
1975 & ang seksyon \\
& $\begin{array}{l}5 \text { ay binanggit } \\
\text { bilang isang } \\
\text { halimbawa dito }\end{array}$
\end{tabular}

Artikulo 23. Lumikha ng isang Pondo para sa Pagpapaunlad ng Katutubo na ang layunin ay upang tustusan ang mga espesyal na programa na naglalayong paunlarin ang mga katutubo at pamayanan, na pamamahalaan ng Korporasyon.

5. Ang mga tungkulin ng Tribunal ay dapat-

(a) upang magtanong at gumawa ng mga rekomendasyon, alinsunod sa Batas na ito, ng anumang pag-angkin na isinumite sa Tribunal sa ilalim ng seksyon 6:

(aa) upang gumawa ng mga rekomendasyon, alinsunod sa seksyon 8D, na ang lupa o mga interes sa lupa ay hindi na napapailalim sa resumpsyon sa ilalim ng seksyon 27B ng StateOwned Enterprises Act 1986 o seksyon 212 ng Batas sa Edukasyon 1989:

(ab) upang gumawa ng mga rekomendasyon o pagtitiyak na ang Tribunal ay kailangan o nabigyang kapangyarihan na lumikha sa ilalim ng Schedule 1 of the Crown Forest Assets Act 1989:

(ac) upang gumawa ng mga rekomendasyon alinsunod sa seksyon 8HE na ang lupa, o anumang bahagi ng anumang lupa, na napapailalim sa isang lisensya sa kagubatan ng Crown sa ilalim ng Crown Forest Assets Act 1989, ay hindi na mananagot na ibalik sa pagmamay-ari ng Maori sa ilalim ng seksyon 36 ng Batas na iyon:

(ad) upang gumawa ng mga rekomendasyon alinsunod sa seksyon 8D (tulad ng inilapat ng seksyon $8 \mathrm{HJ}$ ) na ang lupa o anumang interes sa lupang iyon, kaagad bago isasama sa isang kumpanya ng transferee ng Crown alinsunod sa seksyon 6 ng New Zealand Railways Corporation Restructuring Act1990, ay lupang pag-aari ng Crown o interes na pagmamay-ari ng Crown sa lupa, ay hindi na mapapailalim sa resumpsyon sa ilalim ng seksyon 39 ng Batas na iyon:

(b) upang suriin at iulat, alinsunod sa seksyon 8, ang anumang iminungkahing lehislasyon na tinukoy sa Tribunal sa ilalim ng seksyong iyon.

\begin{tabular}{|c|c|}
\hline $\begin{array}{l}\text { Ang Pilipinas, } \\
\text { Pambansang } \\
\text { Komisyon sa } \\
\text { mga Katutubo na } \\
\text { Itinatag ng Batas sa } \\
\text { mga Karapatan ng } \\
\text { Mga Katutubo } \\
1997\end{array}$ & $\begin{array}{l}\text { Titulo, Tsapter } \\
\text { VII, partikular } \\
\text { sa seksyon } 38, \\
39 \text { at } 44\end{array}$ \\
\hline
\end{tabular}

Isang Batas upang kilalanin, protektahan at itaguyod ang mga karapatan ng mga kultural na pamayanang

katutubo/katutubo, na lumilikha ng isang Pambansang Komisyon sa mga Katutubo, na nagtatatag ng mga mekanismo ng pagpapatupad, naglalaan ng mga pondo doon, at para sa iba pang mga layunin.

TSAPTER VII Pambansang Komisyon sa Mga Katutubo(NCIP)

SEKSYON 38. Pambansang Komisyon sa Mga Katutubong Kultural na Komunidad / Mga Katutubo (NCIP).

-- Upang maisakatuparan ang mga patakaran na nakalagay dito, magkakaroon ng National Commission on ICCS/IPs (NCIP), na magiging pangunahing ahensya ng gobyerno na responsable para sa pagbuo at pagpapatupad ng mga patakaran, plano, at programa upang itaguyod at protektahan ang mga karapatan at kagalingan ng mga ICC/ IP at ang pagkilala sa kanilang mga ninunong dominyo pati na rin ang mga karapatan dito.

SEKSYON 39. Mandato. - Poprotektahan at isusulong ng NCIP ang interes at kagalingan ng mga ICC/IP na may pagsaalang-alang sa kanilang mga paniniwala, kaugalian, tradisyon at institusyon.

SEKSYON 44. Mga Kapangyarihan at Tungkulin. - Upang maisakatuparan ang mandato nito, ang NCIP ay dapat magkaroon ng mga sumusunod na kapangyarihan, hurisdiksyon at tungkulin:
Itinataguyod ang CONADI sa ilalim ng Ministry of Social Development and Family Itinataguyod ang Waitangi Tribunal bilang isang espesyalisadong komisyon ng pagtatanong na maaaring gumawa ng mga rekomendasyon sa mga pagangkin na inilabas ng mga katutubong Maori na may kaugnayan sa gobyerno at mga paglabag sa mga karapatan sa tratado
Itinatatag ang Pambansang Komisyon sa Mga Katutubo at tinutukoy ang mandato at mga pangunahing tungkulin nito 
a) Upang maglingkod bilang pangunahing ahensya ng gobyerno na kung saan ang mga ICC/IP ay maaaring humingi ng tulong sa gobyerno at bilang daluyan, kung saan maaaring mapalawig ang nasabing tulong; b) Upang suriin ang mga kondisyon ng mga ICC/IP kasama ang mga umiiral nang mga batas at patakaran na nauugnay dito at upang imungkahi ang mga nauugnay na batas at patakaran upang tugunan ang kanilang papel sa pambansang kaunlaran;

c) Upang magbalangkas at magpatupad ng mga patakaran, plano, programa at proyekto para sa ekonomiko, panlipunan at pangkulturang pagpapaunlad ng mga ICC/IP at upang masubaybayan ang pagpapatupad nito;

d) Upang humiling at makisali sa mga serbisyo at suporta ng mga eksperto mula sa iba pang mga ahensya ng gobyerno o gumamit ng mga pribadong eksperto at tagakonsulta na maaaring kailanganin sa pagtaguyod ng mga layunin nito;

e) Upang mag-isyu ng isang sertipiko ng titulo ng mga lupaing minana / domeyn;

f) Napapailalim sa umiiral na mga batas, upang makapasok sa mga kontrata, kasunduan, 0 kaayusan, kasama ang gobyerno o mga pribadong ahensya o entidad na maaaring kinakailangan upang makamit ang mga layunin ng Batas na ito, at napapailalim sa pag-apruba ng Pangulo, upang makakuha ng mga pautang mula sa mga institusyon sa pautang ng gobyerno at iba pang mga institusyon sa pautang upang tustusan ang mga programa nito;

g) Upang makipagnegosasyon para sa mga pondo at upang tanggapin ang mga grant, donasyon, regalo, at/o mga pag-aari sa anumang anyo at mula sa anumang mapagkukunan, lokal at internasyonal, na napapailalim sa pag-apruba ng Pangulo ng Pilipinas, para sa kapakinabangan ng mga ICC/IP at pangasiwaan pareho alinsunod sa mga tuntunin nito; o sa kawalan ng anumang kundisyon, sa paraang naaayon sa interes $\mathrm{ng}$ mga ICC/IP pati na rin sa mga umiiral na batas;

h) Upang iugnay ang mga programa sa pag-unlad at proyekto para sa pagsulong ng mga ICC/IP at upang mabantayan ang wastong pagpapatupad nito;

i) Upang magtawag ng mga pana-panahong kumbensiyon o pagpupulong ng mga IP upang suriin, tasahin pati na rin magmungkahi ng mga patakaran o plano;

j) Upang payuhan ang Pangulo ng Pilipinas sa lahat ng mga bagay na may kinalaman sa ICCs/IPs at magsumite sa loob ng animnapung (60) araw pagkatapos ng bawat taon ng kalendaryo, ng isang ulat ng mga operasyon at mga nakamit nito;

k) Upang isumite sa Kongreso ang naaangkop na mga panukalang lehislatibo na inilaan upang isakatuparan ang mga patakaran sa ilalim ng Batas na ito;

l) Upang maihanda at isumite ang naaangkop na badyet sa Opisina ng Pangulo;

m) Upang mag-isyu ng naaangkop na sertipikasyon bilang paunang kondisyon sa pagbibigay ng permiso, pag-upa, grant, o ano pa mang katulad na awtoridad para sa disposisyon, paggamit, pamamahala at paglalaan ng sinumang pribadong indibidwal, korporadong entidad o anumang ahensya ng gobyerno, korporasyon o subdibisyon nito sa anumang parte o bahagi ng ninunong dominyo na isinasaalang-alang ang nagkakaisang pag-apruba ng mga kinauukulang ICC/IP; 
n) Upang magpasya sa lahat ng mga apela mula sa mga desisyon at kilos ng lahat ng iba`t ibang tanggapan sa loob ng Komisyon;

o) Upang maiproklama ang kinakailangang mga patakaran at regulasyon para sa pagpapatupad ng Batas na ito;

p) Upang magamit ang iba pang mga kapangyarihan at tungkulin na maaaring idirekta ng Pangulo ng Republika ng Pilipinas.

\begin{tabular}{l|l}
$\begin{array}{l}\text { Estados Unidos, } \\
\text { Ang Komite ng } \\
\text { Senado tungkol } \\
\text { sa Indian Affairs }\end{array}$ & $\begin{array}{l}\text { Panuntunan sa } \\
\text { Senado XXV, }\end{array}$ \\
$\begin{array}{l}\text { Itinatag ng Senate } \\
\text { Resolution 4, Sec. }\end{array}$ & (2) at (3), at (c) \\
105, 95th Congress, \\
$\begin{array}{l}\text { 1st Session } \\
\text { 1977 }\end{array}$
\end{tabular}

(b) ...

(2) Tungkulin ng piling komite na magsagawa ng isang pag-aaral ng anuman at lahat ng mga bagay na nauugnay sa mga problema at pagkakataon ng mga Indian, kabilang ngunit hindi limitado sa, mga responsibilidad sa pamamahala sa lupaing Indian at tiwala sa responsibilidad, edukasyong Indian, kalusugan, mga espesyal na serbisyo, at mga programa sa pagpapautang, at mga pag-angkin ng Indian laban sa Estados Unidos.

(3) Ang piling komite ay dapat mag-ulat sa panapanahon sa Senado, sa pamamagitan ng panukalang batas o kung hindi man, ng mga rekomendasyon nito patungkol sa mga bagay na tinukoy sa piling komite o kung hindi man sa loob ng hurisdiksyon nito.

(c)(1) Para sa mga layunin ng seksyon na ito, ang piling komite ay pinahintulutan, sa paghuhusga nito,

(A) upang magsagawa ng mga pagsisiyasat sa anumang bagay sa loob ng hurisdiksyon nito...
Itinataguyod ang Committee on Indian Affairs kasama ang Senado ng Estados Unidos upang tingnan at mag-ulat sa Senado tungkol sa mga isyu na nauugnay sa mga katutubo

Nagbibigay sa Komite ng awtoridad sa pagsisiyasat 


\section{MGA NAPAG-ALAMAN}

Sagot sa tanong (Oo/Hiindi) at iba pang mga tala at obserbasyon tungkol sa kung gaano kahusay na tinutugunan $n g$ konstitusyon ang (mga) isyu na itinanong. Isama ang mga makabuluhang mga probisyon ((mga) numero $n g$ artikulo at teksto $n g$ (mga) probisyon). Tandaan din ang hindi konsistent at/o magkasalungat na mga probisyon, o kung walang umiiral na mga kaugnay na probisyon.

\section{MGA HAKBANG}

Iminungkahing adbokasiya at iba pang mga kasunod na hakbang upang matugunan o mapalaganap ang mga natuklasan. 


\title{
Pagprotekta at pagtataguyod sa mga karapatan ng mga katutubo
}

\author{
Ipinapahiwatig ba ng konstitusyon, sa maraming latag na estruktura \\ ng estado, kung aling (mga) antas ng pamahalaan ang pangunahing \\ responsable para sa koordinasyon, proteksyon at pagsulong $\mathrm{ng} \mathbf{m g a}$ \\ karapatan ng mga katutubo?
}

\section{PALIWANAG}

Bilang pagkilala sa karapatang sa sariling pagpapasya at mga kasamang karapatanawtonomiya at sariling pamahalan, ang pinakamahusay na kasanayan mula sa pananaw ng mga karapatan ng mga katutubo ay kilalanin ang mga katutubo at kanilang tradisyunal na awtoridad bilang isang kapantay na sangay o antas ng gobyerno sa loob ang estado. Kung saan ang mga katutubo ay may teritoryal na awtonomiya, ang kanilang mga institusyon na sariling nmamahala ay maaaring isama sa mga institusyon ng estado sa pantay na pamantayan sa iba pang mga yunit ng subnasyunal. Sa kabila ng pinakamahusay na kasanayang ito, ang mga konstitusyon sa isang maraming baitang na estruktura ng estado ay madalas na magtalaga ng isang antas ng pamahalaan na sa huli ay responsable para sa pagkonsulta at pakikipagnegosasyon sa mga kasunduan at ugnayan sa mga katutubo, at posible rin para sa pagtataguyod at pagprotekta sa mga karapatan ng mga katutubo. Partikular na mahalaga ito para sa pederal o lubos na desentralisadong mga estado kung saan nakatira ang mga pamayanan ng mga katutubo sa loob (at lampas) ng mga hangganan ng teritoryo. Bilang bahagi ng isang pagtatasa sa konstitusyon ng mga karapatan ng mga katutubo, mahalagang maunawaan kung ang konstitusyon ay nagtatalaga ng mga naturang kakayahan/awtoridad sa isang antas o mga antas ng pamahalaan at, kung gayon, kung aling antas o mga antas. Ang atas o saklaw ng kakayahan na ito ay tumutukoy sa mga pangunahing stakeholder sa mga ugnayang katutuboestado at binabalangkas ang mga kaugnay na proseso at mekanismo upang protektahan, respetuhin at itaguyod ang mga karapatan ng mga katutubo.

Ang mga pamamaraang konstitusyonal ay may maraming anyo. Sa Estados Unidos, ang pamahalaang pederal (sentral) ay may pangunahing responsibilidad para sa pamamahala ng mga gawain sa mga nasyong India ngunit, sa praktika, ang ilan sa mga pinagsanib na estado ng USA ay nakabuo din ng mga ugnayan, batas, at patakaran upang tugunan ang mga isyu ng mga katutubo, at ang pederal na gobyerno ay binabaan ang ilang mga responsibilidad na nauugnay sa mga tribo sa mga gobyerno ng estado sa pamamagitan ng pambansang lehislasyon. Sa Canada at Mehiko, ang responsibilidad para sa mga karapatan ng mga katutubo ay ibinabahagi ng iba't ibang antas ng gobyerno. Sa praktika, ang Canada ay gumamit ng isang hanay ng pantay na 'patakaran sa lupa' para sa negosasyon ng konstruktibong kaayusan sa mga katutubo na kinakailangang kasangkot ang mga katutubong nasyon, mga awtoridad ng probinsya (substate) at pamahalaang pederal. Ang kakayahan para sa proteksyon at pagsulong ng mga karapatan ng mga katutubo sa pambansang antas samakatwid ay ibinabahagi sa pamahalaang pederal at mga lalawigan. Sa Mehiko, ang ibinahaging responsibilidad na ito ay mas malinaw, kasama ang mga partikular na obligasyon ng pederal, estado, at mga lokal na awtoridad na detalyado sa Konstitusyon.

Kahit na sa mga bansang hindi pederal, ito ay isang mahalagang isyu na dapat isaalang-alang. Halimbawa, sa Pilipinas, ang awtonomong pamahalaan sa Bangsamoro ay binibigyan ng kakayahang pamahalaan ang mga isyu at ugnayan ng mga katutubo sa antas ng subnasyunal. Ang nasyonal na pamahalaan sa Pilipinas ay nagpapanatili ng responsibilidad na ito sa buong bansa ngunit ang isang espesyal na pagbubukod ay ginawa ng Bangsamoro Organic Law na nagbibigay sa Pamahalaang Bangsamoro ng pagbabahagi ng awtoridad sa mga gawain ng mga katutubo. Maaari itong maging positibo ngunit maaari ring iwanan ang mga katutubo na bulnerable sa kakulangan ng mga serbisyo at proteksyon kung ang paglilinya ng awtoridad ay hindi malinaw. 


\begin{tabular}{|c|c|c|}
\hline $\begin{array}{l}\text { Konstitusyon } \\
\text { ng Mehiko } \\
1917\end{array}$ & Artikulo 2 & $\begin{array}{l}\text {... Ang karapatan ng mga katutubo sa sariling } \\
\text { pagpapasya ay dapat isailalim sa Konstitusyon } \\
\text { upang masiguro ang pagkakaisang pambansa. } \\
\text { Ang mga konstitusyon at batas ng mga Estado } \\
\text { at Pederal na Distrito ay dapat kilalanin ang mga } \\
\text { katutubo at pamayanan, isinasaalang-alang ang mga } \\
\text { pangkalahatang prinsipyo na itinatag sa mga nakaraang } \\
\text { talata, pati na rin ang pamantayang etniko-linggwistiko } \\
\text { at pag-areglo sa lupa. } \\
\text { A. ...Ang mga konstitusyon at batas ng Estadoat ang } \\
\text { Pederal na Distrito ay magtatatag ng mga elemento } \\
\text { ng sariling pagpapasya at awtonomiya na maaring } \\
\text { pinakamahusay na maipahayag ang mga kondisyon } \\
\text { at mithiin ng mga katutubo sa bawat Estado, pati na } \\
\text { rin ang mga patakaran, alinsunod sa kung aling mga } \\
\text { katutubong pamayanan ang natukoy bilang mga } \\
\text { entidad ng interes ng publiko. } \\
\text { B. Upang maitaguyod ang pantay na mga pagkakataon } \\
\text { para sa mga katutubo at matanggal ang mga } \\
\text { kasanayan sa diskriminasyon, ang Pederasyon, } \\
\text { Pederal na Ditito, ang mga Estado, at ang } \\
\text { mga lokal na konseho ay magtatatag ng mga } \\
\text { kinakailangang institusyon at patakaran upang } \\
\text { magarantiyahan ang mga karapatan ng mga } \\
\text { katutubo at komprehensibong pagpapaunlad ng } \\
\text { mga pamayanang katutubo. Ang mga nasabing } \\
\text { institusyon at patakaran ay dapat na idinisenyo at } \\
\text { patakbuhin kasama nila. }\end{array}$ \\
\hline
\end{tabular}

Konstitusyon ng Estados Unidos 1789
Artikulo 1, seksyon 8
Ang Kongreso ay magkakaroon ng Kapangyarihan ...

Upang maregula ang Komersyo sa mga banyagang Nasyon, at kabilang sa maraming mga Estado, at sa mga Tribo ng India.
Inilalagay ang responsibilidad na protektahan at itaguyod

ang mga karapatan ng mga katutubo, kabilang ang mga karapatan sa sariling pagpapasya, sa mga awtoridad ng pederal, estado, at lokal na konseho

May kasamang isang serye ng mga tiyak na obligasyon ng estado sa pagtatapos na ito

Nagbibigay sa Kongreso (pambansang pamahalaan) ng awtoridad na pangalagaan ang kalakalan-at sa mga teoryang ugnayan - sa mga katutubo

Tala: Sa kabila ng konstitusyonal na pagtatalaga ng mga usaping Indian sa pamahalaang pederal, maraming mga pederal na batas ang nagbigay sa mga estado $\mathrm{ng}$

isang antas ng hurisdiksyon o kapwa-hurisdiksyon sa mga bagay na nauugnay sa katutubo. Kasama sa mga batas na ito ang:

- Public Law Act 280 (1953), na nagpapahintulot sa limang (sub) estado na ipagpalagay ang pangkalahatang kriminal at ilang sibil na hurisdikasyon sa mga reserbasyong Indian (lupang tribo) sa loob ng mga estado

- Indian Child Welfare Act (1978), na nagtatag ng mga pamamaraan at dalawahang hurisdiksyon sa pagitan ng mga estado at mga tribo, at pagsasandig sa mga tribong pamahalaan

Binibigyan ang pamahalaan ng Bangsamoro Autonomous Region ng kakayahan/awtoridad na pamahalaan

ang isyu ng mga karapatan ng mga katutubo

(ss. ) Karapatan ng mga katutubo; 


\section{MGA NAPAG-ALAMAN}

Sagot sa tanong (Oo/Hiindi) at iba pang mga tala at obserbasyon tungkol sa kung gaano kahusay na tinutugunan $n g$ konstitusyon ang (mga) isyu na itinanong. Isama ang mga makabuluhang mga probisyon ((mga) numero $n g$ artikulo at teksto $n g$ (mga) probisyon). Tandaan din ang hindi konsistent at/o magkasalungat na mga probisyon, o kung walang umiiral na mga kaugnay na probisyon.

\section{MGA HAKBANG}

Iminungkahing adbokasiya at iba pang mga kasunod na hakbang upang matugunan o mapalaganap ang mga natuklasan. 


\section{Pagprotekta at pagtataguyod sa mga karapatan ng mga katutubo}

\section{9 'pasama ba sa konstitusyon ang mga patakaran para sa ang karapatan ng mga katutubo sa pag-abot sa korte?}

PALIWANAG

Ang pagkakaroon ng mga karapatan sa papel ay mahalaga ngunit upang matiyak na ang mga karapatang ito ay makabuluhan, ang mga katutubo ay dapat na magdala ng mga kaso na hinahamon ang mga aksyon at batas ng gobyerno na sumasalungat sa mga karapatang ito. Ang kakayahang magdala ng mga kaso ay madalas na natutukoy sa malaking bahagi ng isyu ng 'paninindigan'. Ang paninindigan ay ang kakayahan ng isang partido (isang tao, samahan o iba pang ligal na nilalang) na magdala ng isang demanda sa korte o upang 'manindigan' sa harap ng isang hukom. Ang paninindigan ay isang katangiang tinukoy ayon sa batas sa ugnayan sa pagitan ng partido at ng aksyon ng gobyerno o batas na hinahamon. Ang paninindigan ay maaaring tukuyin sa konstitusyon ukol sa mga tiyak na karapatan, tulad ng pangunahing mga karapatan, pati na rin sa mga batas.

Ito ay isang partikular na mahalagang isyu para sa mga katutubo na ayon sa kasaysayan ay pinagkaitan ng paninindigan noong nakaraan, bilang bahagi ng makasaysayang pagsisikap na pagkaitan ang soberanya ng mga katutubo bilang mga mamamayan, at kanilang dignidad bilang mga indibidwal. Halimbawa, noong 1919 ang Privy Council, ang pinakamataas na korte sa British Empire, ay tumanggi na kilalanin ang ligal na personalidad ng mga katutubo dahil sa kanilang pagiging 'napakababa sa sukat ng organisasyong panlipunan na ang kanilang mga paggamit at konsepto ng mga karapatan at tungkulin ay hindi dapat ipagkasundo sa mga institusyon at ligal na ideya ng sibilisadong lipunan' (Goodhart 2016). Noong 1928, ang Permanent Court of International Arbitration ay inangkin na ang mga katutubo ay walang paninindigan habang inilalarawan sila bilang 'taong mabangis' (ibid.). Upang mapigilan ang mga maling sanhi ng mga pananaw na ito at ang kanilang kinahinatnan na pagkakait sa mga karapatan ng mga katutubo upang makamit ang hustisya at sa mabisang pagremedyo para sa mga paglabag sa mga karapatan, napakahalaga na makilala ang paninindigan ng mga katutubo.

Sa pangkalahatan, ang mas malawak na mga panuntunan sa paninindigan ay nangangahulugang mas bukas at mas malawak na pag-akses para sa mga marhinalisadong indibidwal at grupo sa pormal na sistema ng hustisya ng estado. Para sa maraming mga isyu, ang paninindigan ay nangangailangan na ang partido na naghahabol ay may koneksyon sa, at nakaranas ng ilang uri ng pinsala mula sa, kilos o batas na pinag-uusapan. Gayunpaman, ang nexus sa pagitan ng mga kahulugan ng 'koneksyon' at 'pinsala' ay magkakaiba. Ang pagpapahintulot sa isang indibidwal o pangkat na hindi kinakailangang nakaranas ng direkta (hal. personal) na pinsala upang magdala ng isang kaso sa ngalan ng iba ay nangangahulugang ang mga may higit na mapagkukunan ay maaaring ligal na magtaguyod para sa mga may mas kaunting mapagkukunan. Dagdag dito, pinapayagan ang paninindigan para sa mga kaso na nagdudulot ng ipotetikong pinsala (sa halip na nangangailangan ng tunay na pinsala) ay pinoprotektahan ang mga katutubo na maaaring makaranas ng pinsala kung ang isang aksyon o batas ng gobyerno ay pinapayagan na magpatuloy. Ang paninindigan ay nauugnay din sa isyu ng pagkilala sa mga kolektibo bilang may-ari ng mga karapatan at mga ligal na entidad (tingnan ang Tanong 8), hangga't maaari nitong matukoy kung may paninindigan ang mga kolektibo. Dahil dito, maraming mga halimbawa ng paninindigan ang nasasakop sa Tanong 8. Sa Ecuador noong 2017, ang mga katutubo ay nakapagdala ng kaso laban sa mga kumpanya ng palm oil batay sa kanilang ligal na personalidad bilang isang kolektibo at mga karapatan na bagong iginawad sa kalikasan noong 2008 Konstitusyon; ang kasong ito ay ang una din kung saan ang 'kalikasan' ay binigyan ng ligal na katayuan, kasama ang mga katutubong komunidad ng La Chiquita at ang pamayanang Awá ng Guadualito.

Ang isang ombudsman o espesyalisadong komisyon ng gobyerno (tingnan ang Tanong 27) ay maaari ring bigyan ng awtoridad na hamunin ang konstitusyonalidad ng isang batas o aksyon ng gobyerno. Ang nasabing probisyon ay lalong nagpapalawak ng pag-akses sa hustisya para sa mga may mas kaunting mapagkukunan, dahil pinapayagan nito ang ombudsman o komisyon na magsagawa ng mga konstitusyonal na paglabag nang direkta sa mga korte at hindi umaasa sa mga mapagkukunan at kakayahan ng mga indibidwal at mga hindi pang-gobyernong organisasyon. Sa kawalan ng naturang probisyon, ang pagtiyak sa pag-akses sa ligal na tulong para sa mga maaaring magkaroon ng problema sa pag-akses sa mga korte ay lalong nagiging mahalaga. 


\begin{tabular}{|c|c|c|c|}
\hline $\begin{array}{l}\text { Konstitusyon } \\
\text { ng Argentina } \\
1994\end{array}$ & Artikulo 43 & $\begin{array}{l}\text { Ang sinuman ay maaaring umapela nang madalian } \\
\text { at mabilis na pagkilos ng ‘amparo,' sa tuwing walang } \\
\text { umiiral na ibang naaangkop na paraang hudisyal, laban } \\
\text { sa anumang kilos o omisyon ng mga pampublikong } \\
\text { awtoridad o ng mga pribadong indibidwal, na } \\
\text { kasalukuyan o nagbabanta ng pinsala, pagpigil, pagbago } \\
\text { o pananakot, sa isang arbitraryo o maliwanag na iligal } \\
\text { na pamamaraan, ang mga karapatan at garantiyang } \\
\text { kinikilala ng Konstitusyong ito, ng isang tratado, } \\
\text { o ng isang batas. Kung naaangkop, ang hukom ay } \\
\text { maaaring ideklara ang pamantayan kung saan ang hindi } \\
\text { nakapipinsalang kilos o omisyon ay natagpuang hindi } \\
\text { konstitusyonal. [Kapag] ang aksyon na ito ay nagreklamo } \\
\text { ng anumang uri ng diskriminasyon, o umuukol sa mga } \\
\text { karapatang nagpoprotekta sa kapaligiran, kumpetisyon, } \\
\text { gumagamit, konsyumer, o mga karapatan kolektibo } \\
\text { ang kalikasan sa pangkalahatan, maaari itong dalhin } \\
\text { ng apektadong partido, ang Tagapagtanggol ng mga } \\
\text { Mamamayan [ombudsman], at ang mga asosasyong } \\
\text { sumusuporta sa mga layuning ito ay nakarehistro } \\
\text { ayon sa hinihiling ng isang batas na tutukoy sa mga } \\
\text { kinakailangan at anyo ng kanilang samahan. }\end{array}$ & $\begin{array}{l}\text { Nagsasaad na kapag ang } \\
\text { lahat ng iba pang mga ligal } \\
\text { na remedyo ay hindi sapato } \\
\text { kulang, ang isang apektadong } \\
\text { indibidwal o isang taong } \\
\text { kumikilos sa kanilang ngalan ay } \\
\text { maaaring lumapit sa korte } \\
\text { Binibigyan ng kapangyarihan } \\
\text { ang Ombudsman bilang isang } \\
\text { tagapagtanggol ng mga } \\
\text { mamamayan upang isulong } \\
\text { ang anumang kaso, partikular } \\
\text { ang mga koektibo sa likas na } \\
\text { katangian, na may kaugnayan sa } \\
\text { diskriminasyon o mga banta sa } \\
\text { kapaligiran }\end{array}$ \\
\hline $\begin{array}{l}\text { Konstitusyon } \\
\text { ng Ecuador } \\
2008\end{array}$ & $\begin{array}{l}\text { Artikulo 10, } \\
\text { 11(1) at } 71\end{array}$ & $\begin{array}{l}\text { TITULO II. MGA KARAPATAN } \\
\text { TSAPTER 1. PRINSIPYO PARA SA PAGPAPATUPAD NG } \\
\text { KARAPATAN } \\
\text { ARTIKULO } 10 \\
\text { Ang mga tao, pamayanan, mamamayan, at bansa ay } \\
\text { may taglay na mga karapatan at tatangkilikin ang mga } \\
\text { karapatang garantisado sa kanila sa Konstitusyon at sa }\end{array}$ & $\begin{array}{l}\text { Kinikilala ang mga kolektibo } \\
\text { at ang kalikasan bilang may- } \\
\text { aring mga karapatan na may } \\
\text { paninindigan upang mapanagot } \\
\text { ang gobyerno. Tandaan na } \\
\text { bahagi ito ng kabanata tungkol } \\
\text { sa pagpapatupad ng mga } \\
\text { karapatan }\end{array}$ \\
\hline
\end{tabular}

mga internasyunal na instrumento.

Ang kalikasan ay magiging paksa ng mga karapatang kinikilala ng Saligang Batas para dito.

\section{ARTIKULO 11}

Ang paggamit ng mga karapatan ay dapat mapamahalaan ng mga sumusunod na alituntunin:

1. Ang mga karapatan ay maaaring gamitin, maisulong at ipatupad nang indibidwal o kolektibo sa harap ng mga may kakayahang awtoridad; igagarantiya ng mga awtoridad na ito ang kanilang pagpapatupad.

\section{TSAPTER 7. MGA KARAPATAN SA KALIKASAN}

\section{ARTIKULO 71}

Ang kalikasan, o Pacha Mama, kung saan ang buhay ay muling ginawa at nangyayari, ay may karapatang magsama ng integral na paggalang

para sa pag-iral nito at para sa pagpapanatili at pagpapanumbalik ng mga siklo ng buhay, estruktura, mga tungkulin at proseso ng ebolusyon.

Ang lahat ng mga tao, pamayanan, mamamayan at bansa ay maaaring manawagan sa mga pampublikong awtoridad na ipatupad ang mga karapatan ng kalikasan. Upang ipatupad at bigyang kahulugan ang mga karapatang ito, ang mga prinsipyong nakalagay sa Konstitusyon ay dapat sundin, kung naaangkop.

Konstitusyon ng Seksyon 38
Timog Aprika
1996

Nagbibigay sa kalikasan ng mga tiyak na karapatan at binibigyan ng kapangyarihan ang mga tao na maghain ng mga kaso sa ngalan ng kalikasan, sa gayon ay nagbibigay ng paninindigan $n g$ kalikasan sa korte
Ang sinumang nakalista sa seksyon na ito ay may karapatang lumapit sa isang karampatang korte, na nagsasabing ang isang karapatan sa Katipunan ng mga Karapatan ay nilabag o binantaan, at ang korte ay maaaring magbigay ng naaangkop na kaluwagan, kabilang ang isang pagdeklara ng mga karapatan. Ang mga taong maaaring lumapit sa isang korte ay:

a. sinumang kumikilos sa kanilang sariling interes;

b. sinumang kumikilos sa ngalan ng ibang tao na hindi kayang kumilos sa kanilang sariling pangalan;
Nagbibigay ng napakalawak na katayuan sa pamamagitan ng pagtiyak na ang Ombudsman, mga apektadong indibidwal at pati na rin ang iba na hindi apektado (mga indibidwal o grupo) ay maaaring lumapit sa korte para sa nakaraan o inaasahang mga paglabag sa karapatan 


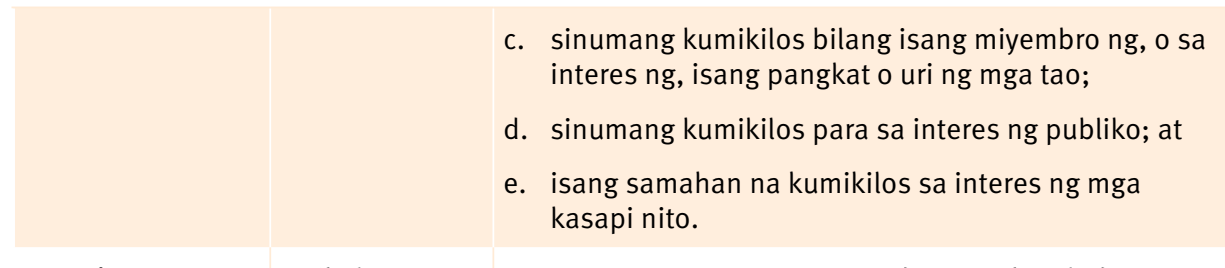

Konstitusyon Artikulo 85 ng Zimbabwe 2013

\begin{tabular}{l|l|}
$\begin{array}{l}\text { New Zealand, } \\
\text { Kasunduan } \\
\text { ng Tutohu } \\
\text { Whakatupua } \\
2012\end{array}$ & Parapo 2.4, \\
\hline
\end{tabular}
mga karapatan at isang gawa ng kompensasyon.
1. Anuman sa mga sumusunod na tao, katulad ng-

a. sinumang kumikilos sa kanilang sariling interes;

b. sinumang kumikilos sa ngalan ng ibang tao na hindi maaaring kumilos para sa kanilang sarili;

c. sinumang na kumikilos bilang isang miyembro, 0 para sa interes, ng isang pangkat o klase ng mga tao;

d. sinumang kumikilos para sa interes ng publiko;

e. anumang samahan na kumikilos para sa interes ng mga kasapi nito; ay may karapatang lumapit sa isang korte, na sinasabing ang isang pangunahing karapatan o kalayaan na nakalagay sa Tsapter na ito [Tsapter 4: Deklarasyon ng Mga Karapatan], ay nilabag, o nilalabag o malamang na natapakan, at ang korte ay maaaring magbigay ng naaangkop na kaluwagan, kabilang ang isang pagdeklara ng

2. Ang katotohanang ang isang tao ay lumabag sa isang batas ay hindi nagdedebar sa kanila mula sa paglapit sa isang korte para sa kaluwagan sa ilalim ng subseksyon (1).

3. Ang mga patakaran ng bawat korte ay dapat magbigay ng pamamaraan na susundan sa mga kaso kung saan hinahangad ang kaluwagan sa ilalim ng subseksyon (1), at dapat matiyak ng mga patakarang iyon-

a. ang karapatang lumapit sa korte sa ilalim ng subseksyon (1) ay ganap na pinamahalaan;

b. ang mga pormalidad na nauugnay sa paglilitis, kasama na ang kanilang pagsisimula, ay pinananatili sa minimum;

c. ang korte, habang sinusunod ang mga patakaran sa likas na hustisya, ay hindi wala sa katwirang pinaghihigpitan ng mga teknikal na pamamaraan; at

d. ang isang taong may partikular na kadalubhasaan ay maaaring, na may pahintulot ng korte, lumitaw bilang isang kaibigan ng korte.

2.4 Ang kasunduan ay magbibigay para sa pagkilala ayon sa batas ng Ilog Whanganui bilang Te Awa Tupua. Ang mga nakasaad na salita para sa pagkilala ayon sa batas ng Te Awa Tupua ay ang mga sumusunod:

Ang Te Awa Tupua ay binubuo ng Ilog Whanganui bilang isang hindi nahahati at nabubuhay na buo, mula sa

bundok tungong dagat, isinasama ang mga tributaryo at lahat ng mga pisikal at metapisikal na elemento.

2.6 Ang pagsasaayos ay magbibigay para sa pagkilala sa Te Awa Tupua bilang isang ligal na entidad.

2.7 Ang paglikha ng isang ligal na personalidad para sa Ilog ay inilaan na:

2.7.1 sumasalamin sa pananaw $\mathrm{ng}$ Whanganui Iwi na ang $\mathrm{llog}$ ay isang buhay na entidad sa sarili nitong karapatan at walang kakayahang 'pagmay-arian' sa isang absolutong kahulugan; at

2.7.2 paganahin ang llog na magkaroon ng ligal na katayuan sa sarili nitong karapatan.
Pinapayagan para sa mga apektadong indibidwal o grupo, o iba pa na kumikilos sa kanilang ngalan o para sa interes $n g$ publiko, upang lapitan ang korte para sa nakaraan o inaasahang mga paglabag sa karapatan

Nagmamandato na ang mga pamamaraan ng korte ay namamahala sa pagkamit ng hustisya para sa lahat

\section{Kinakatawan ang isang}

halimbawa ng pagbibigay ng isang entidad na ligal na "paninindigan'; umuukol sa pinsala sa kapaligiran, ang isang pangkat ng katutubo ang nagdala $n g$ isang panukala upang bigyan ang isang tiyak na ilog ng sarili nitong ligal na katayuan-kinilala ng korte ang kahalagahan ng ilog at binigyan ito ng sarili nitong ligal na personalidad 


\section{MGA NAPAG-ALAMAN}

Sagot sa tanong (Oo/Hiindi) at iba pang mga tala at obserbasyon tungkol sa kung gaano kahusay na tinutugunan $n g$ konstitusyon ang (mga) isyu na itinanong. Isama ang mga makabuluhang mga probisyon ((mga) numero $n g$ artikulo at teksto $n g$ (mga) probisyon). Tandaan din ang hindi konsistent at/o magkasalungat na mga probisyon, o kung walang umiiral na mga kaugnay na probisyon.

\section{MGA HAKBANG}

Iminungkahing adbokasiya at iba pang mga kasunod na hakbang upang matugunan o mapalaganap ang mga natuklasan. 


\section{Pagprotekta at pagtataguyod sa mga karapatan ng mga katutubo}

\section{0}

Ginagarantiya ba ng konstitusyon ang ligal na tulong para sa mga tao at
pangkat na hindi kayang bayaran ang pribadong ligal na representasyon?

PALIWANAG

Tulad ng nabanggit sa Tanong 29 sa paninindigan, ang mga karapatan ay may katuturan lamang hangga't maaari itong ipatupad. Ang isang panimulang isyu para sa pagpapatupad ng mga karapatan ay ang paninindigan, o ang kakayahan ng mga tao na magdala ng mga kaso laban sa gobyerno dahil sa mga paglabag sa kanilang mga karapatan. Kahit na ang mga indibidwal o grupo ay mayroong paninindigan, subalit, ang pag-akses sa mga korte ng hustisya at pagkuha ng epektong litigasyon at iba pang mga pangunahing kaso ay magastos, burukratikong kumplikado at labis na gugugol ng oras. Maraming marhinalisadong mamamayan ang nahihirapan sa kakayahang barayan ang mga abugado na tutulong sa kanila sa pagsulong ng kaso at pag-navigate sa sistemang ligal. Dahil dito, upang matiyak ang pantay na pag-akses sa hustisya, hindi bihira para sa mga konstitusyon na magbigay ng isang karapatan sa ligal na representasyon na sumasaklaw sa isang karapatan sa isang abugadong pinopondohan ng publiko kung sakaling ang indibidwal o grupo ay hindi kayang kumuha o makakuha ng pribadong ligal na representasyon.

Ang karapatang sa ligal na tulong (suporta upang magbayad para sa ligal na representasyon at payo, o walang bayad na ligal na representasyon at payo na ibinigay ng estado) ay maaaring maging napakaimportante upang pahintulutan ang mga mamayang marhinalisado at ekonomikong desbentahado na magkaroon ng pantay na pagakses sa sistema ng hustisya. Ang isang mahalagang pagsasaalang-alang kapag tinatasa ang mga probisyon sa ligal na tulong ay kung ang garantiya ay nalalapat sa mga kasong sibil at administratibo pati na rin ang mga kaso sa kriminal na batas. Napakahalaga nito para sa mga katutubo na ang mga karapatan ay sumasaklaw sa mga isyu tulad ng lupa at pag-aari, pati na rin ang representasyon sa gobyerno. Ang pagtiyak sa ligal na tulong para sa lahat ng mga kaso ay ang pinakamahusay na praktika ngunit maraming mga bansa ang naglilimita sa pagkakaloob ng ligal na tulong na probisyon sa mga nasasakdal na nahaharap sa mga kasong kriminal. Ang isa pang pagsasaalang-alang ay kung ang ligal na tulong ay limitado sa mga mamamayan o naipaabot sa lahat ng mga residente o mamamayan na nahaharap sa mga kaso sa isang korte ng batas.

MGA PAMANTAYANG PANG-INTERNASYUNAL AT PAMBANSANG MGA HALIMBAWA

\begin{tabular}{l|l|}
$\begin{array}{l}\text { Mga Alituntunin } \\
\text { at Patnubay ng }\end{array}$ & Parapo 26, 32 \\
United Nations & at 33 \\
sa Pag-akses sa & \\
Ligal na Tulong sa & \\
Criminal Justice & \\
Systems & \\
2013 &
\end{tabular}

26. Dapat tiyakin ng mga estado ang pagbibigay ng ligal na tulong sa lahat ng mga tao anuman ang edad, lahi, kulay, kasarian, wika, relihiyon o paniniwala, pampulitika o iba pang mga opinyon, nasyonal o panlipunang pinagmulan o pag-aari, pagkamamamayan o tirahan, kapanganakan, edukasyon o katayuan sa lipunan o ibang katayuan.

32. Ang mga espesyal na hakbang ay dapat gawin upang matiyak ang makabuluhang pag-access sa ligal na tulong para sa mga kababaihan, bata at mga pangkat na may espesyal na pangangailangan, kabilang ang, ngunit hindi limitado sa, mga matatanda, minorya, mga taong may kapansanan, mga taong may sakit sa pag-iisip, mga taong nabubuhay na may HIV at iba pang mga seryosong nakakahawang sakit, gumagamit ng droga, katutubo at natibong mamamayan, taong walang estado, mga naghahanap ng asilo, mga dayuhang mamamayan, mga migrante at mga manggagawang migrante, mga refugee, at mga taong pinalayas sa sariling tahanan. Ang nasabing mga hakbang ay dapat tumutugon sa espesyal na pangangailangan ng mga grupong iyon, kabilang ang mga sensitibo sa kasarian at naaangkop sa edad na hakbang.

33. Ang mga estado ay dapat ding tiyakin na ang ligal na tulong ay ibinibigay sa mga taong naninirahan sa kanayunan, malayo, at pang-ekonomiko at panlipunang desbentahadong mga lugar at sa mga taong kasapi ng mga pangkat na desbentahado sa ekonomiya at lipunan.
Kinikilala ang partikular na kahalagahan ng ligal na tulong para sa mga marhinalisadong komunidad, kabilang ang mga katutubo at ang mga nakatira sa malalayong lugar 


\begin{tabular}{l|l} 
Konstitusyon & Artikulo $39 \mathrm{~A}$ \\
ng India &
\end{tabular}

\section{9}

\begin{tabular}{|c|c|c|}
\hline $\begin{array}{l}\text { Kazakhstan } \\
\text { Constitution } \\
1995\end{array}$ & Artikulo 13(3) & $\begin{array}{l}\text { 3. Ang bawat isa ay may karapatan sa kwalipikadong legal } \\
\text { na tulong. Sa mga kasong itinakda ng batas, ang ligal na } \\
\text { tulong ay dapat ibigay nang walang bayad. }\end{array}$ \\
\hline
\end{tabular}

$\begin{array}{ll}\text { Konstitusyon ng } & \text { Artikulo II, } \\ \text { Marshall Islands } & \text { seksyon 4(4) }\end{array}$ 1979

$\begin{array}{ll}\begin{array}{l}\text { Ang Konstitusyon } \\ \text { ng Pilipinas }\end{array} & \begin{array}{l}\text { Artikulo III, } \\ \text { seksyon 11 at } \\ 1987\end{array} \\ \begin{array}{l}\text { artikulo VIII, } \\ \text { seksyon 5 }\end{array}\end{array}$

Konstitusyon

Artikulo 108 2014

Finland, Batas sa
Ligal na Tulong
2002

Sisiguraduhin ng Estado na ang pagpapatakbo ng sistemang ligal ay nagtataguyod ng hustisya, batay sa pantay na pagkakataon, at dapat, sa partikular, pagbibigay ng libreng ligal na tulong, sa pamamagitan ng angkop na batas o mga iskema o sa anumang iba pang paraan, upang matiyak na ang mga pagkakataon para sa pagsigurado ng hustisya ay hindi ipinagkakait sa sinumang mamamayan dahil sa pang-ekonomiko o iba pang mga kapansanan.

Sa lahat ng kriminal na prosekusyon, tatamasain ng akusado ang karapatang masabihan kaagad at detalyado ng kalikasan at sanhi ng akusasyon laban sa kanya; upang simulan ang isang pagpapasyang panghukuman kung mayroong mabuting dahilan upang hawakan siya para sa paglilitis; sa isang mabilis at pampublikong paglilitis sa harap ng isang walang kinikilingan na tribunal; upang magkaroon ng sapat na oras at pasilidad para sa paghahanda ng kanyang pagtatanggol; upang ipagtanggol ang kanyang sarili nang personal o sa pamamagitan ng ligal na tulong na kanyang sariling piniliat, kung kulang siya sa pondo upang makuha ang naturang tulong, upang tanggapin ito nang walang bayad kung kinakailangan ng mga interes ng hustisya; upang harapin ang mga saksi laban sa kanya, at magkaroon ng sapilitang proseso para sa pagkuha ng mga saksi na pabor sa kanya.

Artikulo III, seksyon 11

Ang libreng pag-akses sa mga korte at mga quasi-hudisyal na kinatawan at sapat na ligal na tulong ay hindi ipagkakait sa sinuman dahil sa kahirapan.

Artikulo VIII, seksyon 5

Ang Korte Suprema ay magkakaroon ng mga sumusunod na kapangyarihan:

...

5. Magproklama ng mga patakaran tungkol sa pangangalaga at pagpapatupad ng mga konstitusyonal na karapatan, pagsusumamo, kasanayan, at proseso sa lahat ng mga korte, ang admisyon sa pagsasagawa ng batas, ang Integrated Bar, at ligal na tulong sa mga mahihirap. Ang nasabing mga panuntunan na dapat magbigay $\mathrm{ng}$ isang pinasimple at murang pamamaraan para sa mabilis na disposisyon ng mga kaso, ay magiging pare-pareho para sa lahat ng mga korte ng parehong antas, at hindi dapat bawasan, taasan, o baguhin ang mga substantibong karapatan.

Ang karapatan sa litigasyon at ang karapatan sa pagtatanggol ay ginagarantiyahan. Pinamahalaan ng batas ang pag-akses sa hustisya at nagbibigay ng ligal na tulong sa mga walang kakayahan sa pananalapi.

1) Ang ligal na tulong ay ibibigay sa mga taong naninirahan sa Finland, pati na rin sa mga mamamayan ng isang kasaping estado ng European Union o sa European Economic Area na nagtatrabaho o naghahanap ng trabaho sa Finland, tulad ng hinihiling ng Regulasyon sa kalayaan sa pagkilos para sa mga manggagawa sa loob ng Komunidad (EEC) Blg. 1612/68 at ang Kasunduan sa European Economic Area.

2) Bilang karagdagan, ang ligal na tulong ay ibibigay anuman ang mga pamantayan na isinaad sa parapo (1), kung ang tao ay may isang bagay na dapat dinggin $\mathrm{ng}$ isang korte $\mathrm{ng}$ batas ng Finnish o kung mayroon man isang espesyal na dahilan para ibigay ang tulong na ligal. Ang ligal na payo, bilang bahagi ng ligal na tulong, ay dapat ibigay anuman ang mga pamantayan na inilaan sa parapo (1) sa ilalim ng mga kundisyon na inilatag sa Convention on International Access to Justice (TrS 47/1988).
Nagsasaad na ang sistema ng hustisya ay batay sa prinsipyo ng pantay na pagkakataon at walang sinumang mamamayan ang pagkakaitan sa pag-access sa hustisya

sa pang-ekonomiko o iba pang mga desbentaha

Nagbibigay ng malawak na karapatan sa ligal na tulong sa lahat ng mga mamamayan

Iginagarantiya ang ligal na tulong ngunit para lamang sa mga akusado sa mga kasong kriminal

Nagsasaad ng ligal na tulong sa lahat ng mga kaso anuman ang uri, ngunit partikular na kasama ang mga kaso na kinasasangkutan ng paglabag sa mga karapatang konstitusyonal

Nagbibigay ng ligal na tulong para sa lahat ng nangangailangan nito, anuman ang uri ng kaso

Nagpapaabot ng ligal na tulong sa lahat ng mga mamamayan ng EU na nasa Finland para sa trabaho kahit na hindi mamamayan ng Finland 


\section{MGA NAPAG-ALAMAN}

Sagot sa tanong (Oo/Hiindi) at iba pang mga tala at obserbasyon tungkol sa kung gaano kahusay na tinutugunan $n g$ konstitusyon ang (mga) isyu na itinanong. Isama ang mga makabuluhang mga probisyon ((mga) numero $n g$ artikulo at teksto $n g$ (mga) probisyon). Tandaan din ang hindi konsistent at/o magkasalungat na mga probisyon, o kung walang umiiral na mga kaugnay na probisyon.

\section{MGA HAKBANG}

Iminungkahing adbokasiya at iba pang mga kasunod na hakbang upang matugunan o mapalaganap ang mga natuklasan. 


\section{Pagprotekta at pagtataguyod sa mga karapatan ng mga katutubo \\ Malinaw bang tinukoy ng konstitusyon ang mga pinapayagang batayan o proseso para sa mga limitasyon ng mga karapatan, at tinitiyak na makatarungan ang mga ito?}

PALIWANAG

Maaaring tukuyin ng mga konstitusyon ang mga dahilan o pangyayari na kung saan ang ilang mga karapatan ay maaaring limitado, tulad ng sa panahon ng state of emergency o kapag lumalabag ito sa mga karapatan ng iba. Tinawag itong isang 'panghahamak' sa mga karapatan. Ang ilang mga karapatan, gayunpaman, ay hindi nahahamak, tulad ng karapatan sa buhay. Batay ito sa ICCPR, na nagsasaad na: 'Ang bawat tao ay may likas na karapatan sa buhay. Ang karapatang ito ay poprotektahan ng batas. Walang sinuman ang dapat na arbitraryong pagkaitan ng kanyang buhay' (United Nations 1966a: artikulo 6 (1)). Gayunpaman, ang mga limitasyon sa mga karapatan ay karaniwang tampok ng mga konstitusyon, lalo na tungkol sa mga karapatan sa kalayaan sa pamamahayag at asosasyon. Kapag ang mga limitasyon ay inilalagay sa pundamental na mga karapatan, dapat itong malinaw na masabi kung kailan nalalapat ang mga limitasyon at kung ano ang saklaw ng kanilang aplikasyon. Ang isang hudikatura o iba pang kinatawan ng independiyenteng resolusyon sa alitan ay madalas na binibigyan ng awtoridad na subukan ang proporsyonalidad, pagbibigay-katwiran, at pagkamakatwiran ng mga limitasyon sa mga karapatan.

Ang pagtiyak sa mapanganib na pag-ungali mula sa iba ay hindi pinapayagan.

Ang mga karapatan ay maaaring lehitimong limitado, tulad ng kung sumasalungat sila sa mga karapatan ng iba. Ang pananalita na nag-uudyok ng poot, hostilidad, diskriminasyon, hindi pagtanggap at/o karahasan ay madalas na limitado sapagkat lumalabag ito sa mga karapatan ng iba at maaaring lumabag sa mga gabay na alituntunin ng estado, tulad ng pagbuo ng isang demokratikong lipunan, paghanap ng panlipunang hustisya, pagkakapantaypantay at dignidad ng tao. Ang pananalita na nag-uudyok ng karahasan o diskriminasyon laban sa mga katutubo ay nakapipinsala sa kanilang pundamental na mga karapatan at pinapahina ang pagkakapantay-pantay, lalo na sa pamamagitan ng pagpapatuloy ng mga pagkakahon. Sa ganitong paraan, ang mga limitasyon sa karapatan na pipigil sa karapatan ng isang tao na malayang makapagsalita kung nagsusulong sila ng karahasan ay maaaring pakinabangan ng mga katutubo. Ang ganitong uri ng limitasyon ay kinikilala ng UNDRIP, na nagbabawal sa 'anumang uri ng propaganda na idinisenyo upang itaguyod o hikayatin ang diskriminasyon sa lahi o etniko na itinutok laban sa’ mga katutubo (United Nations 2007: artikulo 8). Ang pagbabawal na ito ay maaaring magkaroon ng pagtunggali sa karapatan ng isang tao sa malaya pananalita at ang pagbabalanse ay kailangang mangyari.

Tinitiyak na ang mga limitasyon ay makatwiran

Ang mga limitasyon sa mga karapatan ay maaaring madaling gamitin nang mali kung hindi makatwiran o mahusay na binigyang kahulugan. Halimbawa, kung ang pambansang seguridad o pagkakaisa sa lipunan ay kinikilala bilang batayan kung saan lilimitahan ang mga karapatan, kung gayon sino ang tumutukoy kung ano ang pambansang seguridad o pagkakasundo sa lipunan at kung sila ay nasa peligro? Ang mga katwirang ito ay ginamit ng mga pamahalaan dati upang malimitahan ang adbokasiya sa mga isyu ng mga katutubo o ang pagbuo ng mga partido batay sa relihiyon, uri, etnisidad, kasarian o rehiyon. Kapag mas malinaw na tinutukoy ang mga limitasyon sa mga karapatan, mas mababa ang saklaw para sa pang-aabuso. 


\begin{tabular}{|c|c|c|}
\hline $\begin{array}{l}\text { ICCPR } \\
1966\end{array}$ & Artikulo $20(2)$ & $\begin{array}{l}\text { 2. Anumang pagtataguyod ng pambansa, panlahi } \\
\text { o relihiyosong poot na bumubuo sa pag-uudyok } \\
\text { sa diskriminasyon, hostilidad, o karahasan ay } \\
\text { ipinagbabawal ng batas. }\end{array}$ \\
\hline $\begin{array}{l}\text { Konstitusyon } \\
\text { ng Fiji } \\
2013\end{array}$ & $\begin{array}{l}\text { Artikulo 17(3) } \\
\text { (b) at (4) }\end{array}$ & $\begin{array}{l}\text { (3) Sa saklaw na kinakailangan, ang isang batas ay } \\
\text { maaaring limitahan, o maaaring pahintulutan ang } \\
\text { limitasyon ng, mga karapatan at kalayaan na nabanggit } \\
\text { sa subseksyon (1) para sa interes ng: } \\
\text {... } \\
\text { (b) proteksyon o pagpapanatili ng reputasyon, pagiging } \\
\text { pribado, dignidad, karapatan o kalayaan ng ibang mga } \\
\text { tao, kasama na - } \\
\text { (i) ang karapatang maging malaya mula sa mapoot na } \\
\text { pananalita, nakadirekta man laban sa mga indibidwal } \\
\text { o grupo; } \\
\text {... } \\
\text { (4) Sa seksyong ito, ang 'hate speech' ay } \\
\text { nangangahulugang isang ekspresyon sa anumang anyo } \\
\text { na naghihikayat, o may epekto ng paghihikayat sa } \\
\text { diskriminasyon sa isang batayang nakalista o inireseta } \\
\text { sa ilalim ng seksyon } 26 \text {. }\end{array}$ \\
\hline
\end{tabular}

\begin{tabular}{l|l|}
$\begin{array}{l}\text { Konstitusyon } \\
\text { ng Honduras } \\
1982\end{array}$ & Artikulo 64 \\
\hline
\end{tabular}

Konstitusyon ng Timog Aprika 1996

Seksyon 36 at 37(5)
Ang mga batas at probisyon ng gobyerno o anumang iba pang mga probisyon na nagreregula sa pagpapatupad ng mga deklarasyon, karapatan, at garantiyang kinikilala ng Konstitusyong ito ay hindi ipapatupad kung

binabawasan, hinihigpitan, o iniiwasan ang mga naturang karapatan at garantiya.

\section{Seksyon 36}

1. Ang mga karapatan sa Katipunan ng mga Karapatan ay maaaring limitado lamang sa mga tuntunin ng batas ng pangkalahatang aplikasyon sa lawak na ang limitasyon ay makatwiran at makatarungan sa isang bukas at demokratikong lipunan batay sa dignidad ng tao, pagkakapantay-pantay at kalayaan, na isinasaalang-alang ang lahat ng makabuluhang mga kadahilanan, kabilang-

a. ang likas na katangiang tama;

b. ang kahalagahan ng layunin ng paglilimita;

c. ang likas na katangian at lawak ng limitasyon;

d. ang ugnayan sa pagitan ng limitasyon at layunin nito; at

e. hindi gaanong mahigpit na mga paraan upang makamit ang layunin.

2. Maliban sa isinaad sa subseksyon (1) o sa anumang ibang probisyon ng Konstitusyon, walang batas na maaaring limitahan ang anumang karapatang nakapaloob sa Katipunan ng mga Karapatan.

Seksyon 37(5)

5. Walang Batas ng Parlamento na nagpapahintulot sa isang pagdedeklara ng isang state of emergency, at walang lehislasyon na naisabatas o ibang aksyon na ginawa bilang resulta ng isang deklarasyon, ang maaaring hayaan o pahintulutan:
Ang pagpapakita na kahit ang ICCPR ay pinapayagan ang mga limitasyon sa mga karapatan, sa kasong ito sa kalayaan sa pamamahayag, sa ilalim tiyak na mga pangyayari

Pinapayagan ang mga limitasyon sa mga karapatan batay sa isang hanay ng mga tinukoy na batayan at pangyayari
Idinedeklara na ang mga karapatan ay hindi dapat limitahan
Pinahihintulutan ang isang makitid na hanay ng mga limitasyon sa mga karapatan, at isinasaad na ang limitasyon ay kinakailangang alinsunod sa tinukoy na pamantayan 


\section{Konstitusyon \\ ng Zimbabwe} 2013 c. ang anumang derogasyon mula sa isang seksyon Natutukoy ang mga hindi na nabanggit sa haligi $1 \mathrm{ng}$ Talahanayan ng Mga nahahamak na karapatan. Karapatan na Hindi Nahahamak, hanggang sa lawak na ipinahiwatig sa tapat ng seksyon na iyon sa haligi $3 \mathrm{ng}$ Talahanayan.

Seksyon Bilang - 9. Titulo ng Seksyon - Pagkakapantaypantay. Ang lawak kung saan protektado ang karapatan - Na patungkol sa hindi patas na diskriminasyon lamang sa batayan ng lahi, kulay, etniko o panlipunang pinagmulan, kasarian, relihiyon, o wika.

1. Ang mga pundamental na karapatan at kalayaan na itinakda sa Tsapter na ito ay dapat na gamitin nang makatwiran at may wastong pangangaalaga sa mga karapatan at kalayaan ng ibang tao.

2. Ang mga pundamental na mga karapatan at kalayaan na itinakda sa Tsapter na ito ay maaaring limitado lamang sa mga tuntunin ng isang batas ng pangkalahatang aplikasyon at hanggang sa saklaw na ang limitasyon ay patas, makatwiran, kinakailangan at makatarungan sa isang demokratikong lipunan batay sa pagiging bukas, hustisya, dignidad ng tao, pagkakapantay-pantay at kalayaan, na isinasaalang-alang ang lahat ng makabuluhang mga kadahilanan, kabilang:

a. ang likas na katangian ng karapatan o kinauukulang kalayaan;

b. ang layunin ng limitasyon, sa partikular kung kinakailangan sa mga interes ng depensa, kaligtasan ng publiko, kaayusan ng publiko, moralidad ng publiko, kalusugan ng publiko, pagpaplano sa rehiyon o bayan o ang pangkalahatang interes ng publiko;

c. ang likas na katangian at lawak ng limitasyon;

d. ang pangangailangang matiyak na ang pagtamasa ng mga karapatan at kalayaan ng sinuman ay hindi pineprehuwisyo ang $\mathrm{mga}$ karapatan at kalayaan ng iba;

e. ang ugnayan sa pagitan ng limitasyon at layunin nito, sa partikular kung ito ay nagpapataw ng higit na kinakailangang paghihigpit sa karapatan o kalayaan upang makamit ang layunin nito; at

f. kung mayroong anumang mga mas mahigpit na paraan ng pagkamit ng layunin $\mathrm{ng}$ limitasyon.

3. Walang batas na maaaring limitahan ang mga sumusunod na karapatang nakalagay sa Tsapter na ito, at walang sinuman ang maaaring lumabag sa kanila:

a. ang karapatan sa buhay, maliban sa saklaw na tinukoy sa seksyon 48;

b. ang karapatan sa dignidad ng tao;

c. ang karapatang huwag matortyur o mapailalim sa malupit, hindi makatao o naka-iinsultong pagtrato o parusa;

d. karapatang hindi mailagay sa pagkaalipin o pagkaalila;

e. ang karapatan sa isang patas na paglilitis;

f. ang karapatang makakuha ng isang utos ng habeas corpus na isinaad sa seksyon 50 (7) (a)
Pinapayagan ang isang makitid na hanay ng mga limitasyon sa mga karapatan, at isinasaad na ang limitasyon ay kinakailangang alinsunod sa tinukoy na pamantayan
Tumutukoy sa mga karapatang hindi maaaring limitahan 


\section{MGA NAPAG-ALAMAN}

Sagot sa tanong (Oo/Hiindi) at iba pang mga tala at obserbasyon tungkol sa kung gaano kahusay na tinutugunan $n g$ konstitusyon ang (mga) isyu na itinanong. Isama ang mga makabuluhang mga probisyon ((mga) numero $n g$ artikulo at teksto $n g$ (mga) probisyon). Tandaan din ang hindi konsistent at/o magkasalungat na mga probisyon, o kung walang umiiral na mga kaugnay na probisyon.

\section{MGA HAKBANG}

Iminungkahing adbokasiya at iba pang mga kasunod na hakbang upang matugunan o mapalaganap ang mga natuklasan. 


\section{Pagprotekta at pagtataguyod sa mga karapatan ng mga katutubo}

Nakasaad ba sa konstitusyon na ang mga tratadong pang-internasyunal na karapatang pantao ay awtomatikong eepekto sa sandaling mapagtibay, 0 kinakailangan pa ang pangalawang proseso $\mathrm{ng}$ domestikasyon?

PALIWANAG

Ang mga bansa, kung saan ang batas pang-internasyunal ay maaaring mailapat sa mga domestikong korte, ay itinuturing na mga 'monistang' bansa, samantalang ang mga bansa kung saan ang pang-internasyunal na batas ay dapat na gamitin nang pormal sa tratado-sa-tratadong batayan upang mailapat sa mga domestikong korte ay mga 'dualista'.

Maaaring maging mas mahusay para sa mga pirmado at niratipikang mga tratadong internasyunal na direktang mailapat-iyon ay, upang awtomatikong maging batas. Maaaring mayroong isang makabuluhan o perpetwal na pagkaantala sa pag-integra ng internasyunal na batas sa domestikong batas para sa ibát ibang mga kadahilanan, kabilang ang kawalan ng pampulitikang pagkukusa o oposisyon mula sa isang makapangyarihang nasasakupan. Ang hindi direktang aplikasyon ng mga tratadong pang-internasyunal at mga kumbensyon ay nangangailangan na maipasa ang domestikong lehislasyon upang maipatakbo ang mga obligasyong nakapaloob sa mga instrumento. Ang direktang aplikasyon ay magbibigay sa mga katutubo ng mas mabilis na pag-akses sa mga karapatang nakapaloob sa mga internasyunal na kasunduan, kumbensyon, atbp. Sa kabilang banda, mas makabubuti na ang parlamento ay kailangang maipatupad ang mga internasyunal na obligasyon sa domestikong batas, upang magkaroon sila ng domestikong politikal na lehitimasiya.

Ang ilang mga konstitusyon at lehislasyon ay maaaring direktang sumasangguni sa internasyunal na batas. 


\begin{tabular}{l|l|}
$\begin{array}{l}\text { Konstitusyon } \\
\text { ng Brazil } \\
1988\end{array}$ & Artikulo 5(3) \\
\hline & \\
\hline $\begin{array}{l}\text { Konstitusyon } \\
\text { ng Bolivia } \\
2009\end{array}$ & Artikulo 14(III) \\
\hline
\end{tabular}

\begin{tabular}{l|l} 
Konstitus-yon & Artikulo $74(3)$ \\
ng Dominican & \\
Republic & \\
2015 & \\
\end{tabular}

Konstitusyon

Artikulo 2(5)

ng Kenya

2010

at 2(6)

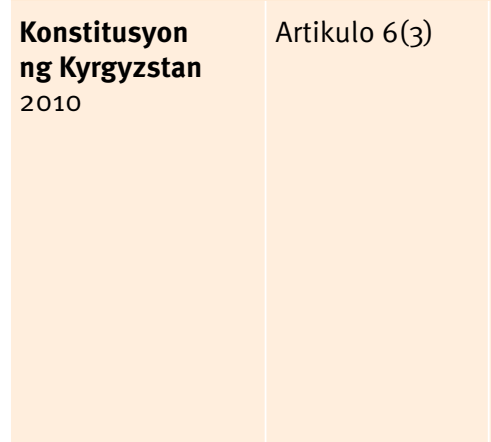

Konstitusyon ng Artikulo 9(3) South Sudan 2011
(3) Mga internasyonal na tratado at kumbensyon tungkol sa karapatang pantao na inaprubahan ng parehong kapulungan ng Pambansang Kongreso, sa dalawang sesyon ng magkaibang pagboto, sa pamamagitan ng tatlong-ikalimang boto ng kanikanilang mga miyembro, ay magiging katumbas ng Mga Amyenda sa Konstitusyon.

III. Ginagarantiyahan ng Estado ang lahat ng tao at lahat ng mga kolektibo, nang walang diskriminasyon, ang malaya at mabisang paggamit ng mga karapatang itinatag sa Konstitusyong ito, ang mga batas at internasyonal na mga tratado sa karapatang pantao.

3. Ang mga kasunduan, pakto, at mga kombensyon na nauugnay sa karapatang pantao, na isinalin at niratipika ng Dominican State ay mayroong konstitusyonal na herarkiya at para sa direkta at agarang aplikasyon ng mga korte at iba pang mga organo ng Estado.

(5) Ang pangkalahatang mga patakaran ng batas internasyonal ay dapat maging bahagi ng batas ng Kenya.

(6) Anumang tratado o kumbensyon na niratipika ng Kenya ay dapat maging bahagi ng batas ng Kenya sa ilalim ng Konstitusyong ito.

(3) Ang mga internasyunal na tratado kung saan ang Republika ng Kyrgyz ay isang partido na npumasok sa puwersa sa ilalim ng itinatag na ligal na pamamaraan at gayundin ang mga unibersal na kinikilalang prinsipyo at pamantayan $\mathrm{ng}$ internasyunal na batas ay ang magiging bahagi ng ligal na sistema ng Republika ng Kyrgyz. Ang mga probisyon ng mga tratadong pang-internasyonal sa mga karapatang pantao ay dapat na may direktang pagkilos at dapat unahin sa paggalang ng mga probisyon ng iba pang mga tratadong panginternasyonal.

3) Lahat ng mga karapatan at kalayaan na nakalagay sa internasyonal na mga tratado sa karapatang pantao, kasunduan at mga instrumento na niratipika o tinanggap ng Republika ng South Sudan ay magiging isang integral na bahagi ng Batas na ito.
Nagbibigay sa mga niratipikang tratado ng parehong katayuan ng Konstitusyon

Ginagarantiyahan ang lahat ng mamamayan ng kapangyarihang magamit ang

internasyonal na karapatang pantao

Nagbibigay sa mga tratado ng karapatang pantao ng katayuang konstitusyonal bilang pinakamataas na batas sa bansa at pianghahawakan ang mga ito na direktang nalalapat sa mga korte at iba pang mga kinatawan ng estado

Pinanghahawakan na ang internasyunal na batas ay dapat isaalang-alang na batas sa Kenya

Nagsasaad na ang mga tratadong pang-internasyonal ay magkakaroon ng direktang bisa, na may partikular na priyoridad sa mga tratado sa karapatang pantao

Itinataguyod ang sistemang monista kung saan ang lahat ng mga tratadong panginternasyonal na niratipika ay itinuturing na bahaging konstitusyonal na kaayusan 


\section{MGA NAPAG-ALAMAN}

Sagot sa tanong (Oo/Hiindi) at iba pang mga tala at obserbasyon tungkol sa kung gaano kahusay na tinutugunan $n g$ konstitusyon ang (mga) isyu na itinanong. Isama ang mga makabuluhang mga probisyon ((mga) numero $n g$ artikulo at teksto $n g$ (mga) probisyon). Tandaan din ang hindi konsistent at/o magkasalungat na mga probisyon, o kung walang umiiral na mga kaugnay na probisyon.

\section{MGA HAKBANG}

Iminungkahing adbokasiya at iba pang mga kasunod na hakbang upang matugunan o mapalaganap ang mga natuklasan. 


\section{Pagprotekta at pagtataguyod sa mga karapatan ng mga katutubo \\ Pinahihintulutan, hinihikayat o hinihiling ba ng konstitusyon ang mga korte na isaalang-alang ang mga dayuhang batas kapag binibigyang kahulugan nila at inilalapat ang mga probisyon ng karapatang pantao?}

\section{PALIWANAG}

Kung ang mga karapatan ng mga katutubo ay bagong-dagdag sa konstitusyon o hindi pa malawak na nailapat o nasubok, maaaring maging kapaki-pakinabang para sa mga korte na tumingin sa dayuhang batas at batas sa dayuhang kaso kapag pinauunlad ang kanilang sariling hurisprudensiya tungkol sa mga karapatan ng mga katutubo, partikular sa mga kumplikadong usapin tulad ng karapatan sa sariling pagpapasya o sa malaya, nauna at malinang na kapahintulutan (FPIC). Ang isang konstitusyon ay maaaring pahintulutan, hikayatin o mangailangan sa mga korte na isaalang-alang ang mga batas ng ibang mga bansa sa paggawa ng mga pagpapasya. Ang pagsasaalang-alang kung paano naintindihan at tinutugunan ng ibang mga bansa ang mga katulad na isyu ay maaaring magsulong ng hudisyal na interpretasyon na nakahanay sa mga pamantayang pang-internasyunal at pinakamahusay na kasanayan at maaaring magbigay ng inspirasyon sa inobatibong konstitusyonal na interpretasyon na kung saan ang isa o isang maliit na bilang ng iba pang mga bansa ay naunawaan o natanto ang mga karapatan ng mga katutubo sa mga bagong pamamaraan.

MGA PAMANTAYANG PANG-INTERNASYUNAL AT MGA PAMBANSANG MGA HALIMBAWA

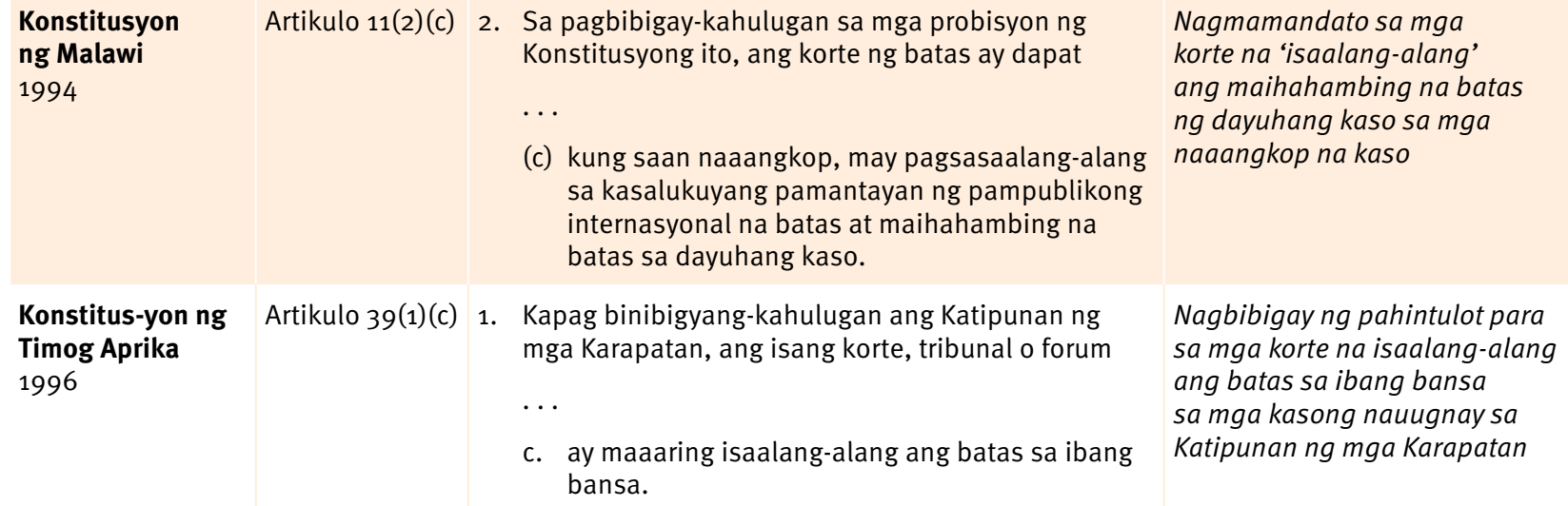

(c) kung saan naaangkop, may pagsasaalang-alang sa kasalukuyang pamantayan ng pampublikong internasyonal na batas at maihahambing na batas sa dayuhang kaso.

Konstitus-yon ng Artikulo 39(1)(c) 1. Kapag binibigyang-kahulugan ang Katipunan ng Timog Aprika 1996 mga Karapatan, ang isang korte, tribunal o forum

...

c. ay maaaring isaalang-alang ang batas sa ibang bansa.

Nagmamandato sa mga korte na 'isaalang-alang' ang maihahambing na batas ng dayuhang kaso sa mga naaangkop na kaso

Nagbibigay ng pahintulot para sa mga korte na isaalang-alang ang batas sa ibang bansa sa mga kasong nauugnay sa Katipunan ng mga Karapatan

\section{Konstitusyon ng Zimbabwe 2013}

Artikulo 46(1)

(e)
Pinapayagan ang mga korte na isaalang-alang ang batas sa ibang bansa
Kapag binibigyang-kahulugan ang Tsapter na ito, ang isang korte, tribunal, forum, o kinatawan

$\cdots$

(e) ay maaaring isaalang-alang ang makabuluhang batas sa ibang bansa.

\section{然}




\section{MGA NAPAG-ALAMAN}

Sagot sa tanong (Oo/Hiindi) at iba pang mga tala at obserbasyon tungkol sa kung gaano kahusay na tinutugunan $n g$ konstitusyon ang (mga) isyu na itinanong. Isama ang mga makabuluhang mga probisyon ((mga) numero $n g$ artikulo at teksto $n g$ (mga) probisyon). Tandaan din ang hindi konsistent at/o magkasalungat na mga probisyon, o kung walang umiiral na mga kaugnay na probisyon.

\section{MGA HAKBANG}

Iminungkahing adbokasiya at iba pang mga kasunod na hakbang upang matugunan o mapalaganap ang mga natuklasan. 


\section{Pagprotekta at pagtataguyod sa mga karapatan ng mga katutubo}

\section{Hinihikayat o hinihingi ba ng konstitusyon ang mga korte at iba pang mga kinatawan na isaalang-alang ang internasyunal na batas kapag binibigyang kahulugan nila at inilalapat ang mga probisyon $\mathrm{ng}$ karapatang pantao?}

PALIWANAG

Ang lawak ng internasyunal na batas para sa karapatang pantao, na nakuha sa mga panrehiyong tratado/ kumbensyon at sa mga internasyonal na deklarasyon at prinsipyo ('mahinang batas')—at ang lalim ng patnubay sa interpretasyon nito sa pamamagitan ng mga hatol ng mga internasyunal na korte, eksperto at rekomendasyon ng mga komisyon/mga komiteng may mandato na pangasiwaan ang pagpapatupad ng mga tratado-maaaring maging mahalaga kapag ang mga korte ay nagpapaliwanag ng mga konstitusyon at mga makabuluhang bahagi ng batas na nauugnay sa mga katutubo at ibang karapatang pantao. Ang internasyunal na batas at 'mahinang batas' ay maaaring maging partikular na kapaki-pakinabang sa mga kaso kung ang pamantayan para sa pagprotekta ng mga karapatan ng mga katutubo ay maaaring mas mataas kaysa sa domestikong konteksto, o kung saan malabo o tahimik ang domestikong batas ukol sa isang isyu. Ang mga interpretasyong ito ay makakatulong sa paggabay sa mga hukom patungo sa mas mahusay na proteksyon at pagsulong ng mga karapatang ito. Mahusay na kasanayan na mangailangan, o kahit papaano ay pahintulutan, ang mga korte upang isaalang-alang o sanggunian ang internasyunal na batas, kasama na ang mga interpretasyon ng internasyonal na abugado sa karapatang pantao at iba pang mga dalubhasang opinyon, sa pagpapasya ng mga kaso ng karapatang pantao. Ang 'pahintulot' na ito ay madalas na matatagpuan sa isang konstitusyon.

MGA PAMANTAYANG PANG-INTERNASYUNAL AT PAMBANSANG MGA HALIMBAWA

\begin{tabular}{|c|c|c|c|}
\hline $\begin{array}{l}\text { Konstitusyon } \\
\text { ng Maldives } \\
2008\end{array}$ & Artikulo 68 & $\begin{array}{l}\text { Kapag binibigyang-kahulugan at inilalapat ang mga } \\
\text { karapatan at kalayaan na nilalaman sa loob ng Tsapter } \\
\text { na ito [Tsapter II, Pundamental na Mga Karapatan at } \\
\text { Kalayaan], ang isang korte o tribunal ay magtataguyod } \\
\text { ng mga halagahang nakaangkla sa isang bukas at } \\
\text { demokratikong lipunan batay sa dignidad ng tao, } \\
\text { pagkakapantay-pantay at kalayaan, at isasaalang- } \\
\text { alang ang mga internasyonal na tratado kung saan ang } \\
\text { Maldives ay isang partido. }\end{array}$ & $\begin{array}{l}\text { Kinakailangan ang mga korte/ } \\
\text { tribunal na isaalang-alang ang } \\
\text { mga internasyunal na tratado na } \\
\text { ang Maldives ay isang partido } \\
\text { kapag maglalapat ng mga } \\
\text { karapatan at kalayaan }\end{array}$ \\
\hline $\begin{array}{l}\text { Konstitusyon } \\
\text { ng Timor-Leste } \\
2002\end{array}$ & Seksyon 23 & $\begin{array}{l}\text { Ang mga pundamental na karapatang nakapaloob } \\
\text { sa Konstitusyon ay hindi dapat ibukod ang anumang } \\
\text { iba pang mga karapatang isinaad ng batas at dapat }\end{array}$ & $\begin{array}{l}\text { Pinanghahawakan na ang } \\
\text { Konstitusyon ay dapat bigyang- } \\
\text { kahulugan alinsunod sa UDHR }\end{array}$ \\
\hline
\end{tabular}




\section{MGA NAPAG-ALAMAN}

Sagot sa tanong (Oo/Hiindi) at iba pang mga tala at obserbasyon tungkol sa kung gaano kahusay na tinutugunan $n g$ konstitusyon ang (mga) isyu na itinanong. Isama ang mga makabuluhang mga probisyon ((mga) numero $n g$ artikulo at teksto $n g$ (mga) probisyon). Tandaan din ang hindi konsistent at/o magkasalungat na mga probisyon, o kung walang umiiral na mga kaugnay na probisyon.

\section{MGA HAKBANG}

Iminungkahing adbokasiya at iba pang mga kasunod na hakbang upang matugunan o mapalaganap ang mga natuklasan. 


\section{Mga sanggunian at karagdagang babasahin}


African Commission on Human and Peoples' Rights, Centre for Minority Rights Development (Kenya) and Minority Rights Group International on behalf of Endorois Welfare Council v. Kenya (276/2003), $<$ https://www.refworld.org/cases,ACHPR,4b8275a12.html>, inakses 1 Hulyo 2020

Arneson, R., 'Equality of Opportunity' in The Stanford Encyclopedia of Philosophy (Summer 2015), E. N. Zalta (ed.), <https://plato.stanford.edu/archives/sum2015/entries/equal- opportunity/>, inakses 25 Mayo 2020

Asia Pacific Forum (APF) and Office of the United Nations High Commissioner for Human Rights (OHCHR), The United Nations Declaration on the Rights of Indigenous Peoples: A Manual for National Human Rights Institutions (Sydney and Geneva: APF and OHCHR, 2013), < https://www.ohchr.org/documents/issues/ ipeoples/undripmanualfornhris.pdf >, inakses 20 Mayo 2020

Australian Human Rights Commission, The Community Guide to the UN Declaration on the Right of Indigenous Peoples (Sydney: Australian Human Rights Commission, 2010), < https://humanrights.gov.au/our-work/ aboriginal-and-torres-strait-islander-social-justice/publications/ community-guide-un $>$, inakses 20 Mayo 2020

—, 'Constitutional reform: Fact Sheet - Recognising Aboriginal \& Torres Strait Islander people in the Constitution', [n.d.], <https://www.humanrights.gov.au/publications/constitutional-reform-fact-sheetrecognising-aboriginal-torres-strait-islander-people>, inakses 19 Mayo 2020

Beetham, D., Carvalho, E., Landman, T. and Weir, S., Assessing the Quality of Democracy: A Practical Guide (Stockholm: International IDEA, 2008), < https://www.idea.int/publications/catalogue/ assessing-qualitydemocracy-practical-guide>, inakses 20 Mayo 2020

Benson, C., 'The Importance of mother tongue-based schooling for educational quality', Background paper prepared for Education for all Global Monitoring Report: The Quality Imperative, UNESCO document 2005/ED/EFA/MRT/PI/9, 2004, <https://unesdoc.unesco. org/ark:/48223/pf0000146632>, inakses 1 Hulyo 2020

Böckenförde, M., Hedling, N. and Wahiu, W., A Practical Guide to Constitution Building (Stockholm: International IDEA, 2011), <https:/www.idea.int/publications/catalogue/practical-guide- constitutionbuilding $>$, inakses 20 Mayo 2020

Bulmer, E., What is a Constitution? Principles and Concepts, International IDEA Constitution-Building Primer No. 1 (Stockholm: International IDEA, 2014), <https://www.idea.int/publications/ catalogue/what-is-aconstitution>, inakses 20 Mayo 2020

Cats-Baril, A., Self-determination, Constitution Brief (Stockholm: International IDEA, 2018), <https://www. idea.int/publications/catalogue/self-determination>, inakses 23 Hunyo 2020

Comparative Constitutions Project, 2016, <http://comparativeconstitutionsproject.org>, inakses 23 Hunyo 2020

Danish Parliament, The, 'The Greenland Committee', [n.d.], <https://www.thedanishparliament.dk/en/ committees/committees/gru>, inakses 30 Hunyo 2020

Ghai, Y., 'Chimera of constitutionalism: State, economy and society in Africa', Lecture, 2010, <https://www. up.ac.za/media/shared/Legacy/sitefiles/file/47/15338/chimera of constitutionalism yg1.pdf>, inakses 23 Hunyo 2020

Ghai, Y. and Galli, G., Constitution Building Processes and Democratization (Stockholm: International IDEA, 2006), <https://www.idea.int/publications/catalogue/constitution-building-processes-anddemocratization>, inakses 29 Oktubre 2019

Goodhart, M. E., Human Rights: Politics and Practice, 3rd edn (Oxford: Oxford University Press, 2016), <https://doi.org/10.1093/hepl/9780198708766.003.0001>

Government of Canada, 'Treaties and agreements: Modern treaties', 11 Setyembre 2018, < https:// www.rcaanccirnac.gc.ca/eng/1100100028574/1529354437231\#chp4>, inakses 18 Hunyo 2020 
-, 'Terms of reference for the National Inquiry into Missing and Murdered Indigenous Women and Girls', 1 Agosto 2019, <https://www.rcaanc-cirnac.gc.ca/eng/1470141425998/1534527073231>, inakses 19 Hunyo 2020

—, 'New permanent bilateral mechanisms', 10 Marso 2020, <https://www.rcaanc-cirnac.gc.ca/eng/1499711968 $\underline{320 / 1529105436687>}$, inakses 18 Hunyo 2020

Government of Norway, The Sámi Act (12 Hunyo 1987, No. 56), <https://www.regjeringen.no/en/ dokumenter/the-sami-act-/id449701/>, inakses 28 Mayo 2020

Hanemann, U., 'Literacy for special target groups: indigenous peoples', UNESCO document 2006/ED/EFA/ MRT/PI/40, Abril 2005, <https://unesdoc.unesco.org/ark:/48223/ pf0000146004>, inakses 1 Hunyo 2020

Howard-Hassman, R. E., 'Universality of women's rights since 1970: the centrality of autonomy and agency', Journal of Human Rights, 10/4 (2011), pp. 433-49, <https://doi.org/10.1080/147 54835.2011.619398>

Inter-American Court of Human Rights, Case of the Mayagna (Sumo) Awas Tingni Community v. Nicaragua [ENG], 31 Agosto 2001, <http://www.corteidh.or.cr/docs/casos/articulos/ seriec 79 ing.pdf>, inakses 24 Hunyo 2020

—, Case of Sawhoyamaxa Indigenous Community v. Paraguay, Judgment of Marso 29, 2006 (Merits, Reparations and Costs), <http://www.corteidh.or.cr/docs/casos/articulos/ seriec 146 ing.pdf $>$, inakses 1 Hulyo 2020

International Court of Justice, Western Sahara, Advisory Opinion 1975 I.C.J. 12, 16 Oktubre 1975, <https:// www.icj-cij.org/files/case-related/61/6197.pdf>, inakses 23 Hunyo 2020

International IDEA, Federal Terminology Through Citizen Dialogues (Stockholm: International IDEA, 2014), <https://www.idea.int/publications/catalogue/federal-terminology-through-citizen-dialogues $>$, inakses 20 Mayo 2020

International Labour Organization (ILO), Indigenous and Tribal Peoples Convention (No. 169), 1989, <https:// www.ilo.org/dyn/normlex/en/f?p=NORMLEXPUB:12100:0::NO::P12100 ILO CODE:C169>, inakses 20 Mayo 2020

—, 'Who are the indigenous and tribal peoples?', [n.d.], <http://www.ilo.org/global/topics/ indigenous-tribal/ WCMS 503321/lang--en/index.htm>, inakses 20 Mayo 2020

Martínez Cobo, J. R., Study of the Problem of Discrimination Against Indigenous Populations.

Preliminary Report (New York: United Nations, 1972), UN document E/CN.L/ Sub.2/L.566, <https:// digitallibrary.un.org/record/768953? $\ln =\mathrm{en}>$, inakses 20 Mayo 2020

—, Study of the Problem of Discrimination Against Indigenous Populations. Volume V: Conclusions, Proposals and Recommendations (New York: United Nations, 1987), UN document E/CN.4/Sub.2/1986/7/Add.4, $<$ https://digitallibrary.un.org/record/133666? $\ln =$ en $>$, inakses 20 Mayo 2020

Ministry of Indigenous People's Affairs, Guyana, Social Welfare and Health Department, [n.d.], <https://moipa. gov.gy/social-welfare-department/>, inakses 1 Hulyo 2020

Supreme Court of Canada, Calder et al. v. Attorney-General of British Columbia [1973] SCR 313, 31 Enero 1973, <https://scc-csc.lexum.com/scc-csc/scc-csc/en/item/5113/index.do $>$, inakses 18 Hunyo 2020

—, Andrews v. Law Society of British Coumbia, [1989] 1 SCR 143, 2 Pebrero 1989, <https://scc-csc.lexum. com/scc-csc/scc-csc/en/item/407/index.do $>$, inakses 18 Hunyo 2020

—, R. v Van der Peet [1996] 2 SCR 507, 27-29 Nobyembre 1995, <https://scc-csc.lexum.com/scc-csc/scc-csc/ en/item/1407/index.do $>$, inakses 28 Mayo 2020

—, R. v Kapp [2008] 2 SCR 483, 27 Hunyo 2008, < https://scc-csc.lexum.com/scc-csc/scc-csc/en/item/5696/ index.do $>$, inakses 18 Hunyo 2020

United Nations, Universal Declaration of Human Rights, 10 Disyembre 1948, <https://www. un.org/en/ universal-declaration-human-rights/>, inakses 23 Hunyo 2020

-, International Convention on the Elimination of All Forms of Racial Discrimination, Office of the United Nations High Commissioner for Human Rights, 21 Disyembre 1965, <https:// www.ohchr.org/en/ professionalinterest/pages/cerd.aspx>, inakses 25 Mayo 2020 
-, International Covenant on Civil and Political Rights, Office of the United Nations High Commissioner for

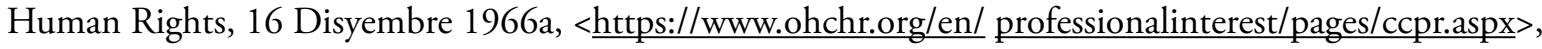
inakses 20 Mayo 2020

-, International Covenant on Economic, Social and Cultural Rights, Office of the United Nations High Commissioner for Human Rights, 16 Disyembre 1966b, <https://www.ohchr. org/en/professionalinterest/ pages/cescr.aspx>, inakses 20 Mayo 2020

—, Convention on Biological Diversity, 1992, <https:/www.cbd.int/doc/legal/cbd-en.pdf>, inakses 28 Mayo 2020

—, The Mataatua Declaration on Cultural and Intellectual Property Rights of Indigenous Peoples, Commission on Human Rights, UN document E/CN.4/Sub.2/AC.4/1993/CRP.5, Hunyo 1993, <https://www.wipo. $\mathrm{int} / \mathrm{export} / \mathrm{sites} / \mathrm{www} / \mathrm{tk} / \mathrm{en} /$ databases/creative_heritage/docs/mataatua.pdf>, inakses 28 Mayo 2020

- General Comment adopted by the Human Rights Committee under article 40, paragraph 4, of the International Covenant on Civil and Political Rights, Human Rights Committee, UN document CCPR/C/21/Rev.1/Add.5, 26 Abril 1994, <https://digitallibrary.un.org/ record/193319?!n=en>, inakses 25 Mayo 2020

-, Note by the Chairperson-Rapporteur of the Working Group on Indigenous Populations, Ms. Erica-Irene A. Daes, on criteria which might be applied when considering the concept of indigenous peoples, United Nations Economic and Social Council, UN document E/CN.4/ Sub.2/AC.4/1995/3, 21 Hunyo 1995,

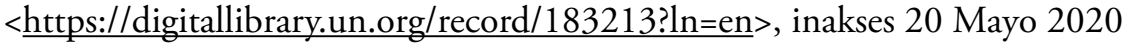

—, Committee on the Elimination of Racial Discrimination, General Recommendation XXI (48), 8 Marso 1996, Annex VIII, B, to Report of the Committee Elimination of Racial Discrimination (New York: United Nations, 1996a), UN document A/51/18, < https:// digitallibrary.un.org/record/223129? ln=en>, inakses 27 Mayo 2020

-, Working Paper by the Chairperson-Rapporteur, Mrs. Erica-Irene A. Daes, on the concept of 'indigenous people', Economic and Social Council, UN document E/CN.4/Sub.2/AC.4/1996/2, 10 Hunyo 1996b, $<$ https://digitallibrary.un.org/record/236429?!n=en>, inakses 20 Mayo 2020

—, 'Fact Sheet No. 9 (Rev. 1), The Rights of Indigenous Peoples', Office of the United Nations High Commissioner for Human Rights, 1997a, <https://www.ohchr.org/Documents/ Publications/ FactSheet9rev.1en.pdf>, inakses 20 Mayo 2020

-, Human Rights Committee, Francis Hopu and Tepoaitu Bessert v. France, Communication No. 549/1993, UN document CCPR/C/60/D/549/1993/Rev.1. (1997), 29 Hulyo 1997b, <http://hrlibrary.umn.edu/ undocs/549-1993.html>, inakses 28 Mayo 2020

—, Study on Treaties, Agreements and other Constructive Arrangements between States and Indigenous Populations, Final report by Miguel Alfonso Martínez, Special Rapporteur, Commission on Human Rights, UN document E/CN.4/Sub.2/1999/20, 1999, <https://documents-dds-ny.un.org/doc/UNDOC/ GEN/G99/137/73/PDF/G9913773. pdf?OpenElement>, inakses 26 Mayo 2020

—, Economic and Social Council, Human rights and indigenous issues : report of the Special Rapporteur on the Situation of Human Rights and Fundamental Freedoms of Indigenous People, Rodolfo Stavenhagen, UN document E/CN.4/2006/78, 16 Pebrero 2006, <https:// digitallibrary.un.org/record/568128?ln=en>, inakses 20 Mayo 2020

—, Declaration on the Rights of Indigenous Peoples, A/RES/61/295, 13 Setyembre 2007, <https://www.un.org/ development/desa/indigenouspeoples/wp-content/uploads/ sites/19/2018/11/UNDRIP E web.pdf>, inakses 20 Mayo 2020

—, Department of Economic and Social Affairs, Indigenous Peoples, 'Martínez Cobo Study', 8 Setyembre 2014, $<$ https://www.un.org/development/desa/indigenouspeoples/publications/2014/09/martinez-cobo-study/>, inakses 20 Mayo 2020

United Nations Development Group, Guidelines on Indigenous People's Issues (New York and Geneva: United Nations, 2009), UN document HR/P/PT/16, < https://unsdg.un.org/sites/ default/files/UNDG guidelines EN.pdf>, inakses 22 Mayo 2020 
United Nations General Assembly, Report of the Special Rapporteur on the rights of indigenous peoples, James Anaya, Addendum, Report on the situation of human rights of indigenous peoples in Brazil, UN document A/HRC/12/34/Add.2, 26 Agosto 2009, < https:// digitallibrary.un.org/record/663918? ln=en>, inakses 20 Mayo 2020

—, Report of the Special Rapporteur on the rights of indigenous peoples, James Anaya, Addendum, The situation of the Sami people in the Sápmi region of Norway, Sweden and Finland, UN document A/ HRC/18/35/Add.2, 6 Hunyo 2011, <https://digitallibrary.un.org/ record/709556? $\ln =$ en $>$, inakses 20 Mayo 2020

United Nations Office on Drugs and Crime, United Nations Principles and Guidelines on Access to Legal Aid in Criminal Justice Systems (New York: United Nations, 2013), <https://www.unodc.org/ documents/justiceand-prison-reform/UN_principles_and_guidlines_on_access_to legal_ aid.pdf $>$, inakses 28 Mayo 2020

United Nations Permanent Forum for Indigenous Issues, Handbook for Participants (New York: United Nations, 2007), <https://www.un.org/esa/socdev/unpfii/documents/guide_participants_en.pdf>, inakses 28 Mayo 2020

United Nations Sub-Commission, Indigenous Peoples Preparatory Meeting: Comments on the First Revised Text of the Draft Declaration on Rights of Indigenous Peoples, Hulyo 1989, UN document E/CN.4/ Sub.2/AC.4/1990/3/Add.2

Watson, J. and Quince, A., 'How might an Indigenous voice to Parliament work? Here's some ideas from Nordic nations', ABC Radio National, 5 Disyembre 2018, <https://www. abc.net.au/news/2018-12-06/ sami-parliament-example-for-australia-of-indigenous- voice/10586566 >, inakses 17 Hunyo 2020

Working Group on Indigenous Populations, 'Standard-setting: Legal commentary on the concept of free, prior and informed consent. Expanded working paper submitted by Mrs. Antoanella- Iulia Motoc and the Tebtebba Foundation offering guidelines to govern the practice of Implementation of the principle of free, prior and informed consent of indigenous peoples in relation to development affecting their lands and natural resources', United Nations document E/CN.4/Sub.2/AC.4/2005/WP.1, 14 Hulyo 2005, <https:// www.ohchr.org/Documents/Issues/IPeoples/WG/E-CN4-Sub2-AC4-2005-WP1.doc>, inakses 20 Mayo 2020

\section{Mga konstitusyon at halimbawang binanggit bilang karagdagan sa mga sanggunian}

\section{Mga konstitusyon}

Ang lahat ng mga konstitusyong nabanggit ay magagamit upang mabasa nang buo sa Constitute Project, <https:// constituteproject.org/>.

\section{Iba pang mga pambansang halimbawa}

\section{Bangladesh}

Chittagong Hill Tracts Accord, 1997

<http://peaceaccords.nd.edu/wp-content/accords/Chittagong Hill Tracts Peace Accord.pdf>

Chittagong Hill Tracts Regional Council Act, 1998

$<$ https://mochta.portal.gov.bd/sites/default/files/files/mochta.portal.gov.bd/page/ ec9cf485 6ba5 4fb3 b574 ef96bffee7d9/CHTRC\%20Act.pdf>

\section{Brazil}

Law No. 5,371, 1967

<http://www.planalto.gov.br/ccivil 03/LEIS/1950-1969/L5371.htm> 


\section{Canada}

Canadian Human Rights Act, 1977

$<$ https://laws-lois.justice.gc.ca/eng/acts/h-6/page-1.html>

Constitution Act, 1982

<http://www.legislation.gov.uk/ukpga/1982/11>

Inuit Nunangat Declaration on Inuit-Crown Partnership, 2017

$<$ https://pm.gc.ca/en/news/statements/2017/02/09/inuit-nunangat-declaration-inuit-crown- partnership>

Nunavut Land Claims Agreement Act, 1993

$<$ https://www.gov.nu.ca/sites/default/files/Nunavut Land Claims Agreement.pdf $>$

\section{Chile}

Law No. $19.253,1993$

$<$ http://www.mapuche.info/indgen/ley-1.html\#indice

\section{Finland}

Act on the Sámi Parliament, 1995

<https://www.finlex.fi/en/laki/kaannokset/1995/en19950974.pdf>

Legal Aid Act, 2002

$<$ https://www.finlex.fi/fi/laki/kaannokset/2002/en20020257 20110720.pdf>

Sámi Language Act, 2003

$<$ https://www.eui.eu/Projects/InternationalArtHeritageLaw/Documents/NationalLegislation/ Finland/ samilanguageact2003.pdf $>$

\section{Greenland}

Act on Greenland Self-Government, 2009

$<\underline{\text { https://www.stm.dk/ p 13090.html> }}$

\section{Nepal}

National Foundation for Development of Indigenous Nationalities Act, 2002

$<$ http://www.nfdin.gov.np/uploads/ck/5df9de0c60dda.pdf $>$

\section{New Zealand}

Maori Representation Act, 1867

$<$ https://teara.govt.nz/en/zoomify/33905/maori-representation-act-1867>

Treaty of Waitangi, 1840

$<$ https://nzhistory.govt.nz/politics/treaty/read-the-treaty/english-text>

Treaty of Waitangi Act, 1975

<http://www.legislation.govt.nz/act/public/1975/0114/107.0/DLM435368.html>

Tūtohu Whakatupua Agreement, 2012

$<$ https://www.govt.nz/assets/Documents/OTS/Whanganui-Iwi/Whanganui-Iwi-Agreement-re- WhanganuiRiver-claims-Tutohu-Whakatupua-30-Aug-2012.pdf> 


\section{Norway}

Sámi Act, 1987

<https://www.regjeringen.no/en/dokumenter/the-sami-act-/id449701/>

\section{The Philippines}

Bangsamoro Organic Law, 2018

<https://www.lawphil.net/statutes/repacts/ra2018/ra_11054_2018.html>

Indigenous Peoples' Rights Act, 1997

<https://www.officialgazette.gov.ph/1997/10/29/republic-act-no-8371/>

\section{South Africa}

White Paper for Social Welfare, 1997

$<$ https://www.gov.za/sites/default/files/gcis document/201409/whitepaperonsocialwelfare0.pdf>

\section{South Sudan}

Local Government Act, 2009

$<$ https://www.icj.org/wp-content/uploads/2014/06/South-SudanLocal-Government-Act-2009. pdf >

\section{United States}

Senate Resolution 4, Sec. 105, 95th Congress, 1st Session, 1977

$<$ https://www.congress.gov/bill/95th-congress/senate-resolution/4 >

State of Maine House of Representatives, The House Rules, 2018

$<$ https://legislature.maine.gov/house/house/Documents/HouseRules> 


\section{Karagdagang babasahin}

\section{Sa mga konstitusyon at pagbuo ng konstitusyon}

Ang kumpletong serye ng International IDEA Constitution-Building Primers ay matatagpuan sa: <http:// www. constitutionnet.org/primers>. Maaari kang manood ng isang maikling video, na may pamagat na 'What is a Constitution?', sa <https://www.idea.int/news-media/media/what-constitution>.

Ahmed, D., Religion-State Relations, International IDEA Constitution-Building Primer No. 8 (Stockholm: International IDEA, 2014), <https://www.idea.int/publications/catalogue/ religion-state-relations $>$, inakses 20 Mayo 2020

Ahmed, D. and Bulmer, E., Limitation Clauses, International IDEA Constitution-Building Primer No. 11 (Stockholm: International IDEA, 2014), <https://www.idea.int/publications/ catalogue/limitation-clauses $>$, inakses 20 Mayo 2020

—, Social and Economic Rights, International IDEA Constitution-Building Primer No. 9 (Stockholm: International IDEA, 2014), <https:/www.idea.int/publications/catalogue/social- and-economic-rights>, inakses 20 Mayo 2020

Böckenförde, M., Constitutional Amendment Procedures, International IDEA Constitution-Building Primer No. 10 (Stockholm: International IDEA, 2014), <https://www.idea.int/publications/ catalogue/constitutionalamendment-procedures>, inakses 20 Mayo 2020

Bulmer, E., Judicial Appointments, International IDEA Constitution-Building Primer No. 4 (Stockholm: International IDEA, 2014), <https://www.idea.int/publications/catalogue/ judicial-appointments $>$, inakses 20 Mayo 2020

-, Judicial Tenure, Removal, Immunity and Accountability, International IDEA Constitution-Building Primer No. 5 (Stockholm: International IDEA, 2014), <https:/www.idea.int/publications/ catalogue/judicialtenure-removal-immunity-and-accountability>, inakses 20 Mayo 2020

- What is a Constitution? Principles and Concepts, International IDEA Constitution-Building Primer No. 1 (Stockholm: International IDEA, 2014), < $\underline{\text { https://www.idea.int/publications/ catalogue/what-is-a- }}$ constitution>, inakses 20 Mayo 2020

—, Federalism, International IDEA Constitution-Building Primer No. 12 (Stockholm: International IDEA, 2015), <https://www.idea.int/publications/catalogue/federalism>, inakses 20 Mayo 2020

—, Emergency Powers, International IDEA Constitution-Building Primer No. 18 (Stockholm: International IDEA, 2018), <https://doi.org/10.31752/idea.2018.29>

\section{Sa mga karapatan at isyu ng mga katutubo}

Anaya, S. J., Indigenous Peoples in International Law, 2nd edn (Oxford: Oxford University Press, 2004)

—, 'Indigenous peoples' participatory rights in relation to decisions about natural resources extraction: The more fundamental issue of what rights indigenous peoples have in lands and resources', Arizona Journal of International and Comparative Law, 22/8 (2005), pp. 7-17, <https://pame.is/mema/MEMAdatabase/377 Anaya-INDIGENOUS\%20PEOPLES\%20 PARTICIPATORY\%20RIGHTS.pdf >, inakses 21 Hulyo 2020

Carmen, A., 'The right to free, prior and informed consent: a framework for harmonious relations and new processes for redress', in J. Hartley, P. Joffre and J. Preston (eds), Realizing the UN Declaration on the Rights of Indigenous Peoples: Triumph, Hope and Action (Saskatoon: Purich Publishing, 2010)

Centro de Estudios Jurídicos e Investigación Social and Oxfam, 'Case study: Bolivian Government Consultation with the Guaraní Indigenous Peoples of Charagua Norte and Isoso: Proposed hydrocarbons exploration project in San Isidro Block, Santa Cruz, Bolivia', 15 Nobyembre 2010, <https://www.oxfamamerica.org/ 
explore/research-publications/case-study-bolivian- government-consultation-with-the-guarani-indigenouspeoples-of-charagua-norte-and- isoso/>, inakses 20 Mayo 2020

Clavero, B., 'The indigenous rights of participation and international development policies', Arizona Journal of International of International and Comparative Law, 22/1 (2005)

Daes, E. I. A., 'Some considerations on the right of indigenous peoples to self-determination', Transnational Law and Contemporary Problems, 3/1 (1993), pp. 1-11

Engle, K., The Elusive Promise of Indigenous Development: Rights, Culture, Strategy (Durham, NC: Duke University Press, 2010), <https://doi.org/10.1215/9780822392965>

Indigenous Peoples' International Centre for Policy Research and Education (Tebtebba), Indigenous People's SelfDetermined Development (Philippines: Tebtebba, 2010)

—, Forest Peoples Programme, Extrayendo Promesas: Pueblos indígenas, industrias extractivas y el Banco Mundial (Philippines: Tebtebba, 2003), <http://www.forestpeoples.org/sites/default/files/ publication/2010/10/ eirinternatwshopsynthesisrepmay03sp.pdf>, inakses 20 Mayo 2020

Inter-American Commission on Human Rights (IACHR), Indigenous and Tribal Peoples' Rights Over Their Ancestral Lands and Natural Resources, OEA/Ser.L/V/II. Doc.56/09 (Washington, DC: IACHR, 2010), <https://www.oas.org/en/iachr/indigenous/docs/pdf/AncestralLands.pdf >, inakses 20 Mayo 2020

International Council on Mining and Metals (ICMM), Good Practice Guide. Indigenous Peoples and Mining (London: ICMM, 2010), <https://www.icmm.com/en-gb/publications/mining-and- communities/ indigenous-peoples-and-mining-good-practice-guide>, inakses 20 Mayo 2020

International Labour Organization (ILO), Indigenous and Tribal Peoples: An Ethnic Audit of Selected Poverty Reduction Strategy Papers (Geneva: ILO, 2005), <https://www.ilo.org/global/ publications/ WCMS 071681/lang--en/index.htm>, inakses 23 Hunyo 2020

Inter-Parliamentary Union (IPU) and United Nations Development Programme (UNDP), Diversity in Parliament: Listening to the Voices of Minorities and Indigenous Peoples (Geneva: IPU, and New York: UNDP, 2010), <https://www.ipu.org/resources/publications/reports/2016-07/ diversity-in-parliament-listeningvoices-minorities-and-indigenous-peoples $>$, inakses 20 Mayo 2020

Lewis, J., Freeman, L. and Borreill, S., Free, Prior and Informed Consent and Sustainable Forest Management in Congo Basin (Switzerland: Intercooperation, Swiss Foundation for Development and International Cooperation, Berne and Society for Threatened Peoples Switzerland, 2008), $<$ https://www.gfbv.ch/wpcontent/uploads/kongobecken-bericht-en.pdf>, inakses 20 Mayo 2020

McGee, B., 'The community referendum: participatory democracy and the right to free, prior and informed consent to development', Berkeley Journal of International Law, 27/2 (2009), pp. 570-635, <http://doi. org/10.15779/Z38T94C>

Page, A., 'Indigenous peoples' free, prior and informed consent in the inter-American human rights system', Sustainable Development Law \& Policy, 4/2 (2004), pp. 16-20, < https:// digitalcommons.wcl.american.edu/ cgi/viewcontent.cgi?article $=1374 \&$ context $=$ sdlp $>$, inakses 20 Mayo 2020

Scheinin, M., Indigenous Peoples' Land Rights under the International Covenant on Civil and Political Rights (Torkel, Norway: Norwegian Centre for Human Rights, University of Oslo, 2004), <https:// ir.lib.uwo.cal cgi/viewcontent.cgi?article=1249\&context=aprci>, inakses 23 Hunyo 2020

Stamatopoulou, E., Cultural Rights in International Law (Leiden/Boston: Martinus Nijhoff Publishers, 2007)

Tauli-Corpuz, V., Good Practices on Indigenous Peoples' Development (Philippines: Tebtebba Foundation, International Centre for Policy Research and Education and United Nations Permanent Forum on Indigenous Issues, 2006)

United Nations, Declaration on the Granting of Independence to Colonial Countries and Peoples, 14 December

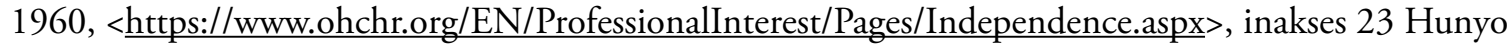
2020

—, Indigenous Women and the United Nations System - Good Practices and Lessons Learned (New York: United Nations, 2007), <http://www.un.org/esa/socdev/publications/Indigenous/ indwomen07.htm>, inakses 23 Hunyo 2020 
—, Department of Economic and Social Affairs, Resource Kit on Indigenous Peoples' Issues (New York: United Nations, 2008), < https://www.un.org/esa/socdev/unpfii/documents/resource kit indigenous 2008.pdf>, inakses 23 Hunyo 2020

—, Human Rights Council, Human Rights Bodies and Mechanisms, Study on Lessons Learned and Challenges to Achieve the Implementation of the Rights of Indigenous Peoples to Education, Report of the Expert Mechanism on the Rights of Indigenous Peoples, UN document A/HRC/12/33, 31 August 2009, <https:// www2.ohchr.org/english/bodies/hrcouncil/docs/12session/A-HRC-12-33.pdf>, inakses 20 Mayo 2020

- General Comment No. 21, Committee on Economic, Social and Cultural Rights, 43rd session, November 2009, UN document E/C.12/GC/21, <https://digitallibrary.un.org/ record/679354?ln=en>, inakses 24 Hunyo 2020

—, Human Rights Council, Report of the Special Rapporteur on the right to food, Olivier De Schutter, Largescale land acquisitions and leases: A set of minimum principles and measures to address the human rights challenge, UN document A/HRC/13/33/Add.2, 28 December 2009, <https://www2.ohchr.org/english/ bodies/hrcouncil/docs/13session/A-HRC-13-33-Add2.pdf>, inakses 20 Mayo 2020

United Nations General Assembly, Permanent Sovereignty over Natural Resources, GA Res 1803 (XVII), 14 December 1962, shttp://www.ohchr.org/EN/ProfessionalInterest/Pages/NaturalResources.aspx $>$, inakses 23 Hunyo 2020

United Nations Permanent Forum on Indigenous Issues, Integration of Indigenous Peoples' Perspective in Country Development Processes: Review of selected CCAs and UNDAFs (New York: United Nations, 2006), <http:// www.un.org/esa/socdev/unpfii/documents/ccaundafs.pdf>, inakses 23 Hunyo 2020

—, MDG Reports and Indigenous Peoples: A Desk Review (New York: United Nations, 2006), <https:// www. un.org/esa/socdev/unpfii/documents/MDGRs2006.pdf>, inakses 23 Hunyo 2020

-, Integration of Indigenous Peoples' Perspective in Country Development Processes: Review of Selected CCAs and UNDAFs No. 2 (New York: United Nations, 2007), <http://www.un.org/esa/socdev/unpfii/ documents/ ccaundaf2 final.pdf>, inakses 23 Hunyo 2020

—, MDG Reports and Indigenous Peoples: A Desk Review, No. 2 (New York: United Nations, 2007), <https:// www.un.org/esa/socdev/unpfii/documents/MDGRs 2007.pdf>, inakses 23 Hunyo 2020

—, UNPFII Recommendations Database, <https://www.un.org/development/desa/ indigenouspeoples/ recommendations-database.html>, inakses 23 Hunyo 2020

Ward, T., 'The right to free, prior and informed consent: indigenous peoples' participation rights within international law', Northwestern Journal of International Human Rights, 10/2 (2011), pp. 54-84, <https:// scholarlycommons.law.northwestern.edu/njihr/vol10/iss2/2/>, inakses 20 Mayo 2020

Xanthaki, A., 'Indigenous rights and United Nations standards: self-determination, culture and land', Human Rights Law Review, 9/3 (2009), pp. 511-17, <https://doi.org/10.1093/hrlr/ ngp014>

\section{Mga institusyunal na website}

Mechanism on the Rights of Indigenous Peoples

$<\underline{\text { https://www.ohchr.org/en/issues/ipeoples/emrip/pages/emripindex.aspx }>}$

Fundação Nacional do Índio (FUNAI) [National Indian Foundation], Brazil

$<$ http://www.funai.gov.br/>

Government of Canada, Crown-Indigenous Relations and Northern Affairs, $<$ https://www.canada.ca/en/crown-indigenous-relations-northern-affairs.html $>$ 
Indigenous Peoples' Center for Documentation, Research and Information

$<\underline{\text { http://www.docip.org }>}$

International Working Group on Indigenous Affairs

$<$ https://www.iwgia.org/en/>

Te Arawhiti-The Office for Māori Crown Relations, New Zealand

$<$ http://www.tearawhiti.govt.nz/about-us/>

United Nations Permanent Forum on Indigenous Issues

$<$ https://www.un.org/development/desa/indigenouspeoples/about-us/permanent-forum-on- indigenous-issues.html>

United States Senate Committee on Indian Affairs

$<$ https://www.indian.senate.gov/about-us>

Waitangi Tribunal, New Zealand

$<$ https://waitangitribunal.govt.nz/> 


\section{Karugtong 1. Kumbensyon ng ILO 169: Kumbensyon ng mga katutubo at tribong mamamayan, 1989}

\section{Panimula}

Ang Pangkalahatang Kumperensya ng International Labor Organization,

Ipinatawag sa Geneva ng Lupong Tagapamahala ng International Labor Office, at nagkita sa ika-76 na Sesyon nito noong 7 Hunyo 7 1989, at

Itinatala ang mga pamantayang pang-internasyonal na nilalaman ng Indegenous and Tribal Populations Convention and Recommendation, 1957, at

Pagbabalik-tanaw sa mga tuntunin ng Universal Declaration of Human Rights, ang International Covenant on Economic, Social and Cultural Rights, the International Covenant on Civil at Political Rights, at ang maraming mga instrumentong pang-internasyunal sa pagpigil sa diskriminasyon, at

Isinasaalang-alang na ang mga pagpapaunlad na naganap sa batas internasyonal mula pa noong 1957, pati na rin ang mga pagpapaunlad sa sitwasyon ng mga katutubo at tribong mamamayan sa lahat ng mga rehiyon ng mundo, na ginawang angkop na isalin ang mga bagong pamantayang pang-internasyonal sa paksa na may hangaring alisin ang oryentasyong asimilasyonista ng mga naunang pamantayan, at

Kinikilala ang mga mithiin ng mga taong ito na gamitin ang kontrol sa kanilang sariling mga institusyon, paraan ng pamumuhay, at pag-unlad ng ekonomiya at panatilihin at paunlarin ang kanilang mga pagkakakilanlan, wika, at relihiyon, sa loob ng balangkas ng mga Estado kung saan sila nakatira, at

Mapapansin na sa maraming bahagi ng mundo ang mga mamamayang ito ay hindi matamasa ang kanilang pundamental na mga karapatang pantao sa parehong antas tulad ng natitirang populasyon ng mga Estado kung saan sila nakatira, at ang kanilang mga batas, halagahan, kaugalian at pananaw ay madalas na binabalewala, at

Pagtawag ng pansin sa natatanging mga kontribusyon ng mga katutubo at tribong mamamayan sa kultural na dibersidad at panlipunan at ekolohikal na pagkakasundo ng sangkatauhan at sa internasyonal na kooperasyon at pag-unawa, at

Itinatala na ang mga sumusunod na probisyon ay nakabalangkas sa kooperasyon ng United Nations, ang Food and Agriculture Organization ng United Nations, ang United Nations Educational, Scientific and Cultural Organization, at ang World Health Organization, pati na rin ang Inter-American Indian Institute, sa naaangkop na antas at sa kani-kanilang larangan, at iminungkahi na ipagpatuloy ang kooperasyong ito sa pagtataguyod at pagtiyak ng aplikasyon ng mga probisyong ito, at

Napagpasyahan ang pagsasalin ng ilang mga panukala na patungkol sa bahagyang rebisyon ng Indigenous and Tribal Populations Convention, 1957 (Blg. 107), na siyang ikaapat na aytem sa adyenda ng sesyon, at

Napagpasyahan na ang mga panukalang ito ay kukuha ng isang porma ng pandaigdigang internasyonal na Kumbensyon na binabago ang Indigenous and Tribal Populations Convention, 1957; pinagtibay ngayong ikadalawampu't pitong araw ng Hunyo ng taong isang libo siyam na raan at walumpu't siyam ang sumusunod na Kumbensyon, na maaaring banggitin bilang Indigenous and Tribal Peoples Convention, 1989; 


\section{BAHAGI I. PANGKALAHATANG PATAKARAN}

\section{Artikulo 1}

1. Nalalapat ang Kumbensyon na ito sa:

(a) mga tribong mamamayan sa mga independiyenteng bansa na ang mga kalagayang panlipunan, pangkultura, at pang-ekonomiya ay nakikilala sila mula sa ibang mga seksyon ng pambansang pamayanan, at na ang kanilang katayuan ay nireregula nang buo o bahagya ng kanilang sariling mga kaugalian o tradisyon o ng mga espesyal na batas o regulasyon;

(b) ang mga tao sa mga independiyenteng bansa na itinuturing na katutubo sanhi ng kanilang pinagmulan mula sa mga populasyon na naninirahan sa bansa, o isang pangheograpiyang rehiyon kung saan kabilang ang bansa, sa panahon ng pananakop o kolonisasyon o ang pagtatatag ng kasalukuyang mga hangganan ng estado at sinuman, hindi alintana ang kanilang ligal na katayuan, na pinananatili ang ilan o lahat ng kanilang sariling mga institusyong panlipunan, pang-ekonomiya, pangkultura at pampulitika.

2. Ang pagkakakilanlan sa sarili bilang katutubo o tribo ay dapat isaalang-alang bilang isang pundamental na pamantayan para sa pagtukoy ng mga pangkat kung saan nalalapat ang mga probisyon ng Kumbensyon na ito.

3. Ang paggamit ng termino na mga tao sa Kumbensyon na ito ay hindi dapat ipakahulugan na mayroong anumang mga implikasyon hinggil sa mga karapatan na maaaring maglakip sa termino sa ilalim ng internasyunal na batas.

\section{Artikulo 2}

1. Ang mga pamahalaan ay may pananagutan para sa pagpapaunlad, na may paglahok ng mga mamamayang kinauukulan, ng koordinado at sistematikong aksyon upang protektahan ang mga karapatan ng mga mamamayang ito at upang igarantiya ang respeto sa kanilang integridad.

2. Ang nasabing pagkilos ay dapat magsama ng mga hakbang para sa:

(a) pagtiyak na ang mga miyembro ng mga mamamayang ito ay nakikinabang sa pantay na kalagayan mula sa mga karapatan at oportunidad na ipinagkakaloob ng mga pambansang batas at regulasyong grant sa ibang mga kasapi ng populasyon;

(b) nagtataguyod ng buong pagsasakatuparan ng mga karapatang panlipunan, pang-ekonomiya, at pangkultura sa mga mamamayang ito na may paggalang sa kanilang panlipunan at kultural na identidad, kanilang mga kaugalian at tradisyon at kanilang mga institusyon;

(c) pagtulong sa mga miyembro ng kinauukulang mamamayan na alisin ang mga sosyo-ekonomikong agwat na maaaring umiiral sa pagitan ng mga katutubo at iba pang mga kasapi ng pambansang pamayanan, sa paraang katugma sa kanilang mga hangarin at pamumuhay.

\section{Artikulo 3}

1. Ang mga katutubo at tribo ay tatamasa ang buong sukat ng karapatang pantao at pundamental na mga kalayaan nang walang hadlang o diskriminasyon. Ang mga probisyon ng Kumbensyon ay dapat mailapat nang walang diskriminasyon sa mga kalalakihan at kababaihang miyembro ng mga mamamayang ito.

2. Walang uri ng puwersa o pamimilit ang gagamitin sa paglabag sa mga karapatang pantao at pundamental na mga kalayaan ng mga mamamayang kinauukulan, kasama na ang mga karapatang nakapaloob sa Kumbensyong ito.

\section{Artikulo 4}

1. Ang mga espesyal na hakbang ay isasalin bilang angkop sa pangangalaga ng mga tao, institusyon, pag-aari, paggawa, kultura, at kapaligiran ng mga mamamayang kinauukulan.

2. Ang nasabing mga espesyal na hakbang ay hindi dapat salungat sa malayang ipinahayag na mga hangarin ng mga kinauukulang mamamayan.

3. Ang pagtamasa ng pangkalahatang mga karapatan ng pagkamamamayan, nang walang diskriminasyon, ay hindi dapat maprehuwisyo sa anumang paraan ng mga espesyal na hakbang.

\section{Artikulo 5}

Sa paglalapat ng mga probisyon ng Kumbensyong ito: 
(a) ang mga halagahang panlipunan, pangkultura, relihiyoso, at pang-espiritwal at mga kasanayan ng mga mamamayang ito ay kikilalanin at poprotektahan, at ang angkop na pagtatala ay isasaalang-alang sa kalikasan ng mga problema na kanilang kinakaharap sa kapwa bilang mga grupo at bilang mga indibidwal;

(b) iginagalang ang integridad ng mga halagahan, kasanayan at institusyon ng mga mamamayang ito;

(c) mga patakaran na naglalayong mapagaan ang mga paghihirap na naranasan ng mga mamamayang ito sa pagharap sa mga bagong kondisyon ng buhay at trabaho ay dapat isalin, sa pakikilahok at kooperasyon ng mga mamamayang apektado.

\section{Artikulo 6}

1. Sa paglalapat ng mga probisyon ng Kumbensyon na ito, ang mga gobyerno ay dapat:

(a) kumunsulta sa mga mamamayang kinauukulan, sa pamamagitan ng naaangkop na mga pamamaraan at sa partikular sa pamamagitan ng kanilang kinatawang mga institusyon, tuwing isasaalang-alang ang mga lehislatibo o administratibong mga hakbang na maaaring direktang makaapekto sa kanila;

(b) magtaguyod ng mga paraan kung saan malayang makikilahok ang mga mamamayang ito, sa saklaw na katulad sa iba pang mga sektor ng populasyon, sa lahat ng antas ng paggawa ng desisyon sa mga panghalalang institusyon at administratibo at iba pang mga kinatawang responsable para sa mga patakaran at programa na nauukol sa kanila;

(c) magtaguyod ng mga paraan para sa buong pag-unlad ng sariling mga institusyon at inisyatiba ng mga mamamayang ito, at ang mga hindi naaangkop na kaso ay nagbibigay ng mga mapagkukunang kinakailangan para sa hangaring ito.

2. Ang mga konsultasyong isinasagawa sa paglalapat ng Kumbensyong ito ay dapat isagawa, sa mabuting hangarin at sa isang anyo na naaangkop sa mga pangyayari, na may layuning makamit ang kasunduan o pahintulot sa mga iminungkahing hakbang.

\section{Artikulo 7}

1. Ang mga mamamayang kinauukulan ay may karapatang magpasya ng kanilang sariling mga priyoridad para sa proseso ng kaunlaran dahil nakaaapekto ito sa kanilang buhay, paniniwala, institusyon, at kagalingang espiritwal at ang mga lupain na inookupa nila o ginagamit man, at upang magsagawa ng kontrol, hangga't makakaya, sa kanilang sariling pang-ekonomiya, panlipunan at pangkulturang pag-unlad. Bilang karagdagan, lalahok sila sa pagbubuo, pagpapatupad at ebalwasyon ng mga plano at programa para sa pambansa at panrehiyong kaunlaran na maaaring direktang makaapekto sa kanila.

2. Ang pagpapabuti ng mga kondisyon ng buhay at trabaho at antas ng kalusugan at edukasyon ng mga mamamayang kinauukulan, kasama ang kanilang pakikilahok at kooperasyon, ay dapat maging isang bagay na priyoridad sa mga plano para sa pangkalahatang pag-unlad ng ekonomiya ng mga lugar na kanilang tinitirahan. Ang mga espesyal na proyekto para sa pagpapaunlad ng mga lugar na pinag-uusapan ay dapat ding idisenyo upang maitaguyod ang naturang pagpapabuti.

3. Titiyakin ng mga pamahalaan na, tuwing naaangkop, na isinasagawa ang mga pag-aaral, sa pakikipagtulungan sa mga mamamayang kinauukulan, upang matasa ang panlipunan, espiritwal, pangkultura at pangkapaligiran epekto sa kanila ng mga nakaplanong aktibidad sa pag-unlad. Ang mga resulta ng mga pag-aaral na ito ay isasaalang-alang bilang pundamental na pamantayan para sa pagpapatupad ng mga aktibidad na ito.

4. Ang mga pamahalaan ay dapat gumawa ng mga hakbang, sa pakikipagtulungan sa mga mamamayang kinauukulan, upang maprotektahan at mapangalagaan ang kapaligiran ng mga teritoryo na kanilang tinitirhan.

\section{Artikulo 8}

1. Sa paglalapat ng mga pambansang batas at regulasyon sa mga kinauukulang mamamayan, dapat isaalang-alang ang kanilang kaugalian o mga nakaugaliang batas.

2. Ang mga mamamayang ito ay magkakaroon ng karapatang mapanatili ang kanilang sariling kaugalian at institusyon, kung saan ang mga ito ay hindi ingkompatible sa mga pundamental na karapatan na tinukoy ng pambansang sistemang ligal at may internasyonal na kinikilalang mga karapatang pantao.

3. Ang mga pamamaraan ay dapat maitaguyod, kung kinakailangan, upang malutas ang mga tunggalian na maaaring lumitaw sa paglalapat ng prinsipyong ito. 
4. Ang paglalapat ng mga parapo 1 at $2 \mathrm{ng}$ Artikulong ito ay hindi pipigil sa mga kasapi ng mga mamamayang ito mula sa paggamit ng mga karapatang ipinagkaloob sa lahat ng mga mamamayan at mula sa ipinagpapalagay na mga kaukulang tungkulin.

\section{Artikulo 9}

1. Sa lawak na katugma sa pambansang ligal na sistema at internasyonal na kinikilalang mga karapatang pantao, ang mga pamamaraang kaugalian na isinasagawa ng mga mamamayang kinauukulan para sa pagharap sa mga opnesang ginawa ng kanilang mga kasapi ay igagalang.

2. Ang mga kaugalian ng mga mamamayang ito hinggil sa mga usapin sa penal ay isasaalang-alang ng mga awtoridad at korte na tumatalakay sa mga nasabing kaso.

\section{Artikulo 10}

1. Sa pagpapataw ng mga parusa na inilatag ng pangkalahatang batas sa mga miyembro ng mga mamamayang ito, kukuha ng kanilang mga katangiang pang-ekonomiya, panlipunan at pangkultura.

2. Ang preperensiya ay ibibigay sa mga pamamaraan ng parusa maliban sa pagkakakulong sa bilangguan.

\section{Artikulo 11}

Ang pagkuha mula sa mga kasapi ng mga kinauukulang mamamayan ng sapilitang personal na serbisyo sa anumang anyo, binayaran man o hindi nabayaran, ay ipagbabawal at maparurusahan ng batas, maliban sa mga kaso na iminungkahi ng batas para sa lahat ng mga mamamayan.

\section{Artikulo 12}

Ang mga mamamayang kinauukulan ay papangalagaan laban sa pang-aabuso sa kanilang mga karapatan at makakapagsagawa ng ligal na paglilitis, bilang indibidwal man o sa pamamagitan ng kanilang kinatawang mga bahagi, para sa mabisang proteksyon ng mga karapatang ito. Ang mga hakbang ay gagawin upang matiyak na ang mga miyembro ng mga mamamayang ito ay nakauunawa at maunawaan sa mga ligal na paglilitis, kung saan kinakailangan sa pamamagitan ng pagkakaloob ng interpretasyon o ng iba pang mabisang pamamaraan.

\section{BAHAGI II. LUPA}

\section{Artikulo 13}

1. Sa paggamit ng probisyon sa Bahaging ito ng Kumbensyon, ang mga pamahalaan ay nararapat na igalang ang espesyal na kahalagahan ng mga kultura at ispiritwal na halagaan ng kaukulang mga mamamayan sa kanilang kaugnayan sa mga lupain o teritoryo, o maaring pareho kung nalalapat, kung saan nila inookupa o sa ibang paraan gingamit, at sa partikular ang kolektibong aspekto ng kaugnayang ito.

2. Ang paggamit ng terminong lupain sa Arikulo 15 at 16 ay nararapat na isama ang konsepto ng mga teritoryo, na kung saan sakop ang kabuuan ng kalikasan ng mga lugar na ang mga mamamayang kinuukulan ay inookupa o sa ibang paraan ginagamit.

\section{Artikulo 14}

1. Ang mga karapatan sa pagmamay-ari at posesyon ng mga kinauukulang mamamayan sa mga lupain na kanilang tradisyonal na inookupa ay kikilalanin. Dagdag pa, nararapat na ipatupad ang mga hakbang sa naaayong mga kaso upang pangalagaan ang karapatan ng mga kinauukulang mamamayan na gamitin ang lupain na hindi eksklusibong inookupa nila, ngunit dito sila tradisyunal na may akses para sa pamumuhay at tradisyonal na mga gawain. Bibigyan ng partikular na tutok sa kalagayan ng mga taong lagalag at palipat-lipat na magsasaka sa ganitong paggalang.

2. Nararapat na gumawa ng mga hakbang ang mga pamahalaan upang kilalanin ang mga lupain na tradisyonal na inookupa ng mga mamamayang kinauukulan, at upang siguraduhin ang mabisang proteksiyon sa kanilang mga karapatan sa pagmamay-ari at posesyon.

3. Sapat na mga hakbang ang nararapat na itatag sa loob ng pambansang sistemang ligal upang maresolba ang mga pag-aangkin ng lupain ng kinauukulang mga mamamayan. 


\section{Artikulo 15}

1. Ang karapatan ng kaukulang mga mamamayan sa likas-yaman na nauukol sa kanilang lupain ay nararapat na espesyal na pangalagaan. Kasama sa mga karapatang ito ang karapatan na lumahok sa paggamit, pangangasiwa at konserbasyon sa mga likas-yamang ito.

2. Sakaling panatilihin ng Estado ang pagmamay-ari ng mga yamang mineral o sub-surface na mapagkukunan o karapatan sa iba pang yaman kaugnay ng lupain, dapat ang mga pamahalaan ay magtatag o panatilihin ang mga pamamaraan sa pamamagitan ng pagkonsulta sa mga mamamayang ito, na may paglilinaw upang matiyak kung anong antas ang kanilang interes ay mapeprehuwisyo, bago isagawa o pahintulutan ang anumang programa para sa eksplorasyon at pagsasamantala sa naturang mapagkukunan kaugnay ng kanilang lupain. Ang mga kaukulang mamamayan ay sasali sa anumang posibleng mga gawain na kanilang mapapakinabangan, at makatatanggap ng patas na kompensasyon sa anumang pinsala na maaaring matamo nila bilang resulta ng naturang mga gawain.

\section{Artikulo 16}

1. Batay sa sumusunod na mga parapo ng Artikulong ito, ang mga kaukulang mamamayan ay hindi dapat paalisin sa mga lupain na kanilang inookupa.

2. Kung ang relokasyon ng mga nasabing mga mamamayan ay isinasalang-alang na kailangan bilang tanging hakbang, ang ganu'ng relokasyon ay isasagawa lamang nang kasama ang kanilang malaya at malinang na pahintulot. Kung hindi makuha ang kanilang pahintulot, ang naturang relokasyon ay magagawa lamang sa pagsunod sa mga angkop na proseso na itinatag ng mga pambansang batas at regulasyon, kasama rin ang angkop na pampublikong pagsisiyasat, na siyang magbibigay ng pagkakataon para sa epektibong representasyon ng mga kaukulang mamamayan.

3. Kung maaari, ang mga mamamayang ito ay may karapatan upang bumalik sa kanilang tradisyonal na lupain, sa sandaling tumigil na ang umiiral na mga batayan sa relokasyon.

4. Kung hindi maaari ang nasabing pagsasauli, batay sa kasunduan o, sa kawalan ng naturang kasunduan, sa pamamagitan ng angkop na mga alituntunin, ang mga mamamayang ito sa lahat ng posibleng kaso ay dapat bigyan ng lupaing may kalidad at sa ligal na kalagayan ay kahit man lamang katumbas ng lupain sa dati nilang inookupa, na babagay sa kanilang kasalukuyang pangangailangan at kaunlaran sa hinaharap. Kung ang kinauukulang mga mamamayan ay nagpahayag ng nais na bigyang kompensasyon sa pera o anumang uri ng kabayaran, kailangang sila ay bigyan ng kompensasyon sa ilalaim ng naayong mga garantiya.

5. Ang mga tao na nareloka ay maaaring makompensa nang buo para sa anumang nagresultang pagkawala o pinsala.

\section{Artikulo 17}

1. Nararapat na igalang ang mga patakarang binuo sa pamamagitan ng mga kaukulang mamamamyan para sa transmisyon ng mga karapatan sa lupa ng mga miyembro ng mga mamamayang ito.

2. Ang mga kaukulang mamamayan ay nararapat na ikonsulta kung ibibigay ang konsiderasyon sa kanilang kapasidad upang humiwalay sa kanilang lupain o kung ilipat ang kanilang mga karapatan sa labas ng sarili nilang komunidad.

3. Ang mga taong hindi kabilang sa naturang mga mamamayan ay dapat na pigilan mula sa pang-aapi ng kanilang kaugalian o kakulangan sa pag-unawa ng mga batas sa panig ng kanilang mga miyembro upang masigurado ang pagmamay-ari, posesyon o ang paggamit ng mga lupaing ari-arian nila.

\section{Artikulo 18}

Nararapat patawan ng sapat na kaparusahan mula sa batas sa sinumang hindi pinahihintulutang manghimasok, o gumamit, sa mga lupain ng kaukulang mamamamayan, at ang mga pamahalaan ay dapat na gagawa ng karampatang hakbang upang pigilan ang ganu'ng mga opensa.

\section{Article 19}

Ang mga pambansang programa sa agraryo ay dapat na siguruhin sa mga kaukulang mamamayan ng pagtratongkatumbas na ibinibgay sa iba pang sektor ng populasyon kaugnay ng:

(a) probisyon ng maraming lupain para sa mamamayang ito kapag wala silang lugar na kinakailangan upang magbigay ng mga esensyal sa isang normal na pag-iral, o kaya sa anumang posibleng pagtaas ng kanilang bilang;

(b) probisyon ng mga pamamaraang kailangan upang maitaguyod ang pag-unlad ng mga lupaing mayroon na ang mga mamamayang ito. 


\section{BAHAGI III. PAGREKLUTA AT KONDISYON NG PAGTATRABAHO}

\section{Artikulo 20}

1. Ang mga pamahalaan, sa loob ng balangkas ng mga pambansang batas at regulasyon, at sa pakikipagtulungan ng mga kaukulang mamamayan, ay magsasalin ng mga espesyal na hakbang upang masigurado ang mabisang proteksyon patungkol sa pagrekluta at kalagayan sa trabaho ng mga manggagawa na kabilang sa mga mamamayang ito, na aabot sa punto na hindi sila nabibigyan ng epektibong proteksyon ng mga batas para sa mga manggagawa sa kabuuan.

2. Gagawin ng mga pamahalaan ang lahat ng posibleng paraan upang maiwasan ang diskriminasyon sa pagitan ng mga manggagawa na kabilang sa mga kaukulang mamamayan at sa ibang manggagawa, sa partikular na kaugnay ng:

a) pagpasok sa trabaho, kasama na ang bihasang hanapbuhay, gayundin ang mga hakbang sa promosyon at pagsulong;

b) pantay na kabayaran para sa pantay na halaga ng trabaho;

c) medikal at sosyal na tulong, kaligtasan at kalusugan sa trabaho, lahat ng benipisyo ng social security at iba pang kaugnay sa trabahong benipisyo, at pabahay;

d) ang karapatan sa samahan at kalayaan sa lahat ng mga gawain ng unyon ng manggagawa, at ang karapatan na tapusin ang kolektibong kasunduan sa mga taga-empleyo at mga organisasyon ng taga-empleyo.

3. Ang mga hakbang na gagamitin ay isasama ang mga hakbang upangsiguraduhin na:

(a) ang mga manggagawa na kabilang sa mga kaukulang mamamayan, kasama na ang mga pana-panahon, kaswal, at migranteng manggagawa sa pang-agrikultura at iba pang trabaho, gayundin ang mga nagtatrabaho sa pamamagitan ng mga kontraktor sa paggawa, ay tinatamasa ang proteksyong iginagawad ng pambansang batas at gamitin sa iba pang manggagawa ng parehong mga sektor, at na dapat na sila ay nabigyan ng buong impormasyon hinggil sa kanilang mga karaapatan sa ilalim ng batas paggawa at ng pamamaraan ng pagwawasto na maaabot nila.

(b) na ang mga manggagawa na kabilang sa mga mamamayang ito ay hindi isasalang sa kondisyon sa trabaho na mapanganib sa kanilang kalusugan, partikular na ang ma-expose sa pestisidyo o iba pang nakakalasong kemikal.

(c) na ang mga manggagawang kabilang sa mga mamamayang ito ay hindi isasalang sa sistemang pamimilit na pagrekluta, kasama na ang bond sa paggawa at ibang anyo ng pang-aalila sa utang;

(d) ang mga manggagawang kabilang sa mga mamamayang ito ay matatamasa ang pantay na oportunidad at pantay na pagtrato sa trabaho para sa kalalakihan at kababaihan, at proteksyon mula sa sekwal na pang-aabuso.

4. Partikular na atensyon ang dapat na ibigay sa pagbuo ng sapat na serbisyong inspeksyon sa paggawa sa mga lugar kung saan ang mga manggagawang kabilang sa mamamayang ito ay nakararanas ng sahod sa paggawa, upang masiguradong tumatalima sa mga probisyon sa Bahaging ito ng Kumbensyon.

\section{BAHAGI IV. BOKASYONAL NA PAGSASANAY, MGA LIKHANG-KAMAY AT MGA RURAL NA INDUSTRIYA}

\section{Artikulo 21}

Ang mga miyembro ng mga kaukulang mamamayan ay tatamasain ang mga oportunidad na pantay sa ibang mamamayan kaugnay ng mga hakbang sa bokasyonal na pagsasanay.

\section{Artikulo 22}

1. Karampatang mga hakbang ang dapat na gamitin upang itaguyod ang boluntaryong partisipasyon ng mga miyembro ng kaukulang mga mamamayan sa mga programa ng bokasyonal na pagsasanay sa pangkalahatang aplikasyon. 
2. Sa sandaling ang umiiral na mga programa ng bokasyonal na pagsasanay sa pangkalahatan ay hindi natugunan ang mga pangangailangan ng kaukulang mga mamamayan, nararapat na siguraduhin ng mga pamahalaan sa partisipasyon ng mga mamamayang ito ang probisyon ng espesyal na mga programa ng pagsasanay at mga pasilidad.

3. Anumang espesyal na mga programa ng pagsasanay ay dapat ibatay sa ekonomikong kapaligiran, sosyal at kultural na kalagayan at praktikal na mga pangangailangan ng mga kaukulang mamamayan. Anumang mga pagaaral na isinagawa kaugnay nito ay dapat ipatupad sa pakikipagkooperasyon sa mga mamamayang ito, na dapat konsultahin hinggil sa organisasyon at operasyon ng ganu'ng mga programa. Kung maaring gawin, dapat ang mga mamamayang ito ay progresibong gampanan ang mga responsibilidad para sa organisasyon at operasyon ng naturang espesyal na porgrama ng pagsasanay, kung padedesisyunan man nila.

\section{Artikulo 23}

1. Ang mga likhang-kamay, rural at batay sa komunidad na mga industriya, at ikinabubuhay na ekonomiya at mga tradisyonal na gawain ng mga kaukulang mamamayan, gaya ng pangangaso, pangingisada, panghuhuli at paglilikom, ay nararapat na kilalanin bilang mga mahahalagang salik sa pagpapanatili ng kanilang mga kultura at sa kanilang pag-asa sa sarili at kaunlaran. Ang mga pamahalaan, sa partisipasyon ng mga mamamayang ito at kung kailan naangkop, ay dapat na matiyak na mga mga gawaing nabanggit ay mapatitibay at maitataguyod.

2. Batay sa kahilingan ng mga kaukulang mamamayan, naangkop na teknikal at pinansyal na tulong ang dapat ibigay sa saanman posible, nang binibigyang tala ang mga tradisyonal na tekonolohiya at kultural na mga katangian ng mga mamamayang ito, gayundin ang halaga ng sustenable at karampatang kaunlaran.

\section{BAHAGI V. SOSYAL NA SEGURIDAD AT KALUSUGAN}

\section{Artikulo 24}

Ang mga iskema sa sosyal na seguridad ay nararapat sumaklaw nang progresibo upang mabigyan ang mga kaukulang mamamayan, at mailapat nang walang diskriminasyon laban sa kanila.

\section{Artikulo 25}

1. Ang mga pamahalaan ay dapat siguraduhin na ang sapat na serbisyong pangkalusugan ay mapakikinabangan ng kaukulang mga mamamayan, o dapat na bigyan sila ng pagkukunang yaman upang sila'y makadisenyo at makapaghatid ng ganoong mga serbisyo sa sarili nilang responsibilidad at kontrol, upang kanilang matamasa ang pinakamataas na maaabot na pamantayan ng pisikal at mental na kalusugan.

2. Ang mga serbisyong pangkalusugan, sa pinakamalawak na posibleng paraan, ay nararapat na nakabatay sa komunidad. Ang mga serbisyong ito ay dapat nakaplanoat pinangangasiwaan sa pakikipagtulugan sa kaukulang mga mamamayan at isaalang-alang ang kanilang ekonomiko, geograpiko, sosyal at kultural na mga kalagayan ganyundin ang kanilang tradisyonal na prebentibong pangangalaga, mga kasanayan sa panggagamot at mga medisina.

3. Ang sistema sa pangkalusugang pangangalaga ay dapat pagtuunan ang mga pagsasanay at trabaho ng lokal na manggagawang pangkalusugan, at magpokus sa pangunahing pangangalaga sa kalusugan habang napananatili ang matibay na ugnayan sa iba pang lebel ng serbisyong pangkalusugan pangangalaga.

4. Ang probisyon sa mga naturang sebisyong pangkalusugan ay dapat na kaakibat ng ibang sosyal, ekonomiko at kultural na mga hakbang sa bansa.

\section{BAHAGI VI. EDUKASYON AT PAMAMARAAN SA KOMUNIKASYON}

\section{Artikulo 26}

Dapat na magkaroon ng mga hakbang upang masigurado na ang mga miyembro ng kaukulang mga mamamayan ay mayroong oportunidad na magtamo ng edukasyon sa lahat ng antas sa pamamagitan ng pantay man lang na katayuan tulad ng iba pang nasa nasyonal na komunidad. 


\section{Artikulo 27}

1. Ang mga programa at serbisyong pang-edukasyon ng kaukulang mga mamamayan ay dapat na mapaunlad at maipatupad sa pakikipagtulungan sa kanila upang matugunan ang kanilang espesyal na pangangailangan, at dapat na maisama ang kanilang mga kasaysayan, kaalaman at teknolohiya, kanilang sistema sa halagahan at iba pang sosyal, ekonomiko at kultural na mga hangarin.

2. Ang may kasanayang awtoridaday nararapat na siguraduhin ang pagsasanay ng mga miyembro ng kaukulang mga mamamayan at ang kanilang pakikilahok sa pagbuo at pagpapatupad ng mga programang pang-edukasyon, na may pananaw sa progresibong paglipat ng responsibilidad upang isagawa ang mga programang ito sa mga mamamayon ayon sa kaangkupan.

3. Bilang karagdagan, ang mga pamahalaan ay nararapat na kilalanin ang karapatan ng mga mamamayang ito na magtatag ng kanilang sariling mga pasilidad at institusyong pang-edukasyon, sa kondisyon na ang mga naturang institusyon ay matutugunan ang minimum na pamantayang binuo ng mga may kasanayang awtoridad sa konsultasyon sa mga mamamayang ito. Angkop na mga pagkukunan ay nararapat na ibigay para sa layuning ito.

\section{Artikulo 28}

1. Ang mga batang nabibilang sa kaukulang mga mamamayan, saan mang praktikal na magagawa, ay nararapat na turuang bumasa at sumulat sa kanilang sariling katutubong wika o wikang karaniwang sinasalita ng grupo na kanilang kinabibilangan. Kung hindi ito praktikal na magagawa, ang mga may kasanayang awtoridad ay nararapat na magsailalim ng mga konsultasyon sa mga mamamayang ito na may pananaw sa pag-angkop ng mga hakbang upang makamit ang layuning ito.

2. Sapat na mga hakbang ang nararapat na gamitin upang siguraduhin na ang mga mamamayang ito ay may mga oportunidad upang matamo ang katatasan sa pambansang wika o sa isa sa mga opisyal na wika ng bansa.

3. Ang mga hakbang ay nararapat na gamitin upang mapangalagaan at maitaguyod ang kaunlaran at pagsasanay sa katutubong mga wika ng kaukulang mga mamamayan.

\section{Artikulo 29}

Ang pagbabahagi ng pangkalahatang kaalaman at kasanayan na makatutulong sa kanilang mga anak na kabilang sa mga kaukulang mamamayan upang buong makilahok at sa pantay na kalagayan sa kanilang sariling komunidad at nasyonal na komunidad ay nararapat na tunguhin sa edukasyon ng mga mamamayang ito.

\section{Artikulo 30}

1. Nararapat na ang mga pamahalaan ay magpatibay ng mga angkop na hakbang sa mga tradisyon at kultura ng kaukulang mga mamamayan, upang kanilang malaman ang kanilang mga karapatan at tungkulin, lalo na kung kaugnay sa paggawa, mga ekonomikong oportunidad, edukasyon at usapin sa kalusugan, kapakanang sosyal at ang kanilang mga karapatan na kinuha mula sa Kumbensyong ito.

2. Kung kinakailangan, ito ay nararapat na gawin sa anumang mga pamamaraanng naisulat na pagsasalin at sa pamamagitan ng paggamit ng pangmasang komunikasyon sa mga wika ng mga mamamayang ito.

\section{Artikulo 31}

Ang mga edukasyonal na hakbang ay nararapat na gamitin sa lahat ng mga seksyon ng nasyonal na komunidad, at partikular na doon sa pinakadirektang kontak ng mga kaukulang mamamayan, sa layuning alisin ang mga prehuwisyo na maaaring mamuo sa kabila ng paggalang sa mga mamamayang ito. Sa puntong ito, gagawin ang mga pagsisikap upang siguraduhin na ang mga pangkasaysayang teksbuk at iba pang materyales sa edukasyon ay magbigay ng patas, tumpak at impormatibong paglalarawan ng mga lipunan at kultura ng mga mamamayang ito.

\section{BAHAGI VII. MGA UGNAYAN AT KOOPERASYON SA MGA HANGGANAN}

\section{Artikulo 32}

Ang mga pamahalaan ay nararapat na gumamit ng angkop na hakbang, kabilang ang pamamaraan ng internasyunal na mga kasunduan, upang mapangasiwaan ang mga ugnayan at kooperasyon sa pagitan ng mga katutubo at 
tribal na mga mamamayan sa lahat ng mga hangganan, kasama na ang mga mga aktibidad sa ekonomiko, sosyal, kultural, espiritwal at pangkapaligirang larangan.

\section{BAHAGI VIII.ADMINISTRASYON}

\section{Artikulo 33}

1. Ang may pananagutang awtoridad ng pamahalaan sa mga usaping sakop ng Kumbensyong ito ay nararapat siguraduhin na ang mga ahensya o iba pang angkop na mga mekanismong umiiral upang pangasiwaan ang mga programang makaaapekto sa kaukulang mga mamamayan, at sisiguraduhin din na sila ay may mga paraan sila na kinakailangan para sa tamang pagsasakatuparan ng mga tungkuling nakaatas sa kanila.

2. Isasama sa mga programang ito:

(a) ang pagpaplano, koordinasyon, pagsasagawa at ebalwasyon, sa pakikipagtulungan sa kaukulang mga mamamayan, sa mga hakbang na ibinigay sa Kumbensyong ito;

(b) ang pagmumungkahi ng lehislatibo at ibang hakbang sa may kasanayang awtoridad at pamamahala sa paglalapat ng mga hakbang na inilunsad, sa pakikipagtulungan sa mga kaukulang mamamayan.

\section{BAHAGI IX. PANGKALAHATANG MGA PROBISYON}

\section{Artikulo 34}

Ang kalikasan at saklaw ng mga hakbang na gagamitin na makapagbibigay epekto sa Kumbensyong ito ay nararapat na matiyak sa maluwag na paraan, na may pagsasaalang-alang sa mga kondisyong katangian ng bawat bansa.

\section{Artikulo 35}

Ang aplikasyon ng mga probisyon ng Kumbensyong ito ay nararapat na hindi makaapekto nang masama sa mga karapatan at benipisyo ng mga kaukulang mamamayan alinsunod sa ibang Kumbensyon at mga Rekomendasyon, mga internasyonal na instrumento, mga tratado, o mga nasyonal na batas, mga gawad, mga kaugalian at kasunduan.

\section{BAHAGI X. PANGHULING MGA PROBISYON}

\section{Artikulo 36}

Ang Kumbensyong ito ay nirerebisa ang Indigenous and Tribal Populations Convention, 1957.

\section{Artikulo 37}

Ang pormal na pagraratipika ng Kumbensyong ito ay nararapat na ipabatid sa Direktor-Heneral ng International Labour Office para sa rehistrasyon.

\section{Artikulo 38}

1. Ang Kumbensyong ito ay may bisa lamang doon sa mga Miyembro ng International Labour Organisation kung saan ang mga ratipikasyon ay narehistro kasama ang Direktor-Heneral.

2. Nararapat na isabisa ito pagkaraan ng labindalawang buwan na kung saan ang ratipikasyon ng nito ay nirehistro ng dalawang Miyembro kasama ng Direktor-Heneral.

3. Pagkatapos noon, ang Kumbensyong ito ay nararapat na isabisa sa anumang Miyembro matapos ang labindalawang buwan ng parehistro ng ratipikasyon.

\section{Artikulo 39}

1. Ang isang Miyembro na nagratipika ng Kumbensyong ito ay maaring ireklamo ito matapos ang sampung taong pagkakapaso mula sa petsa kung saan ang Kumebsyong ito ay unang nagkabisa, sa pamamagitan ng pakikipagkomunikasyon sa Direktor-Heneral sa International Labour Office para sa rehistrasyon. Ang ganoong reklamo ay hindi magkakabisa hanggàt isang taon ang makalipas mula petsa ng rehistrasyon nito. 
2. Bawat Miyembro na nagratipika ng Kumbensyong ito at kung saan hindi, sa loob ng sumunod na taon ng pagkakapaso ng panahon ng sampung taong nabanggit sa naunang talata, isasagawa ang karapatan sa pagbatikos na isinaad sa Artikulong ito, ay bibigyan ng bisa ng karagdagang panahon na sampung taon at, pagkatapos noon, maaring ireklamo ang Kumbensyong ito sa pagtatapos ng bawat sampung taong kapanahunan sa ilalim ng mga terminong ipinapabatid ng Artikulong ito.

\section{Artikulo 40}

1. Ang Direktor-Heneral sa International Labour Office ay nararapat na magbigay-alam sa lahat ng Miyembro ng International Labour Office hinggil sa rehistrasyon ng lahat ng mga ratipikasyon at mga batikos na ipinabatid sa kanya ng mga Miyembro ng Organisasyon.

2. Sa pagbibigay-alam sa mga Miyembro ng Organisasyon hinggil sa rehistrasyon ng pangalawang ratipikasyon na ipinabatid sa kanya, ang Direktor-Heneral ay nararapat na tawagin ang atensiyon ng mga Miyembro ng Organisasyon sa petsa ng pagkakaroon ng bisa ng Kumbensyon.

\section{Artikulo 41}

Ang Direktor-Heneral sa International Labour Office ay nararapat na makipag-ugnayan sa PangkalahatangKalihim ng United Nations para sa ganap na rehistrasyon alinsunod sa Artikulo 102 ng Tsarter ng United Nations buong partikularidad ng lahat ng mga ratipikasyon at mga aksyon ng pagbatikos na inirehistro niya alinsunod sa mga probisyon ng naunang mga Artikulo.

\section{Artikulo 42}

Sa ganoong panahon na ito ay kailangang isasaalang-alang, ang Namamahalang Lupon ng International Labor Office ay nararapat na ilahad sa Pangkalahatang Kumperensiya ang ulat hinggil sa pagsasagawa ng Kumbensyong ito at nararapat na suriiin ang kanais-nais na paglalagay ng adyenda ng Komperensiya ang tanong tungkol sa kabuuan o parte lamang ng rebisyon nito.

\section{Artikulo 43}

1. Ang Kumperensiya ay nararapat na mag-angkop ng isang bagong Kumbensyon matapos ang pagrerebisa sa Kumbensyong ito sa kabuuan o bahagi lamang, maliban kung ang bagong Kumbensyon sa ibang paraan ay nilalaan-
(a) ang ratipikasyon ng isang Miyembro sa bagong nirerebisang Kumbensyon ay nararapat na sa pamamagitan ng batas siguraduhing kasama ang kagyat na mga batikos ng Kumbensyong ito, sa kabila ng nakatindig na mga probisyon ng Artikulo 39 sa itaas, kung at kailan ang bagong nirerebisang Kumbensyon ay magkakaroon ng bisa;
(b) batay sa petsa kung kailan ang bagong nirerebisang Kumbensyon ay magkakaroon ng bisa, ang Kumbensyong ito ay nararapat na tumigil sa pagbukas ng mga ratipikasyon ng mga Miyembro.

2. Ang Kumbensyong ito sa anumang kalagayan ay mananatiling may bisa sa aktwal nitong anyo at nilalaman para doon sa mga Miyembro na nagratipika nito ngunit hindi nagratipika sa nirerebisang Kumbensyon.

\section{Artikulo 44}

Ang bersiyon ng teksto ng Kumbensyong ito na nakasulat sa Ingles at Pranses ay kapwa parehong awtoratibo. 


\section{Karugtong 2. Deklarasyon ng United Nations ukol sa Mga Karapatan ng Mga Katutubong}

Resolusyong pinagtibay ng Pangkalahatang Asembliya noong 13 Setyembre 132007 [nang walang pagsangguni sa isang Pangunahing Komite (A/61/L.67 and Add.1)]

\section{1/295. Deklarasyon ng United Nations ukol sa Mga Karapatan ng Mga Katutubo}

Ang Pangkalahatang Asembliya,

Sa pagkuha ng tala ng rekomendasyon ng Human Rights Council na nakapaloob sa $1 / 2$ resolusyon nito noong 29 Hunyo 2006, kung saan pinagtibay ng Konseho ang teksto ng Deklarasyon ng United Nations ukol sa Mga Karapatan ng mga Katutubo,

Ginugunita ang resolusyon nitong 61/178 ng 20 Disyembre 2006, ${ }^{13}$ kung saan nagpasya itong ipagpaliban ang pagsasaalang-alang at aksyon sa Deklarasyon upang bigyan ng oras para sa karagdagang mga konsultasyon tungkol dito, at nagpasya din na tapusin ang pagsasaalang-alang nito bago matapos ang ikaanimnapu't isang sesyon ng Pangkalahatang Asembleya,

Pinagtibay ang Deklarasyon ng United Nations ukol sa Mga Karapatan ng Mga Katutubo na nakapaloob sa karugtong sa kasalukuyang resolusyon.

107th pagpupulong ng plenaryo 13 September 2007 


\section{Karugtong Deklarasyon ng United Nations ukol sa Mga Karapatan ng Mga Katutubo}

Ang Pangkalahatang Asembliya,

Pinapatnubayan ng mga layunin at prinsipyo ng Tsarter ng United Nations, at mabuting hangarin sa pagtupad ng mga obligasyong ipinapalagay ng mga Estado alinsunod sa Tsarter,

Pinapatunayan na ang mga katutubo ay pantay-pantay sa lahat ng iba pang mga mamamayan, habang kinikilala ang karapatan ng lahat ng mga mamamayan na maging iba, upang isaalang-alang ang kanilang sarili na naiiba, at igalang bilang ganoon,

Pinapatunayan din na ang lahat ng mga mamamayan ay nag-aambag sa dibersidad at kayamanan ng mga sibilisasyon at kultura, na bumubuo sa karaniwang pamana ng sangkatauhan,

Pinapatunayan pa na ang lahat ng mga doktrina, patakaran at kasanayan na nakabatay sa o nagtataguyod ng superyoridad ng mga mamamayan o indibidwal batay sa pambansang pinagmulan o lahi, relihiyon, etniko o kulturang pagkakaiba-iba ay rasista, mali sa agham, hindi wasto sa batas, ipinagbabawal sa moralidad at hindi makatarungan sa lipunan,

Pinatutunayan muli na ang mga katutubo, sa pagpapatupad ng kanilang mga karapatan, ay dapat na hindi makaranas ng anumang diskriminasyon,

Nag-aalala na ang mga katutubo ay nagdusa mula sa makasaysayang mga kawalang katarungan bilang isang resulta, liban sa iba pa, ng kanilang kolonisasyon at pang-aagaw ng kanilang mga lupa, teritoryo at mapagkukunan, sa gayon pinipigilan silang gamitin, lalo na, ang kanilang karapatan sa kaunlaran alinsunod sa kanilang sariling mga pangangailangan at interes,

Kinikilala ang kagyat na pangangailangan na igalang at itaguyod ang likas na mga karapatan ng mga katutubo na nagmula sa kanilang istrukturang pampulitika, pang-ekonomiya at panlipunan at mula sa kanilang mga kultura, mga espiritwal na tradisyon, kasaysayan at pilosopiya, lalo na ang kanilang mga karapatan sa kanilang mga lupain, teritoryo at mapagkukunan,

Kinikilala rin ang kagyat na pangangailangan na igalang at itaguyod ang mga karapatan ng mga katutubo na pinatunayan sa mga tratado, kasunduan at iba pang konstruktibong kaayusan ng mga Estado,

Malugod na tinatanggap ang katotohanan na ang mga katutubo ay nag-oorganisa ng kanilang mga sarili para sa pulitikal, ekonomiko, panlipunan at pangkulturang pagpapahusay upang wakasan ang lahat ng uri ng diskriminasyon at pang-aapi saan man ito maganap,

Naniniwala na ang kontrol ng mga katutubo sa mga pagpapaunlad na nakaaapekto sa kanila at kanilang mga lupain, teritoryo at mapagkukunan ay magbibigay-daan sa kanila upang mapanatili at mapalakas ang kanilang mga institusyon, kultura at tradisyon, at itaguyod ang kanilang kaunlaran alinsunod sa kanilang mga hangarin at pangangailangan,

Kinikilala na ang paggalang sa katutubong kaalaman, kultura at tradisyunal na kasanayan ay nag-aambag sa sustenable at pantay na kaunlaran at wastong pamamahala ng kapaligiran,

Binibigyang-diin ang kontribusyon ng demilitarisasyon ng mga lupa at teritoryo ng mga katutubo sa kapayapaan, ekonomiya at panlipunang kaunlaran, pag-unawa at pakikipagkaibigan sa mga bansa at mga mamamayan sa buong mundo,

Kinikilala sa partikular ang karapatan ng mga katutubong pamilya at pamayanan na mapanatili ang ibinahaging responsibilidad para sa pagpapalaki, pagsasanay, edukasyon at kagalingan ng kanilang mga anak, na naaayon sa mga karapatan ng bata,

Isinasaalang-alang na ang mga karapatang pinatunayan sa mga tratado, kasunduan at iba pang konstruktibong kaayusan sa pagitan ng mga Estado at katutubo, sa ilang sitwasyon, mga bagay na may internasyonal na ukol, interes, responsibilidad at katangian,

Isinasaalang-alang din na ang mga tratado, kasunduan at iba pang konstruktibong kaayusan, at ang ugnayan na kinakatawan nila, ay ang batayan para sa isang pinalakas na pakikipagtulungan sa pagitan ng mga katutubo at Estado, 
Kinikilala na ang Tsarter ng United Nations, ang Internasyonal na Kasunduan sa Mga Pangkabuhayan, Panlipunan at Pangkulturang Karapatan ${ }^{1}$ at ang Internasyonal na Kasunduan sa Mga Karapatang Sibil at Politikal, ${ }^{1}$ pati na rin ang Deklarasyon ng Vienna at Programa ng Pagkilos, ${ }^{2}$ ay pinapatunayan ang pundamental na kahalagahan ng karapatang sa sariling pagpapasya ng lahat ng mga mamamayan, kung saan malaya nilang tinutukoy ang kanilang katayuang pampulitika at malayang isinusulong ang kanilang pang-ekonomiya, panlipunan at pangkulturang pag-unlad,

Isinasaalang-alang sa isip na walang anuman sa Deklarasyong ito ang maaaring magamit upang pagkaitan ang sinumang mga mamamayan ng kanilang karapatan sa sariling pagpapasya, na naisagawa alinsunod sa internasyunal na batas,

Naniniwala na ang pagkilala sa mga karapatan ng mga katutubo sa Deklarasyong ito ay magpapahusay sa maayos at kooperatibong ugnayan sa pagitan ng Estado at mga katutubo, batay sa mga prinsipyo ng hustisya, demokrasya, paggalang sa karapatang pantao, kawalang diskriminasyon at mabuting hangarin,

Hinibimok ang mga Estado na sumunod at mabisang ipatupad ang lahat ng kanilang mga obligasyon habang naglalapat sila sa mga katutubo sa ilalim ng mga instrumentong pang-internasyonal, lalo na ang mga nauugnay sa karapatang pantao, sa konsultasyon at kooperasyon sa mga kaukulang mamamayan,

Binibigyang diin na ang United Nations ay may mahalaga at patuloy na papel na ginagampanan sa pagtataguyod at pagprotekta sa mga karapatan ng mga katutubo,

Naniniwala na ang Deklarasyong ito ay isang karagdagang mahalagang hakbang pasulong para sa pagkilala, promosyon at proteksyon ng mga karapatan at kalayaan ng mga katutubo at sa pagpapaunlad ng mga makabuluhang aktibidad ng sistema ng United Nations sa larangang ito,

Kinikilala at muling pinapatunayan na ang mga indibidwal na katutubo ay may karapatan na walang diskriminasyon sa lahat ng mga karapatang pantao na kinikilala sa internasyunal na batas, at ang mga katutubo ay nagtataglay ng kolektibong mga karapatan na lubhang kinakailangan para sa kanilang pag-iral, kagalingan, at integral na kaunlaran bilang mga mamamayan,

Kinikilala na ang sitwasyon ng mga katutubo ay nag-iiba sa bawat rehiyon at bawat bansa at ang kabuluhan ng pambansa at panrehiyong mga partikularidad at iba `t ibang pangkasaysayan at pangkulturang pinagmulan ay dapat isaalang-alang,

Taimtim na ipinapahayag ang sumusunod na Deklarasyon ng United Nations ukol sa Mga Karapatan ng mga Katutubo bilang isang pamantayan ng tagumpay na kakamtin sa isang diwa ng pakikipagtulungan at paggalang sa isa't isa:

\section{Artikulo 1}

Ang mga katutubo ay may karapatan na buong matamasa, bilang kolektibo o bilang indibidwal, ang lahat ng mga karapatang pantao at pundamental na mga kalayaan na kinikilala sa Tsarter ng United Nations, ang Unibersal na Deklarasyon ng Karapatang Pantao ${ }^{3}$ at internasyonal na batas para sa karapatang pantao.

\section{Artikulo 2}

Ang mga katutubo at indibidwal ay malaya at pantay sa lahat ng iba pang mga mamamayan at indibidwal at may karapatang hindi maranasan ang anumang uri ng diskriminasyon, sa pagpapatupad ng kanilang mga karapatan, na sa partikular, batay sa kanilang katutubong pinagmulan o pagkakakilanlan.

\section{Artikulo 3}

Ang mga katutubo ay may karapatan sa sariling pagpapasya. Sa bisa ng karapatang iyon, malaya nilang natutukoy ang kanilang katayuang pampulitika at malayang tinutuloy ang kanilang pang-ekonomiya, panlipunan at pangkulturang pag-unlad.

\section{Artikulo 4}

Ang mga katutubo, sa pagpapatupad ng kanilang karapatan sa sariling pagpapasya, ay may karapatang sa awtonomiya o sariling pamahalaan sa mga usapin na nauugnay sa kanilang panloob at lokal na gawain, pati na rin ang mga daan at pamamaraan para sa pagtustos ng kanilang awtonomong tungkulin.

1 Tingnan ang resolusyon $2200 \mathrm{~A}(\mathrm{XXI})$, karugtong.

2 A/CONF.157/24 (Bahagi I), tsap. III.

3 Resolusyon 217 A (III). 


\section{Artikulo 5}

Ang mga katutubo ay may karapatang magmantene at palakasin ang kanilang natatanging pampulitika, ligal, pang-ekonomiya, panlipunan at pangkulturang mga institusyon, habang pinapanatili ang kanilang karapatang lumahok nang buo, kung pipiliin nila, sa pampulitika, pang-ekonomiya, panlipunan at pangkulturang buhay ng Estado.

\section{Artikulo 6}

Ang bawat katutubong indibidwal ay may karapatan sa isang nasyonalidad.

\section{Artikulo 7}

1. Ang mga katutubong indibidwal ay may mga karapatan sa buhay, pisikal at mental na integridad, kalayaan at seguridad ng tao.

2. Ang mga katutubo ay may kolektibong karapatan na mamuhay sa kalayaan, kapayapaan at seguridad bilang magkakaibang mga tao at hindi mapailalim sa anumang akto ng pagpatay ng lahi o anumang iba pang akto ng karahasan, kabilang ang puwersahang pag-aalis ng mga bata sa pangkat patungo sa ibang pangkat.

\section{Artikulo 8}

1. Ang mga katutubo at indibidwal ay may karapatang hindi mapailalim sa sapilitang asimilasyon o pagsira sa kanilang kultura.

2. Ang mga estado ay dapat magbigay ng mabisang mekanismo para sa pag-iwas, at pagwawasto para sa:

(a) Anumang hakbang na mayroong hangarin o epekto ng pagkakait sa kanila ng kanilang integridad bilang magkakaibang mga tao, o ng kanilang mga halagahan sa kultura o pagkakakilanlang etniko;

(b) Anumang hakbang na mayroong hangarin o epekto ng pang-aagaw ng kanilang mga lupa, teritoryo o mapagkukunan;

(c) Anumang uri ng sapilitang paglipat ng populasyon na may layunin o epekto ng paglabag o pagpapahina ng anuman sa kanilang mga karapatan;

(d) Anumang anyo ng sapilitang asimilasyon o integrasyon;

(e) Anumang uri ng propaganda na idinisenyo upang itaguyod o hikayatin ang panglahi o etnikong diskriminasyon na idinirekta laban sa kanila.

\section{Artikulo 9}

Ang mga katutubo at indibidwal ay may karapatang mapabilang sa isang katutubong pamayanan o bansa, alinsunod sa mga tradisyon at kaugalian ng kaukulang pamayanan o bansa. Walang diskriminasyon ng anumang uri ang maaaring umusbong mula sa paggamit ng naturang karapatan.

\section{Artikulo 10}

Ang mga katutubo ay hindi maaaring sapilitang alisin mula sa kanilang mga lupain o teritoryo. Walang relokasyon na magaganap nang walang paghingi ng malaya, nauna at malinang na kapahintulutan sa mga kaukulang katutubo at pagkatapos ng kasunduan sa makatarungan at patas na kompensasyon at, kung posible, na may opsyong makabalik.

\section{Artikulo 11}

1. Ang mga katutubo ay may karapatang magsanay at buhayin ang kanilang mga kultural na tradisyon at kaugalian. Kasama rito ang karapatang panatilihin, protektahan at paunlarin ang nakaraan, kasalukuyan, at hinaharap na mga manipestasyon ng kanilang mga kultura, tulad ng mga arkeolohikal at makasaysayang mga lugar, artepakto, disenyo, seremonya, teknolohiya, at biswal at itinatanghal na sining at panitikan.

2. Ang mga estado ay magkakaloob ng pagwawasto sa pamamagitan ng mga mabisang mekanismo, na maaaring magsama ng pagbabayad, na binuo kasama ng mga katutubo, na may paggalang sa kanilang kultural, intelektwal, relihiyoso at espiritwal na pag-aari na kinuha nang hindi humihingi ng malaya, nauna at malinang na kapahintulutan o lumalabag sa kanilang mga batas, tradisyon at kaugalian. 
1. Ang mga katutubo ay may karapatang magpakita, magsanay, bumuo at magturo ng kanilang mga espiritwal at relihiyosong tradisyon, kaugalian at seremonya; ang karapatang magmantene, protektahan, at magkaroon ng akses nang pribadong sa kanilang relihiyoso at kultural na lugar; ang karapatan sa paggamit at pagkontrol ng kanilang mga seremonyal na bagay; at ang karapatan sa pagpapauwi ng labi ng kanilang kasamahan..

2. Hangad ng mga estado na paganahin ang pag-akses at/o pagpapabalik ng mga seremonyal na bagay at mga labi ng tao na pag-aari nila sa pamamagitan ng mga patas, malinaw at mabisang mekanismo na binuo kasabay ng mga kaukulang katutubo.

\section{Artikulo 13}

1. Ang mga katutubo ay may karapatang buhayin, gamitin, paunlarin at ipadala sa mga susunod na henerasyon ang kanilang mga kasaysayan, wika, oral na tradisyon, pilosopiya, sistema ng pagsulat at panitikan, at italaga at panatilihin ang kanilang sariling mga pangalan para sa mga pamayanan, lugar at tao.

2. Ang mga Estado ay magsasagawa ng mga mabisang hakbang upang matiyak na ang karapatang ito ay protektado at upang matiyak din na ang mga katutubo ay nakauunawa at maunawaan sa pampulitika, ligal, at administratibong paglilitis, kung saan kinakailangan sa pamamagitan ng pagkakaloob ng interpretasyon o ng iba pang naaangkop na pamamaraan.

\section{Artikulo 14}

1. Ang mga katutubo ay may karapatang magtatag at makontrol ang kanilang mga sistemang pang-edukasyon at mga institusyong nagbibigay ng edukasyon sa kanilang sariling mga wika, sa paraang naaangkop sa kanilang mga kultural na pamamaraan ng pagtuturo at pag-aaral.

2. Ang mga katutubong indibidwal, partikular ang mga bata, ay may karapatan sa lahat ng antas at anyo ng edukasyon ng Estado nang walang diskriminasyon.

3. Ang mga Estado ay dapat, kasabay ng mga katutubo, magsagawa ng mabisang hakbang, upang ang mga katutubong indibidwal, partikular ang mga bata, kasama ang mga nakatira sa labas ng kanilang mga komunidad, na magkaroon ng akses, kung maaari, sa isang edukasyon sa kanilang sariling kultura at inilaan sa kanilang sariling wika.

\section{Artikulo 15}

1. Ang mga katutubo ay may karapatan sa dignidad at dibersidad ng kanilang mga kultura, tradisyon, kasaysayan at mithiin na angkop na masasalamin sa edukasyon at impormasyon sa publiko.

2. Ang mga Estado ay magsasagawa ng mabisang hakbang, sa konsultasyon at kooperasyon sa mga kaukulang katutubo, upang labanan ang prehuwisyo at alisin ang diskriminasyon at itaguyod ang pagpapaubaya, pag-unawa, at mabuting ugnayan sa mga katutubo at lahat ng iba pang mga bahagi ng lipunan.

\section{Artikulo 16}

1. Ang mga katutubo ay may karapatang magtaguyod ng kanilang sariling midya sa kanilang sariling mga wika at upang magkaroon ng akses sa lahat ng anyo ng di-katutubong midya nang walang diskriminasyon.

2. Magsasagawa ang mga Estado ng mabisang hakbang upang matiyak na ang midya na pagmamayari ng Estado ay dapat na tapat na sumasalamin sa dibersidad ng katutubong kultura. Ang mga Estado, nang walang prehuwisyo upang matiyak ang buong kalayaan sa pamamahayag, ay dapat na hikayatin ang pribadong pinagmamay-ariang medya na sapat na maipakita ang dibersidad ng katutubong kultura.

\section{Artikulo 17}

1. Ang mga katutubong indibidwal at mamamayan ay may karapatang tangkilikin nang buo ang lahat ng mga karapatang itinatag sa ilalim ng naaangkop na batas pang-internasyonal at domestikong paggawa.

2. Ang mga Estado ay dapat na kumunsulta at makipagtulungan sa mga katutubo na gumawa ng mga tiyak na hakbang upang mapangalagaan ang mga katutubong bata mula sa pagsasamantala sa ekonomiya at mula sa paggawa ng anumang trabaho na maaaring mapanganib o makagambala sa edukasyon ng bata, o mapanganib sa kalusugan ng bata o sa pisikal, mental, espiritwal, moral o panlipunang pag-unlad, nang isinasaalang-alang ang kanilang espesyal na bulneribilidad at importansya ng edukasyon para sa kanilang pagbibigay-kapangyarihan.

3. Ang mga katutubong indibidwal ay may karapatang hindi mapailalim sa anumang diskriminatoryong kondisyon sa paggawa at, liban sa iba, trabaho o suweldo. 


\section{Artikulo 18}

Ang mga katutubo ay may karapatang lumahok sa paggawa ng desisyon sa mga bagay na makaaapekto sa kanilang mga karapatan, sa pamamagitan ng mga kinatawan na kanilang pinili alinsunod sa kanilang sariling mga pamamaraan, pati na rin mapanatili at mapaunlad ang kanilang sariling mga katutubong mapagpasyang institusyon.

\section{Artikulo 19}

Ang mga Estado ay dapat kumunsulta at makipagtulungan na may mabuting hangarin sa mga kaukulang katutubo sa pamamagitan ng kanilang sariling kinatawang institusyon upang makahingi ng kanilang malaya, nauna at malinang na kapahintulutan bago gamitin at ipatupad ang mga lehislatibo o administratibong mga hakbang na maaaring makaapekto sa kanila.

\section{Artikulo 20}

1. Ang mga katutubo ay may karapatang panatilihin at paunlarin ang kanilang mga pampulitika, pangekonomiya at panlipunang mga sistema o institusyon, upang maging ligtas sa pagtamasa ng kanilang sariling paraan ng pamumuhay at kaunlaran, at malayang makisali sa lahat ng kanilang tradisyonal at iba pang pangekonomiyang gawain.

2. Ang mga katutubo na pinagkaitan ng kanilang mapagkukunang pamumuhay at kaunlaran ay may karapatan sa makatarungang pagwawasto.

\section{Artikulo 21}

1. Ang mga katutubo ay may karapatan, nang walang diskriminasyon, sa pagpapabuti ng kanilang kalagayang pang-ekonomiya at panlipunan, kasama, liban sa iba, sa mga larangan ng edukasyon, trabaho, bokasyonal na pagsasanay at muling pagsasanay, pabahay, kalinisan, kalusugan at panlipunang seguridad.

2. Magsasagawa ang mga Estado ng mabisang hakbang at, kung naaangkop, mga espesyal na hakbang upang matiyak ang patuloy na pagpapabuti ng kanilang kalagayang pang-ekonomiya at panlipunan. Ang partikular na pansin ay ibibigay sa mga karapatan at espesyal na pangangailangan ng mga katutubong matatanda, kababaihan, kabataan, bata at mga taong may kapansanan.

\section{Artikulo 22}

1. Ang partikular na pansin ay ibibigay sa mga karapatan at espesyal na pangangailangan ng mga katutubong matatanda, kababaihan, kabataan, bata at mga taong may kapansanan sa pagpapatupad ng Deklarasyong ito.

2. Ang mga Estado ay magsasagawa ng mga hakbang, kasabay ng mga katutubo, upang matiyak na ang mga katutubong kababaihan at bata ay matatamasa ang buong proteksyon at garantiya laban sa lahat ng uri ng karahasan at diskriminasyon.

\section{Artikulo 23}

Ang mga katutubo ay may karapatang matukoy at mabuo ang mga priyoridad at mga estratehiya para sa paggamit ng kanilang karapatan sa kaunlaran. Sa partikular, ang mga katutubo ay may karapatang maging aktibong kasangkot sa pagbuo at pagtukoy ng mga programang pangkalusugan, pabahay at iba pang pang-ekonomiya at panlipunang programa na nakaaapekto sa kanila at, hangga't maaari, upang pangasiwaan ang mga nasabing programa sa pamamagitan ng kanilang sariling mga institusyon.

\section{Artikulo 24}

1. Ang mga katutubo ay may karapatan sa kanilang tradisyunal na mga gamot at panatilihin ang kanilang mga kasanayan sa kalusugan, kasama ang pangangalaga ng kanilang mga mahahalagang halamang gamot, hayop at mineral. Ang mga katutubong indibidwal ay may karapatang maabot, nang walang anumang diskriminasyon, ang lahat ng serbisyong panlipunan at pangkalusugan.

Ang mga katutubong indibidwal ay may pantay na karapatan na matamasa ang pinakamataas na maaabot na pamantayan ng pisikal at mental na kaisipan. Gagawin ng mga Estado ang mga kinakailangang hakbang na may pananaw upang makamit nang progresibo ang buong pagsasakatuparan ng karapatang ito.

\section{Artikulo 25}

Ang mga katutubo ay may karapatang magmantene at palakasin ang kanilang natatanging espiritwal na ugnayan sa kanilang tradisyunal na pagmamay-ari o kung hindi man ay inookupa at ginamit na mga lupain, teritoryo, 
katubigan at babay-dagat at iba pang mga mapagkukunan at upang itaguyod ang kanilang mga responsibilidad sa mga susunod na henerasyon hinggil dito.

\section{Artikulo 26}

1. Ang mga katutubo ay may karapatan sa mga lupa, teritoryo at mapagkukunan na tradisyonal nilang pinagmamay-arian, inokupa o kung nagamit man o nakuha.

2. Ang mga katutubo ay may karapatang magmay-ari, gumamit, bumuo at makontrol ang mga lupa, teritoryo at mapagkukunan na posesyon nila sanhi ng tradisyunal na pagmamay-ari o iba pang tradisyunal na okupasyon o paggamit, pati na rin ang mga kung saan ay nakuha nila.

3. Ang mga Estado ay dapat magbigay ng ligal na pagkilala at proteksyon sa mga lupa, teritoryo at mapagkukunan na ito. Ang naturang pagkilala ay dapat isagawa nang may paggalang sa kaugalian, tradisyon at mga sistema ng panirikan sa lupa ng mga kaukulang katutubo.

\section{Artikulo 27}

Itataguyod at ipapatupad ng mga Estado, kasabay ng mga kaukulang katutubo, ang isang patas, malaya, walang kinikilingan, bukas at malinaw na proseso, na nagbibigay ng angkop na pagkilala sa mga batas, tradisyon, kaugalian at mga sistema ng panirikan sa lupa ng mga katutubo, upang kilalanin at husgahan ang mga karapatan ng mga katutubo na nauukol sa kanilang mga lupain, teritoryo at mapagkukunan, kabilang ang mga tradisyonal na pinagmamay-arian o kung inokupa man o ginamit. Ang mga katutubo ay may karapatang lumahok sa prosesong ito.

\section{Artikulo 28}

1. Ang mga katutubo ay may karapatan sa pagwawasto, sa pamamagitan ng paraan na maaaring isama ang pagbabayad o, kung hindi ito posible, makatarungan, patas at karampatang kompensasyon, para sa mga lupa, teritoryo at mapagkukunan na tradisyonal na pinagmamay-arian o kung inokupa man o ginamit, at kung saan nakumpiska, kinuha, inokupa, ginamit o napinsala nang wala ang kanilang malaya, nauna at malinang na kapahintulutan.

2. Maliban kung malayang napagkasunduan ng mga kaukulang mamamayan, ang kompensasyon ay dapat na may anyo ng mga lupa, teritoryo at mapagkukunan na pantay ang kalidad, laki at ligal na katayuan o ng kaperahang kompensasyon o iba pang naaangkop na pagwawasto.

\section{Artikulo 29}

1. Ang mga katutubo ay may karapatan sa pangangalaga at proteksyon ng kalikasan at ang produktibong kakayahan ng kanilang mga lupain o teritoryo at mapagkukunan. Ang mga Estado ay magtatatag at magpapatupad ng mga programa ng tulong para sa mga katutubo para sa naturang pangangalaga at proteksyon, nang walang diskriminasyon.

2. Magsasagawa ang mga Estado ng mabisang hakbang upang matiyak na walang pag-iimbak o pagtatapon ng mga mapanganib na materyales ang magaganap sa mga lupa o teritoryo ng mga katutubo nang walang paghingi ng malaya, nauna at malinang na kapahintulutan.

3. Ang mga Estado ay dapat ding gumawa ng mabisang hakbangin upang matiyak, kung kinakailangan, na ang mga programa para sa pagsubaybay, pagpapanatili at pagpapanumbalik ng kalusugan ng mga katutubo, na binuo at ipinatupad ng mga mamamayan na apektado ng naturang mga materyales, ay dapat na ipatupad.

\section{Artikulo 30}

1. Ang mga aktibidad ng militar ay hindi dapat maganap sa mga lupain o teritoryo ng mga katutubo, maliban kung nabigyang-katwiran ng isang makabuluhang pampublikong interes o kung malayang sumang-ayon o hiniling ng mga kaukulang katutubo.

2. Ang mga Estado ay magsasagawa ng mabisang konsultasyon sa mga kaukulang katutubo, sa pamamagitan ng mga naaangkop na pamamaraan at sa partikular sa pamamagitan ng kanilang mga kinatawang institusyon, bago gamitin ang kanilang mga lupain o teritoryo para sa mga aktibidad ng militar.

\section{Artikulo 31}

1. Ang mga katutubo ay may karapatang panatilihin, kontrolin, protektahan at paunlarin ang kanilang pamana sa kultura, tradisyonal na kaalaman at tradisyonal na pagpapahayag ng kultura, pati na rin ang mga 
manipestasyon ng kanilang mga agham, teknolohiya at kultura, kabilang ang mga mapagkukunan ng tao at henetiko, binhi, gamot, kaalaman sa mga katangian ng fauna at flora, oral na tradisyon, literatura, disenyo, isports at tradisyonal na mga laro at biswal at itinatanghal na sining. Mayroon din silang karapatang mapanatili, kontrolin, protektahan at paunlarin ang kanilang intelektuwal na pag-aari sa naturang pamana ng kultura, tradisyunal na kaalaman, at tradisyonal na pagpapahayag ng kultura.

2. Kasabay ng mga katutubo, ang mga Estado ay magsasagawa ng mabisang hakbang upang kilalanin at protektahan ang paggamit ng mga karapatang ito.

\section{Artikulo 32}

1. Ang mga katutubo ay may karapatang matukoy at mabuo ang mga priyoridad at estratehiya para sa pagunlad o paggamit ng kanilang mga lupain o teritoryo at iba pang mapagkukunan.

2. Ang mga Estado ay dapat kumunsulta at makipagtulungan na may mabuting hangarin sa mga kaukulang katutubo sa pamamagitan ng kanilang sariling kinatawang mga institusyon upang makahingi ng kanilang malaya, nauna at malinang na kapahintulutan bago ang pag-apruba ng anumang proyekto na nakaaapekto sa kanilang mga lupain o teritoryo at iba pang mapagkukunan, na partikular na may kaugnayan sa kaunlaran, paggamit o pagsasamantala ng mineral, katubigan o iba pang mapagkukunan.

3. Ang mga Estado ay dapat magbigay ng mga mabisang mekanismo para sa makatarungan at patas na pagwawasto sa anumang mga naturang aktibidad, at ang mga naaangkop na hakbang ay gagawin upang mapagaan ang masamang pangkapaligiran, pang-ekonomiya, panlipunan, pangkultura o pang-espiritwal na epekto.

\section{Artikulo 33}

1. Ang mga katutubo ay may karapatang matukoy ang kanilang sariling pagkakakilanlan o pagiging miyembro alinsunod sa kanilang kaugalian at tradisyon. Hindi nito pinipinsala ang karapatan ng mga katutubong indibidwal na makakuha ng pagkamamamayan ng mga Estado kung saan sila nakatira.

2. Ang mga katutubo ay may karapatang matukoy ang mga estruktura at pumili ng pagiging kasapi ng kanilang mga institusyon alinsunod sa kanilang sariling mga pamamaraan.

\section{Artikulo 34}

Ang mga katutubo ay may karapatang itaguyod, paunlarin at panatilihin ang kanilang mga institusyonal na estruktura, at ang kanilang natatanging kaugalian, espiritwalidad, tradisyon, pamamaraan, kasanayan at, sa mga kaso kung saan sila umiiral, mga sistemang hudisyal o kaugalian, alinsunod sa internasyonal na mga pamantayan ng karapatang pantao.

\section{Artikulo 35}

Ang mga katutubo ay may karapatang matukoy ang mga responsibilidad ng mga indibidwal sa kanilang mga pamayanan.

\section{Artikulo 36}

1. Ang mga katutubo, lalo na ang mga nahahati sa mga internasyonal na hangganan, ay may karapatang panatilihin at paunlarin ang mga kontak, ugnayan, kooperasyon, kasama ang mga aktibidad para sa mga espiritwal, kultural, pampulitika, pang-ekonomiya at panlipunan hangarin, kasama ng kanilang sariling mga miyembro pati na rin ang ibang mga mamamayan sa mga hangganan.

2. Ang mga Estado, sa konsultasyon at kooperasyon sa mga katutubo, ay dapat gumawa ng mabisang hakbang upang pangasiwaan ang pagsasagawa at matiyak ang pagpapatupad ng karapatang ito.

\section{Artikulo 37}

1. Ang mga katutubo ay may karapatan sa pagkilala, pagtalima at pagpapatupad ng mga tratado, kasunduan at iba pang konstruktibong kaayusan na natapos sa mga Estado o ang kanilang mga kahalili at upang igalang ng mga Estado ang mga naturang tratado, kasunduan, at iba pang mga konstruktibong kaayusan.

2. Walang anuman sa Deklarasyong ito ang maaaring ipakahulugan bilang pagbawas o pag-aalis ng mga karapatan ng mga katutubo na nakapaloob sa mga tratado, kasunduan, at iba pang mga konstruktibong kaayusan.

\section{Artikulo 38}

Ang mga estado na may konsultasyon at kooperasyon sa mga katutubo, ay dapat gumawa ng mga naaangkop na hakbang, kabilang ang mga lehislatibong hakbangin, upang makamit ang mga layunin ng Deklarasyong ito. 


\section{Artikulo 39}

Ang mga katutubo ay may karapatang makakuha ng pinansyal at teknikal na tulong mula sa mga Estado at sa pamamagitan ng kooperasyong internasyonal, para sa kasiyahan ng mga karapatang nakapaloob sa Deklarasyong ito.

\section{Artikulo 40}

Ang mga katutubo ay may karapatang magbigay ng agarang pagpapasya sa pamamagitan ng makatarungan at patas na mga pamamaraan para sa resolusyon ng mga tunggalian at pagtatalo sa mga Estado o iba pang mga partido, pati na rin sa mabisang remedyo para sa lahat ng mga paglabag sa kanilang indibidwal at kolektibong mga karapatan. Ang nasabing desisyon ay magbibigay ng angkop na pagsasaalang-alang sa kaugalian, tradisyon, panuntunan at mga sistemang ligal ng mga kaukulang katutubo at internasyonal na karapatang pantao.

\section{Artikulo 41}

Ang mga organo at espesyalisadong ahensya ng sistema ng United Nations at iba pang mga interpamahalaang organisasyon ay dapat magbigay ng kontribusyon sa buong pagsasakatuparan ng mga probisyon ng Deklarasyong ito sa pamamagitan ng mobilisasyon, liban sa iba, ng kooperasyong pampinansyal at teknikal na tulong. Ang mga daan at paraan ng pagtiyak sa pakikilahok ng mga katutubo sa mga isyung nakaaapekto sa kanila ay dapat maitaguyod.

\section{Artikulo 42}

Ang United Nations, ang mga kinatawan nito, kasama ang Permanent Forum on Indigenous Issues, at mga espesyalisadong ahensya, kasama ang antas ng bansa, at ang mga Estado ay magsusulong ng paggalang at buong aplikasyon ng mga probisyon ng Deklarasyong ito at isunod ang bisa ng Deklarasyong ito.

\section{Artikulo 43}

Ang mga karapatang kinikilala rito ay bumubuo ng minimum na pamantayan para sa kaligtasan, dignidad at kahusayan ng mga katutubo sa buong mundo.

\section{Artikulo 44}

Ang lahat ng mga karapatan at kalayaan na kinikilala dito ay pantay na ginagarantiya sa mga indibidwal na katutubong kalalakihan at kababaihan.

\section{Artikulo 45}

Walang anuman sa Deklarasyong ito ang maaaring ipakahulugan bilang pagbawas o pag-alis sa mga karapatan na mayroon ngayon ang mga mamamayan o maaaring makuha sa hinaharap.

\section{Artikulo 46}

1. Walang anuman sa Deklarasyong ito ang maaaring ipakahulugan bilang nagpapahiwatig para sa anumang Estado, mamamayan, pangkat o tao ng anumang karapatang makisali sa anumang aktibidad o upang makagawa ng anumang kilos na salungat sa Tsarter ng United Nations o ipinalalagay bilang pahintulot o paghihikayat sa anumang aksyon na makakapag-alis o makapipinsala, buo o bahagi lamang, sa integridad ng teritoryo o pagkakaisa sa pulitika ng mga soberano at malayang Estado.

2. Sa pagpapatupad ng mga karapatang binanggit sa kasalukuyang Deklarasyon, igagalang ang mga karapatang pantao at pundamental na mga kalayaan ng lahat. Ang paggamit ng mga karapatang nakasaad sa Deklarasyong ito ay sasailalim lamang sa mga limitasyong tinutukoy ng batas at alinsunod sa mga pandaigdigang obligasyon sa karapatang pantao. Anumang mga naturang limitasyon ay dapat na hindi diskriminatoryo at mahigpit na kinakailangan lamang para sa hangarin na matiyak ang nararapat na pagkilala at paggalang sa mga karapatan at kalayaan ng iba at para matugunan ang makatarungan at pinakanakakahimok na mga kinakailangan sa isang demokratikong lipunan.

3. Ang mga probisyon na nakalagay sa Deklarasyong ito ay dapat bigyang kahulugan alinsunod sa mga prinsipyo ng hustisya, demokrasya, paggalang sa karapatang pantao, pagkakapantay-pantay, kawalang diskriminasyon, mabuting pamamahala at mabuting pananampalataya 


\section{Karugtong 3. \\ Listahan ng mga katanungan}

I. Pagkilala at pagkamamamayan

1 Partikular ba na kinikilala, tinutukoy o binibigyang kahulugan ng konstitusyon ang mga katutubo, kasama ang proteksyon ng karapatan pagkilala sa sarili?

2 Kinikilala ba ng konstitusyon ang estado bilang multikultural, multinasyunal o multi-etniko, o nagtataguyod ng mga kahalagahan ng pagkakaiba-iba at pagsasama sa iba pang mga paraan?

3 Tinitiyak ba ng konstitusyon ang pambansang pagkamamamayan para sa mga katutubo at may kasamang garantiya na ang pag-angkin ng katutubong pagkakakilanlan ay hindi makaaapekto sa karapatan sa pambansang pagkamamamayan?

\section{Karapatan sa pagkakapantay-pantay at kontra-diskriminasyon}

$4 \quad$ Tinitiyak ba ng konstitusyon ang pagkakapantay-pantay sa harap ng batas at ipinagbabawal ang diskriminasyon? Kung gayon, kinikilala ba ang pang-etniko, panglahi o pangkultural na entidad bilang isa sa maraming ipinagbabawal na batayan para sa diskriminasyon?

5 Pinapayagan ba ng konstitusyon ang magmandato ng mga espesyal na hakbang na naglalayong makamit ang substantibong pagkakapantay-pantay para sa mga katutubo?

\section{Mga pundasyon para sa mga karapatan ng mga katutubo}

$6 \quad$ Kinikilala ba ng konstitusyon ang mga karapatan ng mga katutubo bilang karagdagan sa, at hindi kapalit ng, mga pundamental na karapatan na ginagarantiya sa lahat ng mga mamamayan?

7 Kinikilala ba ng konstitusyon ang karapatan ng mga katutubo sa sariling pagpapasya bilang isang pundasyon para sa mga karapatan ng ibang mga katutubo?

8 Kinikilala ba ng konstitusyon ang mga kolektibong karapatan? Kung gayon, ito ba ay isang pangkalahatang pagkilala o espesipiko sa mga katutubo?

9 Ang konstitusyon ba ay naglalaan ng kung paano ang mga pundamental na mga karapatan ng mamamayan at karapatang pantao, kabilang ang pagkakapantay-pantay sa harap ng batas at mga proteksyon para sa kababaihan at iba pang mga magkakaugnay na bulnerableng grupo, ay dapat na maipagkasundo sa mga karapatan ng mga katutubo?

\section{Awtonomiya: Paggawa ng kasunduan at sariling pamahalaan}

10 Iginagalang ba $\mathrm{ng}$ konstitusyon ang makasaysayan at panghinaharap na paggawa $\mathrm{ng}$ kasunduan o mga pagsasaayos $\mathrm{ng}$ tratado sa pagitan $\mathrm{ng}$ mga katutubo at $\mathrm{ng}$ estado sa paraan na nagpapatunay sa likas na soberanya (awtonomiya) ng mga katutubo?

11 Kinikilala ba ng konstitusyon ang mga karapatan ng mga katutubo sa awtonomiya at sariling pamahalaan, teritoryo o hindi?

12 Ang konstitusyon ba ay nagbibigay ng karapatan sa mga katutubo upang mapanatili at mailapat ang kanilang mga nakaugaliang batas at proseso ng paglutas ng hindi pagkakasundo sa kanilang mga teritoryo? 
13 Pinoprotektahan ba ng konstitusyon ang karapatan ng mga katutubo sa konsultasyon sa pamamagitan ng kanilang piniling mga kinatawan sa pormal na pagkilala sa mga samahan ng mga katutubo o kung hindi man ay sa pagtatatag ng isang espesyalisadong mekanismo ng pagkonsulta sa pagitan ng mga katutubo at ng gobyerno?

14 Kinikilala ba at naglalaan ang konstitusyon ng isang mekanismong elektoral para matiyak ang karapatan ng mga katutubo sa pulitikal na pakikilahok at representasyon, partikular sa lehislatura ng estado?

15 Naglalaan ba ang konstitusyon ng mga mekanismo upang maisulong ang representasyon ng mga katutubo sa ehekutibong sangay ng pamahalaan?

16 Tinitiyak ba ng konstitusyon na ang representasyon ng mga katutubo sa hudisyal na sangay ay isinasaalangalang at ang mga mekanismo ng hudisyal na pagtatalaga, lalo na ang mga sa kataas-taasan o konstitusyonal na korte, ay nagsusulong sa ingklusyon ng mga katutubo?

17 Iginagarantiya o isinusulong ba ng konstitusyon ang pangangalap o pagtatalaga ng mga katutubo sa mga posisyon ng serbisyo sibil, mga independiyenteng kinatawan at militar?

\section{Karapatan sa lupa, teritoryo at likas na yaman}

18 Kinikilala ba ng konstitusyon ang espesyal na ugnayan sa pagitan ng mga katutubo at sa lupa, kasama na ang pagprotekta sa kolektibong mga karapatan sa pagmamay-ari sa mga lupang ninuno at teritoryo at pagtataguyod ng mataas na pataw para sa pang-aagaw sa mga lupain ng mga katutubo?

19 Makakaya ba ng konstitusyon ang mga espesyal na karapatan ng mga katutubo sa kanilang mga likas na yaman sa loob/mismo/ilalim ng kanilang mga lupain at teritoryo? Humihiling ba ang konstitusyon sa mga katutubo ng pagbabahagi ng benepisyo sa mga kapwa katutubo hinggil sa mga isinasagawang gawain sa kanilang lupain na nauugnay sa likas na yaman?

20 Inaatasan ba ng konstitusyon ang gobyerno na kumunsulta nang may mabuting hangarin sa mga katutubo 0 humingi ng kanilang malaya, nauna at malinang na kapahintulutan (FPIC) bago ipatupad ang mga proyektong pangkaunlaran at iba pang mga patakaran na may epekto sa mga katutubong lupain, teritoryo, karapatan at yaman?

\section{Karapatan sa kultura, at panlipunan at pang-ekonomiking pag-unlad}

21 Pinoprotektahan ba ng konstitusyon ang mga karapatan ng mga katutubo na panatilihin at paunlarin ang kanilang mga kultura, pagkakakilanlan at kasanayan sa kultura, at igalang sila?

22 Kinikilala ba ng konstitusyon ang mga katutubong wika at ang mga kauugnay na karapatan sa wika?

23 Pinoprotektahan ba ng konstitusyon ang karapatan ng mga katutubo sa sariling wika at angkop-sa-kulturang edukasyon?

24 Pinoprotektahan ba ng konstitusyon ang karapatan ng mga komunidad ng katutubo upang patuloy na magsanay ng kanilang mga aktibidad sa pamumuhay (tradisyunal na paraan ng hanapbuhay)?

25 Pinoprotektahan ba ng konstitusyon ang karapatan sa kalusugan ng mga katutubo, kasama na ang paggamit sa mga tradisyunal na gamot at serbisyo?

26 Kinikilala ba ng konstitusyon ang mga karapatan ng mga katutubong komunidad sa pagmamay-ari ng intelektwal na ari-arian sa kabila ng kanilang tradisyunal na kaalaman at tradisyonal na ekspresyon sa kultura? 
27 Nagtatatag ba ang konstitusyon ng pambansang komisyon ng mga katutubo, ministeryo o iba pang espesyalisadong kinatawan ng gobyerno upang itaguyod at protektahan ang mga karapatan ng mga katutubo?

28 Ipinapahiwatig ba ng konstitusyon, sa maraming latag na estruktura ng estado, kung aling (mga) antas ng pamahalaan ang pangunahing responsable para sa koordinasyon, proteksyon at pagsulong ng mga karapatan ng mga katutubo?

29 Kasama ba sa konstitusyon ang mga patakaran para sa 'paninindigan' na bukas sa publiko at aksesible upang matiyak ang karapatan ng mga katutubo sa pag-abot sa korte?

30 Ginagarantiya ba ng konstitusyon ang ligal na tulong para sa mga tao at pangkat na hindi kayang bayaran ang pribadong ligal na representasyon?

31 Malinaw bang tinukoy ng konstitusyon ang mga pinapayagang batayan o proseso para sa mga limitasyon sa mga karapatan, at tinitiyak na makatarungan ang mga ito?

32 Nakasaad ba sa konstitusyon na ang mga tratadong pang-internasyonal na karapatang pantao ay awtomatikong eepekto sa sandaling mapagtibay, o kinakailangan pa ang pangalawang proseso ng domestikasyon?

33 Pinahihintulutan, hinihikayat o hinihiling ba ng konstitusyon ang mga korte na isaalang-alang ang dayuhang batas kapag binibigyang kahulugan nila at inilalapat ang mga probisyon ng karapatang pantao?

34 Hinihikayat o hinihingi ba ng konstitusyon ang mga korte at iba pang mga kinatawan na isaalang-alang ang internasyunal na batas kapag binibigyang kahulugan nila at inilalapat ang mga probisyon ng karapatang pantao? 


\section{Tungkol sa may-akda}

Si Amanda Cats-Baril ay Senior Program Officer ng International IDEA para sa pagbuo ng konstitusyon sa Asya at Pasipiko. Sa kapasidad na ito, sinusuportahan niya ang mga proseso ng pagbuo ng konstitusyon sa Nepal, Myanmar at Pilipinas, bukod sa iba pang mga konteksto, sa pamamagitan ng pagbibigay ng teknikal na tulong sa mga gobyerno, mga sibil na samahan ng lipunan at mga proyekto ng International IDEA.

Si Cats-Baril ay isang internasyunal na abogado na espesyalisado sa konstitusyonal na batas, karapatang pantao, mga transisyon pagkatapos ng tunggalian at demokratisasyon. Partikular siyang nakatuon sa pagsusulong at proteksyon ng mga karapatan at interes ng mga katutubo sa konteksto ng malakihang pag-unlad at mga proseso ng reporma sa gobyerno.

Nang magtapos mula sa NYU School of Law, si Cats-Baril ay nagsilbing Arthur Helton Fellow na sumusuporta sa adbokasiya at pakikipag-ugnayan sa mga katutubong grupo sa proseso ng pagsulat ng konstitusyon ng Nepal. Nagsagawa siya ng ligal na pagsusuri at disenyo ng programa sa buong Asya para sa mga internasyonal na organisasyon kabilang ang UNDP, ICJ, ang World Bank at ang International Working Group on Indigenous Affairs.

Bago sumali sa International IDEA, si Cats-Baril ay nagsilbi bilang isang espesyalista sa demokrasya at pamamahala sa USAID/Nepal, na namamahala ng isang portfolio sa pagbuo ng kapayapaan, pagpapagaan ng sigalot at mga proyekto sa pamamahalaang lokal, at pagpayo sa gobyerno ng Estados Unidos tungkol sa mga konstitusyonal na isyu, transisyonal na hustisya at pagkasensitibo sa tunggalian. 


\section{Tungkol sa taga-disenyo}

Ipinanganak sa Adelaide, South Australia, si Sarrita King ay anak ng isang kilala at maimpluwensyang katutubong alagad ng sining, ang yumaong William King Jungala. Ang kanyang mga kumbinasyon ng mga estilo, pilosopiya, at nakalarawang pagkukuwento ay naging katangian ng kanyang trabaho, na nagreresulta sa pagkilala, at rekognisyon sa buong mundo.

Sinusubukan ng aking mga gawa na makuha ang mga pilosopiya at elemento ng buhay na maaaring makaugnay ang lahat at maramdaman ang koneksyon nito. Dinadala nito ang manonood sa likhang sining at tumutulong sa kanila na maunawaan ang kulturang Katutubo.

(Sarrita King)

Ang kanyang mga taon ng pagkabata ay ginugol sa kalupitan sa Hilagang Teritoryo, naging malapit siya sa diwa ng kanyang mga mamamayan, ang tribo ng Gurindji, at araw-araw niyang naramdaman ang pagkasira, pagkaayos, pag-asa at kagandahan ng isang lupain na patuloy na nag-iiba, nagugulo at nagbabago. Sa edad na 16, nagsimula siyang magpinta. Ang mga buhanging burol, kidlat, puwang, direksyon, masa, malakas na ulan, apoy, mga ilog sa buhangin—saanman ang inspirasyon ay laganap at sagana. Ang pagrepresenta sa mga biswal na nakamamangha at dramatikong mga ikono ng Australia sa kambas ay ang hamon na tinanggap at dinodomina ni Sarrita.

Bilang mga anak na babae ng dakilang katutubong alagad ng sining na si William King, si Sarrita at ang kanyang kapatid na babae ay palaging nasa presensya ng isang tila omnisyente at artistikong mata na nagdadala ng pandaigdig na elemento sa isang buhay na buhay at visceral na realidad na hindi maaaring balewalain. Nang tanungin tungkol sa kanyang ama, sinabi ni Sarrita: 'Ang kanyang pagiging bukás, pilosopiya sa buhay at pagkukuwento ay pinilit kaming pareho na sundin ang kanyang mga yapak at dalhin ang kanyang pamana sa pamamagitan ng sining.'

Si Sarrita ay isang tapat sa sarili na pintor ngayon—hindi siya nahihiyang pagsamahin ang mga pamamaraan at teknik mula sa nakaraan at kasalukuyang panahon at bumuo ng isang panghinaharap na estilo para sa lahat ng henerasyon na matamasa. Inamin niya na ang 'dotting' ay hindi kinakailangang isang mahabang tradisyon ng mga katutubong pintor at ginagamit niya ito sa iba't ibang mga pamamaraan, na kapag pinagsama ay nagdadala ng nakaeengganyo at masidhing enerhiya sa kanyang kasalukuyang gawain.

Ang kanyang istilo ay natatanging sa kanya lamang at pinalakpakan hindi lamang sa Australia kundi sa buong entablado ng mundo sa hanggang Europa, Canada at kung saan pa.

Ang pagsasama-sama ng masaganang tradisyonal na kultura at mga pamamaraan ng mga katutubong artista na may mga kontemponeong pag-uugali at mga bagong teknik ay nakita kay Sarrita na bumubuo ng isang bagong estilo ng katutubong sining. Pinagsikapan niyang manatiling tapat sa luma habang niyayakap ang bago, na ipinapakita na ang katutubong sining ay hindi lamang tungkol sa kung ano ang mayroon, ngunit tungkol sa pagbibigay-diin dito, sa ngayon at sa hinaharap.

Ang bagong henerasyon ay may tungkuling ibahagi at ipagpatuloy ang landas na itinakda sa atin ng mga naunang henerasyon. Ang motibasyon sa paglikha at pagbahagi ng aking likhang sining ay nagmumula sa pagnanais na isama ang mundo sa mayamang pamana ng katutubo ng Australia.

(Sarrita King)

\section{Tungkol sa International IDEA}

Ang International Institute for Democracy and Electoral Assistance (International IDEA) ay isang intergovernmental na organisasyon na may misyon na isulong ang demokrasya sa buong mundo, bilang isang unibersal na hangarin ng tao at tagapagtaguyod ng sustenableng pag-unlad. Ginagawa namin ito sa pamamagitan ng pagsuporta sa pagbuo, pagpapatibay, at pag-iingat ng mga demokratikong pulitikal na institusyon at proseso sa lahat ng antas. 
Ang aming pananaw ay isang mundo kung saan ang mga demokratikong proseso, mga aktor, at institusyon ay ingklusibo at may pananagutan at naghahatid ng sustenableng pag-unlad sa lahat.

\section{Ano ang aming ginagawa?}

Sa aming gawain, nakatuon kami sa tatlong pangunahing mahahalagang epektong larangan: mga proseso ng eleksyon; proseso ng pagbuo ng konstitusyon; at pulitikal na pakikilahok at representasyon. Ang mga tema ng kasarian at ingklusyon, pagiging sensitibo sa tunggalian at sustenableng pag-unlad ay mga pangunahingnaming ibinabandila sa lahat ng lugar ng aming gawain.

Nagbibigay ang International IDEA ng mga pagsusuri sa pandaigdigan at panrehiyong mga demokratikong trend; gumagawa ng paghahambing ng kaalaman sa mga demokratikong kasanayan; nag-aalok ng teknikal na tulong at pagbuo ng kapasidad sa reporma sa mga aktor na lumalahok sa mga demokratikong proseso, at nagtitipon ng diyalogo tungkol sa mga isyung nauugnay sa pampublikong debate tungkol sa demokrasya at pagbuo ng demokrasya.

\section{Saan kami nagtatrabaho?}

Ang aming punong tanggapan ay matatagpuan sa Stockholm, at mayroon kaming mga rehiyonal at pambansang tanggapan sa Africa, Asya at ang Pasipiko, Europa, at Latin Amerika at ang Caribbean. Ang International IDEA ay isang Permanenteng Tagamasid sa United Nations at naka-accredit sa mga institusyon ng European Union.

$<\underline{\text { https://www.idea.int }>}$ 


\section{Ang \\ Kasangakapan sa}

Pagtatasa sa Karapatan ng mga Katutubo

sa Konstitusyon ay tumutulong sa mga gagamit

upang pag-aralan ang isang konstitusyon mula sa pananaw

ng mga karapatan ng mga katutubo. Paggamit ng isang serye

ng mga katanungan, maikling paliwanag at halimbawang mga

probisyon mula sa mga konstitusyon sa buong mundo, ang Kasangkapan

sa Pagtatasa ay gumagabay sa mga gagamit nito sa pamamagitan ng teksto

ng isang konstitusyon at pinapayagan ang sistematikong pagsusuri ng wika at mga probisyon ng isang tekstong konstitusyonal upang matasa kung gaano kasigla ang mga karapatan ng mga katutubo ay sinalamin rito. Ang isang konstitusyon ay nagpapahayag ng isang pananaw na sumasalamin sa mga halagahan at kasaysayan ng estado, pati na rin ang mga mithiing obhetibo para sa hinaharap. Bilang kataastaasang batas ng estado, binibigyang kahulugan ng konstitusyon ang mga estruktura

at institusyon nito, na kritikal na tinutukoy ang ugnayan sa pagitan ng mga mamamayan at gobyerno. Ang paglatag sa konstitusyunal na pagkilala at mga

proteksyon na nakabatay sa mga karapatan para sa mga tiyak na pangkat, tulad ng mga katutubo, ay maaaring magbigay sa mga pangkat na ito ng pinahusay na proteksyon ng kanilang mga karapatan. Maaari itong maisulong sa pamamagitan ng paglalaan ng mga espesyalisadong institusyon at proseso upang mapalalim ang pagsasakatuparan ng mga karapatang iyon \%

\section{sa praktika.} 86 3
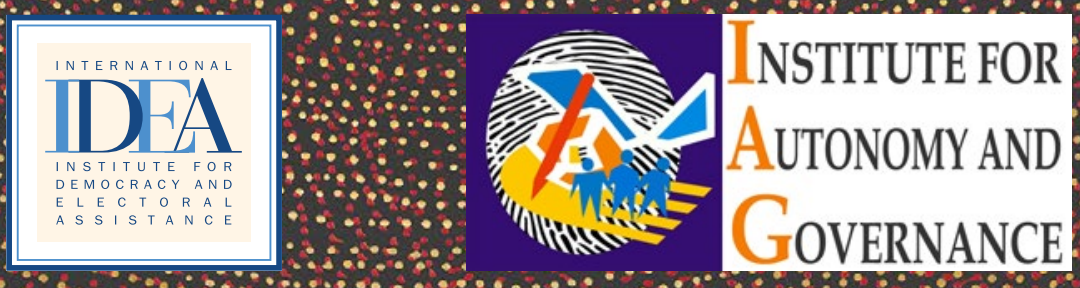

International IDEA Strömsborg

SE-103 34 Stockholm SWEDEN

Telephone: +4686983700

Email: info@idea.int

Website: 〈http://www.idea.int

Institute for Autonomy and Governance

Notre Dame University,

Notre Dame Avenue, Cotabato City

PHILIPPINES

Telefax: +63645571638

Email:info@iag.org.ph

Website: 〈http://iag.org.ph〉

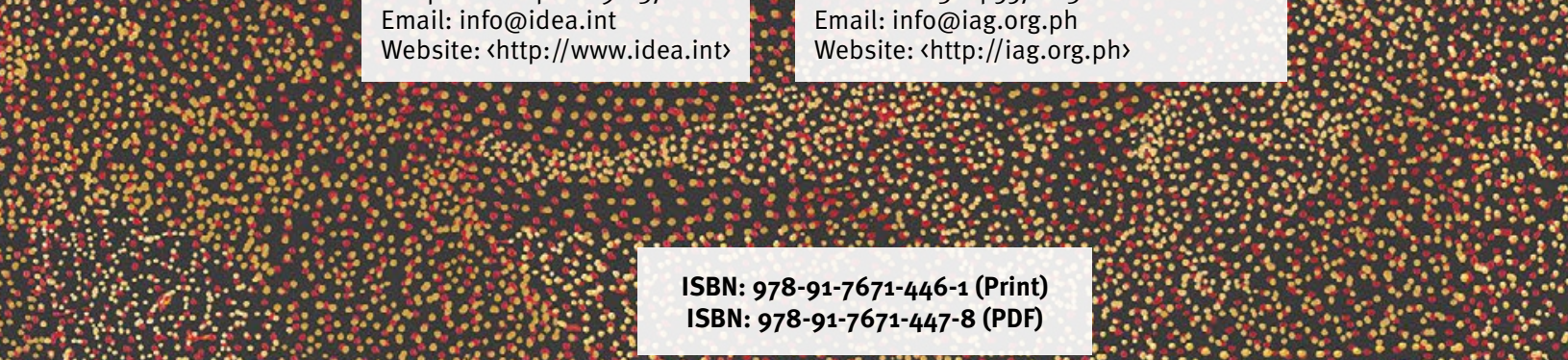

